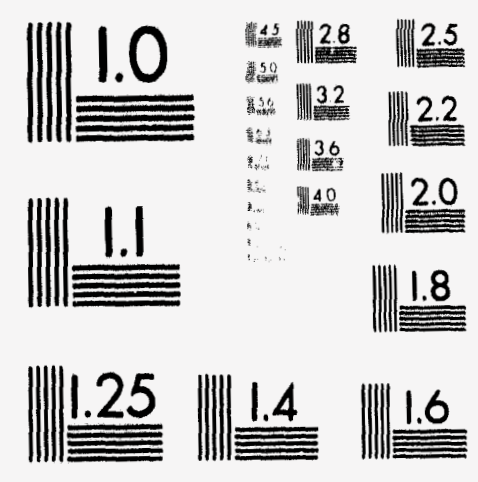



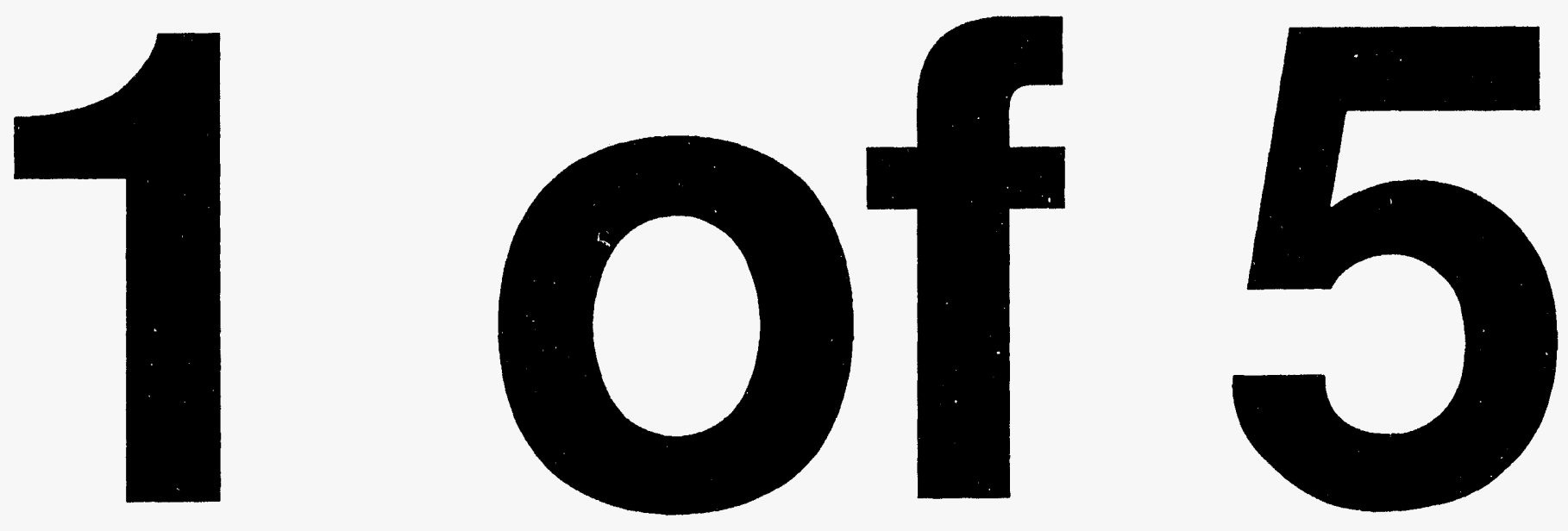
Energy Systems Environmental Restoration Program Y-12 Environmental Restoration Program

\section{Remedial Investigation Work Plan for Bear Creek Valley \\ Operable Unit 1 (S-3 Ponds, Boneyard/Burnyard, Oil Landfarm, Sanitary Landfill I, and the Burial Grounds, Including Oil Retention Ponds 1 and 2) at the Oak Ridge Y-12 Plant, Oak Ridge, Tennessee}

Volume 1. Main Text

Date Issued-September 1993

Prepared by

Science Applications International Corporation

Oak Ridge, Tennessee

under subcontract 18B-99069C, Y-05

Prepared for

U.S. Department of Energy

Office of Environmental Restoration and Waste Management under budget and reporting code EW 20

OAK RIDGE Y-12 PLANT

Oak Ridge, Tennessee 37831-8169 managed by

MARTIN MARIETTA ENERGY SYSTEMS, INC.

for the

U.S. DEPARTMENT OF ENERGY

under contract DE-AC05-84OR21400

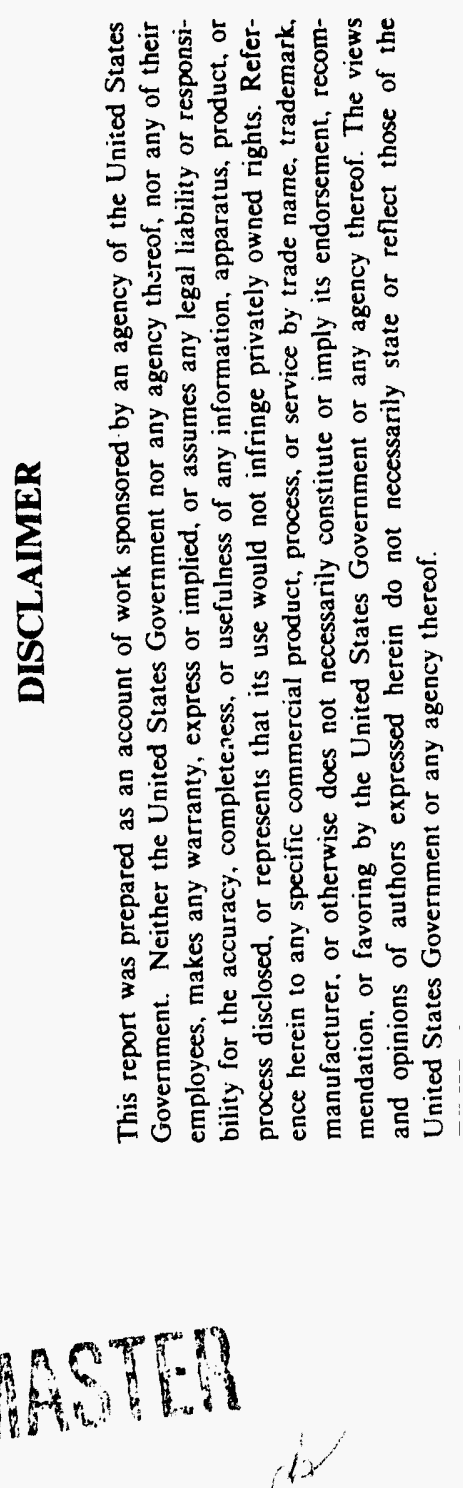




\section{CONTENTS}

FIGURES $\ldots \ldots \ldots \ldots \ldots \ldots \ldots \ldots \ldots \ldots \ldots \ldots \ldots \ldots \ldots \ldots \ldots \ldots \ldots$

TABLES $\ldots \ldots \ldots \ldots \ldots \ldots \ldots \ldots \ldots \ldots \ldots \ldots \ldots \ldots \ldots \ldots \ldots \ldots \ldots$

ACRONYMS $\ldots \ldots \ldots \ldots \ldots \ldots \ldots \ldots \ldots \ldots \ldots \ldots \ldots \ldots \ldots \ldots \ldots \ldots$

EXECUTTVE SUMMARY $\ldots \ldots \ldots \ldots \ldots \ldots \ldots \ldots \ldots \ldots \ldots \ldots \ldots$ xxiii

1. INTRODUCTION $\ldots \ldots \ldots \ldots \ldots \ldots \ldots \ldots \ldots \ldots \ldots \ldots \ldots \ldots \ldots$

1.1 REGULATORY INITIATIVE ................... 1 .

1.2 DOE-ORO ENVIRONMENTAL RESTORATION PROGRAM . $1-2$

$1.3 \quad$ Y-12 PLANT ER PROGRAM $\ldots \ldots \ldots \ldots \ldots \ldots \ldots \ldots \ldots . \ldots \ldots$

1.4 FACILITY OU STRATEGY $\ldots \ldots \ldots \ldots \ldots \ldots \ldots \ldots \ldots . \ldots \ldots$

1.5 INTENT AND SCOPE OF THE RI WORK PLAN . . . . . . . 1 1-10

1.6 SPECIAL PROBLEMS $\ldots \ldots \ldots \ldots \ldots \ldots \ldots \ldots \ldots \ldots \ldots \ldots . \ldots \ldots$

1.7 BCV OU 1 PROJECT OBJECTIVES $\ldots \ldots \ldots \ldots \ldots \ldots \ldots \ldots . \ldots 1-12$

1.8 DATA QUALITY OBJECTIVES . . . . . . . . . . . . . . 1-13

1.8.1 Statement of the Problem .................. 1-17

1.8.2 Decisions To Be Made ................... 1-19

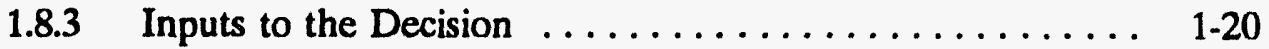

1.8.4 Boundaries of the Study ................. 1-21

1.8.5 Decision Rule . . . . . . . . . . . . . . . . . . 1-22

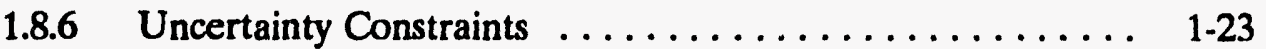

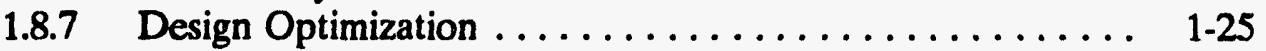

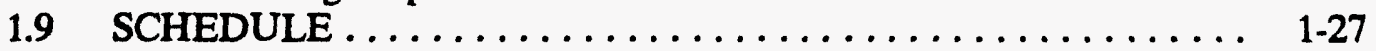

1.10 QUALITY ASSURANCE $\ldots \ldots \ldots \ldots \ldots \ldots \ldots \ldots \ldots \ldots . \ldots \ldots \ldots$

1.10.1 Program Planning and Implementation .......... 1-27

1.10 .2 Project-Specific Planning $\ldots \ldots \ldots \ldots \ldots \ldots \ldots \ldots \ldots \ldots . \ldots \ldots$

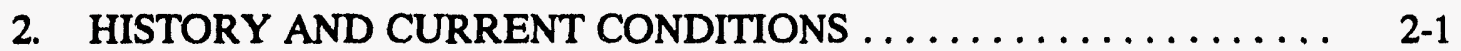

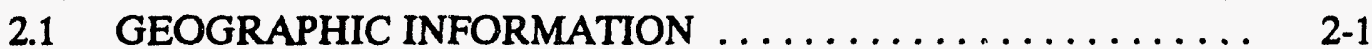

2.2 BACKGROUND INFORMATION $\ldots \ldots \ldots \ldots \ldots \ldots \ldots \ldots . \ldots \ldots$

2.3 OPERATIONAL INFORMATION $\ldots \ldots \ldots \ldots \ldots \ldots \ldots \ldots . \ldots 2-5$

$2.3 .1 \quad S-3$ Ponds ......................... $2-5$

2.3.2 Oil Landfarm ....................... 2-14

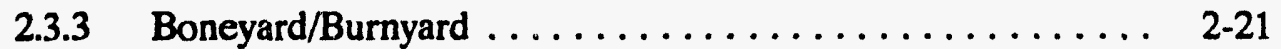

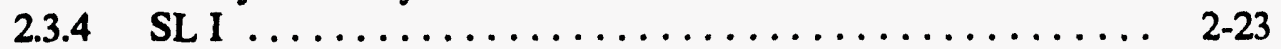

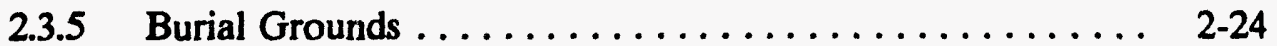

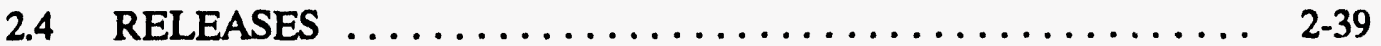

3. CHARACTERIZATION OF ENVIRONMENTAL SETTING

AND SITE CONCEPTUAL MODEL $\ldots \ldots \ldots \ldots \ldots \ldots \ldots \ldots \ldots$ 3-1

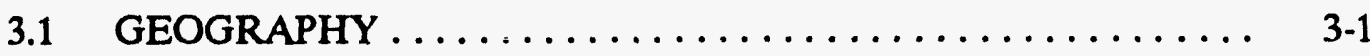

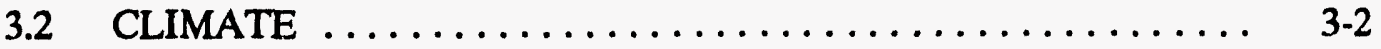


3.3 DEMOGRAPHY $\ldots \ldots \ldots \ldots \ldots \ldots \ldots \ldots \ldots \ldots \ldots . \ldots \ldots$

3.3.1 Population Information . . . . . . . . . . . . . . $3-4$

3.3.2 Land Use . . . . . . . . . . . . . . . . . . . . 3.4

3.4 GEOLOGY AND SOILS $\ldots \ldots \ldots \ldots \ldots \ldots \ldots \ldots \ldots \ldots \ldots . \ldots \ldots$

3.4.1 General Geology ..................... 3-9

3.4.2 Soil and Stream Sediment Contamination $\ldots \ldots \ldots \ldots \ldots .3-23$

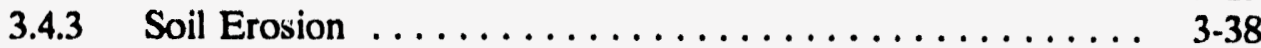

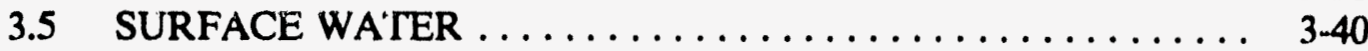

3.5.1 Bear Creek ......................... 3-40

3.5.2 Effects of the Solution Cavity System . . . . . . . . . . $3-42$

3.5.3 Stormflow System .................... 3-42

3.5.4 Surface Water Contamination ................ 3-44

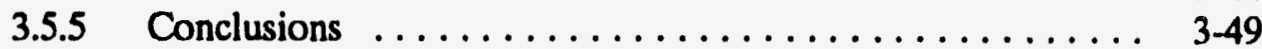

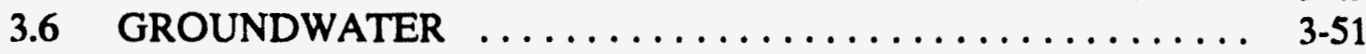

3.6.1 Existing Well Information and Descriptions $\ldots \ldots \ldots \ldots 3-51$

3.6.2 Bear Creek Hydrologic Regime .............. 3-53

3.6.3 Groundwater Contamination ............... 3-65

3.6.4 Conclusions ...................... 3-75

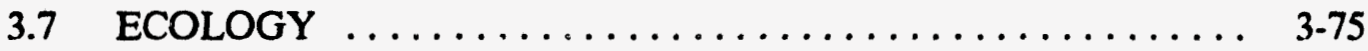

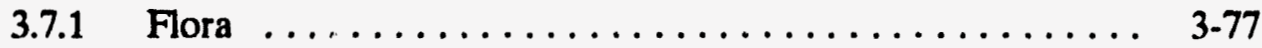

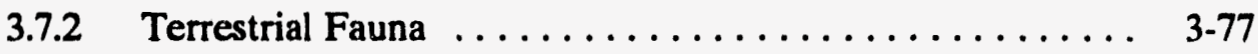

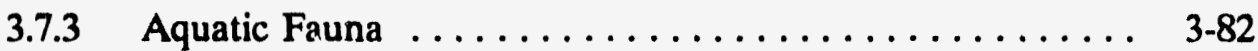

3.8 RADIOLOGICAL SURVEY $\ldots \ldots \ldots \ldots \ldots \ldots \ldots \ldots \ldots \ldots . \ldots \ldots$

3.9 SITE CONCEPTUAL MODEL $\ldots \ldots \ldots \ldots \ldots \ldots \ldots \ldots \ldots \ldots . \ldots \ldots$

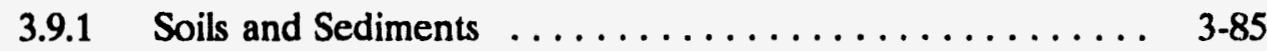

3.9.2 Groundwater ..................... 3-85

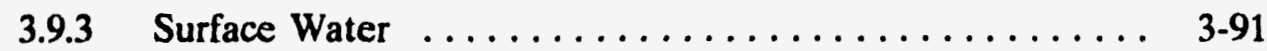

3.9.4 Site Conceptual Model for Human Receptors . . . . . . . 3 3-92

4. POTENTIAL RECEPTORS AND EXPOSURE PATHWAYS $\ldots \ldots \ldots$ 4-1

4.1 HUMAN POPULATIONS $\ldots \ldots \ldots \ldots \ldots \ldots \ldots \ldots \ldots \ldots \ldots, 4-2$

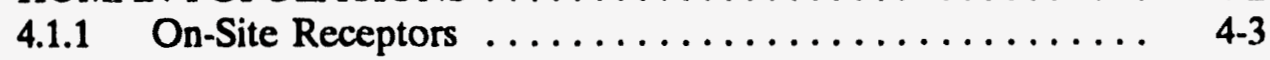

4.1.2 Off-Site Receptors .................. 4-3

4.2 ECOLOGICAL POPULATIONS $\ldots \ldots \ldots \ldots \ldots \ldots \ldots . \ldots \ldots$ 4-4

4.2.1 Flora: Terrestrial and Aquatic .............. 4.5

4.2.2 Fauna: Terrestrial and Aquatic ............. 4-5

4.2.3 Future Land Use . . . . . . . . .

5. IDENTIFICATION OF INVESTIGATION REQUIREMENTS . . . . . 5-1

5.1 IDENTIFICATION OF ARARS $\ldots \ldots \ldots \ldots \ldots \ldots \ldots \ldots \ldots . \ldots \ldots$

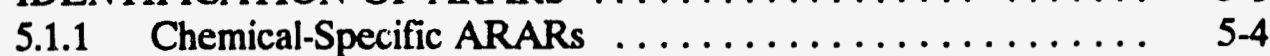

5.1 .2 Radiation Protection Standards ................ $5-10$

5.1.3 Location-Specific ARARs .................. 5-14

5.1.4 Action-Specific ARARs ................. 5-19 


\subsection{IDENTIFICATION OF PRELIMINARY REMEDIATION}

GOALS ............................. $5-19$

5.2.1 Soil PRGs Based on Direct Exposures ........... 5-20

5.2.2 Soil PRGs Based on Migration to Groundwater ....... 5-21

5.2.3 Soil PRGs for BCV OU $1 \ldots \ldots \ldots \ldots \ldots \ldots \ldots$. $5-25$

5.3 IDENTIFICATION OF POTENTIAL CLASSES

OF REMEDIAL TECHNOLOGIES $\ldots \ldots \ldots \ldots \ldots \ldots \ldots \ldots, \quad 5.30$

5.3.1 Removal Actions $\ldots \ldots \ldots \ldots \ldots \ldots \ldots \ldots \ldots \ldots, \quad 5.30$

5.3.2 Remedial Actions $\ldots \ldots \ldots \ldots \ldots \ldots \ldots \ldots \ldots \ldots, \quad 5.30$

6. SITE DATA NEEDS $\ldots \ldots \ldots \ldots \ldots \ldots \ldots \ldots \ldots \ldots \ldots \ldots \ldots \ldots$ 6.1

6.1 PHYSICAL CHARACTERIZATION ACTIVITIES ........ 6.6

6.1.1 General Site Physical Characterization Activities ........ 6-6

6.1.2 Site-Specific Physical Characterization Activities ........ 6-19

6.2 SAMPLING AND ANALYTICAL REQUIREMENTS $\ldots \ldots \ldots \ldots$ 6-31

6.3 DATA EVALUATION AND INTERPRETATION ......... 6-31

6.4 RISK ASSESSMENT $\ldots \ldots \ldots \ldots \ldots \ldots \ldots \ldots \ldots \ldots \ldots, 6.32$

6.4.1 Human Health Risk Assessment for BCV OU $1 \ldots \ldots \ldots$ 6-32

6.4.2 Ecological Risk Assessment for BCV OU $1 \ldots \ldots \ldots \ldots$ 6-33

6.5 FEASIBILITY STUDY $\ldots \ldots \ldots \ldots \ldots \ldots \ldots \ldots \ldots, 6.6 \ldots \ldots$

6.5.1 FS Contractor Responsibilities $\ldots \ldots \ldots \ldots \ldots \ldots \ldots$ 6-33

6.5.2 Scope and Assumptions $\ldots \ldots \ldots \ldots \ldots \ldots \ldots \ldots, 6.34$

6.6 REMEDIAL DESIGN AND RA PLAN . . . . . . . . . . . . 6-36

6.6.1 Remedial Design $\ldots \ldots \ldots \ldots \ldots \ldots \ldots \ldots \ldots .6 \ldots \ldots$

6.6.2 Remedial Action ...................... 6-38

7. FIELD SAMPLING PLAN $\ldots \ldots \ldots \ldots \ldots \ldots \ldots \ldots \ldots \ldots \ldots \ldots \ldots, 7-1$

7.1 INTRODUCTION AND PURPOSE $\ldots \ldots \ldots \ldots \ldots \ldots \ldots \ldots, 7-1$

7.2 PROJECT ORGANIZATION AND RESPONSIBILITIES ..... $7-2$

7.3 PROJECT DESCRIPTION $\ldots \ldots \ldots \ldots \ldots \ldots \ldots \ldots \ldots, \quad \mathbf{7 - 2}$

7.3.1 History and Current Conditions $\ldots \ldots \ldots \ldots \ldots \ldots, 7-2$

7.3.2 Site Conceptual Model ................ $7-7$

7.3.3 Identification of Investigation Requirements ........ $7-8$

7.4 SITE ACTION PLAN $\ldots \ldots \ldots \ldots \ldots \ldots \ldots \ldots \ldots \ldots, \quad 7.8$

7.4.1 Technical Procedures for Sample Collections $\ldots \ldots \ldots \ldots$ 7-9

$7.4 .2 \quad$ S-3 Site $\ldots \ldots \ldots \ldots \ldots \ldots \ldots \ldots \ldots \ldots \ldots \ldots, \quad 7-12$

7.4.3 Oil Landfarm .............................. 7-16

7.4.4 Boneyard/Burnyard and HCDA $\ldots \ldots \ldots \ldots \ldots \ldots \ldots, 7-23$

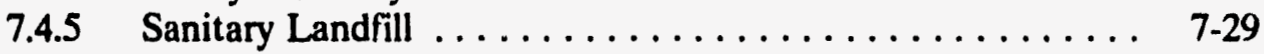

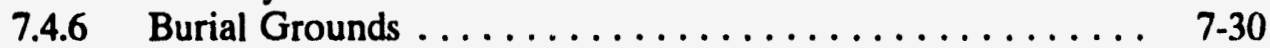

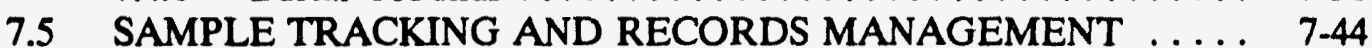

7.5 .1 Objectives .......................... 7.44

7.5 .2 Roles and Responsibilities ...................... 7.44

7.5.3 Presampling Database $\ldots \ldots \ldots \ldots \ldots \ldots \ldots \ldots \ldots, 7-44$

7.5.4 Site Logbook . ............................. $7-45$

7.5 .5 Corrections to Documents ..................... $7-46$

7.5.6 Sample Identification Numbers $\ldots \ldots \ldots \ldots \ldots \ldots \ldots \ldots, 7-46$

7.5.7 Data Entry of Field Information $\ldots \ldots \ldots \ldots \ldots \ldots \ldots \quad 7-48$ 
7.5.8 Processing of Information on Samples Sent to and Received from Analytical Laboratories ... . . . . . 7-48

7.5.9 Receipt and Preliminary Processing of Analytical Data Packages and Diskettes ................... 7-49

7.5.10 Data Consolidation and Storage $\ldots \ldots \ldots \ldots \ldots \ldots \ldots .49$

7.5.11 Data and Document Archival ............... 7.50

7.6 DATA ASSESSMENT AND INTERPRETATION $\ldots \ldots \ldots \ldots .7-50$

8. QUALITY ASSURANCE PROJECT PLAN . . . . . . . . .

8.1 DATA QUALITY OBJECTIVES ................. 8-1

8.1.1 QC Level of Field Laboratory Analysis and Data Quality

Parameters ........................ 8-2

8.1.2 QC Level of Analytical Laboratory and Data Quality

Parameters ........................ 8-4

8.2 SAMPLE COLLECTION PROCEDURES $\ldots \ldots \ldots \ldots \ldots \ldots .8 .7$

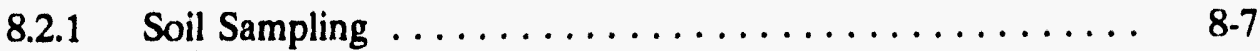

8.2 .2 Sediment Sampling $\ldots \ldots \ldots \ldots \ldots \ldots \ldots \ldots \ldots \ldots . . \ldots \ldots$

8.2.3 Surface Water Sampling $\ldots \ldots \ldots \ldots \ldots \ldots \ldots \ldots \ldots$ 8-11

8.2.4 Groundwater Sampling ................. 8-15

8.2.5 Field Measurement of Physical Parameters . . . . . . . . 8 8-19

8.2.6 Sample Compositing and Special Sample

Collection Procedures .................. 8-20

8.3 SAMPLE PREPARATION AND ANALYSIS PROCEDURES ... 8 8-23

8.3.1 Sample Containers, Sample Preservatives,

and Holding Times $\ldots \ldots \ldots \ldots \ldots \ldots \ldots \ldots \ldots \ldots$ 8-23

8.3.2 Analytical Procedures $\ldots \ldots \ldots \ldots \ldots \ldots \ldots \ldots \ldots \ldots . . \ldots \ldots$

8.4 SAMPLE CUSTODY $\ldots \ldots \ldots \ldots \ldots \ldots \ldots \ldots \ldots \ldots \ldots, \mathbf{8 - 3 6}$

8.4.1 Field Documentation $\ldots \ldots \ldots \ldots \ldots \ldots \ldots \ldots \ldots \ldots \ldots$

8.4.2 Shipping Custody Procedures $\ldots \ldots \ldots \ldots \ldots \ldots \ldots \ldots$ 8-38

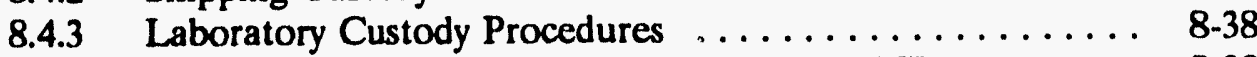

8.5 CALIBRATION PROCEDURES AND FREQUENCY ........ 8. 89

8.5.1 Field Instrument Calibration Procedures and Frequency ... 8-39

8.5.2 Laboratory Instrument Calibration Procedures

and Frequency $\ldots \ldots \ldots \ldots \ldots \ldots \ldots \ldots \ldots \ldots \ldots . \ldots \ldots$

8.5.3 Equipment Categories $\ldots \ldots \ldots \ldots \ldots \ldots \ldots \ldots \ldots, 8.42$

8.5.4 Calibration Failures $\ldots \ldots \ldots \ldots \ldots \ldots \ldots \ldots \ldots \ldots . \ldots \ldots$ 8-42

8.5.5 Calibration Records .................. 8-43

8.6 PREVENTIVE MAINTENANCE PROCEDURES/SCHEDULE . 8-43

8.7 DATA REDUCTION AND REPORTING $\ldots \ldots \ldots \ldots \ldots \ldots$ 8-45

8.7.1 Field Data Reduction and Reporting . . . . . . . . . 8 8-45

8.7.2 Laboratory Data Reduction $\ldots \ldots \ldots \ldots \ldots \ldots \ldots . \ldots . \ldots .45$

8.8 OC CHECKS ............................. 8.48

8.8.1 Field QC Checks .................... 8.48

8.8.2 Laboratory QC Procedures ................. 8-49

8.9 DATA VALIDATION PROCEDURES .............. 8-52

8.9.1 Analytical Laboratory Data Verification and Validation ... 8-52

8.9.2 Precision . . . . . . . . . . . . . . . . . . . . . . . .

8.9.3 Accuracy $\ldots \ldots \ldots \ldots \ldots \ldots \ldots \ldots \ldots \ldots \ldots \ldots . \ldots \ldots$ 
8.9.4 Representativeness . . . . . . . . . . . . . . . . . . 8-54

8.9 .5 Completeness . . . . . . . . . . . . . . . . . 8-55

8.9 .6 Comparability . . . . . . . . . . . . . $\ldots \ldots \ldots$ 8.56

8.10 AUDITS AND SURVEILLANCES $\ldots \ldots \ldots \ldots \ldots \ldots \ldots \ldots . . \ldots . \ldots \ldots$

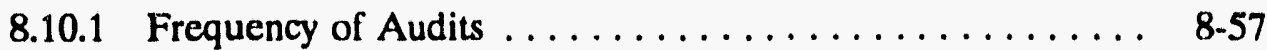

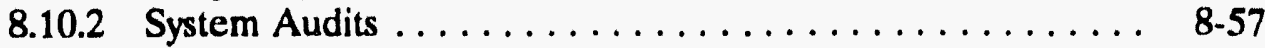

8.10 .3 Performance Audits $\ldots \ldots \ldots \ldots \ldots \ldots \ldots \ldots \ldots \ldots$ 8.57

8.10 .4 Surveillances $\ldots \ldots \ldots \ldots \ldots \ldots \ldots \ldots \ldots \ldots \ldots \ldots$ 8-57

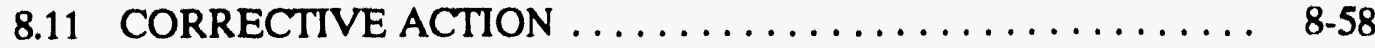

8.11.1 Responsibilities of Project Participants . . . . . . . . . 8 8-59

8.11.2 Nonconformance and Corrective Action Procedures ..... 8. 89

8.12 QA REPORTS TO MANAGEMENT ............... 8-59

9. HEALTH AND SAFETY PLAN $\ldots \ldots \ldots \ldots \ldots \ldots \ldots \ldots \ldots \ldots$

9.1 SITE HEALTH AND SAFETY PERSONNEL $\ldots \ldots \ldots \ldots \ldots .9$.

9.2 SAFETY RISK ANALYSIS . . . . . . . . . . . . . . 9.2

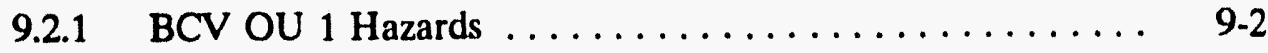

9.2.2 Physical Hazards . . . . . . . . . . . . . . . .

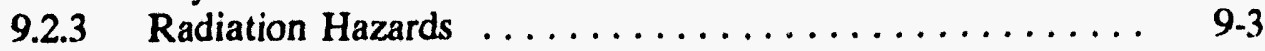

9.2.4 Chemical Hazards . . . . . . . . . . . . . . . . . 9-4

9.3 FIELD PERSONNEL TRAINING REQUIREMENTS ........ 9.4

9.4 PERSONAL PROTECTIVE APPAREL AND EQUIPMENT .... 9.5

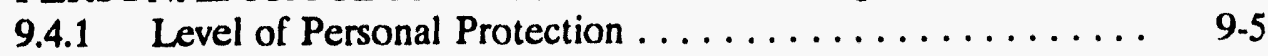

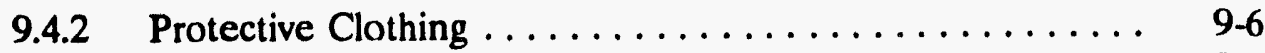

9.5 PERSONAL HYGIENE $\ldots \ldots \ldots \ldots \ldots \ldots \ldots \ldots \ldots \ldots \ldots . \ldots \ldots$

9.6 ADDITIONAL EQUIPMENT $\ldots \ldots \ldots \ldots \ldots \ldots \ldots \ldots \ldots . \ldots \ldots$

9.7 MEDICAL SURVEILLANCE $\ldots \ldots \ldots \ldots \ldots \ldots \ldots \ldots \ldots . \ldots \ldots$

9.8 MONITORING EQUIPMENT $\ldots \ldots \ldots \ldots \ldots \ldots \ldots \ldots \ldots \ldots . \ldots \ldots$

9.9 SITE CONTROL MEASURES $\ldots \ldots \ldots \ldots \ldots \ldots \ldots \ldots \ldots \ldots$.

9.10 DECONTAMINATION AND DISPOSAL ............ 9.12

9.11 CONTINGENCY PLAN $\ldots \ldots \ldots \ldots \ldots \ldots \ldots \ldots \ldots \ldots \ldots . \ldots \ldots$

9.11.1 Emergency Actions for Noncontaminated Areas ........ 9-12

9.11.2 Emergency Actions Within Contaminated Areas ........ 9-13

9.11.3 First Aid ........................ 9-14

9.12 ON-SITE COMMUNICATIONS ............... 9 -14

10. WASTE MANAGEMENT PLAN $\ldots \ldots \ldots \ldots \ldots \ldots \ldots \ldots \ldots \ldots$ 10-1

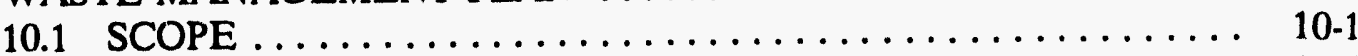

10.2 GENERAL INFCRMATION . . . . . . . . . . . . . 10-5

10.3 INVESTIGATION-DERIVED WASTE POLICY $\ldots \ldots \ldots \ldots \ldots 10.5$

10.4 HISTORY AND EXPECTED CONTAMINANTS . . . . . . . . . 10-6

10.5 APPLICABLE AND REFERENCE DOCUMENTS . . . . . . . . 10-6

10.5.1 Regulations . . . . . . . . . . . . . . . . 10-8

10.5.2 Energy Systems Policies, Standards, and Procedures . . . . . 10-10

10.5.3 Energy Systems Environmental Surveillance Procedures . . . 10-10

10.5.4 ER Division Procedures .................. 10-10

10.5.5 Waste Management Division Operating Procedures . . . . . 10-10

10.5.6 Y-12 Plant Procedures and Standard Practices ........ 10-11 
10.6 PROJECT CONTACTS $\ldots \ldots \ldots \ldots \ldots \ldots \ldots \ldots \ldots \ldots \ldots$. . . . . . . . . . . . .

10.7 PROJECT WASTE MANAGEMENT/WASTE HANDLING . . . . 10 10-11

10.7.1 Anticipated Decontamination Activities .......... 10-11

10.7.2 Investigation Derived Waste $\ldots \ldots \ldots \ldots \ldots \ldots \ldots \ldots \ldots$ 10-14

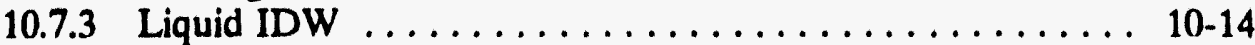

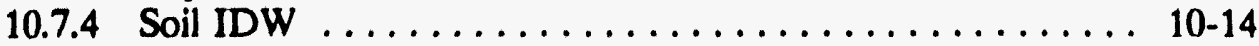

10.7.5 Solid IDW ........................ 10-14

10.8 CONTAINERIZING AND LABELING REQUIREMENTS . . . . 10 14

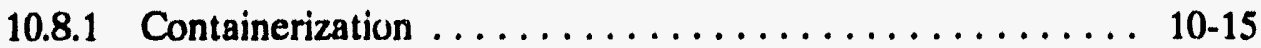

10.8.2 Labeling . . . . . . . . . . . . . . . . . . . 10-16

10.9 WASTE ESTIMATES $\ldots \ldots \ldots \ldots \ldots \ldots \ldots \ldots \ldots \ldots \ldots$ 10-17

10.10 SAMPLE MANAGEMENT-WASTE ANALYSIS

AND CHARACTERIZATION PLAN FOR DISPOSAL . . . . . 10-17

10.10.1 Classified Samples . . . . . . . . . . . . . . . . 10 19

10.10.2 Nonclassified Samples . . . . . . . . . . . . . . . . 10-21

10.10.3 Shipment for Analysis $\ldots \ldots \ldots \ldots \ldots \ldots \ldots \ldots \ldots \ldots \ldots$ 10-23

10.10.4 Analytical Waste ...................... 10-23

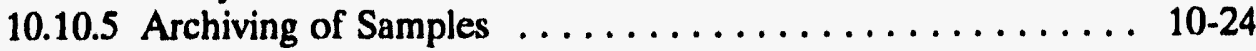

10.11 WASTE MINIMIZATION $\ldots \ldots \ldots \ldots \ldots \ldots \ldots \ldots \ldots \ldots \ldots$ 10-24

10.12 PROJECT PARTICIPANTS $\ldots \ldots \ldots \ldots \ldots \ldots \ldots \ldots \ldots \ldots$ 10-24

10.13 FIELD STAGING AREAS $\ldots \ldots \ldots \ldots \ldots \ldots \ldots \ldots \ldots \ldots$ 10-25

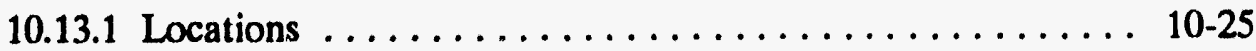

10.13.2 Special Requirements . . . . . . . . . . . . . . . 10-25

10.13.3 Responsible Organizations . . . . . . . . . . . . 10-27

10.14 REQUIRED TRANSPORT ACROSS PUBLIC ACCESS ROADS 10-27

10.14.1 TSD Evaluation and RFD Documentation . . . . . . 10-27

10.14.2 Visual Inspection of Waste Containers . . . . . . . . . 10-27

10.14.3 Transportation ..................... 10-28

10.15 WASTE STORAGE REQUIREMENTS $\ldots \ldots \ldots \ldots \ldots \ldots \ldots$ 10-28

10.16 RCRA SATELLITE AND 90-D ACCUMULATION AREA

REGISTRATION NUMBERS AND LOCATIONS . . . . . . 10-28

10.16.1 Waste Storage Area Locations . . . . . . . . . . . . . 10-29

10.16.2 Waste Acceptance Criteria Requirements . . . . . . . . . 10 10 29

10.16.3 Responsible Organization ................... 10-29

10.17 IDENTIFICATION OF POTENTIAL TREATMENT

OPTIONS AND FACILITIES $\ldots \ldots \ldots \ldots \ldots \ldots \ldots \ldots \ldots \ldots$ 10-29

10.17.1 Special Waste Acceptance Criteria Requirements

of Potential Treatment Facilities . . . . . . . . . . . . 10-29

10.18 IDENTIFICATION OF POTENTIAL DISPOSAL

OPTIONS AND FACILITIES $\ldots \ldots \ldots \ldots \ldots \ldots \ldots \ldots \ldots .10 .30$

10.19 AMENDMENTS $\ldots \ldots \ldots \ldots \ldots \ldots \ldots \ldots \ldots \ldots \ldots \ldots \ldots \ldots$

10.20 WASTE MANAGEMENT PLAN REVIEW/APPROVAL

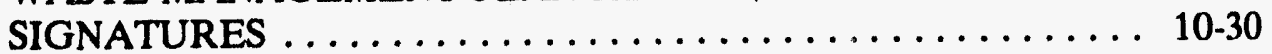

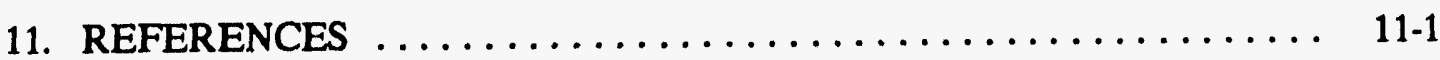


Note: Appendixes A through I can be found in Volume 2 of this document

Appendix A. LISTS OF WASTES GENERATED $\ldots \ldots \ldots \ldots \ldots \ldots \ldots \ldots$ A-1

Appendix B. DESIGNATIONS AND DIMENSIONS

OF BURIAL GROUNDS TRENCHES ............ B-1

Appendix C. SEDIMENT AND SOIL DATA $\ldots \ldots \ldots \ldots \ldots \ldots \ldots \ldots$ C-1

Appendix D. DETECTION LIMITS $\ldots \ldots \ldots \ldots \ldots \ldots \ldots \ldots \ldots \ldots \ldots$ D-1

Appendix E. READINESS REVIEW CHECKLIST $\ldots \ldots \ldots \ldots \ldots \ldots$ E-1

Appendix F. CHAIN-OF-CUSTODY RECORD ............... F-1

Appendix G. HEALTH AND SAFETY CHECKLIST

(EXCEPT BURIAL GROUNDS) $\ldots \ldots \ldots \ldots \ldots \ldots \ldots$ G-1

Appendix H. HEALTH AND SAFETY CHECKLIST

(BURIAL GROUNDS) $\ldots \ldots \ldots \ldots \ldots \ldots \ldots \ldots \ldots \ldots$ H-1

Appendix I. SATELLITE AND 90-D ACCUMULATION AREA

MANAGEMENT (IAD-SPP-4603) STANDARD

PRACTICE PROCEDURE 


\section{FIGURES}

1.1 The relationships between the integrator unit and source units in the same hydrological system $\ldots \ldots \ldots \ldots \ldots \ldots \ldots \ldots \ldots . \ldots \ldots$

1.2 The Staged RI process for a source OU ............... 1-6

1.3 Relationships between sites, OUs, and source and integrator OUs in BCV ............................. 1-11

1.4 The DQO development process $\ldots \ldots \ldots \ldots \ldots \ldots \ldots \ldots \ldots \ldots \ldots$ 1-14

1.5 The relationship between DQOs and the overall work plan

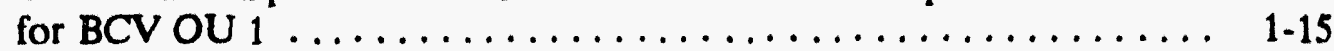

1.6 Schedule for the BCV OU 1 RI/FS through ROD .......... 1-28

$2.1 \quad$ Location of Oak Ridge $\ldots \ldots \ldots \ldots \ldots \ldots \ldots \ldots \ldots \ldots \ldots . \ldots \ldots$

2.2 Location of BCV OU 1 in relation to other OUs in Bear Creek ..... 2-3

2.3 Upper Bear Creek Hydrologic Regime ................ 2-6

2.4 Site map for the $\mathrm{S}-3$ Site ...................... 2-8

2.5 Site map for the Oil Landfarm Area, including the Oil Landfarm,

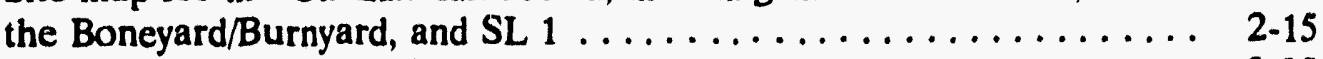

2.6 Site map for the Burial Grounds ................... 2-25

2.7 Locations of trenches, oil disposal pits, standpipes, and the isolation area in BG-A North and BG-A South . . . . . . 2-29

2.8 Locations of trenches in BG-B, -C, -D, -E, and -J and the Walk-In Pits ...................... 2-30

3.1 Location of sites in BCV OU 1 and topographic relief in BCV ..... 3-3

3.2 Annual precipitation record for the Oak Ridge area .......... $3-5$

3.3 1990 wind rose for $10-\mathrm{m}$ level at the west end of the $\mathrm{Y}-12$ Plant .... 3-6

3.4 Bedrock geology for DOE ORR $\ldots \ldots \ldots \ldots \ldots \ldots \ldots \ldots \ldots \ldots, 3-10$

3.5 Bedrock geology in BCV ........................ 3-12

3.6 Soils map for Upper Bear Creek Valley ................ 3-16

3.7 Geologic cross-section based on seismic line on Tennessee $95 . \ldots . \ldots .3-22$

3.8 Location of Bear Creek floodplain soil sampling sites . . . . . . . . . . 3-24

3.9 Location of soil and sediment sample sites

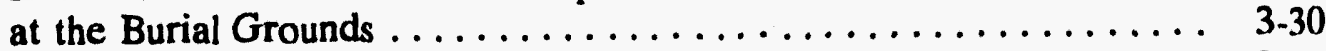

3.10 Oil contamination parallel to slope west of BG-A North ........ 3-31

3.11 Oil contamination in soil near ORP 1 , west of BG-A South ...... $3-32$

3.12 Maps showing the location of soil and sediment samples

3.13 Mean concentrations of PCBs and oil/grease $\ldots \ldots \ldots .36$ Location of soil and stream sediment sample sites
at the S-3 Site $\ldots \ldots \ldots \ldots \ldots \ldots \ldots \ldots \ldots \ldots \ldots \ldots \ldots \ldots \ldots$

3.15 Location of previously sampled surface monitoring sites

3.16 Conceptual model for the stormflow and shallow groundwater
hydrogeologic regime at BCV OU $1 \ldots \ldots \ldots \ldots \ldots \ldots \ldots \ldots$ 
3.17 Location of groundwater monitoring wells for the active flow system in Upper BCV . . . . . . . . . . . . . . . . . . . . . . . . 3-52

3.18 Groundwater elevations in the unconsolidated aquifer in BCV ... . . $3-54$

3.19 Generalized cross-section of BCV showing inferred groundwater flow paths .............................. 355

3.20 Groundwater elevations in the unconsolidated aquifer at the 5.3 Site . . . . . . . . . . . . . . . . . . . . . . . 3-57

3.21 Cross-section $A-A^{\prime}$ at the S-3 Site showing groundwater elevations in relation to the waste unit $\ldots \ldots \ldots \ldots \ldots \ldots \ldots \ldots . \ldots . . \ldots 38$

3.22 Groundwater elevations in the unconsolidated aquifer at the Oil Landfarm . . . . . . . . . . . . . . . . . . . . . . . . 3-60

3.23 Cross-section B-B' at the Oil Landfarm showing groundwater elevations in relation to the waste unit $\ldots \ldots \ldots \ldots \ldots \ldots$ 3-61

3.24 Groundwater elevations in the unconsolidated aquifer at the Burial Grounds .......................... 3-62

3.25 Cross-section $C-C^{\prime}$ at the Burial Grounds showing groundwater elevations in relation to the waste unit $\ldots \ldots \ldots \ldots \ldots \ldots \ldots . \ldots .63$

3.26 Cross-section $D-D^{\prime}$ at the Burial Grounds showing groundwater elevations in relation to the waste unit $\ldots \ldots \ldots \ldots \ldots \ldots \ldots \ldots . \ldots .64$

3.27 Distribution of VOCs in groundwater in the BCHR .......... 3-67

3.28 Nitrate in groundwater in the Maynardville Limestone along the axis of $\mathrm{BCV} \ldots \ldots \ldots \ldots \ldots \ldots \ldots \ldots \ldots \ldots \ldots \ldots$

3.29 Average normalized concentrations of nitrate as nitrogen in $\mathrm{GW}-106$ and $\mathrm{GW}-276 \ldots \ldots \ldots \ldots \ldots \ldots \ldots . \ldots \ldots . \ldots \ldots$

3.30 Average normalized concentrations for major constituents in Bear Creek . . . . . . . . . . . . . . . . . . . . . . . . . 3.74

3.31 Locations of existing biological monitoring sites $\ldots \ldots \ldots \ldots \ldots \ldots . . \ldots$

3.32 General vegetation cover types on the ORR $\ldots \ldots \ldots \ldots \ldots \ldots \ldots$ 3-78

3.33 General wildlife habitats on the ORR ................ 3.80

3.34 Bear Creek Valley conceptual site model for human receptors ....... 3-86

3.35 Bear Creek Valley OU 1 conc sptual site model for human receptors .. 3-87

3.36 Simplified food web for BCV OU 1 ecosystem $\ldots \ldots \ldots \ldots \ldots \ldots \ldots .3-88$

3.37 BCV ecological conceptual model .................... 3.89

3.38 Site conceptual model for transport of contaminants within BCHR $\ldots \ldots \ldots \ldots \ldots \ldots \ldots \ldots \ldots \ldots \ldots \ldots \ldots \ldots . . \ldots \ldots$

6.1 The staged RI/FS process $\ldots \ldots \ldots \ldots \ldots \ldots \ldots \ldots \ldots \ldots \ldots \ldots$ 6-2

6.2 Decision process for Phase I biota sampling and analysis ......... 6-18

7.1 BCV OU 1 RI functional organization chart $\ldots \ldots \ldots \ldots \ldots \ldots \ldots$

7.2 Construction diagram of tubes used for monitoring of water levels in the stormflow zone $\ldots \ldots \ldots \ldots \ldots \ldots \ldots \ldots \ldots \ldots \ldots \ldots . \ldots 7-11$

7.3 Proposed soil samples and monitoring well locations for the $S-3$ Site $\ldots \ldots \ldots \ldots \ldots \ldots \ldots \ldots \ldots \ldots \ldots \ldots \ldots \ldots . \ldots \ldots$

7.4 Proposed monitoring well locations and soil, surface water, and stream sediment sample locations for the Oil Landfarm 
7.5 Proposed soil samples and monitoring well locations for the Boncyard/Burnyard $\ldots \ldots \ldots \ldots \ldots \ldots \ldots \ldots \ldots \ldots \ldots \ldots, \mathbf{7 . 2 4}$

7.6 Proposed soil samples for soil sample area $1 \ldots \ldots \ldots \ldots \ldots \ldots \ldots \ldots .7 .35$

7.7 Proposed soil samples for soil sample area $2 \ldots \ldots \ldots \ldots \ldots \ldots \ldots \ldots .7 .36$

7.8 Proposed soil samples for soil sample area $3 \ldots \ldots \ldots \ldots \ldots \ldots \ldots \ldots, 7.37$

7.9 Proposed soil samples for soil sample area $4 \ldots \ldots \ldots \ldots \ldots \ldots \ldots, \mathbf{7 . 3 8}$

7.10 Proposed soil samples for soil sample area $5 \ldots \ldots \ldots \ldots \ldots \ldots \ldots .7 .39$

7.11 Proposed soil samples for soil sample area $6 \ldots \ldots \ldots \ldots \ldots \ldots \ldots, 7.40$

7.12 Proposed soil samples for soil sample area $7 \ldots \ldots \ldots \ldots \ldots \ldots \ldots, 7.41$

7.13 Sample label and identification structure $\ldots \ldots \ldots \ldots \ldots \ldots \ldots \ldots, 7.47$

9.1 Site control zones $\ldots \ldots \ldots \ldots \ldots \ldots \ldots \ldots \ldots \ldots \ldots \ldots \ldots . \ldots .11$

10.1 Designated AOC at the BCV OU $1 \ldots \ldots \ldots \ldots \ldots \ldots \ldots \ldots \ldots$ 10.7

10.2 General location of FSAs ...................... 10.26

10.3 Example of Approval Signatures Form ............... 10.31 


\section{TABLES}

$1.1 \quad$ Y.12 Plant OUs $\ldots \ldots \ldots \ldots \ldots \ldots \ldots \ldots \ldots \ldots \ldots \ldots \ldots \ldots \ldots$

1.2 Regulatory driven, project objectives, DQOs, data uses,

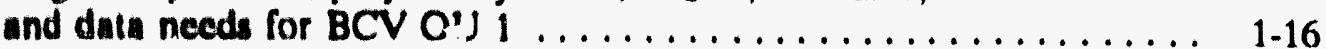

1.3 Remedial units of BCV OU $1 \ldots \ldots \ldots \ldots \ldots \ldots \ldots \ldots \ldots \ldots . \ldots \ldots$

1.4 Crom reference of EPA QAMS 005/80 and ES/ER/TM-4/R2

eloments with BCV OU 1 RI Work Plan sections . . . . . . . . . . . . 1-29

$2.1 \quad$ Upper Bear Creek kilometer (mile) locations ... . . . . . . . . . . . . 2-4

2.2 Summary of possible contaminant types from BCV OU 1

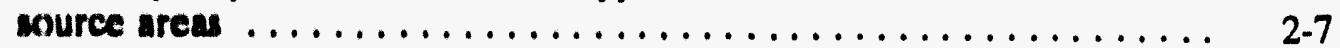

2.3 Chronological list of events at the $\mathbf{S}-3$ Ponds ................ $2-9$

2.4 Waste disposed of in the S.3 Ponds .................... 2-12

2.5 Chemical additions to the northeast quadrant (S-3 Ponds) . . . . . . . 2-13

2.6 Chronological list of events at the Oil Landfarm ............... 2-16

2.7 Summary of waste oil disposal at the Y-12 Plant Oil Landfarm ...... 2-19

2.8 Summary of waste coolant disposal at the Y-12 Plant Oil Landfarm ... 2-20

2.9 Chronological list of events at the Boneyard/Burnyard ......... 2-22

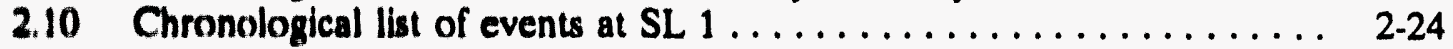

2.11 Chronological list of events at the Burial Grounds ........... 2-26

2.12 Partial summary of waste materials deposited in the Burial Grounds ... 2-31

2.13 Solvents discharged into the isolation area $\ldots \ldots \ldots \ldots \ldots \ldots \ldots . .33$

3.1 Land use data for the Eastern Tennessee Development District . . . . 3 3-7

3.2 Urban land use data for the city of Oak Ridge, Tennessee ........ 3-7

3.3 Stratigraphy of the $Y-12$ Plant area ................. 3-11

3.4 Oak Ridge Reservation background soil analytes evaluated

quantitatively and qualitatively $\ldots \ldots \ldots \ldots \ldots \ldots \ldots \ldots \ldots \ldots$ 3-17

3.5 Soll chemical properties ...................... 3-20

3.6 Soll physical and engineering properties of the predominant

soil groups in the $Y-12$ Plant area $\ldots \ldots \ldots \ldots \ldots \ldots \ldots \ldots \ldots . \ldots \ldots$

3.7 Statistical summary of contaminant levels at the five

floxdplain subsurface soil-sampling localities in Bear Creek

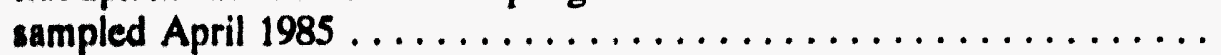

3.8 Statistical summary of contaminant levels in floodplain

surface soils at five sites in Bear Creek sampled April 1985 . . . . . . . 3. 3-27

3.9 Range of estimated [K] values for major soils

on the Low-Level Waste Disposal Development

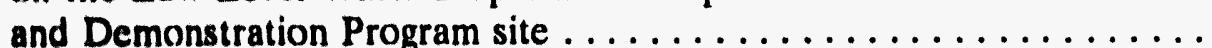

3.10 Summed concentrations of VOCs in Bear Creek surface water at various sites . . . . . . . . . . . . . . . . . . . . . . 3-46

3.11 Mean pH of Bear Creek in three surveys conducted over 10 -year period . . . . . . . . . . . . . . . . . . . . . . 3-47

3.12 Concentrations of major ions in unfiltered Bear Creek water at various sites downstream from the S-3 Site in $1992 \ldots \ldots \ldots$. . . . . . . 
3.13 Maximum concentrations, acute toxicity ranges, and water quality criteria for inorganic ions found at elevated levels in Bear Creek .................. 3-50

3.14 Parameters for hardness-dependent aquatic screening criteria ...... 3-51

3.15 Nitrate, annual mean gross alpha activity, and gross beta activity exceeding MCLs, 1990 ........................... 3-69

3.16 Threatened and endangered plant and animal species on the ORR ... 3-79

5.1 Potential contaminants of concern at BCV OU $1 \ldots \ldots \ldots \ldots . . \ldots 5$

5.2 Chemical-specific federal and state regulations for the protection of groundwater and surface water at BCV OU $1 \ldots \ldots \ldots \ldots . \ldots .6$

5.3 Radiation protection standards that may be ARARs for BCV OU $1 \ldots$ 5-12

5.4 Tentative location-specific ARARs for BCV OU $1 \ldots \ldots \ldots \ldots \ldots .5 .15$

5.5 Parameters used to calculate preliminary remediation goals . . . . . . . $5-22$

5.6 Parameters used in the Summers Model ............... 5-23

5.7 Soil preliminary remediation goals $\ldots \ldots \ldots \ldots \ldots \ldots \ldots \ldots \ldots \ldots .5-26$

5.8 Identification of preliminary remedial action goals, preliminary general response actions, and preliminary

remedial technology types for soil $\ldots \ldots \ldots \ldots \ldots \ldots \ldots \ldots \ldots \ldots .32$

6.1 BCV OU 1 RI work plan site data needs ............... 6-3

6.2 Geotechnical and physical parameters for each soil sample . . . . . . 6. 6-10

6.3 BCV OU 1 groundwater monitoring wells $\ldots \ldots \ldots \ldots \ldots \ldots \ldots .6 .11$

6.4 Assessment policy goals and measurement endpoints .......... 6-20

6.5 Rationale for sampling or not sampling OU 1 sites $\ldots \ldots \ldots \ldots \ldots .6-22$

7.1 Energy Systems and RI subcontractor responsibilities for the Y-12 Plant ER Program assessment ............. $7-4$

7.2 Remedial units of BCV OU $1 \ldots \ldots \ldots \ldots \ldots \ldots \ldots \ldots \ldots$

7.3 Sample apportionment by medium for the $\mathrm{S}-3$ Site $\ldots \ldots \ldots \ldots \ldots$ 7-14

7.4 Number of samples and quality control samples to be collected for the $\mathrm{S}-3$ Site $\ldots \ldots \ldots \ldots \ldots \ldots \ldots \ldots \ldots$ 7-15

7.5 Sample apportionment by medium for the Oil Landfarm and Sanitary Landfill I .................... 7-19

7.6 Number of samples and quality control samples to be collected for the Oil Landfarm . . . . . . . . . . . . . 7-21

7.7 Sample apportionment by medium for the Boneyard/Burnyard ..... 7-26

7.8 Number of samples and quality control samples to be collected for the Boneyard/Burnyard ............ 7-27

7.9 Sample apportionment by medium for the Burial Grounds ....... 7-31

7.10 Number of samples and quality control samples to be collected for the Burial Grounds ............... 7-32

7.11 Groundwater monitoring wells for the Burial Grounds ......... $7-42$

8.1 Recommended sample holding times, sample containers, sample preservation, and minimum sample size $\ldots \ldots \ldots \ldots \ldots \ldots \ldots$

8.2 Analytical methods, parameters, and quantitation limit goals for surface water/groundwater and soil/sediment samples ......... 
8.3 Level I instrument uses, detection limits, and calibration . . . . . . 8 -40

8.4 Data deliverables for EPA Levels III and IV quality assurance . . . . . 8 8-46

10.1 Environmental Restoration Waste Management Project Plan . . . . . . 10-2

10.2 Key project personnel, affiliations, and telephone numbers . . . . . . 10-12

10.3 Active waste management facilities at the $\mathrm{Y}-12$ Plant $\ldots \ldots \ldots \ldots$ 10-13

10.4 Waste generation per site for the BCV OU 1 RI $\ldots \ldots \ldots \ldots \ldots \ldots$ 10-18 


\section{ACRONYMS}

AEA
ALARA
ANSI/ASME
AOC
ARAR
BCAR
BCK
BCV
BG
BMAP
BNI
BOD
BRA
BYBY
CAA
CAMU
CEC
CERCLA
CFR
CLP
CMS
COCs
COPC
CPR
CSFs
CWA
DCGs
DNAPL
DOE
DOE-ORO
DOT
DQO
EDTA
EM
Energy Systems
EPA
EQR
ER
ERA
ET
FBL
FDA
FFA

Atomic Energy Act

as low as reasonably achievable

American National Standards Institute/American Society of Mechanical Engineers

area of contamination

applicable and relevant or appropriate requirement

Bear Creek Hydrologic Regime

Bear Creek Kilometer

Bear Creek Valley

Burial Ground

Biological Monitoring and Abatement Program

Bechtel National, Inc.

Biochemical Oxygen Demand

baseline risk assessment

Boneyard/Burnyard

Clean Air Act

Corrective Action Management Unit

cation exchange capacity

Comprehensive Environmental Response, Compensation, and Liability Act

Code of Federal Regulations

Contract Laboratory Program

Corrective Measures Study

contaminants of concern

chemicals of potential concern

cardiopulmonary resuscitation

carcinogenic slope factors

Clean Water Act

Derived Concentration Guides

dense nonaqueous phase liquid

U.S. Department of Energy

U.S. Department of Energy Oak Ridge Operations Office

U.S. Department of Transportation

Data Quality Objective

ethylenediaminetetracetic acid

electromagnetic induction

Martin Marietta Energy Systems, Inc.

U.S. Environmental Protection Agency

rinsates

Environmental Restoration

ecological risk assessment

East Tributary

field blanks

U.S. Food and Drug Administration

Federal Facilities Agreement 


\begin{tabular}{|c|c|}
\hline FFCA & mixed-waste Federal Facilities Compliance Agreement \\
\hline FID & flame ionization detector \\
\hline$F R$ & Federal Register \\
\hline FS & Feasibility Study \\
\hline FSA & field staging area \\
\hline GC/MS & gas chromatograph/mass spectrophotometer \\
\hline GM & Geiger-Mueller \\
\hline GWQAR & groundwater quality assessment report \\
\hline HAZMAT & hazardous waste and hazardous materials \\
\hline HCDA & Hazardous Chemical Disposal Area \\
\hline HSWA & Hazardous and Solid Waste Amendments \\
\hline HWDU & Hazardous Waste Disposal Unit \\
\hline ICP & inductively coupled plasma \\
\hline IDLH & Immediately Dangerous to Life or Health \\
\hline IDW & investigation-derived waste \\
\hline IP & integration point \\
\hline IRIS & Integrated Risk Information Systern \\
\hline $\mathbf{K}$ & erodibility factor \\
\hline LCS & laboratory control sample \\
\hline LDRs & land disposal restrictions \\
\hline LLW & low-level waste \\
\hline LLWDDD & Low-Level Waste Disposal, Development, and Demonstration \\
\hline LNAPL & light nonaqueous phase liquid \\
\hline M\&TE & measuring and test equipment \\
\hline MCL & maximum contaminant level \\
\hline MCLG & maximum contaminant level goal \\
\hline N.ILE & most likely exposure \\
\hline MOU & Memorandum of Understanding \\
\hline MS & matrix spike \\
\hline MSD & matrix spike duplicate \\
\hline MSDS & Material Safety Data Sheet \\
\hline MTRs & minimum technology requirements \\
\hline NAAQSs & National Ambient Air Quality Standards \\
\hline NCP & National Contingency Plan \\
\hline NEPA & National Environmental Policy Act \\
\hline NERP & National Environmental Research Park \\
\hline NESHAPs & National Emission Standards for Hazardous Air Pollutants \\
\hline NFI & no further investigation \\
\hline NPDES & National Pollutant Discharge Elimination System \\
\hline NPL & National Priorities List \\
\hline NPRM & Notice of Proposed Rulemaking \\
\hline NRC & U.S. Nuclear Regulatory Commission \\
\hline NRDA & Natural Resource Damage Assessment \\
\hline NT & North Tributary \\
\hline ODW & Office of Drinking Water \\
\hline OREIS & Oak Ridge Environmental Information System \\
\hline ORGDP & Oak Ridge Gaseous Diffusion Plant \\
\hline ORNL & Oak Ridge National Laboratory \\
\hline
\end{tabular}




\begin{tabular}{|c|c|}
\hline $\begin{array}{l}\text { ORP } \\
\text { ORR } \\
\text { OSHA } \\
\text { OU } \\
\text { OVA } \\
\text { PA } \\
\text { PAH } \\
\text { PARCC }\end{array}$ & $\begin{array}{l}\text { Oil Retention Pond } \\
\text { Oak Ridge Reservation } \\
\text { Occupational Safety and Health Administration } \\
\text { operable unit } \\
\text { organic vapor analyzer } \\
\text { Preliminary Assessment } \\
\text { polycyclic aromatic hydrocarbon } \\
\text { precision, accuracy, representativeness, completeness, } \\
\text { and comparability }\end{array}$ \\
\hline PCB & polychlorinated biphenyl \\
\hline PCE & perchloroethene (or tetrachlorethene) \\
\hline PGDP & Paducah Gaseous Diffusion Plant \\
\hline FHSO & Project Health and Safety Officer \\
\hline PID & photoionization detector \\
\hline POR'TS & Portsmouth Gaseous Diffusion Plant \\
\hline PPE & personal protective equipment \\
\hline $\begin{array}{l}\text { PRG } \\
\text { QA }\end{array}$ & $\begin{array}{l}\text { preliminary remediation goal } \\
\text { quality assurance }\end{array}$ \\
\hline QAPjP & Quality Assurance Project Plan \\
\hline QC & quality control \\
\hline RA & Remedial Action \\
\hline RAOs & remedial action objectives \\
\hline RCRA & Resciurce Conservation and Recovery Act \\
\hline RD & Remedial Design \\
\hline RFA & RCRA Facility Assessment \\
\hline RfCs & reference concentrations \\
\hline RfDs & reference doses \\
\hline RFI & RCRA Facility Investigation \\
\hline RI & Remedial Investigation \\
\hline RME & reasonable maximum exposure \\
\hline ROD & Record of Decision \\
\hline RPD & relative percent difference \\
\hline RT & retention time \\
\hline SAIC & Science Applicaticns International Corporation \\
\hline SAP & sampling and analysis plan \\
\hline SARA & Superfund Amendments and Reauthorization Act \\
\hline SDWA & Safe Drinking Water Act \\
\hline SEG & Scientific Ecology Group \\
\hline SEN & Secretary of Energy Notice \\
\hline SHSO & Site Health and Safety Officer \\
\hline SI & Site Investigation \\
\hline SL1 & Sanitary Landfill I \\
\hline SMCLs & secondary maximum contaminant levels \\
\hline SOW & statement of work \\
\hline SRM & standard reference material \\
\hline ST & South Tributary \\
\hline SWMU & solid waste management unit \\
\hline SWSA & Solid Waste Storage Area \\
\hline
\end{tabular}


TAL

TBC

TBL

TCA

TCE

TCL

TCLP

TDEC

TDS

TICs

TLD

TLV

TOC

TRU

TSCA

TSD

TUs

TVA

TWRA

UEFPC

USC

USGS

USLE

VOA

VOC

WAG

WDC

WOM

WT

WTSD
Target Analyte List

to be considered

trip blank

Tennessee Code Annotated

trichloroethene

Target Compound List

Toxicity Characteristic Leaching Procedure

Tennessee Department of Environment and Conservation

total dissolved solids

tentatively identified compounds

thermoluminescent dosimeter

Threshold Limit Value

total organic carbon

transuranic

Toxic Substances Control Act

treatment, storage, and disposal

Temporary Units

Tennessee Valley Authority

Tennessee Wildlife Resources Agency

Upper East Fork Poplar Creek

United States Code

U.S. Geologic Survey

Universal Soil Loss Equation

volatile organic analysis

volatile organic compound

Waste Area Grouping

Waste Disposal Coordinator

White Oak Mountain

West Tributary

Waste Treatment, Storage, and Disposal 


\section{EXECUTIVE SUMMARY}

The enactment of the Resource Conservation and Recovery Act (RCRA) in 1976 and the Hazardous and Solid Waste Amendments to RCRA in 1984 created management requirements for hazardous waste facilities. The facilities within the Oak Ridge Reservation (ORR) were in the process of meeting the RCRA requirements when ORR was placed on the Comprehensive Environmental Response, Compensation, and Liability Act (CERCLA) National Priorities List (NPL) on November 21, 1989. To ensure that all necessary steps were undertaken to protect the public health and the environment during the investigation, evaluation, and remediation of all Solid Waste Management Units (SWMUs) and Operable Units (OUs) on the ORR, the Department Of Energy Oak Ridge Operations (DOE-ORO) Office in Oak Ridge, Tennessee, the Tennessee Department of Environment and Conservation (TDEC), and the Environmental Protection Agency have formulated a Federal Facility Agreement (FFA) for ORR. The FFA outlines all deliverables, review times, and schedules to ensure that activities are undertaken in a timely manner.

Under RCRA, actions typically follow the RCRA Facility Assessment/RCRA Facility Investigation/Corrective Measures Study implementation process. Under CERCLA, actions typically follow the Preliminary Assessment/Site Investigation/Remedial Investigation (RI)/Feasibility Study (FS)/remedial design/remedial action process. A goal of the FFA is to coordinate response actions under CERCLA with closure, postclosure care, and corrective measures under way or planned under RCRA and applicable state laws, in such a manner as to maximize flexibility and minimize duplication of investigative actions. The development of this document incorporates the requirements under both CERCLA and RCRA into an RI work plan. Further studies of the sites in Bear Creek Valley (BCV) OU 1 will follow the CERCLA process.

BCV OU 1 is one of three source OUs within BCV. It is comprised of five sites that are located on the northern side of BCV to the west of the Y-12 Plant. All sites in this OU are outside the Y-12 Plant boundary. The five sites are the following: the S-3 Site; the Oil Landfarm; the Boneyard/Burnyard, which includes the Hazardous Chemical Disposal Area (HCDA); Sanitary Landfill I (SL 1); and the Bear Creek Burial Grounds (BG-A North, -A South, -B, -C East, $-C$ West, $-D,-E$, and $-J)$, which includes the Oil Retention Ponds (ORPs) 1 and 2, the Walk-in Pits, and the Uranium Vaults.

The S-3 Site, Oil Landfarm, HCDA, and the Burial Grounds have had some previous investigation under the Y-12 Plant RCRA Program. No investigation has been carried out for the Boneyard/Burnyard or SL 1.

S-3 Site. The S-3 Ponds were constructed in 1951 and consisted of four unlined surface impoundments covering a total area of roughly 1.5 ha (3.7 acres) with a storage capacity of 38 million L (10 million gal). During operation, up to $21,000 \mathrm{~L} / \mathrm{d}(5500 \mathrm{gal} / \mathrm{d})$ of effluent was pumped into the ponds through a pipeline from the Y-12 Plant. The S-3 Site underwent RCRA closure in 1988 and was paved to create a parking lot. Groundwater below the S-3 Site is known to be contaminated with nitrate, metals, organics, and radioactive chemicals. Waste remaining below the RCRA cap is known to contain metals and radioactive chemicals. 
Oil Landfarm. The Oil Landfarm was used for the land application of waste oils and coolants that contained beryllium compounds, depleted uranium, polychlorinated biphenyls (PCBs), and chlorinated hydrocarbons. Disposal operations were discontinued in 1982. Final RCRA closure of the site was certified by TDEC in December 1990 . Soils at this site are contaminated with PCBs and uranium; groundwater is contaminated with organics.

Boneyard/Burnyard. The Boneyard/Burnyard consists of $~ 3.2$ ha (8 acres) that were used from 1943 to 1970 as a disposal site for waste from the Y-12 Plant. Burning and disposal of debris and sanitary, metallic, chemical, and radioactive wastes are known to have occurred. The site has been abandoned and is predominantly covered with grassy vegetation. The southeastern portion of this site is overlain by the HCDA. The HCDA covers $\sim 0.8$ ha ( 2 acres) and was used to burn or neutralize liquid and gaseous wastes from 1975 until 1981. The HCDA is covered with a RCRA cap. Groundwater at the Boneyard/Burnyard is contaminated with radioactive chemicals. The nature of soil contamination is not known.

SL 1. SL 1 received various types of nonhazardous wastes from the Y-12 Plant. Waste disposal at SL 1 was carried out from 1962 to 1982, and the site was graded, capped with clay, and closed in 1983 under a TDEC-approved closure plan according to TDEC rules and regulations for sanitary landfills. No hazardous materials have been recorded at this site and no further investigation is recommended.

Burial Grounds. The Burial Grounds are located on the southern slope of Pine Ridge $\sim 3 \mathrm{~km}$ (2 miles) west of the Y-12 Plant. They comprise a series of waste disposal units covering an area of $\sim 140$ ha (350 acres). Each waste disposal unit consists of a series of trenches excavated to between 4.3 and $7.6 \mathrm{~m}$ ( 14 and $25 \mathrm{ft}$ ) below grade. The trenches received a variety of hazardous and nonhazardous solid and liquid wastes from the Y-12 Plant. All hazardous waste disposal uperations were discontinued in 1981. All trenches known to have received RCRA hazardous material have been capped, or are in the process of being capped, as part of RCRA closure. The Burial Grounds include ORPs 1 and 2, the Walk-in Pits, and the Uranium Vaults. The ORPs were constructed to intercept seepage from the Burial Grounds trenches. Both ponds were capped and RCRA-closed in 1990. The Walk-in Pits were used to dispose of solid or drummed liquid wastes including pyrophoric saw fines of uranium and thorium and shock-sensitive chemicals. Details of wastes delivered to the Burial Grounds are contained in an inventory of Y-12 Plant records. It is proposed that this comprehensive list be used to characterize wastes currently in place. The Uranium Vaults were constructed to store enriched uranium waste but were never used for that purpose. A wide range of contaminants may have been disposed of in the Burial Grounds, and groundwater shows the highest levels of organic contamination in BCV. The nature and extent of soil contamination outside capped areas resulting from groundwater transport is not known.

The development of this RI work plan is based on the foundation set by the Data Quality Objective (DQO) process. The purpose of the DOO process is to ensure that data of appropriate and known quality are obtained and are adequate for the intended uses. During the DQO process, data users were identified and were involved at the beginning of the work plan development to identify data types and uses needed for the RI/FS. Historical data for each of the sites were reviewed to develop a list of potential contaminants of concern and to develop conceptual models detailing potential exposure pathways. From this 
preliminary work, the scope of the investigation was narrowed, specific RI goals were defined, and the project objectives were developed.

The intent and scope of the work plan are to assemble all data necessary to facilitate selection of remediation alternatives for the sites in BCV OU 1 such that the risk to human health and the environment is reduced to acceptable levels based on agreements with regulators. The ultimate goal is to develop a final Record Of Decision (ROD) for all of the OUs in BCV, including the integrator OU. However, the initial aim of the source OUs is to develop a ROD for interim measures. For source OUs such as BCV OU 1, data acquisition will not be carried out in a single event, but will be carried out in three stages that accommodate the schedule for developing a ROD for interim measures and the final site-wide ROD. The three stages are as follows:

Stage 1 Assemble sufficient data to support decisions such as the need for removal actions, whether to continue with the RI process, or whether no further action is required.

If the decision is made to continue the RI/FS process, then:

Stage 2 Assemble sufficient data to allow for a ROD for interim measures that reduce risks to the human health and the environment.

Stage 3 Provide input from the source OU that allows a final ROD to be issued for all OUs in the BCV hydrologic regime.

Ideally the interim measures taken at the end of the second stage will be sufficient for the final ROD. Therefore, it is anticipated that the third stage of the process will rely on postremediation performance monitoring data collected at the source.

One goal of the RI work plan will be to ensure that sampling operations required for the initial stage are not repeated at later stages. The overall goals of this RI are to define the nature and extent of contamination so that the impact of leachate, surface water runoff, and sediment from the OU 1 sites on the integrator $O U$ can be evaluated, the risk to human health and the environment can be defined, and the general physical characteristics of the subsurface can be determined such that remedial alternatives can be screened. Specific objectives to meet these goals follow:

- To define the contaminants of concern at each site.

- To quantify the contaminant concentrations in waste and soils at each site and the spacial distributions of contaminants of concern.

- To assess the contribution made by contamination in soils and wastes to the concentrations of dissolved and particulate phases in groundwater and surfaces water.

- To support the FS in the screening of appropriate alternatives during the remedy selection. 
- To provide data input to the site-wide baseline risk assessment that will be carried out to issue a final ROD.

- To provide technically and legally defensible data on which to base credible decisions regarding risk levels and cleanup alternatives.

The BCV OU 1 RI work plan was prepared following the Remedial Investigation Work Plan Annotated Outline DOE/OR/01-1077, Rev 0. This work plan contains summaries of geographical, historical, operational, geological, hydrological, and ecological information specific to sites in BCV OU 1 . The potential for release of contaminants to receptors through various media is addressed, and a sampling and analysis plan is presented to obtain the objectives of the RI. Proposed sampling activities include geophysical and radiological surveys, shallow soil borings, soil borings, piezometer and monitoring well installation, groundwater sampling, surface water sampling, and stream sediment sampling. A field sampling investigation plan, a health and safety plan, and a waste management plan are also included in the work plan. 


\section{INTRODUCTION}

\subsection{REGULATORY INITIATIVE}

The Oak Ridge Reservation (ORR) is comprised of three major installations: the Oak Ridge National Laboratory (ORNL), the Oak Ridge Y-12 Plant, and the Oak Ridge K-25 Site [formerly referred to as the Oak Ridge Gaseous Diffusion Plant (ORGDP)]. These installations were constructed in the early to mid-1940s by the Atomic Energy Commission [predecessor of the U.S. Department of Energy (DOE)] as research, development, and process facilities in support of the Manhattan Project. These installations, along with the Paducah Gaseous Diffusion Plant (PGDP) in Paducah, Kentucky, and the Portsmouth Gaseous Diffusion Plant (PORTS) in Piketon, Ohio, are currently administered by the DOE Oak Ridge Operations (DOE-ORO) office in Oak Ridge, Tennessee.

During the construction and operation of these research, development, and process facilities, the associated decontamination, maintenance, and fabrication processes resulted in the generation of various hazardous and radioactive waste by-products. Hazardous waste treatment, storage, and disposal (TSD) facilities were created at each of the DOE-ORO installations to handle such by-products. Some of these facilities continue to receive hazardous wastes, while others have been decommissioned. All DOE-ORO TSD facilities are currently subject to the requirements of several laws:

- Comprehensive Environmental Response, Compensation, and Liability Act (CERCLA, also referred to as Superfund)-created in 1980 to establish a program to identify sites [operable uinits (OUs)] from which environmental releases of hazardous substances might 'sccur or have occurred. At such sites, Superfund promotes the evaluation of damage to natural resources, ensures cleanup by the responsible party or the government, and creates a claims procedure for parties involved in site cleanup and natural resource reclamation. Sites identified by CERCLA are evaluated and then placed on the National Priorities List (NPL), if appropriate. The ORR was listed on the NPL in the December 1989 Federal Register (54 FR 48184).

- Resource Conservation and Recovery Act (RCRA)-created in 1976 as a hazardous waste management system that mandates permitting currently operating TSD facilities. Under RCRA, these TSD facilities are referred to as solid waste management units (SWMUs). RCRA defines an SWMU as any discernible waste management unit at a RCRA facility from which hazardous waste or hazardous constituents might migrate, irrespective of whether the unit was intended for the management of solid or hazardous waste. Such units include any area at a facility at which hazardous waste or hazardous constituents have been routinely and systematically released.

- Hazardous and Solid Waste Amendments (HSWA)-created as amendments to RCRA (1984) that provide the U.S. Environmental Protection Agency (EPA) with the authority to enforce corrective actions by broadening the scope of the RCRA Corrective Action Program. In addition to evaluating and correcting releases to the uppermost aquifer from regulated RCRA units, HSWA promotes the cleanup of continuing releases to any media resulting from waste management units and practices at RCRA facilities. Among the most significant provisions of the HSWA are the following: 
- Section 3004(u): Corrective Action for Continuing Releases. Section 3004(u) states that for permits issued after November 8,1984 , corrective action is required for releases of hazardous waste or constituents from any SWMU at any TSD facility seeking a permit for permanent operation, regardless of when waste was placed in the unit. Thus, corrective actions apply to releases presently occurring as well as past releases.

- Section 3004(v): Corrective Action Beyond the Facility Boundary. Section 3004(v) authorized EPA to require that corrective action be taken by the facility owner or operator for releases that have migrated beyond the facility boundary (off site). Such action should be taken where necessary to protect human health and the environment unless the owner/operator demonstrates to the satisfaction of the administrator that permission to undertake such action was denied.

- Superfund Amendments and Reauthorization Act (SARA)-created in 1986 as a 5-year extension of the Superfund/CERCLA program to clean up hazardous releases at uncontrolled or abandoned hazardous waste sites.

- National Environmental Policy Act (NEPA)-created in 1968 to direct federal agencies to consider the impacts of their actions (e.g., construction, remediation) on the environment as a part of all decision-making processes.

In anticipation of the ORR being listed on the NPL, DOE-ORO, the Tennessee Department of Environment and Conservation (TDEC), and EPA formulated a Federal Facility Agreement (FFA) for the ORR. The FFA was designed to ensure that all necessary steps were undertaken to protect the public health and the environment during the investigation, evaluation, and remediation of all SWMUs/OUs. A goal of the FFA is to coordinate response actions under CERCLA and applicable state laws, in such a manner as to maximize flexibility and minimize duplication of investigative actions (Energy Systems 1992a). The FFA also outlines all deliverables, review times, and schedules to ensure that activities are undertaken in a timely manner.

DOE and TDEC have formulated an oversight agreement/agreement-in-principle. As stated in this agreement, TDEC is the lead agency for the state of Tennessee. The purposes of this agreement are to ensure compliance with applicable federal, state, and local environmental laws and to ensure the citizens of Tennessee that their health, safety, and environment are being protected through a program of independent monitoring and oversight by the state.

Each of these agreements provides a measure of oversight for all environmental restoration at ORR installations. PGDP and PORTS are not listed on the NPL and therefore have no FFA. (They do, however, have agreements-in-principle with their respective states and regional EPA offices.)

\subsection{DOE-ORO ENVIRONMENTAL RESTORATION PROGRAM}

The mission of the DOE-ORO Environmental Restoration (ER) Program is "to eliminate or reduce to prescribed safe levels the risks to the environment or to human health and safety posed by inactive and surplus ORO-managed sites and facilities that have been contaminated by radioactive, hazardous, or mixed wastes" (Energy Systems 1991). Because 
ORR was placed on the NPL in December 1989, all remedial activitien including characterization, alternative selection, and implementation must meet the requirements of RCRA, CERCLA, and NEPA. Therefore, the DOE ER Program decided to address the requirements of all applicable laws in a scries of "integrated" documentation for each site.

To facilitate consistency in the preparation of these integrated documents at all DOE-ORO facilities, the managing and operating contractor for DOE-ORO facilitien established an ER Division. In addition to central staff who oversec the main program areas, ER site program managers were appointed at each of the DOE.ORO facilities. These site program managers oversee the day-to-day operations of the facility-specific programs and interface with central ER Division staff.

\subsection{Y-12 PLANT ER PROGRAM}

A major objective of CERCLA investigations is to characterize the nature and extent of contamination at uncontrolled hazardous waste sites. HSWA requires assessments to be conducted at all former and current SWMUs at RCRA.permitted facilities. For SWMUs that are suspected to be the source of contaminant releases to the environment, a RCRA Facility Investigation (RFI) is required to define the nature and extent of the release. Descriptions of most of the individual SWMUs at the Y.12 Plant are provided in a report entitled Solid Waste Management Unit Information for the Y.12 Plant RCRA 3004(u) Facility Assessment and in its supplements (Welch and Poore 1987; Welch 1987; Murphy 1989).

Under RCRA, uctions typically follow the RCRA Facility Asseasment (RFA)/RFI/Corrective Measures Study (CMS) implementation process. Under CERCLA, actions typically follow the Preliminary Assessment (PA)/Site Investigation (SI)/Remedial Investigation (RI)/Feasibility Study (FS)/remedial design/remedial action process. The development of this document incorporates the requirements under both CERCLA and RCRA in an RI work plan. Further studies of the sites in Bear Creek Valley (BCV) Operable Unit 1 (OU 1) will follow the CERCLA process.

\subsection{FACILITY OU STRATEGY}

The ORR consists of $\sim 14,300$ ha $(35,300$ acres) of federally owned land in Oak Ridge. Under its RCRA HSWA permit, DOE has begun the RFI process at more than 500 SWMUs at the ORR. Under the present strategy, OUs are defined as sites for which an RI/FS will be performed. The RI/FS will include any necessary removal actions or interim actions. Many of the remediation units on the ORR were grouped not only according to their proximity but also by common physical and hydrological parameters.

Because the hydrogeologic regime of the ORR is complex, and hecause numerous sources contribute to groundwater contamination within a geographical area, more timely investigations can be achieved by separating the sources of contamination from the groundwater and surface water for investigation and remediation. To permit effective evaluation of the cumulative impact of releases from multiple sources of contamination, an approach has been adopted for the ORR that separates studies of the groundwater and surface water from studies of the sources. This was done by assigning waste area groupings (WAGs) as source OUs and the hydrogeologic regimes that are common to more than one 
source OU as integrator OUs. This approach will result in more immediate attention [removal action and/or Records of Decision (RODs) for interim measures] for the source OUs while inventigation continues into remediation alternatives for the integrator OUs (Energy Systems 1992a). Both source and integrator OUs vill achieve a final ROD (Fig. 1.1).

Data acquisition for each $O U$ in an integrator unit will not be carried out in a single event but may be carried out in the following three stages (Fig. 1.2).

- Stage 1-Assemble sufficient data to support making intermediate decisions. Some questions that would need to be answered are the following: Can the site be designated * "Site Evaluation Accomplished"? Should a focused effort be implemented to support a finding of no-further-investigation-required? Is a removal action required or appropriate? Is a focused FS relevant to the site? Should the waste unit proceed to Stage 2 of the CERCLA process?

- Stage 2-Assemble sufficient data to select an acceptable source remediation and obtain a source unit ROD.

- Stage 3-Compile information on postremediation source unit risks and current integrator risks to obtain a $R O D$ for the entire hydrologic regime.

The premise of the staged approach is that the remediation of a CERCLA OU is a complex process, starting with the identification of those sources that warrant investigation on the ORR and continuing through the proposed plan for implementing a remedial action. To implement the entire process on all potential sources at the Y-12 Plant would be impossible. Therefore, the staged approach is designed to provide mechanisms for withdrawing a sile from the process as soon as information is available that suggests it is not necessary for the site to proceed through the entire RI/FS process. The staged approach is also designed to minimize the possibility that a remediated source will have to be revisited in order to obtain an integrator or site-wide ROD.

Each stage supports a different level of decision making and, therefore, would require different types and amounts of data. However, a goal of the RI work plan will be to ensure that sampling operations required for the initial stage are not repeated at later stages. Some of the individual sites within BCV OU 1 have been studied extensively, and Stage 1 may require review, evaluation, and validation of existing data. For other BCV OU 1 sources, additional Stage 1 data may be required. Ideally, the interim measures taken at the end of the sccond stage will be sufficient for the final ROD; therefore, it is anticipated that the third stage of the process will rely on postremediation performance monitoring data collected at the source.

Those units identified as source OUs only will be addressed using interim measures for which RODs will be issued. By the time the interim measures for the proposed source OUs have been completed, sufficient monitoring data from the integrator OUs will be available to determine whether the combination of interim actions for all sources results in an acceptable integrator and valley-wide risk reduction. At this time, additional actions for the source OUs will be needed only if the cumulative contributions of multiple source OUs cause unacceptable risk as measured at the integrator OU now or in the future.

One of the primary goals of the Y-12 Plant strategy is to integrate source OUs and integrator OUs. The primary responsibilities of the integrator unit are as follows: 
Integrator $\mathrm{OU}$

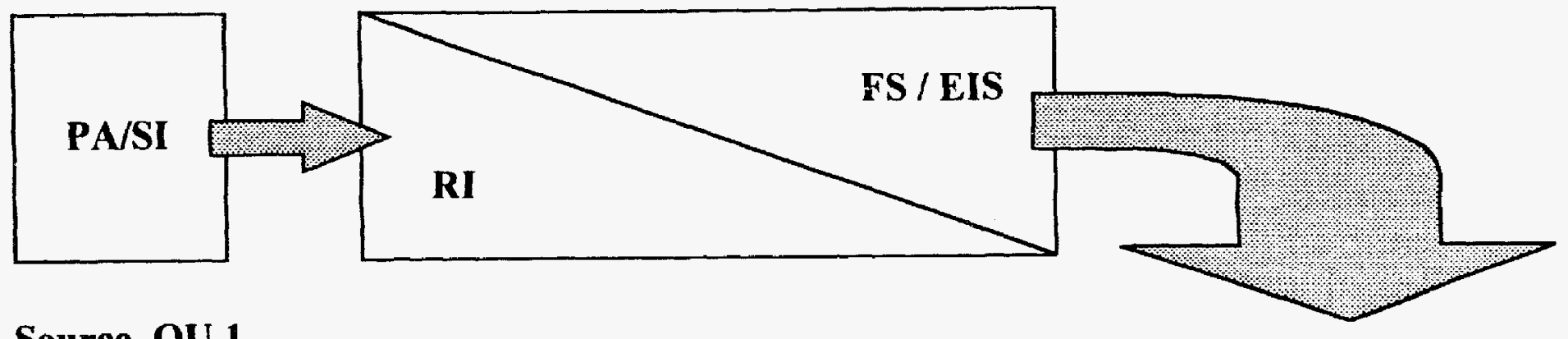

Source OU 1

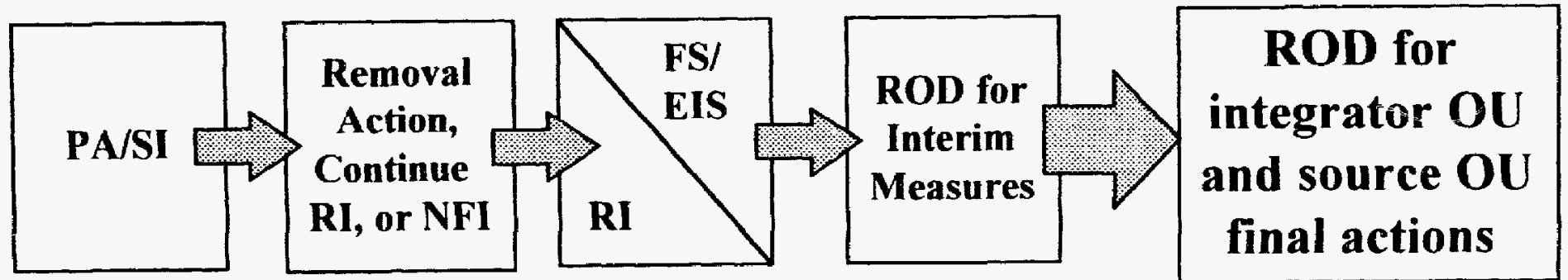

Source OU 2

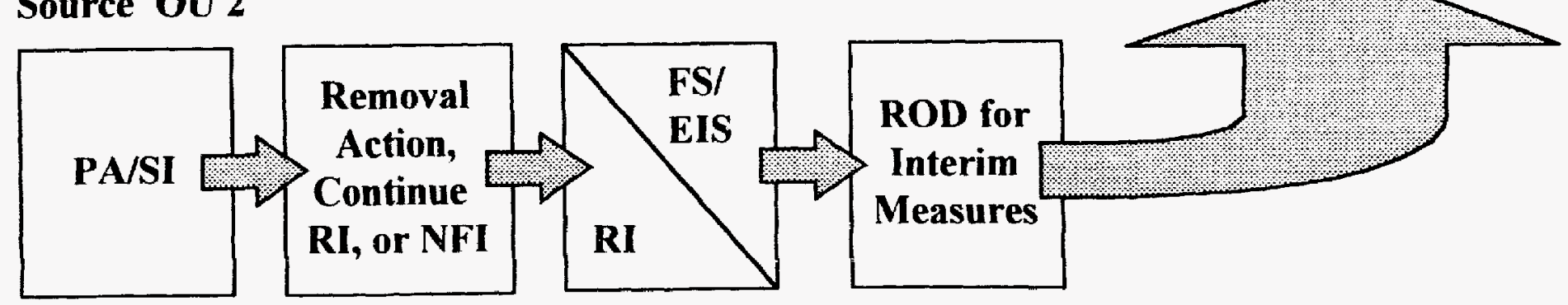

Fig 1.1. The relatiolwhips between the integrator unit and source units in the same hydrological system. 


\section{Stages of the Source OU RI}

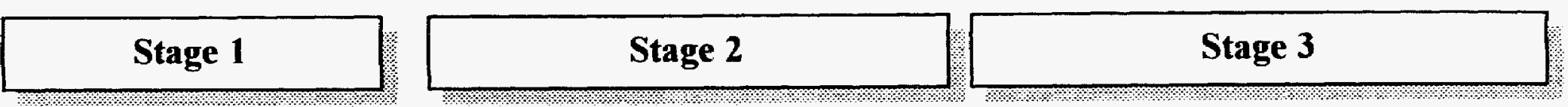

CERCLA process for sources sites not closed under RCRA
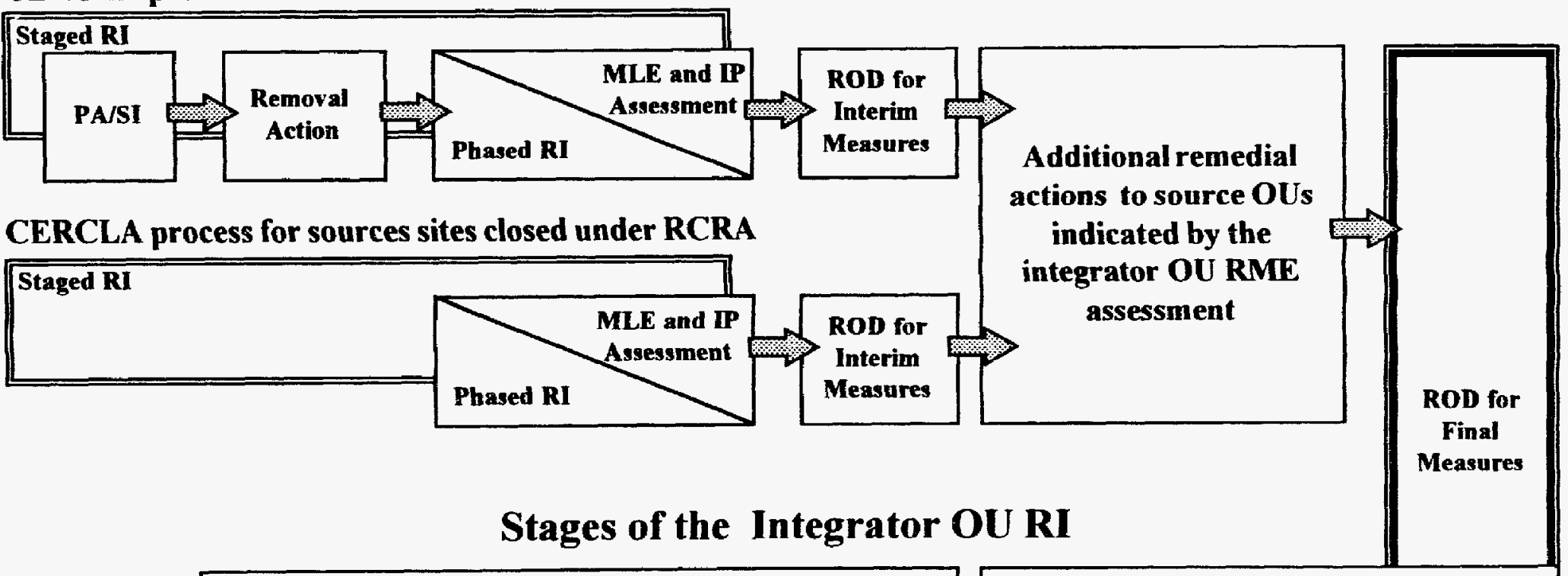

CERCLA process for sources sites closed under RCRA

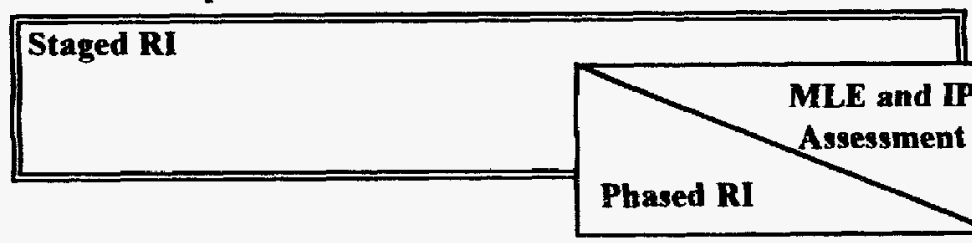

Interim

\section{Stages of the Integrator OU RI}

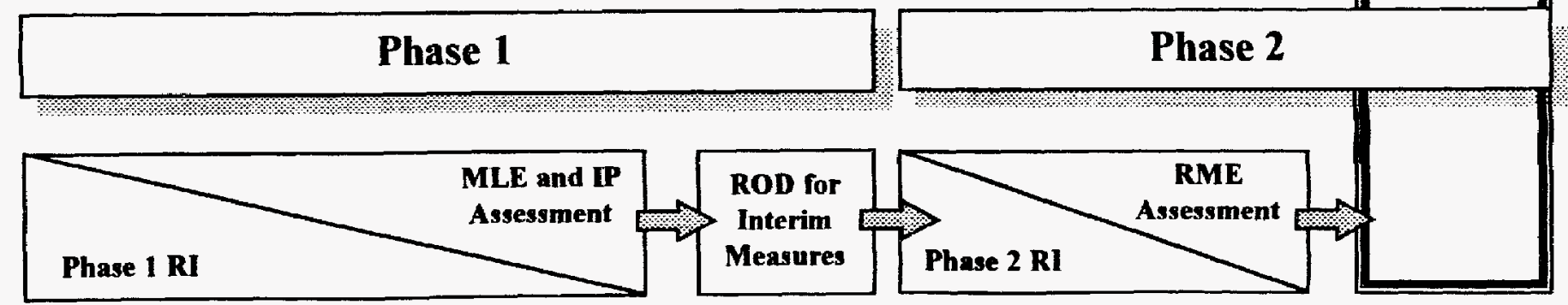

Fig 12 The Staged RI process for a source OU. 
- To identify contamination currently in the environmental media that should be addressed immediately.

- To gain an understanding of the primary flow mechanisms within and between the Nolichucky and Maynardville groundwater formations.

- To gain an understanding of the interaction between the Nolichucky and Bear Creek and Upper East Fork Poplar Creek (UEFPC).

- To gain an understanding of the interaction between groundwater/surface water and the Clinch River.

- To identify points in the environmental media (surface water and groundwater) where high levels of contamination are entering the media (integrator points) to help prioritize the cleanup of the source units.

- To gain an understanding of and provide the tools for quantifying (if possible) contaminant transport through the groundwater system (e.g., identify sorption properties and site-specific water-to-soil distribution coefficients for primary chemicals of concern).

- To develop and provide to the source OUs conceptual and (if possible) quantitative models that should be used to describe unsaturated zone flow, stormflow zone flow, and surface water runoff to ensure that source OUs are using consistent techniques for estimating chemical migration to the integrator.

- To provide source OUs groundwater preliminary remediation goals (PRGs) that can be used to make remediation decisions about the source. These PRGs should be based on risk and applicable or relevant and appropriate requirements (ARARs) and may account for potential risks to both a future on-site receptor and a downgradient off-site receptor. PRGs for the off-site receptor should eventually account for dilution/attenuation that occurs as hazardous substances move through the groundwater. Estimated and measured concentrations of hazardous substances being released from the source unit to the groundwater will be compared to these PRGs to determine if remediation of the source is necessary.

- To provide source OUs surface water PRGs that can be used to make remediation decisions about the source. These PRGs should be risk-based and should account for potential risks to ecological and human receptors. Estimated or measured concentrations of hazardous substances being released from the source to the integrator will be compared to these PRGs to help determine if remediation of the source is necessary.

- To gain an understanding of the off-site risks associated with hazardous substances currently detected in groundwater, surface water, and sediments.

- To gain an understanding of potential future risk associated with continued off-site migration of hazardous substances currently detected in groundwater and sediments (e.g., to learn how this contamination may act as a source for future risk even if source control measures are implemented on source OUs).

- To gain an understanding of potential risks to aquatic species and food chain impacts associated with contamination in surface water and sediments.

- To gain an understanding of the potential risks to terrestrial species that have a large habitat range and that are higher in the food chain (e.g., deer and predator species).

The primary responsibilities of the source OU are as follows: 
- To identify the nature and extent of the source.

- To identify and quantify (with models provided by the integrator unit) potential releases and transport mechanisms from the source to the integrator $O U$, including leaching, transport through the unsaturated zone to the groundwater, movement through the stormflow system to the groundwater, surface water/sediment, and runoff to surface water/sediment.

- To identify and quantify (if possible and necessary) potential releases to the air.

- To collect and provide to the integrator OU information (e.g., runoff and stormflow data) showing the connection and possible integration points between a specific source and the integrator $\mathrm{OU}$.

- To identify and quantify current and future potential on-site risks to humans associated with the source.

- To identify terrestrial ecological effects associated with the source. To gain an understanding of potential risks to species with a small habitat range that are generally low in the food chain and can be connected easily to a specific source (e.g., earthworms).

- To identify potential wetlands within the source OU boundaries and effects on wetlands species.

- To use risk/ARAR-based groundwater PRGs, developed by the integrator OU, to identify whether current or potential future releases could pose a risk to future on-site receptors and current and future off-site receptors. These PRGs will be compared with detected or modeled concentrations to help determine if releases from the source nced to be remediated.

- To use human and ecological-based surface water PRGs, developed by the integrator OU, to discern if current or potential future releases from the source need to be addressed by remediation.

Five integrator OUs have been identified for the ORR: Bethel Valley, Melton Valley, the K-25 Site area, BCV OU 4, and UEFPC OU 1. ORNL WAGs have not yet been assigned to OUs. There have been 14 source OUs identified at the K-25 Site and 8 source OUs identified at the Y-12 Plant. In addition, three combined source and integrator OUs have been identified: Chestnut Ridge at the Y-12 Plant, Lower East Fork Poplar Creek (LEFPC), and ORNL WAGs 11 and 13 with the Oak Ridge Associated Universities (ORAU) site at Freels Bend.

The Y-12 Plant source OUs have been grouped not only by their proximity but also by common physical and hydrogeologic parameters (Table 1.1). Extensive study of the relationship between groundwater movement and contaminant trsnsport at the Y-12 Plant indicates that groundwater can be subdivided into two distinct hydrogeologic regimes: UEFPC and BCV. This subdivision is based on topography, surface water drainage, and groundwater flow patterns. It provides a basis for unifying monitoring efforts at the Y-12 Plant and for tailoring monitoring efforts to the hydrogeologic characterization of each regime. The strategy used to delineate the boundaries of each regime is included in Comprehensive Groundwater Monitoring Plan for the DOE Y.12 Plant, Oak Ridge, Tennessee (Geraghty and Miller 1990). 
Table 1.1. Y-12 Plant OUs

\begin{tabular}{|c|c|c|}
\hline OU & Type & Sites of concern \\
\hline UEFPC OU 1 & Integrator & $\begin{array}{l}\text { Groundwater, surface water, and sediment within the } Y \text {. } \\
12 \text { Plant }\end{array}$ \\
\hline UEFPC OU 2 & Source & Abandoned Nitric Acid Pipeline \\
\hline UEFPC OU 3 & Source & $\begin{array}{l}\text { S-2 Site, Building } 81-10 \text {, Coal Pile Trench, Machine } \\
\text { Coolant Storage Tanks, Waste Coolant Processing } \\
\text { Facility, Tanksite 2063, Salvage Yard Drum Deheader, } \\
\text { Salvage Yard Waste Oll Storage Tanks, Salvage Yard } \\
\text { Ollsolvent Drum Storage Area, and Salvage Yard Scrap } \\
\text { Metal Storage Area }\end{array}$ \\
\hline BCV OU 1 & Source & 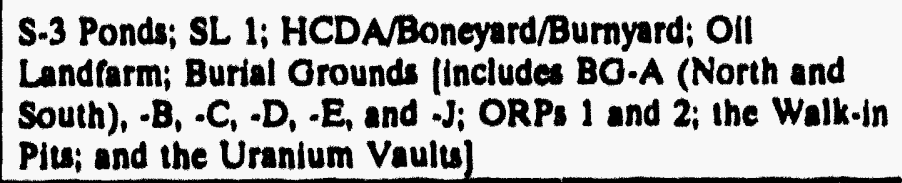 \\
\hline BCV OU 2 & Source & Rust Spoll Area, Spoll Area 1, SY.200 Yard \\
\hline BCV OU 4 & Integrator & $\begin{array}{l}\text { Bear Creek Oroundwater and Surface Flow Regime and } \\
\text { Floodplain Sediments }\end{array}$ \\
\hline Chestnut Ridge OU 1 & Source & $\begin{array}{l}\text { Chestnut Ridge Security Pits Hazardous Waste Disposal } \\
\text { Units }\end{array}$ \\
\hline Chestnut Ridge OU 2 & Source & Filled Conl Ash Pond, Upper McCoy Branch \\
\hline Chestnut Ridge OU 3 & Source & United Nuclear Corporation Disposal Site \\
\hline Chestnut Ridge OU 4 & Source & Rogens Quarry and Lower McCoy Branch \\
\hline LEFPC OU & Integrator/Source & LEFPC Floodplain and Creek \\
\hline
\end{tabular}


BCV OU 1 is one of two source OUs within BCV (Fig. 1.3; refer also to Fig. 2.3 in Chap. 2). The integrator OU for BCV is BCV OU 4, which consists of surface water and groundwater from Bear Creek and its tributaries, as well as floodplain soils and sediments. The boundaries of BCV OU 4 are from the crest of Chestnut Ridge to the crest of Pine Ridge and from the surface water divide near the S-3 Site to the groundwater divide west of State Highway 95 between Bear Creek and Grassy Creek. Source OUs in BCV are as follows:

- BCV OU 1, which is comprised of the S-3 Site; the Oil Landfarm; the Boneyard/Bumyard, including the Hazardous Chemicals Disposal Area (HCDA); Sanitary Landfill I (SL 1); and the Bear Creck Burial Grounds I(BO)-A North, BG.A South, BG.B, BG.C East, BG.C West, BG.D, BG.E, and BG.J)], including Oil Retention Ponds (ORPs) 1 and 2, the Walk-in Pits, and the Uranium Vaults.

- BCV OU 2, which includes the Rust Spoil Area, Spoil Area 1, and the SY-200 Yard.

\subsection{INTENT AND SCOPE OF THE RI WORK PLAN}

BCV OU 1 is the focus of this work plan. The intent of the work plan is to assemble all data necessary to select remediation alternatives for the sites in BCV OU 1 in order to reduce the risk to human health and the environment to acceptable levels based on agreements with the regulators. Because BCV OU 1 is a source OU that is associated with an integrator OU. there are certain constraints on the media that are to be addressed for remediation by the RI/FS and on the scheduling of the RL/FS process. Oroundwater and surface water associated with BCV OU 1 will not be addreased as media to be remediated in the BCV OU 1 RI/FS process; risks to off-source and off-site receptors via groundwater and surface water pathways will be addressed in the BCV OU 4 (iniegrator OU! RME (baseline risk assessment). Floodplain soils will be addreased by the RI for BCV OU 4 and will not be included in the work plan for BCV OU 1 unleas they are within the BCV OU 1 site boundaries.

Application of the observational approach to the development of the RI work plan entailed development of the site conceptual models and lists of likely removal actions and likely remedial alternatives that will be evaluated by the RI. Likely removal actions are as follows:

- Removal or overpacking of drums or other containers.

- Excavation of highly contaminated soils, eapecially those that are radioactive.

- Drainage controls (l.e., capture and treatment) of contaminated shallow groundwater).

- Drainage controls (l.e., capture and treatment) of contaminated seeps.

- Installation of an airborne dust monitoring station.

- Fences, warning signs, or other security measures.

Likely remedial alternatives are as follown:

- No action.

- Institutional controls. 

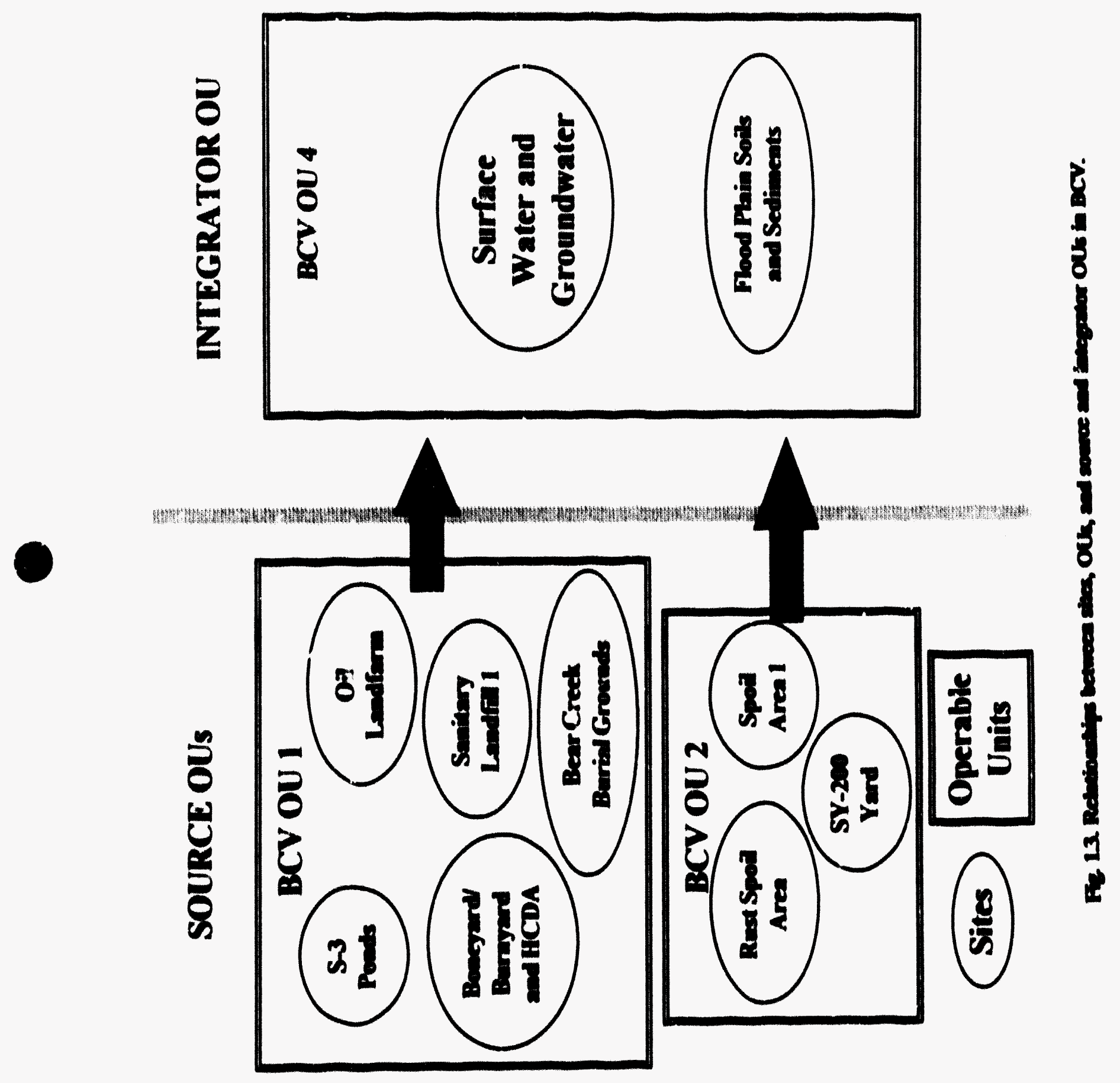
- Source containment.

- Removal/treatment.

Based on the site conceptual model, the activities described in this work plan are designed to support these remedial alternatives and likely removal actions.

The schedule of RI/FS activities in BCV OU 1 will follow the staged approach outlined in the facility OU strategy for the Y-12 Plant outlined in Sect. 1.4. The ultimate goal is to develop a final ROD for all of the OUs in BCV, including the integrator OU. However, the initial aim of the source OUs is to develop a ROD for interim measures that reduces the risk to human health and the environment by way of direct contact pathways from soil (e.g., inhalation) and that reduces the contributions to groundwater and surface water from the source $O U$ such that the sources do not contribute to unacceptable contaminant levels in the integrator OU.

\subsection{SPECIAL PROBLEMS}

Special problems for BCV OU 1 are as followa:

- Wates in BO-B and the Walk.in Pits include pyrophoric saw fines. Wastes in the Walk. in Pits include shock-sensitive chemicals, in addition to pyrophoric saw fines. Thus, intruaive inveatigative methods at these sites are specifically excluded for health and safety reasons. A project is currenily under way to cap theac areas with a RCRA-style cap.

- Parts of BO.A North, BO.A Scuuth, BO.C Weat, the Oil Landfarm, the HCDA, and the S.3 Ponds were closed in place us landfills under RCRA between 1988 and $; 990$. Closure was conducted purnuant in Tennewec Rule 1200)-1-11-.05(14)(c). With the exception of the HCDA, each of theac sites is covered with an engineered cap, and the types of wastes deposited at these sites are documented; therefore, no samples will be taken that call for penetrating cap. Waste in trenches will be characterized using a statistical ample of Y.12 Plant records that ocacribes masses of wasten delivered to the Burial Grounds.

\subsection{BCV OU I PROJECT OBJECTIVES}

The overall RIFS goal for BCV OU 1 is to select cost-effective remediation alternatives that are protective of human health and the environment, that maintain proteciton over time, and that minimize the volume of untreated waste generated. The objective of the RI is to provide aufficient information to ascess the risks to human health and the environment and to support the development, evaluntion, and selection of appropriate reaponse alternatives. To resolve these problems and to meet the project objectives, the following queations need to be posed concerning the environment and contamination at the $O U$ :

- What are the volume and nature of waste materials at the various sites?

- What are the curtent nature and extent of soil contsmination at cach site? 
- What are the expected nature and extent of soil contamination at each site in the future?

- What are the contaminants of concern (COCs) within the site boundaries?

- Which sites contain contaminants in forms and concentrations that adversely affect human receptor and exceed health-based criteria or ARARs?

- Which sites act as contaminant sources that contribute unacceptable levels of contaminants to the integrator OU (via groundwater or surface wates)?

- What are the present and polential future pathways of contaminant migration away from each waste site?

A staged approach to the RI work plan was oullined in Sect. 1.4. Each stage of the RI has different objectives; however, an objective of the work plan is to ensure that data acquired during each stage of the RI is comprehensive and that no repetition of sampling of any media at any location is required as a result of changing objectives. The objective of each sample detalled in the sampling plan is 10 provide sufficient information to support the final remediation of the site.

The following objectives will be inet in order to asses the risks contributed by this OU to the overall risk to human health and the environment in BCV and to allow a ROD to be insued:

- To determine if the wastes pose an on-site risk to human health and the environment at the present time.

- To determine if the wates will pose an on-site riak to human health and the environment in the future.

- To determine if the wastes pose an off-site riak to human health and the environment at the present time.

- To determine if the wastes will pose an off-site risk to human health and the environment in the fulure.

- To determine if the wastes and/or waste derivatives are in compliance with ARARs.

- To support the screening of appropriate alternatives during the remedy selection and provide technically and legally defensible data on which to base credible decisions regarding risk levels and cleanup alternatives.

- To provide duts input to the valley-wide baseline risk ascament.

\section{DATA QUALTY OBJECTIVES}

Data quality objectives (DQOs) have heen developed to meet the project objectives outlined in Sect. 1.7. The DOO development process for BCV OU 1 is outlined in Fig. 1.4; the relationship between the DOOs and the overall work plan is shown in Fig. 1.5. Table 1.2 details the regulatory driven that are applicable to BCV OU I under CERCLA and the subsequent project objectives, DOO, data uses, and data needs that are derived from interpretation of the regulatory drivers. 
State the Problem to be Resolved

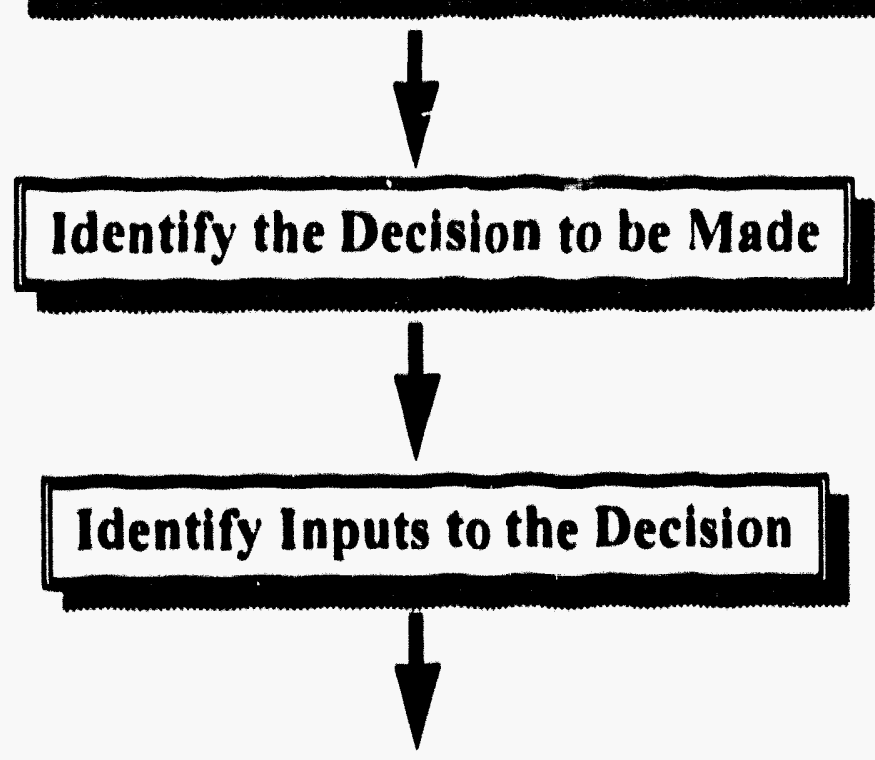

Define the Study Boundaries

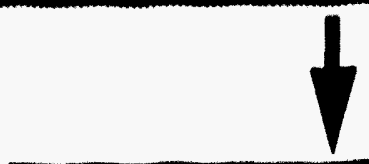

Develop the Decision Rule

Specify Limits on

Uncertainty

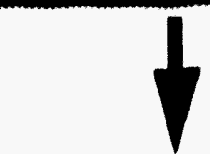

Optimize Design for Obtaining Data

Fig. 1.4. The DQO development process. 


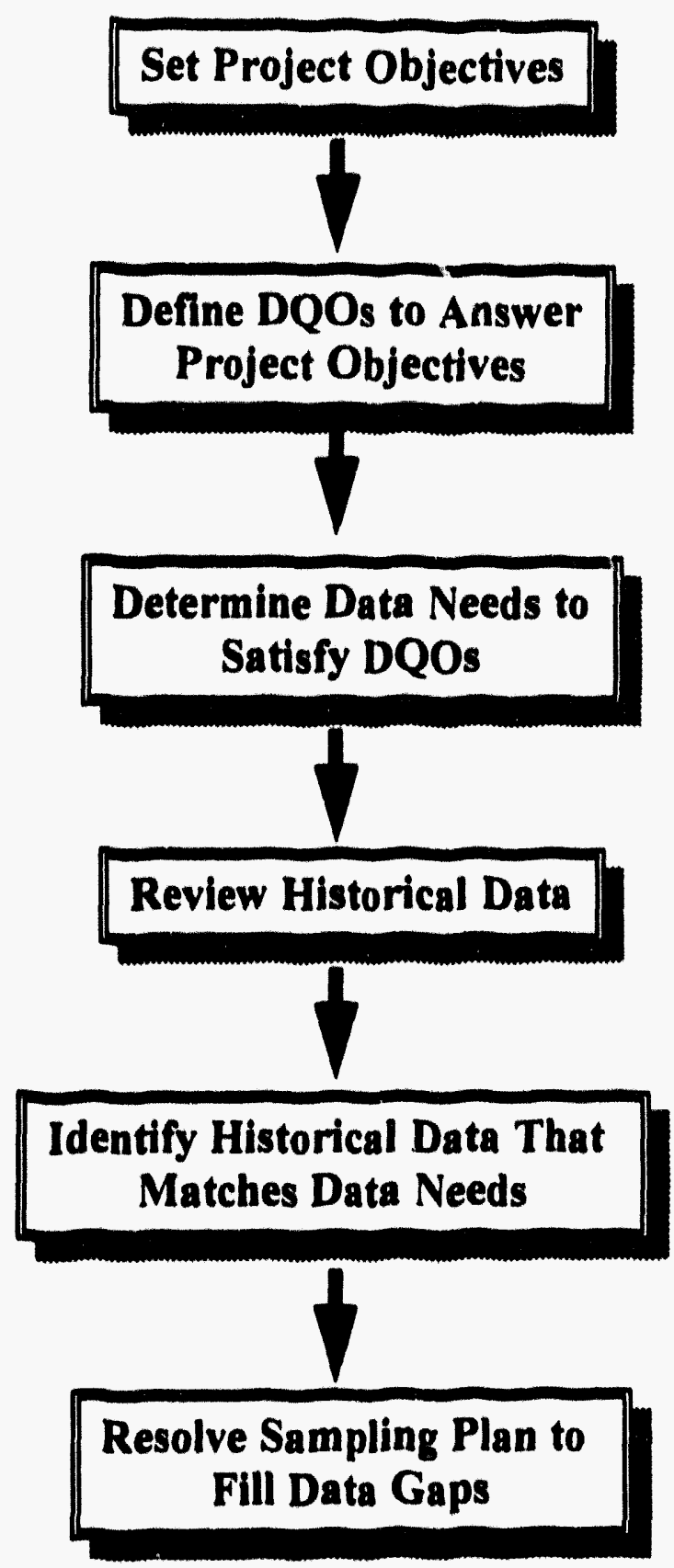

Flg. 1.5. The relationshlp between DQOs and the overall work plan for BCV OU 1. 
Table 1.2 Regublory drivers, project objectives, DOOS, dnta wes, and data nooks for BCV OU 1

\begin{tabular}{|c|c|c|c|c|}
\hline \multirow{2}{*}{ 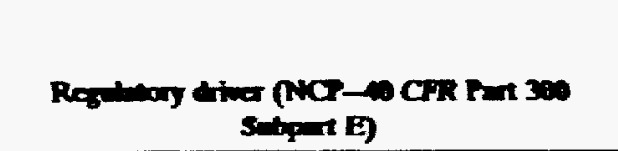 } & \multirow[b]{2}{*}{ rroject aljectios } & \multirow{2}{*}{ Obection pond } & \multicolumn{2}{|c|}{ 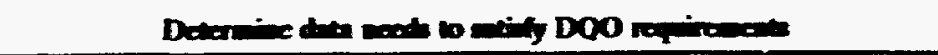 } \\
\hline & & & Dus $=$ & Donesecots \\
\hline \multirow{5}{*}{ 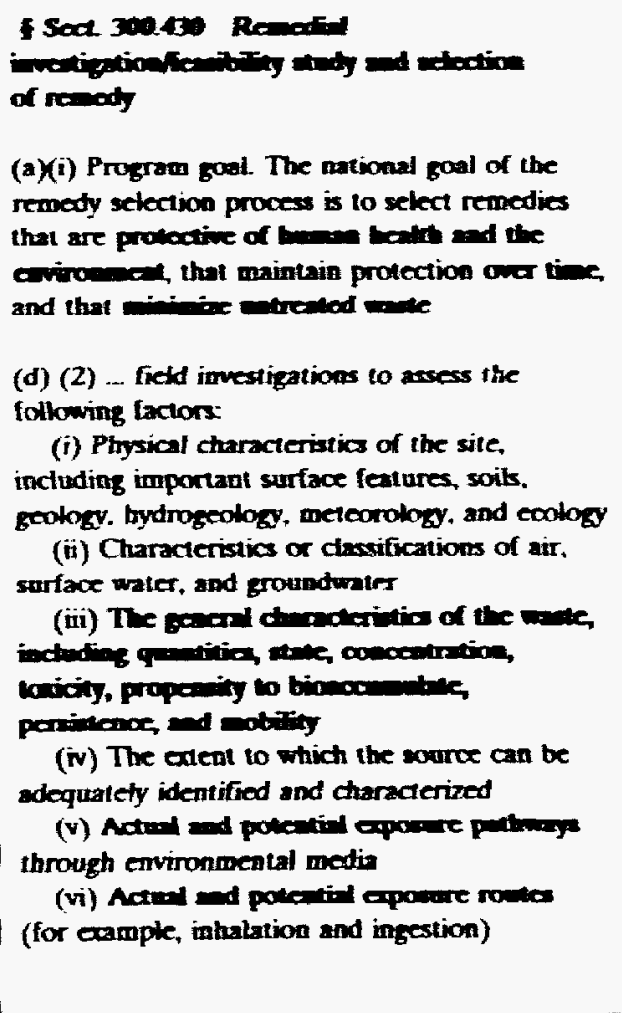 } & \multirow[t]{5}{*}{$\begin{array}{l}\text { Determine if the } \\
\text { waste unit powes an } \\
\text { unsoceptable risk } \\
\text { to humon heath } \\
\text { and the eavironment }\end{array}$} & $\begin{array}{l}\text { Do watos contribute } \\
\text { lo cintex on-site } \\
\text { morter rist? }\end{array}$ & $\begin{array}{l}\text { Evaluale curreat morker exposure } \\
\text { pathways/ristc inhatation. } \\
\text { radiation, derand contact. } \\
\text { incidental ingestion }\end{array}$ & $\begin{array}{l}\text { Current air concentrations, } \\
\text { contamimant concentrations in soil } \\
\text { and waste, opoevere rato }\end{array}$ \\
\hline & & $\begin{array}{l}\text { Does groundwater } \\
\text { of surface witer } \\
\text { of the source erceed } \\
\text { ARARs? }\end{array}$ & $\begin{array}{l}\text { Evaluste source contritution } \\
\text { to curtent of -site migration } \\
\text { and off site oppourre pathways: } \\
\text { exposure to groundwater } \\
\text { or surface water }\end{array}$ & $\begin{array}{l}\text { Groundwater and surface water } \\
\text { concentrations in current leactaic } \\
\text { from waste unit; water ARARs } \\
\text { at point that source feats integrator } \\
\text { OU }\end{array}$ \\
\hline & & $\begin{array}{l}\text { Do wastes contribute } \\
\text { to on-site or off-site } \\
\text { coological risks? }\end{array}$ & 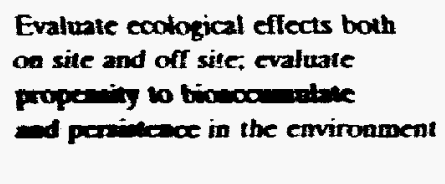 & $\begin{array}{l}\text { Concentrations in soit; concentrations } \\
\text { in vegetation; terrestrial species- } \\
\text { population surveyfody burden; water } \\
\text { ARARs al point where source leceds } \\
\text { integration OU }\end{array}$ \\
\hline & & $\begin{array}{l}\text { Will wastes contribute } \\
\text { to futere on-aite rist? }\end{array}$ & 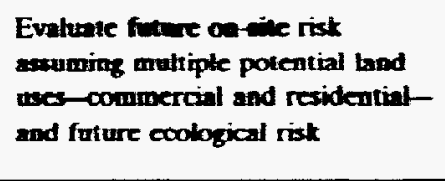 & $\begin{array}{l}\text { Contaminant waste concentrations; } \\
\text { future mase flex (contaminamt } \\
\text { volumed, contaminant leachate } \\
\text { concentrations) }\end{array}$ \\
\hline & & $\begin{array}{l}\text { Is it likety that } \\
\text { groundwater } \\
\text { or surface water } \\
\text { at the source will } \\
\text { croced ARARs in the } \\
\text { future? }\end{array}$ & $\begin{array}{l}\text { Evaluate potential future } \\
\text { grountwaler/surfmce water hux } \\
\text { and rist off site }\end{array}$ & $\begin{array}{l}\text { Contaminant maste concentrations, } \\
\text { contaminant concentrations } \\
\text { in kactate. ARARs at porint that } \\
\text { source feeds integrator OU; nature } \\
\text { of containment }\end{array}$ \\
\hline 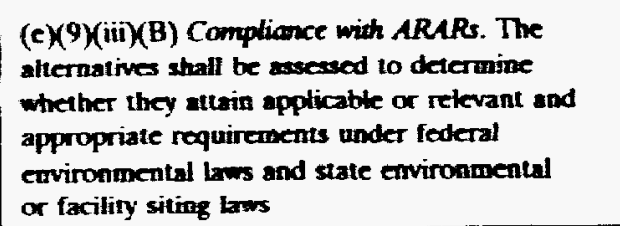 & $\begin{array}{l}\text { Determine if the } \\
\text { remediation } \\
\text { atternatives are } \\
\text { in compliance } \\
\text { with ARARs }\end{array}$ & $\begin{array}{l}\text { Are contaminast } \\
\text { conoentrations greater } \\
\text { than regulatory } \\
\text { leveb? }\end{array}$ & $\begin{array}{l}\text { Compere contaminant } \\
\text { concentrations to ARARs }\end{array}$ & $\begin{array}{l}\text { Contaminant concentrations-in waste } \\
\text { unit, surrounding environment. } \\
\text { and keachate }\end{array}$ \\
\hline
\end{tabular}




\subsubsection{Statement of the Problem}

Six sites at three discrete areas in BCV have been included in BCV OU 1 to be evaluated as contaminant source OUs. The site name, unit number, and unit status for each site in BCV OU 1 are presented in Table 1.3. Chapters 2 and 3 present detailed descriptions of each site. A brief sescription of each site follows:

S-3 Ponds. The S-3 Ponds were constructed in 1951 and consisted of four unlined surface impoundments covering a total area of -1.5 ha $(3.7$ acres) with a storage capacity of 38 million L (10 million gal). During operation, up to $21,000 \mathrm{~L} / \mathrm{d}(5500 \mathrm{gal} / \mathrm{d})$ of eflluent was pumped to the pond via a pipeline from the Y-12 Plant. The S-3 Site underwent RCRA closure between 1988 and 1990, with TDEC accepting final closure on November 15, 190. The site was paved to create a parking lot. Primary contaminants are nitrate, uranium, metals. and organic solvents.

Oil Landfarm. The Oil Landfarm was used from 1973 to 1982 for the land application of waste oils and coolants that contained beryllium compounds, depleted uranium. polychlorinated biphenyls (PCBs), and chlorinated hydrocarbons. Final RCRA closure of the site was accepted by TDEC on November 15, 1990.

Boneyard/Burnyard. The Boneyard/Burnyard consists of -3.2 ha (8 acres) used from 194.3 to 1970 as a disposal site for waste from the Y.12 Plant. Burning and disposal of debris and sanitary, metallic, chemical, and radioactive wastes are known to have occurred. The site hus been abandoned and is predominantly a gravel area with grasay vegetation. The southeastern portion of this site is overlain by the HCDA. The HCDA covers $\sim 0.8$ ha (2 acres) and was used to burn or neutralize liquid and gaseous wastes from 1975 until 1981. The HCDA is covered with a RCRA-type cap, and the linal closure was accepted by TDEC in November 1990.

SL 1. SL 1 received various types of nonhazardous waste from the Y.12 Plant from 1968 to 1982. The site was graded, capped with clay, and closed in 1983 under a TDEC. approved closure plan according to TDEC rules and regulations for sanitary landinils.

Burial Grounda. The Burial Grounds are located on the southern slope of Pine Ridge $-3 \mathrm{~km}$ (2 miles) west of the Y-12 Plant with various portions operational from 1955 to 1993. They consist of a series of waste disposal units covering an area of -140 ha ( 350 acrea). Each waste disposal unit consists of a series of trenches excavated to between 4.3 and $7.6 \mathrm{~m}$ (14 and $25 \mathrm{ft}$ ) below grade. The trenches received a variety of hazardous and nonhazardous solid and liquid wastes from the Y.12 Plant. All hazardous waste disposal operations were discontinued in 1981, and all radiological waste disposal operations ceased by mid-1991. The last disposal to the Burial Grounds was sewage sludge from Oak Ridge disposed in Pit A.18 in 1993. All trenches known to have received RCRA hazardous material have been capped, or are in the process of being capped, as part of RCRA closure. The Burial Orounds include ORPs 1 and 2, the Walk-in Pits, and the Uranium Vaults, as well as BO.A (North and South), $-B,-C,-D,-E$, and $-J$. The ORPs were constructed to intercept seepage from the Burial Grounds trenches (-A North). Both ponds were capped and closed under RCRA in 1990. The Walk-in Pits were used to dispose of solid or drummed liquid wastes, including pyrophoric uranium and thorium saw fines and shock-sensitive chemicals. The Uranium Vauls have not been mentioned in previous environmental reports of the Burial Grounds, as they were only recently identified. A vide range of contaminants may have been disposed of in the 
Table 1.3. Remedial units of BCV OU 1

\begin{tabular}{|l|l|l|}
\hline \multicolumn{1}{|c|}{ Remedial unit } & \multicolumn{1}{|c|}{ Unit no. } & \multicolumn{1}{c|}{ Status } \\
\hline S-3 Ponds & T-004 & $\begin{array}{l}\text { Closed under RCRA in 1988; } \\
\text { TDEC accepted 11/90 }\end{array}$ \\
\hline ORPs 1 and 2 & T-008, T-009 & $\begin{array}{l}\text { Closed under RCRA in 1990; } \\
\text { TDEC accepted 12/90 }\end{array}$ \\
\hline OIl Landfarm & T-014 & $\begin{array}{l}\text { Closed under RCRA in 1990; } \\
\text { TDEC accepted 11/90 }\end{array}$ \\
\hline Burial Grounds & D-024 & $\begin{array}{l}\text { BG-A (North and South) } \\
\text { ciosed under RCRA; TDEC } \\
\text { accepted 12/90. WIPs } \\
\text { currently undergoing closure. } \\
\text { Other sites not RCRA }\end{array}$ \\
\hline SL 1 & Closed in 1983 \\
\hline HCDA & D-101 & $\begin{array}{l}\text { Closed under RCRA; TDEC } \\
\text { accepted 11/90 }\end{array}$ \\
\hline Boneyard/Burnyard & D-024-HC & Not a RCRA site \\
\hline
\end{tabular}


Burial Grounds, and a sample of Y-12 Plant records has been used to characterize the volumes and masses of the various waste components.

The problem that needs to be resolved for BCV OU 1 is essentially a two-phase question. First, do the wastes and soil contamination associated with each site pose a risk to human health or the environment at this time or are these sites likely to pose a risk in the future? And second, if any of these sites do pose a risk now or in the future, what are the most feasible alternatives for reducing this risk to acceptable levels?

A conceptual model (Sect. 3.9) has been created to assist in the development of the DQOs. This model identifies COCs from historical site data, probable migration pathways, and potentially exposed receptors. Based on this model, environmental data needs have been proposed to characterize the site. Historical data have been reviewed to determine where data are available that can be used in the RI. Data gaps have thus been identified and the sampling plan adjusted to meet the data needs.

General data that will be required to answer the problems outlined in Table 1.2 include: (1) the physical characteristics of the site, including surface features, soils, geology, hydrogeology, meteorology, and ecology; (2) the physical distribution of contaminants in the soil, vadose zone, groundwater, surface water, and vegetation at each site; (3) the chemical and physical nature of the various contaminants; and (4) the mobility that can be expected for each contaminant. A complete description of the data needs is given in Chap. 6.

Potential exposure routes are direct contact with contaminated soils (by ingestion and dermal contact), inhalation of particulates or volatiles, external exposure to radionuclides, and contact with contaminated groundwater or surface water (by inhalation, ingestion, and dermal contact).

Sampling of wastes constitutes a health risk to the RI contractor and site workers; sampling of waste materials and contaminated soils needs to be conducted in a manner that will not expose workers to unacceptable risks or increase the net risk to human health and the environment. Waste sampling need not be considered where the risk to site workers is determined to be unacceptable.

\subsection{Decisions To Be Made}

From a scrutiny of earlier investigations, the BCV OU 1 sites have been identified as having contamination within their boundaries that might adversely affect human health or contribute unacceptable levels of contaminants to the integrator OU. The ultimate decisions for each site, then, are whether or not the site must be remediated and what might be the most effective remedial action. The decision to remediate will be based on the results of the risk assessment, and the amount and type of remediation will be based on the nine criteria of CERCLA and compliance with NEPA and NRDA requirements, which are grouped into four categories: Threshold Criteria, Primary Balancing Criteria, Modifying Criteria, and Regulatory Criteria. The 11 criteria within these categories are as follows:

\section{- Threshold Criteria}

- Overall protection of human health and the environment

- Compliance with ARARs 
- Primary Balancing Criteria

- Long-term effectiveness and performance

- Reduction of toxicity, mobility, or volume through treatment

- Short-term effectiveness

- Implementability

- Cost

- Modifying Criteria

- State acceptance

- Community acceptance

- Regulatory Criteria

- Compliance with NEPA requirements

- Compliance with NRDA requirements

Within the staged approach for the BCV OU 1 work plan described in Sect. 1.5, the initial decision that is made is whether to carry out a removal action and continue the RI; whether to continue the RI with no removal action; or whether to document a no-furtherinvestigation (NFI) required. This decision is based on a preliminary hazard evaluation of each site, which evaluates short-term human health and ecological hazards (before initiating remedial actions). If the RI/FS process is continued, the next decision that is made involves what form of remedial action is required at this site to obtain a ROD for interim measures that will reduce risks to acceptable levels and isolate the source of contamination from groundwater and surface water. The final decision that is made involves what additional actions are required to gain the final $R O D$ and is based on input from the baseline risk assessment carried out in the integrator OU RI/FS.

\section{8 .3 Inputs to the Decision}

Inputs to a decision should be derived from two broad areas: data users and data uses.

\subsubsection{Data users}

An RI conducted under CERCLA is designed to characterize the site environment and the nature and extent of contamination by using historical data to the fullest extent and by acquiring new data through field sampling operations. The data obtained by the RI should allow the subsequent participants of the process to accomplish their tasks. For instance, data on the contaminant concentrations permit the risk assessors to calculate the chronic toxicity and the risk of excess lifetime cancers under certain exposure assumptions. The same data allow the planners and engineers in the FS to screen remedial alternatives and make recommendations regarding cleanup options.

The following is a description of the data users for BCV OU 1 and their responsibilities:

- RI Contractor-solicits input and concurrence from the other participants for data needs and designs an investigation to obtain those data; evaluates the data and determines the nature and extent of contamination at each site as well as the potential risk to human and ecological receptors. 
- FS Contractor-uses the results of the RI to assess the magnitude of the cleanup task and screens the remedial alternatives in a systematic manner to make recommendations for the RODs.

- Integrating Contractor (Energy Systems ER Division)-organizes the overall approach to the RINFS and evaluates the results and conclusions to ensure uniformity with the FFA and regulators; coordinates the contractors for the RI, FS, Engineering Design, and Construction Management tasks.

- Lead Agency (DOE-ORO ER Division)-has primary responsibility for the success of the Environmental Restoration Program; initiates and oversees the entire process while closely coordinating input and approval from the other FFA participants.

- FFA Participants (DOE, EPA, and TDEC)-have concurrent approval authority on any recommendations or initiatives and have regulatory responsibilities to ensure public health and safety and to respond to public needs. DOE has lead agency oversight on the approach, schedule, and budget for the environmental programs.

- General Public and Public Interest Groups-participate in making policy decisions by providing input on basic considerations such as the definition of acceptable risk and what constitutes a worthwhile benefit.

\subsubsection{Data uses}

Data uses are defined as those data applications that allow the problems identified in Sect. 1.8.1 to be answered. Data will also be used to make the decisions outlined in Sect. 1.8.3. Table 1.2 outlines how the data uses fit in with the overall strategy of defining the DQOs. Specific data uses that will facilitate solving the problems and making the decisions are as follows:

- Evaluations of current on-site worker exposure pathways/risks (by industrial land use).

- Evaluations of source contribution to current off-site migration and off-site exposure pathways.

- Evaluations of future on-site risk assuming multiple potential land uses: commercial, residential, and recreational (hunters and fishermen).

- Evaluations of source contribution to potential future off-site migration and off-site exposure pathways.

- Evaluations of ecological effects: bioaccumulation, persistence, toxic and chronic effects, and populations.

- Comparisons of contaminant concentrations in on-site groundwater and surface water to ARARs, trending data over time.

\subsubsection{Boundaries of the Study}

The boundaries of the various sites for BCV OU 1 are defined by both the conceptual model (Sect. 3.9) and the geographic limits of the site.

Geographic boundaries are derived from knowledge of the site histories and previous field investigations that indicate the extent of contaminants in soils in the vicinity of a waste 
site. Contaminants that have migrated away from the waste sites and exist in foodplain soils of Bear Creek are not considered in BCV OU 1, but are included in BCV OU 4. Actual geographic boundaries for each waste site are outlined in Sect. 2.3. Where there is evidence of likely contamination outside the physical boundaries of a site that is the result of past operations at that site, the boundaries of the site will be extended to include contamination.

Conceptual boundaries for BCV OU 1 are those derived from the separation of source and integrator OUs in BCV. Where COCs exist in groundwater, their remediation is no longer within the scope of BCV OU 1, except where isolation of the source from groundwater is concerned. However, the nature and extent of contamination in groundwater and surface water will be addressed to define migration pathways for COCs to the integrator OU. Therefore, groundwater and surface water will also be characterized at each site to assess migration away from each site, in a manner consistent with the approach being taken for the groundwater OU.

\subsection{Decision Rule}

The decision rule to be followed for cleanup of the Y.12 Plant and its related source and integrator OUs is described in the Oak Ridge Reservation Site Management Plan for the Environmental Restoration Program (Energy Systems 1992a). In this decision-rule approach. the purpose is to provide for early remedial actions as information becomes available to support remedy selection while still facilitating a final remedy. The intent is to achieve control of contaminant sources that may be affecting the integrator OU and that constitute unacceptable risks via direct contact and exposure pathways. The ultimate intent is to determine if each source OU contributes to unacceptable risks at the site and in the integrator OU. The decision rule is incorporated in the facility OU strategy outlined in Fig. 1.1.

The decision-rule approach for use within the BCV OU 1 source OU is described in Sects. 1.4 and 1.5. The initial approach will lead to a recommendation of no further investigation, a removal action, or a continuation of the CERCLA process leading to a ROD for interim measures and eventually a ROD for final measures. Once the investigation is complete, an RI report will be issued that describes the results of the site characterization activities as well as the on-site risk assessment.

Following the RI, a limited number of alternatives will be developed in the FS for remediation of the site to ensure long-term protection of human health and the environment. An analysis of alternatives will then be performed using the 11 criteria established (Sect. 1.8.2). Based on the analysis of all alternatives studied in the FS and the evaluation of the alternatives against these criteria, DOE will recommend preferred alternatives for cleanup. After review and comment on the plan by the regulators and after those comments have been addressed and resolved, the plan will be made available for public comment. Initially, comments will be addressed and incorporated in a ROD for interim measures, followed by remedial design/remedial action for that interim action. Ultimately, the source OUs in Bear Creek Valley, together with the integrator OU, will develop a final valley-wide BRA to be able to issue a ROD for the whole valley. 


\section{8 .6 Uncertainty Constraints}

Two sets of data will be evaluated to make the final decisions for the various sites within BCV OU 1. The historical data from multiple past studies will be weighed for their reliability and usefulness and incurporated in a site-specific screening-level risk asseasment that will be used to make decisions in Stage 1 of the RI. Considerations that give weight to the usefulnes of historical data are the degree of documentation available both for sample collection and for laboratory analysis, the physical coverage of sampling over the site, and the spectrum of analytes determined in the laboratory analysis. The criteria for determining the usefulness and reliability of historical data are very site specific. The usefulness of data refen to whether the data can be used to meet project DOOs. In Chap. 6 of the work plan, the data requirements are outlined, and where historic data exists that can meet these requirements, the data are identified in the site action plan (Chap. 7). More recent studies (circa 1990), in general, support a broader range for uses of the data than did older sampling events. Uncertainty is usually inherent when using any historical data because of incomplete documentation of quality assurance (QA) procedures. Exact sampling locations and methods may not be well known, and documentation in the form of field logboxks may not be available for answering questions or supporting field decisions affecting sample integrity. Laboratory analyain may have been conducted under an unknown level of quality control (OC) and statement of work. thereby undermining confidence in precision, accuracy, and sensitivity levels.

The approach taken for BCV OU 1 is that if the preliminary hazard evaluation indicates that a problem exists or data gapa prevent a complete hazard evaluation. then an investigation will be conducted to fill data gaps and carry out validation of historical data for which $O A$ is lacking through confirmatory sampling. If the preliminary hazard evaluation deces not indicute that a problem exists. then the quality of the historical data will he evaluated in order to support an NFI, which may invelve sampling to verify these data. Where historical data are deemed to have insumicient OA controls, the sampling plan will propose additional samples to confirm values in this data set, allowing the data to be used in the Rl.

Any data derived from the sampling proposed in this work plan will be collected and documented in such a manner as to be lechnically and legally defensible. Specific methods (I) ensure defensibility are discussed in Chap. 8, the Quality Assurance Project Plan (OAPjP). Sampling designs will be set forth to determine the nature and extent of contamination and to characterize the distribution of the contaminants. Sampling will be performed according to Energy Systems Environmental Surveillance Procedures (ESPs) (Kimbrough at al. 1990), and, in general, laboratory methods will be performed according to the EPA.Contract Laboratory Program (CLP) statement of work (SOW) protocols. Sampling procedures will be documented with field loghxolss and chain-of-custody records. Each laboratory analysis will have a data package documenting the procedures followed for the analysis. Dexumentation at all stages of sampling and analysis will include details of procedures used to minimize cross: contamination and to confirm accuracy and precision. In cases where decisions do not require that specific contaminants be analyzed to the level of accuracy defined by the CL.P protocols. other more cost-effective analytical methods may be used. For example. NAA may be used for analysis of metals in soils where the quantification required by the DOOs is not below $100 \mathrm{ppm}$. 
Uncertaintics exist for both the historical and proponed new data sets. The primary uncertaintica are related to the physicochemical nature of the contamination and the iransport medium. The heterogeneity of the wasle and soll mediums, the lenchability of the waste materials, the mobility of apecific contaminants, interaction between contaminants, and the physical media (affecting fate and iranaport) will impart a degree of uncertainty to the reaulas. Two objectives will be moal affected. Firal, because of the heterngeneity of the waste and soils, precise characterization of the wastes and of woil contuminant concentrations is difficult. Field duplicates can eatimate the variance of the soil contaminants within apecified level of confidence. Second, the contribution of the contaminants from the wastes and the asil to the groundwater cannot be accurately catimated. Bench-acale leaching studies are inaccurate in duplicating the environmental conditions: gecochemical models cannot account for unknown/unquantified variables; and partitioning estimates based on concentrations observed in the soil and thoue obmerved in the groundwatef are highly inaccurate. The resulus of this inveatigation muat be considered in light of theac uncertaintica, and decisions must be made accordingly. Statistical methods will be used 10 calculate uncertainties resulting from media heterogeneity, and uncertaintias will be minimized, where poushle, by employing stutiatically besed sampling plans. A special subuet of uncertainty exisu for the analysis of Y.12 Plant records that has been carried out to characterize the wate materials in the Bear Creek Burial Orounds (Energy Syntems 1993a). Approximately 50,000) individual diapoanis to the Burial Grounds have been tabulated from the Y.12 Plant records. The disposal records cover three main types of dispesal practices: (1) blanket diaposals that account for aboul Iwo.thirds of the total waste in the Burial Grounds. (2) nonroutine hazardous dispowals that account for a small portion of the total wates, and (3) other disposals that account for about one-third of the total waste. Volumes of masues of wastea have heen determined using in order of completenose and usability of the datu, tha following sources:

- Y.12 Mainconance Dtraion Monthly Aetwity Reporta. These reports are available from January 1957 to the present (with roughly 1 monih misuing from the fllea per year).

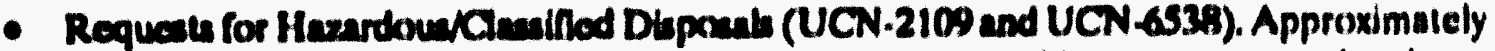
11,300 UCN-2109 and 1,6:X) UCN-6534, have been entered into a compuler dala hase.

- Karda Blanket Flea Approximately 600 cards with 27,(X00 entries from 1964-1981) covering waste dispoual under 170 blankeus have been anulyeed.

- Tanter Loe. These records cover -1,800) liquid dispxusuls on 25 different blankes between 1971 and 1980. Theac loge have been iranacribed into a computer dati base.

- Vehicle Trip Los. These log cover blanket, hazardous/clasaified, and other deliveries from 1960 to 1980. Most of the information in vehicle trip loge is already recorded in the previous files and records, and the logs themuclves are not standardized $w$ ) they are difricult 10 evaluate. For these reasons, roughy $8 \%$ of vehicle trip loge (covering 290 days) were sampled and examined to statistically extimate the total deliveries for this time period. This analysis has been verified by comparison to the ongoing SWIMS program.

- Wate Management Inventory-Manifoat Syatom. Since 1920, all disposal information has been placed on a computerized data base. Over 13,000 disposals to the Bear Creek Burial Grounds have been recorded by this system. Since 1980), disposal records are complete, and the quantitica and compositions of waste disposed of in the Burial Grounds since that time can be determined precisely. 
The quantity and composition of $-80 \%$ of the blankel diapouals mentioned in the Monihly Activity Reports have been iabulated. The blanket diapowals account for -iwo-thirde of the total wate in the Burial Orounds; thus. $33 \%$ of the waste materials in the Burial Orounds has been labulated using theac records. If is asumed that the wate documented by the $20 \%$ of blanket records that have not been tabulated are similar to those recorded in the 80\% of recorda that have been tahulated. Thefefore, through the wae of these blanket diapual recorda, the wastes in the Burial Grounda can be characterized.

The total number of UCN.2109 for hazardoua/claulfed diaposals mentioned in the Monihly Activily Reports corresponds clowely to the number of records iabulated, wo the records of inis type are ementially complete. The hazardous/clauified deliverics account for amall fraction of total deliverias to the Burial Orounda; however, the composition of many of these deliveriea is of greater potential interat.

For the ealimated one.third of all Bear Creek deliveriea that were neither harardous nor blanket. the Vehicle Trip Loge have been used to determine the quantity and makeup of the westes. For these muterials, a rundom sample of work day and a siatiatical analyats of the sample have been cartiod out and are detailed in the wate inventory report (Energy Syatems 1933). Uoin thit random sample, the volume and compowition of this remaining one-1hird of the wates have been determined with ranges at apecified levels of uncertainty.

In summary the exiluing analyath of the waste delivery records and document activiliea at the Burial Orounds provides an inventory of the wate muterials with a mesurable degree of uncertainty. This provides a better characterization of wate materials than can be obiained by sampling all irenches in the Burlal Orounds and with leas risk poued to RI penonnel (Enervy Syicems, 19a3, Partu 1-10).

\section{Dealp Opulatudioe}

The objective of the BCV OU I ampling design is to characterize the nature, extent, and distribution of contaminanis within the site in a siatiatically valid and legally defenable manner. A statbically based sampling dealgn is used during the RI because If allows the resulu to be extrapolated from the cel of samplea collected in BCV OU I to the entire site under investigution in a ceientifically and lechnically valid Cahion. This sampling dealgn will allow the RI inveatiguton to catimate contaminant concentrations means and aseociated confidence intervals to determine whether or not contaminant exceeds background level or proes riak to human health and the environment. In addition. II will provide the FS investigaton with an spproximation of medil effect above the levels of preliminary remediation goals and delineate areas to be screened during the actual cleanup operation. While providing thewe data, the sampling dealgn aluo minimizes worker health ritk, cost, and time by focusing on the most effective methods for satisfying the DOOA.

As is diecuesed in detall in Chap. 3, number of prowlous studies at the sltes in OU 1 hove shown that potential COCa currently exiat in the solla, sediments, surface water, and groundwater in the vicinity of BCV OU 1. Specilleally, PCB, uranium, and cadmiun contumination has been found in surface soils and sediments: nitrate, uranium, aluminum, and cadmium contamination hes been found in surface waten: and contaminant plumes of VOC and nitrate have been lound in groundwater samples. 
In order to determine the magnitude of the contamination and the relative localion of the contaminant aources (Irenches, pits, ponds) for these various contuminants, iwo-phased sampling dealgn ts proposed bused on the DQO previously diacused. During the fint phase of the RI Inveutigation, the nature and magnitude of contaminant concentrations will be determined in OU 1. During the second phase, the distribution and extent of the major COC (a identifed during Phase 1) will be determined.

\subsection{Pheve I eampling dealph}

A stratified und systemailc randoin sampling dealgn hes been used during Phase 1 of the RI. As will be diacuesed in Chap. 7, BCV OU I is divided into a number of different sirute (wate arew): the S.3 Slte, the Oil Landform, the Boneyard/Bumyard, and the varioun wate areas (Irench grouping) within the Bear Creek Burial Orounds. The Phase I sampling locations at the S.3 Site will be selected uaing data from an initial radiological and geophyalcal survey of the areas downgradient of the alte. Sampling at the Sanitary Landrill I will be IImited to one exploratory boring and groundwater well since it is poesible that no hazardous muterlal exiats at this slte. Within each of the remaining BCV OU I strata, number (30-50 depending upon the size of the site) of potential sampling points have been selected that are localed immediately downgradient from each of the wale areas (or capped area) diacuased in Chap. 7. A systematic random sample will then be selected for each area with the number of amples selected beling proportional to the relative size of uach area.

The following example should help to explain the proposed sampling dealen for Phase 1 of the RI. For Sample Area 2 in the Bear Creek Burial Orounds (Fig. 7.8 in Chap. 7 of inis work plan), a eample specing of 250-275 $n$ hes been selected. Potential sampling points are located immediately downyradient from the entire wate area (trenches A-8 to A.15) located on a iramect parallel to the slie boundarles. This iransect b $1,300 \mathrm{n}$ long and ts divided into 52 twenty-five-fool cegments with 53 potential sampling points at the nodes. A single starting location batween 1 and 11 (one. Ifrth of 53 potential ampling points rounded to the next integer) has been colected at random, and four additional campling points are aytematically locuted every eloventh sumple location. The randomly selected atarting point bs seven and a sample will be collected at locations 7, 18, 29, 40, and 51. This style of sumple location is carried out for all areas of the Burial Orounds (with the exception of Burial Oround B and the WTP) and for the Oil Landfarm. All sample locations are -250-275 II apart along the tranects shown in Fig. 7.3 and 7.6-7.12 in Chap. 7.

Arter the amples for the Phase I RI have been collected and analyzed, Iive.part decision rule will be employed, using the EPA's Rlsk Assessment Guidance for Superfund. Vol. l: Human Heallh Evaluation Manual, Part A (EPA 19:99d) to determine whother the concentration in the samples collected in BCV OU I exceeds eatublished detection limits. backeround conceniration (if known), established action levels, or preliminary remediation goals. Specifically, potential COCs will be considered for further evaluation if any one of the Collowing appliea:

- The analyte was positivaly detected in at least one sample.

- The analyte concentration was messured at lovels signiflcantly higher than naturally cecurring levels (background) of the same analyte.

- The analyte concentration exceeded eatabliahed action levels. 
- The analyte was identified hut the exaci concentration was unknown (i.e., J-qualified data) of was detected at levels significanily higher than the same chemicals detected in aucciated blank samples.

- The anulyte concentration wus higher than eatablished preliminary remediation goala.

A systematic process, following the decision rule just discuseed, will be used to narrow the list of potential COCa. All anaigtes that "fall out" as a result of applying the decision rule process will be declared COCa and will be further inveatigated during Phase 2 of the RI.

\subsection{Phere 2 sumpling douign}

The specific sumpling design to be used in Phase 2 of the RI will largely depend on the reaulus obtained in Phuse 1. A with Phase 1, atatistically baed ampling design will be ueod to characterize the distribution and extent of the specine COCs determined in Phase 1.

Since the list of contaminanta to be inveatigated in Phase 2 should be considerably smaller than the list of contaminanis analyzed in Phase 1. many more samples can be collected to characterize the extent of contamination. A series of rapid field screening tochniques that involve rapid sample collection and analyais techniques (including hydropunch sampling and field $\mathrm{OC}$ ) will be used to quickly identify locutions of potential contumination. The reaulu from these sumple collections and survey will be verified by subsequent analytical laboratory analyais for atatisically selected subsets of samples.

\subsection{SCHEDUL:}

The schedule for the BCV OU I RI is provided in Fig. 1.6.

\subsection{QUALTY ASSURANCE}

\subsubsection{Progrm Planning and Implementation}

The overall planning and implementation of OA and OC activities for the BCV OU 1 RI are deacribed in Chap. 8 and are governed by the Envinonmental Restoration Division Qualiny Assurance Program Plan, ES/ER/TM-4, Rov. 2 (Energy Systems 1992b), which incorporates the guidance in Imierim Guidelines and Specifications for Preparing Qualiny Assurance Project Plans, QAMS 005/20 (EPA 19906) and Enercy Syitems procedures; the American Society of Mochanical Engineen document Qualiny Assurance Program Requiremenus for Nucl-ar Facillites, NOA.I (ANSU/ASME 1986); and applicable DOE orders.

\subsection{Project Spodile Planning}

Project-specific OA planning is described in detall in Chapa. 7 and 8. AN OAMS 005/80 QNOC and ER Oublity Program Plan requirements are addreseed in this work plan. A project-specific kecator page is presented as Table 1.4 . 


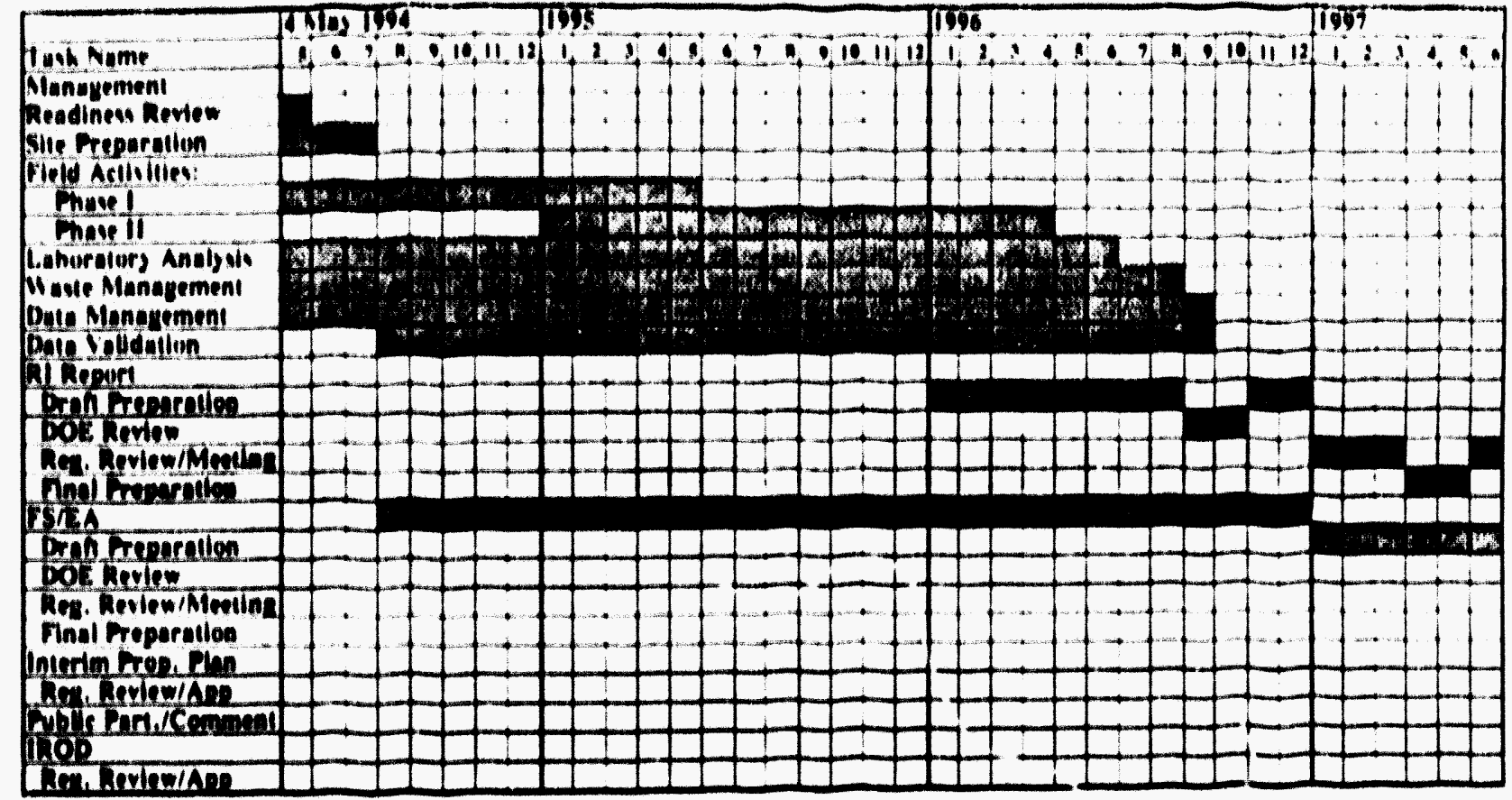

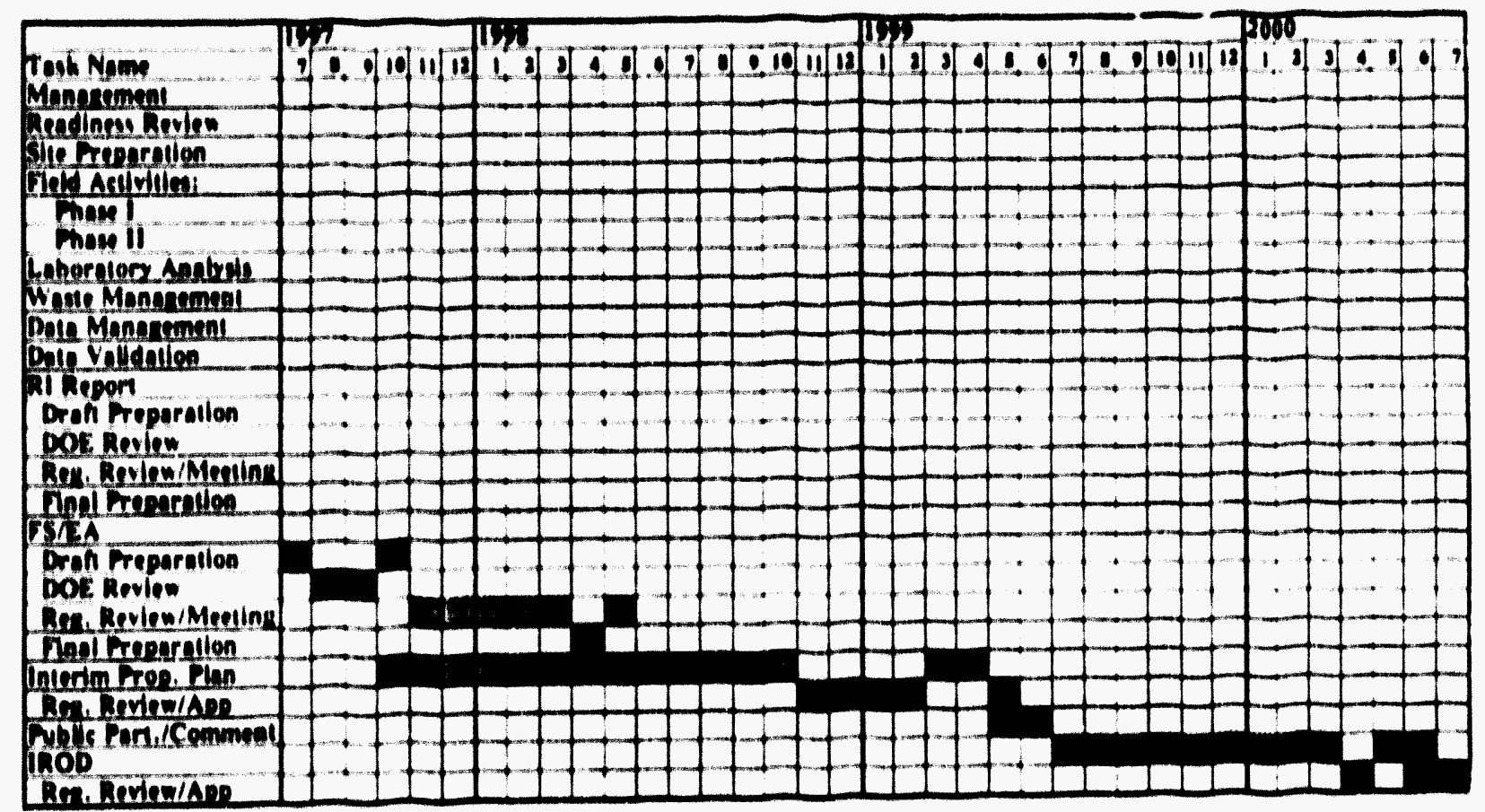

Fie 1.6. schedule for the BCV OU I RIFS through ROD. 
Thble 1.4. Cone reference of BPA QAMS 005/60 and BS/ER/TM-4/R2 clements with BCV OU 1 RI work plan sections

\begin{tabular}{|c|c|c|}
\hline EPA QAMS OOS/OO & BS/ER/M-4R2 doment & $\begin{array}{l}\text { Location in RI } \\
\text { work plen }\end{array}$ \\
\hline 1. Tille Page & $\begin{array}{l}\text { 4.1.2 QA Project Plan } \\
\text { Document Control }\end{array}$ & $\begin{array}{l}\text { Title Page; Chaps. } 8 \text {, } \\
9, \text { and } 10\end{array}$ \\
\hline 2. Table of Conients & $\begin{array}{l}\text { 4.1.2 QA Project Plan } \\
\text { Document Control }\end{array}$ & Contents \\
\hline 3. Project Description & 1.6.2.2.1 Project Description & Executive Summary \\
\hline $\begin{array}{l}\text { 4. Project Organization } \\
\text { and Responsibility }\end{array}$ & $\begin{array}{l}\text { 1.5 Organization and Program } \\
\text { Responsibilities }\end{array}$ & Sect. 7.2 \\
\hline 5. QA Objectives & $\begin{array}{l}\text { 6.1.1. QA Objectives } \\
\text { for Measurement Data }\end{array}$ & Sect. $1.8,8.1$ \\
\hline 6. Sampling Procedures & $\begin{array}{l}\text { 5.3.1 Sampling Procedures } \\
\text { 6.1.2 Sampling Procedures }\end{array}$ & Sect. 7.4.1, 8.2 \\
\hline 7. Sample Custody & 5.3.2 Sample Custody & Sect. 8.4 \\
\hline $\begin{array}{l}\text { 8. Callbration Procedures } \\
\text { and Frequency }\end{array}$ & $\begin{array}{l}5.4 \text { Control of Measuring } \\
\text { and Testing Equipment }\end{array}$ & Sect. 8.5 \\
\hline 9. Analytical Procedures & $\begin{array}{l}\text { S.3.3 Analytical Procedures } \\
\text { 6.1.6 Specific Routine } \\
\text { Procedures }\end{array}$ & Sect. 8.3 \\
\hline $\begin{array}{l}\text { 10. Daln Reduction, Validation, } \\
\text { and Reporting }\end{array}$ & 6.1.3 Analytical Procedures & Sect. 8.7 \\
\hline 11. Internal QC Checks & $\begin{array}{l}8.2 \text { Inspection, Testing, } \\
\text { and Operating Status }\end{array}$ & Sect. 8.8 \\
\hline $\begin{array}{l}\text { 12. Performance and System } \\
\text { Audits }\end{array}$ & $\begin{array}{l}9.3 \text { Field Audits } \\
\text { and Survelllances } \\
9.4 \text { Analytical Laboratory } \\
\text { Audits and Surveillances } \\
10.1 \text { Audits and Survelliances } \\
10.1 .3 \text { Field and Laboratory } \\
\text { Audits and Survelllances }\end{array}$ & Sect. 8.10 \\
\hline 13. Preventive Maintenance & $\begin{array}{l}5.4 \text { Control of Measuring } \\
\text { and Testing Equipment }\end{array}$ & Sect. 8.6 \\
\hline $\begin{array}{l}\text { 14. Specific Routine Procedures } \\
\text { Used to Assess Data } \\
\text { Prectsion, Accuracy, } \\
\text { Representativeness. } \\
\text { Completeness, and } \\
\text { Comparability }\end{array}$ & $\begin{array}{l}\text { 6.1.5 Internal Quality Control } \\
\text { Checks and Frequency }\end{array}$ & Sect. 8.9 \\
\hline
\end{tabular}


Table 1.4 (continuod)

\begin{tabular}{|l|l|l|}
\hline \multicolumn{1}{|c|}{ EPA QAMS 005/:0 } & \multicolumn{1}{|c|}{ BS/ER/TM-4/R2 clement } & \multicolumn{1}{|c|}{$\begin{array}{c}\text { Location in RI } \\
\text { work plan }\end{array}$} \\
\hline 15. Corrective Actions & $\begin{array}{l}3.2 \text { Control of Nonconforming } \\
\text { llems }\end{array}$ & Sect. 8.11 \\
\hline 16. OA Reports in Management & $\begin{array}{l}1.6 .2 .2 .2 \text { OA Reports } \\
\text { to Management } \\
\text { 3.2 Control of Nonconforming } \\
\text { liems }\end{array}$ & Sect. 8.12 \\
\hline
\end{tabular}




\section{HISTORY AND CURRENT CONDITIONS}

BCV OU 1 consists of the S.3 Site, the Boneyard/Burnyard, the Oil Landfarm, SL. 1, and the Burial Grounds source areas in BCV. This chapter summarizes the avallable information on the nature, quantity, and concentration of contaminants in each of the source areas (formerly identified as SWMUs) located in BCV OU 1. In the absence of direct evidence (measurements) of the contents of each source area, the nature and concentration of contaminants in receiving media (surface water, soil/sediment, groundwater) immediately adjacent to each source area will be summarized. The purpose is to identify those contaminants that may have been or may be released from each source area.

\section{GEOGRAPHIC INFORMATION}

The DOE ORR is located within the corporate limits of the city of Oak Ridge in eastern Tennessee, $-16 \mathrm{~km}$ (10 miles) southeast of the Cumberland Mountains and $11.3 \mathrm{~km}$ ( 70 miles) northwest of the Great Smoky Mountains. Figure 2.1 shows the city's location approximately 20 miles northwest of Knoxville, Tennessee, which is east of Nashville. Tennessec, and north of Allanta, Georgia, at the intersection of 1-40 and 1.75. The area is serviced by Interatates 40 and 75, which intersect in nearby Knoxville, Tennessee, east of Oak Ridge. The reservation, 14,300 ha $(35,300$ acres) of federally owned land, houses three facilities (the K-25 Site, ORNL, and the Y-12 Plant), which are managed for DOE by Martin Marietu Energy Systems, Inc. (Energy Systems).

The Y.12 Plant contains -324 ha ( 800 acres) and is located adjacent to the corporate center of the city of Oak Ridge. The plant occupies a valley between Chestnut Ridge, to the south, and Pine Ridge, to the north of the plant. The plant complex, built predominantly in the mid-1940s, is roughly divided into two portions; the western portion was previously devoted to DOE weapons-manufacturing activities, and the castern portion is devoted to ORNL research programs, general plant operations, and maintenance activities.

Extensive geographical information concerning the Y.12 Plant, its facilitics, and the surrounding area is given in Welch (1989). The Y.12 Plant is located in the Valley and Ridge Physiographic Province, which lies between the Cumberland Mountains to the northwest and the Great Smoky Mountains to the southeast. This province is characterized by roughly parallel, alternating ridges and valleys. The main facilities of the $Y \cdot 12$ Plant lie on the BCV floor, with auxiliary facilities located along Pine Ridge and Chestnut Ridge.

Bear Creek originates east of the former S.3 Ponds near the western margin of the Y-12 Plant. BCV OU 1 is located immediately west of the main Y.12 Plant facilities and extends $-3.2 \mathrm{~km}$ (2 miles) west down BCV along the north side of Bear Creek and Bear Creek Valley Road (Fig. 2.2). From east to west, the BCV OU 1 consists of the S.3 Site, the Oil Landfarm, the Boneyard/Burnyard, SL 1, and the Burial Grounds (Fig. 2.2).

The BCV OU 1 source areas are located within the upper portion of the Bear Creek watershed and several of the creek's tributaries flow through BCV OU 1. In this document, as in previous studies (Turner et al. 1991), monitoring and sampling sites are referred to by "creek kilometers." Sites are designated as "BCK." for "Bear Creek Kilometer," plus the kilometer value (e.g., BCK-12.36). As indicated in the footnote to Table 2.1, tributaries are 


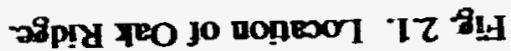

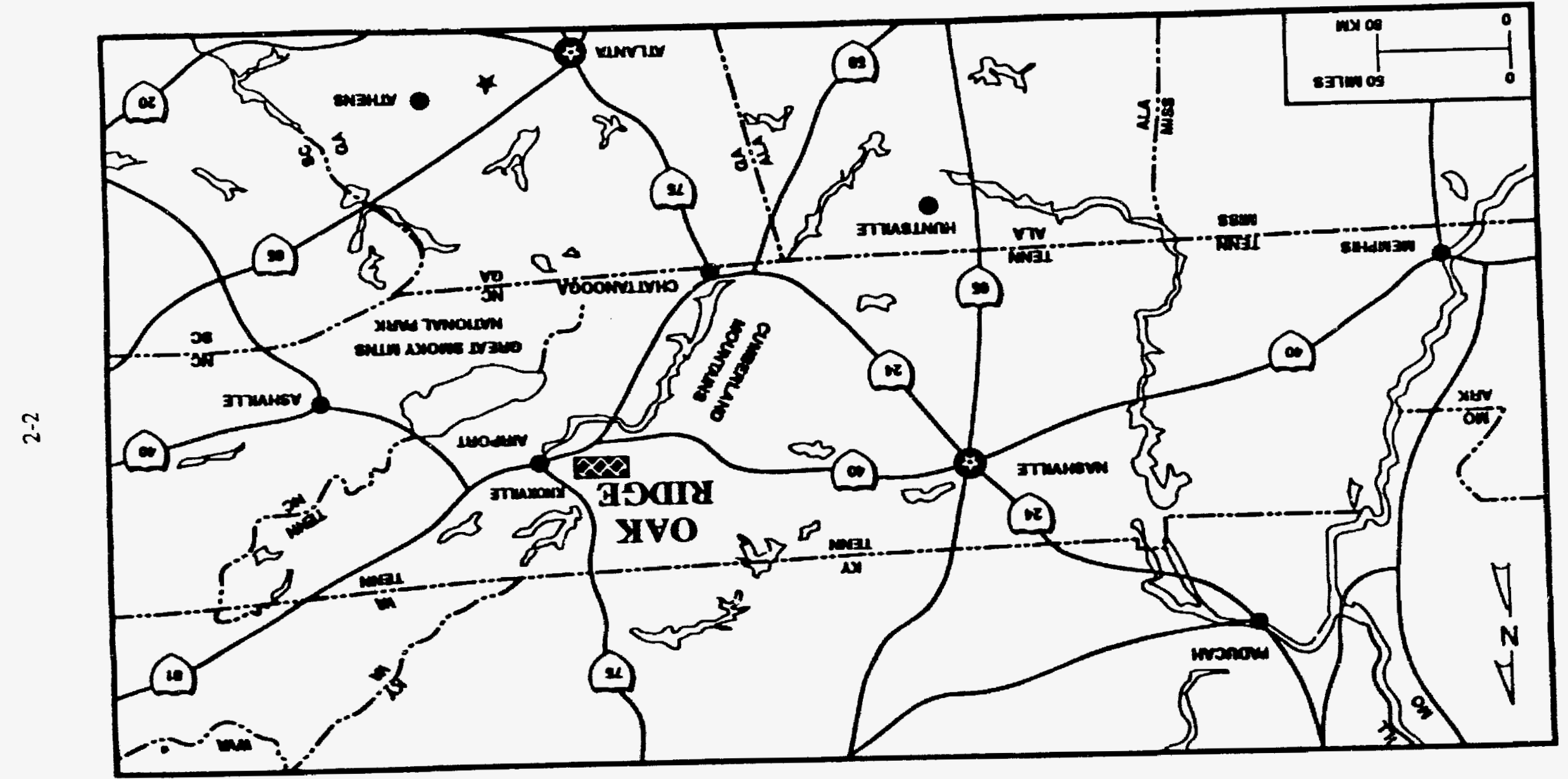




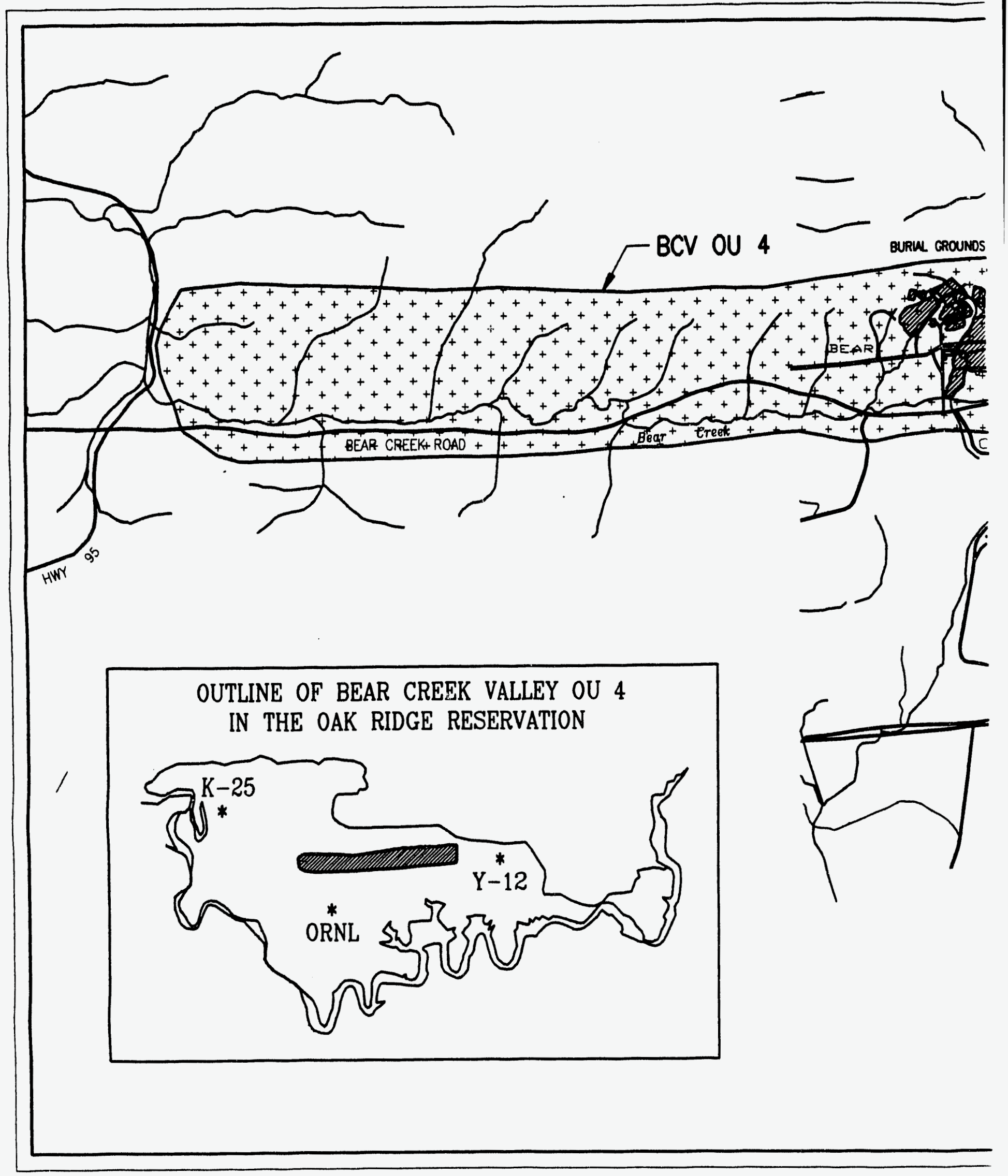

Fig 22. Location of BCV OU 1 in relat 


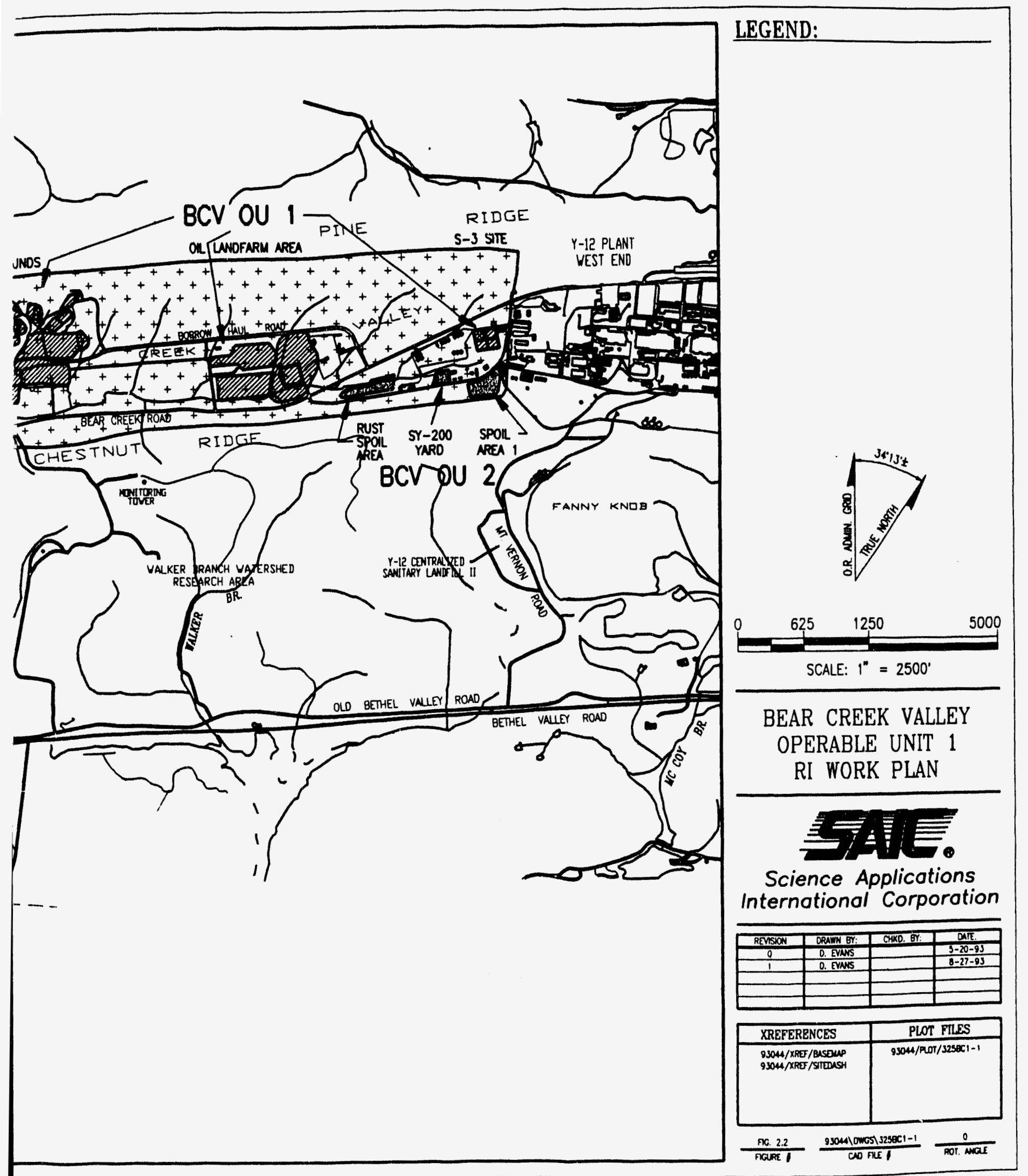

elativn to other OUs in Bear Creek. 
Table 21. Upper Bear Creek kilometer (mile) locations

\begin{tabular}{|c|c|c|}
\hline Kilometer & Mile & Landmark \\
\hline 12.87 & 8.00 & Headwaters near S-3 Ponds \\
\hline 12.46 & 7.74 & Road (gravel) crossing between "lagoons" \\
\hline 12.39 & 7.70 & Confluence with tributary NT-1 \\
\hline 12.38 & 7.69 & Confluence with spring SS-1 \\
\hline 11.97 & 7.44 & Bear Creek Road crossing \\
\hline 11.96 & 7.43 & Confluence with tributary NT-2 \\
\hline 11.84 & 7.36 & Road (gravel) crossing at east end of Oil Landfarm \\
\hline 11.68 & 7.26 & Confluence with spring SS-2 \\
\hline 11.67 & 7.25 & Confluence with spring SS-3 \\
\hline 11.59 & 7.20 & Confluence with tributary NT-3 \\
\hline 11.28 & 7.01 & Road (gravel) crossing at west end of Oil Landfarm \\
\hline 11.15 & 6.93 & Confluence with tributary NT-4 \\
\hline 10.94 & 6.80 & Confluence with tributary ST-1 \\
\hline 10.78 & 6.70 & Confluence with tributary NT-5 \\
\hline 10.40 & 6.46 & Confluence with tributary NT-6 \\
\hline 10.27 & 6.38 & Road (gravel) crossing at entrance to Burial Grounds \\
\hline 10.14 & 6.30 & Confluence with spring SS-4 \\
\hline 9.99 & 6.21 & Confluence with tributary NT-7 \\
\hline 9.98 & 6.20 & Road (gravel) crossing at west end of Burial Grounds \\
\hline 9.45 & 5.87 & Confluence with tributary NT-8 \\
\hline 9.42 & 5.86 & Road (asphalt) crossing (Bear Creek Rd) \\
\hline 9.41 & 5.85 & Confluence with spring SS-5 \\
\hline 9.06 & 5.63 & Confluence with tributary NT-9 \\
\hline 8.67 & 5.39 & Confluence with tributary NT-10 \\
\hline
\end{tabular}

oNaming convention: NT = northern tributary, ST = southern tributary, SS = south side spring. 
designated as NT, ST, WT, or ET plus a value representing the tributary number counting from the headwaters. BCV OU 1 is located between BCK 12.87 and BCK 9.41 and is transected by Tributaries NT-1 through NT-7 (Fig. 2.3). Table 2.1 lists creek landmarks referenced to kilometers or miles within the upper portion of Bear Creek. Thus, NT.4 is the fourth tributary originating on the north side of Bear Creek. Figure 2.3 shows some important locations on the upper section of Bear Creek using this site naming system.

\section{BACKOROUND INFORMATION}

The Oak Ridge Y-12 Plant was built by the U.S. Army Corps of Engineers in 1943 as part of the Manhattan Project. The original mission of the Plant was to separate the fissionable isotope of uranium $\left({ }^{235} U\right)$ using an electromagnetic separation process. After World War II, this process was discontinued in favor of a more economical gaseous diffusion process conducted at the nearby Oak Ridge K-25 Site (Welch 1989).

Since its inception, the Y.12 Plant has developed into a sophisticated manufacturing and developmental engineering facility. Current manufacturing activities at the Y.12 Plant include chemical processing of lithium and uranium compounds and precision fabrication of components from lithium, uranium, and many other materials. Metallurgical and machine shop operations are conducted at the plant to support these activities.

For the purpose of this RI work plan, the S-3 Ponds, Boneyard/Burnyard, Oil Landfarm, SL 1, and Burial Grounds are considered to be the primary contaminant sources in BCV OU 1 (Fig. 2.2). The source areas and the possible contaminant types associated with each are summarized in Table 2.2. The general contaminant types are based on a combination of operational information detailed in Sect. 2.3 and the results of site-specific sampling that are detailed in Sects. 3.4, 3.5, and 3.6.

\subsection{OPERATIONAL INFORMATION}

The following subsections contain descriptions of the wastes managed in each source area as well as information about their generation, disposal methods, and any subsequent treatment or cleanup activities at the source area. Where monitoring data have been obtained that are specific to a source area, those results are also included.

\subsection{S-3 Ponds}

The S-3 Ponds were located adjacent to the west end of the Y-12 Plant and were a part of the former S-3 Waste Management Area (Fig. 2.4). A chronological list of events at the S-3 Ponds is provided in Table 2.3. Constructed in 1951, these were four unlined impoundments covering an area of roughly $120 \times 120 \mathrm{~m}(400 \times 400 \mathrm{ft})$. The original pond excavations penetrated residual soil and fill materials but, based on the depth of bedrock in wells surrounding the site, did not extend down to the bedrock. Before closure in 1988, the ponds were $-5 \mathrm{~m}$ (17 ft) deep and contained variable amounts of sludge ranging from 0.6 to $1.5 \mathrm{~m}$ ( 2 to $5 \mathrm{ft}$ ) thick. The sludges were produced by the neutralization and in situ denitrification of wastewater in the ponds. While in operation, each pond had a storage capacity of 9.5 million L (2.5 million gal). The site of the S-3 Ponds was closed with a multilayered RCRA cap and covered with asphalt to create a parking lot. 


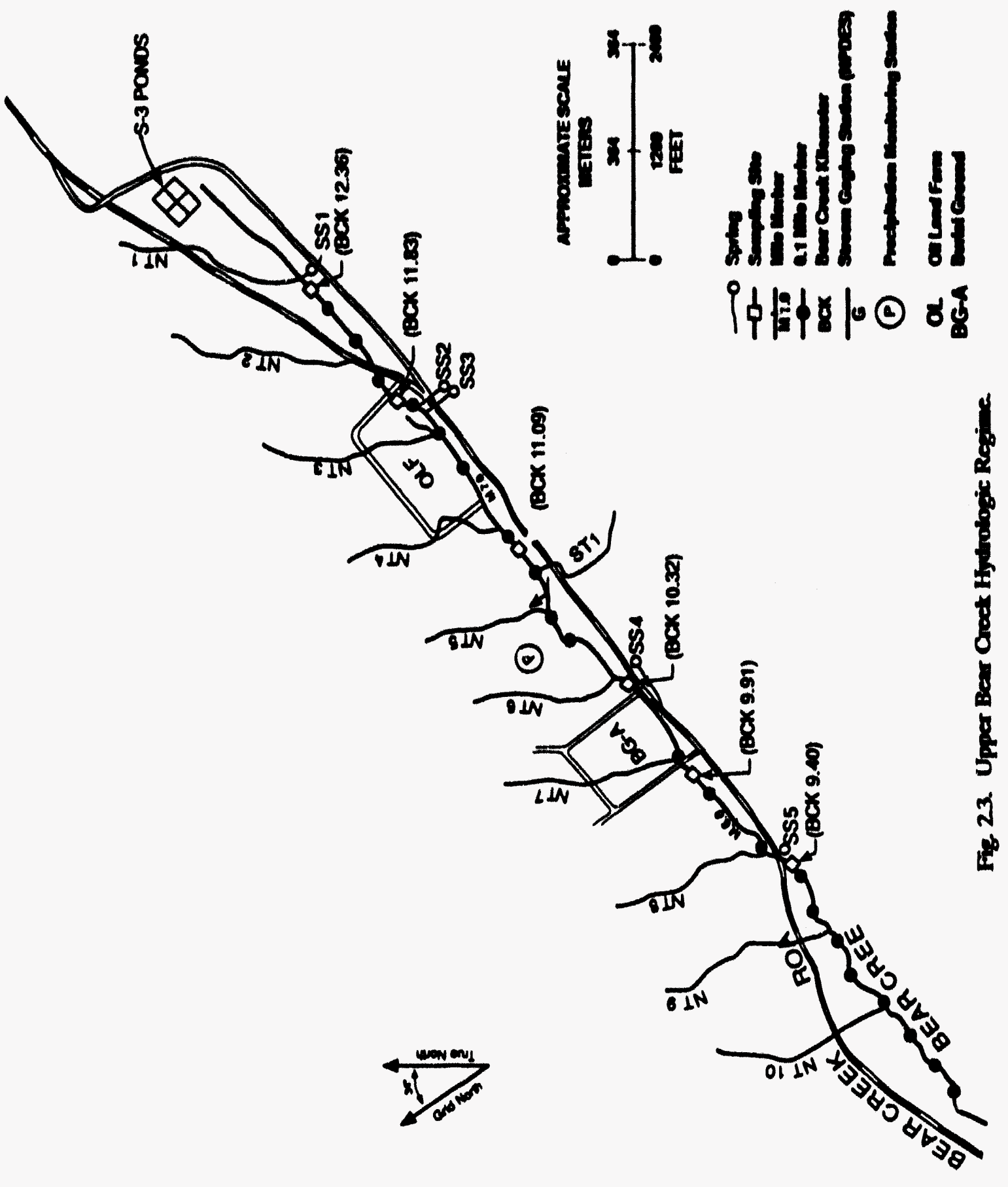

8
8
8
8
8
8
5
5
5
0
0

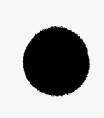


Table 22 summery of posible contaminant typen from BCV OU 1 sourse areen

\begin{tabular}{|c|c|}
\hline Source arean & Ponalbla conterminunte \\
\hline \multirow[t]{4}{*}{ S.3 Ponds } & Metalu-Ba, $\mathrm{Pb}, \mathrm{Cr}$ \\
\hline & Radionuclidea-U, Pu, Tc \\
\hline & Nitrate \\
\hline & voc \\
\hline \multirow[t]{4}{*}{ Boneyard/Burnyard } & Radionucliden-U \\
\hline & voc \\
\hline & Peaticides/PCB. \\
\hline & Other unknowns \\
\hline \multirow[t]{4}{*}{ Oll Landfarm } & Metalas $-\mathrm{Be}_{0} \mathrm{Cr}_{r}, \mathrm{As}_{3}, \mathrm{~Pb}, \mathrm{H}_{\mathrm{B}}$ \\
\hline & Radionuclidea $-U$ \\
\hline & VOC \\
\hline & PCBs \\
\hline SL 1 & Unknown \\
\hline \multirow[t]{4}{*}{ Burial Grounds } & Metals-Be, As, Cr, Pb \\
\hline & Radionuclides-U, Th \\
\hline & VOCs \\
\hline & PCBs \\
\hline
\end{tabular}




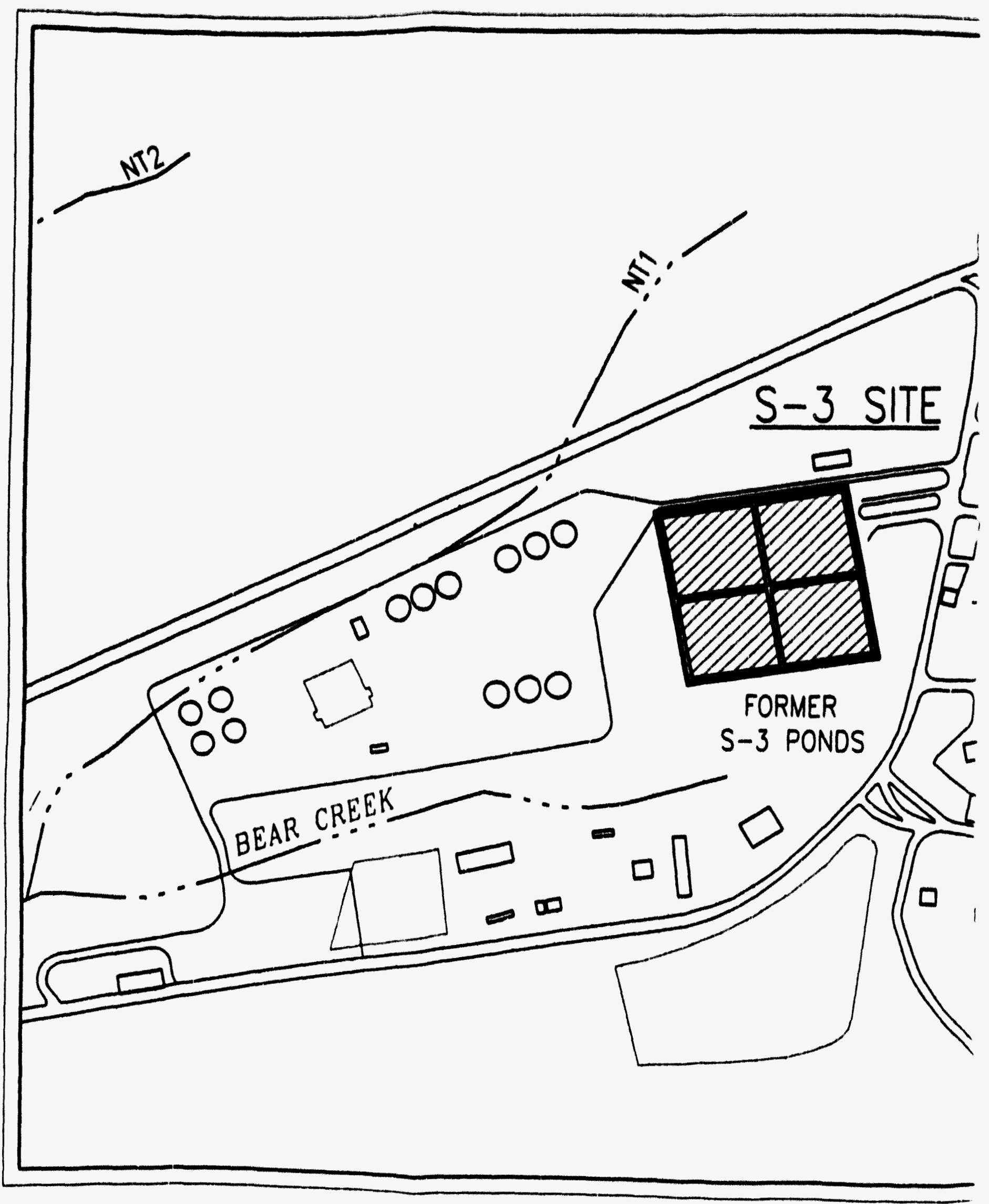

Fif. 24. Site map for the 
LEGEND:

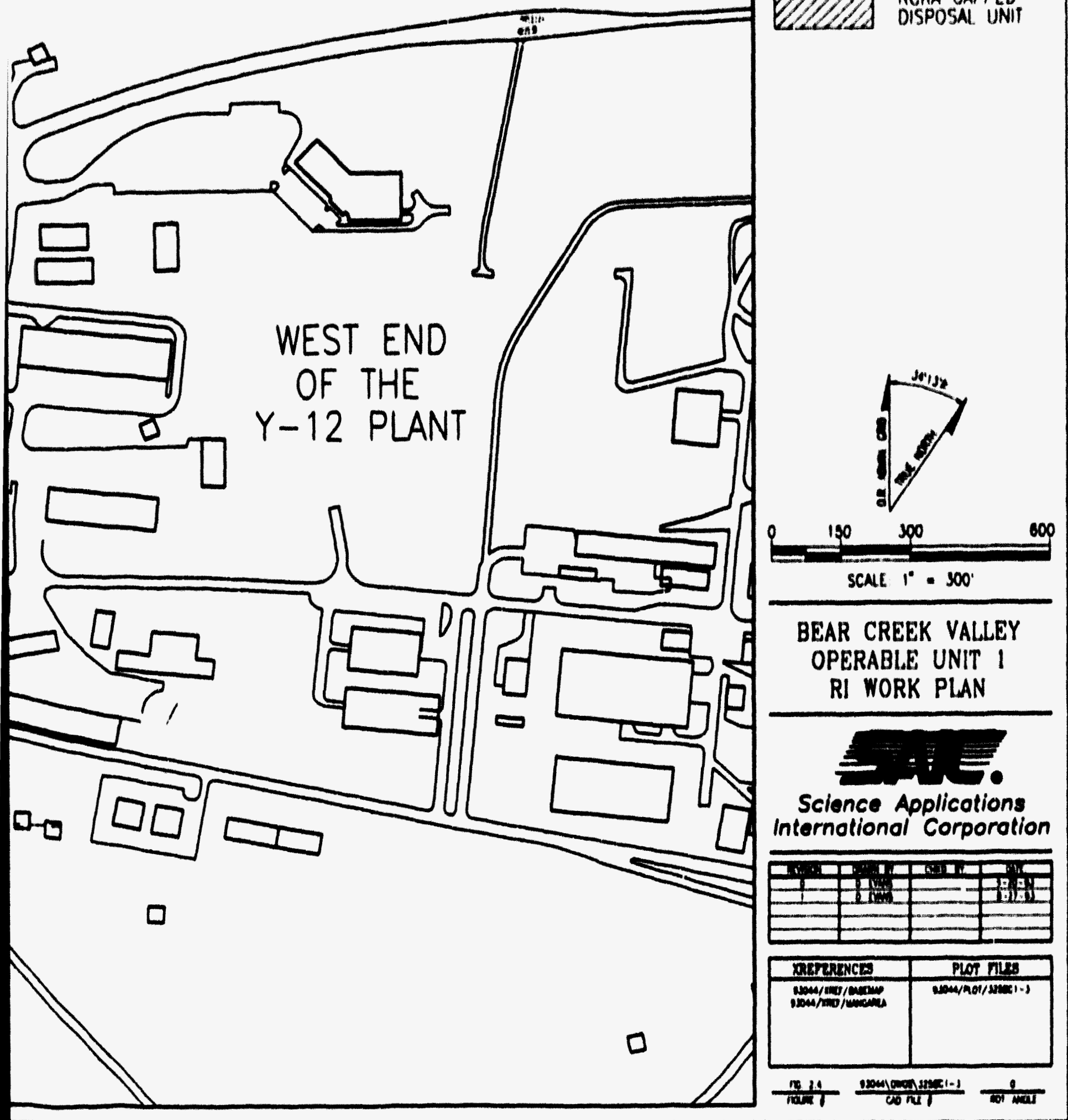

RCRA CAPPED

DISPOSAL UNIT

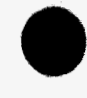




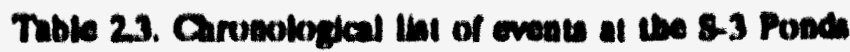

\begin{tabular}{|c|c|c|}
\hline Your & Bvent & Raterenos \\
\hline 1951 & $\begin{array}{l}\text { The } 5.3 \text { Ponds were consiructed. They } \\
\text { consisted of four unlined surface } \\
\text { impoundments with a loial slorage capacity } \\
\text { of } 38 \text { million } L \text { ( } 10 \text { million gal) }\end{array}$ & Enerdy Syitems $1992 c$ \\
\hline Mid.1950 & $\begin{array}{l}\text { Uranyl nitrate solutions containing small } \\
\text { amounts of plutonium were discharged } \\
\text { into ponds }\end{array}$ & \\
\hline $1951-1993$ & 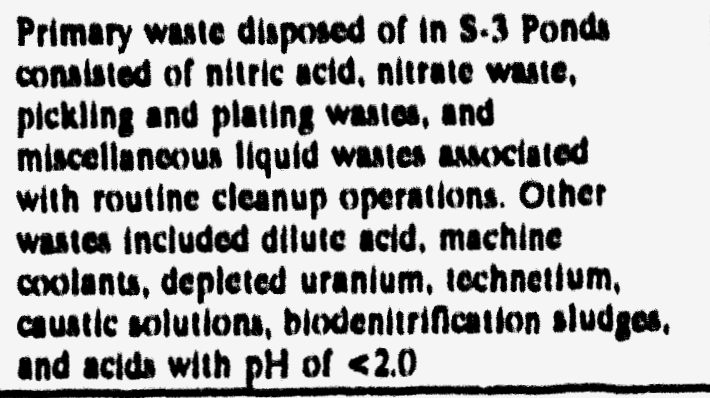 & \\
\hline 1976 & $\begin{array}{l}\text { The nliric acid recovery aystem } \\
\text { hocame operatlonal }\end{array}$ & \\
\hline 1963 & $\begin{array}{l}\text { Annual llquid waste entering the ponds was } \\
\text { reported io be }-10.3 \text { million } L \\
\text { (2.7 million gal) }\end{array}$ & \\
\hline 1963 & $\begin{array}{l}\text { The underground pipeline uned to iramport } \\
\text { waste to the S.3 Ponds wes plugeged and } \\
\text { abandoned }\end{array}$ & Enercy Systema 1987a \\
\hline March 1983 & $\begin{array}{l}\text { Nll weste discharges into the ponds were } \\
\text { terminuted }\end{array}$ & \\
\hline 1983 & $\begin{array}{l}\text { Characterizalion monitoring at the S.3 } \\
\text { Ponds began in reaponse to Memorandum } \\
\text { of Underiunding (MOU) signed by DOE, } \\
\text { EPA and TDEC }\end{array}$ & $\begin{array}{l}\text { Jeter } 1983 \text { and } \\
\text { Turner el al. } 1991\end{array}$ \\
\hline 1983 & $\begin{array}{l}\text { In silu treatment of wastewater in the ponds } \\
\text { began }\end{array}$ & \\
\hline May-November 1983 & Luquid in all four ponds was neutralized & \\
\hline $\begin{array}{l}\text { May } 1983 \\
\text { Seplember } 1984\end{array}$ & $\begin{array}{l}\text { Blodentritication of liqulds occurred. Nitrate } \\
\text { levelis in the pond water decteanod } \\
\text { in }-100 \mathrm{ppm}\end{array}$ & \\
\hline September 1984 & $\begin{array}{l}\text { In situ treutment of westowater was } \\
\text { completed. Nitrate levels were maintained } \\
\text { helow } 50 \mathrm{ppm}\end{array}$ & \\
\hline December 19:4 & $\begin{array}{l}\text { S.3 Ponds HWDU: was granted interim } \\
\text { status under TN Rule } 1200 \cdot 1 \cdot 11 \cdot .07(3)\end{array}$ & \\
\hline
\end{tabular}


Table L3 (continued)

\begin{tabular}{|c|c|c|}
\hline Yoar & Event & Reforences \\
\hline 1989 & 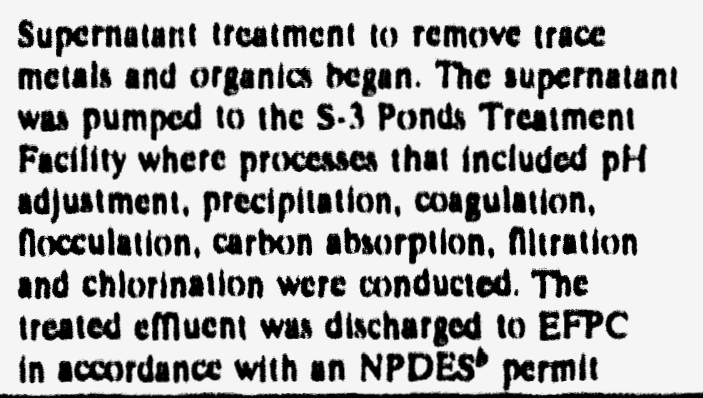 & \\
\hline January 19:6 & $\begin{array}{l}\text { Ascessment monituring was initiated at the } \\
\text { S.3 Ponds }\end{array}$ & \\
\hline Spring $19 \%$ & $\begin{array}{l}\text { Supernatant irouiment proceases were } \\
\text { completed }\end{array}$ & \\
\hline Murch 1987 & $\begin{array}{l}\text { The formalized Oroundwater Quality } \\
\text { Aseasment Plan for the slie was submilled } \\
\text { in TDEC }\end{array}$ & $\begin{array}{l}\text { Oeraghty and Miller } \\
1987\end{array}$ \\
\hline 1968 & 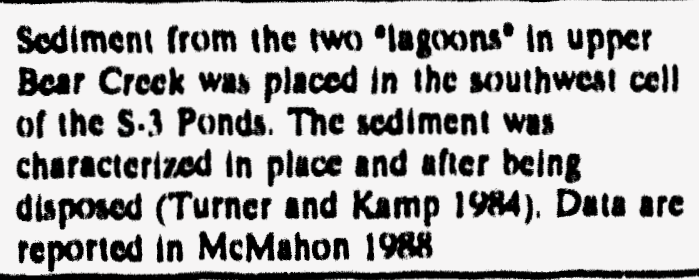 & EMD HSEAD 1988 \\
\hline Fobruary 1948 & RCRA Closure Plan was revised & EMD HSEAD 1948 \\
\hline 1928 & $\begin{array}{l}\text { The S.3 Ponds were closed with a mulli. } \\
\text { layered RCRA cap. Currenily, the slte is } \\
\text { covered with asphalt and used as a parking } \\
\text { lot }\end{array}$ & Stone 1990 \\
\hline November $15,(99)$ & $\begin{array}{l}\text { Final climure of the S.3 Ponds was accepled } \\
\text { by TDEC }\end{array}$ & \\
\hline September 30, 1991 & $\begin{array}{l}\text { TDEC issued a RCP.A posiclosure permit } \\
\text { lor the S.3 Ponds }\end{array}$ & \\
\hline
\end{tabular}

"HWDU = Hazardous Waste Disposal Unit.

-NPDES - National Pollutani Discharge Elimination System. 
Accurate records of the types and amounts of waste disposed of in the S-3 Ponds are not available. However, three different sources of waste (generally classified as toxic, corrosive, and radioactive) are known to have been disposed of in the S-3 Ponds. The three sources are (1) liquid wastes generated by Y.12 Plant operations and other facilities, (2) sludges generated from the in situ neutralization and biodenitrification of the pond waters and sludges generated from the treatment of acid raffinate, and (3) contaminated sediments from upper Bear Creek. Table 2.4 is a generic summary of the waste materials known to have been disposed of in the S.3 Ponds.

Waste products were discharged into the ponds from tank trucks, smull containers, and an underground nitric acid pipeline, which was abandoned and plugged in 1983. The wastes consisted primarily of nitric acid, nitrate waste, pickling and plating wastes, and miscellaneous liquid wastes associated with routine cleanup operations (e.g., mop water). Other wastes included dilute acid, machine coolants, caustic solutions, and acids with a pH of less than 2.0. During the mid.1950s, uranyl nitrate solutions containing small amounts of plutonium were discharged into the ponds. Depleted uranium in nitric acid solution and technetium contained in raffinate and condensate alas may have been placed in the ponds while they remained in operation. All waste discharges into the ponds were terminated in March 1983.

Influent discharge rates varied throughout the period of operation, but the amount of waste was significanily reduced when a nitric acid recovery system became operational in 1976. In 1983, the annual quantity of liquid waste entering the ponds was reported to be about 10.3 million L (2.7 million gal). The annual loss from the ponds caused by evaporation was estimated to be one-half to two-thirds the annual input from direct rainfall, or about 11.4 million L (3 million gal) (Energy Systems 1987a); the remainder, plus waste inputs into the ponds, is assumed to have infiltrated to the groundwater.

\subsection{1 \&-3 Ponds trentment and closure}

In situ treatment of wastewater in the S.3 Ponds began in 1983 and continued until September 1984. Between May and November 1983, liquids in all four of the ponds were neutralized. Biodenitrification of the liquids occurred from May 1983 to September 1984, causing nitrate levels in the pond water to decrease to -100 parts per million (ppm). Nutrients continued to be added to the ponds to maintain the bioreaction, and aerators agitated the sludge to denitrify the residuals (Table 2.5). Subsequently, nitrate levels were maintained below $50 \mathrm{ppm}$ in the pond water.

After denitrification, the contents of the ponds were allowed to settle, and the supernatant was pumped to the S-3 Ponds Treatment Facility for removal of trace metals and organics. A llexible hose attached to the suction side of the pump allowed the decanting of remaining small pockets of liquid on the surface of the sludge. The treatment steps for the supernatant included $\mathrm{pH}$ adjustment, precipitation, coagulation, flocculation, carbon adsorption, filtration, and chlorination. Treated effluent was discharged to EFPC in accordance with a National Pollutant Discharge Elimination System (NPDES) permit. The supernatant treatment began in 1985 and was completed by the spring of 1986.

Immediately before structural stabilization and filling for closure of the S-3 Ponds in 1988 (Energy Systems 1988), sediment that had accumulated in two "lagoons" in upper Bear Creek adjacent to the S.3 Ponds was placed in the southwest cell of the S.3 Ponds. Turner and Kamp (1984) characterized this material in place and each truckload of sediment placed in 
Table 24. Waste disposed of in the S-3 Pondat

\begin{tabular}{|c|c|}
\hline Substance & Consification \\
\hline \multicolumn{2}{|l|}{ Liquid wate } \\
\hline Nitrate wastes & Corrosive \\
\hline Machine coolants & Toxic \\
\hline Caustic solutions & Corrosive \\
\hline Pickling wastes & Toxic \\
\hline Plating wastes & Toxic \\
\hline Mop water & Toxic \\
\hline Nitric acid & Corrosive \\
\hline Miscellaneous dilute acids & Corrosive \\
\hline Miscellaneous acids $(\mathrm{pH}<2)$ & Corrosive \\
\hline Depleted uranium (in nitrate solutions) & Radioactive \\
\hline Plutonium (in uranyl nitrate solutions) & Radioactive \\
\hline Technetium (In raffinate and condensate) & Radioactive \\
\hline Miscellaneous radiological waste ${ }^{e}$ & Radioactive \\
\hline Blodenitrification sludges & Toxic \\
\hline Contaminated Bear Crock rediments & Toxic \\
\hline
\end{tabular}

The annual volume of waste was 2.7 million gal in 1983. This volume is reduced from pre-1976 quantities.

The ponds were operated from 1951 to 1984.

- See complete list in Appendix A. 
Table 25. Chemical additions to the nortbeast quadrat (\$-3 Ponds)

\begin{tabular}{|l|l|}
\hline Date & \multicolumn{1}{|c|}{ Chemleal addition } \\
\hline $4 / 26 / 88$ & $38,000 \mathrm{~L}(10,000 \mathrm{gal})$ of acetic acid and lime slurry \\
\hline $4 / 28 / 88$ & $19,000 \mathrm{~L}(5000 \mathrm{gal})$ of acetic acid and lime slurry \\
\hline $4 / 29 / 88$ & $38,000 \mathrm{~L}(10,000 \mathrm{gal})$ of acetic acid and lime slurry \\
\hline $5 / 04 / 88$ & $408 \mathrm{~kg}(900 \mathrm{lb})$ of lime slurry \\
\hline $5 / 09 / 88$ & $318 \mathrm{~kg}(700 \mathrm{lb})$ or lime slurry \\
\hline $5 / 11 / 88$ & $1270 \mathrm{~kg}(2800 \mathrm{lb})$ of lime slurry \\
\hline $5 / 12 / 88$ & $1451 \mathrm{~kg}(3200 \mathrm{lb})$ of lime slurry \\
\hline $5 / 18 / 88$ & $2280 \mathrm{~kg}(600 \mathrm{gal})$ of acetic acid and $1361 \mathrm{~kg}(3000 \mathrm{lb})$ of lime slurry \\
\hline $5 / 19 / 88$ & $3.8 \mathrm{~L}(1 \mathrm{gal})$ of triethyl phosphate and $907 \mathrm{~kg}(2000 \mathrm{lb})$ of lime slurry \\
\hline $5 / 23 / 88$ & $1361 \mathrm{~kg}(3000 \mathrm{lb})$ of lime slurry \\
\hline $5 / 24 / 88$ & $2280(600 \mathrm{gal})$ of acetic acid and $2359 \mathrm{~kg}(5200 \mathrm{lb})$ of lime slurry \\
\hline $5 / 25 / 88$ & $380 \mathrm{~L}(100 \mathrm{gal})$ of acetic acid and $3.8 \mathrm{~L}(1 \mathrm{gal})$ of triethyl phosphate \\
\hline
\end{tabular}

Source: Adapted from Stone 1990. 
the ponds was also characterized by sampling and laboratory analyses. The data from the 1988 sampling and characterization have been tabulated in Appendix A.

Water and sludges in the S-3 Ponds have been extensively characterized on several uccasions (Jeter 1983; Kimbrough and Turner 1987). Although the pond water chemistry varied from pond to pond and from year to year, in general, pond water chemistry remained highly acidic, dominated by the nitrate anion, with extremely high concentrations of the major cationic constituents (calcium, magnesium, potassium, aluminum) and moderately high concentrations of trace metals. The few organics analyses available for the pond waters indicate that concentrations of organics could have been highly variable over the period of operation. Sludges in the ponds were characterized both before and following neutralization/biodenitrification (Jeter 1983; Kimbrough and Turner 1987). Appendix A gives selected results of investigations of the composition of water and sludges in the S-3 Ponds that remained after neutralization.

The S.3 Ponds Hazardous Waste Disposal Unit (HWDU) was granted interim status under TN Rule 1200-1-11-.07(3) in December 1984 and is therefore subject to the groundwater monitoring requirements described in TN Rule 1200-1-11-.05. Before this date, groundwater monitoring at the S-3 Ponds was conducted in accordance with two DOE monitoring programs: historical and characterization monitoring. Characterization monitoring at the S-3 Ponds began in 1983 in response to the Memorandum of Understanding (MOU) signed by DOE, EPA, and TDEC and continued until 1986. Assessment monitoring was initiated at the S-3 Ponds in January 1986. However, a formalized Groundwater Quality Assessment Plan for the site was not submitted to TDEC until March 1987 (Geraghty and Miller 1987).

TDEC granted final closure of the S-3 Ponds in November 1990. The site was closed as an HWDU and is subject to postclosure care under TN Rule 1200-1-11-.05(14)(e). TDEC issued a RCRA postclosure permit for the S-3 Ponds HWDU on September 30, 1991. The permit contains a technical definition of the boundaries or vertical line of compliance of the regulated unit as well as maximum contaminant levels for regulated contaminants at specified monitoring points. The permit was appealed by DOE and Energy Systems on October 30, 1991.

\subsubsection{Oil Landfarm}

The Oil Landfarm (Fig. 2.5) is a unit that was included in the former Oil Landfarm Waste Management Area. A chronological list of the activities at the site is included in Table 2.6. The Oil Landfarm is located $-2.4 \mathrm{~km}$ (1.5 miles) west of the Y-12 Plant, north of SL 1 and Bear Creek Road (Fig. 2.2). Landfarming activities ended in 1982, after 9 years of operation during which -3.8 million $\mathrm{L}$ (1 million gal) of liquid wastes were disposed (Turner et al. 1991). The oils and coolants deposited in the Oil Landfarm are known to have been contaminated with beryllium compounds, depleted uranium, PCBs, tetrachloroethene, and 1,1,1-trichloroethane. In 1990, the Oil Landfarm was closed as a landfill with a multilayered engineered cap pursuant to TN Rule 1200-1-11-.05(14)(e).

The facility was used for the biological degradation of waste oil and machine coolants through landfarming, a process involving the application of waste oils and coolants to nutrient-adjusted soil during the dry months of the year (April to October). After application, 


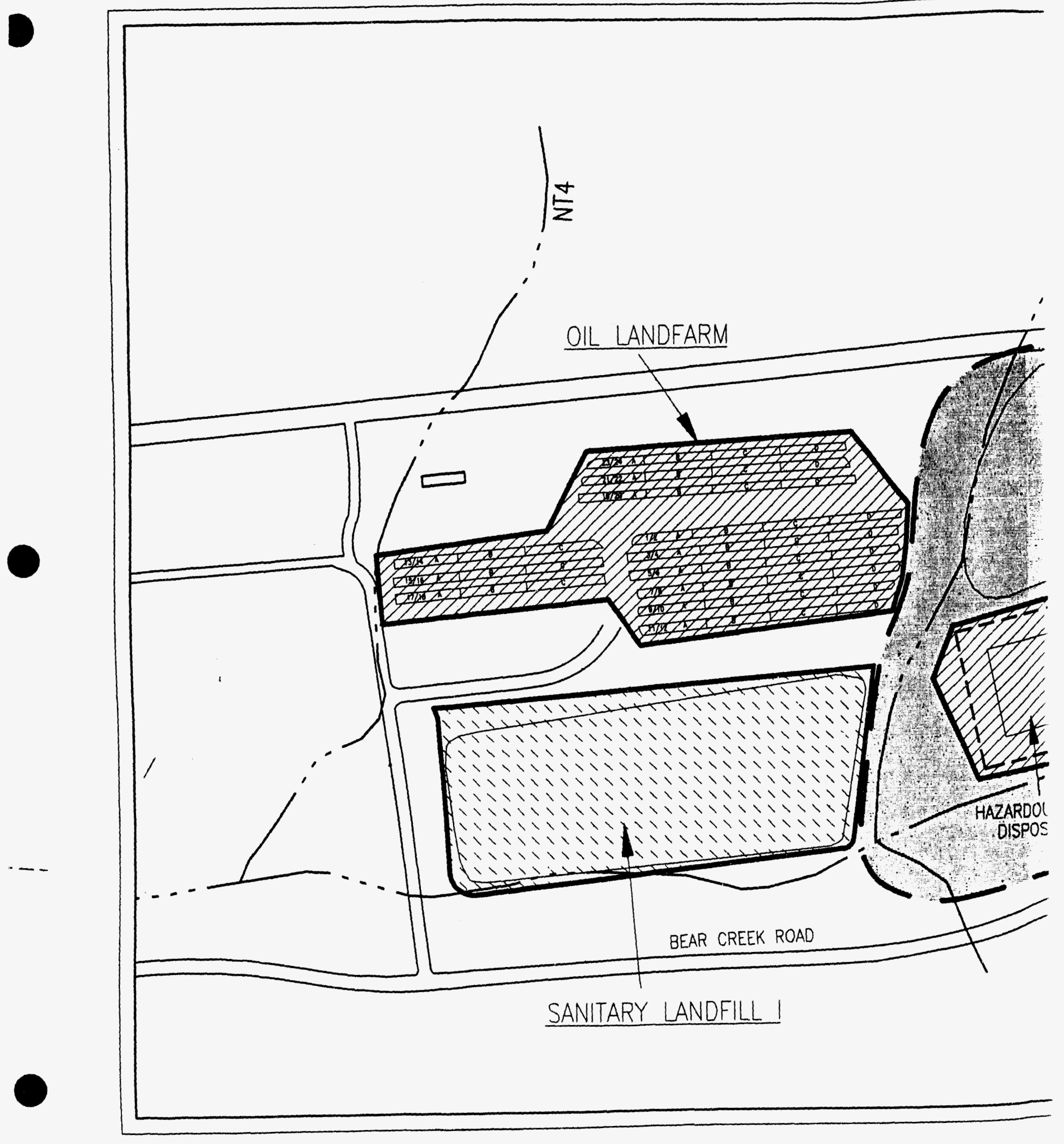

Fig. 25. Site map for the Oil Landfarm Area, including the 


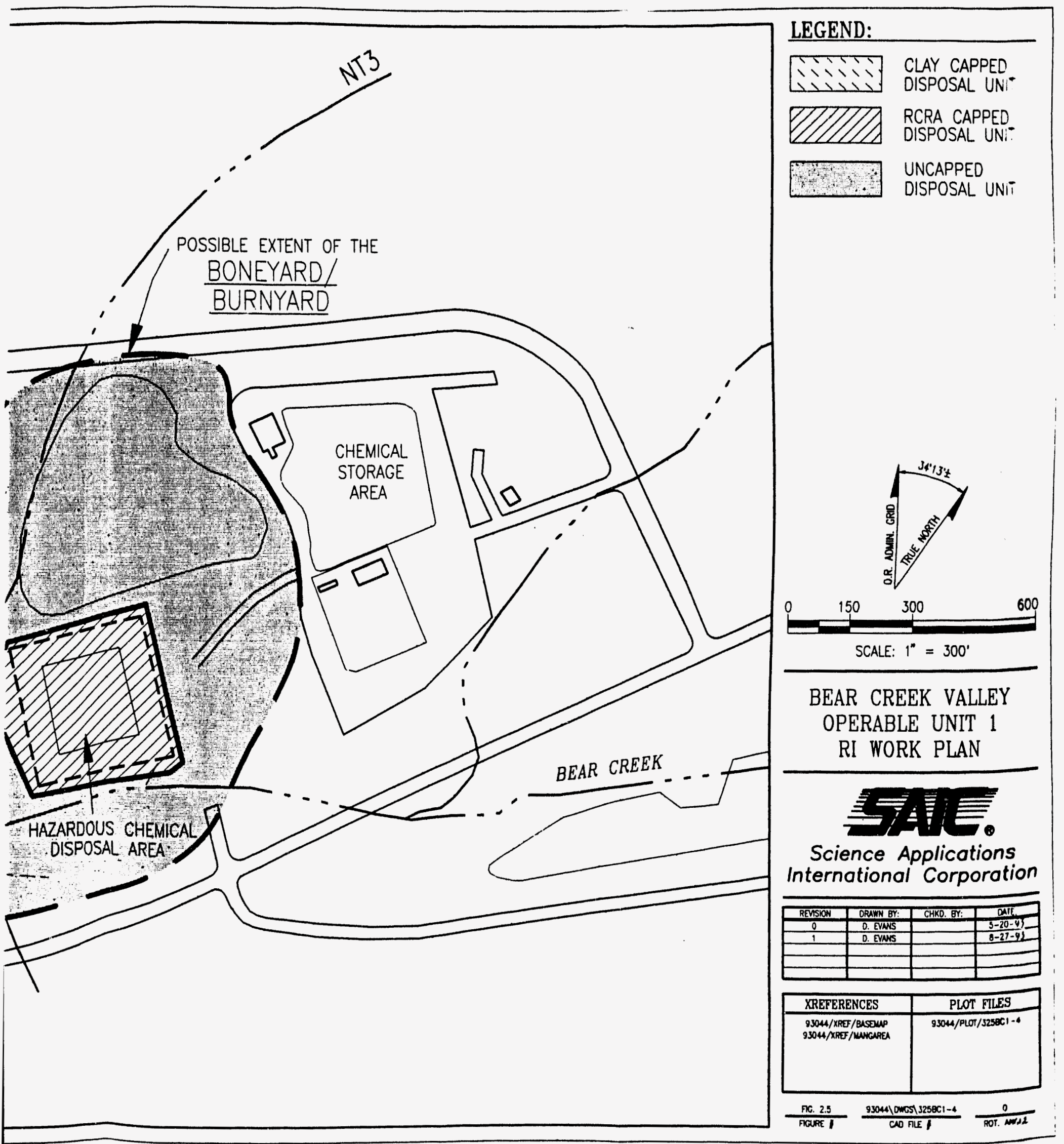

hcluding the Oil Landfarm, the Boneyard/Burnyard, and SL 1. 
Table 26. Chronological list of events at the Oil Landfarm

\begin{tabular}{|c|c|c|}
\hline Year & Event & Reference \\
\hline 1973 & $\begin{array}{l}\text { Landfarming activities began at the site. Waste } \\
\text { oils and coolants that contained beryllium } \\
\text { compounds, depleted uranium, PCBs, and } \\
\text { chlorinated organic compounds, mop waters, } \\
\text { tanker oils from the K-25 Site, wastes } \\
\text { from cooling towers and the Burial Grounds, and } \\
\text { unidentified miscellaneous liquid wastes were } \\
\text { disposed of at the site }\end{array}$ & Energy Systems 1991 \\
\hline $1974-1975$ & $\begin{array}{l}57,000 \mathrm{~L}(15,000 \mathrm{gal}) \text { of oil skimmed from the } \\
\text { surface of the two Oil Retention Ponds in BG-A } \\
\text { were disposed of in the Landfarm }\end{array}$ & \\
\hline 1975 & $\begin{array}{l}\text { Historical monitoring at the site began as part } \\
\text { of DOE monitoring programs }\end{array}$ & \\
\hline 1979 & $\begin{array}{l}\text { Analyses of waste were implemented } \\
\text { before application to the Landfarm. The } \\
\text { analytical results for oil samples collected } \\
\text { from the surface of one of the ponds in the } \\
\text { Burial Grounds indicated the presence of PCBs }\end{array}$ & \\
\hline 1979 & $\begin{array}{l}\text { Oils were analyzed for uranium, beryllium, } \\
\text { thorium, and PCBs. Permissible concentration } \\
\text { levels of } 5 \mathrm{mg} / \mathrm{L} \text { were established for PCBs. Waste } \\
\text { oils containing greater that } 5 \mathrm{mg} / \mathrm{L} \text { with uranium } \\
\text { concentration levels greater that permissible } \\
\text { limits were placed in storage for incineration } \\
\text { at the K- } 25 \text { Site }\end{array}$ & \\
\hline 1981 & $\begin{array}{l}\text { Analyses of waste were expanded to include } \\
\text { chlorinated hydrocarbons with a maximum } \\
\text { permissible concentration of } 3 \%\end{array}$ & \\
\hline 1982 & $\begin{array}{l}\text { Landfarm activities ceased. Approximately } \\
3.8 \text { million } L \text { ( } 1 \text { million gal) of liquid waste were } \\
\text { disposed of during the operational history. A } \\
\text { total of } 2.2 \text { million } L(583,500 \text { gal) of waste } \\
\text { coolant and } 1.6 \text { million } L(430,800 \text { gal) of waste } \\
\text { oil were reported to be disposed of at the site } \\
\text { (Union Carbide } 1984 \text { ) }\end{array}$ & Turner et al. 1991 \\
\hline 1983 & $\begin{array}{l}\text { Groundwater characterization monitoring } \\
\text { began in response to the MOU signed by DOE, } \\
\text { EPA, and TDEC }\end{array}$ & \\
\hline 1983 & $\begin{array}{l}\text { Core samples from perimeter monitoring wells } \\
\text { were analyzed for organic contaminants }\end{array}$ & \\
\hline September 1983 & $\begin{array}{l}\text { Composite soil samples were collected from plots } \\
1-12,13-18 \text {, and } 19-24 \text { and analyzed for VOCs, } \\
\text { acid-and base-neutral extractables, inductively } \\
\text { coupled plasma metals, and pesticide/PCBs }\end{array}$ & \\
\hline
\end{tabular}


Table 26 (continued)

\begin{tabular}{|c|c|c|}
\hline Year & Event & Reference \\
\hline $1983-1984$ & $\begin{array}{l}\text { Water and sediment samples were collected } \\
\text { at tributaries NT-3 and NT-4. Levels of VOCs, } \\
\text { phenols, and beryllium were all below detection } \\
\text { limits }\end{array}$ & Turner et al. 1991 \\
\hline December 1984 & $\begin{array}{l}\text { The Oil Landfarm was granted interim status } \\
\text { under TN Rule } 1200-1-11.07(3)\end{array}$ & \\
\hline 1985 & $\begin{array}{l}\text { A total of } 200 \text { soil samples were collected in a } \\
\text { randomized block design to delineate areas } \\
\text { containing PCB levels }>25 \mu \mathrm{g} / \mathrm{g} \text {. Samples were } \\
\text { also analyzed for uranium }\end{array}$ & Herbes 1988 \\
\hline January 1986 & DOE characterization monitoring ended & \\
\hline January 1986 & $\begin{array}{l}\text { Interim status assessment monitoring was } \\
\text { initiated at the site in lieu of detection } \\
\text { monitoring as required under TN Rule 1200-1-11- } \\
.05(6)(a) 4 \text { due to the detection of contaminants } \\
\text { in groundwater }\end{array}$ & \\
\hline $1986-1987$ & $\begin{array}{l}\text { Groundwater samples from three monitoring } \\
\text { wells bordering the Oil Landfarm were analyzed } \\
\text { for total and dissolved toxic metals and gross } \\
\text { radioactivity }\end{array}$ & \\
\hline 1987 & DOE historical monitoring at the site ended & \\
\hline February 1988 & RCRA Closure Plan was revised & EMD HSEAD 1988 \\
\hline November 1990 & $\begin{array}{l}\text { The Oil Landfarm was closed as a landfill with a } \\
\text { multilayered engineered cap pursuant } \\
\text { to TN Rule } 1200-1-11.05(14)(\mathrm{e})\end{array}$ & Bohrman 1989 \\
\hline December 1990 & $\begin{array}{l}\text { Final RCRA closure for the site was certified } \\
\text { by TDEC }\end{array}$ & Energy Systems 1992c \\
\hline
\end{tabular}


the plots were cultivated frequently to maintain aerobic conditions to enhance biodegradation of the wastes. When possible, waste was not applied immediately before or after periods of precipitation.

Wastes placed in the Oil Landfarm included the following:

- Waste oils.

- Beryllium-contaminated oils.

- Coolants.

- Mop waters.

- Tanker oils from the K-25 Site.

- Wastes from cooling towers and the Burial Grounds.

- Unidentified miscellaneous liquid wastes.

Because operating instructions called for different types of oils to be applied to different plots, both the composition and volume of liquid waste applied varied from plot to plot (BNI 1983). Thus, over $50 \%$ of the total amount of beryllium-contaminated oil disposed of over the lifetime of the Oil Landfarm was administered to Plot $1 / 2$, with most of the remainder being divided nearly equally between Plots $7 / 8$ and 9/10. Tanker oils were applied most heavily to Plots $3 / 4$ and 5/6; coolants were applied most heavily to Plots $3 / 4,5 / 6,11 / 12,13 / 14$, and 15/16. (See Appendix A for a map of plot locations in the Oil Landfarm.) In general, the east plots received more total liquid waste application than the west plots, which received more than the north plots.

Summaries have been compiled for the types and amounts of waste oils (Table 2.7) and waste coolants (Table 2.8) disposed of in the plots during the operating period. While waste oils typically consisted of crankcase, hydraulic, gear, vacuum pump, mineral, and machine coolant oils, the totals for 1974 and 1975 included $-57,000 \mathrm{~L}(15,000 \mathrm{gal})$ of oil skimmed from the surface of the two ORPs located in Y-12 Plant BG-A. The machine coolants included nonsoluble oils and water-soluble mixtures consisting of $-5 \%$ oil and $95 \%$ water.

The typical composition of waste oils and coolants generated at the Y-12 Plant is summarized in Appendix A. The values are considered to be representative of the oily wastes disposed of in the Oil Landfarm plots. As expected, the waste oils exhibit lower densities and higher carbon contents than the oil/water coolant mixtures. Uranium contents of the oily wastes ranged from $\sim 20$ to $80 \mathrm{ppm}$. The data further indicate that waste oils contained high levels of calcium, iron, sodium, silicon, phosphorous, chlorine, zinc, and lead. Analyses of machine coolants show a similar composition, with the exception of barium, which is present in the coolants at levels 10 to 50 tirnes higher than in the oils.

Before 1979, waste oils and criolants were not specifically analyzed for contaminants before application to the Oil Landfarm. In 1979, analytical results for samples of oil that were collected from the surface of one ORP in the Burial Grounds and applied to the Oil Landfarm indicated the presence of PCBs. Thereafter, oils were analyzed for uranium, beryllium, thorium, and PCBs. A nxaximum permissible concentration level of $5 \mathrm{mg} / \mathrm{L}$ was established by the Y-12 Plant for PCBs in waste oils to be landfarmed. Oils containing $>5 \mathrm{mg} / \mathrm{L}$ of PCBs were shipped for commercial disposal if uranium concentrations were less 
Table 27. Summary of waste oil disposals at the Y-12 Plant Oil Landfarm

\begin{tabular}{|c|l|c|c|c|l||}
\hline $\begin{array}{c}\text { Culendar } \\
\text { year }\end{array}$ & \multicolumn{1}{|c|}{ Origin } & $\begin{array}{c}\text { No. of } \\
\text { disposals }\end{array}$ & $\begin{array}{c}\text { Volume } \\
\text { (ga) }\end{array}$ & $\begin{array}{c}\text { Aative plots } \\
\text { (acres) }\end{array}$ & \multicolumn{1}{|c||}{ Description } \\
\hline 1973 & Y-12 & 11 & 42,800 & 0.4 & Waste oll \\
\hline 1974 & Y-12 & 14 & 53,300 & 1.0 & Waste oil \\
\hline 1975 & Y-12 & 4 & 14,600 & 1.0 & Waste oil \\
\hline 1976 & Y-12 & 9 & 25,600 & 1.0 & Waste oil \\
\hline & NR & 5 & 17,700 & 1.0 & No record \\
\hline 1977 & NR & 5 & 14,000 & 1.4 & No record \\
\hline 1978 & Y-12 & 12 & 36,000 & 1.7 & Waste oil \\
\hline & ORGDP & 1 & 1,000 & 1.7 & Mincral oil \\
\hline 1979 & Y-12 & 4 & 16,500 & 2.6 & Waste oil \\
\hline & ORGDP & 16 & 63,900 & 2.6 & Waste oil \\
\hline 1980 & Y-12 & 22 & 72,400 & 2.6 & Waste oil \\
\hline & Y-12 & 5 & 17,800 & 2.6 & Mineral oil \\
\hline & ORGDP & 7 & 22,300 & 2.6 & Waste oil \\
\hline 1981 & NA & NA & NA & 2.6 & No disposals \\
\hline 1982 & Y-12 & 9 & 32,900 & 2.6 & Waste oil \\
\hline TOTAL & & 124 & 430,800 & & \\
\hline & & & & \\
\hline
\end{tabular}

${ }^{a} \mathrm{NR}=$ no record.

${ }^{b} \mathrm{NA}=$ not applicable.

Source: Union Carbide 1984. 
Table 28. Summary of waste coolant disposals at the Y-12 Plant Oil Landfarm

\begin{tabular}{|c|c|c|c|c|}
\hline $\begin{array}{c}\text { Calendrur } \\
\text { year }\end{array}$ & $\begin{array}{c}\text { No. of } \\
\text { disposeals }\end{array}$ & $\begin{array}{c}\text { Volume } \\
\text { (gal) }\end{array}$ & $\begin{array}{l}\text { Active plots } \\
\text { (acres) }\end{array}$ & Description \\
\hline 1973 & $\begin{array}{r}12 \\
8 \\
2\end{array}$ & $\begin{array}{r}34,800 \\
22,500 \\
9,700\end{array}$ & $\begin{array}{l}0.9 \\
0.9 \\
0.9\end{array}$ & $\begin{array}{l}\text { Coolants } \\
\text { Coolants and mop waters } \\
\text { Water contaminated } \\
\text { with nitrate }\end{array}$ \\
\hline 1974 & $\begin{array}{r}22 \\
6\end{array}$ & $\begin{array}{r}104,000 \\
21,000\end{array}$ & $\begin{array}{l}1.6 \\
1.6\end{array}$ & $\begin{array}{l}\text { Coolants } \\
\text { Coolants and mop waters }\end{array}$ \\
\hline 1975 & 21 & 97,500 & 2.0 & Coolants \\
\hline 1976 & $\begin{array}{r}25 \\
3\end{array}$ & $\begin{array}{r}107,000 \\
9,400\end{array}$ & $\begin{array}{l}2.0 \\
2.0\end{array}$ & $\begin{array}{l}\text { Coolants } \\
\text { Water }\end{array}$ \\
\hline 1977 & 23 & 114,000 & 1.6 & Coolants \\
\hline 1978 & 15 & 62,600 & 1.4 & Coolants \\
\hline 1979 & $N A^{a}$ & NA & 1.4 & No disposals \\
\hline 1980 & 1 & 1,000 & 1.4 & Dye penetrant \\
\hline 1981 & NA & NA & 1.4 & No disposals \\
\hline 1982 & NA & NA & 1.4 & No disposals \\
\hline TOTAL & 138 & 583,500 & & \\
\hline
\end{tabular}

- Union Carbide 1984.

Source: Union Carbide, 1984. 


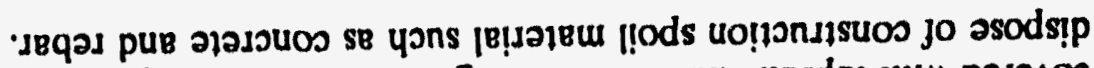

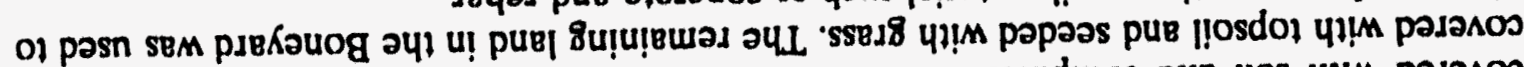

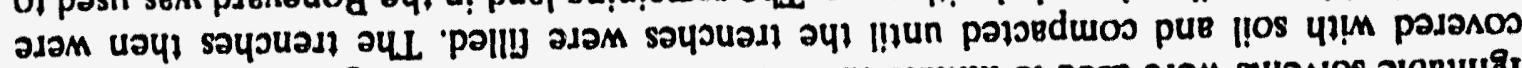

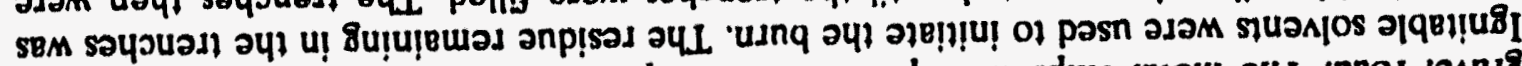

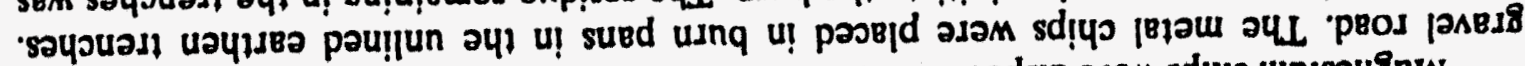

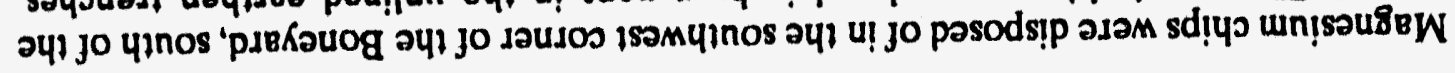

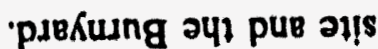

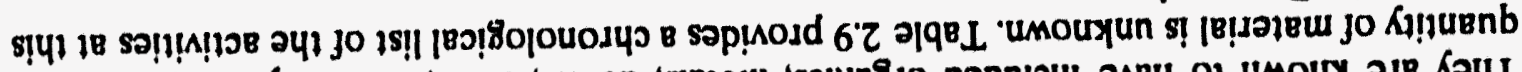

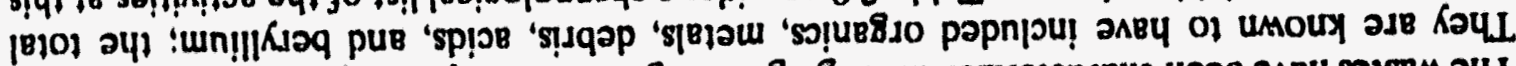

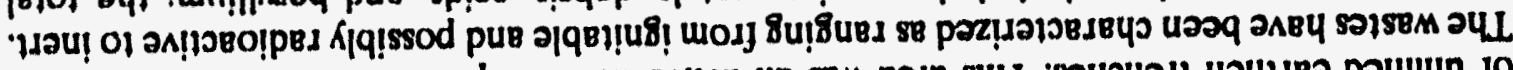

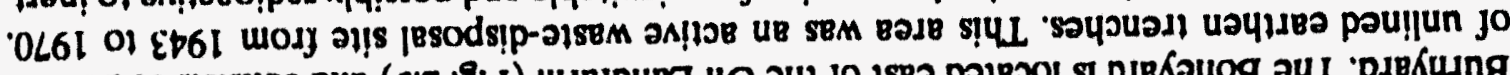

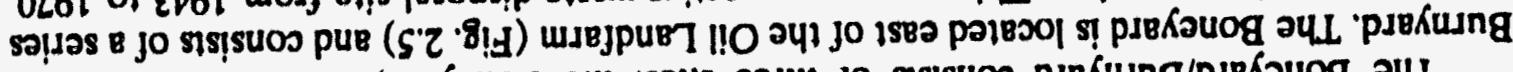

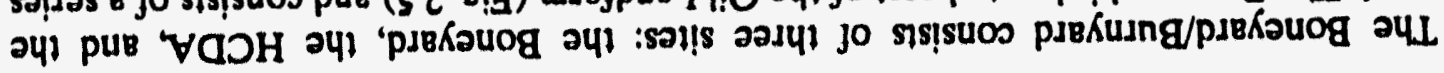

\section{prekumg/prefouog EEZ}

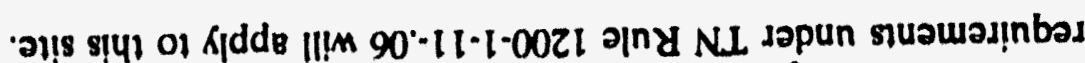

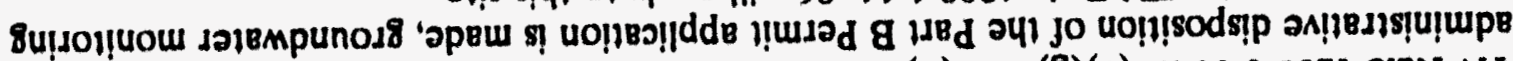

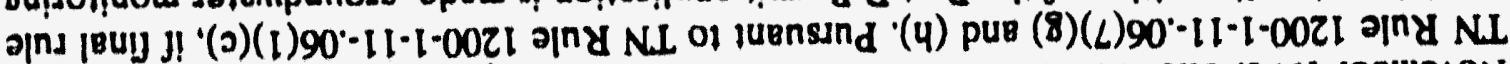

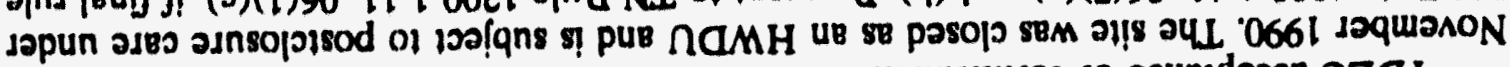

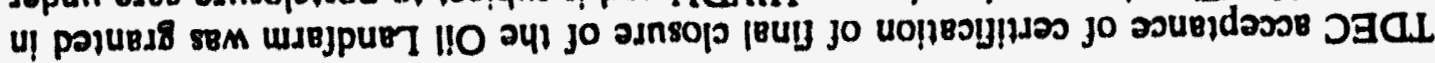

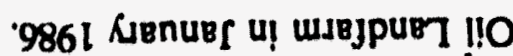

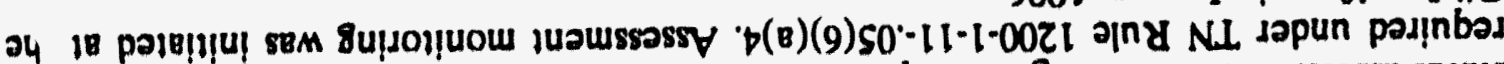

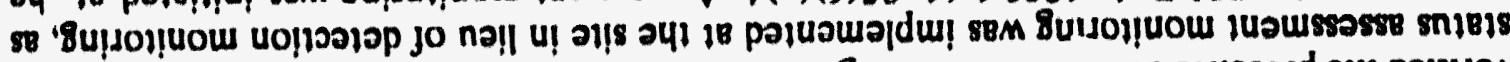
แ!

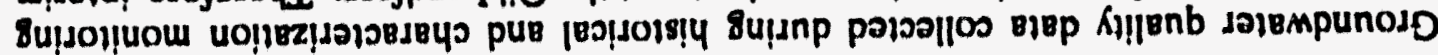

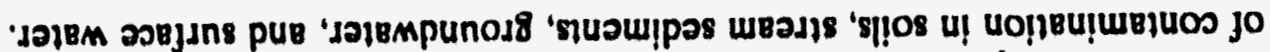

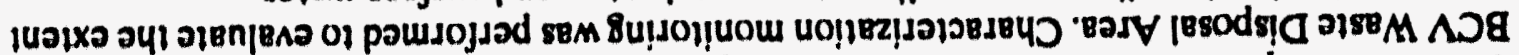

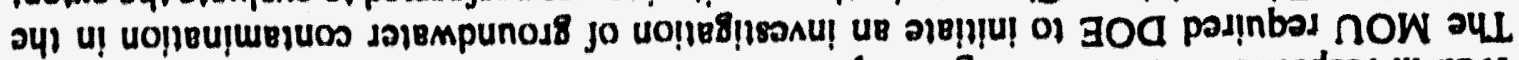

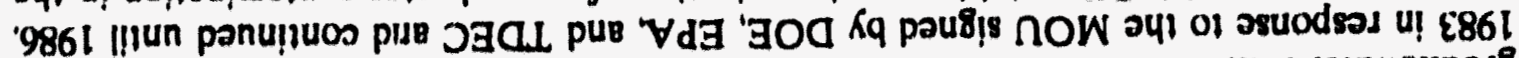

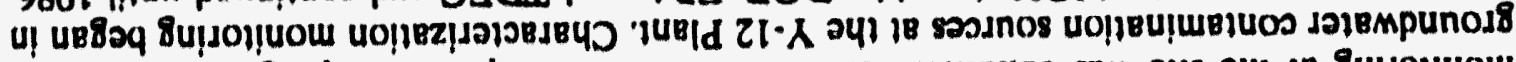

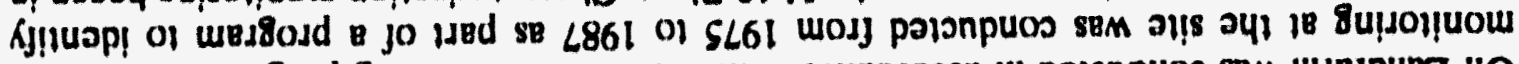

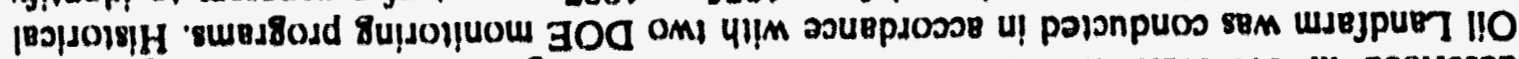

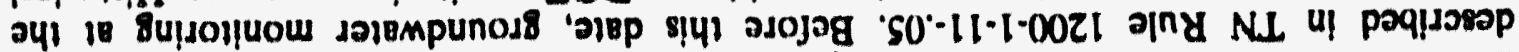

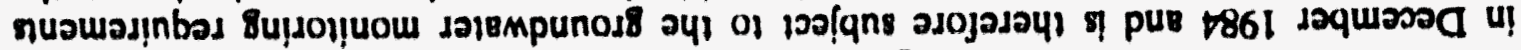

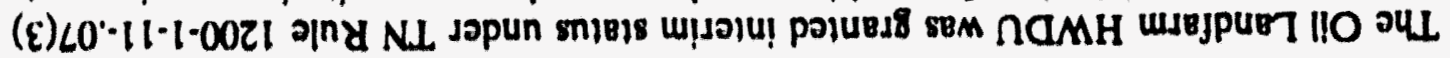

'suoquBsodpKY pajвu!jolyo \%£>

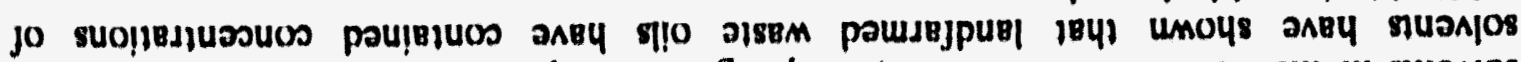

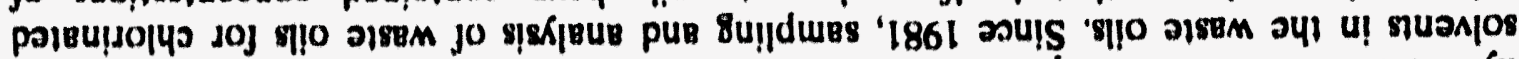

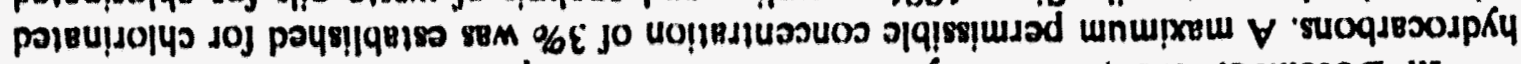

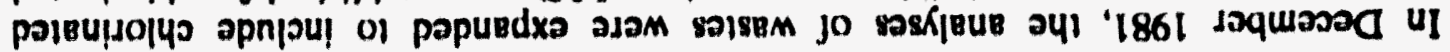

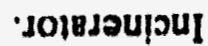

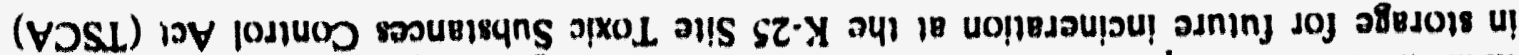

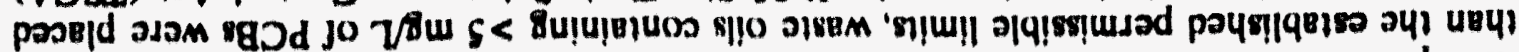

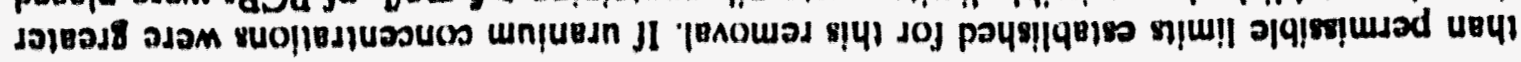


Table 29. Chrosologleal that of oveats at the Bongyard/Burnyard

\begin{tabular}{|c|c|c|}
\hline Year & Event & Roferences \\
\hline 1943 & $\begin{array}{l}\text { The Boneyard was used as a disposal site for waste } \\
\text { from the Y.12 Plant. Burning and disposal of debris } \\
\text { and sanitary, metallic, chemical, and radioactive wastes } \\
\text { are known to have occurred. In the southwest corner } \\
\text { of the Boneyard, metal chips were placed in pans } \\
\text { in unlined earthen trenches and burned. The residue } \\
\text { remaining in the trench was covered with topsoil } \\
\text { and compacted until the trench was nlled. The trench } \\
\text { was then covered with topsoll and seeded with grass }\end{array}$ & Energy Systems 1991 \\
\hline 1943 & $\begin{array}{l}\text { The Burnyard received }-1000 \mathrm{~m}^{3} \text { ( } 4000 \text { yd'year) } \\
\text { of sanitary refuse from plant operations including } \\
\text { solids, liquids, and sludges. The wastes were placed } \\
\text { in two unlined earthen trenches and burned. When } \\
\text { nlled, the trenches were covered with soll }\end{array}$ & \\
\hline 1968 & Disposal of waste at the Burnyard was discontinued & \\
\hline 1970 & $\begin{array}{l}\text { Disposal of waste at the Boneyard site was } \\
\text { discontinued }\end{array}$ & \\
\hline $1975-1981$ & $\begin{array}{l}\text { A Hazardous Chemical Disposal Area was established } \\
\text { on }-2 \text { acres in the southeastern portion of Boneyard/ } \\
\text { Burnyard on lop of the Burnyard. The area was used } \\
\text { to burn or neutralize liquid and gaseous wasies. The } \\
\text { material was broadly characterized as Ignitable. } \\
\text { reactive, corrosive, loxic, highly nammable, or in some } \\
\text { instances inert }\end{array}$ & $\begin{array}{l}\text { Enercy Systems } 1991 \\
\text { Energy Systems } \\
1987 \mathrm{~b}\end{array}$ \\
\hline 1985 & $\begin{array}{l}\text { An investigation conducted by Bechtel National, Inc., } \\
\text { on sediment samples collected down stream of the } \\
\text { Boneyard indicated levels of mercury, uranium, several } \\
\text { polynuclear aromatic hydrocarbons, and phthalates }\end{array}$ & $\begin{array}{l}\text { Energy Systems } \\
1987 b\end{array}$ \\
\hline 1989 & $\begin{array}{l}\text { The Hazardous Chemical Disposal Area was covered } \\
\text { with a RCRA-type cap }\end{array}$ & Energy Sysiems 1991 \\
\hline
\end{tabular}


The Burnyard consisted of two trenches $-90 \mathrm{~m}(300 \mathrm{ft})$ long and $12 \mathrm{~m}(40 \mathrm{ft})$ wide. The site is no longer visible because the HCDA was bullt on top of it and this in lurn has been capped (Fig. 2.6). The Burnyard functioned as an active waste site from 1943 to 1968 . It is estimated that the site received $-90 \mathrm{~m}^{3}\left(350 \mathrm{yd}^{3}\right)$ per month $\left[1000 \mathrm{~m}^{3}(4000) \mathrm{yd}^{3}\right)$ per year of sanitary refuse from plant operations. including solids, liquids, and sludges. The waste materials may have contained empty pesticide containers, metal shavings, solvents, oils, and lab chemicals. The wastes were placed in unlined earthen trenches and burned. Oils and other flammable liquids, possibly transformer oils containing PCBs, were used to start and sustain combustion. Therefore, dioxin/furan contamination is a possibility because they are produced when PCBs are burned at relatively low temperatures. When filled, the trenches were covered with soil. No collection or treatment systems, other than burning, have been used on this site (Energy Sytems 1987b).

The HCDA is part of the Boneyard/Burnyard area; it is located directly southwest of the Boneyard, on top of the former Burnyard site (Fig 2.5). The site received solid, liquid, and gaseous waste materials from 1975 to 1981. It is estimated that during this period $<3.8 \mathrm{~m}^{3}$ $\left(5 \mathrm{yd}^{3}\right)$ of waste per year were deposited (Turner et al. 1991). The material was broadly characterized as ignitable, reactive, corrosive, toxic, highly flammable, or in some instances inert (Energy Systems 1987b).

Generally, the HCDA received wastes that posed safely hazards within the Y-12 Plant. The material came from two sources: gas cylinders with leaking or damaged valves and lab chemicals considered to be reactive or explosive. Gas cylinders containing noncorrosive gases were allowed to leak into the atmosphere or were bled off to expedite the process. Those containing corrosive gases were bled through neutralizing slurries. Empty gas cylinders either were destroyed or transported to another location for repair. The lab chemicals included acids, bases, organics, water-reactive compounds, and explosive compounds such as picric acid, benzoyl peroxide, and ether. Bottles of chemicals were broken under water spray in a concrete vesel that was open to the atmosphere. After the explosion or chemical reaction had taken place, the efluent was discharged into a small unlined surface impoundment and allowed to percolate through the soil. The chemical residue remaining in the concrete vessel was removed periodically and transported to the Burial Grounds (Energy Systems 1987b).

In 1989, the HCDA was covered with a RCRA-type cap (Energy Systems 1991).

\subsection{SL 1}

SL 1 is located $-1.3 \mathrm{~km}$ (0.8 mile) west of the Y-12 Plant just north of Bear Creek and immediately south of the Oil Landfarm as shown on Fig. 2.5. A chronological list of events at this site is included in Table 2.10. The site was used between 1968 and 1980 for the disposal of combustible and decomposable solid wastes. The landfill was permitted for materials such as paper and cardboard, plastics, rubber, wood, brush, animal bedding, organic garbage, textile products, and asphalt roofing materials. Although administrative controls were used to exclude the disposal of toxic chemicals and other contaminated materials, it is possible that some of these materials were disposed of in the landfill (Energy Systems 1987c).

Trenches were excavated to depths of $\sim 6 \mathrm{~m}(20 \mathrm{ft})$ and backfilled to $-4.5 \mathrm{~m}(15 \mathrm{ft}$ ) above grade. Approximately $27,000 \mathrm{~m}^{3}\left(105,000 \mathrm{yd}^{3}\right)$ of refuse were disposed of at the landfill. The

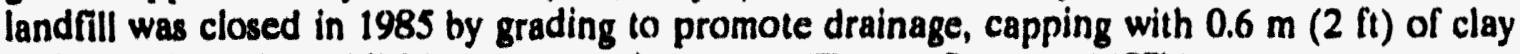
and topsoil, and establishing a vegetation cover (Energy Systems 1987b). 
Table 2.10. Chronological list of ovents at SL 1

\begin{tabular}{|c|c|c|}
\hline Year & Event & Reference \\
\hline $1968-1980$ & $\begin{array}{l}\text { The site was used for the disposal } \\
\text { of combustible and decomposable solld } \\
\text { wastes. A total of }-27,000 \mathrm{~m}^{3}(35,315 \text { yd } \\
\text { of refuse was disposed of al the landfill }\end{array}$ & $\begin{array}{l}\text { Energy Systems } \\
1987 b\end{array}$ \\
\hline 1982 & Waste disposal at the site was terminated & \\
\hline 1985 & $\begin{array}{l}\text { The site was closed by grading, capping } \\
\text { with } 0.6 \mathrm{~m}(2 \mathrm{ft}) \text { of clay, and establishing } \\
\text { vegetative cover }\end{array}$ & $\begin{array}{l}\text { Energy Systems } \\
1987 b\end{array}$ \\
\hline
\end{tabular}

\subsection{Burial Grounds}

The Burial Grounds are located $-3.2 \mathrm{~km}$ (2 miles) west of the Y.12 Plant (Fig. 2.6). The Burial Grounds consist of several principal waste-disposal units designated as BG.A, $\cdot B_{1} \cdot C_{\text {, }}$ $. D, \cdot E$, and.$J ;$ the Walk-in Pits; and the Uranium Vaults. Collectively, these units are referred to in this document as the Burial Grounds. Table 2.11 provides a chronological list of events that are associated with this source area.

Each waste-disposal unit consists of a series of trenches used for disposal of liquid and solid wastes. The trenches are between 4.2 and $7.5 \mathrm{~m}$ (14 and $25 \mathrm{ft}$ ) deep (Figs. 2.7 and 2.8). Appendix B gives the dimensions of the Burial Grounds trenches. In BG.A North and South, perforated standpipes were installed vertically into some trenches for liquid-waste disposal; rock and gravel were backfilled around the standpipes for support and maximum rate of drainage (Fig. 2.7).

The first trench in BG.A was excavated in August 1955 for the disposal of solid wastes. In July 1959, the Y-12 Plant began using this facility for the disposal of certain types of liquid waste. Before 1959, liquids generated at the Y.12 Plant from floor-cleaning operations (mop water) had been placed in the burial facilities at ORNL. Since that time, several types of wastes have been disposed of in the Burial Grounds; Table 2.12 lists the major types of wastes. The actual quantity and identity of materials are uncertain, and other materials may have been disposed of that are not listed in any inventory (Turner et al. 1991).

BG.A operated from 1959 to 1979 , and throughout that period several million gallons of oil and mop water were disposed of by discharge either directly into oil disposal pits in BG.A North and South, discharged into standpipes in the burial trenches in BG-A South, or burned in an open tank in $B G \cdot A$.

Before 1961, liquid and solid wastes were placed in unlined trenches within the Burial Grounds. In 1961, a surface tank was installed in BO-A to hold waste oils and coolants. The accumulations were burned, and liquids that did not burn were drained into adjacent trenches. An estimated $684,000 \mathrm{~L}(180,000 \mathrm{gal})$ of oils and coolants were disposed of by this method 
(1 )ाร 97 )

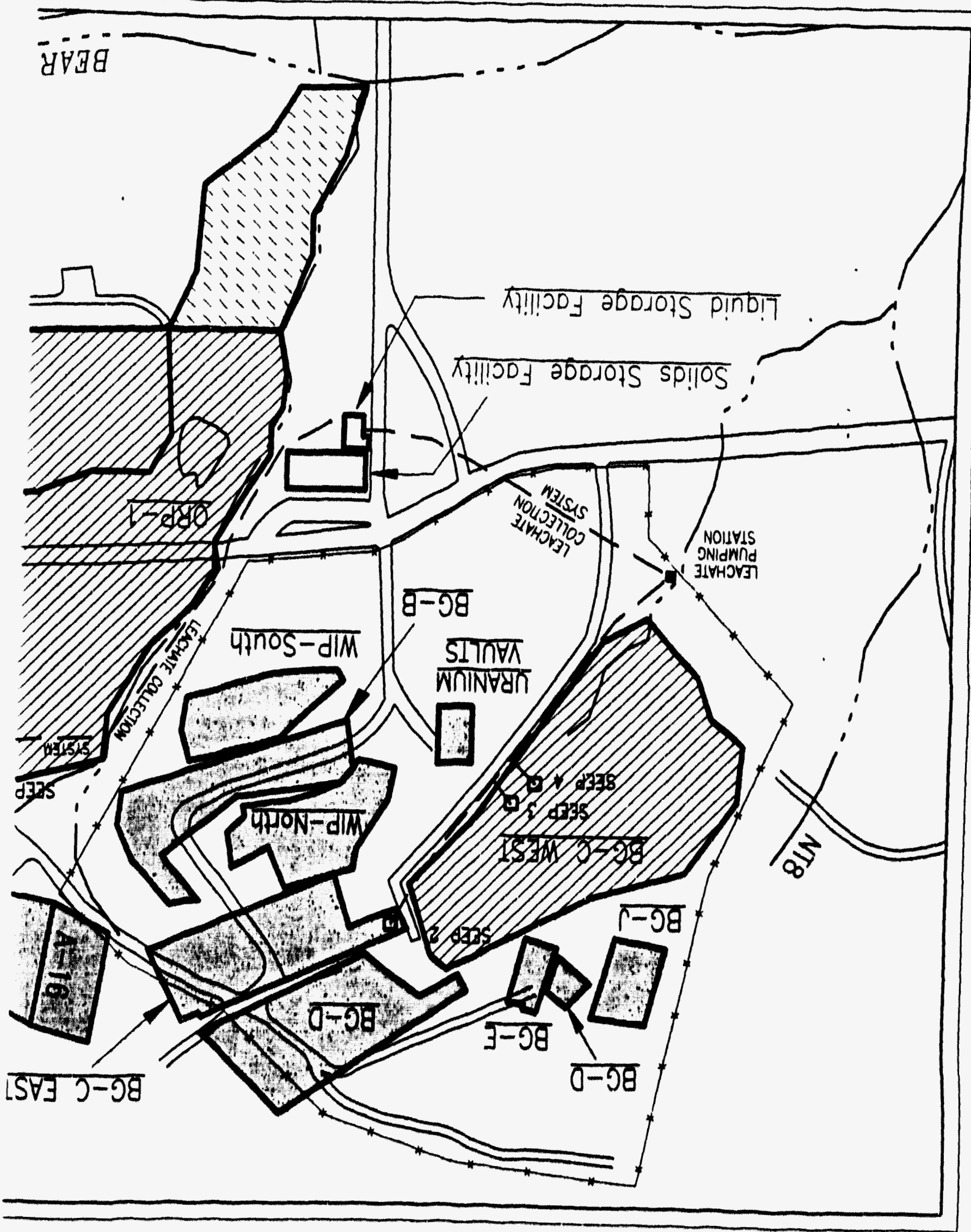




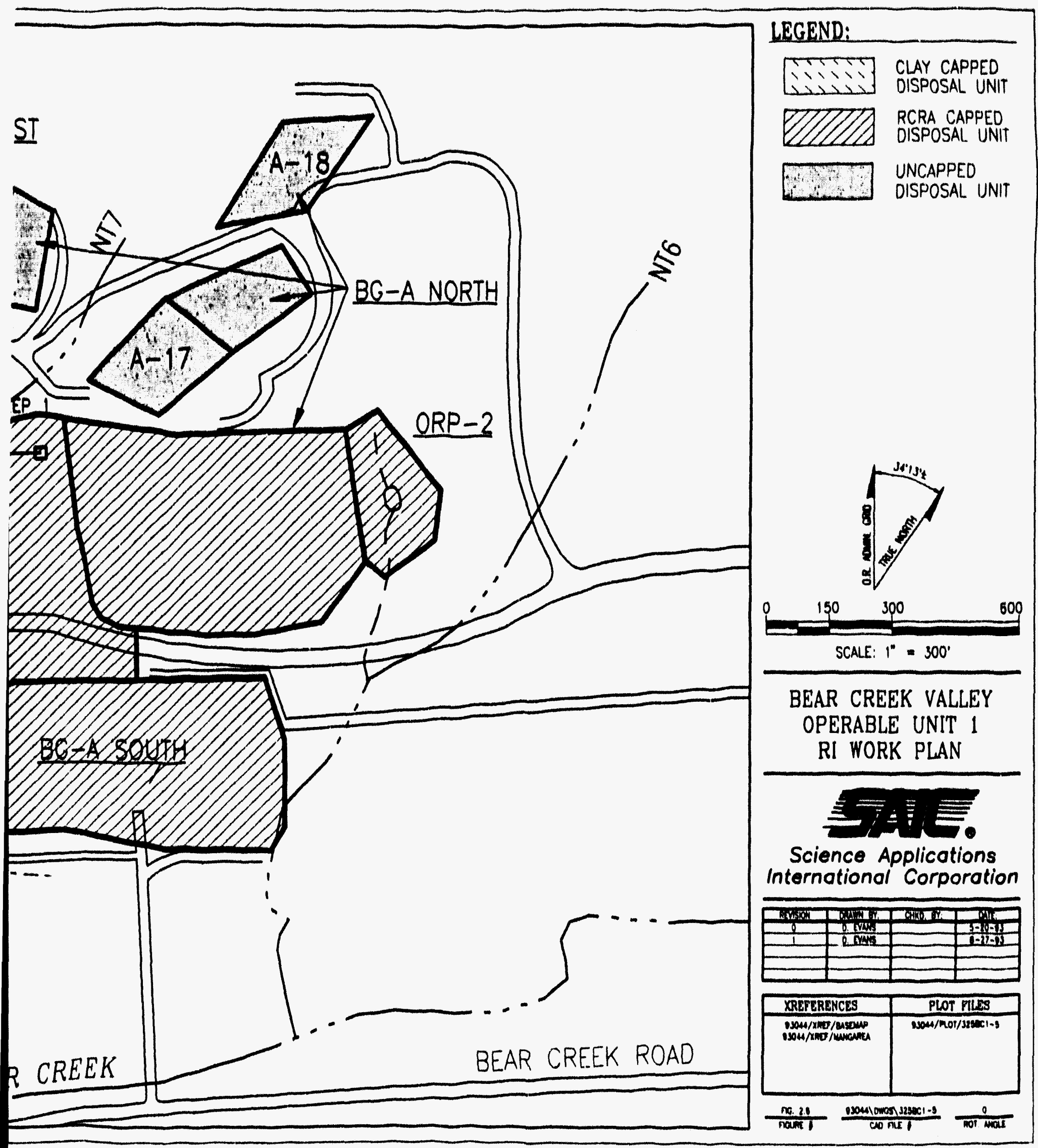

map for the Burial Orounds. 
Table 211. Chronological list of events at the Burial Grounds

\begin{tabular}{|c|c|c|}
\hline Year & Event & Reference \\
\hline August 1955 & $\begin{array}{l}\text { Disposal at the Burial Grounds began with the disposal } \\
\text { of solid waste in Unit A. The Burial Grounds consisted } \\
\text { of waste disposal units A, B, C, D, E, and J. Each unit } \\
\text { consisted of a series of trenches, } 4.3 \text { to } 7.6 \mathrm{~m} \text { (14 } \\
\text { to } 25 \mathrm{ft} \text { ) deep, that were used for the disposal of liquid } \\
\text { and solid wastes }\end{array}$ & Turner et al. 1991 \\
\hline July 1959 & $\begin{array}{l}\text { Large volumes of solvent-contaminated water and oils } \\
\text { began being disposed of in BG-A }\end{array}$ & Turner et al. 1991 \\
\hline 1961 & $\begin{array}{l}\text { A surface tank was installed in BG-A to hold waste oils } \\
\text { and coolants; accumulations were burned. Liquids that } \\
\text { did not burn were drained into trenches. An estimated } \\
684,000 \mathrm{~L}(180,000 \text { gal) of oil and coolants were } \\
\text { disposed of by this method }\end{array}$ & \\
\hline 1962 & $\begin{array}{l}\text { BG-B was opened and used for disposal of depleted } \\
\text { uranium metal and oxides }\end{array}$ & Turner et al. 1991 \\
\hline 1962 & $\begin{array}{l}\text { BG-C was opened for the disposal of beryllium, } \\
\text { beryllium oxide, thorium, and solid waste contaminated } \\
\text { with these materials. Other materials contaminated } \\
\text { with enriched uranium were also disposed of in BG-C }\end{array}$ & Turner et al. 1991 \\
\hline 1966 & $\begin{array}{l}\text { The Walk-In Pits were established in the Burial } \\
\text { Grounds. The area was used to dispose of chemicals } \\
\text { and uranium metal saw fines }\end{array}$ & Turner et al. 1991 \\
\hline 1968 & $\begin{array}{l}\text { Burning of waste oils and coolants was terminated } \\
\text { in BG-A }\end{array}$ & \\
\hline 1968 & BG-B reached waste disposal capacity & \\
\hline 1968 & $\begin{array}{l}\text { BG-D was opened. The area was used to replace BG-B } \\
\text { and received depleted uranium metals and oxides waste }\end{array}$ & \\
\hline $1969-1971$ & $\begin{array}{l}\text { Oil was first observed seeping from the ends } \\
\text { of trenches in BG-A into Tributary NT- } 7 \text { and from the } \\
\text { soil surface above the oil disposal pits }\end{array}$ & \\
\hline $\begin{array}{c}\text { January } \\
1969\end{array}$ & $\begin{array}{l}\text { Oil and coolants were poured into standpipes that were } \\
\text { installed in the trenches }\end{array}$ & \\
\hline $1970-1981$ & $\begin{array}{l}\text { Approximately } 380,000 \mathrm{~L}(100,000 \mathrm{gal}) \text { of waste } \\
\text { solvents were poured into rock piles and into waste- } \\
\text { filled trenches in the southern part of BG-A }\end{array}$ & Turner et al. 1991 \\
\hline 1971-1978 & $\begin{array}{l}\text { An estimated } 2.3 \text { million } L(600,000 \mathrm{gal}) \text { of mop water } \\
\text { were disposed of annually in BG-A }\end{array}$ & Turner et al. 1991 \\
\hline May 1971 & $\begin{array}{l}\text { ORP } 1 \text { was constructed with dimensions of } 55 \mathrm{~m} \\
(180 \mathrm{ft}) \text { long, } 34 \mathrm{~m}(110 \mathrm{ft}) \text { wide, and } 2 \mathrm{~m}(6 \mathrm{ft}) \text { deep }\end{array}$ & Bailey 1979 \\
\hline
\end{tabular}


Table 211 (continued)

\begin{tabular}{|c|c|c|}
\hline Year & Event & Reference \\
\hline May 1972 & $\begin{array}{l}\text { ORP } 2 \text { was constructed on Tributary NT-6 at the } \\
\text { northeast corner of BG-A }\end{array}$ & Bailey 1979 \\
\hline $1974-1975$ & $\begin{array}{l}\text { Approximately } 57,000 \mathrm{~L}(15,000 \mathrm{gal}) \text { of oil were } \\
\text { skimmed and removed from the surfaces of both oil } \\
\text { retention ponds for disposal on the Oil Landfarm }\end{array}$ & \\
\hline 1975 & $\begin{array}{l}\text { Since } 1975 \text {, no significant accumulation of oil has } \\
\text { occurred on surface of ORP } 2\end{array}$ & \\
\hline $1975-1987$ & $\begin{array}{l}\text { Historical monitoring at the site began as part } \\
\text { of a program to identify groundwater contamination } \\
\text { sources at } Y-12 \text { Plant }\end{array}$ & \\
\hline 1979 & $\begin{array}{l}\text { There were } 68,400 \mathrm{~L}(18,000 \mathrm{gal}) \text { of oil removed } \\
\text { from ORP } 1\end{array}$ & \\
\hline 1979 & The disposal of mop water in BG-A was terminateo & Turner et al. 1991 \\
\hline 1979 & Oil disposal ceased in the Burial Grounds & \\
\hline 1980 & $\begin{array}{l}\text { Trenches and disposal areas in the Burial Grounds that } \\
\text { received hazardous wastes were designated and given } \\
\text { interim status }\end{array}$ & \\
\hline 1980,1982 & $\begin{array}{l}\text { A series of soil cores was collected along transects } \\
\text { from the perimeter of ORP } 1 \text { for PCB analysis }\end{array}$ & \\
\hline 1981 & $\begin{array}{l}\text { After 1981, the Walk-in Pits were used for disposal } \\
\text { of uranium metal saw-fines, organics, and laboratory } \\
\text { wastes }\end{array}$ & \\
\hline 1983 & $\begin{array}{l}\text { Water and sediment samples collected from sites } \\
\text { in NT-6 and NT-7 were analyzed for VOCs, metals, } \\
\text { cyanide, phenols, and a number of conventional water } \\
\text { quality parameters. Several VOCs principally including } \\
1,1 \text {-dichloroethane, tetrachloroethylene (PCE), trans- } \\
1,2 \text {-dichloroethylene, and trichloroethylene (TCE) were } \\
\text { found in the sediments of ORP } 1 \text { and in both water } \\
\text { and sediments of NT-7 downstream of the pond. VOCs } \\
\text { were not detected in a water sample collected north } \\
\text { of ORP } 1 \text {, which indicated that the VOC source } \\
\text { differed from that of PCBs }\end{array}$ & Turner et al. 1991 \\
\hline $\begin{array}{l}\text { September } \\
1983\end{array}$ & $\begin{array}{l}\text { Sediment samples collected from ORP } 1 \text { and NT-7 } \\
\text { downstream of the pond did not show elevated levels } \\
\text { of toxic metals, cyanide, or phenols in comparison } \\
\text { to the control site on NT-7 upstream of the Burial } \\
\text { Grounds }\end{array}$ & \\
\hline $\begin{array}{l}\text { September } \\
1983\end{array}$ & $\begin{array}{l}\text { Samples from ORP } 1 \text { were found to contain PCBs } \\
\text { ranging from } 3 \text { to } 31 \mathrm{mg} / \mathrm{L}\end{array}$ & \\
\hline
\end{tabular}


Table 2.11 (continued)

\begin{tabular}{|c|c|c|}
\hline Year & Event & Reference \\
\hline 1983,1984 & $\begin{array}{l}\text { Concentrations of PCBs in NT-7 channel sediments } \\
\text { at the confluence with Bear Creek were reported } \\
\text { to range from } 5.2 \text { to } 28.2 \mathrm{mg} / \mathrm{g}\end{array}$ & McCauley $1984 b$ \\
\hline $\begin{array}{l}\text { December } \\
1984\end{array}$ & $\begin{array}{l}\text { The Burial Grounds were granted interim status and } \\
\text { therefore became subject to the groundwater } \\
\text { monitoring requirements described } \\
\text { in TN Rule 1200-1-11-.05 }\end{array}$ & \\
\hline $1985-1988$ & $\begin{array}{l}\text { Extensive sediment sampling throughout the tributary } \\
\text { system showed that PCBs were present } \\
\text { in concentrations of several hundred milligrams per } \\
\text { gram in surface sediments of NT-7 between ORP } 1 \text { and } \\
\text { the visible area of oil seepage at the west end of Burial } \\
\text { Trench A-14 but declined below } 25 \mathrm{mg} / \mathrm{g} \text { by a depth } \\
\text { of } 60 \mathrm{~cm}(24 \mathrm{in} \text {.) }\end{array}$ & \\
\hline $\begin{array}{c}\text { October } \\
1985\end{array}$ & $\begin{array}{l}\text { Five cores were collected from the bottom of ORP } 1 \\
\text { and subdivided into } 15-\mathrm{cm} \text { (6-in.) intervals for analysis. } \\
\text { Concentrations of PCBs in surface sediments ranged as } \\
\text { high as } 710 \mathrm{mg} / \mathrm{g} \text { but declined to } 3 \mathrm{mg} / \mathrm{g} \text { or less at a } \\
\text { depth of } 67.5 \mathrm{~cm}(27 \mathrm{in} .)\end{array}$ & Herbes 1988 \\
\hline $\begin{array}{c}\text { February } \\
1988\end{array}$ & RCRA Closure Plan was revised & $\begin{array}{l}\text { EMD HSEAD } \\
1988\end{array}$ \\
\hline 1989 & $\begin{array}{l}980 \mathrm{~m}^{3}\left(3,842 \mathrm{yd}^{3}\right) \text { of sludge and soils was excavated } \\
\text { from ORP 1, ORP 2, and NT-7. An engineered cap } \\
\text { was constructed over each pond and NT-7 under an } \\
\text { approved RCRA closure plan. A new channel was } \\
\text { constructed for NT-7, and this tributary was rerouted } \\
\sim 15 \mathrm{~m}(50 \mathrm{ft}) \text { west of its original course }\end{array}$ & Collins $1990 \mathrm{a}$ \\
\hline 1989 & $\begin{array}{l}\text { BG-A and BG-C west were closed in place as a landfill } \\
\text { and covered with an engineered cap under RCRA }\end{array}$ & Collins $1990 \mathrm{~b}$ \\
\hline $\begin{array}{l}\text { November } \\
1990\end{array}$ & TDEC granted approval for the final closure of BG-A & \\
\hline
\end{tabular}




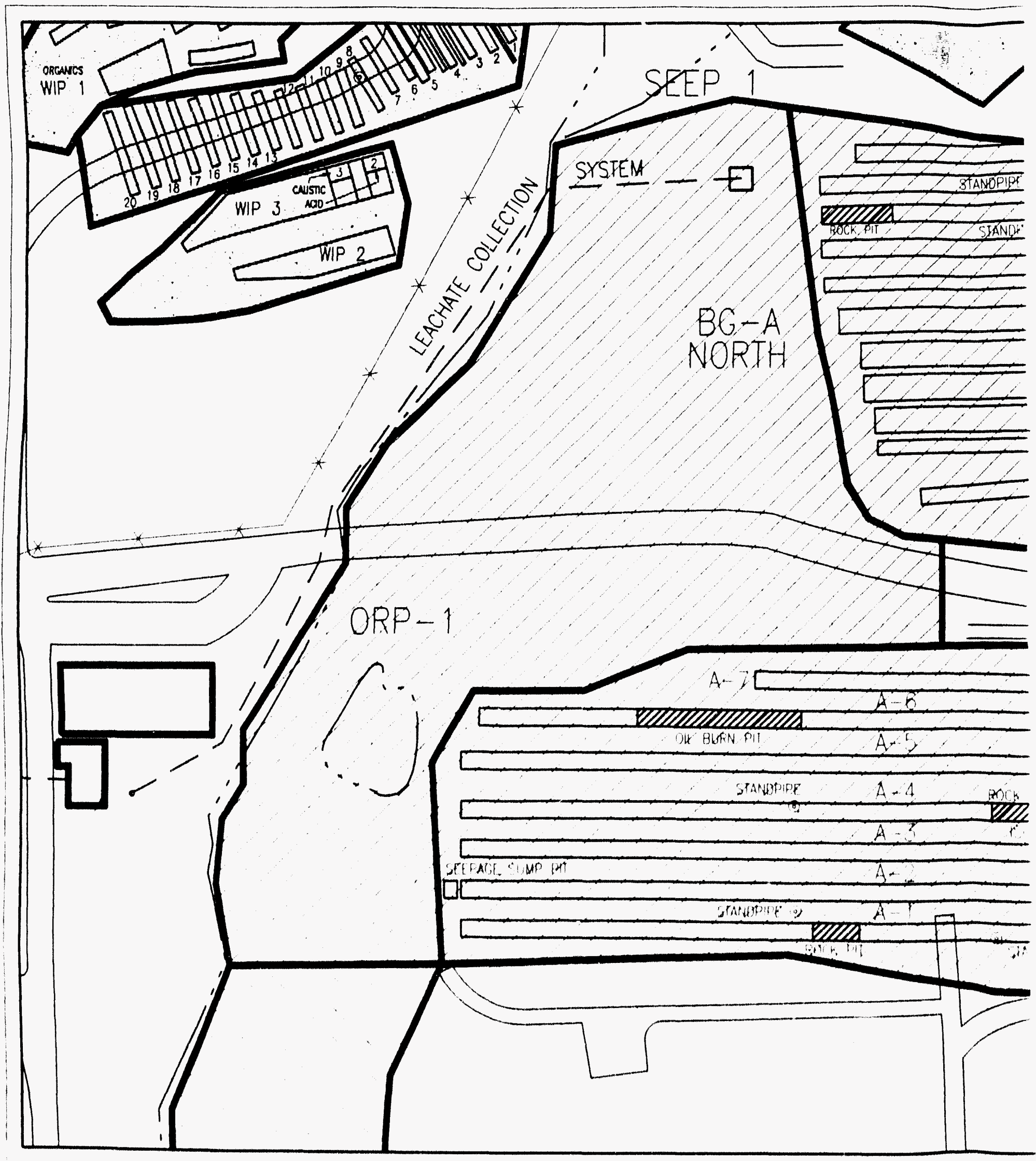

Fig. 27. Lxcations of trenches, oil dispexal pits, st: in BG-A North and BG-A 


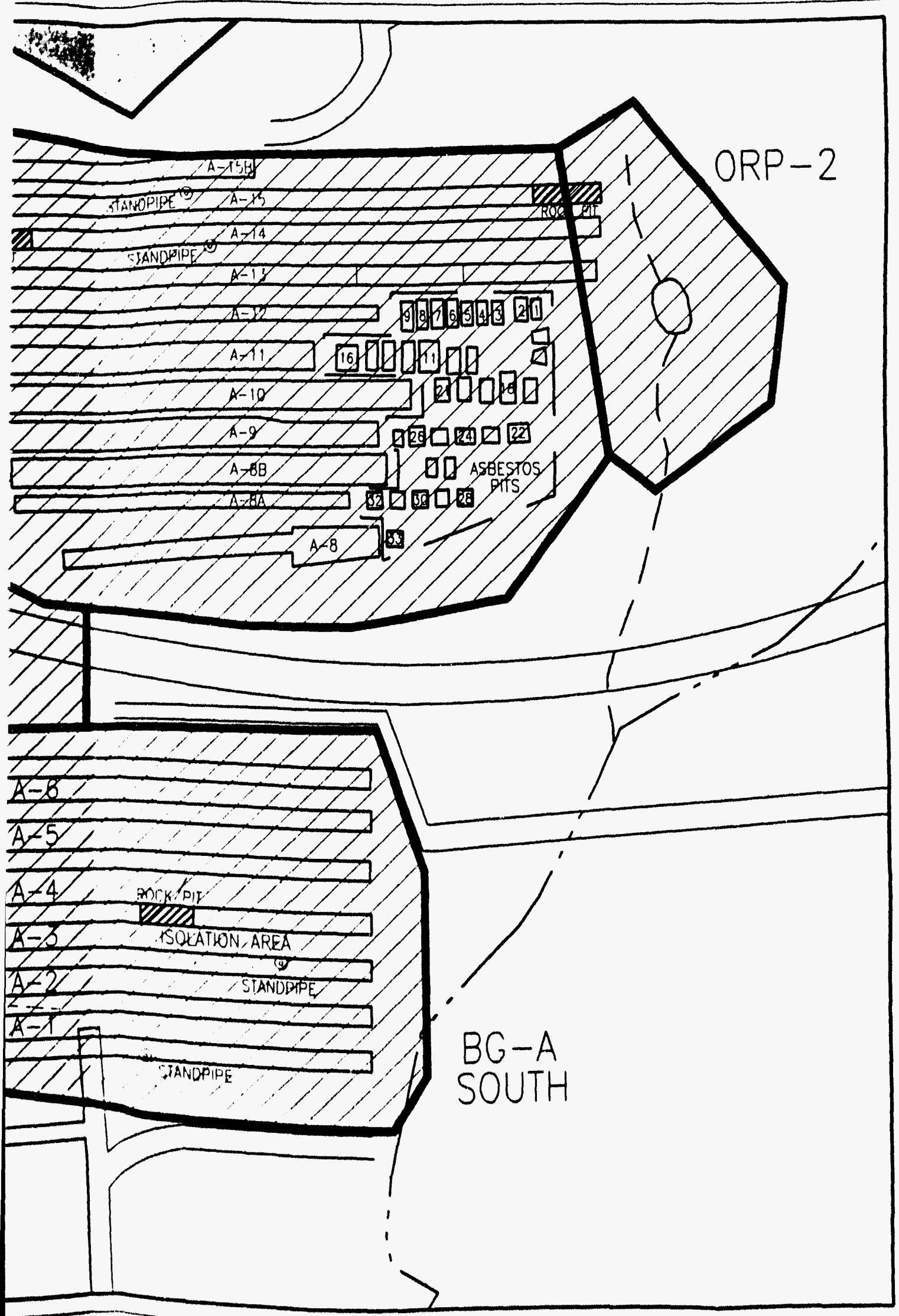

LEGEND:

$\square$ SEEP

बृ. STANDPIPE

$\because \because \because$ CLAY CAPPED

拄访 DISPOSAL UNIT

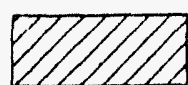

RCRA CAPPED

DISPOSAL UNIT

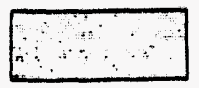

UNCAPPED

DISPOSAL UNIT
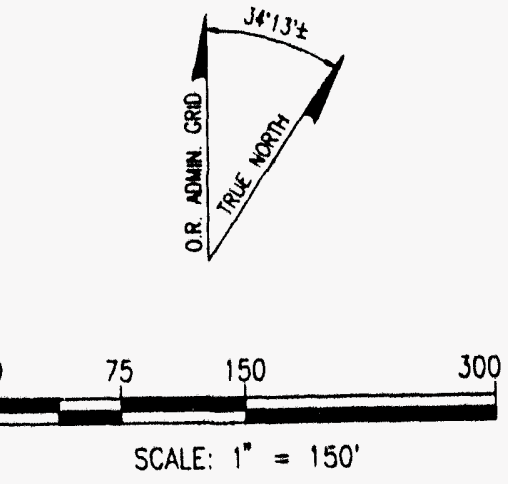

BEAR CREEK VALLEY OPERABLE UNIT 1 RI WORK PLAN

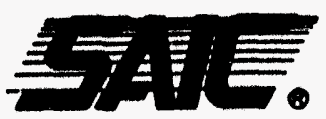

Science Applications International Corporation

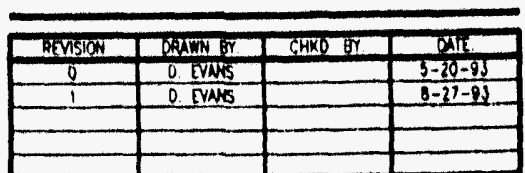

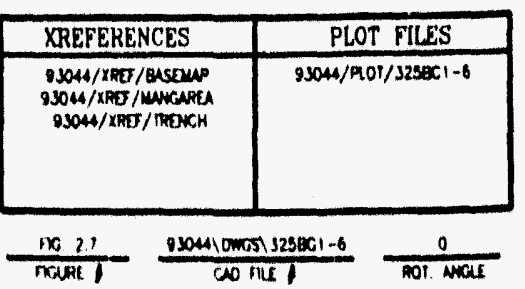

oll dipposal pits, standpipes, and the isolation area -A North add BG.A South. 


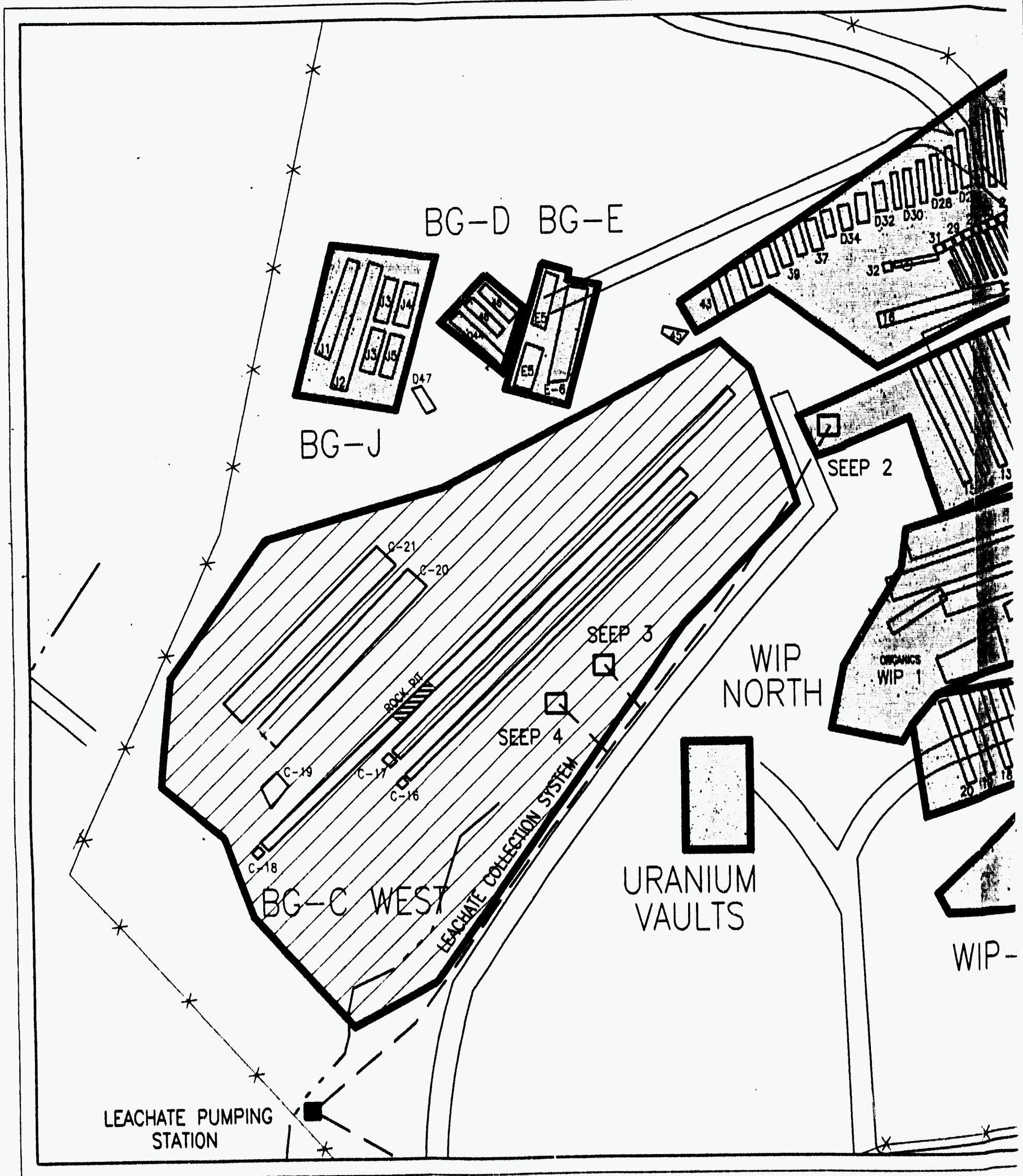

Fi. 28. Locations of trenches in BG-B, - C, -D, 


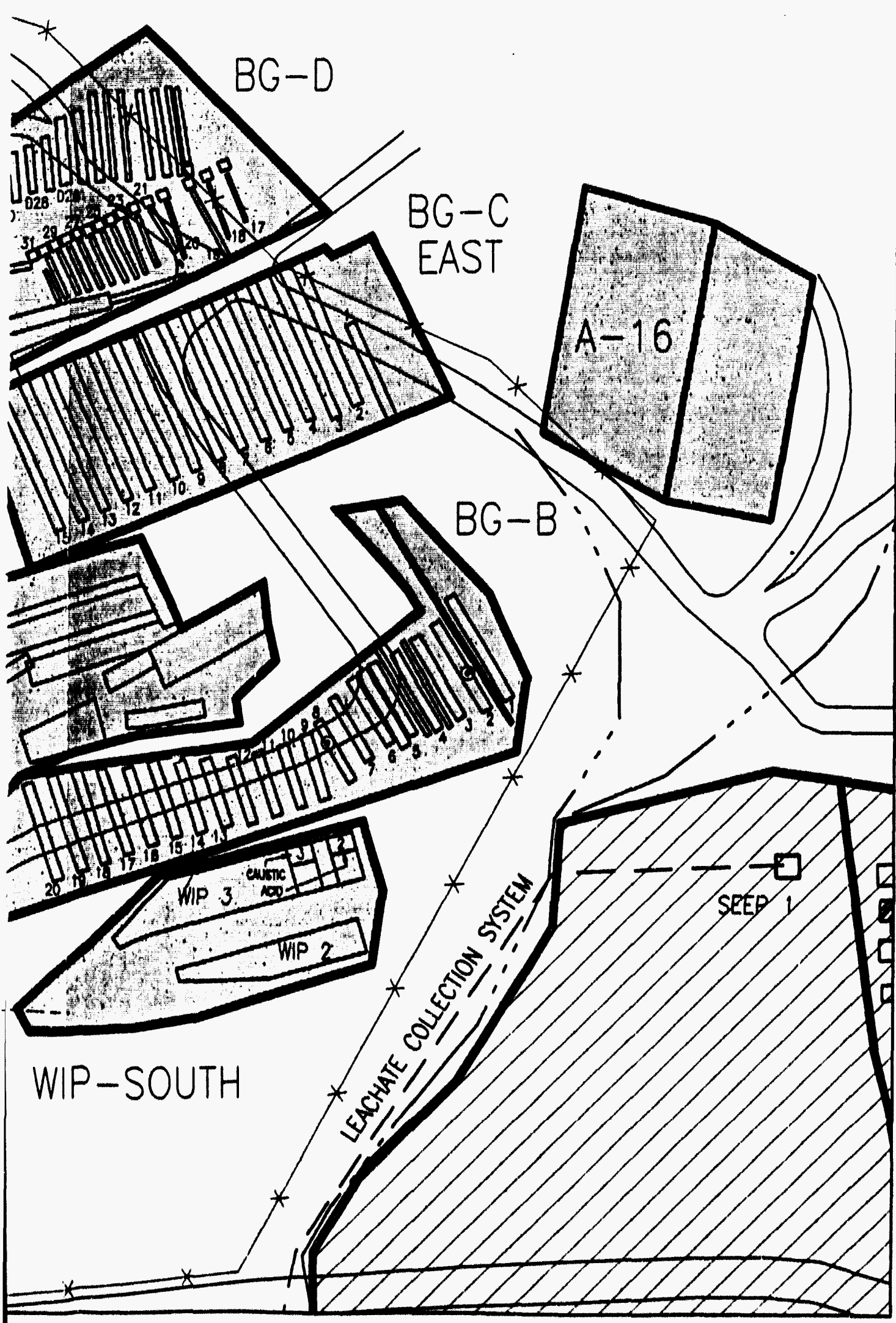

LEGEND:

口........................SEEP

STANDPIPE

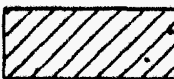

RCRA CAPPED DISPOSAL UNIT

UNCAPPED
.DISPOSAL UNIT
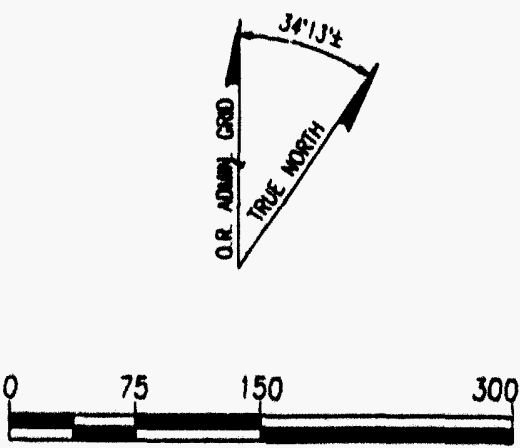

SCALE: $1^{\prime \prime}=150^{\circ}$

BEAR CREEK VALLEY OPERABLE UNIT 1 RI WORK PLAN

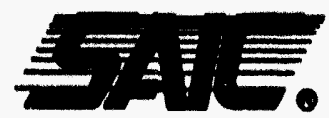

Science Applicotions International Corporation

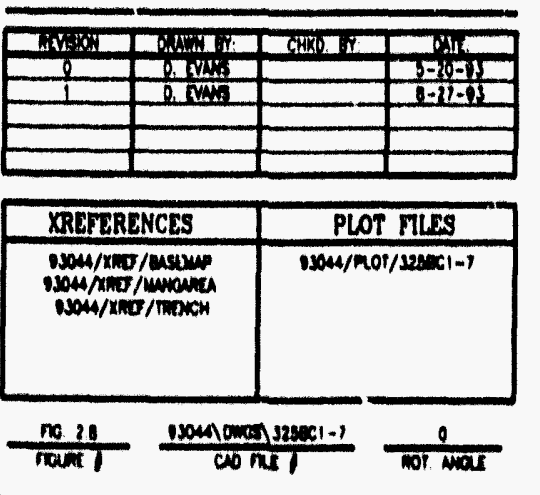

$-B,-C,-D,-E$, and $J$ and the Walk-ln Pita. 
Table 212. Partial summary of waste materials deposited in the Burial Grounds

\begin{tabular}{|l|c|c|c|c|c||}
\hline \multirow{2}{*}{\multicolumn{1}{c|}{ Constituent }} & \multicolumn{5}{c|}{ Burial Grounds } \\
\cline { 2 - 7 } & A & B & C & D & Walk-in Pits \\
\hline Heavy metalsa & Pb & P & P & P & P \\
\hline Olls and coolants & P & Pc & P & Pc & P \\
\hline Salts & P & NI & P & NI & P \\
\hline Debris & P & NI & P & NI & P \\
\hline Solvents & P & NI & P & NI & P \\
\hline Ethylenediaminetetracetic acid (EDTA) & Po & NI & NI & NI & NI \\
\hline Asbestos & P & NI & P & NI & P \\
\hline Material contaminated with radioisotopes & P & P & P & NI & PE \\
\hline Mop water & P & NI & NI & NI & NI \\
\hline
\end{tabular}

Includes beryllium and uranium.

$b_{p}=$ listed in the records as having been deposited.

Trace quantities onty.

${ }^{N I}=$ not identified in the records as having been deposited.

In A-South only.

In A-North only.

In northern Walk.In Pit only.

Source: McCauley 1985a. 
between 1961 and 1968 , when the practice was terminated. Oils burned at this site probably contained PCBs; therefore, dioxin/furan contamination is a possibility.

In January 1969, a new procedure was adopted; the oils and coolants were poured into standpipes installed in the trenches. There are little data concerning specifications of these standpipes. From historic photographs, they appear to be 18-24 in. in diameter and probably extend to the base of the trenches (maximum $20 \mathrm{ft}$ ). Between 1970 and 1981, volatile solvents were also disposed of by pouring into rock-covered areas at the southeastern end of the BG-A South trenches. This area was later called the isolation area (Fig. 2.7). During this period, $-380,000 \mathrm{~L}(100,000 \mathrm{gal})$ of solvents were disposed of in this manner. Table 2.13 summarizes the solvents disposed of during the 12-year period. By 1976, most of the waste oils and coolants were being disposed of at the Oil Landfarm, and in 1979, oil disposal ceased in the Burial Grounds (Turner et al. 1991).

An estimated 2.3 million L $(600,000 \mathrm{gal})$ of mop water were disposed of annually in BG-A between 1971 and 1978; the quantities disposed of before 1971 were not recorded. Disposal of mop water in BG.A was terminated in 1979; after that date, mop water was placed in the S-3 Ponds (Turner et al. 1991).

BG-B was opened in 1962 for the disposal of depleted uranium metal and oxides. BG-C was opened in 1962 for the disposal of beryllium, beryllium oxide, thorium, and solid waste contaminated with these materials; other materials contaminated with enriched uranium were also disposed of in BG-C. BG-D was used after 1968 for the disposal of depleted uranium metals and oxides after BG-B had reached its capacity. An area of the Burial Grounds referred to as the Walk-in Pits was used from 1966 to 1981 for the disposal of chemicals and uranium metal saw fines (Fig. 2.8). Since 1981, the Walk-in Pits have been used solely for the disposal of uranium metal saw fines (Turner et al. 1991).

BG-E and BG-J were used primarily for the disposal of uranium. Through 1983, BG-E had received a total of $-145 \mathrm{~m}^{3}\left(190 \mathrm{yd}^{3}\right)$ of uranium. In addition to the uranium, disposals made to BG.J through 1983 were estimated to include $-22 \mathrm{~m}^{3}\left(29 \mathrm{yd}^{3}\right)$ of debris and $-10 \mathrm{~m}^{3}$ $\left(14 \mathrm{yd}^{3}\right)$ of inorganic salts (Turner et al. 1991).

Another type of disposal area worth mentioning is the Walk-in Pits (BG-WI1, BG-WI2, and BG-WI3). Unlike other trenches that have vertical walls and are filled by dump-truck operations, the Walk-in Pits have a sloped entrance ramp leading to the bottom of the pit. This ailows disposals to be made more carefully, and, in fact, the Walk-in Pits have been used for many disposals of hazardous materials.

\subsubsection{Burial Grounds waste inventory}

An inventory of waste materials delivered to the Burial Grounds between the 1950 s and 1980 was created in 1983 (Energy Systems 1983). Since 1980, the Maintenance Division has placed all disposal information in a computer data base known as the Waste Management Inventory-Manifest System.

Approximately 50,000 individual disposals have been tabulated from records and entered into computer data bases. Hundreds of pages of historical text, many of them handwritter, have been typed. Roughly 15,000 Bear Creek Burial Grounds disposals previously computerized by the Maintenance Division have been accessed. Despite this work, however, 
Table 213. Solvents dischargod into the isobtion area (in ga)

\begin{tabular}{|c|c|c|c|c|c|c|c|c|c|c|c|c|c|}
\hline Solvent & $19 \pi 0$ & 1971 & $19 n$ & 1973 & 1974 & 1975 & 1976 & 197 & $19 \pi$ & $19 \pi$ & 1500 & 1831 & Touns \\
\hline Vythene & 410 & & 50 & 850 & 1575 & 210 & & 555 & 500 & 505 & 1,865 & 1,785 & 8,305 \\
\hline Varsol & 245 & 410 & 1,000 & 720 & 490 & 650 & 615 & 1,000 & 900 & 560 & 810 & 661 & 8,061 \\
\hline Fuel and water & 450 & 500 & 700 & 110 & 15 & 680 & 1,165 & 2,500 & 400 & 250 & 790 & 205 & 7,765 \\
\hline Perchloroethylene & 100 & & & 540 & 180 & 475 & 1,150 & 930 & 1,160 & 710 & 1,000 & 1,390 & 7,635 \\
\hline Freon & 20 & 85 & 520 & & 265 & 345 & & & & & 1,390 & 1,470 & 4,095 \\
\hline Alcohol & 25 & 25 & 550 & 490 & 280 & 210 & 20 & 290 & 600 & 200 & 410 & 189 & 3,289 \\
\hline $\begin{array}{l}\text { Solvents from } \\
\text { Bldg. } 9208 \\
\text { (benzene, toluene, } \\
\text { xylene, alcohol) }\end{array}$ & 40 & 265 & 210 & 125 & 50 & 50 & & 110 & 125 & & 190 & 5 & 1,170 \\
\hline Trichloroethylene & & 75 & 50 & & 220 & & & & 110 & 225 & & 55 & 735 \\
\hline MEK & & & 160 & & 120 & & & & 75 & 175 & & & 530 \\
\hline Miscellaneous & 6,910 & 10,640 & 6,760 & 4,165 & 1,605 & 1,880 & 2,900 & 4,615 & 5,130 & 2,850 & 7,240 & 2730 & 57,425 \\
\hline Gallons discharged & 8,200 & 12,000 & 10,000 & 7,000 & 4,800 & 4,500 & 5,850 & 10,000 & 9.000 & 5,475 & 13,695 & 8,490 & 99,010 \\
\hline
\end{tabular}

Source: McCaukgy 1984 b. 
the resulting picture is incomplete. Many records have been routinely discarded under approved procedures, and many items of information were never recorded at all. Additional documents may yet be uncovered. Nevertheless, the information presented here gives a fairly complete overview of the wastes contained in the Bear Creek Burial Grounds.

Disposals at the Burial Grounds between the 1950 s and 1980 can be categorized according to the following three distinct disposal practices:

- Blanket Disposals (which account for approximately two-thirds of all wastes deliveredi). Operating areas in the Y-12 Plant requested that routine pickups be made of their waste by initiating a "blanket request" to the Maintenance Division. Each blanket was given a number and was for a particular kind of waste. These blankets were valid only for the period of time (months or years) that the particular kind of waste was being generated. There have been -350 blankets active at one time or another since the early 1960s, and they accounted for about two-thirds of the traffic to the Bear Creek Burial Grounds.

- Hazardous Disposals (which account for a small proportion of the total wastes). Several times per day, nonroutine disposals were made of materials that were hazardous in nature-toxic, explosive, reactive, etc. These disposals were made by submitting UCN-2109 forms (i.e., Request for Hazardous Materials Disposal forms) to the Maintenance Division. These forms describe the hazards and handling requirements involved in the disposal, as determined by the requester. A significant portion of these hazardous disposals were made in the Bear Creek Burial Grounds.

- Other Disposals (which account for approximately one-third of all wastes delivered). Many one-time disposals were made of materials that pose no particular hazard. These include such things as cans, bottles, boxes, glass, discarded equipment, and many other miscellaneous items that are generated routinely during industrial operations. This type of material accounts for the bulk of nonblanket material taken to the Bear Creek Burial Grounds.

When material was taken to the Bear Creek Burial Grounds, it was segregated and disposed of in particular areas. Initially, there were only two areas: Burial Ground 1 and Burial Ground 2 (BG-1 and BG-2). As time passed, these areas became subdivided, with BG-1 becoming Burial Ground A (BG-A) and BG-2 being divided into a variety of areas, primarily B, C, D, E, and J (Fig. 2.6).

Trenches were dug in each of these areas as needed, with each trench receiving its own identification number. Thus, BG-A3E, for example, referred to the east end of trench \#3 in the $A$ area. Some areas were set aside for particular materials; these included carbon foam (BG-A8FOAM), aerosol cans (BG-A11AERCAN), asbestos (BG-A12ASBP), crucible oxides (BG-BCRUCOX and BG-CCRUCOX), depleted uranium alloys (BG-BDEPUCPD), depleted uranium (BG-BD38 and BG-CD38), and thorium (BG-BTHOR).

Disposals of waste material in the Bear Creek Burial Grounds came, not only from the Y-12 weapons program but also from ORNL, ORGDP, and outside sources as well. In addition, Y-12 wastes were disposed of in numerous places other than the Bear Creek Burial Grounds, including disposal sites at other installations.

Y-12 Plant Maintenance records contain a number of sources of data for creating the Burial Grounds waste inventory. The following sources of data were used: 
- Activity Reports (Energy Systems 1983, Parts 2 and 3). The records that cover the longest time span are the Maintenance Division's Monthly Activity Reports. These are available from January 1957 to the present, with roughly 1 month per year missing from the files. The waste disposal information in these reports is in two parts: text (Energy Systems 1983, Part 2) and tables (Energy Systems 1983, Part 3).

The text provides a general overview of each month's operations. Prior to 1970, the text was handwritten. All available text has been entered irto the Y.12 work processing system.

The tables record how many pounds and loads were delivered to specific burial trenches, with some brief information on total pounds of alloys and contaminated materials disposed of during the month. The format of the tables changed over the years, and sites other than Bear Creek were included. Some entries are illegible; care was taken to ensure copies of the tables reflect all information that could be discerned.

- Requests for Hazardous/Classified Disposals (2109/65383) (Energy Systems 1983, Parts 4 and 5). For nonroutine disposals of hazardous and/or classified materials, a Request for Hazardous Disposal form (UCN-2109) or Request for Classified Disposal form (UCN-6538) was filled out listing special safety and security considerations for the disposal. Approximately 11,300 UCN-2109s and 1,600 UCN-6538s were found on file at various locations around Y.12, with most dating from 1960 to the present. One file folder with information dating from late 1954 to early 1955 was also found. Information from each of these forms was transcribed and entered into a computer data base. Some entries have been deduced from other available sources. Such entries are denoted by an asterisk, which appears by the entries on the data base printout. Asterisks by the printout observation number indicated a deduced disposal area. This information is presented in Energy Systems 1983, Part 4.

In order to provide a concise tabulation of what materials were disposed, an index of the $2109 / 6538$ information has also been prepared. This index presents only the material description field of the data base sorted in alphabetical order by individual materials along with an item number that can be used to find the complete entry in the detailed report. The 2109/6538 index is presented in Energy Systems 1983, Part 5.

- Karder Blanket File (Energy Systems 1983, Part 6). An early 1963 Activity Report text entry mentions the initiation of a Kardex file in which blanket disposals were recorded. Around 600 cards from this file were located, containing over 27,000 entries from the 1964-1980 time period on over 170 different blankets. Each entry consists of a blanket number, a date, and a quantity. No information on disposal sites was included on the cards, but it is known that many entries did not go to the Bear Creek Burial Grounds. For example, plutonium-contaminated materials were gathered under blanket requests and sent to ORNL for disposal. Definitions of the blanket numbers were obtained from other sources. Data from the Kardex Blanket File are in Energy Systems 1983, Part 6.

- Tanker Logs (Energy Systems 1983, Part 7). These records document roughly 1,800 liquid disposals on -25 different blankets during the 1971-1980 time frame. Little, if any, overlap exists between information on the Kardex Blanket File and the Tanker Logs. Disposal site information for each disposal is included in the Tanker Log data. The 
Tanker Logs are computerized and presented, sorted by burial site, in Energy Systems 1983, Part 7.

- Trip Log (Energy Systems 1983, Parts 8 and 9). Beginning in the 1960, the drivers of Maintenance Division waste disposal vehicles kept logs of what materials were picked up, where they were picked up, and where they were taken. These logs record blanket, hazardous, and other disposals, not only to the Bear Creek Burial Grounds, but to many other areas as well. Approximately three of these Trip Log sheets were generated each working day. These sheets are on file for the years 1965-1979. A stratified sample of 290 days of Trip $\log$ sheets, $8 \%$ of the total, was transcribed and entered into a computer data base. The disposals from these sheets that were delivered to the Bear Creek Burial Grounds are listed in Energy Systems 1983, Part 8.

There are several reasons why only $8 \%$ of the available Trip Logs were tabulated. The lack of standardized format made interpretation of the log entries difficult, and complete tabulation in the time available would have been effectively impossible. Most of the Bear Creek Burial Grounds disposals were already on 2109s, 6538s, and the Kardex Blanket File, all of which were to be completely tabulated. The most significant reason, however, was that the $8 \%$ sample was deemed adequate for statistically estimating what would have been found if all Trip Log sheets had been examined. Verification of this technique was provided when the statistical estimates for total uranium disposed of at the Bear Creek Burial Grounds between 1965 and 1979 equalled the amount recorded by the ongoing SWIMS program (8,700 metric tons). (The equivalent SWIMS figure for 19541964, before Trip Logs were kept, was 3,400 metric tons.) Other verification efforts were also very successful. The results of this mathematical exercise are presented in Energy Systems 1983, Part 9.

- Warte Management Inventory-Manifeat Syatem (Energy Systems 1983, Part 10). Since 1980, the Maintenance Division has placed all disposal information in a computer data base known as the Waste Management Inventory-Manifest System. Tanker Logs, Trip Logs, and the Kardex Blanket File were discontinued at that time, although 2109s, 6538s, and Activity Reports continue to be generated and filed. The majority of this data base refers to material taken to the Y-12 Sanitary Landfill. Over 13,000 disposals to the Bear Creek Burial Grounds have been recorded. These entries, sorted in burial trench order, are detailed in Enerzy Systems 1983, Part 10.

From the use of these data sources an overall inventory of the Bear Creek Burial Grounds was prepared. There exists a certain amount of overlap between the various sources, and this overlap has been used to allow confirmation of some of the values. Although the inventory gives a fairly complete picture of wastes delivered to the Burial Grounds, there are two exceptions.

- No records have been found detailing the composition of disposals made in the initial trenches of Burial Ground 1. (These trenches later became Burial Ground A, trenches \#1 through \#5.)

- An inventory of materials placed in the $B$ and $C$ areas during the early 1960 s comes from an engineering drawing (E-CV-62373). Data from 1960-1964 are not accounted for in any other data source. Data after 1964 probably overlap with other information reported below, but the extent of this overlap is impossible to determine. 
The Maintenance Division's Activity Reports began reporting, in 1963, the number of blanket disposals made during a given month. This information has been tabulated, and a total of $-50,000$ blanket disposals over the past 20 years was obtained. The blanket disposal inventory accounts for 40,000 of these blanket disposals. Thus, $-80 \%$ oi the blanket disposals serviced by Maintenance over the past 20 years have been directly tabulated. Since blanket disposals account for only two-thirds of the total Bear Creek Burial Grounds disposals, the tabulated data accounts for approximately half ( $80 \%$ of two-thirds) of all disposals made at the Bear Creek Burial Grounds since 1963. The remaining 20\% of blanket disposals serviced by Maintenance since 1963 would be on Kardex Blanket File cards that have not been found. Even though the amounts remain unknown, however, the types of waste materials these cards would document are known. In some cases, these blankets were found in the Trip Log Sample and are 80 noted.

Hazardous disposals make up a very small amount of the total material sent to the Bear Creek Burial Grounds, but this small amount is of great potential interest. The great variety of materials found through tabulation of 2109 s and 6538 s does not lend itself to a summary inventory such as that presented for blanket disposals. The number of 2109s found corresponds closely with the number of individual hazardous disposals mentioned in the Maintenance Division's Activity Reports, so the records presented in this area are essentially complete for the time period covered.

The estimated one-third of all Bear Creek Burial Grounds traffic that is neither blanket nor hazardous disposals is roughly equivalent to the "DEBRIS" material type in the statistical estimates presented in Part 9 of Energy Systems 1983 for the 1965-1979 time period.

Another major source of information examined was Nuclear Materials Control and Accountability waybill records. These records document the movement of accountable nuclear materials such as uranium. In general, disposals documented in this system are also recorded in the various Maintenance Division records. However, a type of waybill known as a "741" allows separate identification of material that was shipped to $\mathrm{Y}-12$ from other installations for disposal since 1977.

\subsubsection{Burial Grounds closure activitics}

When RCRA Part A permit applications were submitted, trenches and disposal areas in the Burial Grounds that received hazardous waste after November 19, 1980, were designated and given interim status.

A variety of wastes have been disposed of in the interim-status units in the Burial Grounds. They include the following:

- Walk-in Pits-uranium metal saw fines, organics, and unspecified laboratory wastes.

- Isolation Area-solvents including aicohol, perchloroethylene, trichloroethylene, freon, and others.

- Trenches A-7 through A-12-mostly depleted uranium-contaminated solid waste, including wood, metal, paper, glass, debris, and others; smaller quantities of liquids including oils, machine coolants, and solvents.

- Rock Pits and Standpipes-6ome solvents and machine coolants. 


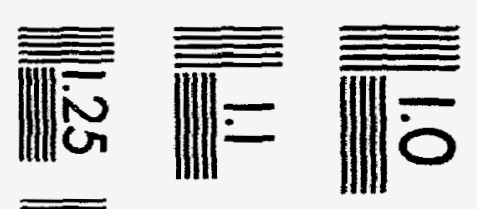

$$
\begin{aligned}
& \text { 咅言 }
\end{aligned}
$$

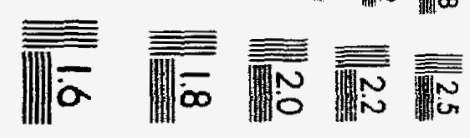



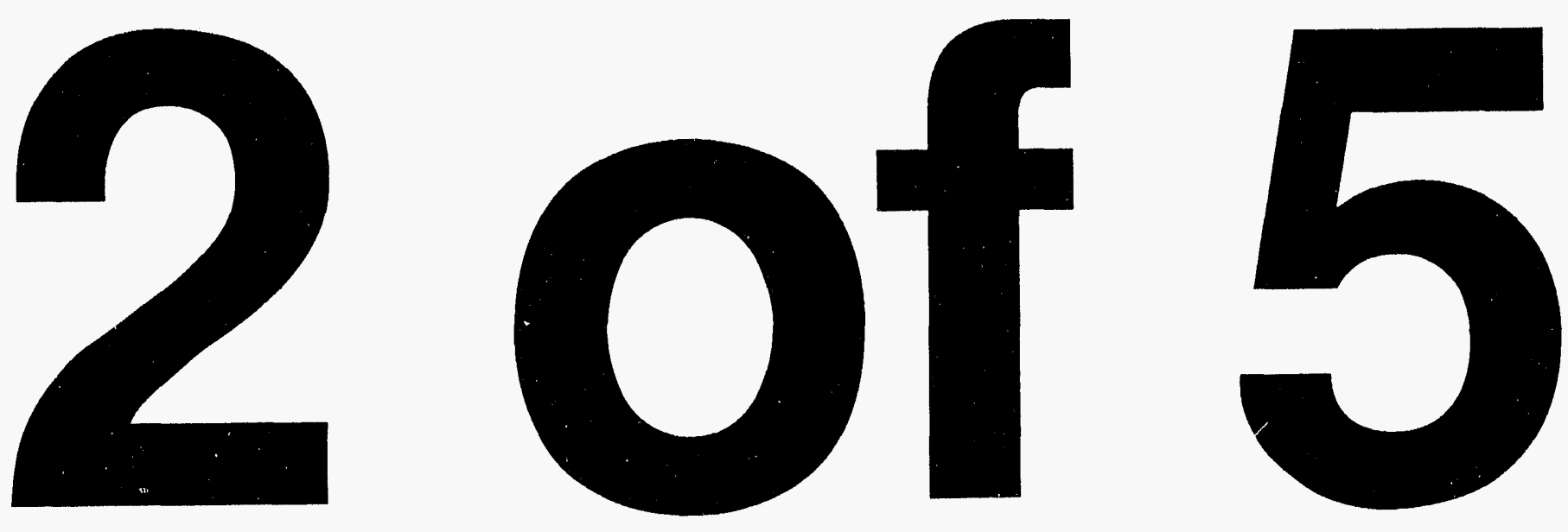
- Trenches C-18, C-20, and C-21-various types of solid wastes contaminated with beryllium, beryllium oxide, thorium, and enriched uranium, some contaminated with solvents; small quantities of acid.

BG-A and BG-C West were closed in place as a landfill and covered with an engineered cap under RCRA in 1989. At the time of this writing, a project was under way to cap BG-C East, BG-B, and the Walk-in Pits with a RCRA-style cap.

The Burial Grounds were granted interim status in December 1984 and therefore are subject to the groundwater monitoring requirements described in TN Rule 1200-1-11-.05. Prior to this date, groundwater monitoring at the site was conducted in accordance with two DOE monitoring programs. Historical monitoring at the site was conducted from 1975 until 1987 as part of a program to identify groundwater contamination sources at the Y-12 Plant. Characterization monitoring at the Burial Grounds began in 1983 in response to the MOU signed by DOE, EPA, and TDEC. The monitoring continued until 1986. Characterization at the site was performed to evaluate the extent of contamination in soils, stream sediments, groundwater, and surface water.

Groundwater quality data collected during historical and characterization monitoring verified the presence of contaminants in groundwater at the Burial Grounds. Therefore, interim status assessment monitoring was implemented at the site in lieu of detection monitoring. TDEC granted approval in November 1990 for the final closure of BG-A. The site was closed as an HWDU and is subject to postclosure care.

\subsubsection{ORPs}

The ORPs were constructed to prevent downstream transport of oil in Tributaries NT-6 and NT-7 (Fig. 2.6). Although overflow of mop water from standpipes had occurred previously, oil was first observed seeping from the west ends of trenches in BG-A into Tributary NT-7 and from the soil surface above the oil disposal pits, between 1969 and 1971. At this time, oil addition to the BG-A South trenches was discontinued (Bailey 1979). To prevent oil transport down Tributary NT-7 to Bear Creek, ORP 1, with maximum dimensions of $55 \mathrm{~m}(180 \mathrm{ft})$ in length, $34 \mathrm{~m}(110 \mathrm{ft})$ in width, and $2 \mathrm{~m}(6 \mathrm{ft})$ in depth, was constructed at the southwest corner of BG-A in May 1971. The pond was equipped with underflow pipes to permit water discharge while retaining floating oils in the impoundment. Simultaneously, a drainage ditch was constructed about 18 to $30 \mathrm{~m}(60$ to $100 \mathrm{ft})$ west of and parallel to the tributary, which rejoined Tributary NT-7 about $15 \mathrm{~m}(50 \mathrm{ft})$ south of the pond, to divert uncontaminated surface runoff around the pond. A sump was later dug at the western end of one of the trenches east of ORP 1 to collect oil, which was pumped into the pond; a pipe was also installed between the end of a second trench and the pond to permit direct oil transfer to the pond (Bailey 1979).

During the mid-1970s, oil seepage was observed from the west-facing slope west of trench A-14 into Tributary NT-7 (Bailey 1979). In 1974, $-57,000 \mathrm{~L}$ (15,000 gal) of oil were removed from the surface of ORP 1 ; an additional $19,000 \mathrm{~L}(5000 \mathrm{gal})$ were removed in early 1975. In 1979, an additional $68,000 \mathrm{~L}(18,000 \mathrm{gal})$ of oil were removed (Battelle 1986).

Oil seepage was observed on a steep slope above Tributary NT-6 at the eastern end of trenches A-14 and A-15 before 1972 (Bailey 1979), and in May 1972 a smaller impoundment, ORP 2, was constructed on Tributary NT-6 in the northeast corner of BG-A. No significant 
oil accumulation was reported on the surface of ORP 2 from 1975 to closure of the pond in 1989 (Battelle 1986).

Both ponds were closed and capped under an approved RCRA closure plan in 1989. During closure operations a total of $980 \mathrm{~m}^{3}\left(3,842 \mathrm{yd}^{3}\right)$ of sludge, sediment, and soil was excavated from ORP 1, ORP 2, and NT-7 (Collins 1990a). A total of 980 screening samples (rapid turnaround) was taken during excavation to guide removal activities. A total of 287 certification samples of remaining soils was taken, and all of the contaminated areas in ORP 1, ORP 2, and NT-7 were certified to have less than $25 \mathrm{ppb}$ PCBs with the exception of the seepage area (Seep 1, Fig. 2.6) to the west of BG-A North. In this area, higher-thananticipated concentrations of PCBs were encountered during excavation (1,200 ppb). This area was closed without achieving the $25 \mathrm{ppb}$ acceptance criteria. The ponds and the section of NT-7 north of ORP 1 were then covered with an engineered multilayered cap. The portion of NT-7 below ORP 1 was capped with a clay cap at this time. A new channel was constructed for NT-7 and this tributary was rerouted $-15 \mathrm{~m}(50 \mathrm{ft})$ to the west of its original course. As part of this effort, a seepage collection system was installed northeast of ORP 1 to intercept seepage from BG-A. The collection system consists of a gravity drain to a currently operational pump station.

The Burial Grounds are drained by Tributaries NT-6, NT-7, and NT-8. Seepage zones from adjacent burial areas have been observed on all three tributaries (Fig. 2.6); thus, all three may serve as sources for contaminant entry into Bear Creek and BCV groundwater. Seepage collection systems have been installed in NT-7 and NT-8 catchments to collect leachate from the Burial Grounds that seeps into surface water. Collection system $A$ is located in Tributary NT-7 and collects an average of $2 \mathrm{~L} / \mathrm{min}(0.5 \mathrm{gpm})$ from Seep 1 (Fig. 2.6). Collection system B, known as the Leachate Collection System (seeps 2, 3, and 4), is located in NT-8. Flow in system B is variable and may reach $76 \mathrm{~L} / \mathrm{min}(20 \mathrm{gpm})$ in rainy weather, whereas flow in system A shows little variation.

\section{RELEASES}

Releases from the Bear Creek source areas, as discussed in preceding sections, were the result of routine operations at land disposal units. Descriptions of releases to soil, sediments, surface water, and groundwater are provided in Chap. 3. 


\section{CHARACTERIZATION OF ENVIRONMENTAL SETTING AND SITE CONCEPTUAL MODEL}

This chapter provides detailed descriptions of the source areas that make up BCV OU 1: S-3 Ponds, SL 1. Boneyard/Burnyard, Oil Landfarm, and Burial Grounds (including ORPs 1 and 2). All of these sites are within the Bear Creek Hydrologic Regime (BCHR); a description of the hydrology of Bear Creek is also included in this chapter.

A substantial amount of sampling/analytical data (surface water, groundwater, and soil/sediment) exists for the BCHR and for the source areas in BCV OU 1. Although the bulk of the environmental monitoring data has been collected since 1982, some historical data from before 1982 are available. This chapter summarizes the environmental monitoring data relevant to the preparation of this document. Most of the data presented have been published or were summarized in previous reports (e.g., Turner et al. 1991).

Where surface water, groundwater, and soil data are discussed in subsequent sections, references are made to health and environmental assessment criteria. These include regulatory as well as guidance and advisory criteria. For example, maximum contaminant levels (MCLs) promulgated under the Safe Drinking Water Act (SDWA) represent one type of assessment criteria for use when evaluating monitoring data for surface water and groundwater. Concentrations of contaminants that are acutely or chronically toxic to aquatic life are another type of assessment criteria. Background concentrations of contaminants in an area of study represent yet another type of criteria.

Sampling and analytical methods for many environmental contaminants have been evolving rapidly over the past decade. Sampling and analytical QA/QC protocols also have become more rigorous during this period, and in some cases substantial amounts of $\mathrm{QA} / \mathrm{QC}$ data exist to accompany sampling/analytical data for units in BCV. These data include results for trip blanks, field blanks, equipment rinsate blanks, process blanks, field duplicates, blind splits, matrix spikes, and standard reference materials.

Evaluation of the quality of the environmental monitoring data for BCV revealed the concordance of results among the various sampling and analytical activities that have been performed in the Bear Creek watershed. Both the nature and concentrations of COCs were similar regardless of which group performed the sampling and analyses. For example, uranium concentrations in Bear Creek surface water are reported consistently by Bechtel National, Inc. (BNI); Roy F. Weston, Inc.; the U.S. Geologic Service (USGS); the Y-12 Plant; and ORNL to occur at levels up to $\sim 1.0 \mathrm{mg} / \mathrm{L}$ in the headwaters and to decrease to $\sim 0.05 \mathrm{mg} / \mathrm{L}$ downstream. This discussion should not be taken to imply that no sampling or analytical problems have occurred during previous monitoring of Bear Creek and its floodplain. The formal and informal $\mathrm{QA} / \mathrm{QC}$ protocols used by each investigative group have detected problems that were either corrected or the data were flagged as suspicious.

\subsection{GEOGRAPHY}

Descriptions of the geographic location of each unit in BCV OU 1 were presented in Chap. 2. BCV OU 1 is located between Bear Creek to the south and Pine Ridge to the north 
(plant grid directions, plant grid is $\sim 34^{\circ} \mathrm{W}$ of true north). Each unit is located on the southfacing slope of Pine Ridge, north of the Bear Creek main stem. Topographic relief varies from shallow near the valley floor, to steep in the highest elevations of the Burial Grounds (Fig. 3.1). Elevations within the study area range from 222 to $390 \mathrm{~m}$ (740 to $1300 \mathrm{ft}$ ) above mean sea level. Tributaries of Bear Creek have eroded V-shaped valleys in the south slope of the Pine Ridge. These valleys trend almost uniformly north-south and have generated localized relief with slopes toward the southeast and northwest.

Installation of caps on some waste sites has modified the local topography of individual units, details of which can be found in the Architect-Engineer Title III Reports for individual sites. In general, the caps have resulted in smooth topographic features: in the valley floors almost level areas of ground raised above the valley floor and on the sides of ridges, smooth mounds.

The S-3 Ponds are located at the head of Bear Creek watershed, close to the drainage divide between the UEFPC Hydrologic Regime and BCHR. The site has been capped and is now an almost level asphalt-covered parking lot located at the western end of the Y-12 Plant (Fig. 2.5).

The Oil Landfarm, SL 1, and Boneyard/Burnyard are all located on the lower slopes of Pine Ridge, near the valley floor west of the S-3 Ponds. A RCRA cap has been installed over the Oil Landfarm. A RCRA-style cap covers the HCDA, and a 0.6-m (2-ft)-thick clay cap covers SL 1. These caps are large, open, grass-covered areas that are almost level. The remainder of the Boneyard/Burnyard that is not capped is gently sloping, uneven ground.

The Burial Grounds occupy the upper and lower slopes of Pine Ridge, extending to the valley floor. RCRA caps have been installed on most of BG-A, on BG-C West, and on ORPs 1 and 2. The topographic relief at these sites is generally low, and the contours are gentle. BG-B and the Walk-in Pits, which have not been capped, occupy an elevated area between BG-A and BG-C. BG-D, BG-E, and BG-J have not been capped and occupy the steeper upper slopes of Pine Ridge above BG-C.

\subsection{CLIMATE}

Detailed discussions of climate can be found in Sect. 4.4 of Vol. I of the RCRA Facility Investigation Plan General Document for the Y-12 Plant (Welch 1989) and in Sect. 3.1 of the Clinch River RCRA Facility Investigation Plan (Energy Systems 1990). Oak Ridge, Tennessee, is part of the southeast climatological region of the United States. This region is characterized by a moderate continental forest climate with mild winters [coldest month above $0^{\circ} \mathrm{C}\left(32^{\circ} \mathrm{F}\right)$ but below $\left.18^{\circ} \mathrm{C}\left(64.4^{\circ} \mathrm{F}\right)\right]$. The Oak Ridge area has a temperate climate that is moderated by the Blue Ridge Mountains to the east and the Cumberland Plateau to the west.

Weather patterns in Oak Ridge are generally temperate, with warm, humid summers and cool winters. The annual mean temperature is about $15^{\circ} \mathrm{C}\left(58^{\circ} \mathrm{F}\right)$, with a January mean of about $3.5^{\circ} \mathrm{C}\left(38^{\circ} \mathrm{F}\right)$ and a July mean of about $25^{\circ} \mathrm{C}\left(77^{\circ} \mathrm{F}\right)$. Relative humidity in mid-afternoon averages about $55 \%$. At night humidity is higher, averaging $85 \%$ at dawn. 


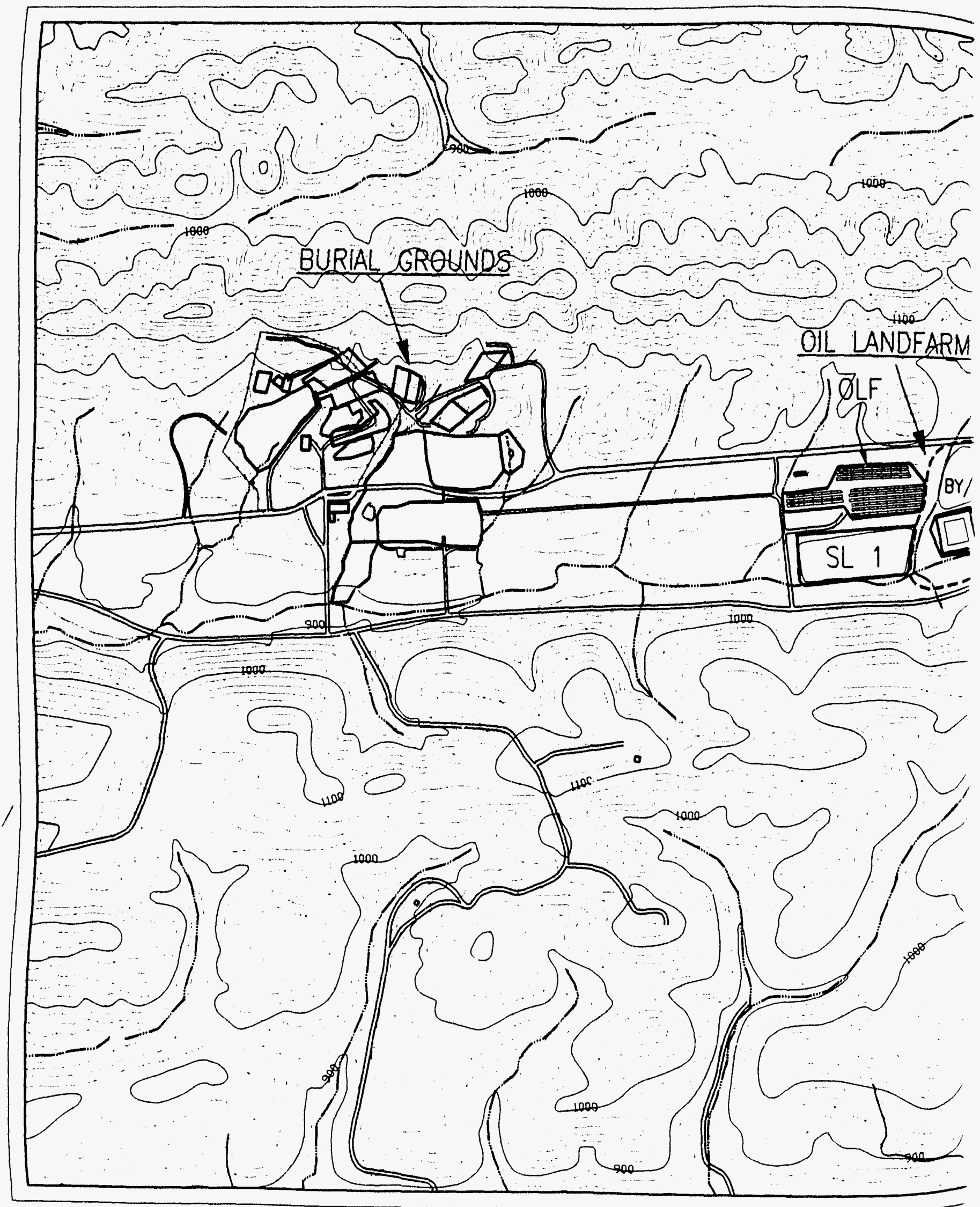

Fig. 3.1. Location of sites in $\mathrm{E}$ 


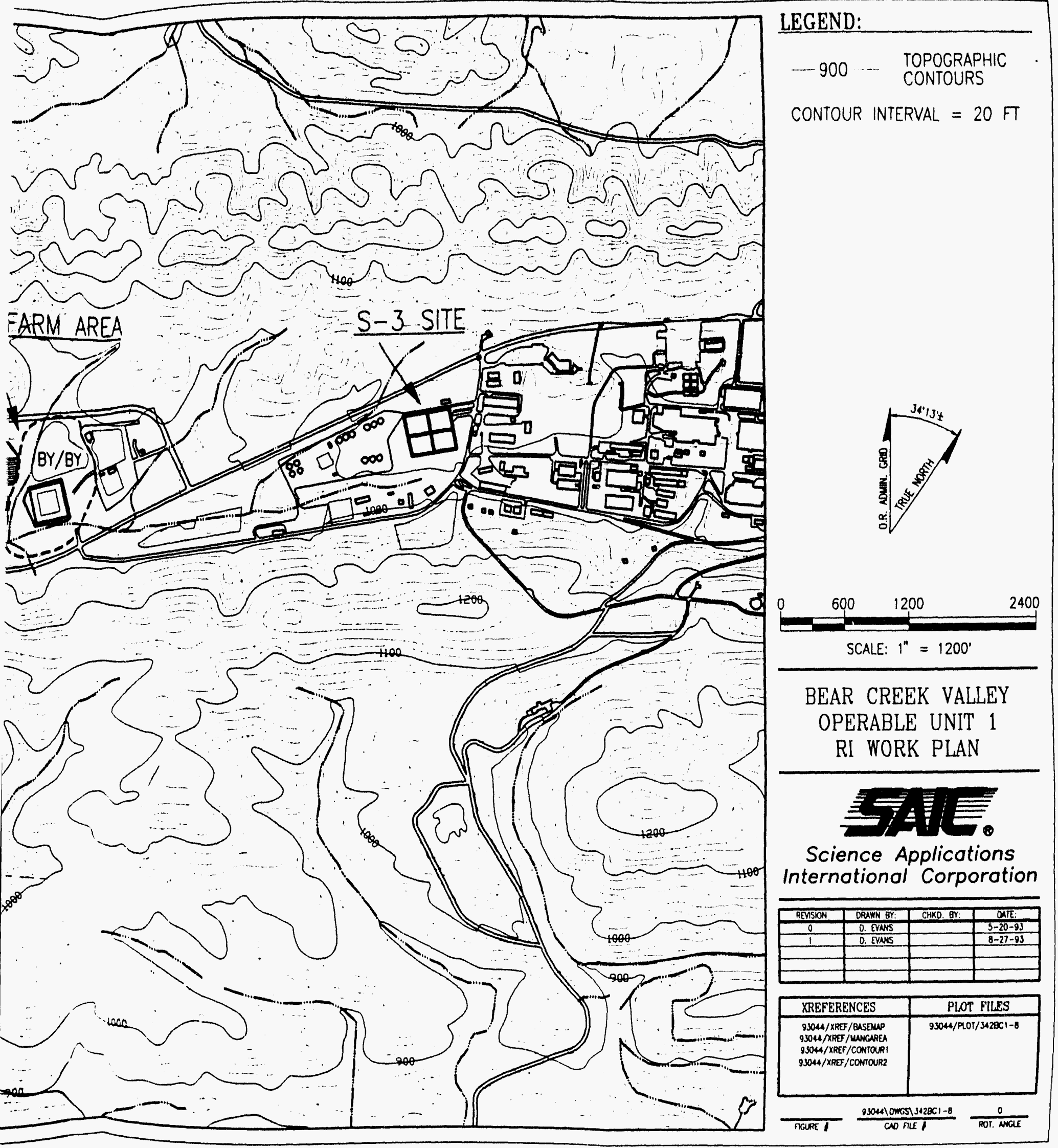

siics in BCV OU 1 and topographic relief in BCV. 
Precipitation in this portion of the Tennessee Valley is seasonally distributed (McMaster 1967). The mean annual rainfall is $-136 \mathrm{~cm}$ (54.4 in.) (Fig. 3.2), but during the drought of 1981-88, yearly precipitation fell below this average value. Winter months usually have the most rain, with another peak in July, when thunderstorms are common. Autumn is usually the season of lowest rainfall.

Precipitation data from the Walker Branch watershed, which is located $\sim 0.8 \mathrm{~km}(0.5$ mile) south of BCV, were used to estimate rainfall in BCV during 1984. In January 1985, Energy Systems installed the Burial Grounds rain gauge to provide daily precipitation data. Comparisons between these gauges have generated confidence concerning the validity of transferring precipitation data between the two catchments.

Average loss of water to the atmosphere by evapotranspiration is about $76 \mathrm{~cm}(30.4$ in.) annually in the Oak Ridge area, or about $55 \%$ of the total annual precipitation. Evapotranspiration is at a maximum from July to September, during the vegetative growing season. Runoff is greatest in the winter when evapotranspiration is at a minimum.

Prevailing winds in the area follow the general topography of the surrounding ridges (Fig. 3.3). The down-valley draft, coming from the northeast and identified with gravitational flow down local slopes and the Tennessee Valley, prevails during inversion conditions of late evening through mid-morning. Daytime up-valley flow is from the southwest when regional or synoptic flows aloft become strong enough to dominate the opposing local gravitational winds.

Oak Ridge is one of the country's calmest wind areas. Average wind speed for the Oak Ridge area is $7.1 \mathrm{kph}(4.4 \mathrm{mph})$. The Cumberland Plateau and the Smoky Mountains divert severe storms; local irregular ridges further minimize the air movement and wind impact.

\subsection{DEMOGRAPHY}

\subsubsection{Population Information}

The Y-12 Plant is located at the northeast boundary of the ORR across Pine Ridge from the commercial center of the city of Oak Ridge, which has a population of 27,310 (U.S. Department of Commerce 1991). As of June 1993, the Y-12 Plant employed 6190 full-time Energy Systems employees and $\sim 1000$ on-site employees of M-K Ferguson, DOE, and ORNL. No drinking water supplies are located within the ORR boundary. A pumping station located on the north bank of Melton Hill Lake at Clinch River supplies water to the Y-12 Plant water treatment facility and the city of Oak Ridge water treatment plant.

\subsubsection{Land Use}

The East Tennessee Development District, which includes the city of Oak Ridge, is rural in character. Knoxville is the district's regional center and the only city in the region with a population in excess of 50,000. Oak Ridge and other cities in the district are within the 7500 to 50,000 population range, are incorporated, and have a definite central core that provides major employment and trade opportunities. Of the district's $1,700,010$ ha $(4,200,800$ acres $), \sim 80 \%$ is in agricultural and forest land use (Table 3.1). 


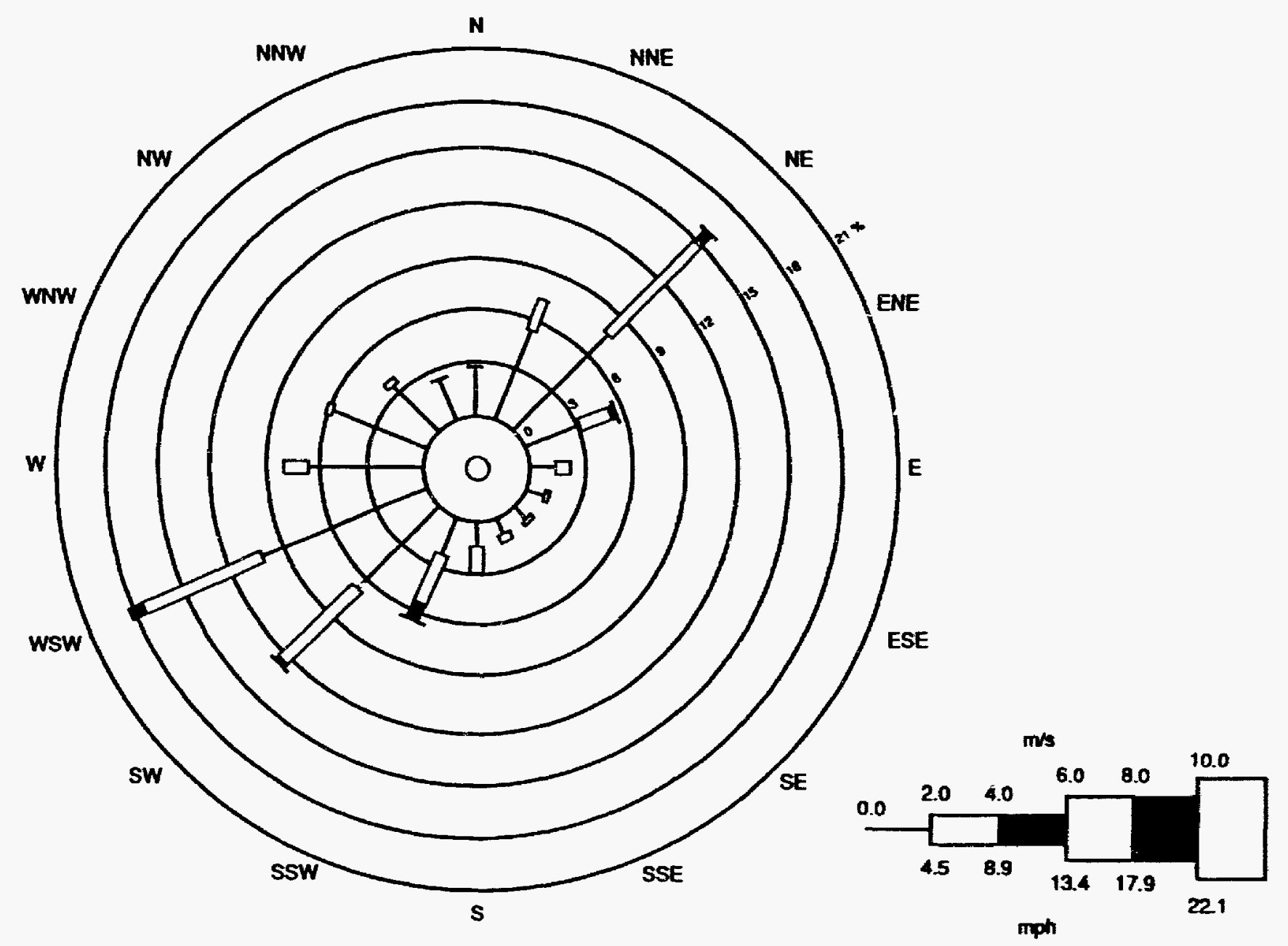

Fig. 3.3. 1990 wind rose for 10-m level at the west end of the Y-12 Ptant (Source: Energy Systems 1991). 
Table 3.1. Land use data for the Bastcrn Tennossee Development District

\begin{tabular}{|l|r|r|r||}
\hline \multicolumn{1}{|c|}{ Land use category } & \multicolumn{1}{c|}{ Hectares } & \multicolumn{1}{c|}{ Acres } & Percent \\
\hline Residential & 35,074 & 86,670 & 2.1 \\
\hline Commercial & 1,950 & 4,820 & 0.1 \\
\hline Industrial & 20,700 & 51,150 & 1.2 \\
\hline Recreational & 269,129 & 665,030 & 15.8 \\
\hline Agricultural & 685,904 & $1,694,900$ & 40.3 \\
\hline Public and quasi-public & 28,430 & 70,250 & 1.7 \\
\hline Forest & 658,823 & $1,627,980$ & 38.8 \\
\hline Total & $1,700,010$ & $4,200,800$ & 100.0 \\
\hline
\end{tabular}

Source: DOE 1982.

In contrast to the district's general land use patterns, the city of Oak Riuge is an urban center with minimal agricultural activities. Land not owned by the federal government consists of 5510 ha (13.615 acres) and is divided into more than 9500 parcels. Table 3.2 categorizes urban land use data for the city of Oak Ridge. Most of this land is either residential or vacant, and more than 1903 ha (4700 acres) of the vacant land is suitable for housing (DOE 1982).

Table 3.2. Urban land use data for the city of Oak Ridge, Tennessece

\begin{tabular}{||l|c|c|c||}
\hline \multicolumn{1}{|c|}{ Land use category } & Hectares & Acres & Percent \\
\hline Residential & 1,640 & 4,050 & 28.9 \\
\hline Vacant & 2,247 & 5,550 & 39.6 \\
\hline Recreational & 749 & 1,850 & 13.2 \\
\hline Commercial & 104 & 256 & 1.8 \\
\hline Industrial & 47 & 115 & 0.8 \\
\hline Public transportation, parking & 480 & 1,185 & 8.5 \\
\hline Private transportation & 33 & 82 & 0.6 \\
\hline Utilities and communications & 52 & 129 & 0.9 \\
\hline Services & 314 & 775 & 5.5 \\
\hline Total & 5,666 & 13,992 & 99.9 \\
\hline
\end{tabular}

-Excludes federally owned lands within the corporate city limits.

Source: DOE 1982. 
Several categoriex of land use are in elose proximity to the ORR. The nearest privalcly owned residential properties are in the Poplar Springs, Sugar Grove Valley, and Oak Ridge communities. Relative to ORR houndaries, Poplat Springs is localed $3.2 \mathrm{~km}(2 \mathrm{miles})$ west across the Clinch River, and Sugar Grove Valley is localed $2.4 \mathrm{~km}$ (1.5 miles) north. Other residential areas include Bradbury, Ldgeworod, and Lawnville. Bradbury is located across the Clinch River $-8 \mathrm{~km}$ (5 miles) south. Edgewored and Lawnville are localed immediately weal. northwest of the Poplat Springs community. Agricultural use includes limited-scale private gardening; raising of tobaceo, corn, wheat, and soybeans as cash crops: raising of hecf caltle. and dairy farming. Some areas are also used for commercial logging.

Industrial land use includes Phyton Technologies. Inc.; Scientific Ecology Group (SEG); and IT Corporation's Bear Creck Radiological Laboratory. SEG. Phyton, and the IT Corporation laboratory are within $3.2 \mathrm{~km}$ (2 miles) of the $\mathrm{Y}-12$ Plant. TVA facilities, including the Melton Hill Dam, the Bull Run Steam Plant, and the Kingston Steam Plant, are all more than $9.6 \mathrm{~km}$ (6 miles) from the Y.12 Plant.

Recreational areas near the ORR include the Watts Bar Lake Einhayment/Clinch River waterway, which is used as a recreational area by both pleasure boaters and fishermen; a number of small camping areas and boat launching ramps: a small dirt-surface racelrack located $-6.4 \mathrm{~km}$ (4 miles) south, which attracts several thousand spectators during the racing season; and a public swimming area $11.3 \mathrm{~km}$ (7 miles) southeast at Multon Hill Dam. There are no public recreational facilities, except the previously mentioned boat launching rump. within $3.2 \mathrm{~km}$ (2 miles) of the ORR. Sport hunting of gume birds and game animals oceurs seasonally in the region, and deer hunting is authorized on some parts of the ORR an a conservation measure.

The ORR lies within the corporate limits of the city of Oak Ridge. A buffer anne surrounds each of the facilities to provide security, space for expansion, and isolation from the general public. Tracts totaling $\sim 5666$ ha $(14,000)$ acres) are allocated around operating reactors, waste disposal areas, and streams that receive routine waste releases and burial ground seepages. Acreage used for high-voltage transmission lines, pipelines, transportation corridors, and security fences amounts 10$)-2023$ ha (5000 acres) (DOE 1982).

About $80 \%$ of the ORR is part of a comprehensive forest management program that divides the reservation into 27 compartments. These compartments range in size from 148 (1) 486 ha (365 to 1200 acres). Vegetational features unique to the area are excluded from timber harvest operations, and $\mathbf{4 0}$ individual sites are designated for environmental research.

The Y-12 Plant is situated at the eastern end of the ORR, adjacent to the commercial center of Oak Ridge and contains -324 ha ( 800 acres). Land uses associated with the Y.12 Plant facility include several waste storage or disposal areas, of which a parcel of $\sim 61$ ha (150 acres) serves as a sanitary waste landfill for solid wastes; -26 ha (65 acres) located west of the main plant within the Bear Creek watershed is used as a burial ground for low-level radioactively contaminated solid wastes generated by the Y.12 Plant; and -1.6 ha (4 acres) is an abandoned quarry outside the Bear Creek watershed that was formerly used as a disposal and dilution basin for selected nonradioactive chemical wastes, primarily sodium. lithium, and potassium from Y-12 Plant operations. 


\section{OBOLOXY AND SOILS}

\subsubsection{Cenerul Cexiknty}

The DOE ORR, which includes BCV OU 1, is located in East Tennessee within the Valley and Ridge Physiographic Province, part of the Appalachian fold and thrust belt (Fin 1.4). The area in characterized by a succession of east-west trending ridges and valleys, which formed as result of differential erosion of the southeast dipping (locally $45^{\circ}$ to vertical) clantic and carbonate lithologies that make up the individual thrust sheets.

BCV in bounded to the north and south (plant grid directions, plant grid is $\sim 34^{\circ} \mathrm{W}$ of Irue north) by Pine Ridge and Chestnul Ridge, respectivcly. Maximum relief of the ridges is $-91 \mathrm{~m}$ (3X) (i). Theac ridges and valleys are part of the White Oak Mountain (WOM) thrust sheel. which expowen Lower Cambrian to Ordovician rock units in this area (Fig. 3.4). The sirnilgraphy of the area. from oldest to youngest (and exposed from grid-north to grid-south), Includes the Lower Cambrian Rome Formation (exposed on Pine Ridge), the Cambrian Conasaugn Group (exposed in BCV), and the Knox Group (exposed on Chestnut Ridge). The Conmanga Group is further divided into six formations of alternating shale and carbonate-rich litholugien. From oldest to youngest these are the Pumpkin Valley Shale, the Friendship Formation, the Rogersville Shale, the Dismal Gap Formation, the Nolichucky Shale, and the Muynardville Limestone (Tuble 3.3).

BCV OU $I$ is underlain hy Cambrian limestones, shales, and siltstones of the Conasauga Group. Sandy shales and siltstones of the Rome Formation underlie Pine Ridge. Chestnut Kidge in formed on siliceous dolostones of the Knox Group. Bedrock throughout the valley to overlain by unconsolidated deposits of varying thickness and composition. Geologic exponure in generally poor, and the locations of geologic contacts in BCV have been inferred for the most part from borchole data (Fig. 3.5) (HSW 1992). The S-3 Site and the Oil Landfarm are located entirely on the Nolichucky Shale; the Boneyard/Burnyard and the SL I are licated partially on the Nolichucky Shale and partially on the Maynardville Limestone. The southern section of the Burial Grounds is located on Nolichucky Shale, and the remainder of the Burial Grounds overlies the Maryville Limestone, the Rogersville Shale, the Friendahip Formation, and the Pumpkin Valley Shale.

At the immediate headwaters of Bear Creek south of the S-3 Ponds, the creek bed lies in the upper Nolichucky Shale. Within $122 \mathrm{~m}(400 \mathrm{ft})$ to the southwest, the creek crosses the contact of the Nolichucky Shale-Maynardville Limestone and remains in the Maynardville Limestone along much of BCV, flowing roughly parallel to regional geologic strike (N55E).

\subsubsection{Stratigraphy}

The strata of greatest interest with respect to contaminant migration in groundwater are the formations of the Conasauga Group (Fig. 3.5), in particular the Maynardville Limestone Formation, which is considered to be part of the Knox aquifer (Solomon et al. 1992). The overlying unconsolidated material, resting on the weathered bedrock surface, is in continuity with this aquifer. For general descriptions of the stratigraphy of other units in the ORR, refer Io Hatcher et al. (1992) for an overview of the ORR geology; to Haase, Walls, and Farmer (1985) for the Conasauga Group and Rome Formation; to Lee and Ketelle (1987) for the Knox Group; and to Lee and Ketelle (1988) for the Chickamauga Group. 


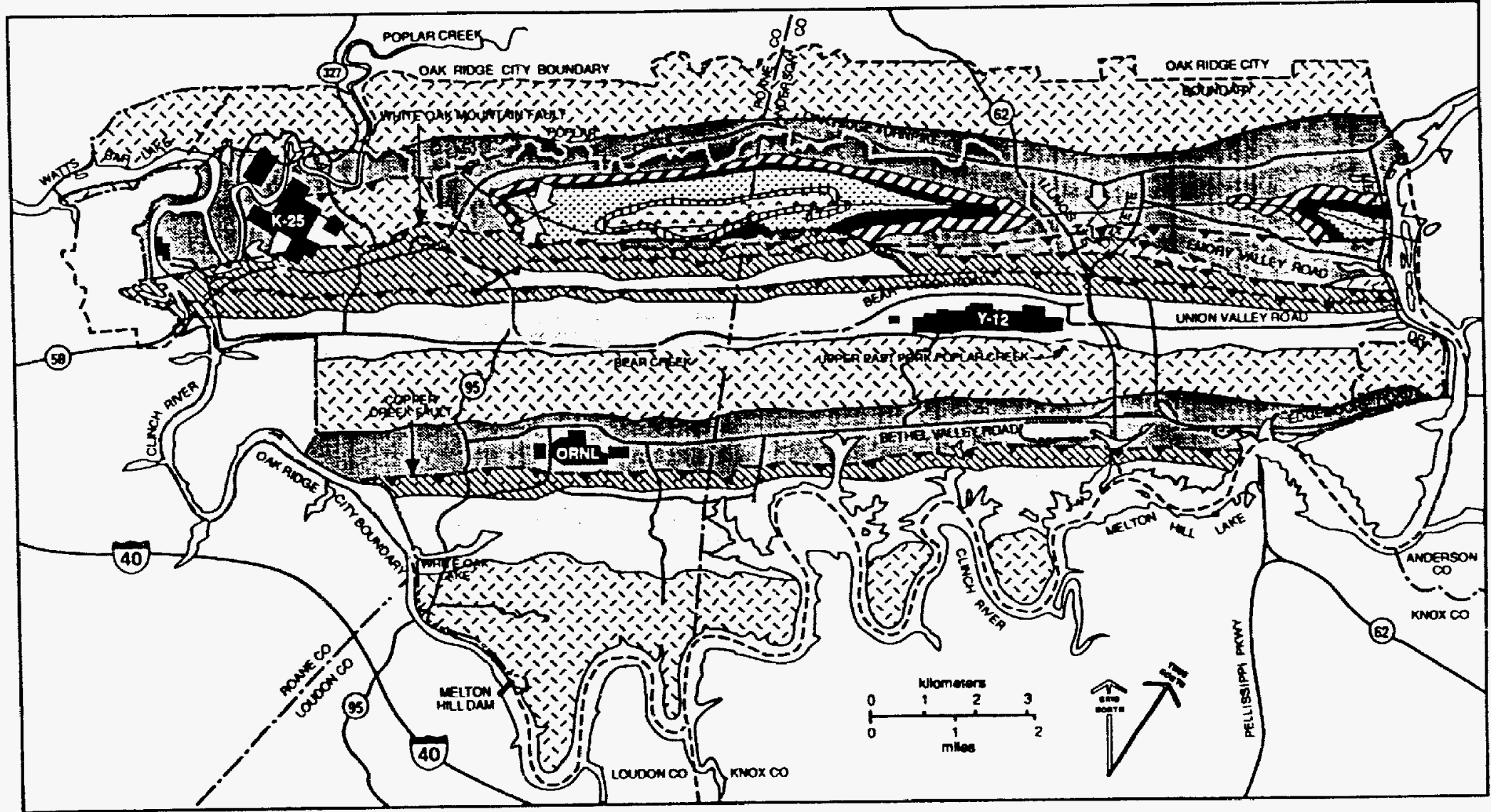

LEGEND

$\mathrm{H}$ Rockwood Formation Sr

Sequatchie Formation Os

DD Reedsville Shale Or

Ealis Chickamauga Limestone Och

$\rightarrow 3$ Knox Group OCk

$\exists$ Fort Payne Chert Mtp $\square$ Conasauga Group Cc

Rome Formation $\mathrm{Cr}$

IIIII) Chattanooga Shale MDC

res Fault Zone

X Syncline

Fig. 3.4. Bedrock goology for DOE ORR. 
Table 3.3. Stratigraphy of the Y-12 Plant area

\begin{tabular}{|c|c|c|c|c|}
\hline Age & Group or formation & $\begin{array}{l}\text { Thictnest } \\
\text { (ft) }\end{array}$ & Lithology and outcrop & $\begin{array}{l}\text { Aquifer/ } \\
\text { aquitard }\end{array}$ \\
\hline $\begin{array}{l}\text { Upper Cambrian- } \\
\text { Lower Ordovician }\end{array}$ & Knox Group & $530-880$ & $\begin{array}{l}\text { Massive dolomite, siliceous } \\
\text { dolomite, bedded chert, } \\
\text { limestone, some clastics; } \\
\text { outcrop on Chestnut Ridge }\end{array}$ & Knox Aquifer \\
\hline \multirow[t]{7}{*}{$\begin{array}{l}\text { Middle to Upper } \\
\text { Cambrian }\end{array}$} & \multicolumn{4}{|c|}{$\begin{array}{c}\text { Conasauga Group (outcrops in the center of BCV and on the South slope of Pine } \\
\text { Ridge) }\end{array}$} \\
\hline & $\begin{array}{l}\text { Maynardville } \\
\text { Limestone }\end{array}$ & $125-145$ & $\begin{array}{l}\text { Dolomitic limestone, } \\
\text { limestone }\end{array}$ & $\begin{array}{l}\text { Part of the } \\
\text { Knox Aquifer }\end{array}$ \\
\hline & Nolichucky Shale & $100-150$ & Shale, limestone & Aquitard \\
\hline & $\begin{array}{l}\text { Dismal Gap } \\
\text { Formation }\end{array}$ & $95-120$ & Limestone, shale & Aquitard \\
\hline & Rogersville Shale & 20-35 & Mudstone, shale & Aquitard \\
\hline & $\begin{array}{l}\text { Friendship } \\
\text { Formation }^{c}\end{array}$ & $30-40$ & Calcareous shale, limestone & Aquitard \\
\hline & $\begin{array}{l}\text { Pumpkin Valley } \\
\text { Shale }\end{array}$ & $90-100$ & $\begin{array}{l}\text { Shale, siltstone, occasional } \\
\text { sandstone }\end{array}$ & Aquitard \\
\hline Lower Cambrian & Rome Formation & $90-125$ & $\begin{array}{l}\text { Shale, siltstone, sandstone, } \\
\text { local dolomite lenses; } \\
\text { outcrops on Pine Ridge }\end{array}$ & Aquitard \\
\hline
\end{tabular}

${ }^{a}$ Onty thicknesses of formations at the Y-12 Plant are given.

${ }^{b}$ Formerly the Maryville Limestone.

'Formerly the Rutledge Limestone.

Source: Hatcher et. al. 1992.

The Conasauga Group conformably overlies the Rome Formation, a sequence of interbedded sandstones, siltstones, and shales of variegated olive, maroon, and drab colors that form Pine Ridge. On the ORR, the Conasauga Group is characterized by an interfingering of carbonate and clastic facies. In the vicinity of BCV OU 1 , the Conasauga Group varies in thickness between 523 and $576 \mathrm{~m}$ (1717 and $1890 \mathrm{ft}$ ). The following discussion provides descriptions for each of the six formations present in the Conasauga Group in BCV (Fig. 3.5).

Pumpkin Valley Shale. Oldest of the Conasauga Group formations, the Pumpkin Valley Shale crops out along the southeastern edges of ridges formed on the Rome Formation. Predominantly an olive and maroon, massive clay shale with thin beds of siltstone and sandstone, the Pumpkin Valley Shale is gradational with the underlying Rome Formation but lacks the sandstone that is characteristic of the Rome Formation. Two members of the Pumpkin Valley Shale have been identified (Law 1975), the upper one being more shale rich than the lower one. The lower member exhibits units that are commonly bioturbated or have wavy parallel stratification. The Pumpkin Valley Shale is a very tight formation that is considered one of the poorest aquifers in East Tennessee (DeBuchananne and Richardson 


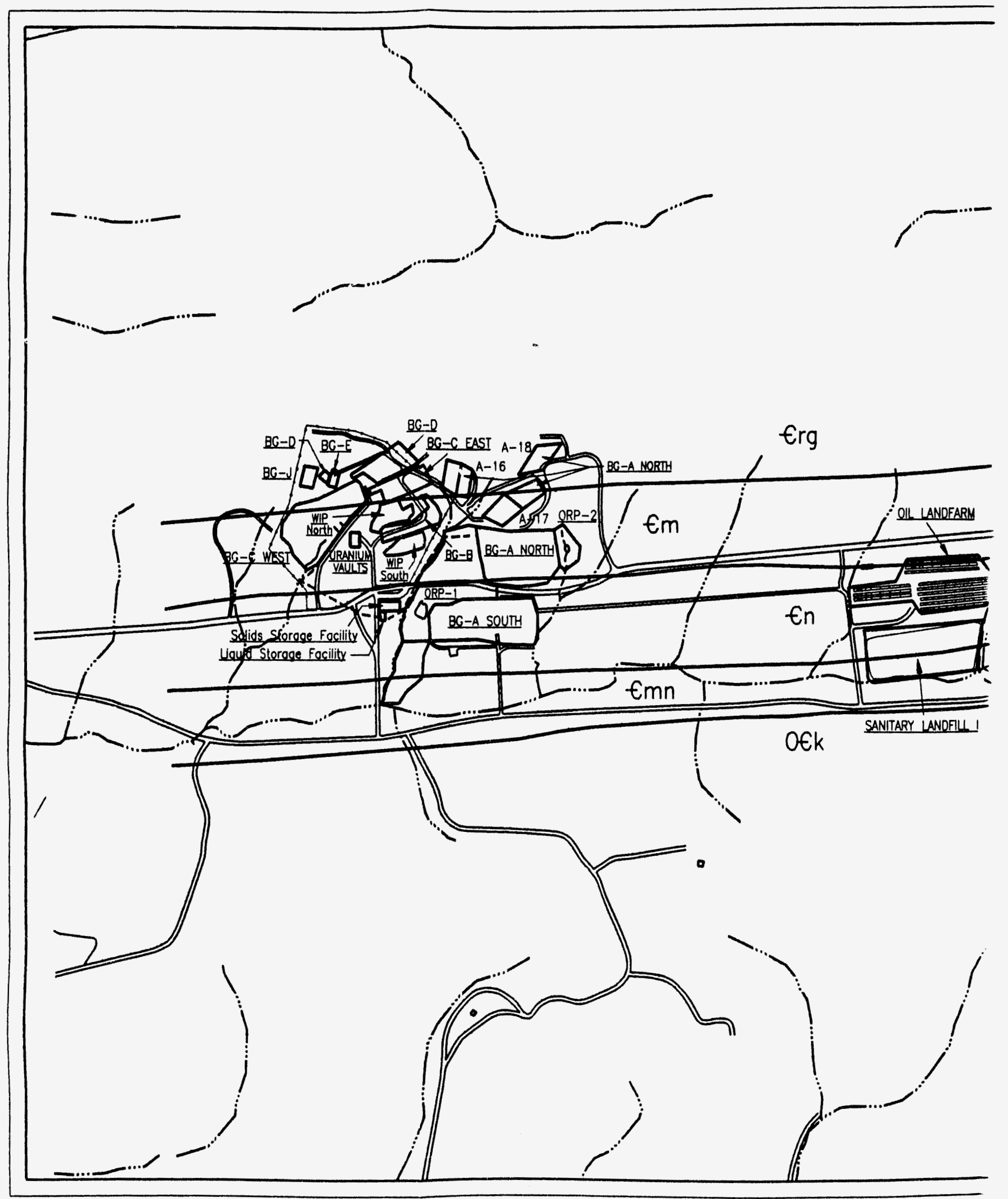

Fig. 3.5. Bedrock geolol 


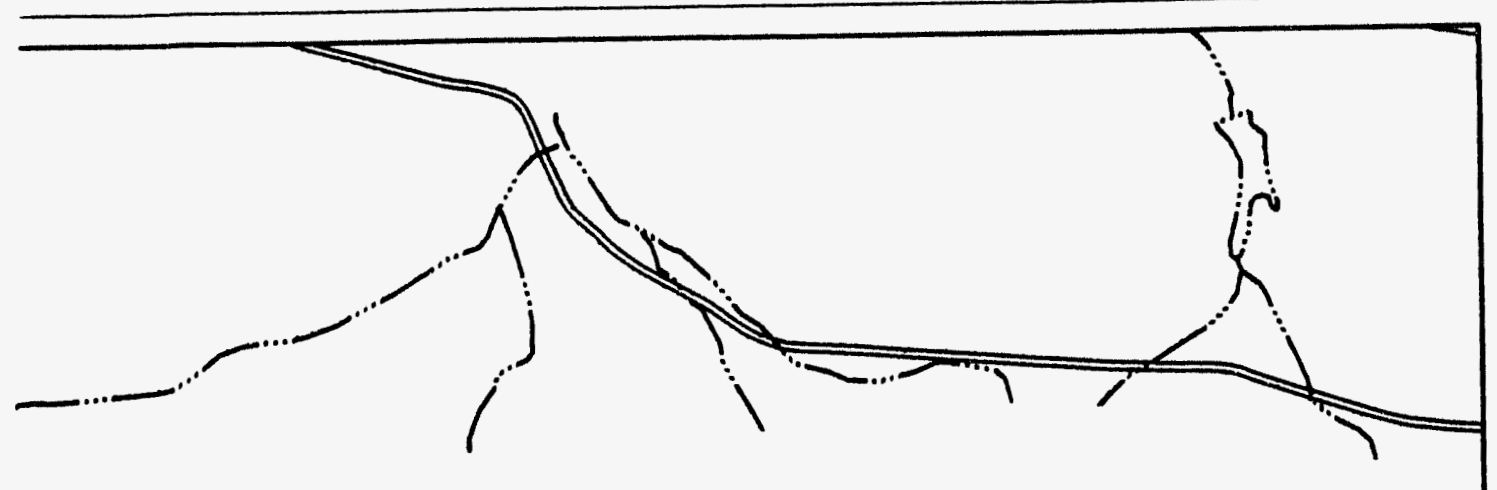

LEGEND:

APPROXIMATE GEOLOGIC CONTACT

OEK KNOX ÚROUP

Emn MA:NARDVILLE LIMESTONE

En NOLICHUCKY SHALE

Em MARYILLE LIMESTONE

Erg ROGERSVILLE SHALE
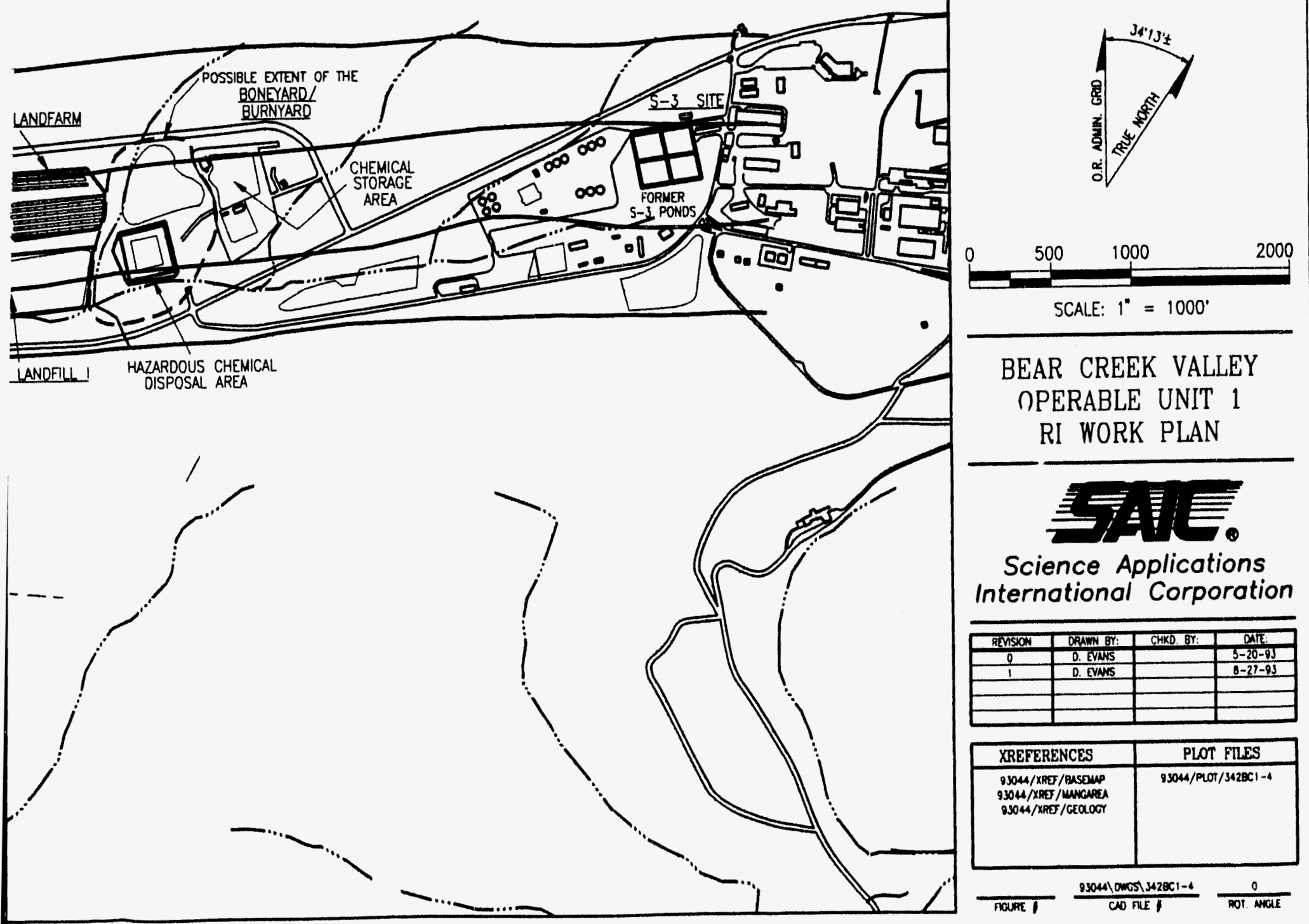

ck geology in BCV (Source: HSW 1992), 
1956). In the vicinity of BCV OU 1 , the formation is $\sim 79$ to $101 \mathrm{~m} \mathrm{(260} \mathrm{to} 330 \mathrm{ft})$ thick and weathers tc form a clay-rich soil with an abundance of shale chips. Soil color varies from reds and violets to green (Hatcher et al. 1992).

Friendship Formation. (Formerly referred to as the Rutledge Limestone.) In the vicinity of BCV OU 1, the Friendship Formation ranges in thickness from 30.5 to $35 \mathrm{~m}$ (100 to 115 $\mathrm{ft}$ ). The formation consists of light grey to white, medium to thinly bedded limestones and micritic limestones, which are interbedded with mudstones and shales that become more calcareous higher in the succession. A persistent, 1.5- to 3-m (5- to 10-ft)-thick bed of maroon to maroon-grey mudstone that occurs near the base of this formation serves as a marker bed within the lower Conasauga Group throughout BCV. Increased amounts of limestone distinguish the Friendship Formation from the overlying and underlying formations. Shale locally represents $75 \%$ of the Friendship Formation, which weathers to form a yellow-brown to yellow-orange soil.

Rogersville Shale. In the vicinity of BCV OU 1, the Rogersville Shale is $-31 \mathrm{~m}(100 \mathrm{ft})$ thick. This formation is comprised of massive to medium-bedded, noncalcareous mudstones, interbedded with brown shales. The shales and mudstones contain subordinate units of glauconitic and/or calcareous siltstones. The rocks of the Rogersville Shale weather to a thin light grey to light red, clayev soil containing shale chips (Hatcher et al. 1992).

Dismal Gap Formation. (Formerly referred to as the Maryville Limestone.) In the vicinity of BCV OU 1, the Dismal Gap Formation ranges in thickness from 116 to $136 \mathrm{~m}$ (382 to 445 $\mathrm{ft})$. The formation consists of light to dark grey, fine to coarsely crystalline limestone interbedded with calcareous shales and shaley-siltstones. The Dismal Gap Formation is informally divided into two members (Haase et al. 1985). The lower member consists of medium to thinly bedded calcareous mudstone interbedded with pelloidal or oolitic calcareous siltstones. Limestones appear as discrete beds in coarsening upward cycles.

The upper member of the Dismal Gap Formation is characterized by the presence of distinctive flat limestone-pebble conglomerates. In places, the intraclastic limestones are glauconitic or oolite-rich. Interbedded with the clastic limestones are siltstone, mudstone, and shale. soil.

Weathering of the Dismal Gap Formation produces a dark red to reddish-brown clayey

Nolichucky Shale. (Foreman et al. 1991; Rothschild et al. 1984.) In the vicinity of BCV OU 1, the Nolichucky Shale ranges in thickness from 161 to $168 \mathrm{~m} \mathrm{(528} \mathrm{to} 550 \mathrm{ft}$ ) (King and Haase 1987). Shale interbedded with intraclastic limestone, thick fossiliferous limestone, and oolitic limestone are characteristic of the Nolichucky Shale in the WOM thrust sheet. Shale is the dominant lithology with an approximate shale to limestone ratio of $1: 1.75$. The Nolichucky Shale Formation can be subdivided into four zones based on dominant lithologies: (1) thrombolytic limestone overlying oolitic limestone and lime mudstone in the uppermost Nolichucky; (2) laminated peloidal packstone, lime mudstone, and shale as the most abundant lithologies toward the top of the Nolichucky Shale; (3) allochthonous oolitic and skeletal packstone and grainstone interbedded with shale as the dominant lithologies in the middle Nolichucky Shale; and (4) intraclastic limestone interbedded with shale and calcareous siltstone as the dominant lithologies in the lower Nolichucky Shale (Foreman et al. 1991). The formation is massive to very thinly bedded and is characterized by a maroon-brown color. The 
interbedded limestones typically contain limestone-pebble conglomerates and oolite-rich beds similar to those occurring in the underlying Dismal Gap Formation. Throughout much of the Nolichucky Shale, mudstone/shale and limestone lithologies alternate on a scale of 0.3 to $0.9 \mathrm{~m}(1$ to $3 \mathrm{ft}$ ), giving the formation a thickly bedded appearance.

During drilling at the Y-12 Plant, solution cavities, opened fractures, and iron precipitate were commonly observed at downhole depths of up to $15 \mathrm{~m} \mathrm{(50} \mathrm{ft)} \mathrm{in} \mathrm{the} \mathrm{Nolichucky} \mathrm{Shale}$ (Rothschild et al. 1984). A comparison of Maynardville Limestone and Nolichucky Shale descriptions suggests the solution cavity development is not as extensive in the Nolichucky Shale as it is in the Maynardville Limestone.

Upon weathering, the Nolichucky Shale develops a brown to yellow color, clay-rich soil containing shale chips.

Maynardville Limestone. (Shevenell et al. 1992) The Maynardville Limestone is the youngest formation of the Conasauga Group and consists primarily of light-gray to tan, massive to thinly bedded limestone with subordinate amounts of dolostone. Data obtained from the ongoing Maynardville Exit Pathway Monitoring Program demonstrate that on the ORR, the Maynardville is more uniformly dolomitic and exhibits more subtle vertical lithologic differentiation than that described in the type section. In BCV, the Maynardville Formation varies in stratigraphic thickness from 70 to $136 \mathrm{~m} \mathrm{(230} \mathrm{to} 445 \mathrm{ft}$ ). The Exit Pathway Monitoring Program subdivided the Maynardville into six different informal lithologic zones and identified a seventh zone to mark the transition between the Maynardville Limestone and the overlying Copper Ridge Dolomite. The zones were divided based on the gamma log signatures and associated lithological characteristics of the individual zones.

The Maynardville Limestone occurs on the northern flanks of Chestnut Ridge and extends to the BCV axis. Much of the groundwater flow through the Maynardville Limestone is controlled by solutionally enlarged fractures and joint sets. Three major joint sets have been identified within the Maynardville Limestone: (1) approximately parallel to geologic strike and along bedding planes; (2) approximately perpendicular to geologic strike N10W and dips steeply; and (3) parallel to strike and perpendicular to bedding planes (Rothschild et al. 1984; Dreier et al. 1987). Dissolution along joints, fractures, and bedding planes in the Maynardville Limestone has formed solutionally enlarged zones, and in some cases, relatively large cavities that have greatly increased the overall permeability of the unit. The larger solution cavities generally occur in the upper part of the saturated zone. A combination of factors, such as structure, depth, and lithology, affect the fracture and water level distribution in the Maynardville Limestone. In general, however, the greatest likelihood of intersecting a cavity in the Maynardville Limestone occurs within Zone 6, whereas Zone 3 appears to be the least likely to contain cavities. Most of the cavities in Zones 6 through 2 were located at depths of $<30.5 \mathrm{~m}(100 \mathrm{ft})$, suggesting that the active karst system may be relatively shallow in the Maynardville Limestone.

\subsubsection{Unconsolidated materials}

Unconsolidated material overlying bedrock in the BCV consists of weathered bedrock (referred to as residuum), man-made fill, alluvium, and colluvium (Petrich et al. 1984). Residuum comprises a majority of the unconsolidated material in this area. The depths to unweathered bedrock differ throughout the valley because of the different thicknesses of fill and alluvium and the particular weathering characteristics of the bedrock units (Geraghty and 
Miller 1985). The total thickness of these materials in the BCV typically ranges from 3 to $15 \mathrm{~m}$ (10 to $50 \mathrm{ft}$ ) (Hoos and Bailey 1986). Figure 3.6 shows the distribution of different unconsolidated material types in BCV. Table 3.4 contains a summary of current soil background data taken from Phase I of the ORR Background Soil Characterization Project annual report (Energy Systems 1993b). Data from Phase II of this study will be available for the RI.

Much of the fill material consists of asphalt, cement blocks, wire, wood, plastic, excavated weathered shale, limestone, and chert intermixed with clay. In many places, a relict soil horizon has been noted below the fill. Rothschild et al. (1984) gives the following description of fill material in the subsurface at the Y-12 Plant: "Color ranges from grey to red brown to yellow brown and dark brown. Generally, it contains angular gravel-sized clasts of dolomite and weathered shale up to 2 in. across mixed with clay. In some cores, pieces of asphalt, wood roots, and wire are found in the fill. The percentage of dolomite and shale clasts varies greatly and ranges up to $\sim 90 \%$ in thin (less than 4 in.) zones. The shale clasts are often stained by manganese oxide and exhibit bedding structure. In some cores, the upper part of the fill is composed dominantly of dolomite clasts, and is highly porous and very unconsolidated. Compactness and consolidation of the fill increases with depth."

Alluvium is present in Bear Creek and its tributaries along present and former stream courses. The alluvium typically is an organic clayey silt with minor amounts of sandy clay, chert, and limestone pebbles. A thin layer of colluvium has been observed at the base of Pine Ridge and Chestnut Ridge in some areas. The colluvium is predominantly a clayey silt containing weathered rock fragments.

Residuum overlies bedrock throughout the valley except in scattered outcrop areas and ranges from silty to sandy clay overlying shale units to a slightly sandy clay overlying limestone units; predominant colors are shades of brown, orange, and grey. With increasing depth, the colors darken and the clay grades to weathered rock that has retained its structural characteristics (saprolite). Bedding planes and joint surfaces in the weathered bedrock commonly are marked by dark reddish-brown and yellow-brown oxide coloration, indicative of a high degree of weathering by circulating groundwater (Rothschild et al. 1984).

Soils of particular importance to BCV OU 1 are those that characteristically develop on the Conasauga Group. These soils include, but are not limited to, the Armuchee, Fullerton, Greendale, Hamblen, Jefferson, Leadvale, Newark, and Sequoia series. Depth to bedrock in the vicinity of BCV OU 1 typically varies from $<3 \mathrm{~m}$ to $9 \mathrm{~m}$ (10 to $30 \mathrm{ft}$ ), with the Montevallo series being the most shallow soil type (Lietzke, Lee, and Lambert 1988). In general, these soils are classed as poor for crop growth or pasture. With the exception of a few areas that are suitable for pasture, the general classification of Y-12 Plant soils is for forestry. In the vicinity of BCV OU 1, the Armuchee and Sequoia soil series are most prevalent. The Armuchee is a shaley, silty clay loam becoming more shaley with depth, and the Sequoia is a yellowish-brown silt loam overlying a residuum of acid shale. Chemical and physical properties of these soils are given in Tables 3.5 and 3.6 (Welch 1989).

\subsubsection{Structural geology}

The Oak Ridge area is underlain by two major northeast/southwest trending thrust faults that dip to southeast and define thrust sheets (Hatcher et. al. 1992) (Fig. 3.7). Pine Ridge, 


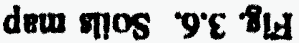

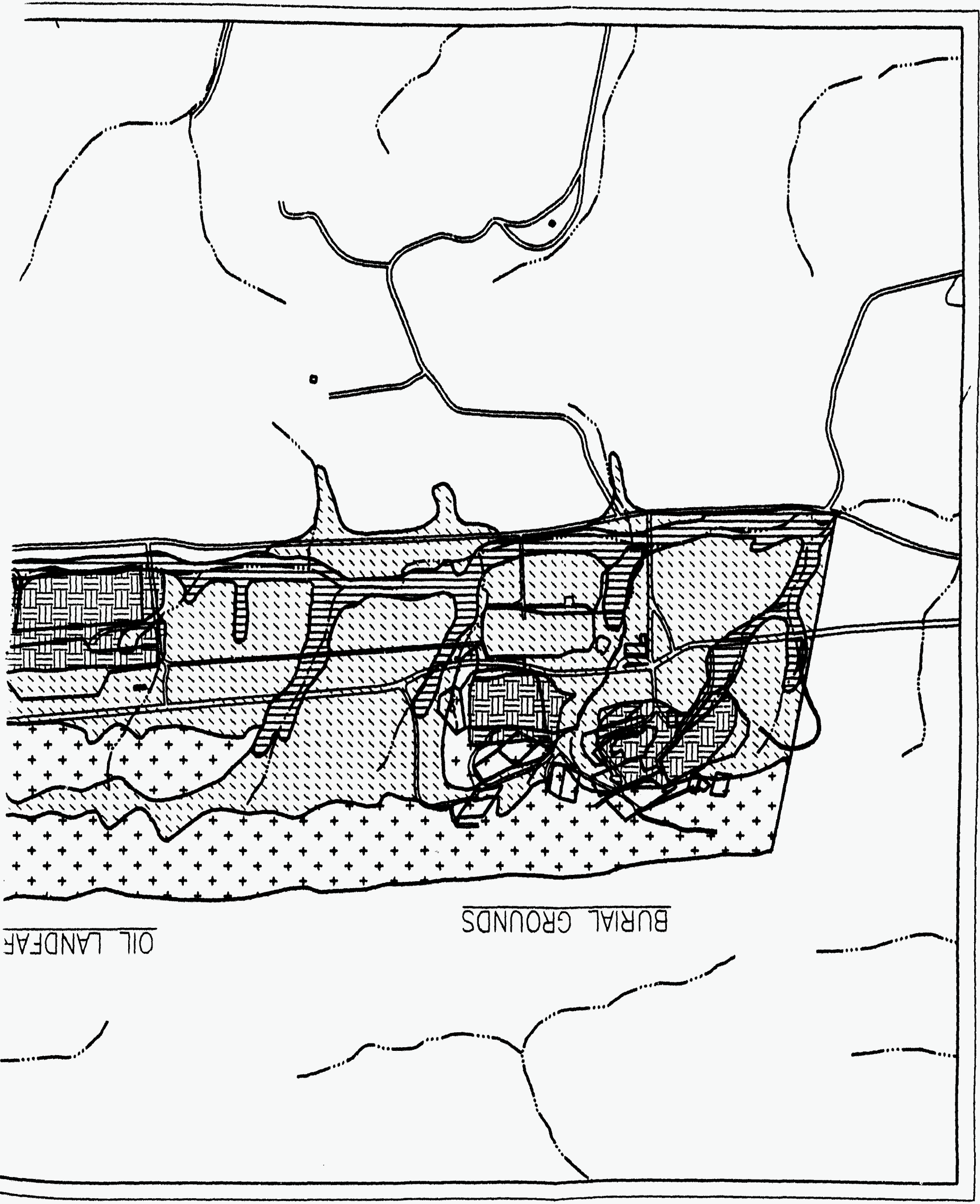

1 


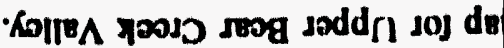

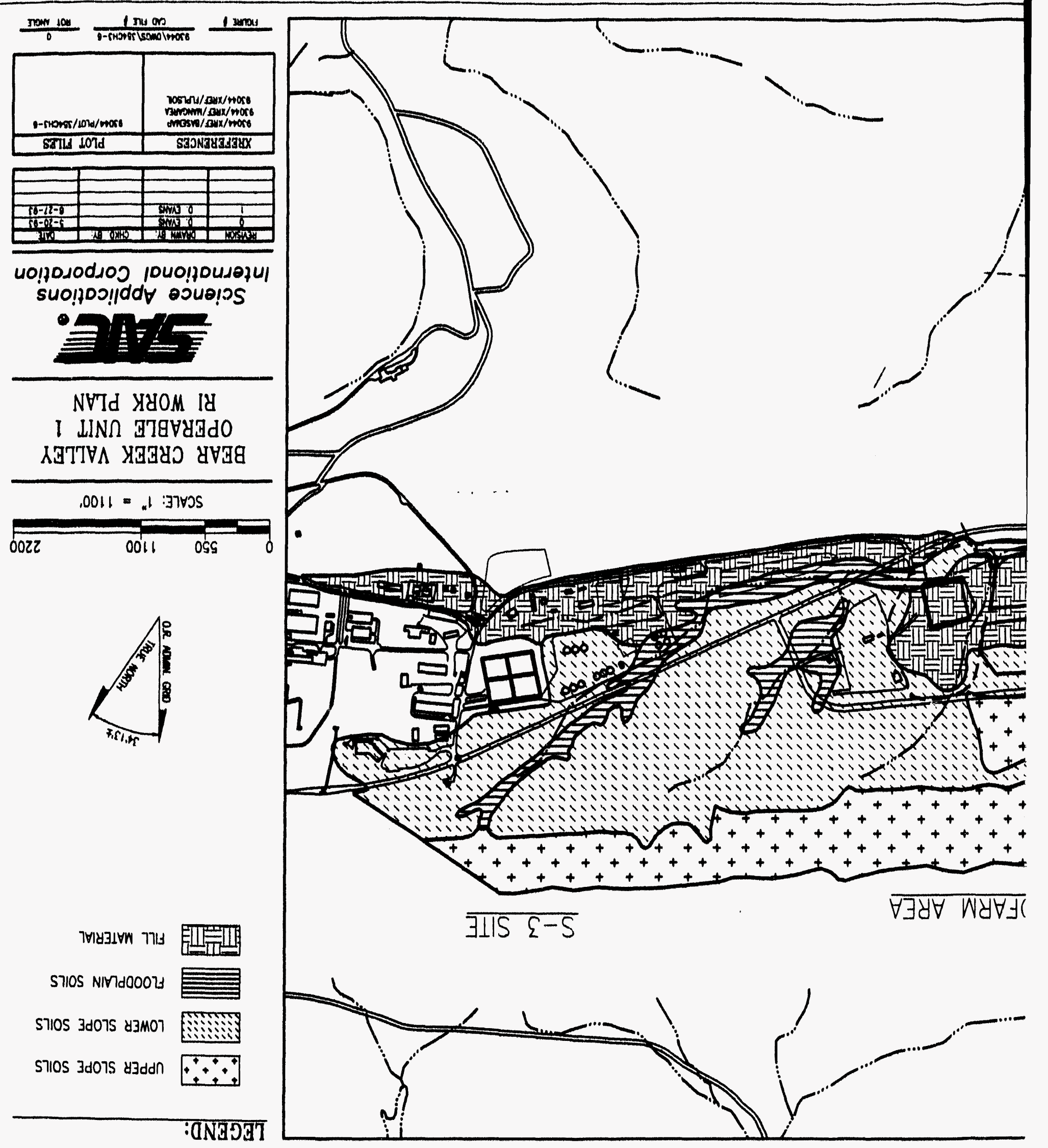


Table 3.4. Oak Ridge Reservation background soll analytes evaluated quantitatively and qualitatively"

\begin{tabular}{|c|c|c|c|c|c|}
\hline Anatyte & $\begin{array}{c}\text { Froquency } \\
\text { of } \\
\text { detection }\end{array}$ & $\begin{array}{c}\text { Minimum } \\
\text { detceted } \\
\text { concentration }\end{array}$ & $\begin{array}{c}\text { Maximum } \\
\text { detected } \\
\text { concentration }\end{array}$ & $\begin{array}{c}\text { Median } \\
\text { detected } \\
\text { concentration }\end{array}$ & $\begin{array}{l}\text { Upper } 95 \% \\
\text { confidence } \\
\text { bound on } \\
\text { the median }\end{array}$ \\
\hline \multicolumn{6}{|c|}{ Dismal Gap-quantitatively } \\
\hline \multicolumn{6}{|c|}{ Inorganics (mg/kg) } \\
\hline Arsenic & $4 / 4$ & 5.300 & 7.300 & 6.23910 & 10.3490 \\
\hline Barium & $4 / 4$ & 77.20 & 212.0 & 99.0600 & 124.690 \\
\hline Beryllium & $4 / 4$ & 0.550 & 2.200 & 0.78063 & 0.99871 \\
\hline Boron & $1 / 3$ & 16.40 & 21.10 & 13.5410 & 23.3130 \\
\hline Chromium VI & $4 / 4$ & 19.40 & 32.10 & 24.6530 & 54.3050 \\
\hline Cyanide & $1 / 3$ & 0.440 & 0.440 & 0.13003 & 0.28146 \\
\hline Manganese & $4 / 4$ & 768.0 & 2220 & 997.070 & 1347.50 \\
\hline Mercury & $4 / 4$ & 0.230 & 0.400 & 0.31591 & 0.34211 \\
\hline Mercury (salts) & $4 / 4$ & 0.230 & 0.400 & 0.31591 & 0.34211 \\
\hline Nickel & $4 / 4$ & 19.50 & 56.70 & 23.4810 & 27.9970 \\
\hline Nickel (salts) & $4 / 4$ & 19.50 & 56.70 & 23.4810 & 27.9970 \\
\hline Strontium & $3 / 3$ & 6.100 & 16.80 & 7.93480 & 10.2180 \\
\hline Vanadium & $4 / 4$ & 27.90 & 54.00 & 34.1560 & 36.8490 \\
\hline Zinc & $4 / 4$ & 42.30 & 108.0 & 50.6480 & 58.1260 \\
\hline \multicolumn{6}{|c|}{ Radionuclides ( $\mathrm{pCl} / \mathrm{g}$ ) } \\
\hline Cesium-137 & $4 / 4$ & 0.0210 & 0.900 & 0.59825 & 2.47050 \\
\hline Europium-155 & $4 / 4$ & 0.0840 & 0.110 & 0.09480 & 0.10530 \\
\hline Potassium-40 & $4 / 4$ & 14.000 & 22.00 & 16.3465 & 20.3483 \\
\hline Radium-226 & $4 / 4$ & 0.7000 & 0.860 & 0.78646 & 0.96091 \\
\hline Thorium-228 & $4 / 4$ & 0.5000 & 0.940 & 0.71322 & 0.86202 \\
\hline Thorium-230 & $4 / 4$ & 0.3100 & 0.830 & 0.56516 & 0.71725 \\
\hline Thorium-232 & $4 / 4$ & 0.4100 & 0.970 & 0.68310 & 0.81335 \\
\hline Thorium-234 & $4 / 4$ & 1.5000 & 1.900 & 1.63470 & 1.77100 \\
\hline $\begin{array}{l}\text { Uranium- } \\
233 / 234\end{array}$ & $4 / 4$ & 0.6100 & 1.400 & 0.93725 & 1.08890 \\
\hline Uranium-235 & $4 / 4$ & 0.0569 & 0.120 & 0.07919 & 0.09499 \\
\hline Uranium-238 & $4 / 4$ & 0.7500 & 1.700 & 1.02470 & 1.1549 \\
\hline
\end{tabular}


Table 3.4 (continued)

\begin{tabular}{|c|c|c|c|c|c|}
\hline Analyte & $\begin{array}{l}\text { Frequency } \\
\text { of } \\
\text { detection }\end{array}$ & $\begin{array}{l}\text { Minimum } \\
\text { detected } \\
\text { concentration }\end{array}$ & $\begin{array}{l}\text { Maximum } \\
\text { detected } \\
\text { concentration }\end{array}$ & $\begin{array}{c}\text { Median } \\
\text { detected } \\
\text { concentration }\end{array}$ & $\begin{array}{l}\text { Upper 95\% } \\
\text { confidence } \\
\text { bound on } \\
\text { the median }\end{array}$ \\
\hline \multicolumn{6}{|c|}{ Dismal Gap-qualitatively } \\
\hline \multicolumn{6}{|c|}{ Inorganics (mg/kg) } \\
\hline Aluminum & $4 / 4$ & 16900 & 44300 & 20656 & 23311 \\
\hline Calcium & $2 / 4$ & 991 & 1860 & 907.04 & 1320.6 \\
\hline Chromium & $4 / 4$ & 19.4 & 32.10 & 24.653 & 54.305 \\
\hline Cobalt & $4 / 4$ & 11.3 & 36.7 & 14.523 & 19.363 \\
\hline Copper & $4 / 4$ & 12.4 & 30.1 & 16.137 & 18.339 \\
\hline Iron & $4 / 4$ & 23800 & 49000 & 29438 & 32946 \\
\hline Lead & $4 / 4$ & 14.6 & 35.4 & 20.306 & 47.993 \\
\hline Lithium & $3 / 3$ & 12.7 & 27.0 & 16.165 & 18.753 \\
\hline Magnesium & $4 / 4$ & 2090 & 7430 & 2845.9 & 3505.9 \\
\hline Potassium & $4 / 4$ & 1890 & 5390 & 2300.3 & 2815.1 \\
\hline Silicon & $4 / 4$ & 461 & 697 & 505.90 & 563.01 \\
\hline Sulfate & $3 / 3$ & 28.0 & 163 & 86.736 & 110.92 \\
\hline Thallium & $1 / 4$ & 0.790 & 0.790 & 0.16355 & 0.60786 \\
\hline \multicolumn{6}{|c|}{ Nolichucky-quantitatively } \\
\hline \multicolumn{6}{|c|}{ Inorganics (mg/kg) } \\
\hline Antimony & $1 / 4$ & 0.490 & 0.490 & 0.46320 & 0.48482 \\
\hline Arsenic & $3 / 4$ & 5.800 & 6.400 & 3.08630 & 5.14460 \\
\hline Barium & $4 / 4$ & 59.70 & 106.0 & 75.3620 & 94.8610 \\
\hline Beryllium & $4 / 4$ & 0.730 & 0.850 & 0.78616 & 1.00580 \\
\hline Chromium VI & $3 / 4$ & 26.40 & 29.90 & 9.37800 & 20.8120 \\
\hline Manganese & $4 / 4$ & 405.0 & 935.0 & 653.480 & 883.140 \\
\hline Mercury & $4 / 4$ & 0.180 & 0.190 & 0.18493 & 0.20027 \\
\hline Mercury (salts) & $4 / 4$ & 0.180 & 0.190 & 0.18493 & 0.20027 \\
\hline Nickel & $4 / 4$ & 15.20 & 20.00 & 17.2860 & 20.6100 \\
\hline Nickel (salts) & $4 / 4$ & 15.20 & 20.00 & 17.2860 & 20.6100 \\
\hline Selenium & $3 / 4$ & 0.560 & 0.740 & 0.56611 & 0.71345 \\
\hline Strontium & $4 / 4$ & 3.200 & 6.100 & 4.5520 & 5.66690 \\
\hline Vanadium & $4 / 4$ & 29.40 & 35.20 & 32.4070 & 34.9620 \\
\hline Zinc & $4 / 4$ & 33.90 & 40.70 & 37.8920 & 43.4870 \\
\hline
\end{tabular}


Table 3.4 (continuod)

\begin{tabular}{|c|c|c|c|c|c|}
\hline Analyze & $\begin{array}{l}\text { Frequency } \\
\text { of } \\
\text { detection }\end{array}$ & $\begin{array}{l}\text { Minimum } \\
\text { detectcd } \\
\text { concentration }\end{array}$ & $\begin{array}{l}\text { Maximum } \\
\text { detectod } \\
\text { concentration }\end{array}$ & $\begin{array}{c}\text { Median } \\
\text { detected } \\
\text { concentration }\end{array}$ & $\begin{array}{l}\text { Upper } 95 \% \\
\text { confidence } \\
\text { bound on } \\
\text { the median }\end{array}$ \\
\hline \multicolumn{6}{|c|}{ Radionuclides (pCi/g) } \\
\hline Cesium-137 & $4 / 4$ & 0.38000 & 0.7100 & 0.52689 & 2.17570 \\
\hline Curium-247 & $2 / 4$ & 0.00530 & 0.0070 & 0.00552 & 0.00649 \\
\hline Europium-155 & $4 / 4$ & 0.08400 & 0.0980 & 0.08955 & 0.09947 \\
\hline Potassium-40 & $4 / 4$ & 14.0000 & 17.000 & 15.1952 & 18.9151 \\
\hline Radium-226 & $4 / 4$ & 0.39000 & 1.4000 & 0.74007 & 0.90422 \\
\hline Thorium-228 & $4 / 4$ & 1.20000 & 2.2000 & 1.50820 & 1.82290 \\
\hline Thorium-230 & $4 / 4$ & 0.85000 & 1.2000 & 0.96648 & 1.22660 \\
\hline Thorium-232 & $4 / 4$ & 1.20000 & 2.0000 & 1.49480 & 1.77980 \\
\hline Thorium-234 & $4 / 4$ & 1.30000 & 1.5000 & 1.42250 & 1.54120 \\
\hline Uranium-235 & $4 / 4$ & 0.04320 & 0.0969 & 0.07127 & 0.08549 \\
\hline \multicolumn{6}{|c|}{ Nolichucky-qualitatively } \\
\hline \multicolumn{6}{|c|}{ Inorganics (mg/kg) } \\
\hline Aluminum & $4 / 4$ & 20800 & 25100 & 22189 & 25041 \\
\hline Calcium & $2 / 4$ & 498 & 952 & 490.00 & 734.28 \\
\hline Chromium & $3 / 4$ & 26.40 & 29.90 & 9.3780 & 20.812 \\
\hline Cobalt & $4 / 4$ & 11.1 & 17.5 & 14.446 & 19.262 \\
\hline Copper & $4 / 4$ & 11.0 & 12.7 & 11.701 & 13.298 \\
\hline Iron & $4 / 4$ & 23000 & 32100 & 27901 & 31226 \\
\hline Lead & $3 / 4$ & 15.3 & 20.4 & 5.5086 & 13.131 \\
\hline Lithium & $4 / 4$ & 7.60 & 15.5 & 10.926 & 12.426 \\
\hline Magnesium & $4 / 4$ & 1730 & 2410 & 2008.0 & 2473.7 \\
\hline Potassium & $4 / 4$ & 2640 & 3230 & 2949.8 & 3610.1 \\
\hline Silicon & $4 / 4$ & 185 & 328 & 244.69 & 272.31 \\
\hline Sulfate & $4 / 4$ & 14.1 & 25.4 & 18.657 & 23.085 \\
\hline
\end{tabular}

'Source: Energy Systems 1993b. 
Table 3.5. Soll chemical propertice

\begin{tabular}{|c|c|c|c|c|c|}
\hline \multirow[b]{2}{*}{ Soll group } & \multicolumn{2}{|c|}{ Corrosivity } & \multirow[b]{2}{*}{ pH mage } & \multicolumn{2}{|c|}{$\begin{array}{c}\text { Estimuled cation } \\
\text { exchange capacity (CEC) }\end{array}$} \\
\hline & Stocl & Concrete & & Surface & Subuoll \\
\hline \multicolumn{6}{|c|}{ Residuum } \\
\hline Rome & low & mod.high & $4.5-6.0$ & $5-15$ & $10-20$ \\
\hline Conasauga & $\bmod$ & $\bmod$ & $4.5-6.0$ & $10-15$ & $15-20$ \\
\hline Knox & high & $\bmod \cdot h i g h$ & $4.5-5.5$ & $5-10$ & $8-20$ \\
\hline \multicolumn{6}{|c|}{ Colluvium } \\
\hline Rome/Conasauga & low-mod & mod.high & $4.5-6.0$ & $5-10$ & $5-10$ \\
\hline Knox & $\bmod$ & $\bmod$ & $4.5-5.5$ & $5-10$ & $5-10$ \\
\hline \multicolumn{6}{|c|}{ Alluvium } \\
\hline Holocene/Modern & mod-high & low.mod & $4.5-7.8$ & $5-10$ & $5-10$ \\
\hline Pleistocene & $\bmod$ & $\bmod$ & $4.5-5.5$ & $5-10$ & $5-10$ \\
\hline
\end{tabular}

Data from Lietzke el al. 1988.

Milliequivalents per $100 \mathrm{~g}$ of soil.

BCV, and Chestnut Ridge all are part of the WOM thrust sheet, which is soled by the WOM thrust fault. The WOM fault is a regional thrust fault of the Valley and Ridge, which demonstrates at least several kilometers of translation. The fault formed during the Permian. Pennsylvanian age Alleghanian Orogeny and has not been historically active. Al the ORR, the fault trends parallel to regional strike (N55E) and dips steeply $\left(45^{\circ}\right)$ to the southeast (King and Haase 1987). Bedding plane dip values measured in outcrops cluster around $45^{\circ}$ but may steepen to vertical as a result of localized small-scale folding or faulting. Elevations within the study area range from 222 to $390 \mathrm{~m}$ (740 to $1300 \mathrm{ft}$ ) above mean sea levels.

The WOM thrust fault north of Pine Ridge is very complex and is characterized by a sequence of cross-cutting imbricate fault splays that repeatedly stack the Rome Formation. In the vicinity of Bear Creek, this fault superposes the Cambrian Rome Formation over the younger Cambrian Copper Ridge Dolomite member of the Knox Group. In addition, north of the WOM thrust fault, in the underlying Kingston thrust sheet, Bear Creek flows over slices of the Knox Group and Chickamauga Group that have heen complexly stacked and rotated as a result of footwall deformation associated with displarement along the WOM fault. Because of the complex deformation associated with the WOM thrust fault and the immediately underlying Kingston sheet, it is anticipated that this region contuins numerous fault-related fracture zones forming areas of enhanced permeability. 


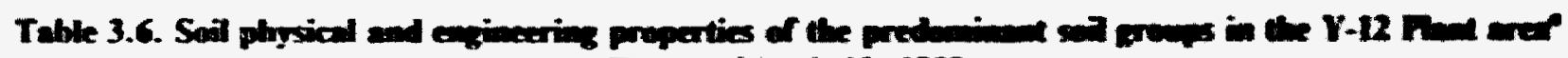
Revised March 10, 15oen

\begin{tabular}{|c|c|c|c|c|c|c|c|c|c|c|}
\hline \multicolumn{6}{|c|}{ Surface } & \multicolumn{5}{|c|}{ Subeil } \\
\hline Group & $\begin{array}{c}\text { Shrink- } \\
\text { swell }\end{array}$ & $\begin{array}{l}\mathrm{LL}^{*} \\
(\%)\end{array}$ & PTe & $\begin{array}{c}\text { Unified } \\
\text { ctass }\end{array}$ & $\begin{array}{c}\mathbf{K} \\
\text { factor }\end{array}$ & $\begin{array}{c}\text { Shrink- } \\
\text { swell }\end{array}$ & $\begin{array}{l}L \\
(x)\end{array}$ & $\mathbf{P I}$ & Unified atoss & $\begin{array}{c}K \\
\text { factor }\end{array}$ \\
\hline \multicolumn{11}{|c|}{ Residurna } \\
\hline Rome & low & $20-30$ & NP-8 & ML,CL & 0.24 & low & $15-40$ & NP-13 & GM, SM & 0.28 \\
\hline Conasauga & low & $20-40$ & $5-15$ & $\mathrm{ML}, \mathrm{CL}$ & 0.32 & $\bmod$ & $45-75$ & $17-40$ & $\mathrm{MH}, \mathrm{ML}, \mathrm{CL}, \mathrm{CH}$ & 0.37 \\
\hline Knox & low & $15-30$ & 3-15 & ML,CL & 0.28 & $\bmod$ & $40-70$ & $20-40$ & MH,ML & 0.24 \\
\hline \multicolumn{11}{|c|}{ Colluvium } \\
\hline $\begin{array}{l}\text { Rome/ } \\
\text { Conasauga }\end{array}$ & low & $20-35$ & $2-10$ & SM,SC & 0.28 & low & $20-35$ & $2-10$ & GM,SM,ML & 0.28 \\
\hline Knox & low & $20-30$ & NP-10 & ML,CL & 0.34 & low & $20-30$ & $5-15$ & $\mathrm{CL}, \mathrm{GC}$ & 0.28 \\
\hline \multicolumn{11}{|c|}{ Alluvium } \\
\hline $\begin{array}{l}\text { Holocene/ } \\
\text { Modern }\end{array}$ & low & $<30$ & NP-10 & ML,CL & 0.32 & low & $20-40$ & $4-20$ & ML,CL & 0.43 \\
\hline Pleistocene & low & $20-30$ & $3-10$ & ML, CL & 0.37 & low & $40-70$ & $10-25$ & CL,ML & 0.32 \\
\hline
\end{tabular}

aAdapted from Lietzke et al. 1988.

${ }^{b} \mathrm{LL}=$ liquid point.

${ }^{\mathrm{T}} \mathrm{PI}=$ plastic index.

${ }^{d} \mathbf{K}=$ soil erodibility factor as defined by the Universal Soil Loss equation (see Sect. 3.4.3).

Source: Welch 1989. 

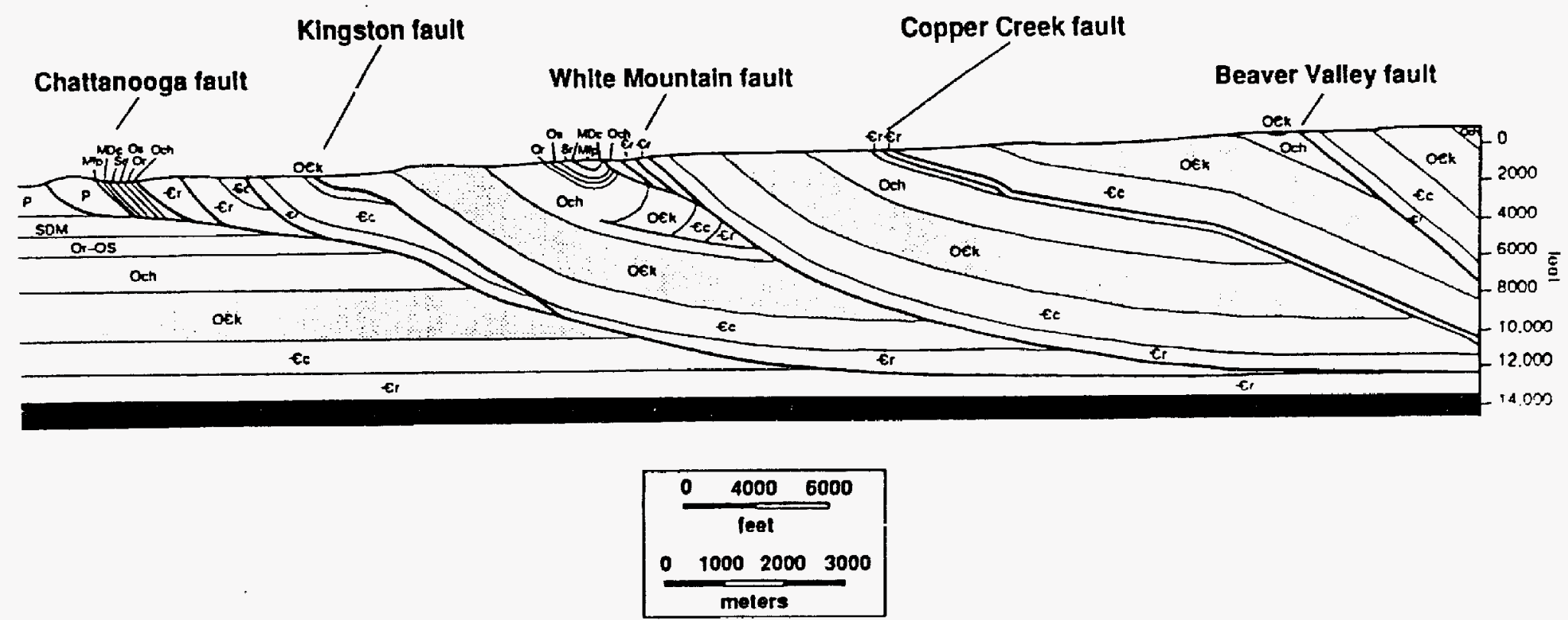

Fig. 3.7. Geologic cross-section based on seismic line on Tennessee 95 (Source: Hatcher et al. 1992). 
Bear Creek is characterized by numerous cross-strike streams that have a consistent north/south trend and are fairly evenly spaced along the valley, usually between 366 to $610 \mathrm{~m}$ (1200 to $2000 \mathrm{ft}$ ) apart. Such a consistent orientation suggests that the location of these creek beds is controlled by a geological structural feature, such as a minor tear fault or a prominent fracture trend. Both features are possible, and in Melton Valley, the White Oak Creek Tear Fault shows a similar north trend. If these structures are faults, they show minor displacement but may have produced an associated fracture zone.

Fractures. Because of the large-scale faulting, all geologic units in the ORR are highly fractured. Detailed investigations of Conasauga Group core by Lutz and Dreier (1988) show that five fracture sets occur consistently throughout the unit. One set is parallel to bedding, but the other four are generally perpendicular to bedding. The parallel bedding fractures are mainly release joints. Recent studies elsewhere in the Appalachians suggest that release joints can form at depths up to a kilometer (Engelder 1985). Assuming a regional strike of N55E, the strikes of the high angle sets are approximately N55E, N75W, N15E, and N20W.

Fracture density varies throughout the cores. The two variables that have the greatest effect on density are lithology and bedding thickness. Density is inversely proportional to bedding thickness. High fracture densities are found in shales and interbedded limestone and shale, whereas limestones exhibit lower densities. Mineralization of fracture planes is almost entirely confined to limestone beds. All fracture sets exhibit vein development; however, the N55E direction is the most commonly mineralized.

\subsubsection{Soil and Stream Sediment Contamination}

There is close physical and chemical association between stream sediments, especially those in tributaries to Bear Creek, and soils in BCV. As a result, these materials have been considered together in many of the studies of contaminant distribution in Bear Creek. These materials, therefore, are considered in the same section of this report. Contaminant background data for soils on the Nolichucky and Dismal Gap formations are available in the Phase I annual report of the ORR Background Soils Characterization Project (Energy Systems 1993b).

\subsubsection{Bear Creek stream sediments}

Soils and sediments in Bear Creek have been sampled and analyzed as part of investigations and studies of contaminant distributions at the various waste sites in BCV. Five locations (BCK 1.30, BCK 4.70, BCK 9.91, BCK 11.09 and BCK 12.10) were selected for screening of contaminants in the Bear Creek floodplain (Fig. 3.8) (Turner et al. 1991). Two or three soil cores up to $67.5 \mathrm{~cm}$ (27 in.) long were collected at each site using a vibracorer. Each core was cut into intervals -7.5 to $20 \mathrm{~cm}$ (3 to 8 in.) long. Core sections were subsampled for analysis for volatile compounds; the remainder were air dried, homogenized, and crushed. The ORNL Analytical Chemistry Division performed all of the chemical analyses except the gamma spectroscopy, which was performed in the Environmental Sciences Division's Low-Level Counting Facility.

Tables 3.7 and 3.8 summarize the results of analyses carried out on these cores. The combined summaries indicate that PCBs in some samples were elevated above the TSCA PCB spill cleanup criterion $(25 \mathrm{mg} / \mathrm{kg}$ ) for soil on the bank of a stream. The summaries also 


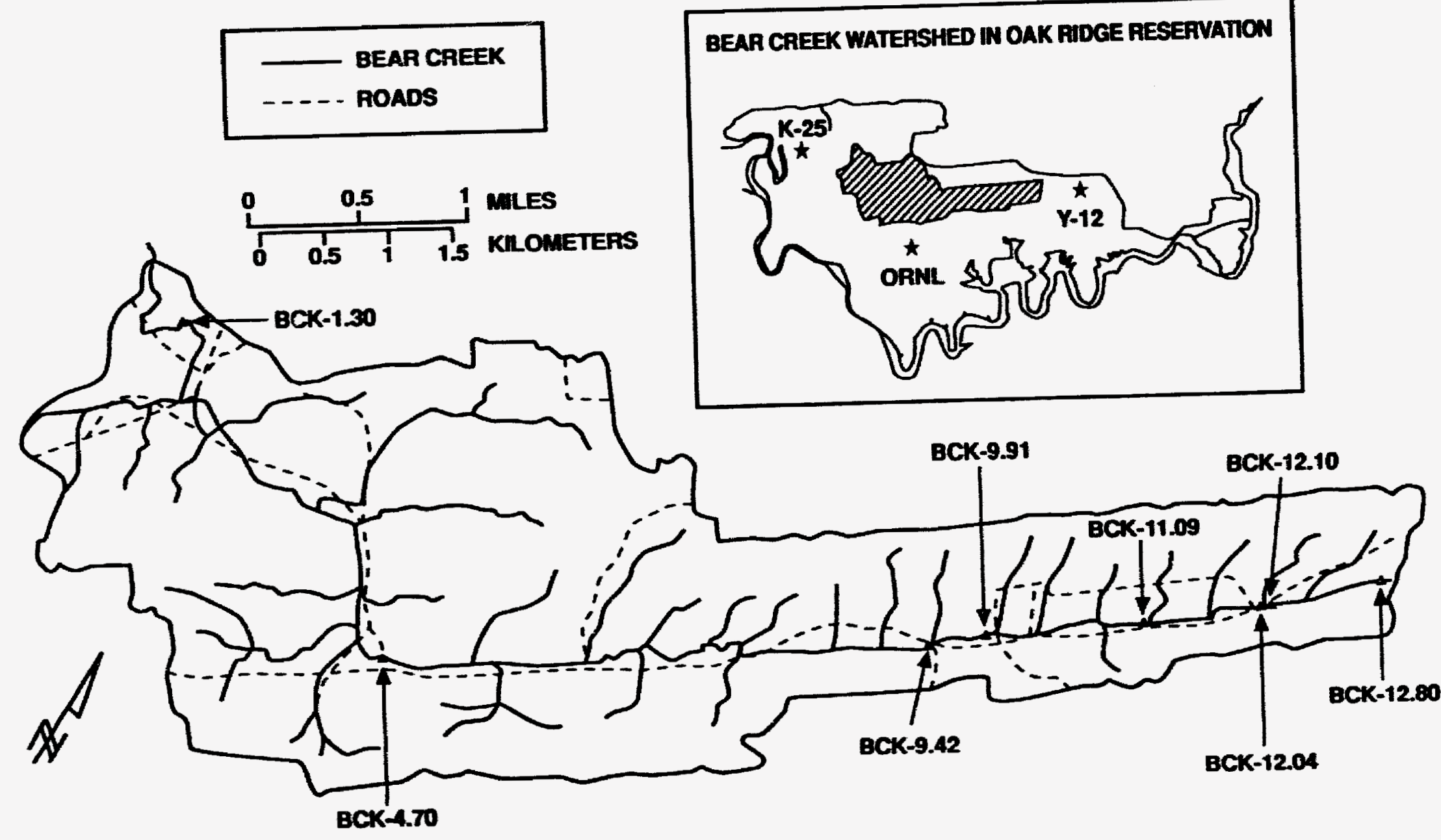

Fig 3. Location of Ber Croek floodphin soil sampling sites. 
Table 3.7. Statistical summary of contaminant levels at the five floodplain subsurface soil-sampling loculities in Bear Creek sampled April 1985"

\begin{tabular}{|c|c|c|c|c|c|}
\hline Parameter & $\mathbf{N}$ & $\begin{array}{c}\text { Number times } \\
<\text { d.l.e }\end{array}$ & Mean & Maximum & Minimum \\
\hline$\Sigma$ Alpha (pCi/g) & 62 & 0 & 22.0 & 103 & 2.4 \\
\hline$\Sigma$ Beta $(p C i / g)$ & 62 & 0 & 22.5 & 119 & 6.5 \\
\hline${ }^{137} \mathrm{Cs}(\mathrm{pCi} / \mathrm{g})$ & 63 & 23 & 0.35 & 2.3 & 0.01 \\
\hline${ }^{\infty} \mathrm{K}(\mathrm{pCi} / \mathrm{g})$ & 63 & 0 & 11.0 & 18.2 & 4.9 \\
\hline${ }^{20 S} \mathrm{U}(\mathrm{pCi} / \mathrm{g})$ & 63 & 51 & 0.27 & 2.8 & 0.07 \\
\hline${ }^{20} \mathrm{U}(\mathrm{pCi} / \mathrm{g})$ & 63 & 36 & 9.9 & 93 & 0.80 \\
\hline$\Sigma$ Uranium & 62 & 0 & 28.0 & 241 & 0.51 \\
\hline TCE & 61 & 52 & 0.03 & 0.45 & 0.01 \\
\hline PCE & 61 & 54 & 0.01 & 0.06 & 0.01 \\
\hline $\mathrm{PCBs}$ & 48 & 0 & 3.87 & 132 & 0.02 \\
\hline Ag & 63 & 63 & 1.49 & 1.70 & 1.10 \\
\hline Al & 63 & 0 & 16,540 & 39,000 & 10,000 \\
\hline As & 63 & 63 & 4.1 & 4.8 & 2.5 \\
\hline $\mathrm{Ba}$ & 63 & 0 & 120 & 270 & 59 \\
\hline $\mathrm{Be}$ & 63 & 0 & 0.96 & 2.2 & 0.66 \\
\hline Ca & 63 & 0 & 1,735 & 14,000 & 670 \\
\hline $\mathrm{Cd}$ & 63 & 1 & 2.4 & 12 & 0.12 \\
\hline Co & 63 & 0 & 16.6 & 37 & 9.8 \\
\hline $\mathrm{Cr}$ & 63 & 0 & 24 & 73 & 13 \\
\hline $\mathrm{Cu}$ & 63 & 0 & 13.0 & 51 & 4 \\
\hline $\mathrm{Fe}$ & 63 & 0 & 17,338 & 39,000 & 1,300 \\
\hline Ga & 63 & 63 & 10 & 12 & 7 \\
\hline $\mathrm{Hg}$ & 50 & 0 & 8 & 15 & 3.6 \\
\hline $\mathrm{Li}$ & 63 & 1 & 19.8 & 58 & 5.0 \\
\hline $\mathrm{Mg}$ & 62 & 0 & 1,402 & 4,100 & 600 \\
\hline $\mathrm{Mn}$ & 63 & 0 & 988 & 2,100 & 220 \\
\hline Mo & 62 & 61 & 0.57 & 2.10 & 0.32 \\
\hline $\mathrm{Na}$ & 62 & 0 & 74 & 180 & 33 \\
\hline
\end{tabular}


Table 3.7 (continued)

\begin{tabular}{|l|c|c|c|c|c||}
\hline \multicolumn{1}{|c|}{ Parameter } & $\mathrm{N}$ & $\begin{array}{c}\text { Number times } \\
<\mathrm{d.1.}\end{array}$ & Mean & Maximum & Minimum \\
\hline $\mathrm{Ni}$ & 62 & 0 & 21 & 63 & 10 \\
\hline $\mathrm{P}$ & 63 & 0 & 273 & 490 & 140 \\
\hline $\mathrm{Pb}$ & 62 & 0 & 29 & 90 & 15 \\
\hline $\mathrm{Sb}$ & 62 & 48 & 8.1 & 17 & 4.8 \\
\hline $\mathrm{Se}$ & 63 & 55 & 9.8 & 33 & 5 \\
\hline $\mathrm{Sr}$ & 62 & 0 & 6.4 & 18 & 3.7 \\
\hline $\mathrm{Ti}$ & 62 & 0 & 63 & 100 & 41 \\
\hline $\mathrm{V}$ & 62 & 0 & 23 & 48 & 13 \\
\hline $\mathrm{Zn}$ & 63 & 0 & 39 & 130 & 20 \\
\hline $\mathrm{Zr}$ & 63 & 1 & 4.3 & 10 & 1.1 \\
\hline
\end{tabular}

Units are $\mu \mathrm{g} / \mathrm{g}$, dry woight, except as noted

'Preliminary remediation gouls for these parameters are discussed in Chap. 3.

'd.I. - delection limil.

Source: Tumer at al. 1991. 
Table 3.8. Statistical summary of contaminant levels in noodpluin surfuce soils at five sites in Beur Creek sumpled April 1985"

\begin{tabular}{|c|c|c|c|c|c|}
\hline Purameter & $\mathbf{N}$ & $\begin{array}{c}\text { Number times } \\
<\text { d.1.: }\end{array}$ & Menn & Muximum & Minimum \\
\hline E Alpha (pCi/g) & 14 & 0 & 39.7 & 103. & 9.4 \\
\hline$\Sigma$ Bota $(\mathrm{pCi} / \mathrm{g})$ & 14 & 0 & 37.2 & 116. & 19.7 \\
\hline${ }^{139} \mathrm{Cs}(\mathrm{pCi} / \mathrm{g})$ & 14 & 0 & 1.04 & 2.30 & 0.14 \\
\hline${ }^{\circ} \mathrm{K}(\mathrm{pCi} / \mathrm{g})$ & 14 & 0 & 11.95 & 18.10 & 5.2 \\
\hline${ }^{2 \mathrm{U}} \mathrm{U}(\mathrm{pCl} / \mathrm{g})$ & 14 & 8 & 0.55 & 2.80 & 0.07 \\
\hline${ }^{20} U(\mathrm{pCi} / \mathrm{g})$ & 14 & 3 & 23.2 & 92.7 & 1.5 \\
\hline$\Sigma$ Uranium & 14 & 0 & 3.4 & 241.0 & 11.0 \\
\hline TCE & 14 & 11 & 0.02 & 0.19 & 0.01 \\
\hline PCE & 14 & 13 & 0.01 & 0.03 & 0.01 \\
\hline PCB: & 14 & 0 & 1.59 & 11.30 & 0.02 \\
\hline$A_{8}$ & 14 & 14 & 1.50 & 1.70 & 1.10 \\
\hline Al & 14 & 0 & 18.286. & 38,000 & 12,000 \\
\hline As & 14 & 14 & 4.04 & 4.85 & 2.50 \\
\hline Ba & 14 & 0 & 120.36 & 150.00 & 95.00 \\
\hline Be & 14 & 0 & 1.05 & 2.20 & 0.69 \\
\hline $\mathrm{Ca}$ & 14 & 0 & 3,721 & 14,000 & 1,300 \\
\hline Cd & 14 & 0 & 3.96 & 12.00 & 0.90 \\
\hline Co & 14 & 0 & 17.3 & 37.0 & 13. \\
\hline $\mathrm{Cr}_{\mathrm{r}}$ & 14 & 0 & 22.9 & 36.0 & 16. \\
\hline $\mathrm{Cu}$ & 14 & 0 & 21.7 & 51.0 & 9.4 \\
\hline Fo & 14 & 0 & 17.214. & 35,000 . & 1,100 \\
\hline O. & 14 & 14 & 10.4 & 12.0 & 7.5 \\
\hline Hf & 11 & 0 & 8.2 & 11.0 & 5.8 \\
\hline $\mathrm{Li}$ & 14 & 0 & 28.4 & 58.0 & 16.0 \\
\hline$M_{8}$ & 14 & 0 & 1,685 & 4,100 & 890. \\
\hline$M n$ & 14 & 0 & 929. & $1,900$. & 610. \\
\hline Mo & 14 & 13 & 0.64 & 2.10 & 0.32 \\
\hline $\mathrm{Na}$ & 14 & 0 & 80. & 180. & 35. \\
\hline
\end{tabular}




\section{3-28}

Table 3.8 (continued)

\begin{tabular}{|c|c|c|c|c|c|}
\hline Parameter & $\mathbf{N}$ & $\begin{array}{c}\text { Number time } \\
<\text { d.1.: }\end{array}$ & Mean & Maximum & Minimum \\
\hline $\mathrm{Ni}$ & 14 & 0 & 30. & 63. & 18. \\
\hline $\mathbf{P}$ & 14 & 0 & 362. & 490. & 220. \\
\hline $\mathrm{Ph}$ & 14 & 0 & 41. & 90. & 15. \\
\hline Sb & 14 & 11 & 8.3 & 17. & 4.8 \\
\hline Se & 14 & 13 & 8.8 & 19. & s. \\
\hline Sr & 14 & 0 & 9.6 & 18. & 5.9 \\
\hline $\mathrm{Ti}$ & 14 & 0 & 63. & 90. & 44. \\
\hline$v$ & 14 & 0 & 23. & 41. & 16. \\
\hline $2 n$ & 14 & 0 & 62. & 130. & 31. \\
\hline$z_{r}$ & 14 & 0 & 5.0 & 6.9 & 3.4 \\
\hline Depth & 14 & 0 & 1.50 & 1.50 & 1.50 \\
\hline
\end{tabular}

Units are $\mu \mathrm{g} / \mathrm{B}$, dry weight, excepl as noted.

Preliminary remediation goals for these panmolen are diseusecod in Chap 5

'd.I. - detection limil

Source: Tumer a 1001 . 
indicate that some samples exceeded the Nuclear Regulatory Commis:ion (NRC)/DOE guideline of 30 to $35 \mathrm{pCi} / \mathrm{g}$ for uranium in soil with unrestricted access. Certain metals, especially cadmium, also slightly exceeded expected background concentrations. In most cases, the highest concentrations of contaminants were in the surface soil samples.

\subsubsection{Burial Orounds coils and stream sediments}

In the early 1980s, soils and stream sediments were analyzed as part of a comprehensive sampling and analysis program carried out to evaluate the extent of contamination at the Burial Grounds (McCauley 1985c). More recent studies of soils and stream sediments at the Burial Grounds have been carried out for NT-7 and ORP I (Geraghty and Miller 1985; 1988), for ORP 1 (Herbes 1988), and for NT-8 (Bogle et al. 1991) (Fig. 3.9 and Appendix C).

Volatile organic priority pollutant compounds have been detected in the soils near the waste sources on the Burial Orounds and in stream sediments from tritsutaries 10 Bear Creck that drain the Burial Grounds. PCBs and metals have been found in soils and sediment near the ORPs and near BG.C West.

Appendix $O$ in Turner et al. (1991) summarizes local background concentrations of a variety of contaminants in surface water and sediment. These background data were collected at Tributary NT.2 upstream of all waste facilities and at two sites (OCK-1.4 and OCK-2.4) in the Grasky Creek watershed, which represents the westward continuation of BCV after Bear Creek turns north through Pine Ridge. A summury of background soil chemical data is in Table 3.4.

PCBa. Several hundred soil and sediment samples for chemical analysis for PCBa have been collected from the ORPs and Tribularies NT.6, NT.7, and NT.8 (Fig. 3.9 and Appendix $C$ ). The results of these analyses confirmed the presence of PCBs at concentrations above the action level of $25 \mathrm{mg} / \mathrm{kg}$ throughout the sediments of ORPs $I$ and 2 and much of Tributary NT.7.

In 1980 and 1982, a series of soil cores was collected from transects on the perimeter of ORP 1 and analyzed for PCBs. Concentrations of PCBs in six samples collected between () and $3.7 \mathrm{~m}(0$ and $12 \mathrm{fi}$ ) from the pond perimeter ranged from $1.3101448 \mu \mathrm{g} / \mathrm{g}$. Several samples collected at a depih of $0.6 \mathrm{~m}$ ( $2 \mathrm{li}$ ) contained between 2.8 and $14 \mu \mathrm{g} g$. Samples collected from the ORP 1 perimeter in July 1985 showed similar concentrations and distributions. Samples collected from ORP 2 during this sume period revealed concentrations as high as $174 \mu \mathrm{g} / \mathrm{g}$ in surface sediments from the perimeter of the pond, with concentrations decreasing with depth and distance from the pond.

In October 1985, live cores were collected from the botlom of ORP I and anulyzed for PCBs. Concentration of PCBs in surfince sediments from these areas ranged as high as $710 \mu \mathrm{g} / \mathrm{g}$ but decreased to $3 \mu \mathrm{g} / \mathrm{g}$ or less at a depth of $67.5 \mathrm{~cm}(27 \mathrm{in.}$ (Herbes 19k8).

Extensive sediment sampling was conducted throughout the tributary system hetween 1985 and 1988 and has shown that PCBs are present at concentrations of several hundred micrograms per gram in surface sediments of 'Tribulary NT.7 between ORP I and the visible area of oil secpage at the west end of BG-A South (Figs. 3.10 and 3.11). However, concentrations decrease with depth to below $25 \mu \mathrm{g} / \mathrm{g}$ at $0.6 \mathrm{~m}$ (2 fi) (Figs. 3.11) and 3.11). 


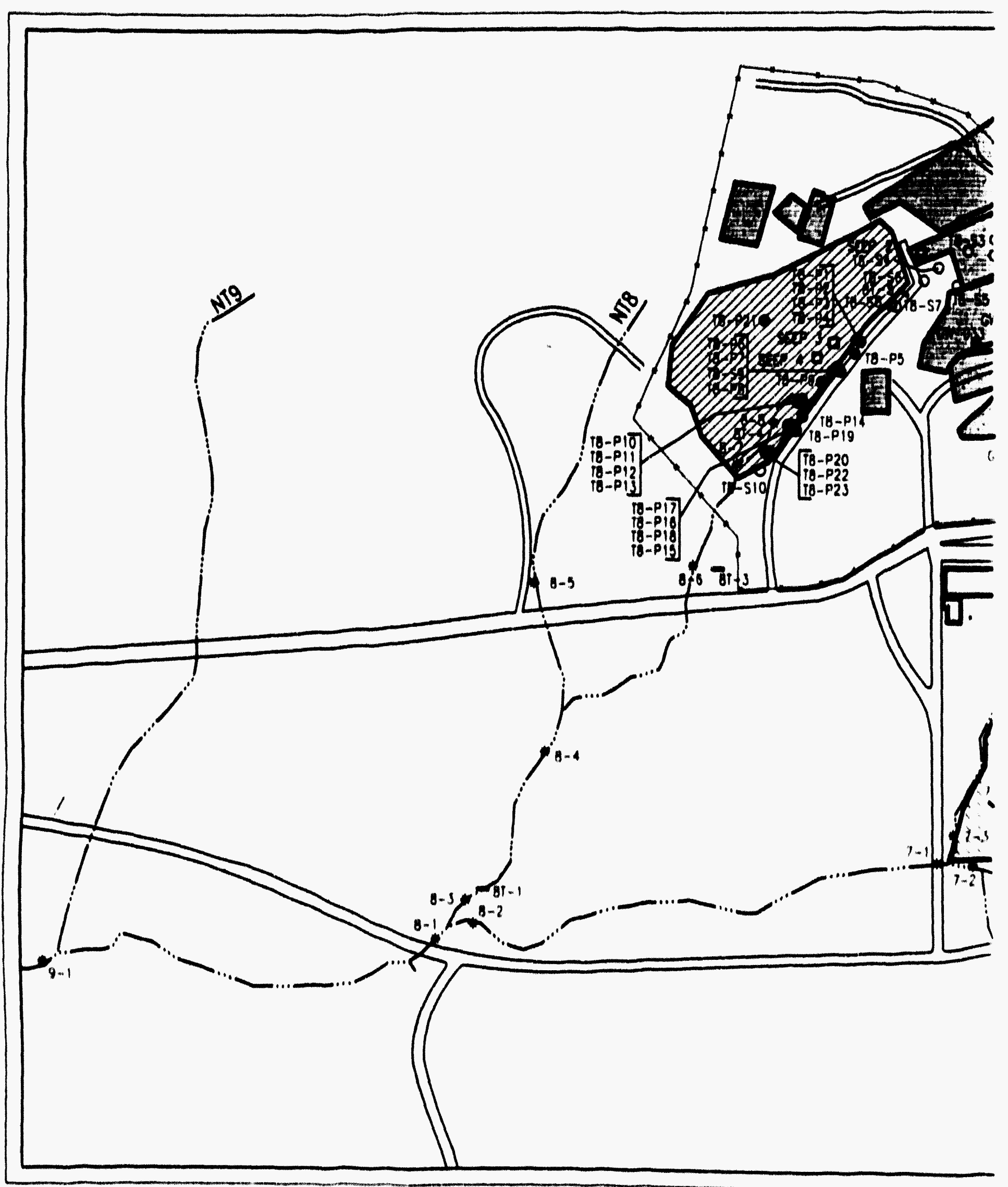

FI. 3.9. Location of soll and codiment sample sites at the 


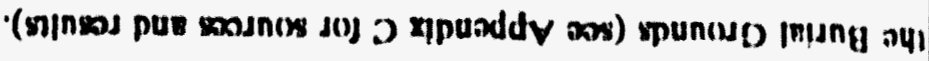
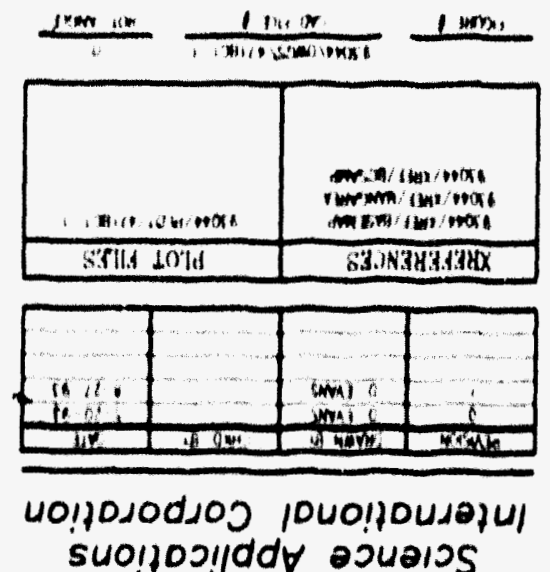

ajuas

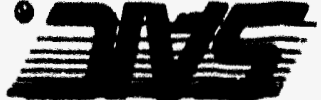

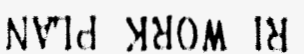

1 LINO I'tgVyAdO

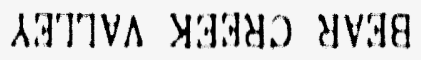
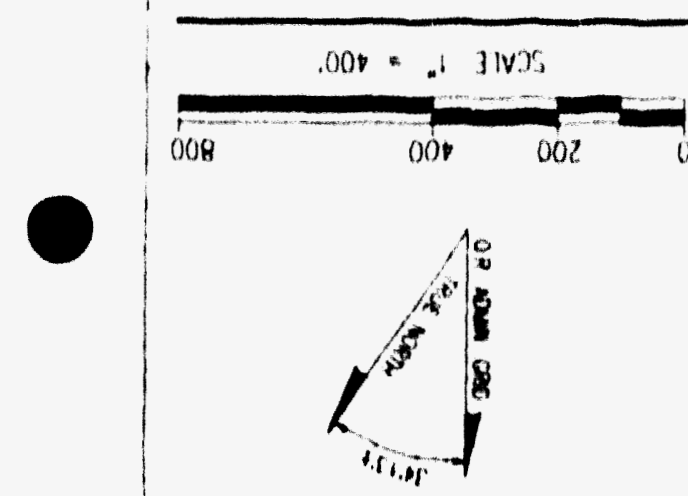

INN IVSOdSIO

OJddVONO

INNI TVSOdSIO

(]ddats vajoy

IINO 7 VSOdSIO

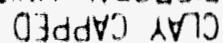

d] 35

1) JSNGZ1

370WVS 7105

INJWIO3S WVJU1S
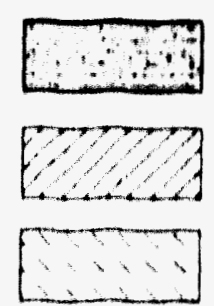

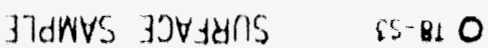
Jy0J 705

$900-1000$

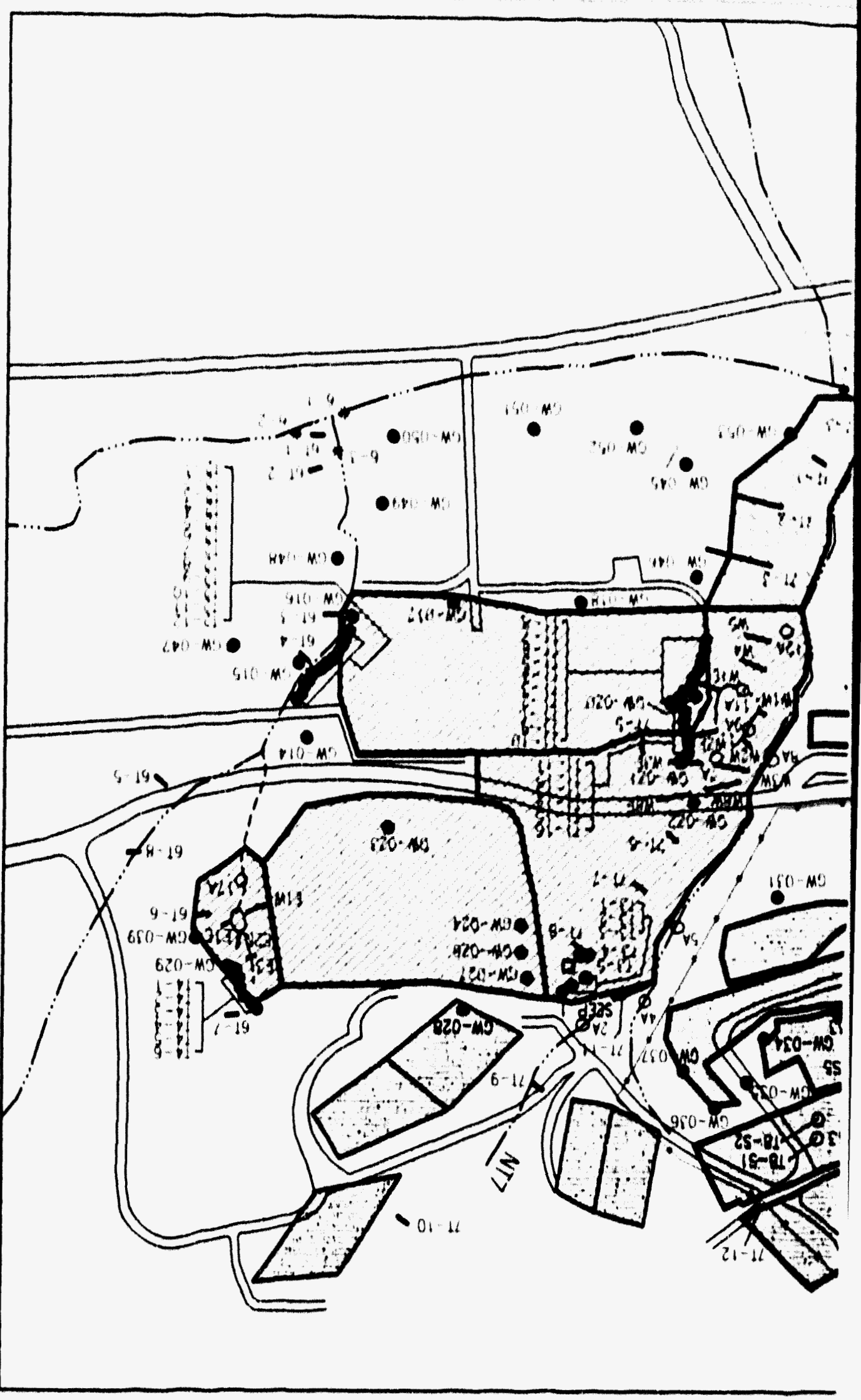




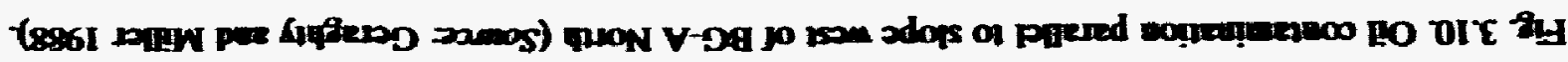
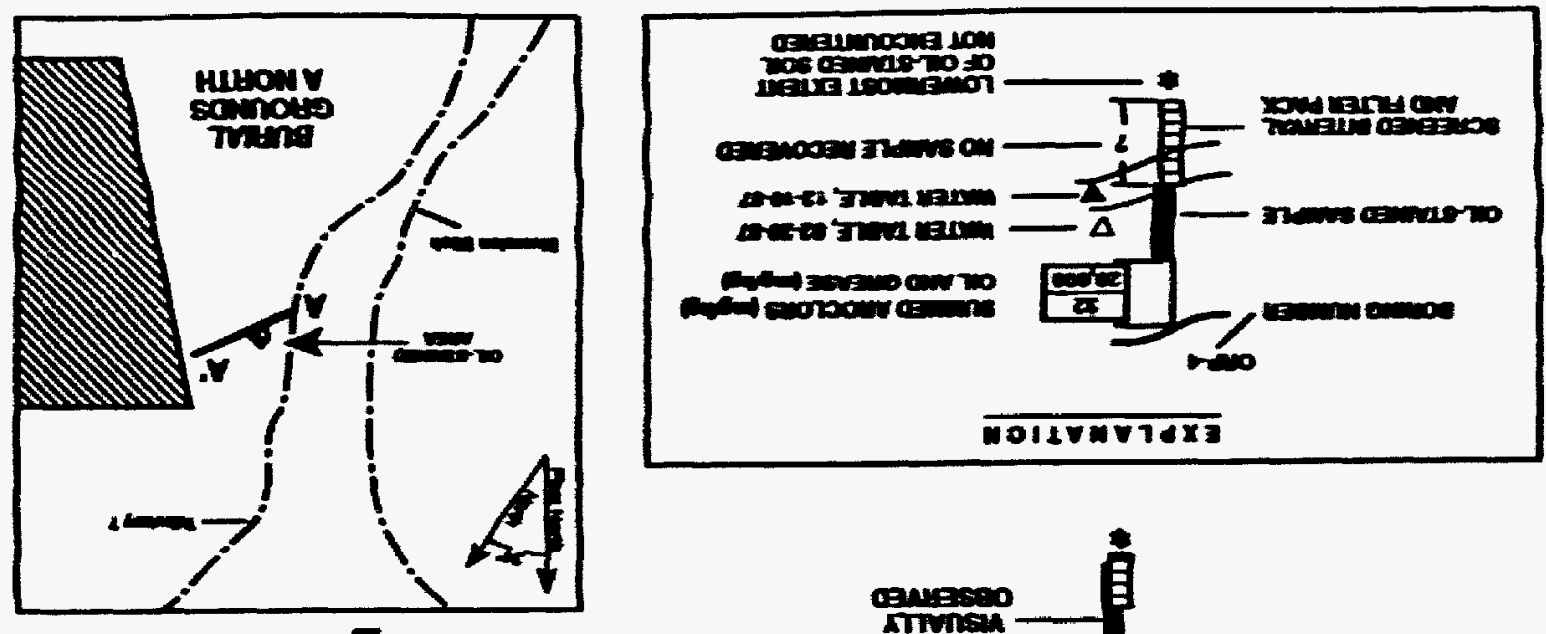

$\dot{m}$
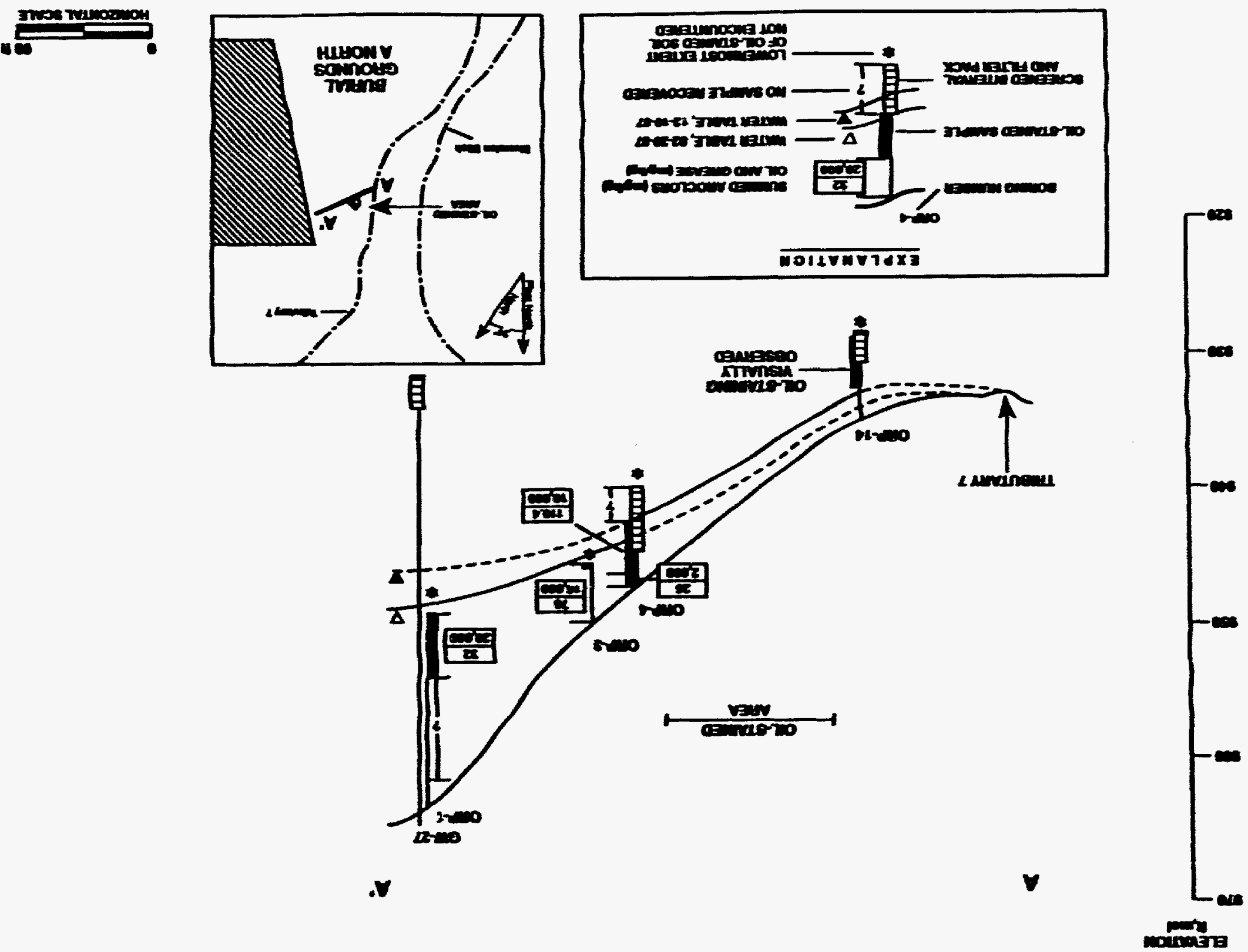
Borings in this study also recorded free-phase light nonaqueous phase liquids (LNAPL) on groundwater (Geraghty and Miller 1988).

PCBs have been found in areas of the Tributary NT-7 noodplain soils south of ORP 1 at depths of concentrations as high as $574 \mu \mathrm{g} / \mathrm{g}$. Because PCBs adhere strongly io suil particles, elevated concentrations in the Tributary NT.7 Hoodplain soils appear to be related to sediment transport from upstream sources (Herbes 1988). Concentrations in Tributary NT-7 sediments at the confluence with Bear Creek were reported 10 range from 5.2 10 $28.2 \mu \mathrm{g} / \mathrm{g}$ in 198.3 and 1984 and from $2.11014 .1 \mu \mathrm{g} / \mathrm{g}$ in 1986 (Herhes 1988 ).

Sediment from the drainage ditch north of ORP 2 had a maximum PCB concentration of $3.3 \mu \mathrm{g} / \mathrm{g}$. PCBs at concentrations between 2.3 and $13.8 \mu \mathrm{g} / \mathrm{g}$ are present in Tributary NT- 6 sediments throughout its length between the confluence with the intermillent stream draining ORP 2 and the confluence with Bear Creck. Concentrations of PCBs in Tributary NT.4 ranged from $<0.1 \mu \mathrm{g} / \mathrm{g}$ on the western branch. which does not llow through the Burial Grounds, to $50 \mu \mathrm{g} / \mathrm{g}$ cellected near the confluence with Bear Creck.

Oil seeping from BG.C into NT.8 was investigated in $1(x)$. Sovils were sampled in transects across visible sites of secpage and had concentrations of PCBs that ranged from below detection limits to $80 \mu \mathrm{g} / \mathrm{g}$. Vertical distribution of PCBs generally decreased with depth, and concentrations of PCBs exceeding $25 \mu \mathrm{g} / \mathrm{g}$ were limited to the upper $30 \mathrm{~cm}(12 \mathrm{ln}$.) of sediment. Based on this sampling event, the total volume of PCB-contaminated sediment in the upper east fork of Tributary NT-8 that exceeds the proposed action limit is estimuled to be $34 \mathrm{~m}^{3}$ (1200) $\mathrm{ft}^{3}$ ) (Bogle et al. 1991).

During closure operations at the ORPs and BG.A. all ssils and sediments with PCBs $>25 \mu \mathrm{g} / \mathrm{g}$ were excavated and removed from ORPs 1 and 2, NT.7, and visible vil stain arems near BG-A North. The channel of NT.7 was rerouted - $15 \mathrm{~m}$ (50 ft) to the east of its original course.

Uranium. Because large quantities of uranium are known to have heen deposited in the Burial Grounds, soil and sediment sampling campaigns conducted in Tributaries NT.6 and NT-7 since 1985 have included total uranium analyses. Concentrations measured in sediments north of the Burial Grounds generally range from $11010 \mu \mathrm{g} / \mathrm{g}$. Unlike PCB concentrations. which are present at far higher levels in Tributary NT.7 sediments than in Tributary NT.6 sediments, uranium concentrations are similar in both tributaries and are as high as $225 \mu \mathrm{g} / \mathrm{g}$ in the lower reaches of the tributaries. The arithmetic mean of nine samples collecied from three locations in the stream channel and adjacent banks from Tributary NT.7 south of ORP 1 was $84 \mu \mathrm{g} / \mathrm{g}$, while the mean of an equal number of samples collected from three similar locations in Tributary NT.6 south of ORP 2 was $98 \mu \mathrm{g} / \mathrm{g}$ (Herbes 1988). Total uranium in the surface sediment collected in January 1999) from the upper reaches of Tributary NT.K ranged from 212.2 to $345 \mu \mathrm{g} / \mathrm{g}$. In sediment cores from NT-8, total uranium values ranged from background concentration to $7250 \mu \mathrm{g} / \mathrm{g}$ (Bogle et al. 1991). No correlation was observed between PCB and uranium concentrations.

Metals, cyanide, and semivolatiles. When compared to a control sile on Tributary NT.7 upstream from the Burial Grounds, sampies collected in September 1983 did not exhibit elevated levels of toxic metals, cyanide, or phenols in ORP 1 or in Tributary NT.7 sediments downstream from the pond (McCauley 1985c. Radian 199.3a). Contaminants found in the sediments were arsenic, beryllium, cadmium, chromium, cobalt, copper, lead, nickel, silver. 
zinc, cyanide, and total phenols. A sample collected at this same location in December 1987 revealed similar results; no semivolatile contaminants were detected in Tributary NT-7.

VOCs. Sediment samples collected along the upper reaches of Tributary NT-8 in January $19 x()$ indicated that elevated levels of VOCs exist in the sediments. Generally, the distribution of VOCs at the sediment sampling locations mirrors their distribution in surface water samples. The highest summed concentration of VOCs in a sediment core was $34,599 \mu \mathrm{g} / \mathrm{g}$. The major VOCs detected in the sediments along the upper reaches of Tributary NT-8 were Irichloroethylene, tetrachloroethylene, 1,1-trichloroethane, 1,1-dichloroethane, cis-1,2-dichloroethene, chloroethane, methylene chloride, vinyl chloride, benzene, toluene, and Freon 113 (Bogle et al. 1991).

Summary. Numerous analyses for PCBs and uranium have been performed in soil and sediments from the ORPs and tributaries NT-6, NT-7, and NT-8. The horizontal and vertical extent of PCB contamination was well defined at the ORPs and along tributaries NT-6, NT-7, and NT-8 prior to RCRA remediation activities. Uranium contamination has been defined 10 a more limited extent; the horizontal and vertical extent of soil contamination within the unsaturated zone has not been fully defined.

\subsubsection{Oil Landfarm soils and stream sediments}

Because of concerns about levels of PCBs that may have been present in the Oil Landfarm from disposal of contaminated oils, several rounds of sampling for PCBs in Oil Landfarm soils have occurred since 1981. The highest level detected in Oil Landfarm ;oil during this peilod was $110 \mu \mathrm{g} / \mathrm{g}$ (BNI 1983). A total of 200 samples were collected in 1985 in a randomized block design with the objective of delineating areas containing PCB levels $>25 \mu \mathrm{g} / \mathrm{g}$. Several portions of plots were identified over this action level; the highest concentration measured was $60.5 \mu \mathrm{g} / \mathrm{g}$. PCB contamination was principally confined to the upper $15 \mathrm{~cm}(6 \mathrm{in}$.) of the soil; concentrations declined by more than $90 \%$ between the surface $[0$ to $15 \mathrm{~cm}$ (0 to $6 \mathrm{in}$.) interval] and the $30-$ to $45-\mathrm{cm}$ (12- to 18 -in.) interval in 10 depth profiles. Highest concentrations were found in the east and west plots (Figs. 3.12 and 3.13) (Herbes 1988) (Appendix A).

Soil samples collected in the 1985 study (Herbes 1988) were also analyzed for uranium. Concentrations of uranium were similarly highest in the east and west plots. The highest mean uranium concentration observed was $204 \mu \mathrm{g} / \mathrm{g}$ (in Plot 7/8). Lowest concentrations were between 13 and $27 \mu \mathrm{g} / \mathrm{g}$ in the north plot group. As was observed for PCBs, uranium concentrations declined rapidly with soil depth (Fig. 3.13).

There were 48 soil samples collected and analyzed by the Y-12 Plant Analytical Laboratc.y for total carbon, PCBs, and a series of metals. The results are summarized in the BNI (1983) report. Maximum levels (in $\mu \mathrm{g} / \mathrm{g}$ ) for the metals analyzed were arsenic (73), barium (340), beryllium (290), cadmium (6), chromium (88), lead (550), mercury (55), selenium (0.4), silver (8), thorium (20), and uranium (273). As would be expected from the historical pattern of oil application, contaminant concentrations were uniformly lowest in the north plots. Concentrations of beryllium were highest in Plots $1 / 2$ (mean of four analyses: 213 $\mu \mathrm{g} / \mathrm{g}), 5 / 6(112)$, and $9 / 10(75)$. Beryllium levels averaged $32 \mu \mathrm{g} / \mathrm{g}$ in the west plots and $8 \mu \mathrm{g} / \mathrm{g}$ in the north plots. With the exception of one sample from Plot $1 / 2$, all mercury and lead concentliations were less than $4 \mu \mathrm{g} / \mathrm{g}$ and $75 \mu \mathrm{g} / \mathrm{g}$, respectively (Appendix A). 


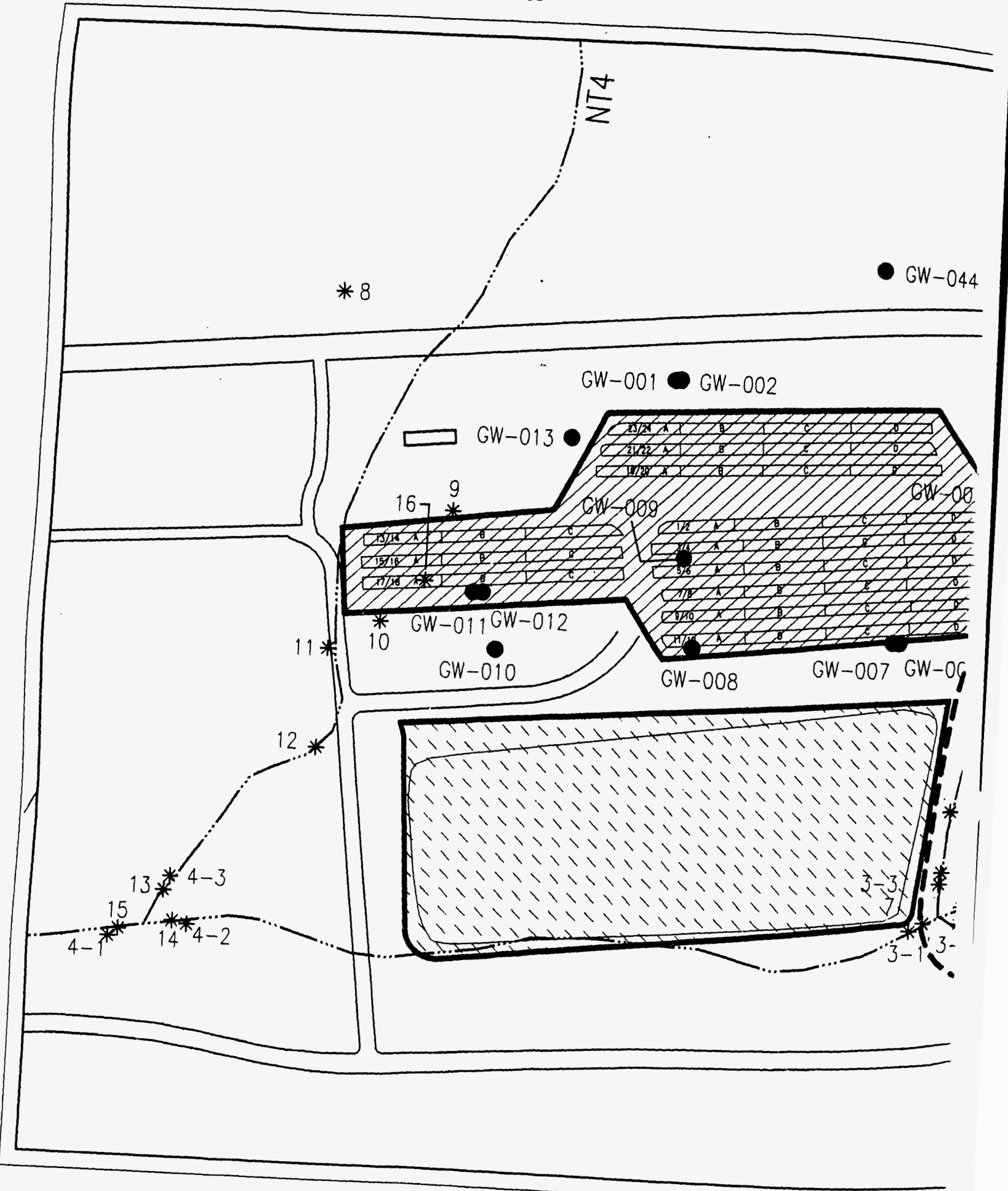

Fig. 3.12. Map showing the location of soil and sediment samplt

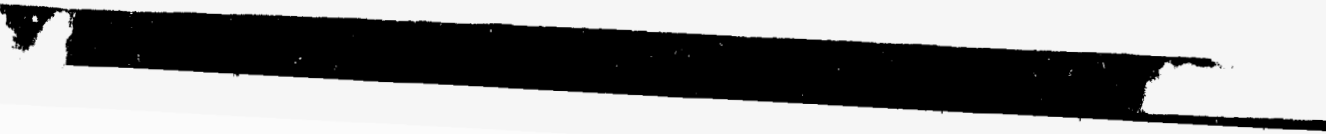




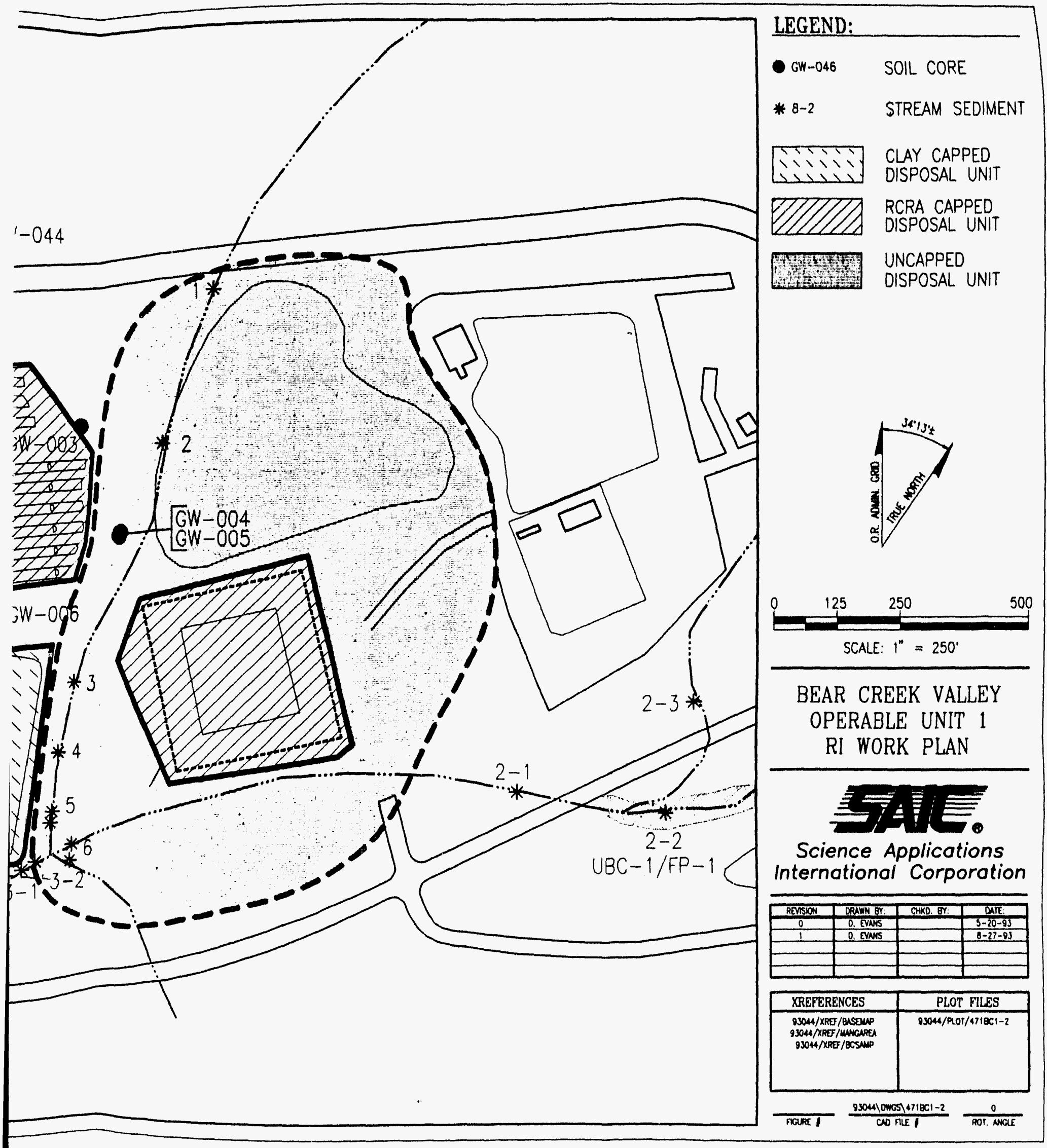

t samples in the Oil Landfarm (see Appendix C for sources of data and results). 


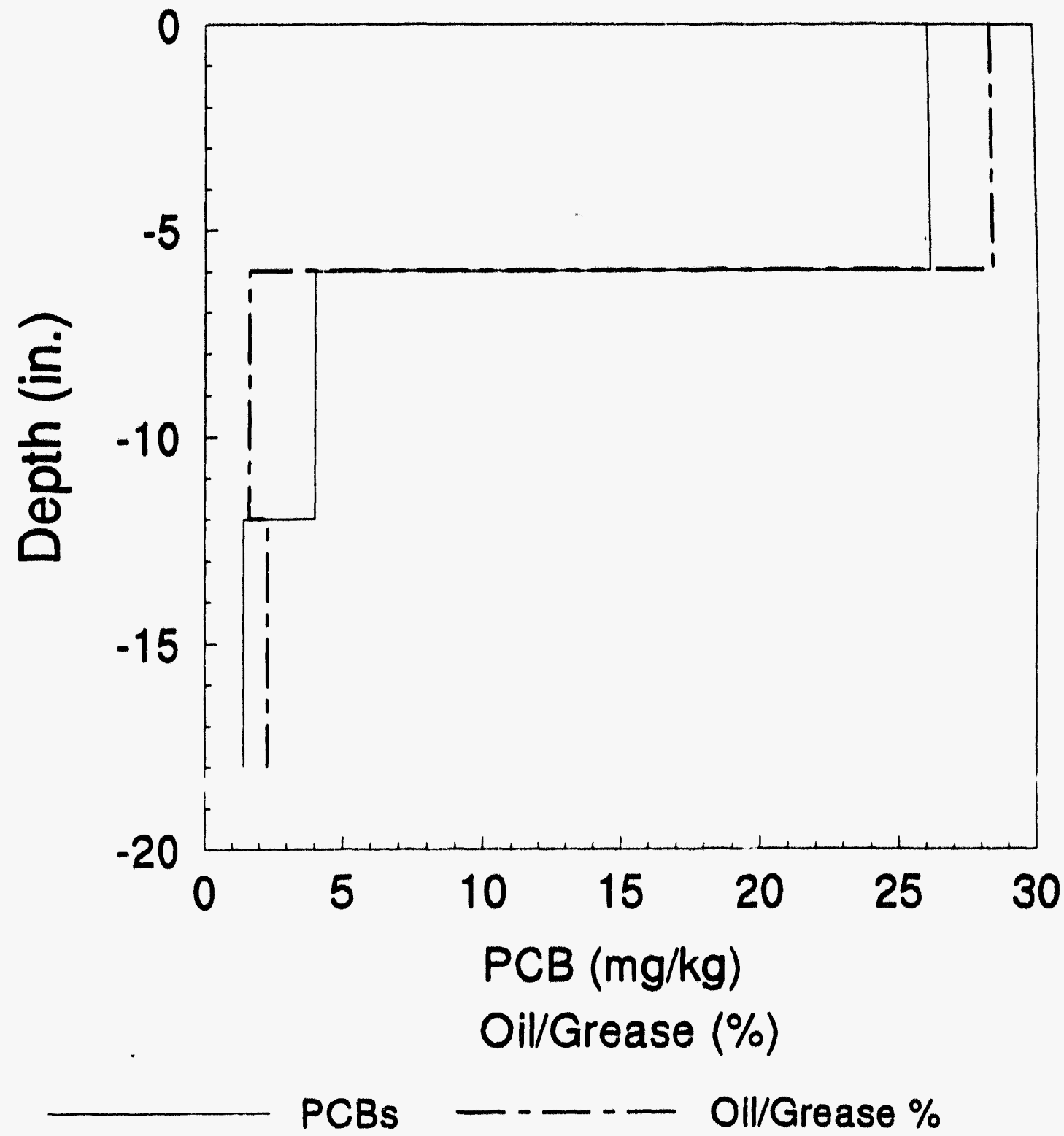

Fig. 3.13. Mean concentrations of PCBs and oil/grease with depth at the Oil Landfarm (Source: Herbes 1989). 
Composite samples were obtained in September 198.3 from "light" and "dark" areas (differentiated visually) of Plots $1-12,13-18$, and 19-24 (the east, west, and north areas, respectively). The five samples (no "dark" area was identified in the north plots) were analyzed for VOCs, acid- and base-neutral extractables. ICP-analyzahle metals, and pesticides/PCBs. The results are summarized in the BNI (1983) report. In general, the Plots 1-12 (east) "dark" sample contained the highest concentrations of contaminants. Major organic contaminants found, and maximum concentrations (in micrograms per gram), were tetrachloroethylene (8.4), trans-1,2-dichloroethylene (2.7), trichloroethylene (0.75), 1,1,1. trichloroethane (0.50), bis(2-ethylhexyl) phthalate (520), fluoranthene (140), phenanthrene (13), phenol (29), and 2.4-dimethylphenol (31).

A number of cores from monitoring wells installed around the perimeter of the Oil Landfarm in 1983 by BNI were analyzed for the organic contaminants just listed (Fig. 3.12. Appendix C). Principal organic contaminants identified, and the highest levels quantified (in micrograms per gram), included toluene (1.6), methylene chloride (0.96), tetrachloroethylene (1.1), and trans-1.2-dichloroethylene (0.40). PCBs were found in three core segments from well GW.5, located east of the Oil Landfarm, at total concentrations of $1.6 \mu \mathrm{g} / \mathrm{g}$ (1) $2.8 \mu \mathrm{g} / \mathrm{g}$ at depths of 0 to $1.5 \mathrm{~m}$ (0 to 5 fi) (BNI 1983).

Several water and sediment samples were collected by BNI near the confluences of tributaries NT-3 and NT.4 with Bear Creek during 198.3 and 1984 (Turner et al. 1991). Levels of VOCs, phenols, and beryllium were all below detection limits $(0.01,0.001$, and $0.0(0) 1 \mathrm{me} / \mathrm{L}$. respectively) in these samples. Both dissolved and particulate PCBs were also below the detection limit ( $(0 .(X X) 3 \mathrm{mg} / \mathrm{L})$ in single samples collected in 198.3.

PCBs were undetectable $(<0.05 \mu \mathrm{g} / \mathrm{g})$ both in tributary and in Bear Creck sediments. Concentrations of beryllium; heavy metals (cadmium, chromium, cobalt, copper, lead, nickel, uranium, and mercury); and phenols showed no increases in the tributary sediments above upstream Bear Creek levels (Turner el al. 1991).

\subsubsection{Boncyard/Burnyard wils and stream sediments}

There is little information available concerning the Boneyard/Burnyard. A number of areas containing radiologically contaminated materials were defined: one on the extreme west perimeter of Boneyard/Burnyard at a depth of $7.51010 \mathrm{~cm}(3104 \mathrm{in}$.) that extended across NT-3 for at least $11 \mathrm{~m}(.35 \mathrm{ft}$ ) toward the SL 1 (maximum beta-gamma of $12(\mathrm{X}) \mathrm{cpm}$ ) and showed no direct source for contamination. The other area of radiological contamination was located near radiologically contaminated barrels that may have contained mop water. One such area was located in the northwest corner of the Boncyard/Burnyard (maximum hetagamma of $3(X) \mathrm{cpm}$ in the soil and $60,(00) \mathrm{cpm}$ in the barrel); the second harrel was located in the southeast corner and had beta-gamma readings of I(XX) cpm. Elevated levels were also indicated in the main stem of Bear Creck during this survey $(3(X) \mathrm{cpm})$.

Data from an investigation carried out by BNI for several grab samples of sediment collected downstream of the Boneyard area show elevated levels of mercury (6.7 to $140 \mu \mathrm{g} / \mathrm{g})$. uranium (18 to $20 x) \mathrm{pCi} / \mathrm{g}$ ), several polynuclear aromatic hydrocarbons, and phthalates (Fig. 3.12. Appendix C). Analytical results for groundwater downgradient of the area also have indicated the possibility of migration of a number of contaminants from the HCDA (Boneyard/Burnyard), including organic compounds and uranium (Turner et al. 1991). 


\subsubsection{S-3 Site soils and atteam exdiments}

Minimal information is available concerning the extent of soil and sediment contami. nation in the vicinity of the S.3 Site. Past sampling efforts have primarily involved the characterization of waste matcrials and of stream sediments and precipitates from Bear Creek. The extent of contamination in uneonsolidated materials surrounding the S.3 Site has not been accurately delineated (Fig. 3.14. Appendix C).

Chemical data for stream sediments, residuum, and sorils near the S.3 Site waste management area are presented by MeCauley (1985a). TVA reported data on additional sediment samples collected from Bear Creek and EFPC. Theac data indicate that the Bear Creek stream sediments downstream from the S.3 Ponds waste management area have a higher metal content than the Bear Creek tributary sediments (hackground). Few organica were detected, and those detected were present in irace quantitics.

Analyses of residuum samplen collected during drilling of moniloring wells $O W \cdot|(X),-|(0)$, $-1(12$, and -103 revealed that arsenic, harium, chromium, lead, and mercury were present in high concentrations relative Io hackground values in Table 3.4 (Fig. 3.14). The total concentration of these metals in each sample exceeded several hundred parts per million (Geraghty and Miller 1985). Only trace levels of organic contaminants were delected in the residuum anmples. No trends assiciated with depth or area vere determined (Appendix C).

Turner et al. (1988) sampled a spoils pile composed of sovils excavated while constructing the tank farm west of the S.3 Site during 1985. While no tested samples exhibited the characteristic of extraction procedure (EP) toxicity, gross alphn activity exceeded the background value of $20 \mathrm{pCi} / \mathrm{g}$ in all samples; gross bela activity exceeded the background value of $55 \mathrm{pCi} / \mathrm{g}$ in 6 of 31 samples. Labxiratory analyxis indicated that mercury was alas) present at leveis above background. There has been no dexumented allempt lo asseas the horizontal or vertical extent of contamination in the unconsolidated materials surrounding the S.3 Ponds.

Treatment of the conlents of the S.3 Ponds produced a sludge of hasic pH. consisting primarily of calcium carbonate, metal hydroxides, and hy-products from hiodenitrification. Compositions of S.3 sludges are described in Chap. 2 and in Appendix A. Metals and radionuclides were not found in leachate from either weak acid (EP Toxicity) or groundwater solutions (Energy Systems 1986). In the fall of 1984, 32 core samples were taken from each of the four ponds for constant head permeability teats. Generally, the sludges in each pond were characterized hy the following permeability values: $3.5 \times 11^{4} \mathrm{~cm} / \mathrm{sec}$ for the soulheast pond, $5.5 \times 10^{5} \mathrm{~cm} / \mathrm{sec}$ for the northeast pond. $1.7 \times 10^{6} \mathrm{~cm} / \mathrm{sec}$ for the southwest pond. and $4.2 \times 11^{s} \mathrm{~cm} / \mathrm{sec}$ for the northwest pond (Energy Systems 19K8).

\subsubsection{Sxill Erroxion}

The erosion potential of soil at a site can be estimated by the use of the Univeraal Soil Loss Equation (USLE) (USDA 1978). The USLE can be used to design soil conservation practices and procedures to minimize accelerated soil loss. Potential erosion hazards can he evaluated for larger tracts of land hy evaluating slope gradient, length of slope, amount of very fine sand and silt in the upper soil, and the thickness of soil that can retain rainfiall before the onset of overland llow. 


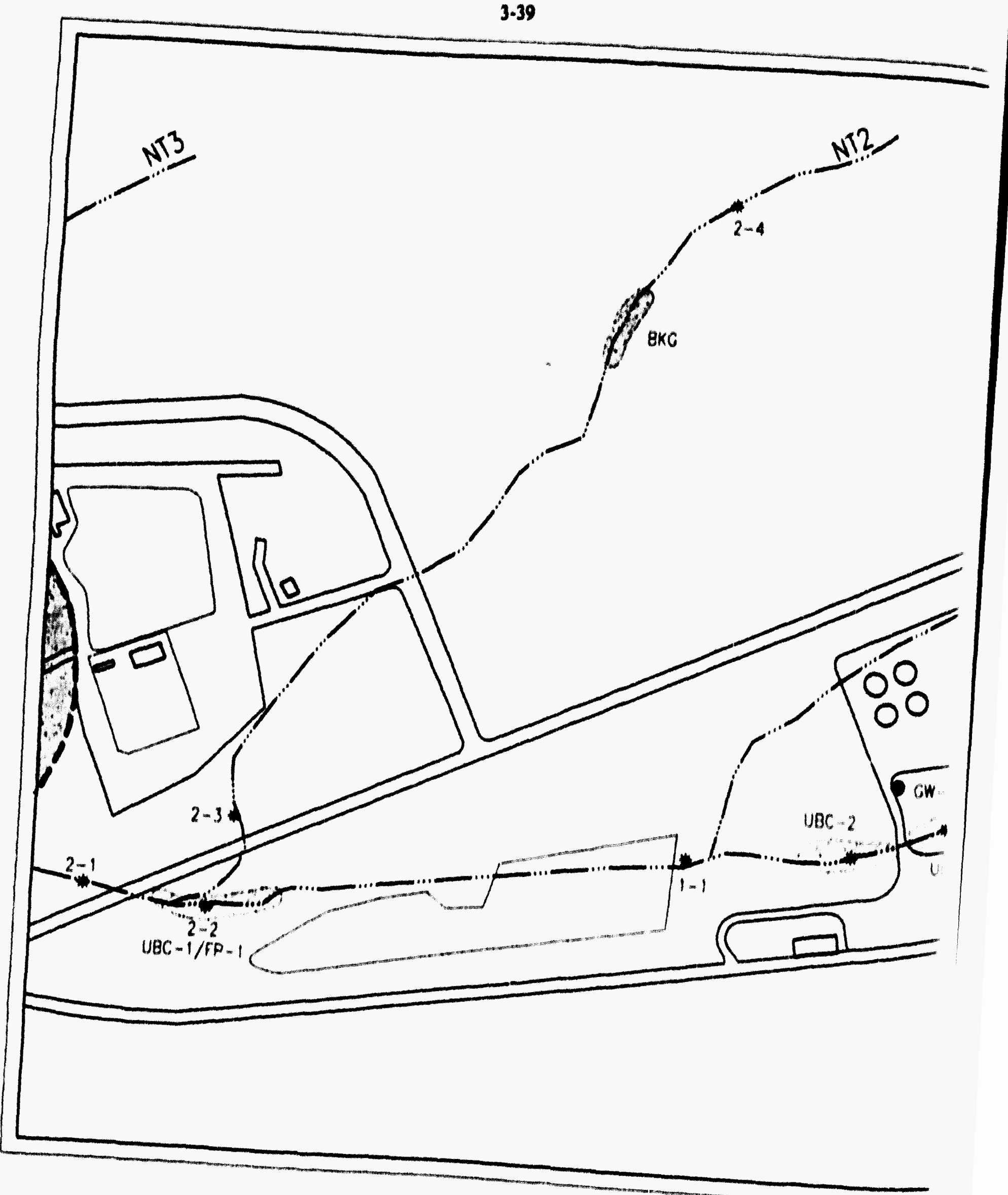

Tr. 3.14. Location of soll and atroum codiment aumple 


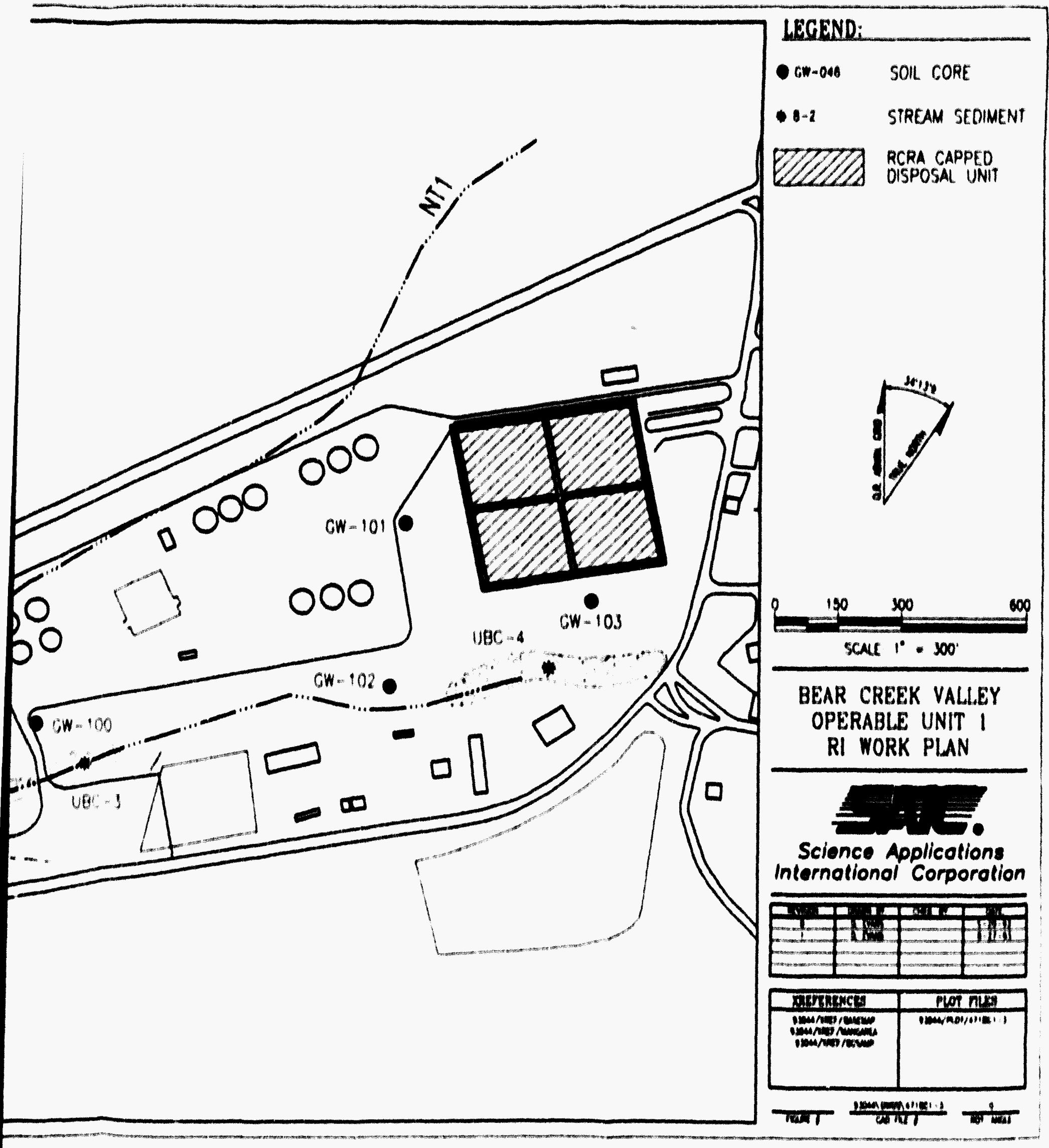

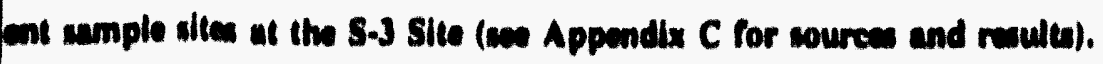


A soil erodibility factor $|K|$ estimates the probability that a soil particle can be detached from the surface and Iransported downslope by rainfull (USDA 1983). The $K$ factor can be ealimated by uaing a nomograph that relatea $K$ factor to five soil propertica: (1) percentage of alli plus very fine sand. (2) percentage of sand $>0.10 \mathrm{~mm}$, (3) organic matter content of the soil layer that is exposed to rainfall, (4) soil structure, and (5) limiting permeability. Lietzke et al. (1988) calculated K factors for soils at the Bear Creek Valley Low.Level Wate Dispasal Development and Demonutration (LLWDDD) Program Site, and these are prewented in Tuble $\mathbf{3 . 9}$.

Lietzke et al. (1948) identified four areas in BCV where soil eroaion potential is high: (1) land with slopes $>25 \%$, (2) all areas that have been serioualy eroded in the pual, (3) shallow wils underlain by bedrock, and (4) wils that have high silt plus clay contact. Moat soila in BCV have the polential for accelerated erodibility if they are disturbed of len unprotected, with the exception of wils in the floxodplains where sediments generally collect.

\subsection{SURPACB WATER}

The surface water system in BCHR is comprised of Bear Creck and its tributaries. Headwaten of Bear Creek are lixcated at the weal end of the Y.12 Plant near the S.3 Ponds. In its upper reaches. Bear Creek follow a relatively atraight course along geologic strike that liea very slowe to the contact between the Conasuuga and Knox Oroups. The original channel, lecated on the weat side of the S.3 Ponda site, wa filled with rubble during pond conatruction and refouted II) is present locution (Law 1983). Approximately $7.2 \mathrm{~km}$ (4.5 milea) downitream of its headwaten. Bear Creek lurns northward ihrough a gap in Pine Ridge and

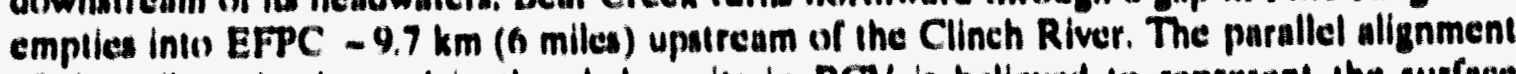
of the tributaries locialed in the shale units in BCV is believed to repreaent the surface expression of juint and fraclure palterns in the bedrock (Oeraghiy and Miller 1985) and/or wher structural features.

An discussed in Sect. 1.5. the scope of BCV OU I RI with respect in surface water is to addreas the extent (1) which units of BCV OU I may be contributing contaminanta lo surface water. In some cases, contaminunis may be transported from source areas io Bear Creek via groundwater llow paths. In these cases, the scope of this work plan uddresses the extent is which the source area may he contributing contaminants (1) groundwater. Remediation of surface water and detailed determination of the interactions between surface water and groundwater will he addressed in the BCV OU 4 RI.

\subsubsection{Bur Crouk}

The channel of Bear Creck along much of its coune through BCV is formed in the shallow alluvium overlying the Maynardville Limestone. Drilling activities in areas proximal (1) Bear Creck have indicated that a enne of potentially interconnected solution cavities is present in the upper part of the sulurated and in this formation. Becuuse of the hydraulic interaction between the creek and this solution cavity syatem, the Bear Creck channel contains lasing reaches where surface water discharges from the creck to the groundwater syatem and guining reaches where groundwater discharges to the creck. 


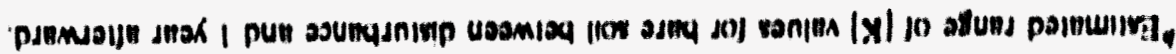
mol in 10 axziari wod meal.

\begin{tabular}{|c|c|c|c|}
\hline $45^{\circ}\left(0-8 e^{\circ} 0\right.$ & $25^{\prime}\left(0-4 x^{\prime \prime}()\right.$ & $25^{\prime}(1)-x \cdot 0$ & uniogs \\
\hline \multicolumn{4}{|c|}{$\begin{array}{l}\text { IS6 oN pos } \\
\text { manniा Mo }\end{array}$} \\
\hline $120-1210$ & $6 t^{\prime}(0-120$ & $2+0-2 t^{*} 0$ & unjos \\
\hline \multicolumn{4}{|c|}{$\begin{array}{l}92 \text { oN nos } \\
\text { mnnpyas colles ondond }\end{array}$} \\
\hline $\left.82^{\prime} 0 \times 1\right) 2^{\prime} 0$ & $270-210$ & $920-610$ & unjos \\
\hline \multicolumn{4}{|c|}{ 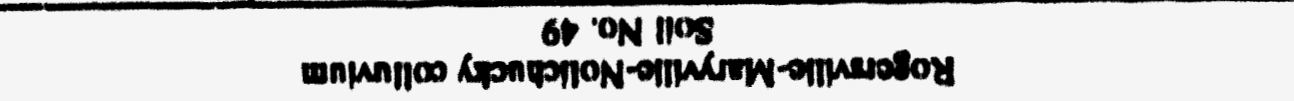 } \\
\hline $410-10 \%$ & $\cos 0-100^{\prime} 0$ & $w^{\prime} 0^{-1}\left(k^{*}\right)$ & alloudng \\
\hline $62^{\prime}(0-410$ & $0 z \cdot 0-910$ & $w^{\prime}\left(0-9 z^{\prime} 0\right.$ & unjos \\
\hline \multicolumn{4}{|c|}{ 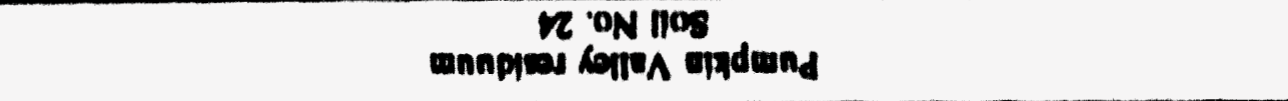 } \\
\hline$(1) \cdot(1)=100$ & $120-100$ & 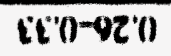 & allododes \\
\hline $4 I^{\prime}(1)-(x)^{\prime} 0$ & $O 1 \cdot(1-20)^{\prime}()$ & $V^{\prime \prime}\left(0=60^{\prime}\right)$ & unjos \\
\hline \multicolumn{4}{|c|}{$\begin{array}{l}\text { or on nos } \\
\text { manpias ompestoy }\end{array}$} \\
\hline $50\left(0-10^{\prime} 0\right.$ & $2010-200$ & $x^{*} 0-1 x^{* 10}$ & slfosdng \\
\hline XI'0-il') & $21^{\prime}(0-1) 10$ & $x 20=610$ & unjog \\
\hline \multicolumn{4}{|c|}{ 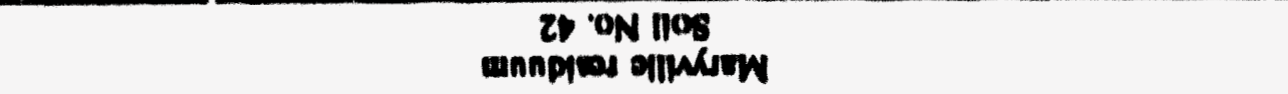 } \\
\hline$\left.{ }^{2} 0\right)^{\prime}\left(0-10^{\prime}(0)\right.$ & $(1)^{\prime} 0-8010$ & $6 b^{\prime}\left(0-1 b^{\prime} 0\right.$ & alloudng \\
\hline n'0-re & $180-120$ & $n^{\prime \prime}()-9 z^{\prime}()$ & unjos \\
\hline \multicolumn{4}{|c|}{$\begin{array}{c}\text { Is oN } 110 \mathrm{~s} \\
\text { annpias kepnconon }\end{array}$} \\
\hline $\begin{array}{l}\text { nor oxoyn } \\
\text { poquina }\end{array}$ & $\begin{array}{l}\text { now onopm } \\
\text { eond-o }\end{array}$ & $\begin{array}{l}\text { Qune oug } \\
\text { cond-g }\end{array}$ & Dopoed \\
\hline
\end{tabular}

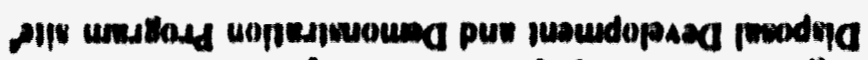

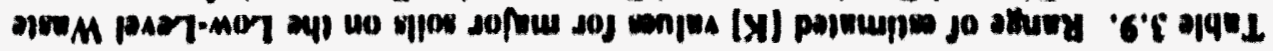


A dye tracer lest was performed in 1989 10 evaluate the hydrologic interaction between Bear Creek and the Maynardville Limestone (Geraghty and Miller 1989). During this study, a review of historic stream. flow data for Bear Creek was performed. Results of this review indicated that Bear Creck loses flow to the groundwater system during extreme low-flow conditions over much of its length from near the S.3 Ponds to) a spring located at BCK 4.56. During normal flow conditions, Bear Creck loses flow to the groundwater system in its upper reaches and gains flow in its lower reaches downstream of BCK 9.41 (Geraghty and Miller 1989). It was concluded from the dye-tracer test that there was strong evidence indicating that surface water lost in losing reaches of Bear Creek between BCK 11.64 and BCK 9.41 is substantially discharged back into Bear Creck from spring SS.5 (Geraghty and Miller 1989).

\subsubsection{Stranm Aow data collection}

Discharge data have been collecled in the upper part of Bear Creck at many locations over different periods from 1986 through 19\%). Monitoring stations ure shown in Fig. 3.15, and their locations are listed according to BCK.

Periodic Now monitoring in Bear Creck has been carried out by the USGS since 1986. Flow and limited chemical data have been monitored by staff in the Environmental Sciences Division at ORNL. Details of past surface water sampling activities along Bear Creek are given in Turner el al. (1991).

Flow data in the main stem. tributaries, and springs allow the different sections of the stream to be classified as losing or gaining reaches. The data also indicate flow in solution cavities in the Maynardville Limestone underlying Bear Creek. This flow apparently conducts water from the upper reaches between BCK 9.53 and BCK 12.46 to lower reaches of Bear Creek.

\subsubsection{Efrocts of the Solution Cavity Syatem}

The solution cavity system within the Maynardville Limestone, which conducts flow westward under Bear Creek, plays an impertant role in the surface water hydrology of BCV. The cavity system is thought to be an important avenue for contaminant transport because contaminants in the surface water can be lost to the system, which extends outside the BCHR. Although the precise outlets of the cavity system are unknown. there is evidence that at least some fow from the cavity system emerges in springs discharging from solution openings along hedding planes and joints in the rock units adjacent to Bear Creck.

Both springs SS4 and SS5 are perennial, nowing from the base of Chestnut Ridge on the southern side of the valley. Both streams also show higher average specific conductivity than the main-stem water. The high specific conductivity is an indication that the water from the headwaters (BCK 12.46) or Tributary NT.I (BCK 12.39), or from a similar source, has been Iransported to these springs.

\subsubsection{Stormflow Systom}

Detailed water budgets for the ORR indicate that - $90 \%$ of active subsurface flow occurs through a 1 - 10 2-m-deep (3.3- 10 6.6-f1) stormflow zone (Solomon et al. 1992). Natural areas of the ORR are heavily vegetated, and the stormflow zone approximately corresponds 


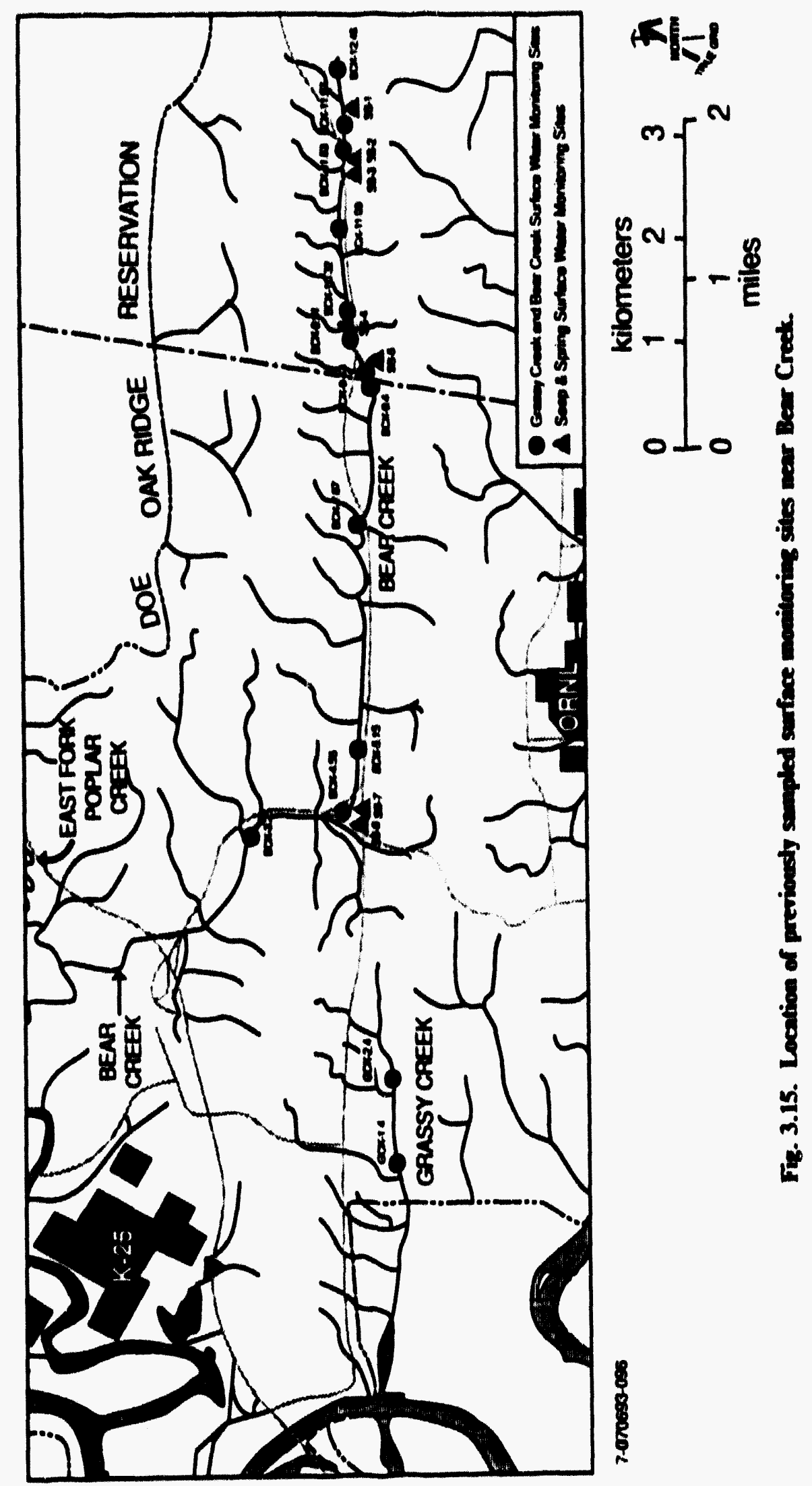


10 the root zone. Infiltration tests indicate that this zone is as much as 1000 times more permeable than the underlying vadose zone. During rain events, the stormflow zone partially or completely saturates and then transmits water laterally to the surface water system (Fig. 3.16). When the stormflow zone becomes completely saturated, overland now occurs.

Where such excavations as waste trenches penetrate the stormflow zone, a commonly observed condition known as bathtubbing can occur in which the excavation fills with water (Ashwond and Spalding 1991) (Fig. 3.16). Between rain events, as the stormflow zone drains, flow rates decrease dramatically, and flow becomes nearly vertical toward the underlying vadose zone. The transmissive capability of the stormflow zone is created primarily by root channels, worm holes, clay aggregation, and fractures, collectively referred to as macro pores. Although highly transmissive, large pores comprise unly $-0.2 \%$ of the total void volume of the stormflow zone. Because most of the water mass resides within less transmissive small pores, advective-diffusive exchange between large pores and small pores reduces contaminant migration rates relative to fluid velocities in large pores.

The effect on stormwater flow of excavation and surface modifications at the various waste sites is not known. Seeps have been identified in NT.7 that apparently drain from the ends of trenches in BG.A. and this implies that the man-made structures in the Burial Grounds have a strong effect on stormflow hydrology. The extent of this effect must be identified as an important data gap hecause the stormflow zone is the most likely pathway for contaminant movement away from sites in BCV OU 1 to Bear Creek and its tributaries.

\subsubsection{Surface Water Contamination}

Surface water in the Upper Bear Creek watershed is affected by surface and subsurface drainage from the waste Burial Grounds, the Oil Landfarm, and the S-3 Ponds. These sources have contributed organic and inorganic chemical contaminants to Bear Creck. In recent years, actions have been taken to reduce the input of contaminants to Bear Creck from several of these sources, and several of these sources have also been closed and capped. Intensive monitoring of stream chemistry was initiated at about the same time many of these actions were being taken.

\subsubsection{Organic contaminants}

Surface waters from Bear Creck and tributaries were analyzed for a broad spectrum of organic priority pollutants during 1983 and 1984 (McCauley 1985c). Further sampling conducted during 1985 and 1986 was restricted to the Bear Creek stem. Surface water sampling is also included in the annual groundwater quality assessment reports (GWQARs) (HSW 1992). Only VOCs were delected in the aqueous phase in the stem of Bear Creek. These compounds consist primarily of halogenated aliphatics and low molecular weight aromatics. Trace levels of tetrachloroethene, toluene, and trichloroethene were detected $(-10 \mu \mathrm{g} / \mathrm{L}$ each) in the uppermost reaches of Bear Creck (BCK 12.36), while much higher levels of organics were detected farther downstream in the vicinity of the Burial Grounds. Trans-1,2-dichloroethene, tetrachloroethene, trichloroethylene, and vinyl chloride predominated; traces of other halogenated aliphatics were detected. Table 3.10 illustrates the summed concentrations $(\mu \mathrm{g} / \mathrm{L})$ of VOCs in Bear Creek surface water at various sites. The results show the highest concentration of VOCs were detected at BCK 9.91 immediately downstream of the Burial Grounds. VOC concentrations decreased rapidly downstream from 


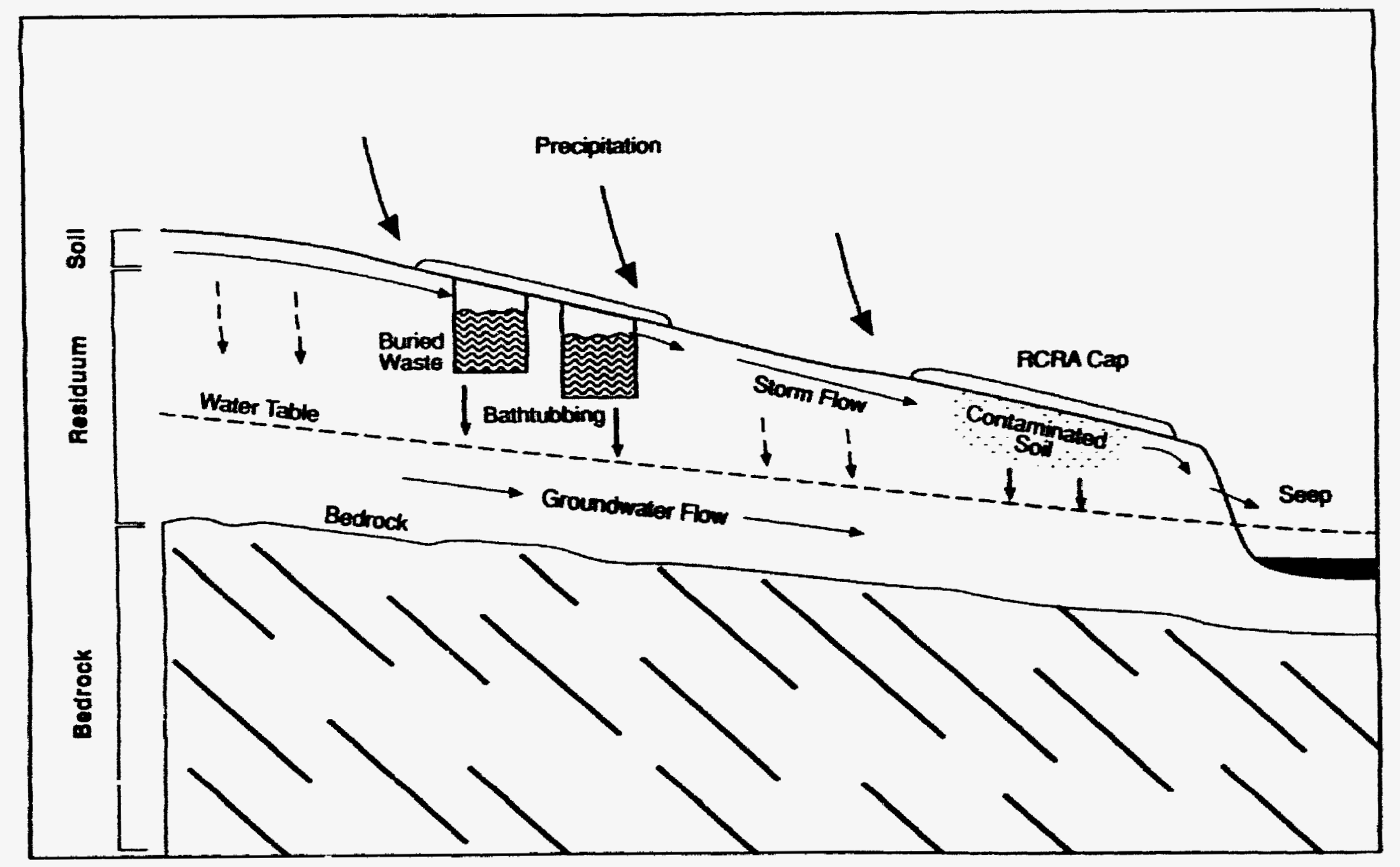

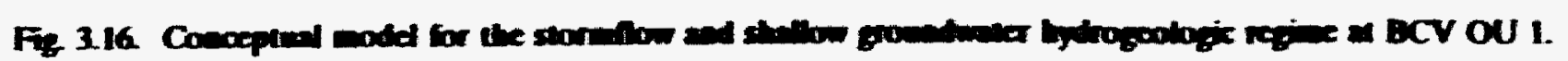


Table 3.10. Summed concentrations ( $\mu / \Omega)$ of VOCs in Bear Creck surface water at various sites

\begin{tabular}{||c|c|c|c|c|c|c|c||}
\hline \multicolumn{1}{|c|}{ Site } & $\begin{array}{c}\text { SepL. } \\
1983\end{array}$ & $\begin{array}{c}\text { Mar. } \\
1984\end{array}$ & $\begin{array}{c}\text { Aug. } \\
1984\end{array}$ & $\begin{array}{c}\text { Aug } \\
1985\end{array}$ & $\begin{array}{c}\text { Jan. } \\
1986\end{array}$ & $\begin{array}{c}\text { May } \\
1986\end{array}$ & $\begin{array}{c}\text { Sept. } \\
1986\end{array}$ \\
\hline BCK 12.39 & NA $^{a}$ & NA & $<10$ & $<10$ & $<10$ & $<10$ & $<10$ \\
\hline BCK 11.83 & NA & NA & $<10$ & $<10$ & 10 & $<10$ & $<10$ \\
\hline BCK 11.49 & ND & $<10$ & ND & $<10$ & $<10$ & $<10$ & NA \\
\hline BCK 11.09 & ND & ND & NA & NA & 10 & NA & $<10$ \\
\hline BCK 10.32 & NA & ND & NA & $<10$ & $<10$ & NA & $<10$ \\
\hline BCK 9.91 & 1291 & 201 & 225 & 147 & 874 & 210 & 210 \\
\hline BCK 9.43 & 52 & 97 & 11 & 46 & 225 & 11 & 23 \\
\hline BCK 9.40 & NA & NA & NA & 24 & 34 & $<10$ & 12 \\
\hline BCK 7.87 & NA & NA & $<10$ & $<10$ & $<10$ & $<10$ & $<10$ \\
\hline BCK 5.15 & NA & NA & NA & $<10$ & $<10$ & $<10$ & $<10$ \\
\hline BCK 3.25 & NA & NA & NA & $65^{c}$ & $<10$ & $<10$ & $<10$ \\
\hline
\end{tabular}

a Not applicable.

"Nol delected.

'Caused by methylene chloride, a likely laboratory contaminant.

Source: McCauley 1985c.

this site, undoubtedly caused by volatilization (Callahan et al. 1979). Concentrations generally dropped $(0)$ about $5 \%$ of the level at BCK 9.91 within $0.5 \mathrm{~km}(0.3$ mile) and were always less than $10 \mu \mathrm{g} / \mathrm{L}$ at BCK 7.87. Sources of the VOCs in this area at that time were BG-A through $B G-D$, which are underlain by groundwater that is highly contaminated by VOCs and d:- ined by tributaries (NT-7 and NT-8) that are contaminated with VOCs to levels 10 to 20 times those observed in Bear Creek.

Levels of summed VOCs in sections of tributaries NT-7 and NT-8 exceeded 2-3 mg/L in March and August 1984. High levels of VOCs were detected in Bear Creek at BCK 9.91 in September 1983 and January 1986. Although tributaries were not sampled at this time, detection of VOCs in the main stem indicates that levels of VOCs in NT-7 and/or NT-8 were also high. Recent measurements (Bogle et al. 1991) of VOCs in the headwater seeps of NT-8 exceeded $3.5 \mathrm{mg} / \mathrm{L}$ (summed concentrations). The observed levels approach those known to produce acute toxicity in sensitive species, and could be chronically toxic to stream biota. 


\subsubsection{Inorganic contaminants}

Before the discontinuing waste inputs to the S-3 Ponds at the headwaters of Bear Creek, the upper reaches of the stream were acidic and highly enriched with many inorganic constituents (ERDA 1975; Turner and Kamp 1984; Energy Systems 1984a). During 1974 and 1975, upper Bear Creek (BCK 11.1, 11.9) exhibited $\mathrm{pH}$ values ranging from 3.5 to 6.8 over a 5-month period (ERDA 1975), while from 1981 through 1983 a pH range of 3.9 to 7.5 was observed in the reach closer to the S-3 Ponds (BCK 12.1, 12.5) (Table 3.11). Before neutralization of the S-3 Ponds in summer 1983, upper Bear Creek (BCK 12.55) pH ranged from 4.0 to 4.5 during July-September (Energy Systems 1984a). High levels of aluminum (more than $100 \mathrm{ppm}$ ) were noted in the acidified waters. The levels of acidity and aluminum observed before September 1983 are toxic to fish and sensitive aquatic invertebrates (Altshuller and Linthurst 1983) and would adversely affect the biotic community of Bear Creek. The acidity in the upper reaches of Bear Creek was neutralized as it was carried farther downstream. It is safe to assume that toxic conditions existed in upper Bear Creek before neutralization of the S-3 Ponds and that this toxicity should have diminished within several kilometers downstream.

Table 3.11. Mean pH (range in parentheses) of Bear Creck in three surveys conducted over a 10-ycar period

(Hydrogen ion concentrations were used in the calculation of mean $\mathrm{pH}$ )

\begin{tabular}{||c|c|c||}
\hline \multirow{2}{*}{} & \multicolumn{2}{|c|}{ Sampling period/number of measurements } \\
\cline { 2 - 3 } & $\begin{array}{c}\text { October-March } \\
1974-75^{a} / \\
5 \text { measurements }\end{array}$ & $\begin{array}{c}\text { July-January 1983-84 } \\
24 \text { measurcments }\end{array}$ \\
\hline \hline BCK 12.55 & NS $^{c}$ & $\begin{array}{c}4.4(4.0-4.6)^{d} \\
6.7(6.1-7.3)^{c}\end{array}$ \\
\hline BCK 12.5 & NS & NS \\
\hline BCK 12.0 & NS & NS \\
\hline BCK 11.9 & $4.68(3.50-5.09)$ & NS \\
\hline BCK 11.1 & $6.32(3.90-6.80)$ & NS \\
\hline BCK 6.3 & NS & NS \\
\hline BCK 4.3 & $7.21(6.95-7.58)$ & NS \\
\hline BCK 1.8 & $7.12(6.88-7.30)$ & NS \\
\hline
\end{tabular}

${ }^{a}$ ERDA 1975.

${ }^{b}$ HSEAD 1984a,b.

${ }^{\top} \mathrm{NS}=$ not sampled.

${ }^{d}$ Before September 29, 1983.

-After September 29, 1983. 
Profound changes in the chemistry of upper Bear Creek occurred following neutralization of the S-3 Site in 1983. Within several months, $\mathrm{pH}$ rose to more than 7.0, aluminum dropped from $97 \mathrm{mg} / \mathrm{L}$ to $4 \mathrm{mg} / \mathrm{L}$, nitrate decreased from 1900 to $300 \mathrm{mg} / \mathrm{L}$, uranium decreased from 21 to $1 \mathrm{mg} / \mathrm{L}$, and other metals also declined significantly (Energy Systems 1984a,b). Intensive chemical and biological monitoring of the Bear Creek watershed was initiated after these changes took place.

Chemical analyses of Bear Creek surface waters, since the S-3 Ponds were neutralized in 1983, have been conducted by BNI (McCauley 1985c); Roy F. Weston, Inc. (Appendix C, Turner et al. 1991 and Southworth et al. 1992); Tennessee Valley Authority (TVA) 1986; USGS (Pulliam 1985); and ORNL (Southworth et al. 1992). These analyses show high concentrations of dissolved inorganic salts in the upper reaches of Bear Creek, typified by electrical conductivities of 2000 to $4000 \mu \mathrm{mho} / \mathrm{cm}$ and total dissolved solids concentrations of 2000 to $5000 \mathrm{mg} / \mathrm{L}$. The contribution of solutes from the S-3 Ponds groundwater plume dominates the major ion inorganic chemistry of Bear Creek. The total salt content, as indexed by conductivity, closely follows the pattern expected if Bear Creek water were diluted only with uncontaminated groundwater downstream from BCK 12.4. Solute inputs and dilution vary as a result of variations in precipitation runoff and infiltration, with the highest solute concentrations generally occurring during periods of low flow. Stream monitoring data from 1992 are summarized in Table 3.12 .

Table 3.12. Concentrations (mg/L) of major ions in unfiltered Bear Creek water at various sites downstream from the S-3 Site in $1992^{\circ}$

\begin{tabular}{||l|c|c|c|c|c||}
\hline \multicolumn{1}{|c|}{ Parameter } & BCK 11.97 & BCK 9.40 & BCK 4.55 & BCK 0.63 & NT 13 \\
\hline \hline Calcium & 209.75 & 60.75 & 45.25 & 27.25 & 18.05 \\
\hline Magnesium & 25.95 & 10.60 & 11.93 & 8.35 & 3.18 \\
\hline Aluminum & 0.50 & 0.64 & 0.49 & 0.26 & 0.57 \\
\hline Sodium & 32.00 & 8.33 & 4.28 & 4.13 & 4.15 \\
\hline Potassium & 4.8 & 2.65 & 1.78 & 1.7 & 1.58 \\
\hline Manganese & 0.86 & 0.08 & 0.07 & 0.10 & 0.77 \\
\hline Strontium & 0.57 & 0.15 & 0.09 & 0.08 & 0.06 \\
\hline Barium & 0.38 & 0.09 & 0.07 & 0.07 & 0.06 \\
\hline Uranium & 0.18 & 0.09 & 0.03 & 0.04 & $<0.001$ \\
\hline Nitrate (NO $\left.{ }_{3}-\mathrm{N}^{\prime}\right)$ & 107.94 & 13.03 & 5.23 & 5.12 & $<0.2$ \\
\hline Sulfate & 47.75 & 19.63 & 12.83 & 10.73 & 10.80 \\
\hline Chloride & 30.98 & 11.4 & 6.03 & 6.38 & 1.03 \\
\hline Alkalinity (as $\mathrm{HCO}_{3}$ ) & 122.50 & 133.25 & 129 & 118 & 59.50 \\
\hline
\end{tabular}

${ }^{a}$ Mean values for four quarterly samples taken on March 10, June 1, September 8, and December 16, 1992. 
Bear Creek surface water is highly enriched [relative to Grassy Creek reference sites (Fig. 3.15)] in many inorganic ions. The downstream variation in major ion chemistry is depicted in Table 3.12. Aluminum, barium, calcium, chloride, magnesium, manganese, nitrate, potassium, sodium, sulfate, strontium, and uranium are conspicuously high in the headwaters of Bear Creek and decline gradually in concentration downstream. Lithium and boron are slightly elevated in the Bear Creek headwaters relative to Grassy Creek reference sites, but the highest levels occur below the Burial Grounds. Ammonia, beryllium, cadmium, cobalt, copper, lead, nickel, silver, and zinc are elevated in the uppermost reaches of Bear Creek, but decline to approximately control levels or below detection limits within a short distance downstream. A comparison of maximum concentrations in Bear and Grassy Creeks, reported toxicity values, and EPA water quality criteria for the protection of freshwater biota are presented in Table 3.13.

Hardness-dependent screening criteria for surface water will be calculated by using sitespecific data for contaminant concentrations and hardness. The 5\% lower-bound concentration of each contaminant will be used as a conservative screen. The equation to be used to calculate the screening criteria is presented in U.S. EPA Region IV guidance (EPA 1992e):

$$
\text { Screening Value }=\exp \{[a \times \ln (\text { Hardness })\}+b\},
$$

where hardness is expressed as $\mathrm{mg} \mathrm{CaCO}_{3} / \mathrm{L}$. In the absence of hardness data, hardness will be estimated as

$$
(\mathrm{mg} \mathrm{Ca} / \mathrm{L}) \times 2.497+(\mathrm{mg} \mathrm{Mg} / \mathrm{L}) \times 4.116
$$

(Standard Methods for the Examination of Water and Wastewater, Method 309A). The parameters $\mathbf{a}$ and $\mathbf{b}$ are specific for each element and are different for acute and chronic exposures. They are listed in Table 3.14.

Most of these inorganics are relatively nontoxic; many, such as calcium, magnesium, sodium, and sulfate, are typical dissolved constituents of fresh waters. The $\mathrm{pH}$ of Bear Creek was generally between six and seven from late 1983 to the present. The high acidity noted before 1983 was not observed.

\subsubsection{Conclusions}

Surface water in Bear Creek and those tributaries localed in the Y-12 Plant waste disposal areas has been sampled extensively, and in some cases, intensively, since 1983. Virtually all sampling has been conducted under non-stormflow conditions. The analyses performed have included both inorganic and organic contaminants and have typically been comprehensive, including in one case EPA Appendix IX contaminants. Results of these analyses suggest that nitrate, uranium, aluminum, and cadmium are the chief contaminants warranting human health and ecological concern. The concentrations of all these contaminants decrease downstream from the headwaters near the S-3 Ponds suggesting that the primary release to surface water is related to this source. Since neutralization of the wastes in the S-3 Ponds and capping of this site, concentrations of contaminants in Bear Creek have diminished. 
Table 3.13. Meximum concentrations ( $m g / 2$ ), acute toxictity rangcs, and water quillty criteria for inorganic ions found at clevalod lovels in Bear Crock

\begin{tabular}{|c|c|c|c|c|c|}
\hline Ion & $\begin{array}{l}\text { Orassy } \\
\text { Creck }\end{array}$ & Bear Crcek & $\begin{array}{l}\text { Acule } \\
\text { toxicity } \\
\left(L C_{30}\right)\end{array}$ & $\begin{array}{l}\text { Water } \\
\text { quallity } \\
\text { critcrion }\end{array}$ & $\begin{array}{l}\text { Chronic } \\
\text { scrocuing } \\
\text { criteria }\end{array}$ \\
\hline Aluminum & 0.6 & 5.8 & $0.2-38.0$ & 0.75 & 0.087 \\
\hline Ammonia & 0.04 & 0.39 & & $3.5^{b}$ & \\
\hline Barium & 0.044 & 1.2 & $13.5-105.0$ & & \\
\hline Boron & 0.01 & 1.1 & 9001.0 & & 0.75 \\
\hline Cadmium & 0.004 & 0.16 & $0.09-7.2$ & $0 .(0) 11^{e}$ & \\
\hline Calcium & 42.0 & $60(0.0$ & & & \\
\hline Chloride & 7.4 & 230.0 & & 860 & 230 \\
\hline Copper & 0.02 & 0.04 & $0.014-1.0$ & $0.012^{r}$ & \\
\hline Fluoride & 0.3 & 2.0 & & & \\
\hline Lead & 0.1 & 0.4 & $1-482$ & $0.00032^{r}$ & \\
\hline Lithium & 0.1 & 0.8 & & & \\
\hline Magnesium & 17.0 & 82.0 & & & \\
\hline Manganese & 0.087 & 8.8 & $1.5-1000.0$ & & \\
\hline Nickel & 0.01 & 0.08 & $1.8-188.0$ & $0.1600^{\circ}$ & \\
\hline Nitrate & 0.6 & 440.0 & & & \\
\hline Potassium & 0.9 & 14.0 & & & \\
\hline Silver & 0.03 & 0.12 & $0.02-1.0$ & $0.120^{\circ}$ & \\
\hline Sodium & 8.2 & 67.0 & & & \\
\hline Strontium & $<0.5$ & 1.5 & $86-10,000$ & & \\
\hline Sulfate & 2.0 & 109.0 & & & \\
\hline Uranium & 2.0 & 2.0 & $2.8-5.0$ & & \\
\hline Zinc & 0.014 & 0.022 & $0.78-14.3$ & 0.110 & \\
\hline
\end{tabular}

${ }^{a}$ EPA Region IV.

${ }^{b} \mathrm{pH} 7,25^{\circ} \mathrm{C}$.

'Hardness dependent, to be calculated from site-specific data.

Sources: Southworth et al. 1992, EPA 1976, EPA 1992e. 


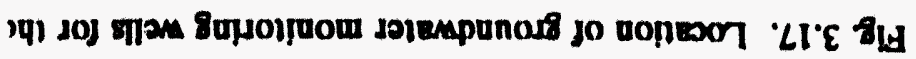

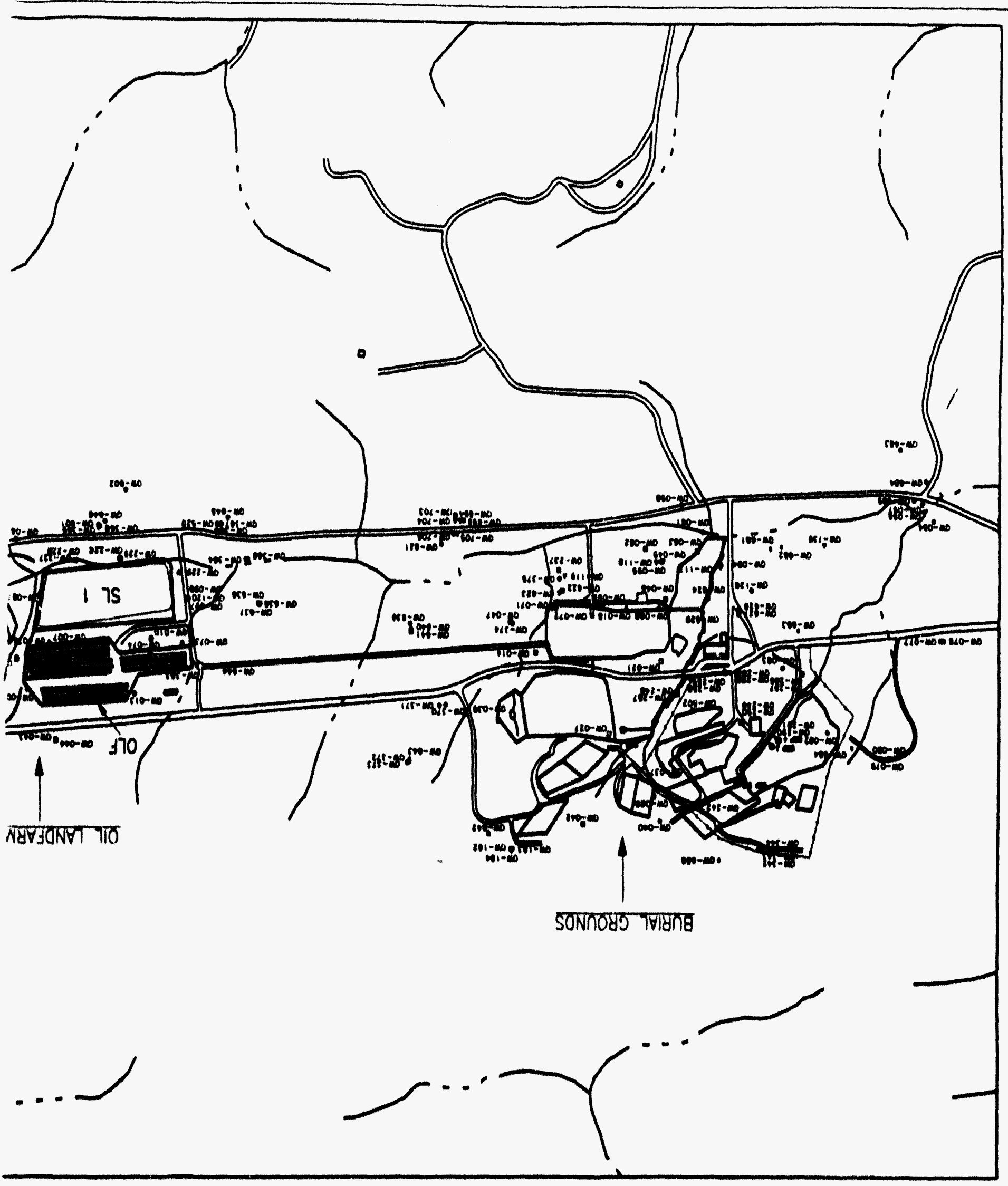




\subsection{2}

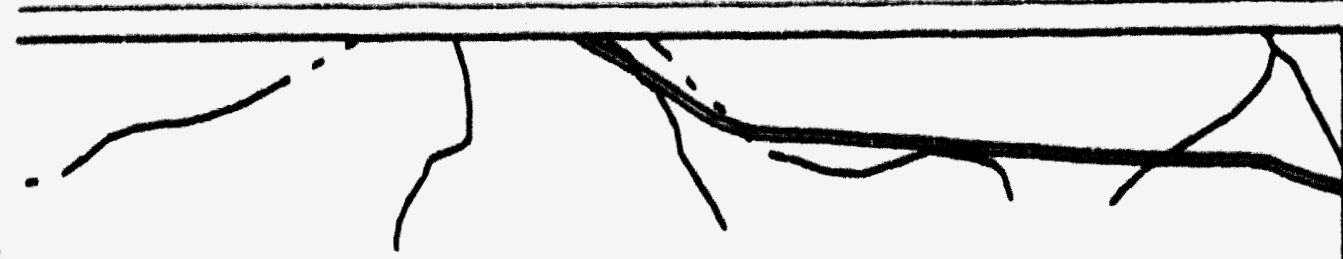

LEGEND:

- BEDROCK WELLS < $200^{\circ}$

- ABANDONED BEOROCK

- WELLS $<200$

口 UNCONSOLIDATED WELLS

- ABANDONED

UNCONSOLIOATED WELLS

$\triangle$ BEDROCK WELLS > 200'

- 1993 COMPLIANCE

* SAMPLINC LOCAFIONS

ARM AREA

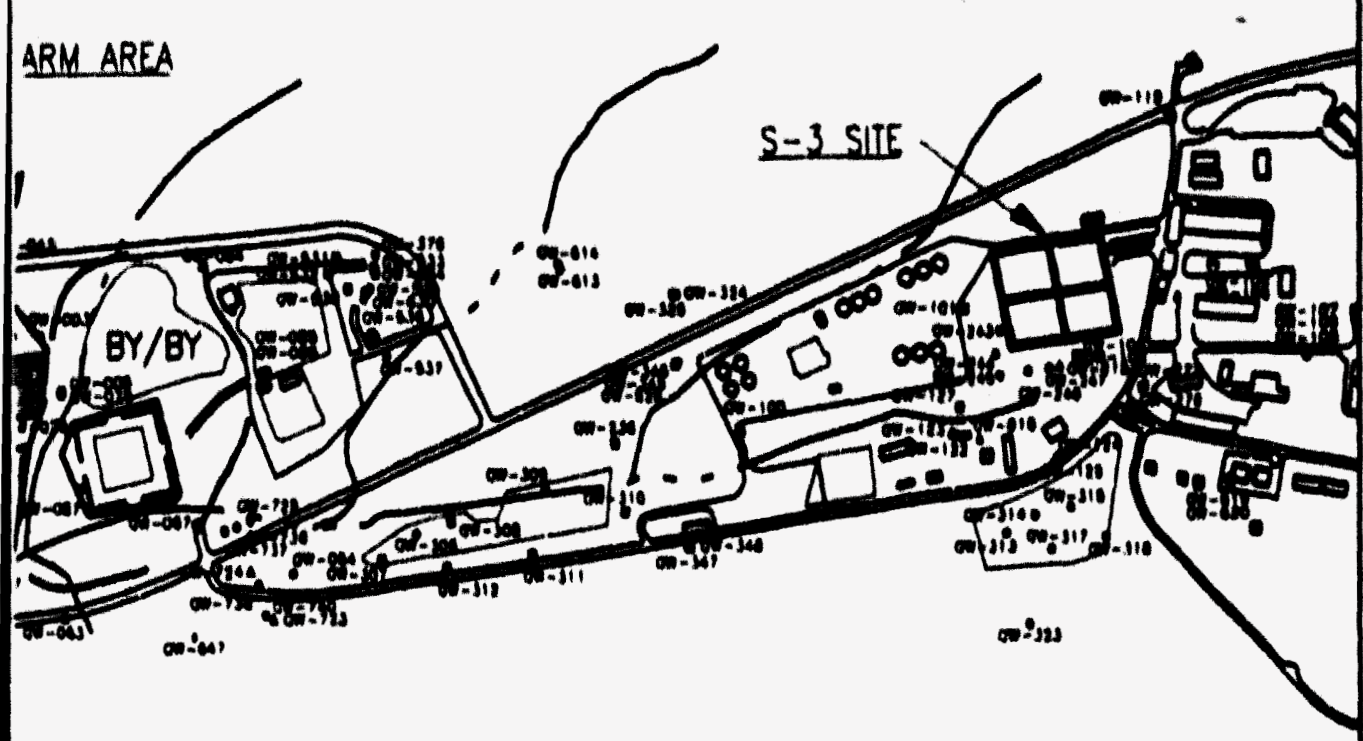

$$
0
$$
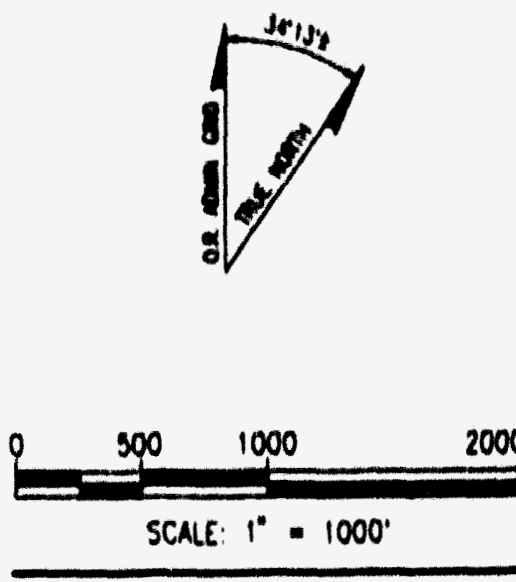

BEAR CREEK VALLEY OPERABLE UNIT 1 RI WORK PLAN
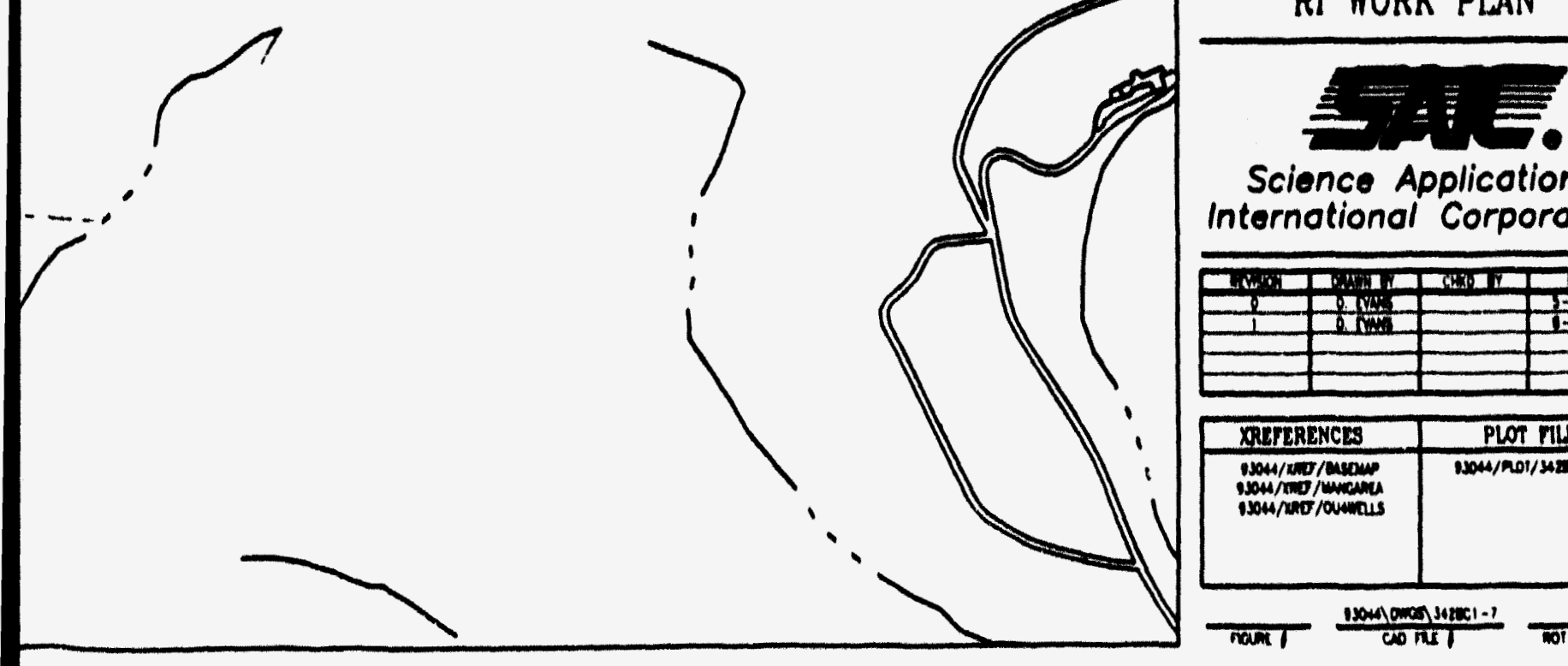

Science Applicotions International Corporation
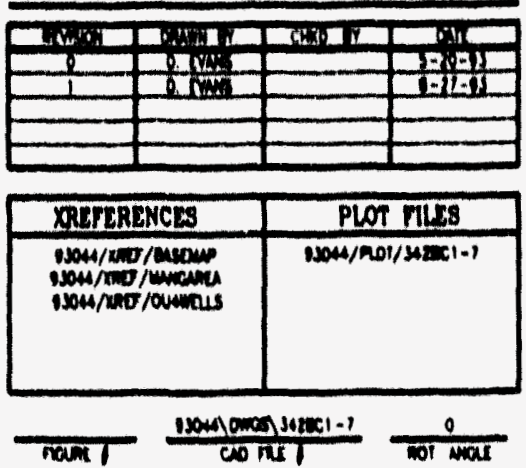

or the active Dow systom in Upper BCV (Sounce: HSW 1992). 
Tuble 3.14. Panmeters for turdecen-depondent aquatic screenlas criteris

\begin{tabular}{|c|c|c|c|c|}
\hline \multirow[b]{2}{*}{ Biomont } & \multicolumn{2}{|c|}{ Acute carealag value } & \multicolumn{2}{|c|}{ Chonk screalos vilus } \\
\hline & $\mathbf{\theta}$ & b & e & 0 \\
\hline Cndmium & 1.128 & -3.826 & 0.7852 & -3.49 \\
\hline Chromium III & 0.019 & 3.698 & 0.819 & 1.561 \\
\hline Copper & 0.9422 & -1.44 & 0.8545 & -1.463 \\
\hline Land & 1273 & -1.48 & 1.273 & -4.703 \\
\hline Nickel & 0.846 & 3.3612 & 0.746 & 1.1645 \\
\hline Silver & 1.72 & -6.52 & $b$ & b \\
\hline Zinc & 0.8473 & 0.9614 & 0.8473 & 0.7614 \\
\hline
\end{tabular}

-Calculated by the following equation: Screening Value $=\exp (\mid a \times$ In(Ilardncas $) \mid+b)$, where hurdneas is expreased as $m$ Caconh.

No criterion set.

Oiven the extensive previous characterization of Bear Creek surface water by several agencies (Y.12 Plant; USOS; Roy F. Weston, Inc.; BNI; and TVA) and the general concordance of results, it seems likely that all contaminants of concern for surface waten have been identilied. However, previous work has not addressed elther the locations of high contaminant input to surface waten (c.g." active aprings) or stormflow tranaport of contaminants from the source areas to the main stem of Bear Creek.

\subsection{OROUNDWATER}

As discussed in Sect. 1.5, the scope of the BCV OU I RI with reapect 10 groundwater is to address the extent to which units of the BCV OU I may be contributing contaminants to groundwater. Migration of contaminants from the individual source areas is being addressed by the BCV OU 4 RI. It is the objective of this RI work plan widentify data gaps and completely characterize contaminant releases and potential teleases at each sitc.

\subsubsection{Existing Well Information and Descriptions}

Information on location and construction details for the wells discussed in this document is available in Updated Subsurface Data Base for Bear Creek Valley, Chesenut Ridge, and Pans of Beithel Valley on the U.S. Deparment of Enery Oak Ridge Reservation (Jones et al. 1992). The locations of current groundwater monitoring wells in BCV are shown in Fig. 3.17. 


\subsubsection{Bar Creet Hydrobole Regime}

Water level dath are collected, al a minimum, each time monitoring wells are sampled a part of the Y.12 Plani compllance program and semiannual water level measurementa independent of sampling events were initiated in Auguat 1992 on over 600 wells in BCV (Fig. 3.17). The results of water level measurements throughoul BCV are summarized in the annual OWQAR (HSW 1992). Recent resulus reveal a groundwater piezometric surface (Fig. 3.18) sloping in from recharge areas on ridges in discharge along Bear Creck. The plezometric surface sugesests a groundwater divide just east of the S.3 Ponda area as the eastern boundary of the BCHR.

The groundwater syatem underlying the BCHR generally consisu of three parta: the alormflow ane (as discusued in Sect. 3.5.3), vadowe ane, and groundwater zone. The groundwater wne consists of an upper saturated zone comprised of unconsolidated materials and shallow bedrock and a lower saturated anne consising of the six formations of the Conasauga Oroup. For practical purposes, the upper and lower zones can be considered a single aquifer of relatively low water iransmilting capacity, with the exception of Iranamiasion in conduits. The occurrence and movement of groundwater in the bedrock are closely related to the presence of bedding planea, joints, fractures, and solution cavilies. In the shale formations, bedding planes and bedding plane fractures have reaulted in preferential flow paths along atrike. Flow perpendicular lo bedding is retarded by the low permeahility of the shale and is largely limited to areas where joints or fiactures cut across bedding.

Depth to groundwater in the BCHR varien buth spatially and tempirally. The configuration of the water table generally in a subdued replica of the surface lopography, being at high elevations beneath hills and at lower elevations in the valley boilloms. In general, elevations of the water table are loweat from Oetober to December and higheat frum January to March.

An upward hydraulic gradient generally is present in the shale formations of the Conasauga Group ihroughout the BCHR ut deptha ranging from it to $152 \mathrm{~m}$ (45 10 S(X) fi). Upward gradients range from (0.(x), in 0.129; gradients at individual sites in BCV OU 1 are described in the following sections. Al shullow depihs, the vertical gradients may be reverned at times in response (1) recharge events (Geraghiy and Miller 1986). Recharge to the shallow groundwater system oceurs through the surface veneer of unconsolidated materials.

\subsubsection{Flow dircection and rate}

Groundwater movement in the BCHR is influenced locally by the surface drainage system and its associated solution cavities. Figure 3.19 illustrates the general paltern of groundwater now.

The direction of groundwater movement generally is controlled by the potentiometric gradient and the permeability of the medium. In a completely isotropic aquifer, the llow direction of groundwater should be normal to the equipesential contouns of the aquifer. 


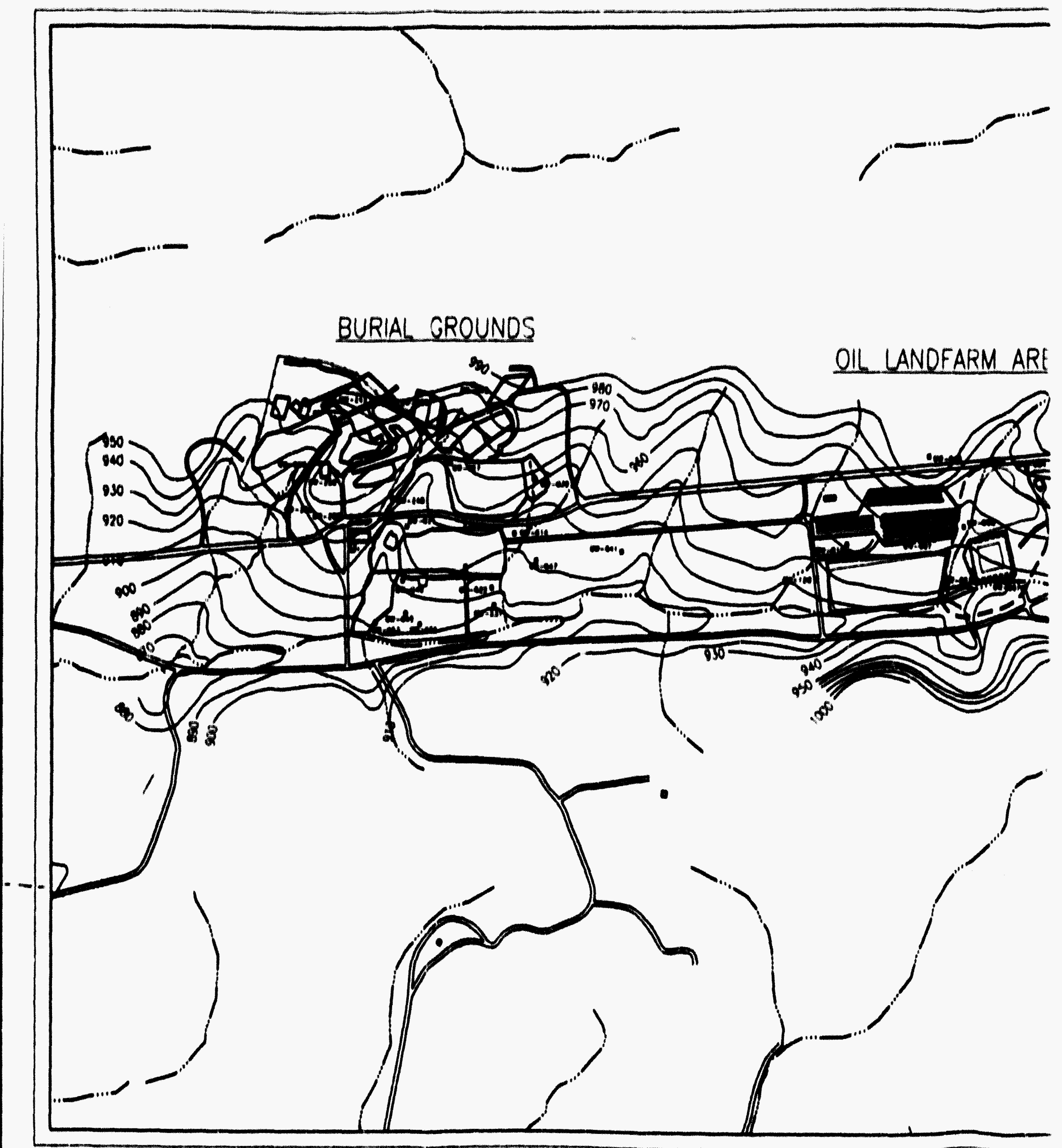

Fe. 3.18. Oroundwater olovations is the unouasolldater 


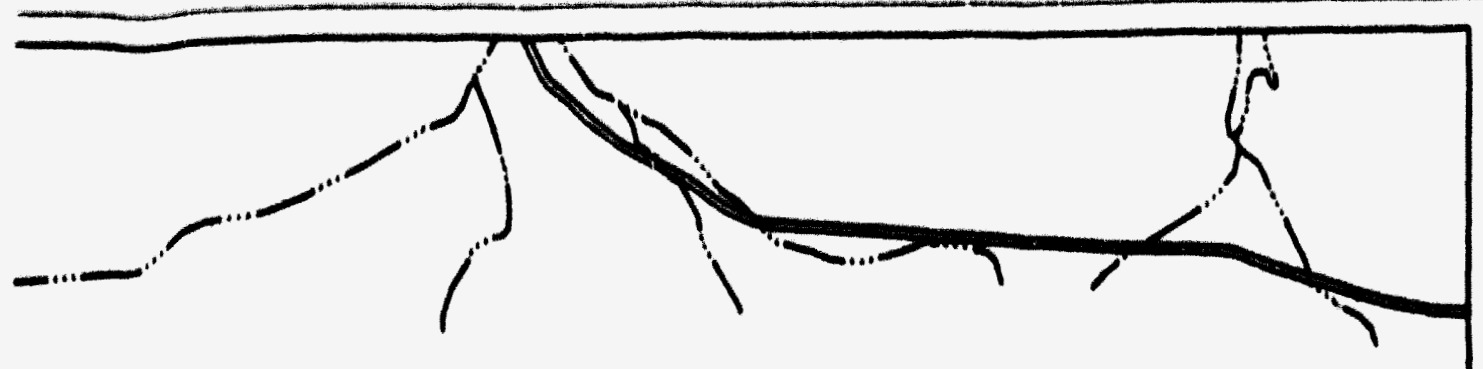

LEGEND:

UNCONSOLIDATED WELLSS ABANDONED

UNCONSOLIDATED WELLS

- 880 - GROUND WATER

GROUNO WATER CONTOUR DATA

FROM APRIL 29 TO MAY 3, 1991

COUNTOUR INTERVAL $=10 \mathrm{FT}$

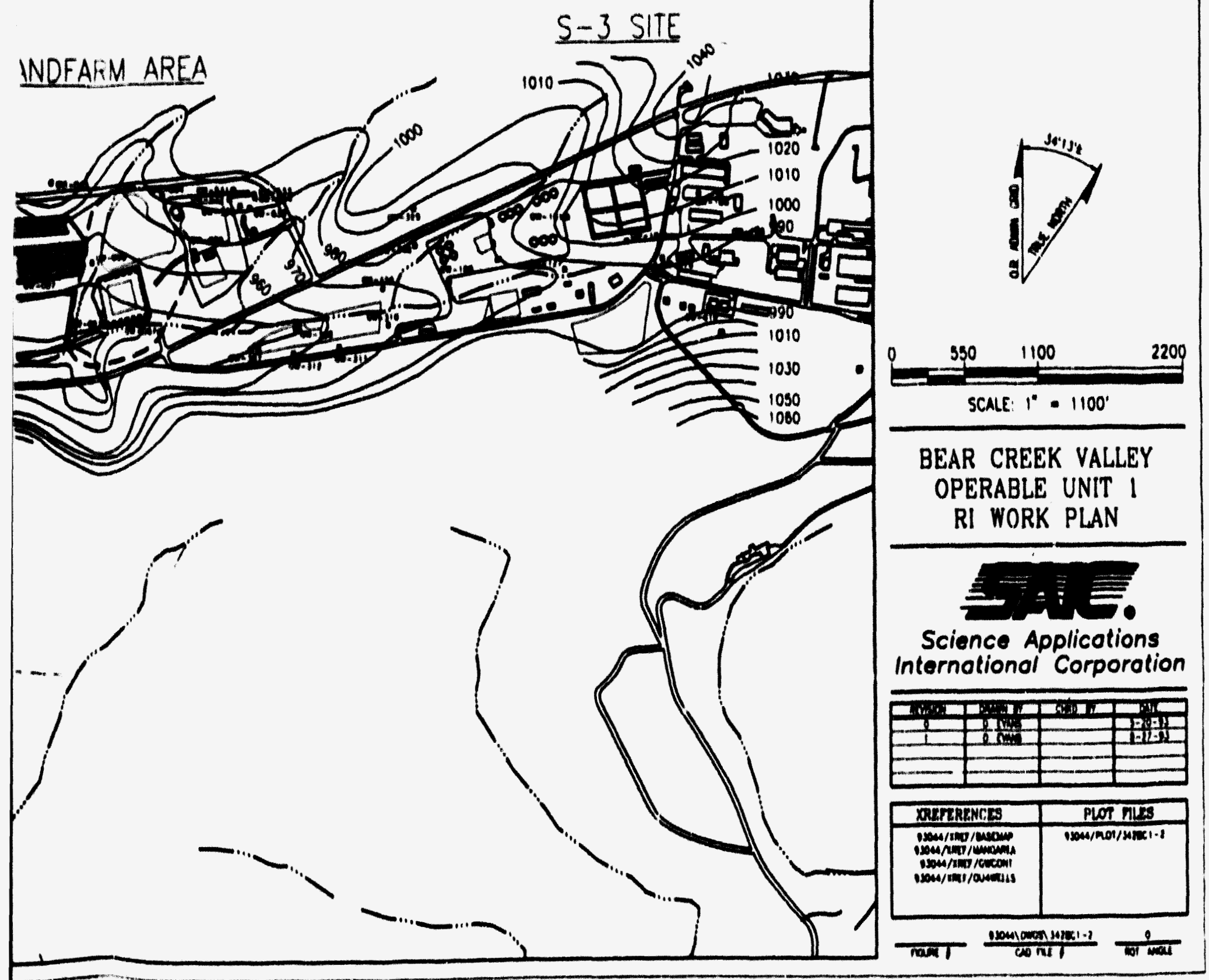

In tho unainsolidated aquifor in BCV (Source: HSW 1982). 


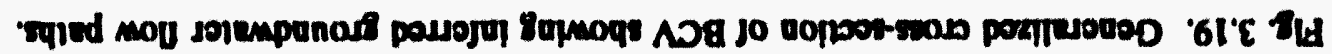

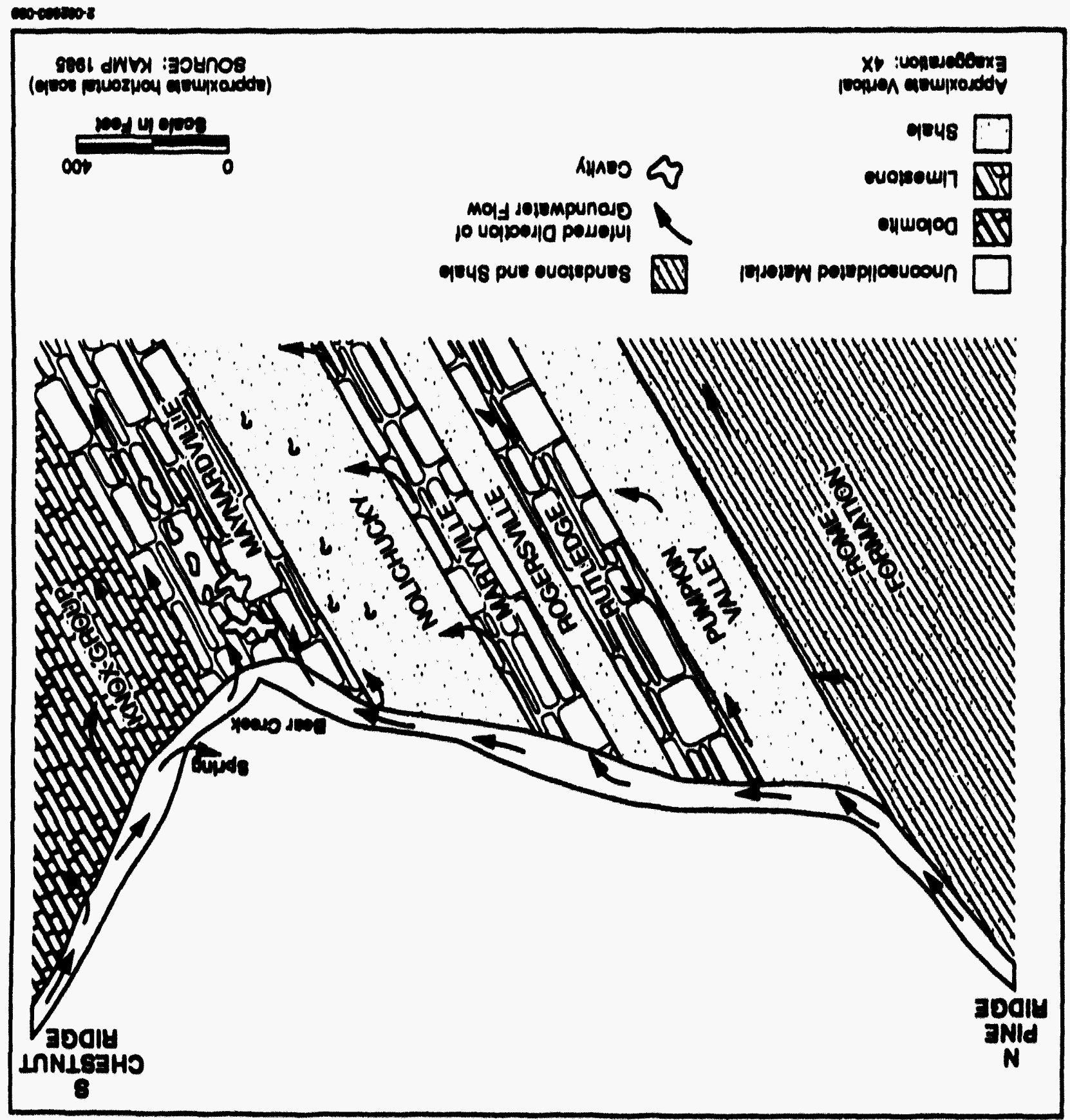


However, in an anisotropic aquifer such as the Conasauga, the local flow directions are strongly controlled by the orientation of the bedding planes, fractures, and joints as well as by the distribution of solution cavities. Thus, a map of potentiometric contours based on observed head differences in wells in BCV indicates only the gencral direction of groundwater now.

Figure 3.18 is a contour map of the water table at the BCHR based on water levels recorded in wells in 1991 (HSW 1992). In the Maynardville Limestone underlying Bear Creek, the direction of groundwater flow is southwest along the valley axis. The water table map is representative of the general water table configuration observed over the past several years (Geraghty and Miller 1986, 1987, 1988, 1989; HSW 1991, 1992). Although the water table nuctuates throughout the year, the pattern of fluctuation is similar in all wells, so that the water table slope remains essentially unchanged. No reversals of horizontal hydraulic gradient have been observed within the BCHR.

The average rate of groundwater flow in the Nolichucky Shale and the Maryville Limestone ranges from -43 to $762 \mathrm{~m} /$ year (140 to $25(\mathrm{~K}) \mathrm{ft} /$ year) (Geraghty and Miller 1989). An average flow rate in the Maynardville Limestone was calculated at $4 \mathrm{~m} / \mathrm{d}(12.8 \mathrm{ft} / \mathrm{d})$; however, a tracer test in the Maynardville Limestone in the Bear Creek drainage basin yielded a rate of travel of $-61 \mathrm{~m} / \mathrm{d}(200 \mathrm{ft} / \mathrm{d})$ through structural/solution features to a spring (Geraghty and Miller 1989). Poor estimates of groundwater flow rate are to be expected when the Darcy equation for groundwater flow is applied to an anisotropic aquifer like this one. The assumptions made for using this equation, such as that groundwater flow paths are parallel to hydraulic gradient, may not apply and, therefore, may give misleading results.

S-3 Ponds. The groundwater divide between BCHR and UEFPC Hydrologic Regime is located just east of the S.3 Site (Fig. 3.20). North of the S.3 Ponds, groundwater movement is toward the south and southeast. South of the ponds, groundwater movement is to the southwest and northeast along the valley axis, defining the groundwater divide. The groundwater contours in Fig. 3.20 are representative of the general groundwater table observed over the past few years (HSW 1991, 1992; Geraghty and Miller 1986, 1987, 1988, 1989). A water table mound that was evident below the S.3 Ponds while the ponds were accepting liquid wastes has diminished in size and is now almost indistinguishable. During the time this groundwater mound was present, the groundwater divide passed under the S.3 Ponds; this is evidenced by the nitrate plume in groundwater below the S-3 Ponds that is in groundwater in both hydrological regimes (Turner et al. 1991).

The range of groundwater levels recorded in wells at this site is shown in Fig. 3.21 in relation to the waste units at the S-3 Site. From these data it is apparent that some of the waste materials in the former S-3 Ponds are located below the groundwater table.

Data obtained from monitoring well clusters at the S-3 Ponds indicate upward hydraulic gradients in the shale formations of the Conasauga Group of between 0.003 and 0.129 (Geraghty and Miller 1986). Water level data from the Maynardville Limestone indicate downward flow in this formation, with gradients ranging from $0 .(0) 8$ to 0.124 . 


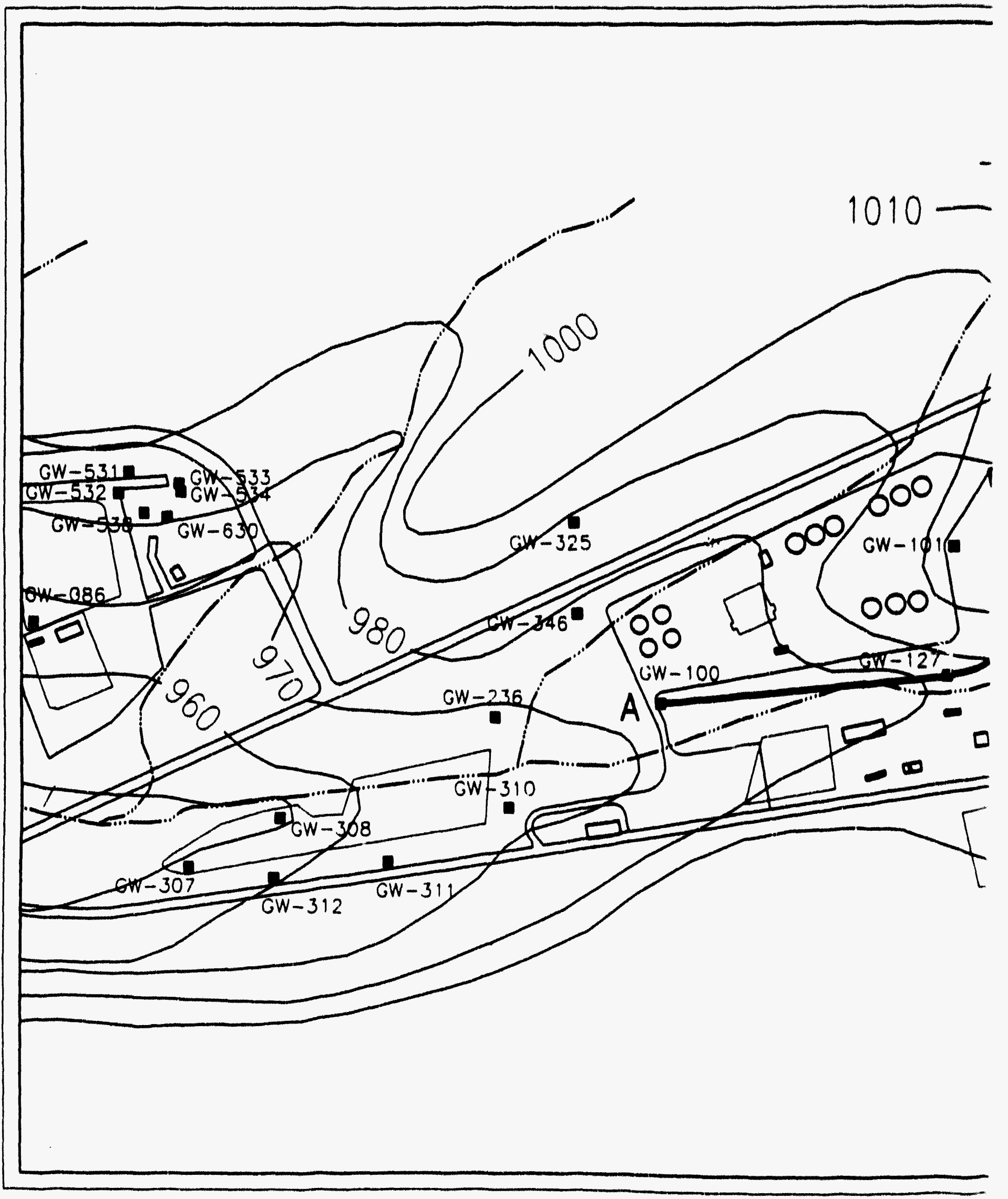

Fig. 3.20. Oroundwater elovations in the unconss) 


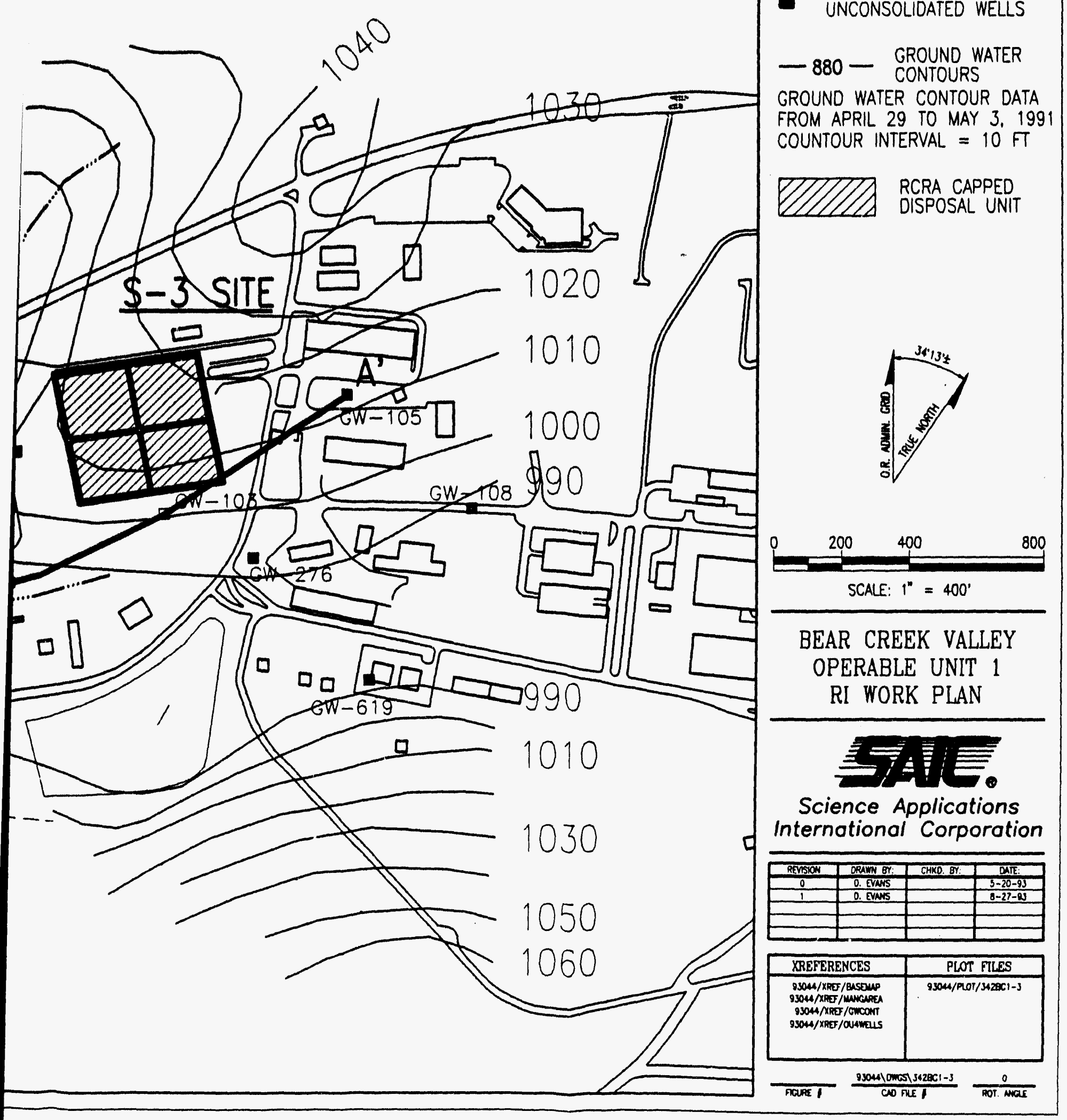

consolidated aquifer at the S-3 Site (Sounce: HSW 1992). 


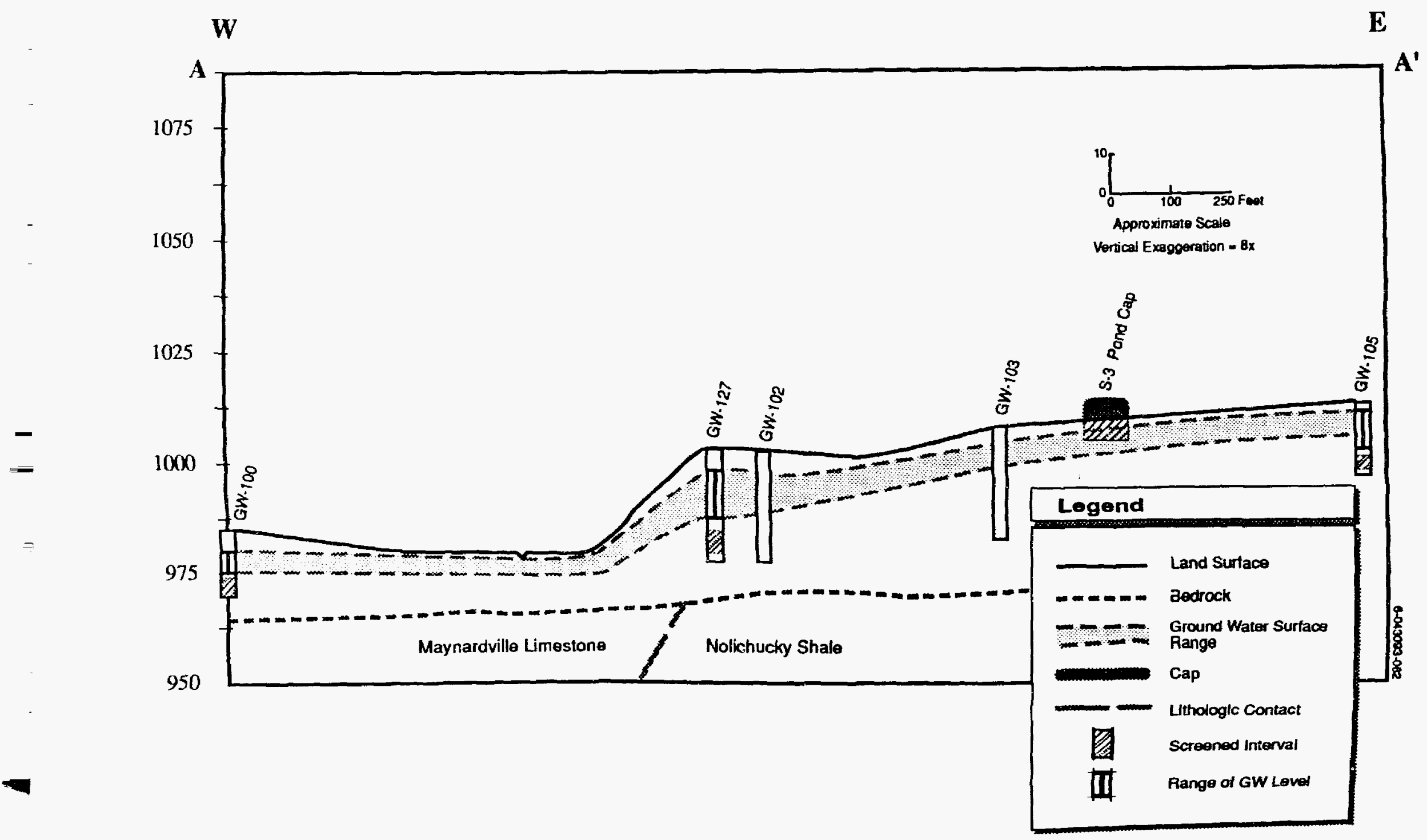

Fig. 3.21. Cross-section A-A' at the S-3 Site showing groundwater clevations in relation to the waste unit. 
Oil Landfarm, SL 1, and Boneyard/Burnyard. The water table contours generally indicate southerly and southeasterly directions of groundwater movement at the Oil Landfarm (Fig. 3.22). Data obtained in October 1986 from monitor well clusters at the Oil Landfarm indicated upward gradients ranging from 0.01 to 0.25 . Water level data from monitor well clusters in the Maynardville Limestone indicate downward flow components to depths as great as $61 \mathrm{~m}(200 \mathrm{ft})$. The calculated downward gradients range from 0.008 to 0.124 (Geraghty and Miller 1989). The downward flow may indicate that the solution cavities common to this unit function as an effective sink for the aquifer system. Horizontal gradients at the Oil Landfarm range from 0.03 to 0.07 .

The range of groundwater levels recorded in wells at this site is shown in Fig. 3.23 in relation to the waste unit and the cap at the Oil Landfarm.

Burial Grounds. The groundwater table contour map for the Burial Grounds (Fig. 3.24) indicates southerly and southeasterly directions of groundwater movement northwest of Bear Creek. In the zone underlying Bear Creek, the direction of groundwater flow is southwest along the valley axis. Data obtained in July 1986 from monitor well clusters at the Burial Grounds indicated upward hydraulic gradients in the Nolichucky Shale ranging from 0.06 to 0.14. Upward gradients were also recorded in the Maynardville Limestone at the Burial Grounds ranging from 0.14 to 0.24 . Horizontal hydraulic gradients in the Burial Grounds range from 0.03 to 0.1 . In general, hydraulic gradients were steeper in areas with steep topographic slopes and also near Bear Creek.

The range of groundwater levels recorded in wells at this site is shown in Figs. 3.25 and 3.26 in relation to the waste units at the Burial Grounds. From these data it is apparent that the bottom of some of the trenches in BG-A and BG-C is located below the groundwater table.

\subsubsection{Aquifer characteristics}

The hydraulic properties of the geologic units that exert the greatest influence on contaminant transport at $\mathrm{BCV}$ OU 1 have been quantified by field tests. Hydraulic conductivity tests have been conducted in the unconsolidated zone and bedrock zone wells at several sites in $\mathrm{BCV}$. In the unconsolidated zone, these values commonly range from 3.4 to $91.4 \mathrm{~m}$ /year (11 to $300 \mathrm{ft} /$ year) (BNI 1983, 1984). In shallow bedrock, the values range from 0.3 to $12 \mathrm{~m} / \mathrm{year}$ ( 1 to $40 \mathrm{ft} /$ year) in the Nolichucky Shale and 274 to $1280 \mathrm{~m} / \mathrm{year}$ (900 to $4200 \mathrm{ft}$ /year) in the Maynardville Limestone. At the S-3 Site, hydraulic conductivity values range from 30 to $232 \mathrm{~m} /$ year (98 to $760 \mathrm{ft} /$ year) in the unconsolidated zone and 3 to $12 \mathrm{~m} /$ year (10 to $40 \mathrm{ft} /$ year) in the shallow bedrock zone (Geraghty and Miller 1987). Results of tests conducted in deep bedrock well were far lower, with the lowest being $0.01 \mathrm{~m} / \mathrm{year}$ ( $0.02 \mathrm{ft} /$ year), indicating a significant decrease in conductivity with depth (Geraghty and Miller 1987).

Mean values for hydraulic conductivity in the Nolichucky Shale and the Maryville Limestone, estimated using the USGS MODFLOW groundwater flow model, range from 0.1 to $0.5 \mathrm{~m} / \mathrm{d}(0.4$ to $1.7 \mathrm{ft} / \mathrm{d})$ in the Nolichucky Shale and from 0.06 to $0.2 \mathrm{~m} / \mathrm{d}(0.2$ to $0.7 \mathrm{ft} / \mathrm{d})$ in the Maryville Limestone (Geraghty and Miller 1989). Effective porosities ranging from $\sim 1$ to $2 \%$ were determined in all samples from the Pumpkin Valley Shale in nearby Melton Valley (deLaguna et al. 1963) and are assumed to be representative of the remainder of the formations in the Conasauga Group, except the Maynardville Limestone. 


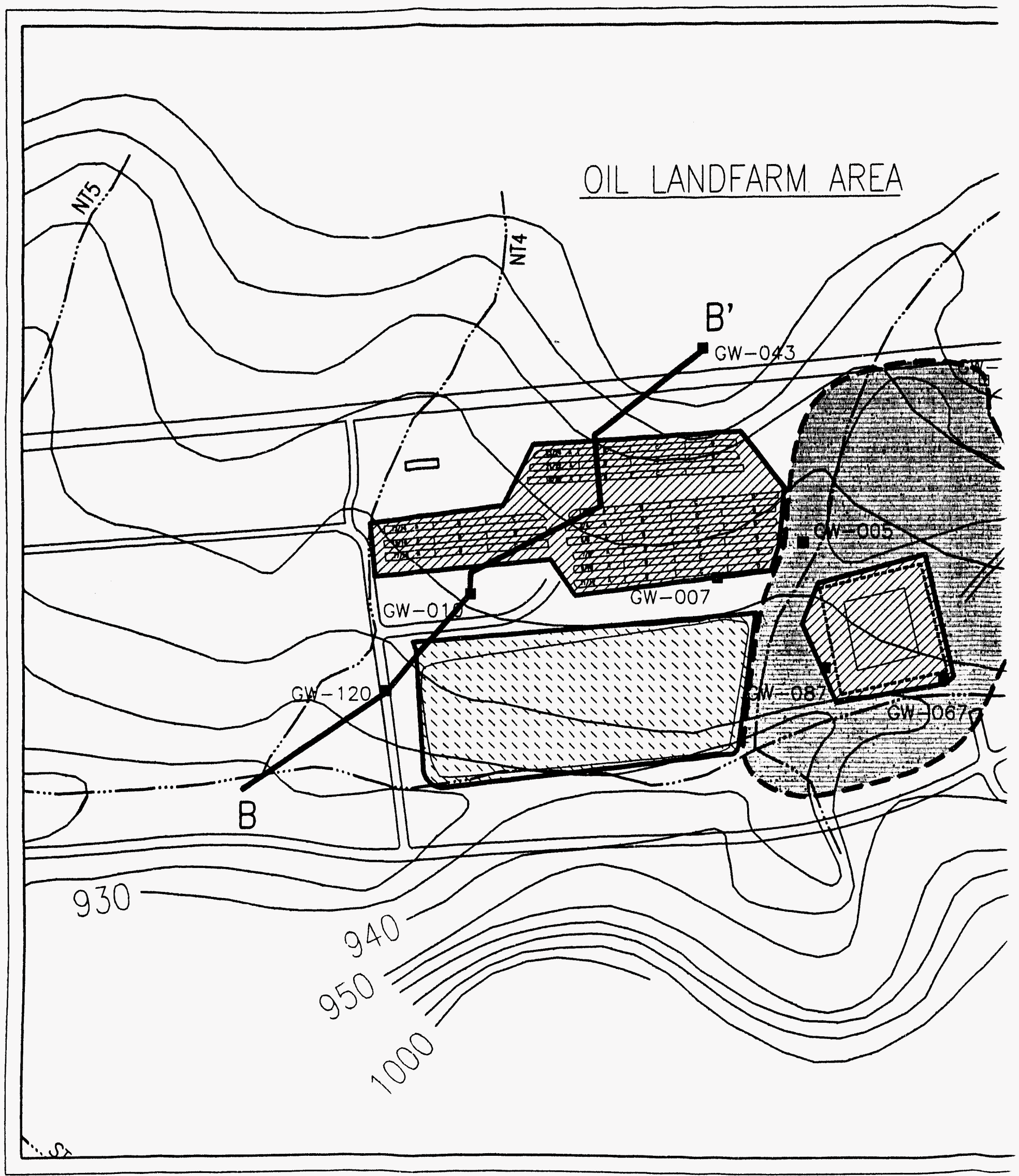

Fig. 3.22. Groundwater elevations in the unconsolidated 


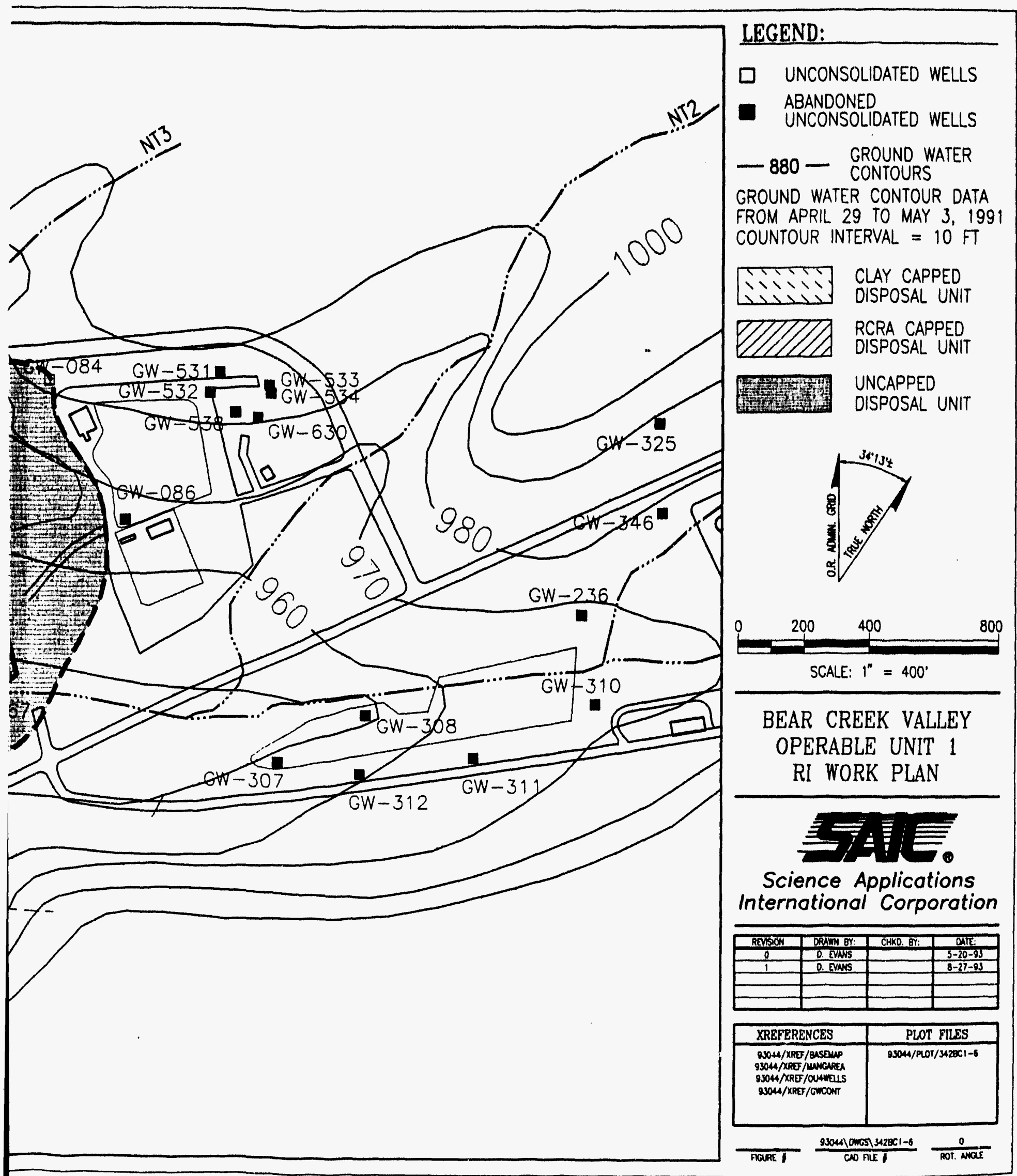

olidated aquifer at the Oil Landfarm (Source: HSW 1992). 


\section{.}

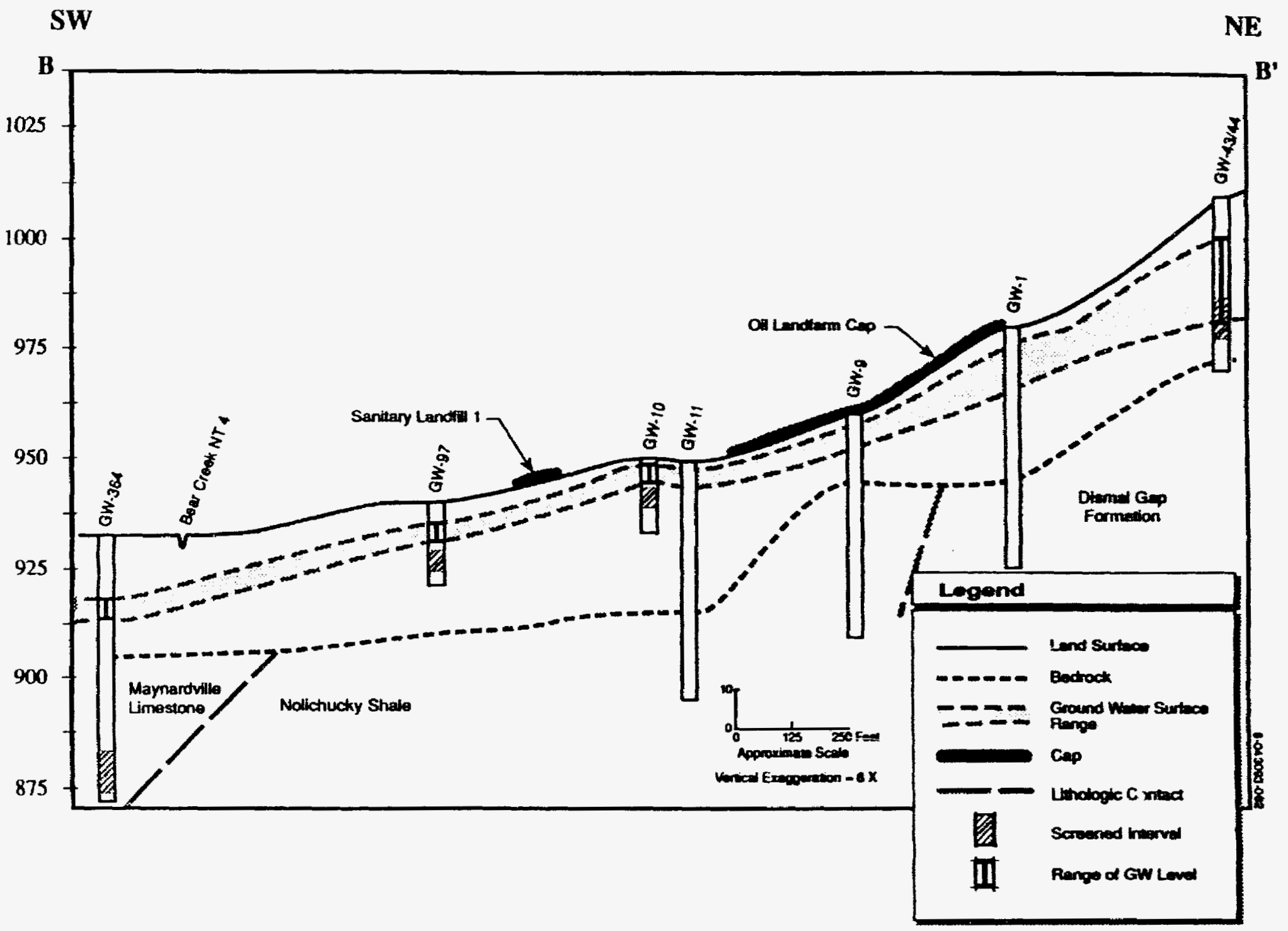

$\ddot{w}$

Fig. 3.23. Cross-section B-B' at the Oil Landfarm showing groundwater clevations in retation wo the waske unil. 


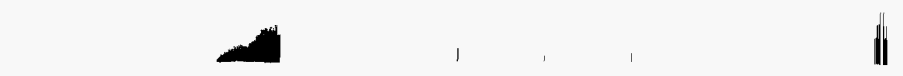

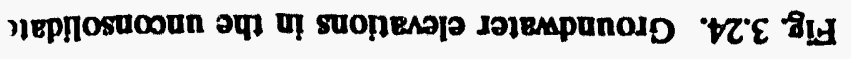

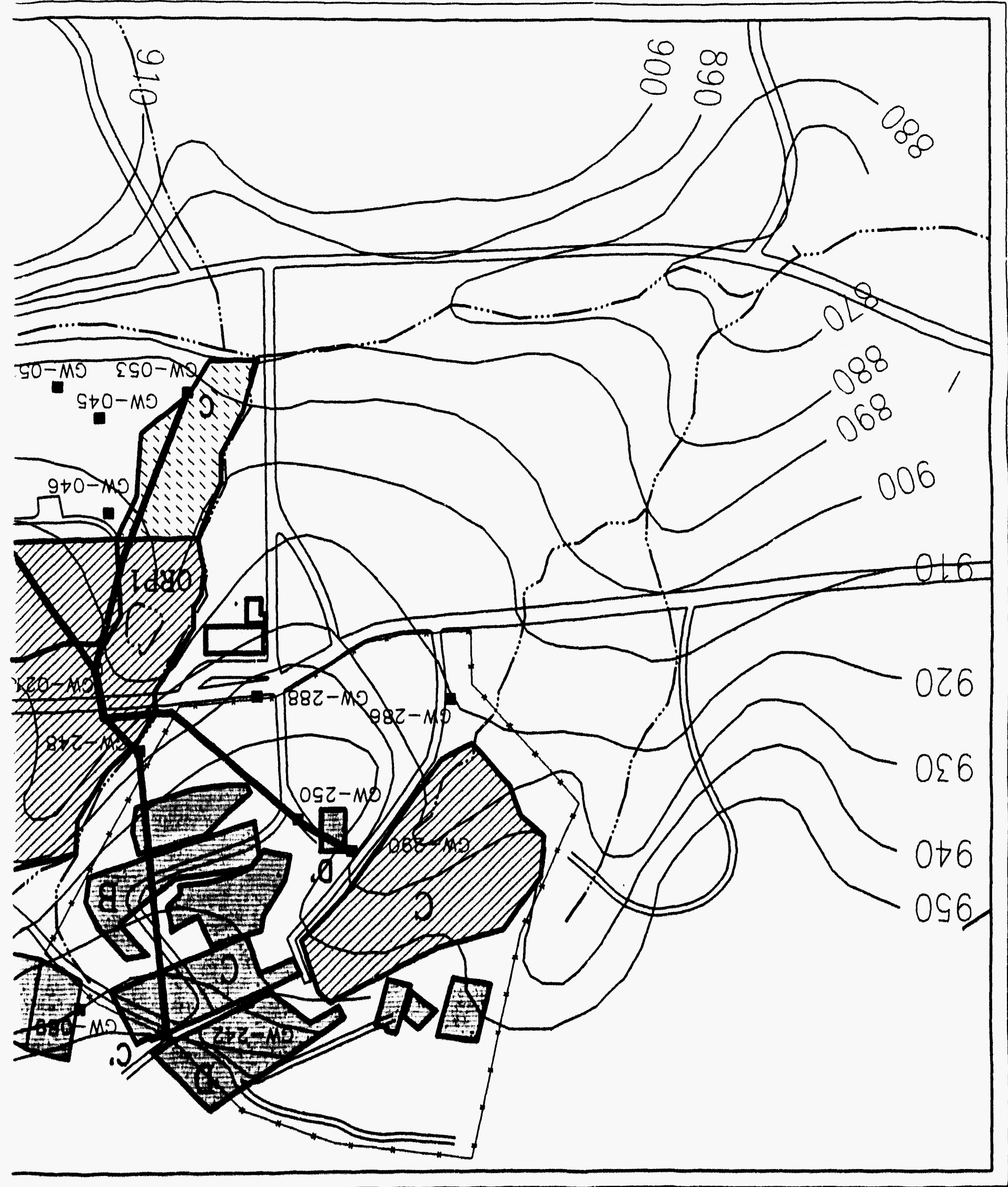




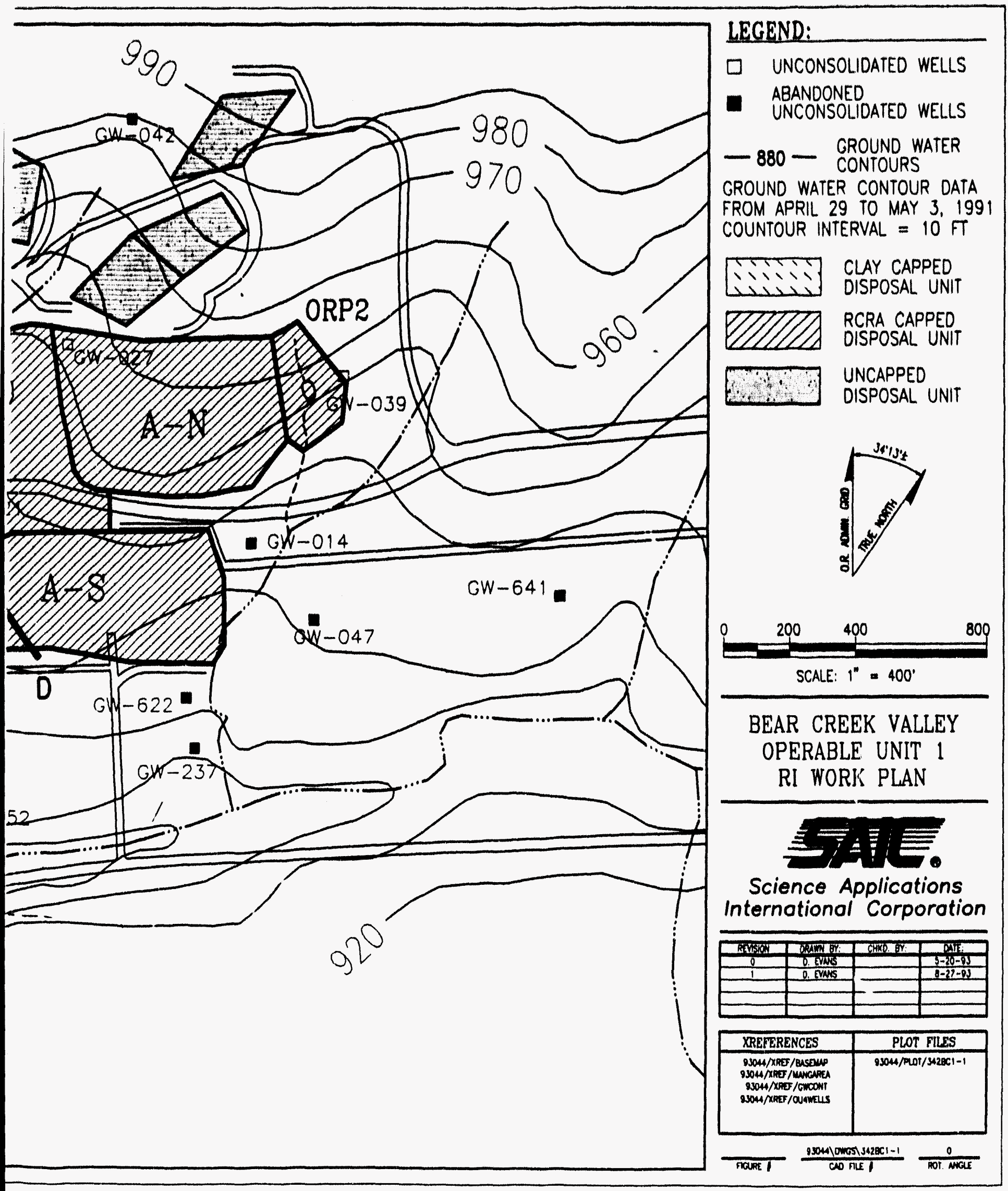

ated aquifer at the Burial Grounds (Source: HSW 1992). 


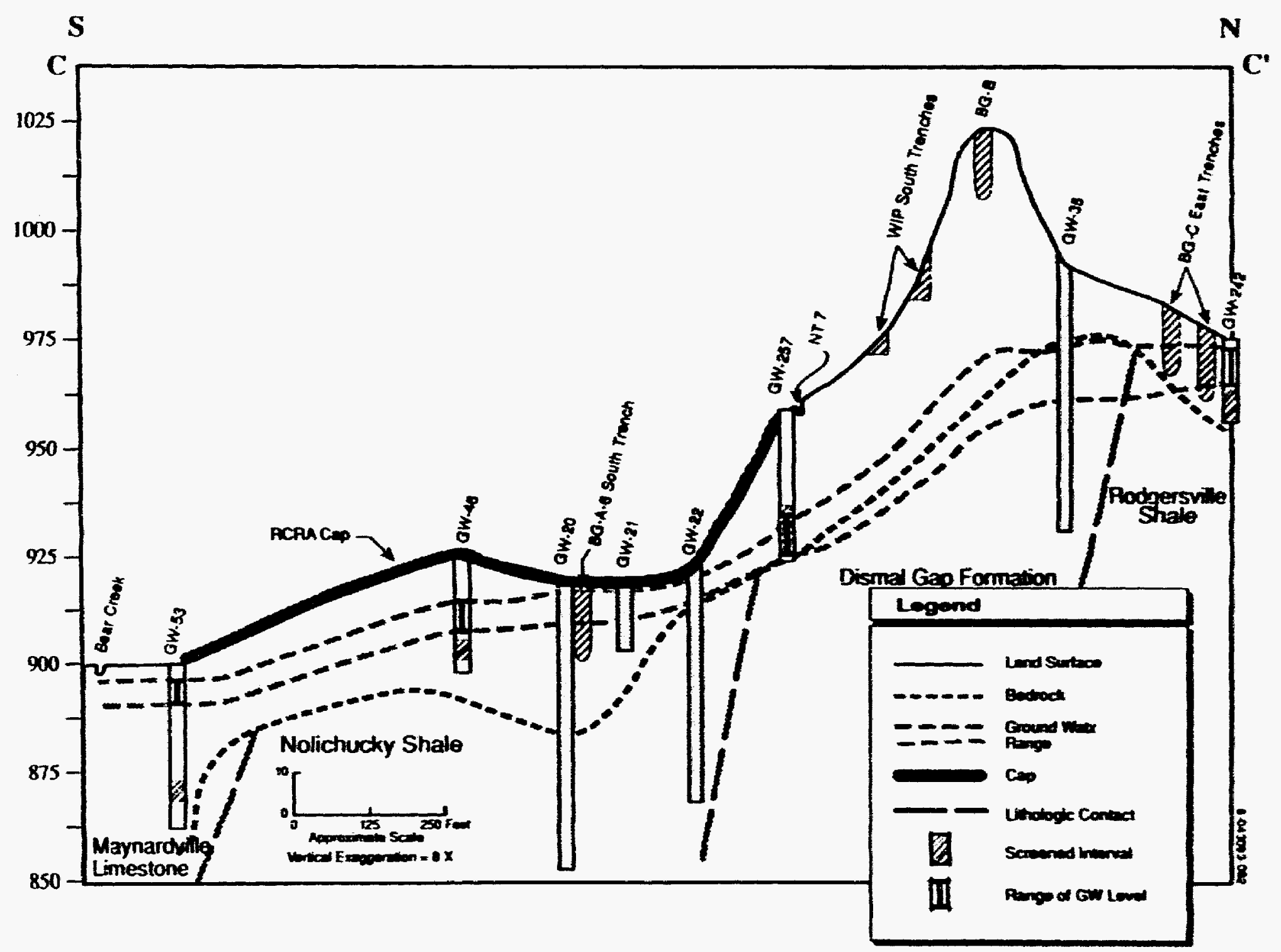

Fig. 325. Cross-soction C-C' at the Burial Grounds showing groundwater elevations in rethtion to the waste unit. 


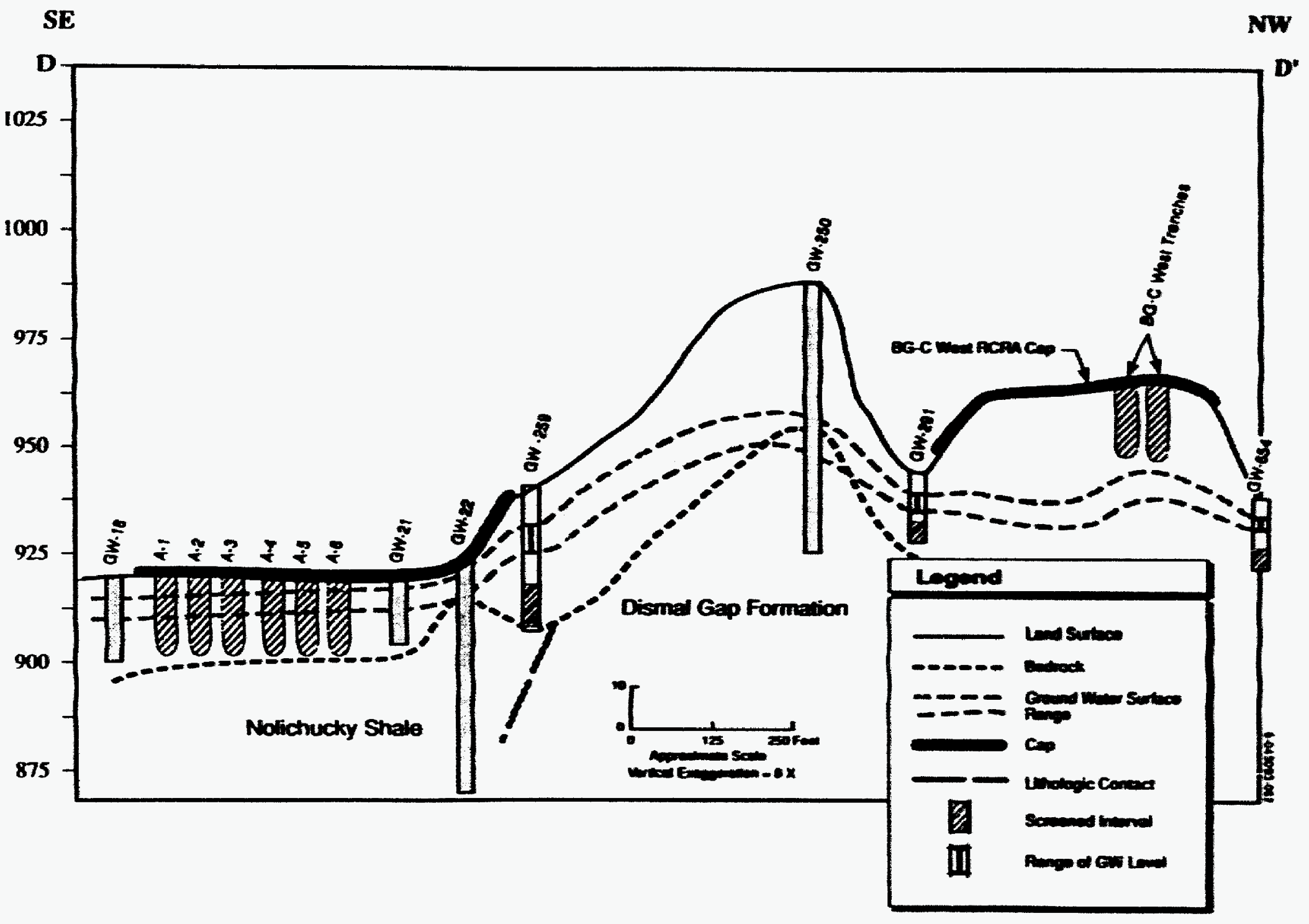

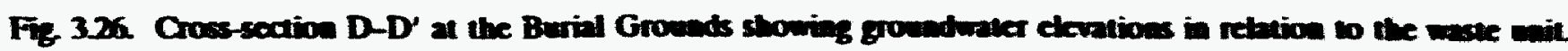


Hydraulic characteristics of the Conasauga Group, including transmissivity and storage coefficient, have been calculated from data oblained from aquifer pumping lests. The anisotropy of the aquifer was confirmed by these teats, each being characterized by elliptical water level cones of depression, elongate in the direction of the strike of strata, which is indicative of a higher degree of transmissivity in that direction.

The transmissivity of the Nolichucky Shale has been determined by pumping leats performed near the Burial Grounds and at the S.3 Site. At the Burial Grounds test site, transmissivity values determined by Law (1983) from wells open to unconsolidated material or bedrock averaged $990 \mathrm{~L}$ per day per $m(\mathrm{Lpd} / \mathrm{m}) \mid 260 \mathrm{gal}$ per day per $\mathrm{ft}(\mathrm{gpd} / \mathrm{ft}))$. Storage coefficients determined from the lest data were about $3 \times 10^{-3}$, indicative of semiconfined conditions. The magnitude of the anisotropy was calculated by Smith and Vaughn (1985) as approximately three times more transmissive along strike. An aquifer pump test with tracers was conducted at the same time which agreed with these resuls (Lozier et al. 1987). Test results also indicated a longitudinal/transverse transmissivity ratio of 20 to 30 , a longitudinal dispersivity of $-3 \mathrm{~m}$ (10) ft), and an effective transport porosity on the order of $4 \times 10^{-3}$.

Pumping tests in the Nolichucky Shale at the S-3 Sitc produced similar estimates of aquifer properties. Transmissivity values determined in wells open only to hedrock ranged from 380 to $440 \mathrm{Lpd} / \mathrm{m}$ ( 100 to $115 \mathrm{gpd} / \mathrm{lt}$ ), and storage coefficients ranged from $1 \times 10^{-2}$ to $4 \times 10^{-4}$ (Geraghty and Miller 1986). Each of the tests in the Nolichucky Shale was characterized by a low discharge rate, $19 \mathrm{~L} / \mathrm{min}(5 \mathrm{gpm})$, with considerable water level drawdown in the pumped well.

\subsubsection{Recharge/diecharge relationship}

Groundwater recharge in the BCV area is from local precipitation, which averages $137.5 \mathrm{~cm} /$ year (55 in./year). Recharge to the bedrock zone is most effective in places where the unconsolidated zone is thin or very permeable. This generally is the case on Pine Ridge. which is believed to be a major recharge area for the formations of the Conasauga Group in the BCV. Short losing sections of Bear Creck also may act locally to recharge the aquifer.

Natural groundwater discharge in the BCV is through streams, springs, and evapotranspiration. Bear Creek, its tributaries, and the solution cavity system along Bear Creek are the major discharge areas for shallow and intermediate depth groundwater moving through the interbedded strata of the BCV. Groundwater discharges sustain the base flow of Bear Creek (Geraghty and Miller 1985).

\subsubsection{Groundwater Contamination}

Groundwater in the BCHR has been affected by subsurface contamination transported from the Burial Grounds, the Oil Landfarm, and the S-3 Site. These sources have contributed organic and inorganic contaminants to groundwater; however, the relative contribution from each unit is not well known. Since actions were taken to isolate wastes from groundwater and surface water, extensive groundwater sampling has been carried out. Numerous reports characterizing groundwater in BCHR have been prepared as part of the GWQARs for the Upper Bear Creek Hydrogeologic Regime at the Y.12 Plant (Geraghty and Miller 1986, 1987, 1988, 1989, 1990; HSW 1991, 1992). These reports specify the locations and construction details for a number of monitoring wells in Bear Creek watershed. Extensive discussions and presentations of groundwater quality data are contained in the BCV OU 4 RI work plan. The 
following sections contain a summary of groundwater contamination in BCHR. For detailed information concerning groundwater quality, refer to the GWQARs just mentioned.

\subsubsection{Organic contamination}

VOCs are the primary organic contaminants of concern detected in groundwater in the BCHR. Dissolved VOCs are present in groundwater at all sites in BCV OU $I$ in the shallow, intermediate, and deep bedrock zones of the underlying Nolichucky Shale. Total VOC concentrations in groundwater underlying the Burial Grounds are among the highest reported in BCHR. At this site they are most widespread in the unconsolidated shallow aquifer, underlying the whole Burial Grounds waste area (Fig. 3.27). The concentrations of VOCs are highest below BG.A. with the maximum value in 1990) of $7556 \mu \mathrm{g}$. (HSW 1991). The VOC plume in the bedrock aquifer below the Burial Grounds is restricted to an area below the BO-A South, and the aerial extent of contamination decreases with increasing depth in the aquifer 10 a minimum of $152 \mathrm{~m}(5 \mathrm{f}) \mathrm{ft})$. VOCs commonly detected in groundwater are letrachloroethene, trichloroethene, trans-1,2-dichloroethene, and 1,1-dichlorothene. Vinyl chloride, 1,1-dichloroethylene, and 1,1,1-trichloroethane have also been detected in samples from wells containing the highest summed VOC concentrations.

A VOC plume is present in the unconsolidated aquifer underlying most of the Oil Landfarm. Concentrations of total VOCs in groundwater below the Oil Landfarm range up to $1000 \mu \mathrm{g} /$ in shallow bedrock. Al shallow and intermediate bedrock depths an apparently continuous dissolved VOC plume extends west from the S.3 Site for about $1829 \mathrm{~m}$ (60)(N) fi) to just west of the Oil Landfarm. The distribution of this plume correlates with the lowermost members of the Maynardville Limestone (HSW 1992). Inputs to this plume have probably come from the S-3 Site, the Oil Landfarm, other sites in the former S.3 Waste Management Area, and sites in BCV OU 2.

Accumulations of dense nonaqueous phase liquids (DNAPLs) were discovered below the southern border of BG.A. Subsequent to this discovery, an investigation was initiated to obtain information on the mode of occurrence and distributions of DNAPLs in groundwater below the Burial Grounds (Haase and King 1990). The DNAPLi consist of free-phase tetrachloroethane, trichloroethene, and 1,1,1-trichlorocthane with concentrations of PCBs ranging from 14,000 to $27,000 \mu \mathrm{g} /$.

Due to the upward hydraulic gradient that exists in the Nolichucky Shale (and some sections of the Maynardville Limestone) it is unlikely that dissolved VOCs have migrated downward through this formation. VOCs in groundwater can migrate via two pathways: as free-phase DNAPLs or as dissolved VOCs. Free-phase DNAPLs will tend to migrate downward and are thought to be relatively immobile in the horizontal plane. The presence of DNAPLs has been confirmed in the bedrock aquifer below the Burial Grounds and DNAPLs may be present below the Oil Landfarm; however monitoring activities here have not encountered any free-phase product.

DNAPLs that migrate through a geologic medium will leave behind a trail of residual DNAPL (i.e., nonmoving free-phase hydrocarbons). Consequently, the DNAPL column acts as a long-term source of dissolved VOCs to groundwater passing through the column. A trail of residual DNAPL that may be leached to groundwater in the future probably remains in the vadose zone helow the Burial Grounds, the Oil Landfarm, and the S-3 Ponds. 


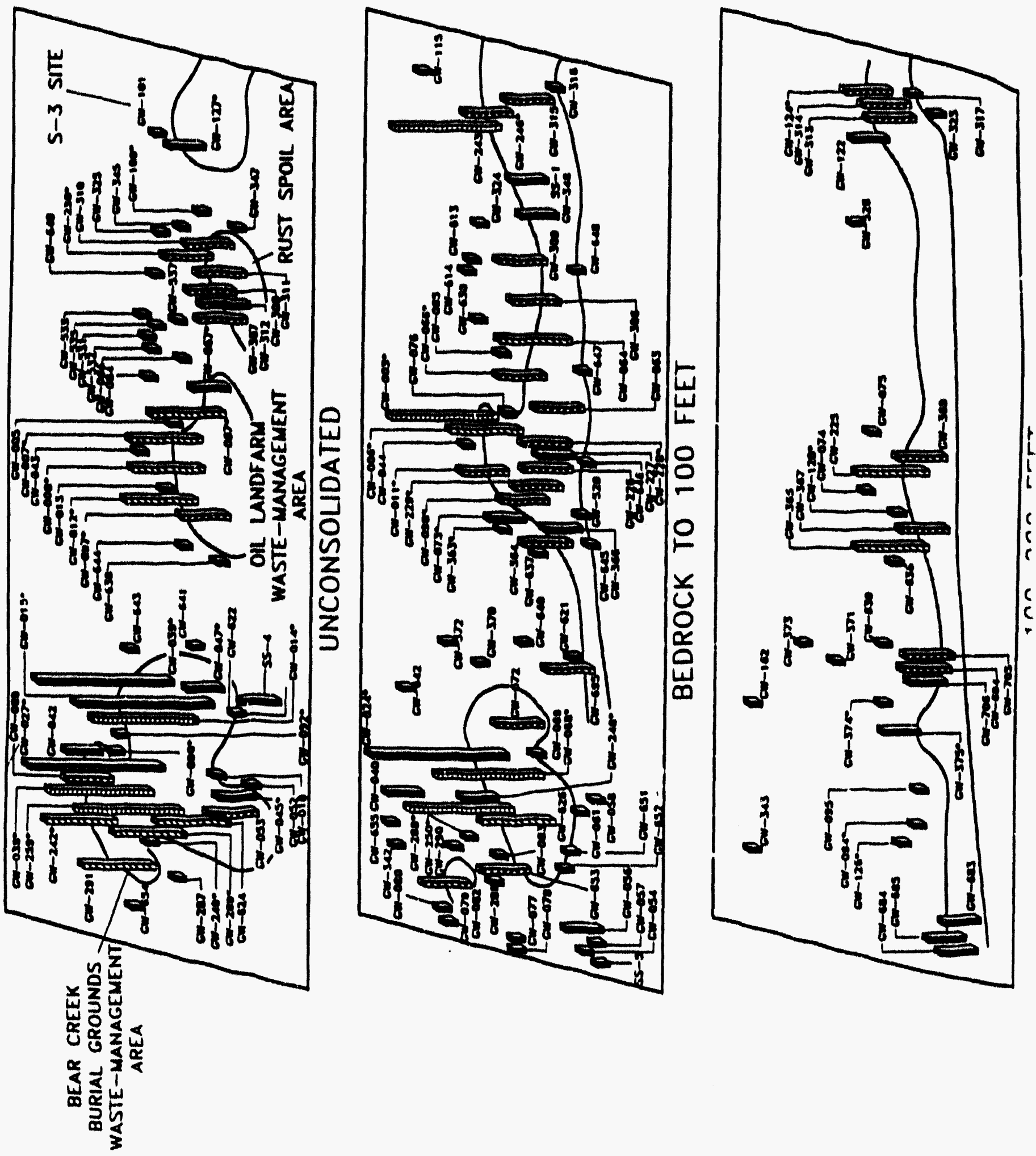



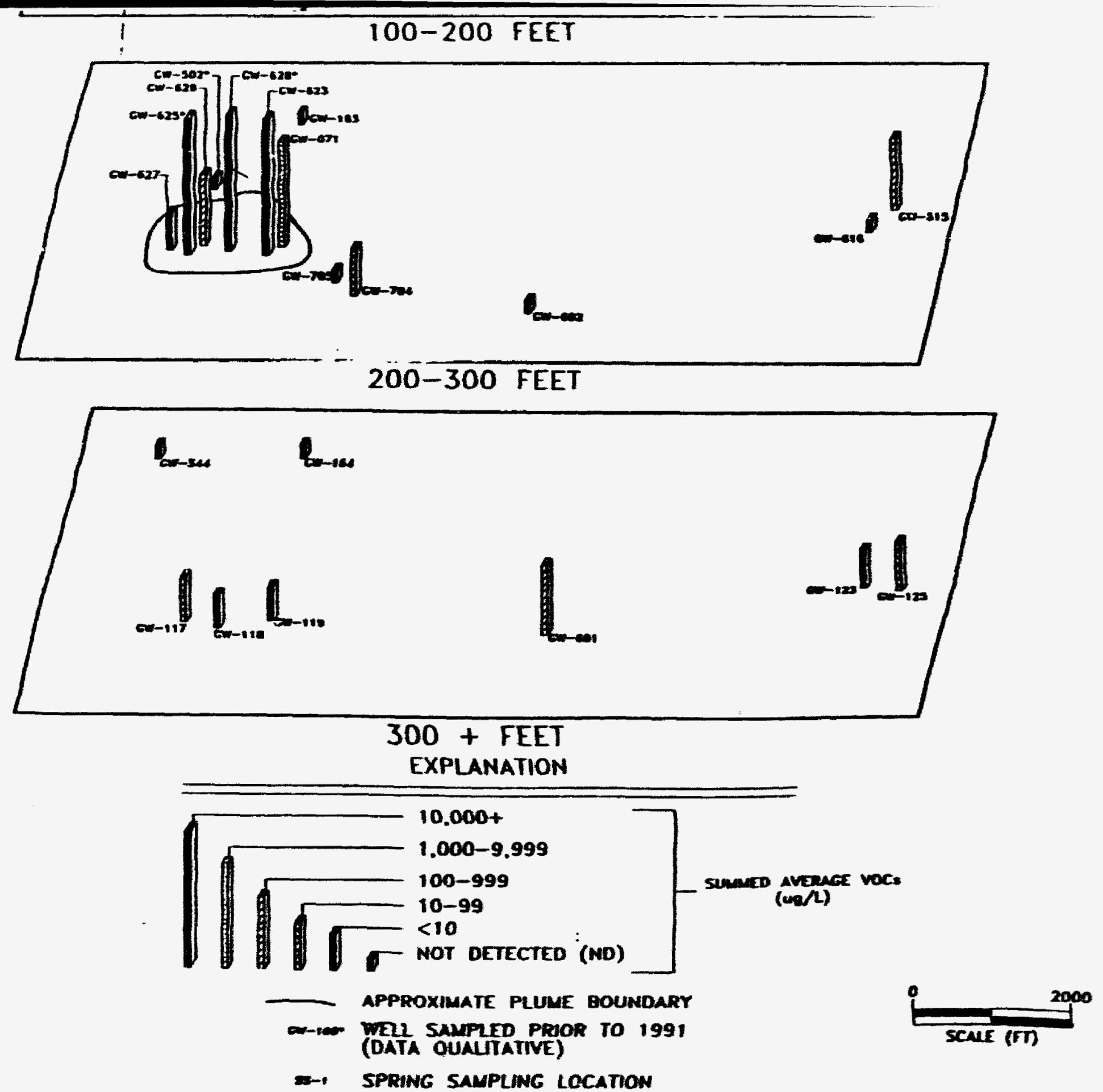

Fig 3.27. Distribution of VOCS is gromberer in the BCHR (Sance HSW 1992) 


\subsubsection{Inorganic contamination}

The primary source of inorganic groundwater contamination appears to be the S-3 Site. Based on discussions of the surface water data presented in Sect. 3.5.2, it is apparent that groundwater discharge to the headwaters reach of Bear Creek is an important part of the water balance and contaminant input for the stream in this region. Monitoring results published in GWQARs (HSW 1992) have demonstrated that shallow groundwater in this region contains significant contaminants whose source was the S-3 Ponds (Table 3.15). Dye tracer tests (Geraghty and Miller 1989) have documented the interaction between the surface water and active groundwater flow system.

Of the range of constituents found in the S-3 Ponds, the nitrate ion is the most mobile component and should be transported conservatively in both surface and subsurface environments. Consequently, it constitutes an important tracer with which to monitor contaminant migration from the source region. Figure 3.28 is a strike parallel section that illustrates the down-valley transport of contaminants (represented by nitrate) from the S-3 Ponds source area. The nitrate plume appears to be concentrated $<61 \mathrm{~m}(200 \mathrm{ft})$ below the ground surface throughout most of the valley. Contaminants may have penetrated deeper near the source due to the dense (high salinity) nature of effluent discharged to the ponds.

Geraghty and Miller (1987) report that discharge of contaminated groundwater to the headwaters reach of Bear Creek has resulted in observed nitrate concentrations ranging between 443 and $1950 \mathrm{mg} / \mathrm{L}$ nitrate- $\mathrm{N}$ for samples collected between 1984 and 1986 at a stream sampling station $\sim 610 \mathrm{~m}(2000 \mathrm{ft})$ downstream from the S-3 Ponds. Recent dye tracer studies have revealed that water from losing reaches of Bear Creek between BCK 11.64 and 9.41 reappears in spring SS-5 (Geraghty and Miller 1989). Recent results from sampling at springs in BCV (HSW 1992) suggest that spring SS-5 may have nitrate concentrations elevated above background (NT-11; see Table 3.12).

Total concentrations of arsenic, barium, cadmium, chromium, lead, mercury, and selenium exceed their respective MCLs or proposed MCLs in groundwater samples from one or more wells in the BCHR. With the exception of elevated concentrations of barium, cadmium, chromium, lead, and mercury in groundwater near the S-3 Ponds, the occurrence of elevated metal concentration is sporadic and could be the result of typical problems associated with sampling low-permeability formations (i.e., large amounts of suspended materials resulting from purging the well). The S-3 Ponds have been identified as the most likely source for metals in groundwater at the headwaters of Bear Creek (HSW 1992).

Moore and Toran (1992) investigated the possibility that, following the closure of the S-3 Ponds, the shallow groundwater and surface water system near the Bear Creek headwaters would be naturally flushed of contaminants and show a temporal decrease in contaminant concentrations. They used the groundwater monitoring data from two water table wells near the S-3 Ponds to illustrate an exponential decrease in nitrate concentrations beginning in mid-1987 (Fig. 3.29). Data from other monitoring wells do not support the natural flushing hypothesis. However, Moore and Toran suggest that purging associated with the sampling process in Nolichucky wells may obscure any trends in data because the water sampled represents a mix of water from fractions that are influenced differently by the matrix diffusion process. 
Table 3.15. Nitrate, annual mean gross alpha activity, and gross beta activity exceeding MCLs, 1990 (After HSW 1992)

\begin{tabular}{|c|c|c|c|c|}
\hline $\begin{array}{c}\text { Well } \\
\text { number }\end{array}$ & $\begin{array}{l}\text { Aquifer } \\
\text { zone }\end{array}$ & $\begin{array}{l}\text { Nitrate } \\
\text { (as N) } \\
\text { (mg/L) }\end{array}$ & $\begin{array}{c}\text { Gross alpha } \\
\text { activity } \\
\text { (pCi/L) }\end{array}$ & $\begin{array}{c}\text { Gross beta } \\
\text { activity } \\
\text { (pCi/L) }\end{array}$ \\
\hline \multicolumn{5}{|c|}{ S-3 Site } \\
\hline $\begin{array}{l}\text { GW-100 } \\
\text { GW-101 } \\
\text { GW-122 } \\
\text { GW-124 } \\
\text { GW-125 } \\
\text { GW-127 } \\
\text { GW-236 } \\
\text { GW-243 } \\
\text { GW-244 } \\
\text { GW-245 } \\
\text { GW-246 } \\
\text { GW-247 } \\
\text { GW-276 } \\
\text { GW-277 } \\
\text { GW-345 } \\
\text { GW-346 } \\
\text { GW-348 } \\
\text { GW-526 } \\
\text { GW-615 } \\
\text { GW-616 }\end{array}$ & $\begin{array}{l}\text { U } \\
U \\
I \\
I \\
D \\
U \\
U \\
S \\
S \\
S \\
S \\
S \\
U \\
S \\
U \\
S \\
S \\
I \\
I \\
I\end{array}$ & $\begin{array}{r}388 \\
2,200 \\
770 \\
160 \\
28 \\
<\mathrm{MCL} \\
421 \\
6,230 \\
\mathrm{NA} \\
4,545 \\
3,530 \\
7,380 \\
454 \\
1,690 \\
398 \\
811 \\
10 \\
845 \\
9,690 \\
274\end{array}$ & $\begin{array}{c}<\mathrm{MCL}^{d} \\
96 \pm 49 \\
<\mathrm{MCL} \\
<\mathrm{MCL} \\
<\mathrm{MCL} \\
267 \pm 35 \\
19 \pm 3 \\
8,205 \pm 386 \\
67 \pm 75 \\
79 \pm 102^{8} \\
143 \pm 86 \\
56 \pm 64 \\
971 \pm 160 \\
<\mathrm{MCL} \\
<\mathrm{MCL} \\
<\mathrm{MCL} \\
<\mathrm{MCL} \\
21 \pm 34 \\
307 \pm 79 \\
22 \pm 41\end{array}$ & $\begin{array}{c}<\mathrm{TL} \\
<\mathrm{TL} \\
<\mathrm{TL} \\
556 \pm 15 \\
<\mathrm{TL} \\
308 \pm 46 \\
203 \pm 9 \\
60,750 \pm 1,345 \\
3,240 \pm 290 \\
2,765 \pm 270 \\
13,900 \pm 540 \\
4,240 \pm 370 \\
4,110 \pm 320 \\
2,900 \pm 290 \\
244 \pm 6 \\
<\mathrm{TL} \\
<\mathrm{TL} \\
<\mathrm{TL} \\
554 \pm 173 \\
<\mathrm{TL}\end{array}$ \\
\hline \multicolumn{5}{|c|}{ Spoil Area I } \\
\hline $\begin{array}{l}\text { GW-314 } \\
\text { GW-315 }\end{array}$ & $\begin{array}{l}S \\
S\end{array}$ & $\begin{array}{l}10 \\
16 \\
\end{array}$ & $\begin{array}{l}<\mathrm{MCL} \\
<\mathrm{MCL} \\
\end{array}$ & $\begin{array}{c}<\mathrm{TL} \\
55 \pm 3 \\
\end{array}$ \\
\hline \multicolumn{5}{|c|}{ Rust Spoil Area } \\
\hline $\begin{array}{l}\text { GW-306 } \\
\text { GW-307 } \\
\text { GW-308 } \\
\text { GW-309 } \\
\text { GW-310 }\end{array}$ & $\begin{array}{l}S \\
U \\
U \\
S \\
U\end{array}$ & $\begin{array}{l}11 \\
18 \\
15 \\
18 \\
23\end{array}$ & $\begin{array}{l}<M C L \\
<M C L \\
<M C L \\
<M C L \\
<M C L \\
\end{array}$ & $\begin{array}{c}<\mathrm{TL} \\
<\mathrm{TL} \\
<\mathrm{TL} \\
50 \pm 4 \\
62 \pm 3 \\
\end{array}$ \\
\hline
\end{tabular}


Table 3.15 (continued)

\begin{tabular}{|c|c|c|c|c|}
\hline $\begin{array}{c}\text { Well } \\
\text { number }\end{array}$ & $\begin{array}{l}\text { Aquifer } \\
\text { zone }\end{array}$ & $\begin{array}{l}\text { Nitrate } \\
\text { (as } N)^{b} \\
\text { (mg/L) }\end{array}$ & $\begin{array}{c}\text { Gross alpha } \\
\text { activity } \\
\text { (pCi/L) }\end{array}$ & $\begin{array}{c}\text { Gross beta } \\
\text { activity } \\
\text { (pCi/L) }\end{array}$ \\
\hline \multicolumn{5}{|c|}{ Oil Landfarm } \\
\hline $\begin{array}{l}\text { GW-005 } \\
\text { GW-064 } \\
\text { GW-085 } \\
\text { GW-087 } \\
\text { GW-225 } \\
\text { GW-226 } \\
\text { GW-227 } \\
\text { GW-228 } \\
\text { GW-369 } \\
\text { GW-537 } \\
\text { GW-601 }\end{array}$ & $\begin{array}{l}U \\
S \\
S \\
U \\
I \\
S \\
S \\
I \\
I \\
U \\
D\end{array}$ & $\begin{array}{r}\mathrm{BDL}^{h} \\
10 \\
185 \\
\mathrm{BDL} \\
97 \\
<\mathrm{MCL} \\
17 \\
37 \\
11 \\
819 \\
29\end{array}$ & $\begin{array}{c}31 \pm 2 \\
<\mathrm{MCL} \\
<\mathrm{MCL} \\
54 \pm 5 \\
<\mathrm{MCL} \\
20 \pm 2 \\
25 \pm 2 \\
<\mathrm{MCL} \\
<\mathrm{MCL} \\
40 \pm 16 \\
<\mathrm{MCL}\end{array}$ & $\begin{array}{c}<\mathrm{TL} \\
<\mathrm{TL} \\
57 \pm 3 \\
<\mathrm{TL} \\
<\mathrm{TL} \\
<\mathrm{TL} \\
69 \pm 3 \\
<\mathrm{TL} \\
<\mathrm{TL} \\
354 \pm 48 \\
<\mathrm{TL}\end{array}$ \\
\hline \multicolumn{5}{|c|}{ Bear Creek Burial Grounds } \\
\hline $\begin{array}{l}\text { GW-052 } \\
\text { GW-061 } \\
\text { GW-621 }\end{array}$ & $\begin{array}{l}\text { U } \\
\text { S } \\
\text { S }\end{array}$ & $\begin{array}{l}28 \\
11 \\
12\end{array}$ & $\begin{array}{l}40 \pm 4 \\
<M C L \\
<M C L\end{array}$ & $\begin{array}{c}120 \pm 8 \\
<\mathrm{TL} \\
<\mathrm{TL}\end{array}$ \\
\hline
\end{tabular}

${ }^{a} \mathrm{U}=$ unconsolidated zone; $\mathrm{I}=$ intermediate depth bedrock zone (85-300 ft);

$D=$ deep bedrock zone ( $>300 \mathrm{ft}$ ); and $\mathrm{S}=$ shallow bedrock zone (Unc-85 ft).

${ }^{b} \mathrm{mg} / \mathrm{L}=$ milligrams per liter.

${ }^{c} \mathrm{pCi} / \mathrm{L}=$ picocuries per liter \pm counting error.

$\mathrm{MCL}=$ maximum contaminant level.

$-<\mathrm{TL}=$ results less than $50 \mathrm{pCi} / \mathrm{L}$ threshold limit.

NA $=$ not analyzed.

'Calculated mean activity including 1989 data.

${ }^{n} \mathrm{BDL}=$ below detection limit. 


\section{SW}

NE

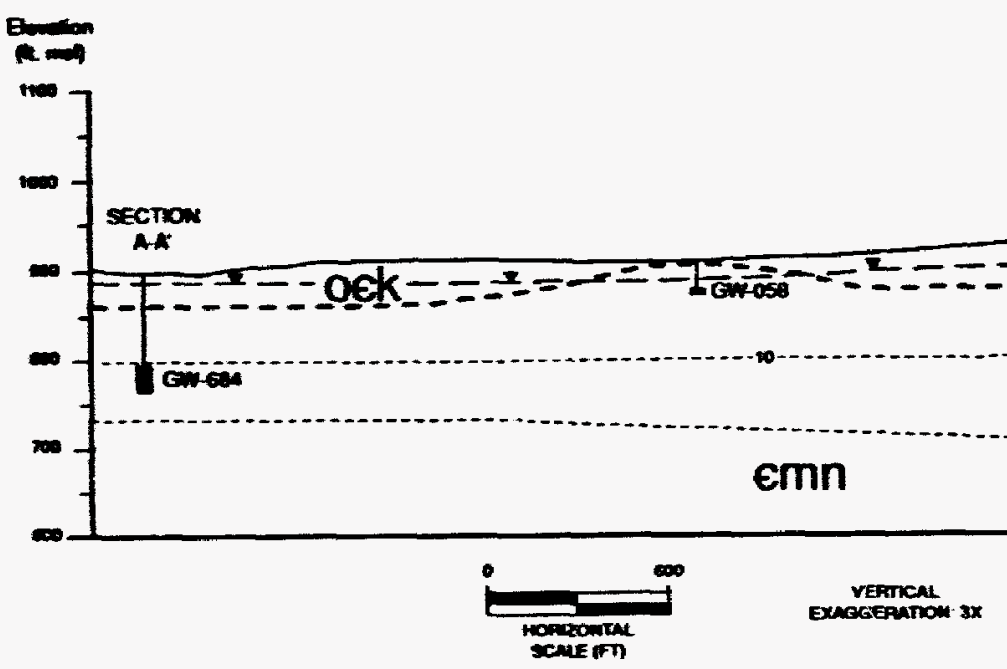

$2002000-000111$

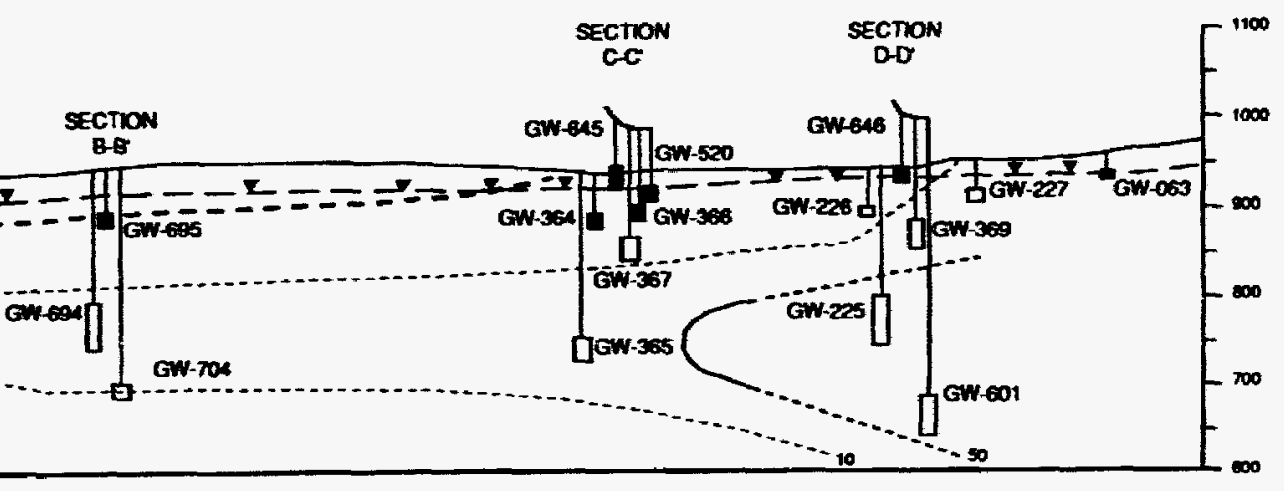

EXPLANATION

\begin{tabular}{|c|c|}
\hline & EXPLANATION \\
\hline GW684 & WELL MUMBER \\
\hline & SCREENED WELL CONSTRUCTION \\
\hline $\mathbf{0}$ & OPENHOE WELL CONSTRUCTION \\
\hline$-1-$ & GPOUNDMATER ELEVATION \\
\hline & APPAOXMUATE GEOLOGKC CONTACT \\
\hline$\infty$ & RNOX GROUP \\
\hline nח & MAMUADVILE LMESTONE \\
\hline$---n-\cdots$ & APPROXEUATE LNE OF EQUNL CONCENTRATION ( $\mathrm{mg}$ ) \\
\hline
\end{tabular}

Fig. 3.28. Nitrate in groundwater in the Maynardville Limestone along the axis of BCV (Source: HSW 1992). 


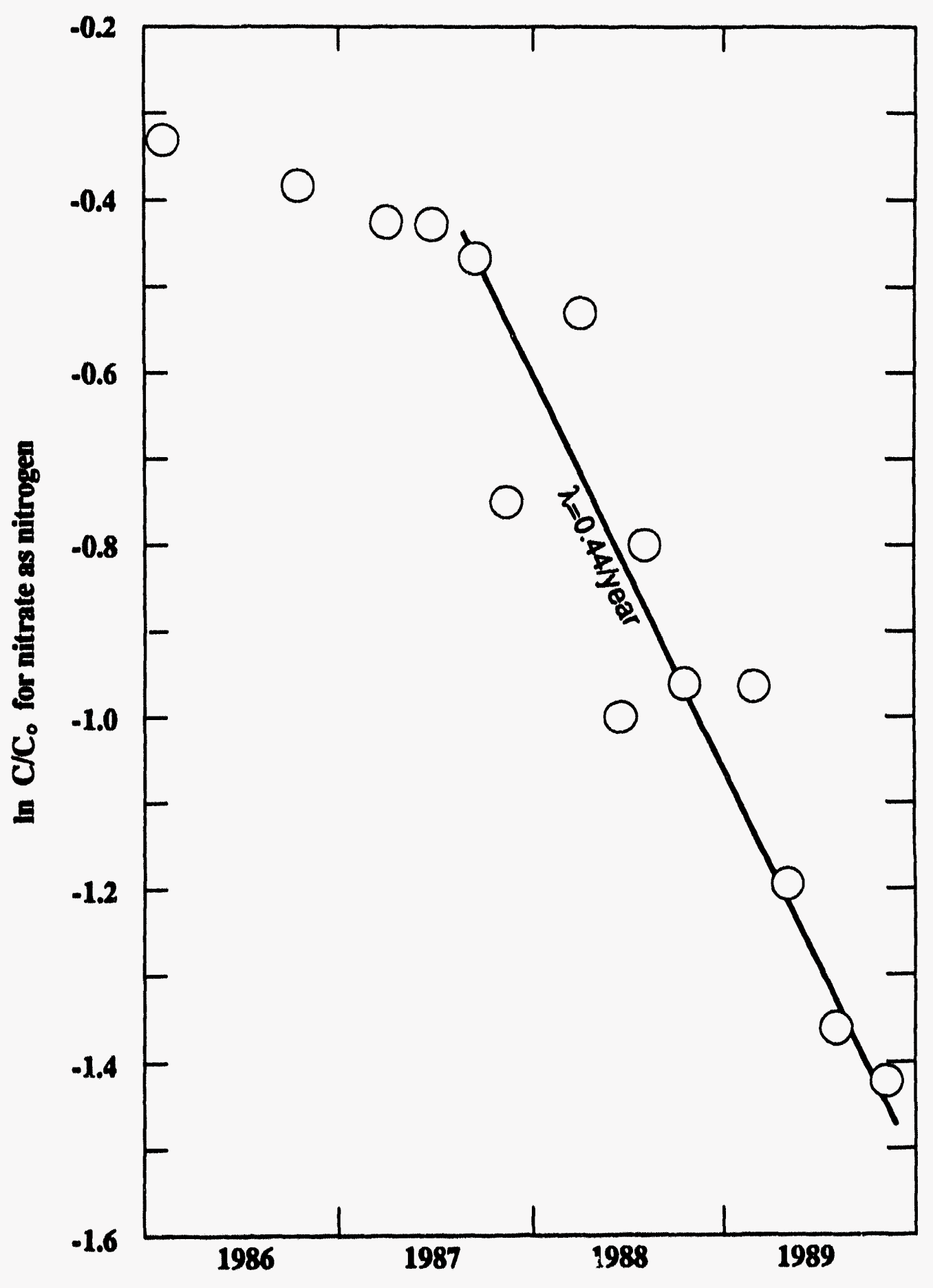

Fig. 3.29. Average normalized concentrations for nituate as nitrogen in GW-106 and OW-276 (Sounce: Moore and Toran 1992). 
The natural flushing hypothesis is supported by historical data from a headwater stream location (BCK 11.97) where Moore and Toran (1992) have recorded decreasing concentrations of major elements (e.g., aluminum, calcium, magnesium) (Fig. 3.30) that may be associated with acid leaching of the rocks as well as decreasing concentrations of constituents associated with the waste disposal (nitrate, uranium).

Additional support for the hypothesis is found in the historical resurgence of fish populations within Bear Creek (Southworth et al. 1992). Their analysis of data from 1984 through 1988 showed that fish populations were returning to the headwaters of Bear Creek after a long absence. Their data for macroinvertebrate populations in the stream bed did not show a similar trend through 1988.

\subsubsection{Radionuclides}

The radiochemical quality of groundwater was evaluated with respect to the $\mathrm{MCL}$ for gross alpha activity $(15 \mathrm{pCi} / \mathrm{L})$ and the threshold value $(50 \mathrm{pCi} / \mathrm{L})$ for gross beta activity. A plume of elevated gross alpha and beta exists in groundwater below the S-3 Ponds (HSW 1992). The plumes are located in both the shallow unconsolidated and the bedrock groundwater aquifers; however, the plumes are more extensive in the unconsolidated aquifer (Table 3.15).

Gross alpha activity is most extensive in the unconsolidated aquifer zone near the S-3 Site (19-971 $\mathrm{pCi} / \mathrm{L})$, and isolated pockets of elevated alpha activity are found in the unconsolidated zone at the Oil Landfarm (31-54 pCi/L). A maximum gross alpha value of $8205 \pm 386 \mathrm{pCi} / \mathrm{L}$ was detected in 1990 in shallow bedrock well GW-243 located adjacent to the S-3 Site. Gross alpha activity in the shallow bedrock zone below the S-3 Ponds was extensive and most wells within $305 \mathrm{~m}(1000 \mathrm{ft})$ downstream of the ponds contain elevated gross alpha counts (10 to $8205 \mathrm{pCi} / \mathrm{L}$ ). A second plume of elevated gross alpha activity in the shallow bedrocl. was detected in the east central portion of the Oil Landfarm that possibly extends further east ( 11 to $18 \mathrm{pCi} / \mathrm{L}$ ). A plume of elevated gross alpha activity has been detected in the intermediate bedrock aquifer but is less extensive than that in the shallow aquifer. Chemical data from 1989 suggest that the primary alpha emitting radionuclide is likely to be uranium; however, isotopes of radium neptunium and americium may also contribute to the gross alpha activity (HSW 1992).

The gross beta activity in groundwater from 19 wells exceeded the $50 \mathrm{pCi} / \mathrm{L}$ threshold value and is usually associated with ${ }^{99} \mathrm{Tc}$. Contamination was detected in plumes below the S-3 Ponds and the Oil Landfarm. The highest mean value for beta activity was reported from a shallow bedrock well located near the S-3 Ponds $(60,750 \pm 1345 \mathrm{pCi} / \mathrm{L})$. Similarly to the gross alpha activities, plumes of elevated gross beta activity exhibited the highest counts and were most extensive in the shallow bedrock zone below the S-3 Ponds $(2900$ to $60,750 \mathrm{pCi} / \mathrm{L})$. Gross beta activities were elevated in the unconsolidated zone and intermediate bedrock aquifers below the S-3 Ponds. Elevated beta activities were also detected in three wells at the Oil Landfarm. 


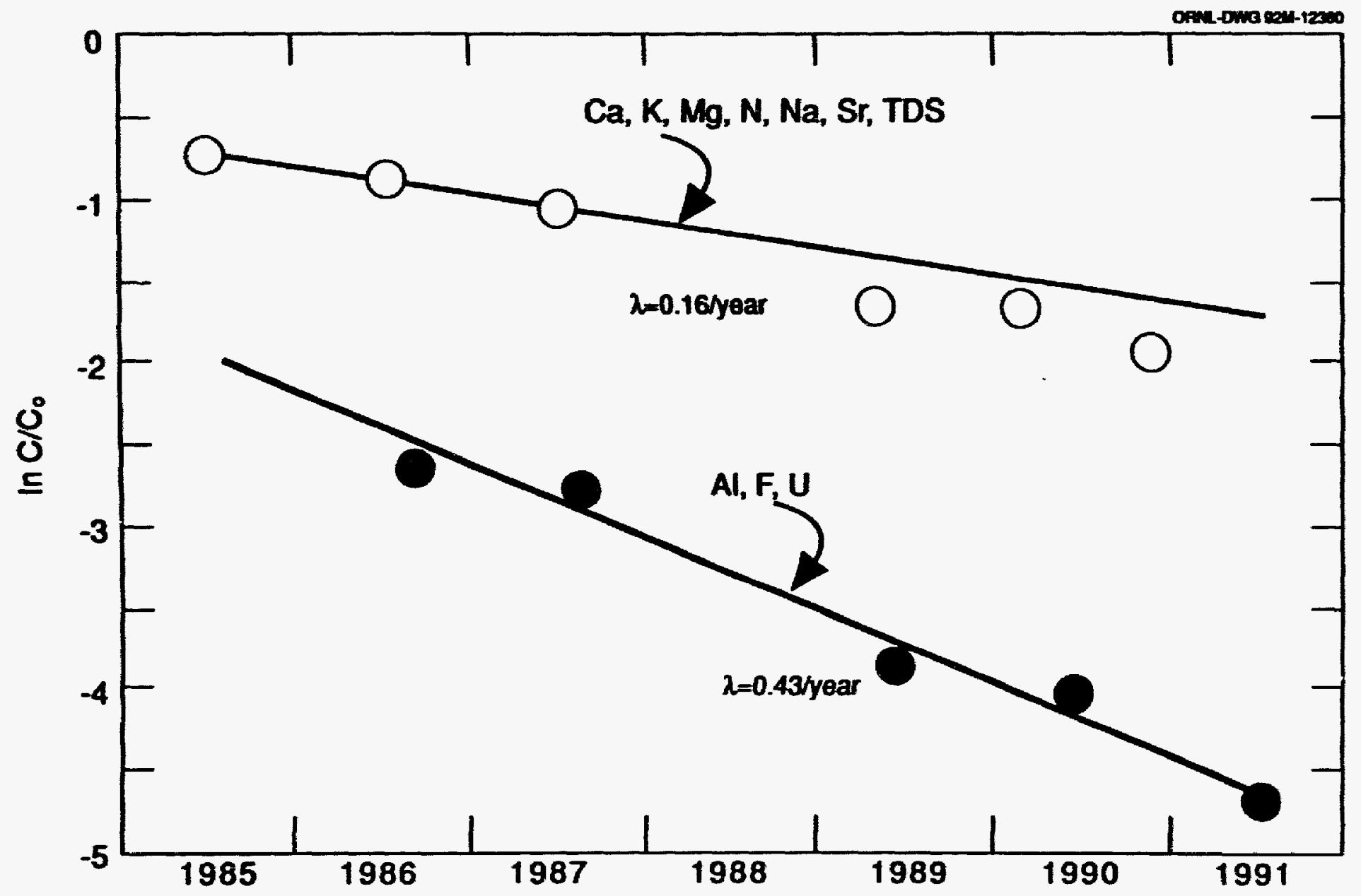

Fig 330. Average nomalized concentrations for major constituents in Bear Creek (Source: Moore and Toran 1992). 


\subsubsection{Conclusions}

Extensive groundwater sampling throughout BCV has revealed contaminant plumes of VOCs emanating from each of the source units in BCV OU 1 and a plume of inorganic contaminants, characterized by nitrate, that emanates from the S-3 Ponds near the headwaters of Bear Creek and underlies Bear Creek for considerable distance downstream.

Free-phase DNAPLs have been detected in the intermediate and shallow groundwater bedrock aquifers. Dissolution of residual DNAPL in the bedrock and unconsolidated zone aquifers is suspected as the major source of dissolved VOCs in groundwater in the BCHR. Dissolved VOCs were detected in high concentrations in groundwater from the shallow and intermediate aquifers. Particularly high concentrations of dissolved VOCs were found in water from the unconsolidated aquifer below the Burial Grounds and the Oil Landfarm.

Detectable concentrations (suggestive of contamination) of nitrate, a relatively mobile anion, are found down valley and generally define the maximum horizontal extent of a contamination plume that extends westward from the S-3 Ponds. Radionuclide contamination associated with this nitrate plume is restricted to within $305 \mathrm{~m}(1000 \mathrm{ft})$ of the S-3 Ponds, reflecting the retardation effect of chemical sorption reactions between radionuclides and geologic media. Radionuclide groundwater contamination is also associated with the Oil Landfarm but is not as extensive as that found at the S-3 Ponds. Most contaminant source areas overlie Nolichucky soils and bedrock. Migration of some contaminants (e.g., metals) within the Nolichucky appears to be retarded. Down-valley transport of contaminant plumes is apparently controlled by more active conduit flow within the Maynardville and interactions between Maynardville groundwater and Bear Creek surface water.

Preliminary analyses of historical groundwater and surface water quality data suggest that source area controls (e.g., RCRA caps) may be producing measurable decreases in contaminant concentrations. These source area controls contribute to the decrease in contaminant concentrations by the halting of waste disposal and neutralizing of the sludges. Verification of these results will require additional analysis of groundwatel and surface water quality data from monitoring points that are demonstrably connected to the actively flowing portion of the groundwater system.

\subsection{ECOLOGY}

BCV OU 1 lies outside the main Y-12 Plant complex and as such is in close proximity to areas of potential ecological sensitivity. Ecological studies of the Bear Creek watershed were initiated in May 1984 and are continuing at the present time. A summary of the results of the sampling conducted from May 1984 through early 1990 is presented in Southworth et al. (1992). These studies consisted of an initial detailed characterization of the benthic invertebrate and fish communities in Bear Creek, followed by an ongoing monitoring phase (Fig. 3.31) with reduced sampling intensities. The characterization phase involved two approaches: (1) in-stream sampling of benthic invertebrate and fish communities in Bear Creek to identify spatial and temporal patterns in distribution and abundance and (2) laboratory bioassiys of water samples from Bear Creek and selected tributaries to identify 


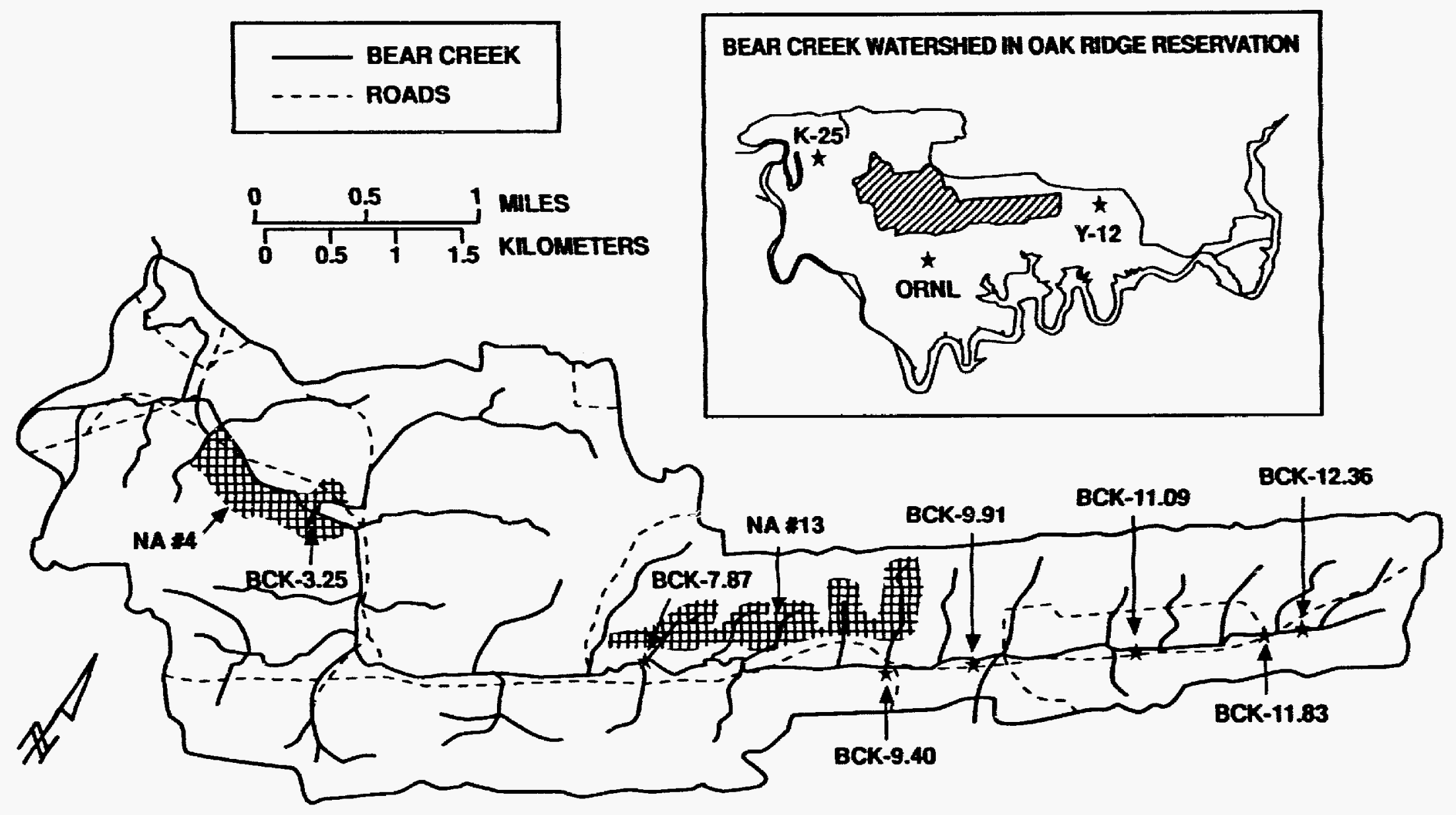

Fig 3.31. Locations of existing biological moaitoring sites. 
potential sources of toxicity to biota. The monitoring phase of the ecological program relates to the long-term goal of identifying and prioritizing contaminant sources and assessing the effectiveness of remedial actions. Activities of the characterization phase are continuing at less frequent intervals.

Before 1940, most of BCV was cleared and used for agriculture (Southworth et al. 1992). Most of the agricultural land has been planted in pines, with a strip of pines and mixed hardwoods bordering much of the stream. About $65 \%$ of the BCV watershed is wooded (McMaster 1967).

\subsubsection{Fora}

Vegetation in the Bear Creek watershed is predominantly oak, oak-hickory associations on the upper slopes and ridgetops, and planted pine along the creek and floodplain area. Pine Ridge is generally an oak, oak-hickory association with chestnut oak, red oak, tulip poplar, white oak, and hickory as the dominant species. The lower areas along Bear Creek and Bear Creek Road are mainly planted loblolly pine with some scattered areas of planted shortleaf, natural pine, and oak-hickory communities. Also of interest is a large area of big bluestem grass that grows along Bear Creek Road. Large stands of this species are uncommon in east Tennessee. Plant communities in Bear Creek are depicted in Fig. 3.32 as components of the general plant communities found on the ORR (Welch 1989). This site is being considered as a National Environmental Research Park (NERP) Reference Area. More detailed information is available for portions of the Bear Creek watershed area on forest compartment maps and in various documents (Bradburn and Rosenbalm 1984; Parr and Pounds 1987). Table 3.16 lists threatened and endangered flora and fauna found within the ORR.

\subsubsection{Rare plant species}

Two areas contain rare plant populations, and these have been designated NERP Natural Areas. The Canada lily (Lilium canadense) occurs in NERP Natural Area 13 at the base of Pine Ridge. It grows along the forested edges of the powerline right-of-way in the Bear Creek drainage area. This plant species is state listed as threatened. The other site, NERP Natural Area \#4, contains the southern rein orchid (Platanthera flava). This is forested area with numerous wetlands around seeps and contains old stream or flood channels. An uncommon aquatic plant, Orontium aquaticum, occurs here also. The southern rein orchid is state listed as a species of special concern. The site has also been registered as a State Natural Area in an agreement between DOE and the TDEC (Howell 1986).

\subsubsection{Terrestrial Fauna}

BCV contains elements of the majority of wildlife habitat types found on the ORR (Fig. 3.33), and, therefore, the expected terrestrial fauna is that described for the entire reservation (Welch 1989).

Hardwood and mixed hardwood/conifer habitats are the most abundant habitat types in Bear Creek watershed, followed by pine plantation and grassland habitats, with considerable riparian habitat along the length of Bear Creek. Species commonly found in these habitats are listed below. 


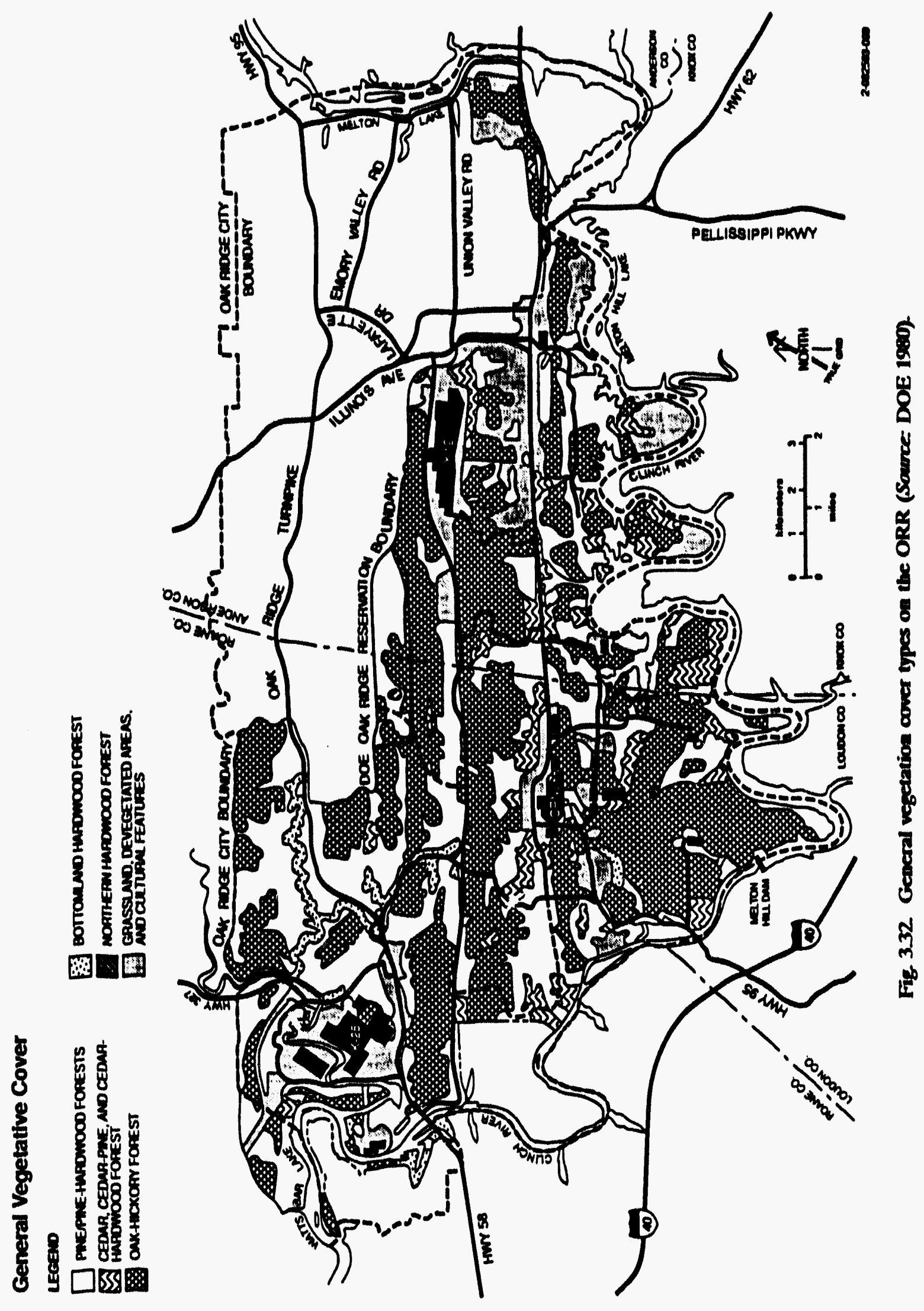


Table 3.16. Threatened and endangered plant und animal species on the ORR (Tenneassee Specific)

\begin{tabular}{|c|c|}
\hline Common name & Scientific name \\
\hline \multicolumn{2}{|c|}{ Flom } \\
\hline Spreading false-foxglove & Aureolaria patula \\
\hline Applachian bugbane & Cimicifuga rubifolia \\
\hline Pink lady-slipper & Cypripedium acuale \\
\hline Tall larkspur & Delphinum exaltatum \\
\hline Northem bush-honeysuckle & Diervilla lonicera \\
\hline Mountain witch-alder & Forhergilla major \\
\hline Golden seal & Hydrastis canadensis \\
\hline Butternut & Juglans cinerea \\
\hline Canada lily & Lillum canadense \\
\hline Fen orchid & Liparis loeselii \\
\hline Ginseng & Panax quinquifolius \\
\hline Tuberculed rein-orchid & Platanthera flava v. herbiola \\
\hline Purple fringeless orchid & Platanithera peramoena \\
\hline \multicolumn{2}{|c|}{ Mammals } \\
\hline River otter & Lutra canadensis \\
\hline Gray bat & Myotis grisescens \\
\hline Indiana bat & Myotis sodalis \\
\hline \multicolumn{2}{|c|}{ Binds } \\
\hline Cooper's hawk & Accipiter cooperil \\
\hline Sharp-shinned hawk & Accipiter striasus \\
\hline Bachman's sparrow & Aimophila aestivalis \\
\hline Grasshopper sparrow & Ammodramus savannarum \\
\hline Northern harrier & Circus cyaneus \\
\hline Peregrine falcon & Falco peregrinus \\
\hline Bald eagle & Haliaeetus leucocephalus \\
\hline Osprey & Pandion haliaetus \\
\hline Red-cockaded woodpecker & Picoides borealls \\
\hline Bewick's wren & Thryomanes bewickil \\
\hline \multicolumn{2}{|c|}{ Fish } \\
\hline Tennessee dace & Phoxinus tennesseensis \\
\hline
\end{tabular}

Source: Kroodsma 1993. 
General Widdife Habitats

\section{LEereno}

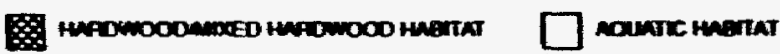

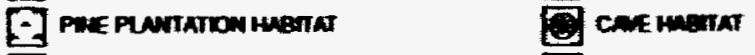

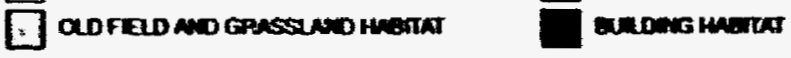

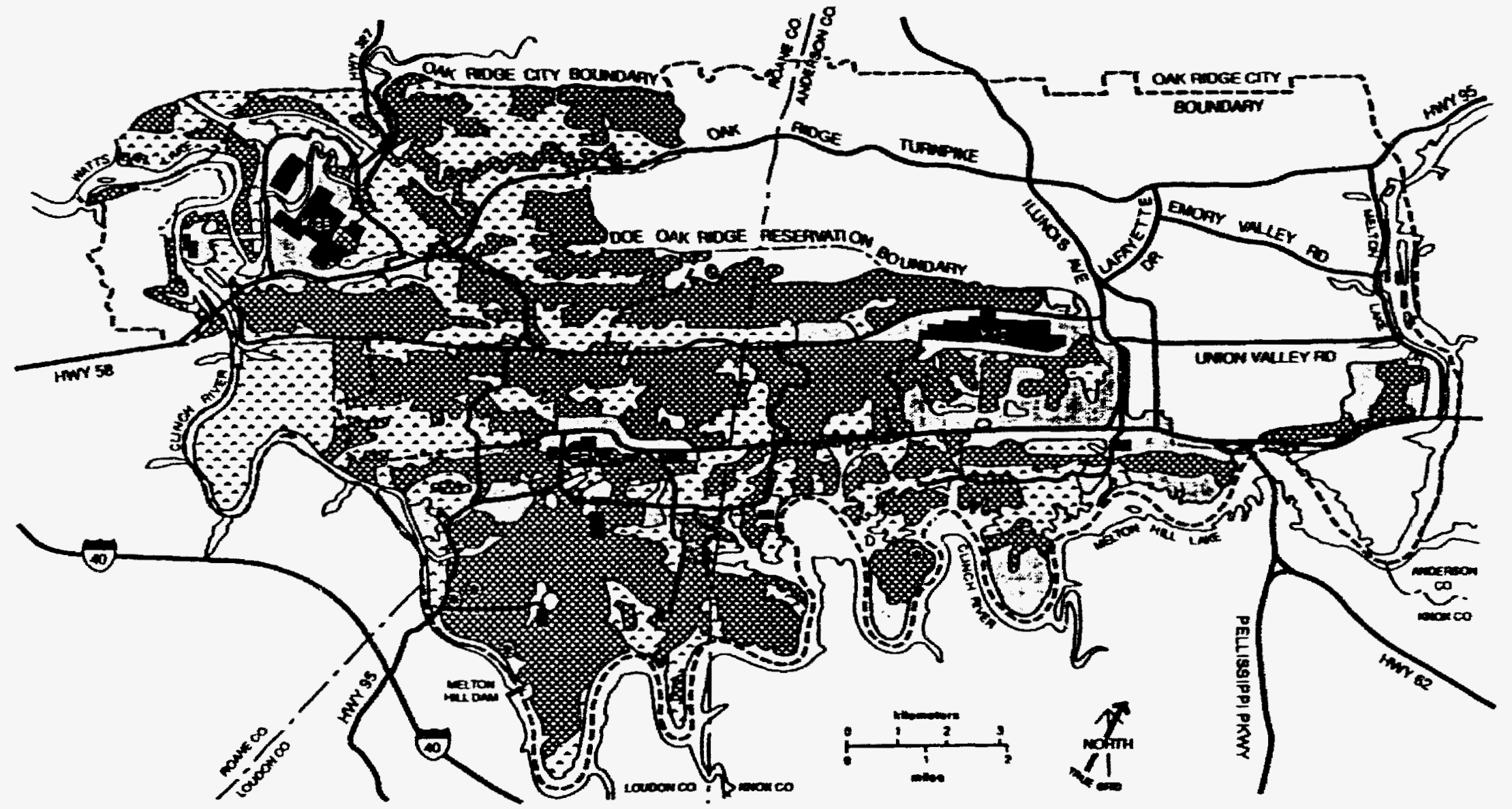

Fig. 333. Gescal wildife tabizts on the ORR (Source DOE 1980). 
Hardwood and mixed hardwoxo/conifer habitats. In wooded at eas the eastern gray and southern flying squirrels, southeastern shrew, eastern mole, short-tisilesi shrew, white-footed mouse, white-tailed deer, and eastern chipmunk may be found. Predators such as the bobeat and weasel occur here. Birds commonly found in forest areas include the yellow-shafted flicker, red-bellied woodpecker, hairy woodpecker, downy woodpecker, blue jay, Kentucky warbler, pine warbler, ovenbird, Carolina chickadee, tufted titmouse, and scarlet tanager. Hawks (red-shouldered, red-tailed, and broad-winged) are commonly found on the ORR, as are wild turkeys, which have been reintroduced to the area in recent years. Amphibians and reptiles found in the forest habitat include the dusky salamander. American toad, eastern box turtle, ground skunk, worm snake, black racer, rat snake, black king snake, milk snake, and copperhead.

Pine plantation habitat. Very early stages of planted pine areas contain species similar to those in old-field habitats, and the small mammals present are much the same as in the late stages of old fields. The populations tend to be smaller, though, because of less tree diversity. Pine plantations with a dense canopy and no understory are essentially barren of both small and large mammals except around the edges. As plantations are thinned and canopies opened, undergrowith develops and provides habitat for species similar to those found in carly- to mid. stage hardwood-mixed hardwood/conifer forests. Avian species have a low preference for the pure pine areas bordering the transmission line corridors. Pine warblers a..d white-throated sparrows are common, but few other species are evident. These habitats are little used by reptiles or amphibians (Johnson 1964).

Old-ficld and grasaland habitat. In the grassland/forb stage of vegetation, the principal species of small mammals are the southeastern shrew, least shrew, short-tailed shrew, eastern harvest mouse, hispid colton rat, pine mouse, and the eastern cottontail rabbit. The eastern mole occurs in areas of loose soil. Closely mowed or grazed areas and dense kudzu growth is good habitat for the groundhog. Also found there are the striped skunk, coyote, red fox, and white-tailed deer. In more brushy vegetation, the white-footed mouse, golden mouse, and opossum may be found. Bird species found in this habitat include bobwhite, red-tailed hawk, field sparrow, towhee, blue grosbeak, meadowlark, and red-winged blackbird. The eastern bluebird population has increased with the establishment of bluebird nesting boxes. The yellow-breasted chat is found in old lields. Numerous frog, toad, lizard, and snake species are found in the old-field areas.

Aquatic and riparian habitats. Many reptiles and amphibians occur in the various aquatic and wetland areas, including turtles, queen snake, water snake, salamanders, and frogs. The muskrat and beaver are bound closely to aquatic habitats. Rice rats, mink, and raccoons are also found in these areas. Many large mammals come frequently to this habitat to drink, and various small species are present at the water's edge. The American bald eagle occurs occasionally as a transient. The Canada goose, great blue herons, and green-backed herons nest on the ORR.

Threatened and endangered specics. Three mammal species on the federal list as endangered may occur on the ORR but have not been verified. These are the gray bat (Myotis grisescens), Indiana bat (Myotis sodalis), and eastern cougar (Felis concolor). Only one mammal species listed by the Tennessee Wildlife Resources Agency (TWRA) as in need of management, the southeastern shrew (Sorex longirostris), is known to occur on the reservation (Kroodsma 1987). The pine snake (Pituophis melanoleucas) is listed as threatened by the TWRA, and its presence in the Bear Creek watershed has been verified. The Cooper's hawk 


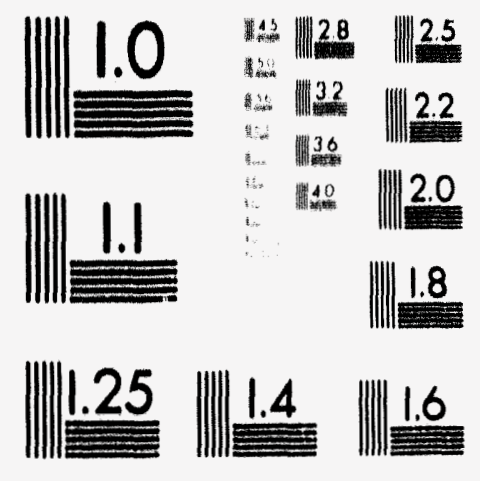



(Accipiter striatus) occurs in fotests throughout the ORR and is listed by the state as threatened (Kroodsma 1987). Rare plants occurring on the Y.12 Plant site have been characterized by Hardy et al. (1992).

\subsubsection{Aquatic Fauna}

There have been 19 species of fish found in Bear Creek in recent quantitative monitoring efforts conducted at seven sites along virtually the entire !ength of Bear Creek (Southworth et al. 1992). Minnows (blacknose dace, Rhinichthys atratulus; Tennessee dace, Phoxinos Tennesseensis; stoneroller, Campostoma anomalum; and creek chub, Semotilus atromaculatus) were the predominant fish species found upstream from the weir at BCK 4.55. Below the weir, larger species (northern hogsucker, Hypentelium nigricans; white sucker, Catastomus commersoni; and rockbass, Ambloplites rupestris) were more common, the diversity of minnow species increased, and darters were found. Conclusions of the recent fish-monitoring studies were that much of Bear Creek had limited fish fauna (low species richness) characterized by robust population parameters (high densities and biomass). The uppermost site (BCK 12.36) did not have a stable, resident fish population. Water from this site was commonly toxic to fathead minnow larvae in toxicity testing and contained high levels of dissolved salts as a result of input of contaminated groundwater from the S-3 Site. The next two monitoring sites downstream, BCK 11.83 and BCK 11.09, had low fish density and biomass in 1984 and 1985 but showed recovery in later sampling. No impacts on the fish of Bear Creek were evident in the vicinity of inputs from the Burial Grounds (BCK 9.91 and BCK 9.40) despite the fact that qualitative surveys found no fish in the tributaries (NT-6-8) draining that site.

The yellowfish madtom (Noturus flavipinnis), listed by the state as endangered, has been found in Bear Creek. The Tennessee dace, a major constituent of the fish population above the weir at BCK 4.55 , is listed as a species in need of management. Its habitat is protected by the state of Tennessee (Starnes and Etnier 1980). In Bear Creek, it occurs at every site above the weir and in at least four tributaries (NT-13, NT-14, NT-18, and ST-7).

Quantitative sampling of benthic invertebrates was conducted monthly at nine sites from BCK 12.36 to BCK 3.25 during June 1984-May 1985 as part of Phase I of the ecological monitoring program for Bear Creek and at quarterly intervals thereafter (Southworth et al. 1992). A total of 126 distinguishable taxa were collected in Bear Creek, including crustaceans (Isopoda, Amphipoda, and Decapoda); aquatic worms (Oligochaeta); snails (Gastropoda); mussels (Pelecypoda); and insects (Insecta). There were 11 orders of insects collected in Bear Creek, including springtails (Collembola), mayflies (Ephemeroptera), dragonflies and damselflies (Odonata), crickets and grasshoppers (Orthoptera), stoneflies (Plecoptera), true bugs (Hemiptera), alderflies and fishflies (Megaloptera), caddisflies (Tricoptera), butterflies and moths (Lepidoptera), beetles (Coleoptera), and true flies (Diptera).

The invertebrate fauna of Bear Creek showed a pattern of increasing density, biomass, and taxonomic diversity and richness with increasing distance downstream from the uppermost sampling site (BCK 12.36) (Southworth et al. 1992). The paucity of benthic invertebrates found in the upper reaches of Bear Creek contrasted sharply with reference sites (unimpacted streams of similar size), which had relatively diverse and abundant assemblages of macroinvertebrates. Water from BCK 12.36 and BCK 11.83 was toxic to Ceriodaphnia, an invertebrate test species, but not to fathead minnow larvae, in toxicity tests run in March 1988. At the time of these tests, streamflow in Bear Creek was higher than normal, and contaminants from the S-3 Ponds groundwater plume were diluted more than would be the 
case under baseflow conditions. Under low-flow conditions, it is likely that Bear Creck water would be toxic to Ceriodaphnia as far downstream as BCK 9.4. While evidence of adverse effects on the fish communities of Bear Creek was not noted at sites downstream from BCK 11.83, the benthic fauna appeared to be more sensitive, with clear differences in faunal composition from unimpacted reference sites at all sites except BCK 3.25, where complete recovery appears to have occurred. Species intolerant of pollution (mayflies, stoneflies, and caddisflies) were absent in the upper reaches and became more common downstream. Mayflies, which are particularly sensitive to toxic metals, were virtually absent at all sites except BCK 3.25. Unlike the fish data, which provide evidence of ecological recovery in Bear Creek since 1984, the benthic macroinvertebrate fauna do not appear to have changed in a manner indicative of either improving or degrading water quality since 1984 (Southworth et al. 1992).

No threatened or endangered species of aquatic macroinvertebrates have been collected in Bear Creek.

A limited amount of data have been collected on the bioaccumulation of contaminants by aquatic biota in Bear Creek. Fish collected from lower Bear Creek contained elevated levels of mercury ( 0.2 to $0.5 \mu \mathrm{g} / \mathrm{g}$, wet weight) in 1982 (Van Winkle et al. 1984) and in 1984 (TVA 1986). While well below the U.S. Food and Drug Administration (FDA) action level, these data do indicate the presence of biologically available mercury in the Bear Creek system. Fish from lower Bear Creek were also analyzed for cadmium, chromium, silver, arsenic, and nickel in 1984 (TVA 1986), and levels were found to be typical of fish from uncontaminated environments.

PCB contamination in fish from Bear Creek was evident in 1982, when rockbass collected from the lower reaches of the creek were found to contain $0.65 \pm 0.29 \mathrm{ppm}$ (wet weight) PCBs (McElhaney 1982). TVA analyzed fish from lower Bear Creek for organic priority pollutants, including PCBs in 1984; levels of all substances were below detection limits. Fish were collected from lower Bear Creek in 1987 as part of an effort to evaluate the importance (relative to other sources) of the UEFPC discharge at New Hope Pond as a source of PCB contamination to lower Poplar Creek and the Clinch River. In this collection, PCBs in rockbass averaged $0.28 \pm 0.12 \mathrm{ppm}(\mathrm{n}=8)$, a value comparable to the level of contamination found in sunfish in the lower third of EFPC and well above the level typical of fish from uncontaminated sites $(0.02 \pm 0.01 \mathrm{ppm})$. Clams held in Bear Creek (BCK 4.55) for 1 month as part of the same study accumulated $1.01 \mathrm{ppm}$ PCBs (versus $0.05 \mathrm{ppm}$ in controls), indicating that Bear Creek now contains a source of biologically available PCBs.

PCB contamination has been observed in fish in EFPC, Poplar Creek, and the Clinch River/Watts Bar Reservoir downstream from Bear Creek (TVA 1986). It is unlikely that a substantial fraction of this contamination is attributable to Bear Creek because sources of PCBs and similar levels of contamination are found in fish from these systems far upstream in EFPC from the mouth of Bear Creek (TVA 1986). A similar situation exists for mercury (TVA 1986).

The Biological Monitoring and Abatement Program (BMAP) studies have contributed a great deal of information on ecological impacts to Lower EFPC of ongoing releases from the Y-12 Plant, especially impacts on the aquatic biota. However, they were not designed to reveal effects of deposited sediments on either aquatic or terrestrial biota. In particular, the BMAP studies do not address the following points. 
- Contribution of in-stream sediments and sediment pore water to contaminant burden in aquatic biota. BMAP sample locations were intentionally chosen in riffle areas to avoid the contributions of heavily contaminated soils and sediments. Although it is clear from BMAP results that $Y-12$ Plant releases are a significant ongoing source of contaminants to the fish and other biota, studies on the effects of in-stream sediments were less definitive.

- Contaminants in fish were determined using fillets rather than whole fish. This approach reflects a concern for human health. However, piscivorous birds and animals consume internal organs, skin, fat, and in some cases bone, as well as muscle tissue. These tissues may selectively accumulate lipophilic contaminants or bone-seeking inorganics and radionuclides. Therefore, to be relevant to an ecological risk assessment, analyses of fish and other animals sampled should be done on whole organisms.

- BMAP was designed to assess impacts of waterborne releases to Lower EFPC. It does not include studies of terrestrial biota, which are more likely to be impacted by contaminants in the floodplain soils and groundwater.

To address these data gaps, the following approaches are proposed. Details of the proposed studies are provided elsewhere in this report:

- Fish and other aquatic biota will be sampled at locations at which in-stream sediments are present in significant quantities to provide a potential to contribute to contaminant loading of the biota.

- Aquatic and terrestrial biota will be analyzed on a whole-body basis rather than using muscle or organ tissue only.

- Terrestrial biota will be sampled as necessary to provide a comprehensive description of the distribution of contaminants through the terrestrial ecosystem.

\subsection{RADIOLOGICAL SURVEY}

An aerial radiological survey was conducted in 1989 encompassing $440 \mathrm{~km}^{2}$ (176 square miles) that included the entire ORR and adjacent areas. Typicai background exposure rates were found to vary from 7 to 11 microroentgens per hour. Preliminary data collected in a 1992 aerial radiological survey corroborate the 1989 data and are currently being evaluated. Data from this and a more recent survey that included several geophysical measurements will be available for use during the RI.

\subsection{SITE CONCEPTUAL MODEL}

Site conceptual models have been developed to illustrate the potential pathways of contaminant migrations, or flows, among various abiotic media and, ultimatcly, to receptors. Chapter 1 outlines the scope of the risk assessment to be carried out by the BCV OU 1 RI as a source unit in the BCV integrator. Ecological risk will be assessed for BCV OU 1 by determining the potential for lower members of the food chain (vegetation, earthworms, tadpoles, shrews) to uptake contaminants and on modeling the potential effects on human health and the ecosystem. Before a site-wide ROD is issued for Bear Creek Valley, an integrated baseline risk assessment for Bear Creek Valley will be carried out, and at that time 
high members of the food chain will be addressed in more detail. The generalized pathways for a human receptor and for ecological receptors are shown in Figs. 3.34, 3.35, 3.36, and 3.37. Figure 3.38 provides the hydrogeological submodel for the BCV OU 1 conceptual model.

\subsubsection{Soils ano' Sediments}

Uraniutin, PCBs, VOCs and various metals have been identified in soils and tributary sediments at each of the units within BCV OU 1. In general, wastes were either placed in unlined pits or spread over the surface. Soil contamination resulted from mixing of wastes with soil, by leaching of contaminants from wastes into surrounding soils, or by deposition of contaminants at seeps where contaminated groundwater discharges. High levels of soil contamination were identified at the Burial Grounds and the Oil Landfarm; however, the aerial extent and depth of contamination at these sites are not well known. Distribution and level of contamination in soils at the Boneyard/Burnyard and the S-3 Ponds is not well defined.

Stream sediments in tributaries that drain the units in BCV OU 1 are derived from erosion of soils within each tributary's catchment area. The nature and extent of contaminants in stream sediments reflect that of the soils in the area and the fact that contaminants may precipitate or sorb to stream sediments because of changes in water chemistry at the point of discharge.

Some areas of high soil and sediment contamination have been excavated and are now capped with RCRA caps; these areas are BG-A and BG-C, ORP 1 and ORP 2, and the Oil Landfarm. The HCDA has been capped with a RCRA-style cap, and sediments in Tributary NT-7 downstream of ORP 1 and SL 1 have been capped with $0.6 \mathrm{~m}(2 \mathrm{ft})$ of clay. The level of contamination in soils surrounding the caps resulting from downgradient migration of contaminants in groundwater or stormflow has not been defined.

\subsubsection{Groundwater}

Each of the major hydrologic units can be subdivided into the following subsurface zones: stormflow, vadose, and groundwater (Fig. 3.38). Flow within and between any of these zones is influenced by topography, surface cover, geologic structure, and lithology. Analyses by Moore (1988) suggest that a combination of topographic relief and a marked decrease in permeability as depth increases restrict the majority of flow to the shallow portions of the system.

The stormflow zone approximately corresponds to the root zone in naturally vegetated portions of the ORR. Moore (1988) suggests that $\sim 90 \%$ of active subsurface flow occurs through a 1- to 2-m-deep (3.3- to 6.6-ft) stormflow zone in those areas. During storm events, the stormflow zone transmits water laterally toward surface water discharge points. Surface runoff occurs when the stormflow zone becomes completely saturated. 


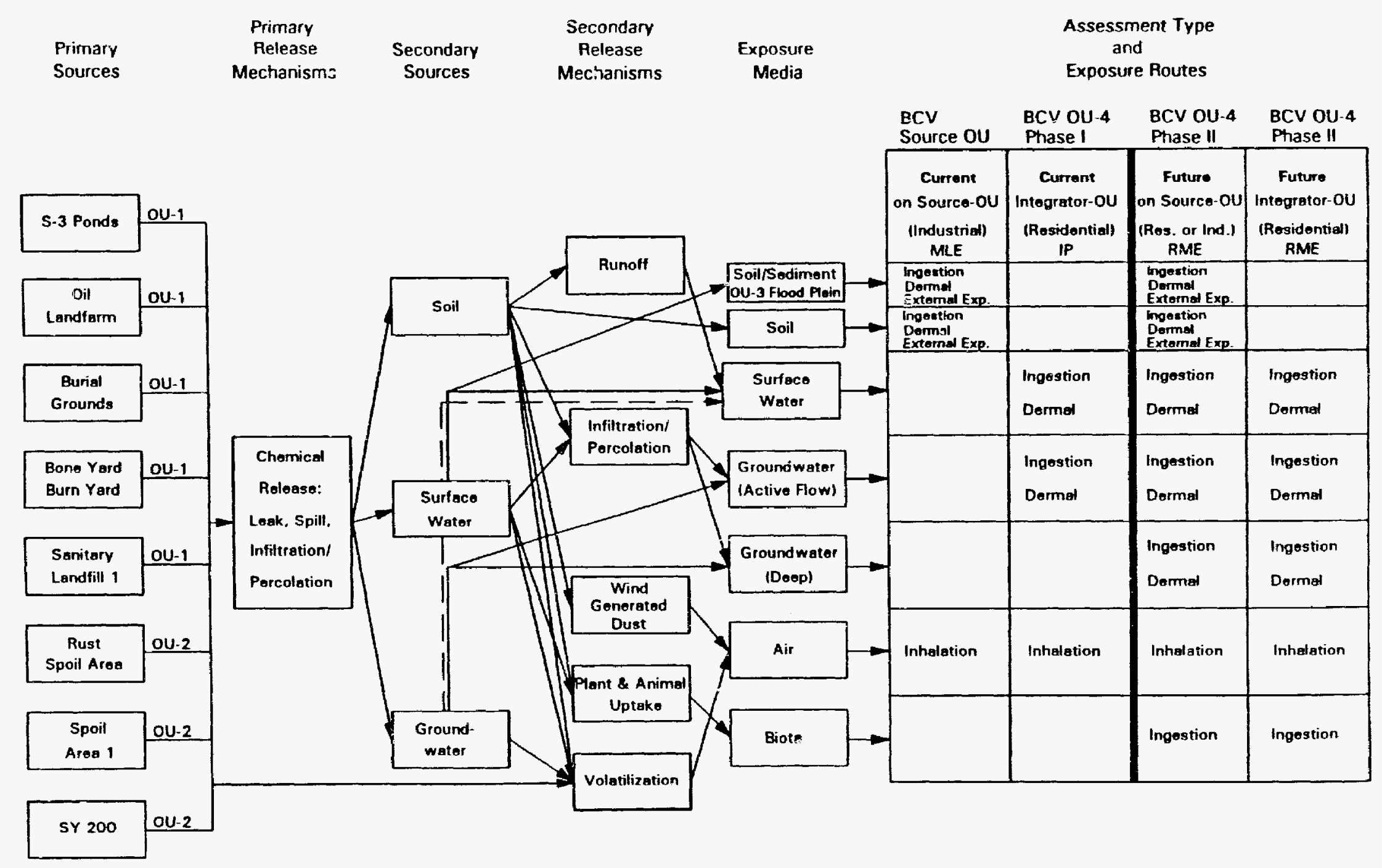

Fig. 334. Bear Creek Valley conceptual site model for human receptors. 


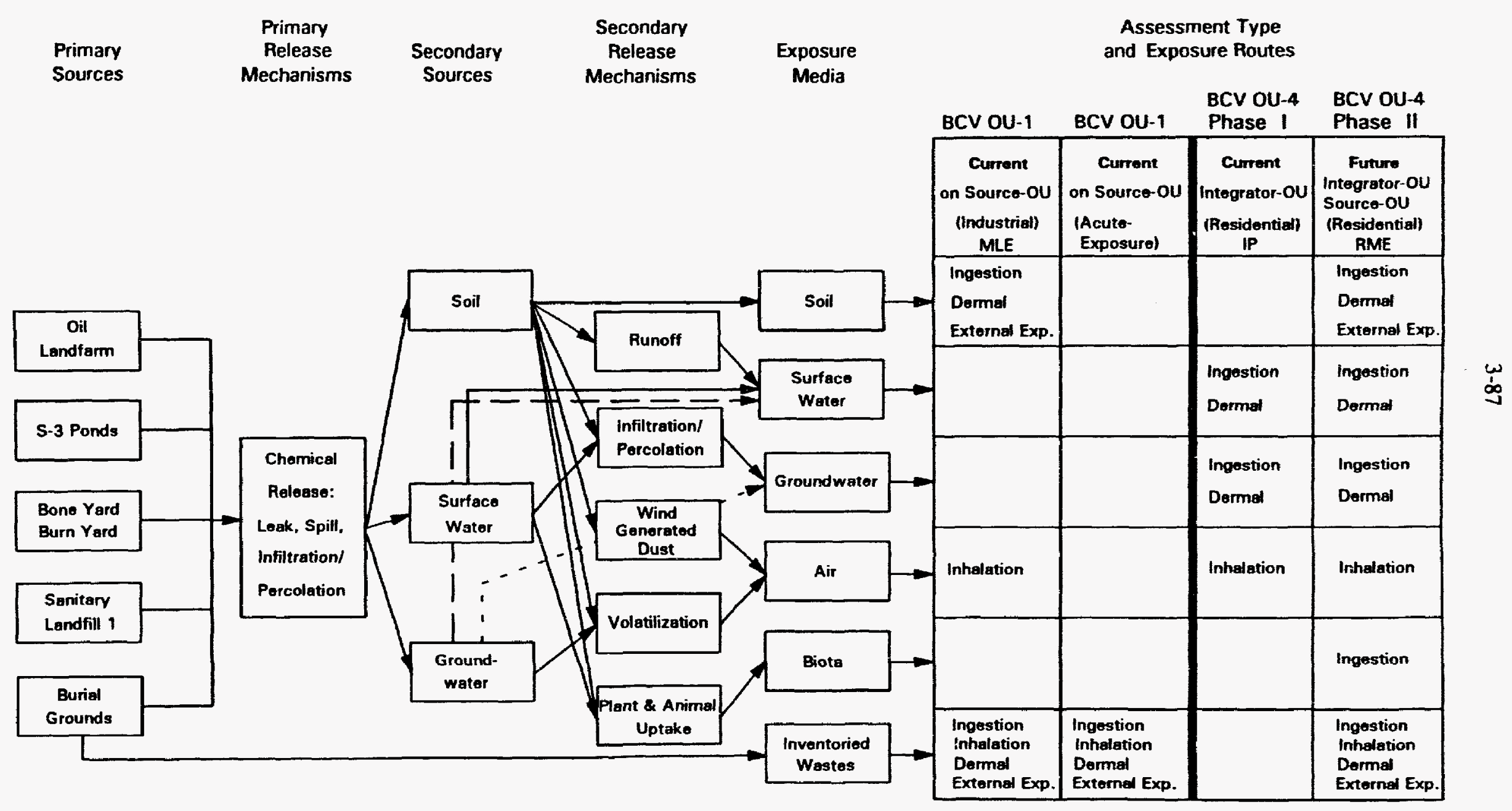

Fig. 3.35. Bear Creek Valley OU 1 conceptual site model for human receptors. 


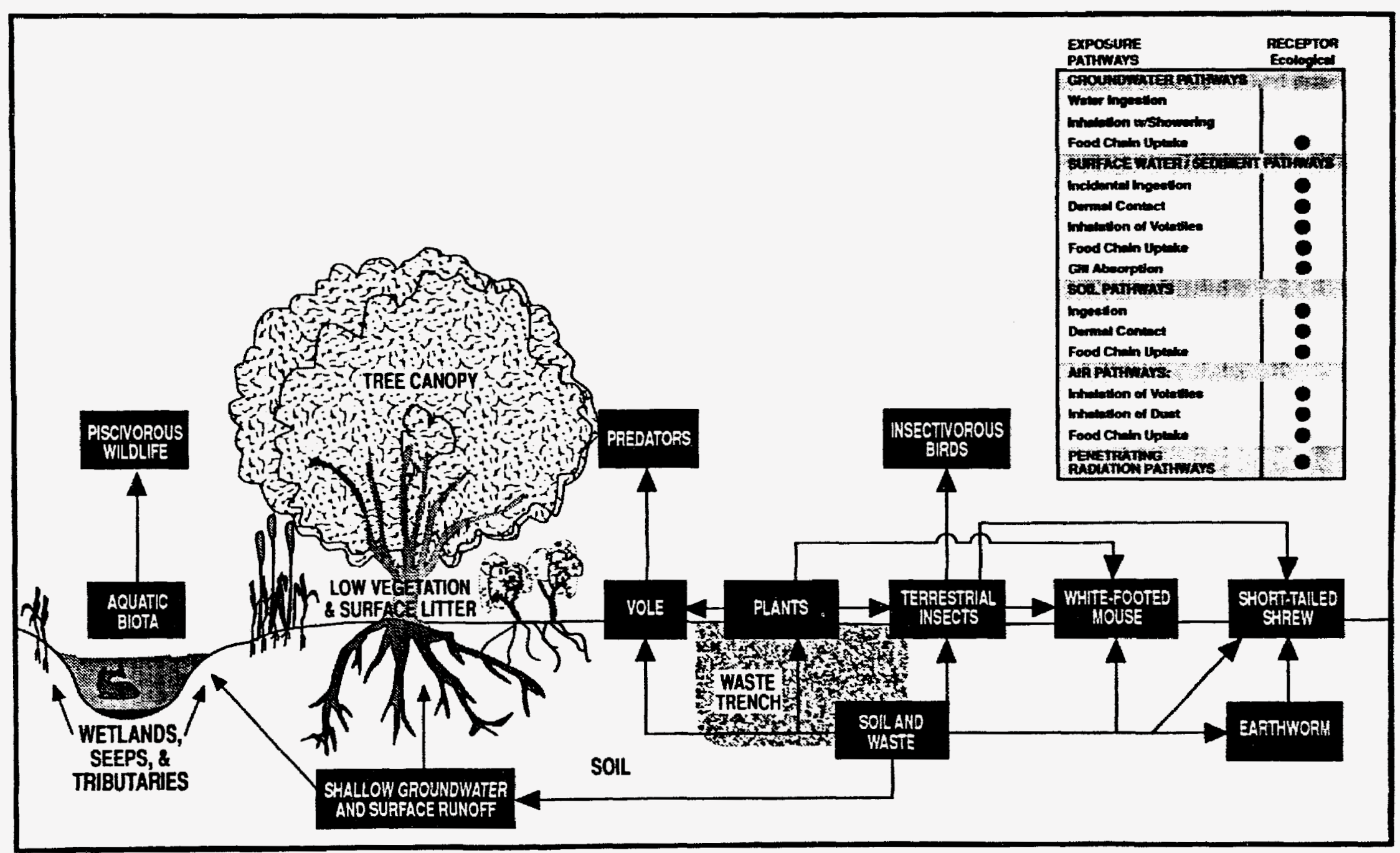

Fig. 3.36. Simplified food web for Bear Creek Valley OU 1 ecosystem. 


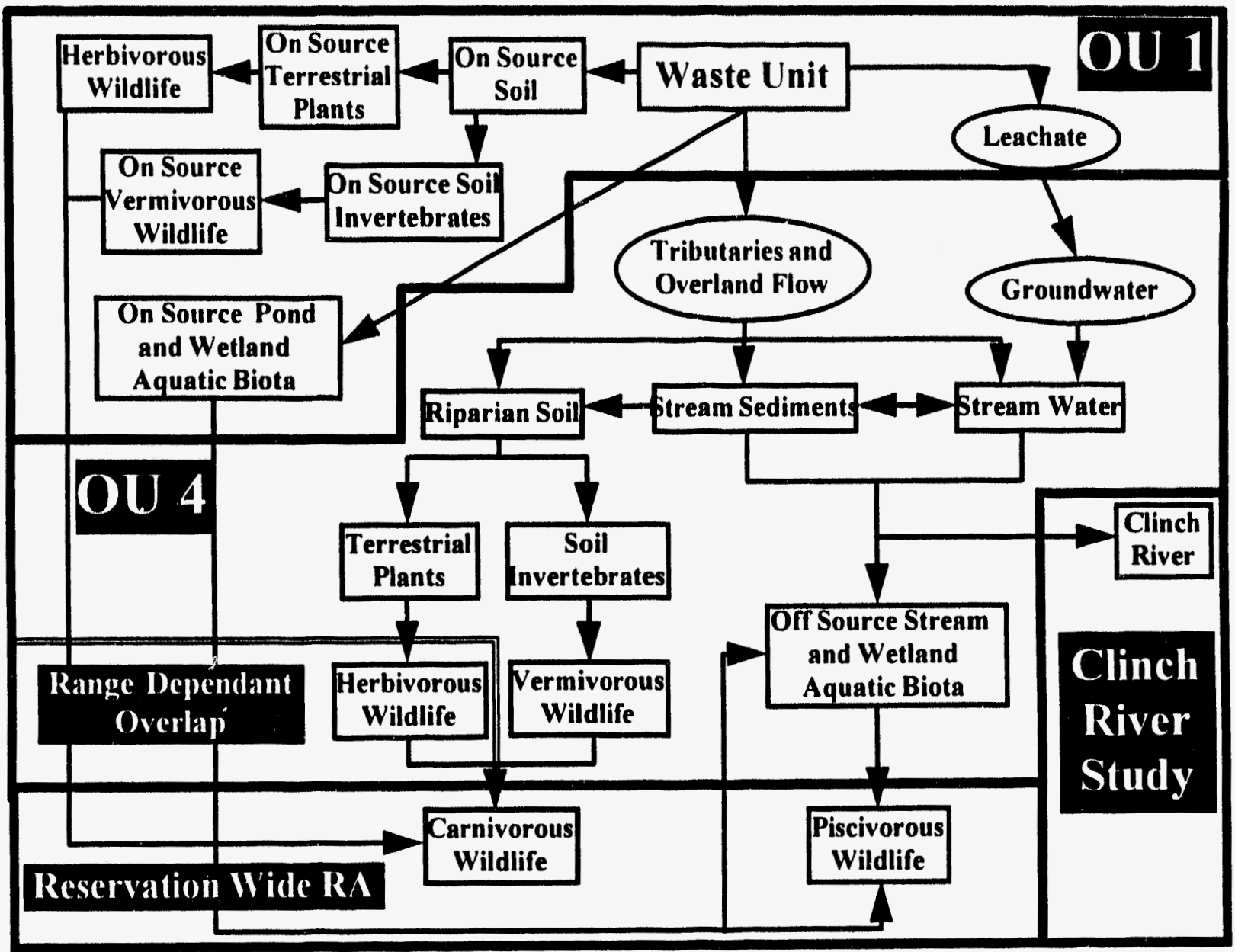

Fig. 3.37. Bear Creek Valley ecological conceptual model. 


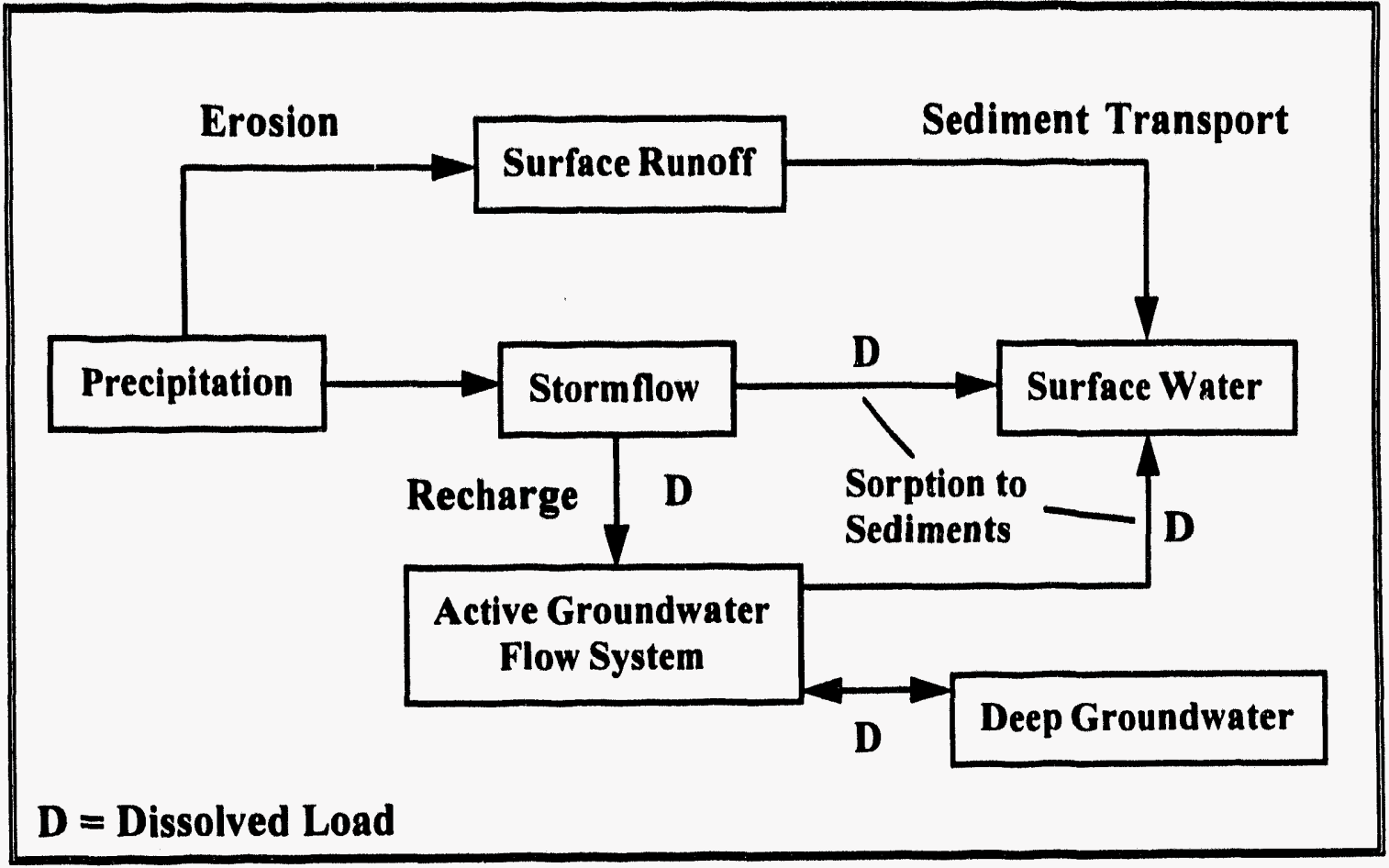

Fig. 3.38. Site conceptual model for transport of contaminants within BCHR. 
Water flow within the stormflow zone occurs primarily through root channels, worm holes, and fractures. While these large pores transmit most of the water, the majority of water mass (and contaminant storage) within the zone resides within the less transmissive surrounding soil matrix wherein hydroscopic forces immobilize the water. Diffusion of contaminants between the matrix and large pores, during times of active stormflow, effectively reduces the rates of contaminant flushing relative to fluid flow through the large pores.

The effect that construction of the Burial Grounds waste pits and RCRA caps has on the hydrology of the stormflow system is uncertain. Caps were not installed with drains or grout curtains designed to prevent stormflow from travelling helow the caps. Upgradient burial trenches that are oriented perpendicular to the topographic slope (such as trenches in BG.A) may collect water, whereas trenches oriented parallel to slope (such as BG.D. .E, and -J) may enhance transmission of water through the stormflow zone.

The vadose zone underlies the stormflow zone and varies in thickness from a maximum near ridge tops to a minimum where the water table approaches the ground surface (e.g., near perennial streams). The vadose zone is comprised of a regolith of clays and silts derived from the weathering of underlying bedrock and, in some cases, extends into the underlying bedrock. The regolith often retains relict structures (e.g., fractures) from the parent bedrock. These structures appear to serve as discrete, oriented, permeable flow paths. Between recharge events, flow within the vadose zone decreases with water moving toward the water table.

The major contaminant source areas in BCV tend to be located in the Nolichucky strike belt. During the operational history of the source areas the contaminants were either shallowly buried within the vadose zone or were spread on the ground surface. As a result, most of the contaminants that are migrating within BCV were mobilized by water moving through the stormflow zone, the vadose zone, and the water table interval of the groundwater zone.

Migration of DNAPLs downward below the Burial Grounds and the Oil Landfarm is evidenced by the high concentrations of organics in groundwater below these sites, and in one case to direct sampling of free-phase product in groundwater. DNAPLs may have migrated to a minimum of $152 \mathrm{~m}(500 \mathrm{ft}$ ) below the surface below the Burial Grounds. The extent to which DNAPLs are being leached from waste pits and the vadose zone at these sites is not known. However, DNAPLs that migrate through geologic media will leave behind a trail of residual DNAPL (i.e., nonmoving free-phase hydrocarbons). In this way there probably remains a trail of residual DNAPL in the vadose zone below the Burial Grounds that may be leached to groundwater in the future. The extent of organic contamination of soil and the vadose zone within BCV OU 1 has not been defined.

\subsubsection{Surface Water}

At any one time, surface water in streams draining the units of BCV OU 1 is comprised of three possible components: water that has entered the stream from springs where shallow groundwater discharges, water from seeps and springs that are the discharge point of the stormflow system, and overland flow. The relative contribution to the total flow of each of these components depends on recent and present precipitation conditions. 


\subsubsection{Site Conceptual Model for Hıman Recepton}

Site conceptual model how diagrams for human receptors, for the entire Bear Creck Valley (i.c., for both the integratur OU and each source OU) and for BCV OU I (A source $\mathrm{OU}$ ), are illustrated in Figs. 3.34 and 3.35, respectively. The Bear Creek Valicy sile conceptual model is shown in order to illustrate the relationship between the various source OUs (BCV OU 1, OU 2, and OU 3) and the integrator OU (BCV OU 4).

\subsubsection{Sitc Conceptual Model for Bear Creck Valkey}

For Bear Creek Vailey (Fig. 3.34), seven potentially contaminated media are considered. including soil, sediment, surface water, shallow groundwater (active flow), groundwater (decp), air, and the food chain. The primary sources of the contaminants are the S.3 Ponds, Oil Landfarm, Burial Grounds, Boneyard/Burnyard, Sanitary Landfill 1. Rust Spoil Area, Spoil Area 1, and SY 200. The primary and secondary release mechanisms are chemical releasea (including leaks and spills), runoff, infiltration/percolation, groundwater discharge, soil resuspension (wind-generated dust), plant and animal uptake, and volatilization.

The soil is a potential pathway of migration via runoff to surface water, percolation/ infiltration into groundwater, resuspension of particles (wind-generated dust) into the air pathway, uptake into plants and animals, and volatilization of contaminants into the air. The soil exposure medium is divided into soil (associated with cach source $O U$ ) and soil/sediment. Soil and sediments will be evaluated, in terms of human health risk, (1) using the current on. source OU industrial scenario [i.e, the most likely exposure (MLE) assasment, discussed in detail in Sect. 6.4) and (2) using in the future the hypothetical on-source OU residential scenario [i.e., the reasonable maximum exposure (RME) assessment, also discussed in Sect. 6.4). The current MLE assessments will be used to prioritize the source OUs in terms of on-source OU exposure and off-source OU migration of contamination. All future source OU RME assessment results will be performed in and included in the final Bear Creck Valley baseline risk assessment [i.e., RME for BCV OU 4 Phase II; refer to Figure 3.34). For soil (BCV OU 1 and OU 2) and sediment, exposure pathways/routes that will be evaluated include ingestion of soil, inhalation of resuspended soil (dust), dermal contact with soil. inhalation of volatiles from the soil, ingestion of biota (meat, milk and vegetables), and external exposure to radionuclides in the soil. For soil/sediment, the future risk evaluation includes exposure to floodplain soils or soils that have been irrigated (for agricultural purposes) with contaminated surface water.

Contaminant releases into the air exposure medium may occur as a result of resuspensiun of dust (from soil) and volatilization of contaminants from soil, surface water, and groundwater; residential uses of surface water and groundwater (e.g., showering) can resulf in volatilization of contaminants. Inhalation is the primary exposure route for contaminants in air, and this media will be evaluated in the current and future on-source $O U$ and integrator OU risk evaluations.

The surface water exposure medium is believed to have the greatest potential for offsource OU exposure. The potential for contaminant movement into groundwater is increased due to surface water infiltration to groundwater. In addition, groundwater can discharge to surface water; in Fig. 3.34, this secondary release mechanism is shown only as a dotted line. Surface water associated with a source OU will be evaluated in an integration point (IP) assessment (refer to Sect. 6.4) in Phase I of BCV OU 4 and in an RME assessment 
(hypothetical reaidential expmaure scenario) in Phasc II of BCV OU 4. Exposure pathways that will twe evalualed for the surface water (on-source $O U$ and off-source $O U$ ) are inhalation (Iol wilatlea). dermal contact, ingealion of biola (fiah), and ingeation of water.

Conumatwater. Both deep and active flow are other potential exposure media and mechaniama foif aft source OU Iranspoul of contaminants (Fig. 3.34). Again, groundwater anuwiated with a source OU will he evaluated in an IP assessment in Phase I of BCV OU 4 and in an RME auesument (hyputhetical residential exposure scenario) in Phase II of BCV OUt the expoure pathways that will be evaluated include ingestion, inhalation of volatiles, and dermal contacl with the groundwater.

Bave. Plank, animals, and fish may accumulate contaminants that are present in the soil and ifrigation water. This exponure medium (i.c., the food chain) will be evaluated using the hymohntical fulure reaidential/agricultural on-source OU scenario (RME assessment; BCV OU 4 Phaw II) and uing the fulure integrator OU (BCV OU 4 Phase II) RME risk meanent for hloth anciated with the iloxd plain soils and surface water (meat, milk, vegeiables, and (tish).

In summary, the sile conceptual model for the entire Bear Creck Valley (Fig. 3.34) is shown in illualfate the relationahip between the source OUs and the integrator OU. In addikm. the different types of risk assessments that will be performed in the short term (Iilkd "Current") and the long lerm (Illied "Fulure") are summarized. In the short term, for Phave I of BCV OU 4 (integrator OU), the surface water integrator and the active flow ifrundwaler will be evalualed in an IP risk assessment. Under current conditions (short (erm). the will markinted with the source OUs (BCV OU $I$ and OU 2) will be evaluated using an MLI. tisk muesment. The MLE assessment will be used to prioritize source OUs relative Wi owh whet. This MLE assessment will also be used together with the IP assessment to printilice ufl source OU exposure, that is, to prioritize how much each source $O U$ is cintrihuiling lo aff-anurce $O U$ release of contamination (to the integrator $O U$ ). In the future (IK V OU Phase II), ull media from each source OU (which includes soil and wastes) and the inceralio OU (which includes all surface water and groundwater associated with all of BCV) will he evaluated and integrated into a Bear Creek Valley RME risk assessment [i.e., haveline risk asesument for BCV (BCV OU 4 Phase II)].

\subsubsection{2 sile Conceptual Model for Bar Creck Valley OU 1}

Illuatrated in Fig. 3.35 is the site conceptual model for BCV OU 1; also included in this ngure are media ankxiated with BCV OU 1 that will be evaluated in the integrator OU (BCV OU 4). There are surface water, groundwater, soil, and wastes associated with this murce OU, the groundwater and surface water will be evaluated in BCV OU 4. Only expmare in mill and the inventoried wastes will be evaluated for this source OU (BCV (0) 1).

The mil asmociated with BCV OU I will be evaluated (in the short-term, current time period) using the industrial (MLE assessment) scenario. Exposure pathways/routes that will he ovaluated include ingestion of soil, inhalation of resuspended soil (dust), dermal contact with will. inhulation of volatiles from the soil, and external exposure to radionuclides in the mill. 
Human receptors (in a hyputhetical land-use scenario) could also be at risk from direct exposure to the wastes (inorganics, organics, and radionuclides) placed in the Burial Grounds; under current land-use conditions, human receptors are not exposed to these wastes. A statistical sampling and analysis of classified and unclassified inventory lists for the BCV OU 1 Burial Grounds is available, and a conservative estimate of the risk to a human receptor will be determined using this list of the wastes (best estimates for the total volume of each contaminant deposited in the pits will be used). Exposure pathways to be considered include ingestion, dermal contact, inhalation, and external exposure. A bounded risk estimate will be determined in which the lower bound will be determined using an MLE assessment and an upper bound will be determined by evaluating an acute exposure scenario.

\subsubsection{Ecological Conceptual Model}

Because they may be mobile and may be consumed by mobile species and because they may concentrate contaminants from exposure media, biota may serve as significant transporters of contaminants. The uptake and transport of contaminants by OU 1 aquatic and terrestrial biota are partially addressed as part of BMAP, a requirement of the Y-12 Plant NPDES permit. Figure 3.37 shows the BCV ecological conceptual model and outlines the sections of this model that will be addressed by the BCV OU 1 RI. The ecological site conceptual model is based on the simplified food web for BCV (Figs. 3.36 and 3.37). BCV OU 1 as a source unit will address ecological receptors with a range that is limited to the source units. These biota are vegetation, soil invertebrates, and on-source herbivorous and vermivorous wildlife. Where the range of a species extends beyond the source OU, risk will be evaluated in the integrator OU (BCV OU 4). Results to date indicate elevated tissue concentrations of mercury and PCBs in Bear Creek biota. Further study of the terrestrial and wetland flora and fauna will be carried out to assess ecological impacts to on-site receptors. 


\section{POTENTIAL RECEPTORS AND EXPOSURE PATHWAYS}

This chapter summarizes potential current and future human and ecological receptors that may be exposed directly or indirectly to contaminants in the BCV OU 1 waste sources. Potential receptors were presented in Chap. 3 as part of the site conceptual model. This chapter discusses in more detail the potential receptors that will be considered while developing the sampling and analysis plan for the site.

Potential receptors to the waste units that compose the BCV OU 1 must be defined for both current and future land use scenarios. Current receptors are identified in order to make intermediate decisions in the CERCLA process, such as determining the need for an expedited removal action. Future receptors must be identified in order to make the decisions involving long-term management of the waste unit.

An exposure pathway is the course that a chemical agent takes as it moves from source to receptor. An exposure pathway may include the following:

- A source of potential contamination

- A mechanism for release from the source [e.g., chemical partitioning from solid to liquid (waste to rainwater) that infiltrates into and through the unit] and a route of migration from the source to a receiving environmental media (e.g., vertical transport through the unsaturated zone to the groundwater)

- A point of exposure (c.g., a stream)

- A route of exposure (e.g., ingestion)

- A receptor (i.e., human or ecological)

The integration of all these factors results in a complete exposure pathway. Complete exposure pathways for BCV OU 1 are presented in Chap. 3 as part of the site conceptual model.

At BCV OU 1, the sources of potential contamination are buried waste and any soils surrounding the waste that have become contaminated by means of leaching from the unit. Some exposures may occur through direct contact with the waste. Other exposures may occur through indirect contact after the waste has migrated away from the source. The primary release and transport mechanisms away from the source to the point of exposure in surrounding media include the following:

- Vertical leaching to the groundwater

- Vertical/horizontal leaching through the stormflow system to surface water

- Runoff to surface water and sediments

- Volatilization into the air

- Particulate emissions into the air

- Penetrating radiation 
Once the exposure point has been identified for each medium, an exposure route must be identified. Exposure routes are the mechanisms by which receptors contact the chemicals. The potential routes of direct exposure associated with the BCV OU 1 receptors include the follcwing:

- Soil/waste ingestion

- Dermal contact with soil/waste

- Direct exposure to contaminants

- acute exposure

- penetrating radiation

Indirect exposure to the waste may occur through the following pathways:

- Groundwater pathways

- ingestion of groundwater

- inhalation while showering

- uptake by plants

- ingestion of lower members of the food chain that are contaminated

- dermal contact with groundwater used for domestic purposes

- dermal contact while showering

- Surface water pathways

- ingestion of surface water

- dermal contact with surface water

- inhalation of volatiles from surface water

- uptake into food chain (aquatic flora and fauna)

- Air pathways

- inhalation of volatiles in soil

- inhalation of fugitive dusts

- inhalation of volatiles in water

Additional secondary pathways may be identified through the course of the RI. Exposure to soil and wastes associated with BCV OU 1 will be evaluated in this RI; groundwater and surface water (for BCV OU 1) will be evaluated in BCV OU 4 Phase I and II.

\subsection{HUMAN POPULATIONS}

EPA proposes that three general types of land use categories be considered during the risk assessment process: residential, industrial, and/or recreational. Current land use of the BCV OU 1 site is light industrial. Although no industrial activity actually takes place in the OU, the waste units in BCV OU 1 support or have supported the Y-12 Plant production operations, and thus light traffic continues around some of the waste units.

It is too early in the CERCLA process to attempt to identify future land use of the ORR. The strategic planning for future use of the government-owned property at the Y-12 Plant is a continuing topic of discussion. It is likely that the results of several source OU risk assessments and cost-benefit analyses performed during FSs will help make the decisions 
concerning future land use. Because future land use for the ORR has not been decided, the BCV OU 1 preliminary hazard evaluation and (this RIWP) baseline risk assessment (BCV OU 4 Phase II) will consider at a minimum the following land use scenarios:

- Government controls remain in place, and activity at the site is industrial.

- Government control is lost, and the land is used for residential purposes.

Additional future land use scenarios, such as residential or recreational, will be evaluated in the site-wide baseline risk assessment (BCV OU 4 Phase II). For scoping purposes, it is assumed that the BCV OU 1 land will be industrial. Data collection activities, however, will provide data to evaluate any (residential, industrial, and recreational) of the potential land use scenarios.

\subsubsection{On-Source OU Receptors}

\subsubsection{Current land use}

Two factors play a role in limiting the number of potential current receptors to the BCV OU 1 area. First, as with the entire Y-12 Plant, BCV OU 1 is a controlled access area, surrounded by fences and guarded by active patrolling. Second, due to the nature of the waste disposal activities at the site and the fact that the waste unit lies outside of the production area, relatively few personnel are routinely in the area. On-source OU human receptors are workers that may be Energy Systems employees or contractor personnel. Transient visitors may enter the site, likely associated with ongoing remediation efforts; however, the frequency and duration of these visitors is likely to be minimal. There is little potential for a trespasser to enter the area because of the emphasis on security at the Y-12 Plant. No sensitive subpopulations are assumed to exist on site.

\subsubsection{Future land use and sensitive populations}

Based on the assumption that the government loses control of the land and that future land use is residential, future potential receptors would include both children and adults who reside and farm on site. Farming includes the food ingestion pathways (vegetable ingestion; meat and milk ingestion). In addition, these receptors could hunt and fish on the land. Based on the assumption that the government retains control of the land, on-source human receptors would likely be industrial/remediation workers.

\subsubsection{Off-Source OU Receptors}

Because BCV OU 1 is a source term OU, and off-source OU receptors are affected by means of migration through media of the integrator OU, protection of off-site receptors will be handled indirectly. Groundwater and surface water flow is being addressed extensively as part of the BCV OU 4 integrator OU. Current risk to off-source receptors exposed to contaminants in these media will be addressed in the IP assessment of the integrator OU RI. However, because the ultimate goal of a source control measure is to decrease or eliminate releases and migration to any receptors, the risk assessment and remedial action selection for the source OU must address migration to the off-source OU receptors. 
To distinguish the scope of the BCV OU 1 risk assessment from that of the BCV OU 4 integrator $O U$, it is assumed that the groundwater and surface water immediately adjacent to the waste sources are receptors and that it is the goal of the source OU to eliminate contaminant migration to these environmental receptors. To do this, the integrator unit will provide groundwater and surface water PRGs at the points where the two OUs interface. These PRGs will be designed to protect the downstream receptors. Additional information for evaluating exposures to off-source OU receptors will likely be generated by the integrator OU (e.g., the dilution attenuation factor from the water adjacent to the source to the off-site receptor). Distinguishing the responsibilities of the BCV OU 1 risk support from those of the BCV OU 4 risk support will continue as the RI/FS for each progresses.

Off-source OU receptors could be members of the general public who live downstream and downgradient of the site and may be exposed indirectly to waste from BCV OU 1; offsource OU receptors also include future potential receptors located adjacent to the source OU.

\subsubsection{Regional demography}

The demography of East Tennessee and the Oak Ridge region is discussed in Sect. 3.3. Current and future off-source OU human receptors are members of the general public who live downstream and downgradient of the site and may be exposed indirectly to waste from BCV OU 1. This off-so urce OU population can be considered a receptor only if it is shown (BCV OU 4) that the BCV OU 1 wastes migrate into the surface water (Bear Creek) and groundwater (and on to the creek and/or the Clinch River) surrounding the sources. Potential receptors include members of the public who may come into contact with waste in the stream outside the plant boundary, users of water in the Clinch River, and recreational users of the Clinch River. Since no groundwater wells exist between BCV and the points at which groundwater mixes with surface water, it was assumed that groundwater well users are not current off-source OU receptors; however, they will be considered as potential future receptors.

\subsubsection{Sensitive populations}

Children who live off-source OU 4 may be considered as sensitive subpopulations in the risk assessment. There are no hospitals, nursing homes, or day-care centers located within a reasonable distance downgradient of $\mathrm{BCV}$.

\subsection{ECOLOGICAI POPULATIONS}

As with the human health assessment, distinguishing the responsibilities of the BCV OU 1 ecological risk support from those of the BCV OU 4 ecological risk support will be an ongoing process. Identifying ecological receptors differs from identifying human receptors in that land use/access contro! does not drive the identification. Future ecological receptors are assumed to be the same as current receptors in the absence of potential remediation and changes of land use.

To distinguish the scope of the BCV OU 1 risk assessment from the scope of the BCV OU 4 integrator OU for this work plan, it is assumed that aquatic receptors in the surface water immediately adjacent to the waste sources are receptors of concern, and that it is the 
goal for the source OU to eliminate contaminant migration to these environmental receptors as well as on-site terrestrial receptors. To do this, the integrator unit should provide ecologically-based surface water PRGs at the points where the two OUs interface. These PRGs will account for protection of the aquatic receptors. It will then be the goal for the source $O U$ to prevent contaminant nigration from the unit to the surface water at levels exceeding the PRGs.

Although the waste units that make up BCV OU 1 are considered light industrial, there are few buildings or concrete areas (with the exception of the asphnalt parking lot near the S-3 Site). The BCV OU 1 area is primarily grass-covered fields surrounded by woodlands. Sume of the units are covered with caps, and thus contact with the waste by ecological receptors may only occur for burrowing animals. However, other units do not have caps, and terrestrial receptors may contact the waste directly. In addition, seeps and springs in several areas of the site may be used as water sources by terrestrial receptors. Thus, on-site terrestrial receptors and associated food chain receptors are of concern for the BCV OU 1 RI. Terrestrial receptors that can be associated specifically with BCV OU 1 may include mammals, insects, worms, reptiles, and plants. Risks to browsing animals and predators, most of which have ranges larger than the source units, will be evaluated in the site-wide baseline ecological risk assessment to be completed as part of the RI for OU 4.

\subsubsection{Flora: Terrestrial and Aquatic.}

Flora on the ORR are described in Sect. 3.7. Flora, including wetland and pond flora, will be addressed as receptors potentially at risk from contaminants and also as a pathway to herbivorous fauna in BCV. Grasses are the food source of some herbivorous animals and are known to accumulate metal and radionuclide contaminants. They will be sampled as monitors of exposure via fond to herbivorous mammals and birds. Vegetation characteristic of contaminated areas identified by Phase I sampling will be sampled later in Phase I to determine the nature of contamination in flora. If significant uptake of contaminants is found, statistically based sampling will be done to determine the distribution of contaminated flora.

\subsubsection{Fauna: Terrestrial and Aquatic}

The abundance and productivity of bird and mammal populations are the primary assessment endpoints for ecological risk assessments on the ORR. Fauna on the ORR are described in Sect. 3.7. All of these fauna are considered likely receptors in the ecological conceptual model. However, risks to birds and mammals with ranges larger than the source units and to aquatic biota in tributaries to Bear Creek will be evaluated as part of the RI for BCV OU 4.

Complete exposure pathways may exist for terrestrial organisms found on and near BCV OU 1. Small mammals, insects, and worms may be directly exposed to wastes and contaminated soils, especially as a result of burrowing in the subsurface soils. Inhalation of volatile organics in burrows or evaporating from soils and seeps may also expose terrestrial biota. Terrestrial mammals may be exposed both topically and through soil ingestion. Birds and mammals may feed on contaminated food and may ingest soils directly. Contaminated soils carried by wind may be inhaled by birds and animals.

Aquatic biota may be exposed to contaminants in surface water by ingestion, direct contact, and gill absorption to contaminants in sediments by ingestion and direct contact, and 
to contaminants in both water and sediment by ingestion of contaminated food. Exposure of aquatic biota to contaminants in the main stem of Bear Creek will be evaluated by the Bear Creek integrator OU RI. However, aquatic biota in tributaries draining the source OUs and in wetlands within the OU boundaries will be addressed by this OU RI.

Radionuclides may cause exposure either internally or by direct irradiation. Terrestrial animals may be exposed by direct irradiation from contaminated soil in which they burrow or on which they forage; the degree of exposure will depend on their behavior.

Perhaps the most significant pathway for exposure to contaminants at the BCV OU 1 area is the food web. Feeding habits and other aspects of lifestyle determine the significance of these exposures. For example, shrews prey on earthworms, which may have exterior contamination from adhering soils and interior contamination from ingesting soils. Therefore, shrews may ingest more soils than voles, whose diet is mainly vegetarian. Some insects of terrestrial origin spend their entire life on or in the soil. Earthworms are highly exposed to contaminants in soil by both dermal contact and ingestion. They are likely sources of contamination for shrews, some birds, and other small animals. Plants are highly exposed to contaminants in soils by root uptake and by surface deposition of airborne dust. Animals may, in turn, feed on the vegetation.

Wetlands constitute areas of special ecological concern because of their legally protected status and because of their unusual ecology. Wetlands are those areas that are inundated or saturated by surface water or groundwater at a frequency and duration sufficient to support, and under normal circumstances do support, a prevalence of vegetation typically adapted for life in saturated soil conditions ( 40 CFR 20.3; 33 CFR 328.3). Wetlands are defined by three essential attributes: wetland hydrology, hydrophytic vegetation, and hydric soils.

Contaminant releases in wetland soils may be different from those in drier soils because water-saturated soils may experience increased or diminished leaching of contaminants and because $\mathrm{pH}$, oxidation level, and other characteristics of soil chemistry are likely to be different from drier sites. Wetlands also typically have different populations of flora and fauna from drier habitats, so transfers into the food web are different and require separate evaluation.

A few indicator species will be used as representatives of their trophic levels in the BCV OU 1 ecosystem. These species were chosen because they are expected to be abundant and easily surveyed or sampled and because they represent a key step in the transfer of contaminants from soil, sediment, or water to predators. Contaminant burden will be measured for aquatic insects and grasses and browse; both population surveys and body burden analyses will be conducted for earthworms, amphibians, and terrestrial mammals.

Wetland areas in BCV OU 1 are likely to act as sinks for contaminants in surface runoff. Although these areas are not significant habitats for fish, they may provide good habitat for amphibians. Amphibian larvae (tadpoles) are exposed to contaminants via water, sediment, and vegetation and are, therefore, good indicators of contamination of the aquatic habitats. They subsequently leave the aquatic habitats in which they are initially exposed and enter the food chain of terrestrial predators, providing a link from surface runoff and sediment transport of contaminants to terrestrial predators at some distance from the areas of contaminant accumulation. Ponds and wetland areas containing amphibian larvae will be 
identified, and the development of larvae will be monitored visually. When they have neared maturity, they will be sampled for contaminant body burden.

Earthworms are continuously exposed to scil contaminants by direct contact and by ingestion. They are a food source to some birds and small mammals. Population densities and cortaminant body burdens, both total and depurated, will be determined by sampling earthworms. If contaminant levels are elevated and population densities are reduced, earthworm toxicity tests will be performed on the soil (see Sect. 6.1.1.4).

Small mammals can be particularly effective biomonitors of soil contaminant effects in the food web if the species used are abundant, easily caught, do not migrate long distances, have a widespread distribution, and have generalized food habits. Their relatively short life span (generally less than 1 year) facilitates long-term monitoring of contaminants because each generation reflects the present type and amount of contaminants in the environment; thus increases, decreases, or the addition of new contaminants can be detected. The small mammals likely to be captured in BCV OU 1 include white-footed mouse (Peromyscus leucopus), short-tail shrew (Blarina brevicauda), masked shrew (Sorex cinereus), and field vole (Microtus pennsylvanicus). Each of these species meets the requirements of good environmental indicators mentioned above. In particular, the insectivorous short-tail shrew is well suited because of its relatively high food intake and dietary needs. It bioaccumulates contaminants such as metals and PCBs if they are present in invertebrate populations, and much of its food source lives in the soil, close to BCV OU 1 contamination, for some part of its life cycle. The white-footed mouse is abundant and is expected to provide a potential pathway to higher trophic levels (i.e., predators); it will be analyzed for contaminant levels. Voles represent exposures via a primarily herbivorous pathway.

Woodchucks (Marmota monax) are exposed to subsurface contaminants by soil ingestion, direct dermal contact, and external irradiation. They will be trapped and analyzed for radionuclide uptake. Although their larger home range makes it difficult to identify the locations of the contaminant sources, they are good indicators of exposures to subsurface soil near and in the waste areas.

\subsection{Future Land Use}

Unmanaged terrestrial habitats typically undergo a succession of changes as grasses are replaced by forbs and trees, with accompanying changes in animal populations. In the absence of institutional controls in BCV OU 1, areas that are currently maintained as grass would revert to forest, with changes in the distribution and abundance of terrestrial biota. In addition, engineered caps may break down or be penetrated by burrowing animals, allowing contaminants to be released to soil and surface water. Therefore, potential future receptors near waste areas include the current potential receptors, as well as birds and other forestdwelling animals.

Residential, industrial, and agricultural are the potential future land uses that will be evaluated. In addition, a potential future land use in which waste sites are allowed to revert to forests would provide a mixture of exposures. Potential receptors under this scenario would be the same in the unmanaged habitat scenario. 


\section{IDENTIFICATION OF INVESTIGATION REQUIREMENTS}

Many of the requirements for performing an effective site investigation are based on the need to evaluate the site in terms of the two CERCLA "threshold" criteria: compliance with ARARs and protection of human health and the environment (EPA 1988b). This chapter provides specific considerations of these requirements. Both compliance with ARARs and evaluation of potential health and ecological risks are dependent on understanding the potential COCs at the site. Table 5.1 lists potential COCs for BCV OU 1 by waste site. These lists were compiled from studies referenced in Chap. 3 of this work plan. To some extent, the $\mathrm{COC}$ list is a reflection of the types and amounts of data available on a site and thus may not be comprehensive. Data with which to develop a COC list are not available for SL 1 or the Boneyard/Burnyard. Thus, one of the goals of the Stage 1 sampling efforts for these sites will be to identify COCs.

\subsection{IDENTIFICATION OF ARARS}

CERCLA was passed by Congress and signed into law on December 11, 1980 (Public Law 96-510). This act was intended to provide for "liability, compensation, cleanup, and emergency response for hazardous substances released into the environn ent and the cleanup of inactive waste disposal sites." SARA, adopted on October 17, 1986 (Public Law 99-499), did not substantially alter the original structure of CERCLA but provided extensive amendments to it.

Even before CERCLA, DOE issued Order 5400.1 to establish environmental protection program requirements, authorities, and responsibilities for DOE operations. This order seeks to ensure compliance with applicable federal, state, and local environmental protection laws and regulations, executive orders, and internal DOE policies. DOE Order 5400.1 has been modified to meet new requirements imposed by amendments to the federal environmental laws.

\$121 of CERCLA specifies that remedial actions for cleanup of hazardous substances must comply with requirements or standards under federal or more stringent state environmental laws that are applicable or relevant and appropriate to the hazardous substances or particular circumstances at a site. Inherent in the interpretation of ARARs is the assumption that protection of human health and the environment is ensured.

The purpose of this report is to supply a preliminary list of available federal and state chemical- and location-specific ARARs that might be considered for the cleanup of soil at BCV OU 1. In addition, tables of groundwater and surface water ARARs are presented for comparison with analytical detection limits for contaminants in these media. If the RI determines that leachate and runoff from the contaminated soils at BCV OU 1 are causing contamination in surface water and groundwater at levels that surpass ARARs for the contaminants, remedial alternatives to isolate and control the sources to prevent further contamination of surface and groundwater will be addressed during the FS phase. Actionspecific ARARs will be identified and analyzed when remedial alternatives are selected during the FS phase. The process of ARAR identification is an iterative one that is continually changing as the RI/FS progresses. Therefore, this list of ARARs represents a compilation of 
Table 5.1. Cremicals of potential concem at BCV OU 1

\begin{tabular}{|c|c|c|c|c|c|c|}
\hline & \multicolumn{3}{|c|}{ 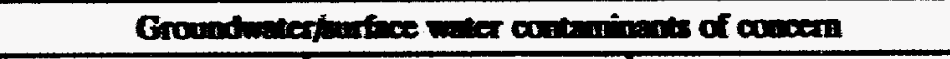 } & \multicolumn{3}{|c|}{ 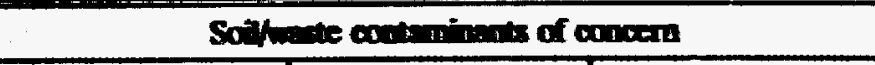 } \\
\hline & Rocionactides & Inorgato & Orgats & Rortancides & Inorgaios & Orgarios \\
\hline Burial Grounds & & $\begin{array}{l}\text { Cadmium } \\
\text { Chronium }\end{array}$ & $\begin{array}{l}\text { 1,1-dichloroethane } \\
\text { 1,1-dichloroethylene } \\
\text { 1,2-dichloroethylene } \\
\text { Tetrachloroethylene } \\
\text { 1,1,1-trichloroethane } \\
\text { Trichloroethylene } \\
\text { PCBs }\end{array}$ & $\begin{array}{l}\text { Thorium-228 } \\
\text { Thorium-230 } \\
\text { Thorium-232 } \\
\text { Uranium-234 } \\
\text { Uranium-235 } \\
\text { Uranium-238 }\end{array}$ & $\begin{array}{l}\text { Comprehensive } \\
\text { Target Analyte } \\
\text { List (TAL) }\end{array}$ & $\begin{array}{l}\text { Comprehensive } \\
\text { Target Compound } \\
\text { List (TCL) } \\
\text { analytes, plus } \\
\text { additional } \\
\text { tentatively } \\
\text { identified } \\
\text { compounds (TICs) }\end{array}$ \\
\hline Oi Landfarm & $\begin{array}{l}\text { Gross alpha } \\
\text { Gross beta } \\
\text { Strontium-90 } \\
\text { Technetium-99 } \\
\text { Tritium }\end{array}$ & $\begin{array}{l}\text { Barium } \\
\text { Cadmium } \\
\text { Chromium } \\
\text { Lead } \\
\text { Mercury }\end{array}$ & $\begin{array}{l}\text { 1,1-dichloroethane } \\
\text { 1,2-dichloroethylene } \\
\text { Tetrachloroethylene } \\
\text { Trichloroethylene } \\
\text { PCBs }\end{array}$ & $\begin{array}{l}\text { Gross alpha } \\
\text { Gross beta } \\
\text { Strontium-90 } \\
\text { Technetium-99 } \\
\text { Tritium } \\
\end{array}$ & $\begin{array}{l}\text { Barium } \\
\text { Cadmium } \\
\text { Chromium } \\
\text { Lead } \\
\text { Mercury } \\
\end{array}$ & $\begin{array}{l}\text { Comprehensive } \\
\text { TCL analytes, plus } \\
\text { additional TICs }\end{array}$ \\
\hline S-3 Site & $\begin{array}{l}\text { Gross alpha } \\
\text { Gross beta } \\
\text { Strontium-90 } \\
\text { Technetium-99 } \\
\text { Thorium-228 } \\
\text { Thorium-230 } \\
\text { Thorium-232 } \\
\text { Tritium } \\
\text { Uranium-234 } \\
\text { Uranium-235 } \\
\text { Uranium-238 }\end{array}$ & $\begin{array}{l}\text { Aluminum } \\
\text { Barium } \\
\text { Beryllium } \\
\text { Boron } \\
\text { Cadmium } \\
\text { Chromium } \\
\text { Cobalt } \\
\text { Copper } \\
\text { Lead } \\
\text { Mercury } \\
\text { Nictel } \\
\text { Nitrate (as N) } \\
\text { Uranium }\end{array}$ & $\begin{array}{l}\text { Acetone } \\
\text { 2-butanone } \\
\text { Carbon tetrachloride } \\
\text { Chloroform } \\
\text { 1,1-dichloroethylene } \\
\text { Methylene chlocide } \\
\text { Tetrachlorocthylene } \\
\text { 1,1,1-trichloroethane }\end{array}$ & $\begin{array}{l}\text { Gross alpha } \\
\text { Gross beta } \\
\text { Ptutonium-238 } \\
\text { Strontium-90 } \\
\text { Technetium-99 } \\
\text { Thorium-228 } \\
\text { Thorium-230 } \\
\text { Thorium-232 } \\
\text { Uranium-234 } \\
\text { Uranium-235 } \\
\text { Uranium-238 }\end{array}$ & $\begin{array}{l}\text { Aluminum } \\
\text { Barium } \\
\text { Beryllium } \\
\text { Boron } \\
\text { Cadmium } \\
\text { Chromium } \\
\text { Cobalt } \\
\text { Copper } \\
\text { Lead } \\
\text { Mercury } \\
\text { Nictel } \\
\text { Nitrate, nitrite } \\
\text { Phosphates } \\
\text { Setenium } \\
\text { Thorium } \\
\text { Uranium }\end{array}$ & $\begin{array}{l}\text { Comprehensive } \\
\text { TCL analytes, plus } \\
\text { additional TICs }\end{array}$ \\
\hline
\end{tabular}


potential ARARs, of which subsets will be used or to which additional ARARs will be added as further site characterization is completed.

It is understood that DOE will comply with the requirements of NEPA as specified in DOE Order 5440.1D, "National Environmental Policy Act Compliance Program." Further, DOE Order 5400.4, "Comprehensive Environmental Response, Compensation, and Liability Act Requirements," calls for integration of NEPA and CERCLA requirements for DOE remedial actions at CERCLA sites. This issue has been reaffirmed in FFA $\$ \mathrm{I}(\mathrm{A})(3)$ and SIII (A)(2) and Secretary of Energy Notice (SEN) of February 5, 1990 (SEN-15-90), which was issued to ensure that DOE's NEPA activities are carried out in a centralized and uniform manner. Therefore, the regulations found in NEPA will not be addressed in this report as ARARs; however, the federal and state regulations protecting environmental resources which may be identified at a site during a NEPA assessment are discussed in Sect. 5.1.3.

Title I, $1111(\mathrm{c})(6)$ of CERCLA mandated that the Occupational Safety and Health Agency (OSHA) promulgate standards for protection of employee health and safety during hazardous waste operations at RCRA or CERCLA sites and during emergency response to hazardous substance releases. The final regulations for "Hazardous Waste Operations and Emergency Response" (29 CFR 1910) have appeared in 54 FR 9294 (Final Rule, March 6, 1989). These regulations are designed to protect workers involved in cleanup operations at uncontrolled hazardous waste sites and to provide for worker protection during initial site characterization and analysis, monitoring activities, materials handling activities, training, and emergency response. These regulations do not apply to those workers who would not be exposed.

Federal construction activities involving no potential for hazardous substance exposure are covered by the OSHA standards in 29 CFR 1926 ("Federal Service Contracts" and 29 CFR 1910 "General Industry"). DOE also addresses occupational safety in DOE Orders 5480.11 ("Radiation Protection for Occupational Workers"), 5480.4 ("Environmental Protection, Safety, and Health Protection Standards"), 5483.1A ("Occupational Safety and Health Program for Contractors at GOCO Facilities"), 5480.9 ("Construction Safety and Health Program"), and 5480.10 ("Contractor Industrial Hygiene Program"). ARARs apply to those federal and state regulations that are designed to protect the environment and do not generally apply to occupational safety regulations. EPA requires compliance with the OSHA standards in $\mathbf{8 3 0 0 . 1 5 0}$ of the National Contingency Plan (NCP), not through the ARARs process. Therefore, neither the regulations promulgated by OSHA nor the DOE orders related to occupational safety are addressed as ARARs in this chapter; these regulations are addressed in the site-specific Health and Safety Plan for BCV OU 1. (See Chap. 9.)

The following is a listing of the definitions of terms used throughout this report:

Applicable requirements are "those cleanup standards, standards of control, and other substantive requirements, criteria, or limitations promulgated under federal environmental or state environmental or facility siting law that specifically address a hazardous substance, pollutant, contaminant, remedial action, location, or other circumstance at a CERCLA site" (40 CFR 300.5).

Relevant and appropriate requirements are "those cleanup standards, standards of control, and other substantive requirements, criteria, or limitations promulgated under federal 
environmental or state environmental or facility siting law that, while not applicable to a hazardous substance, pollutant, contaminant, remedial action, location, or other circumstance at a CERCLA site, address problems or situations sufficiently similar to those encountered at the CERCLA site that their use is well suited to the particular site" (40 CFR 300.5).

Requirements under federal or state law may be either applicable or relevant and appropriate to CERCLA cleanup actions, but not both. However, requirements must be both relevant and appropriate for compliance to be necessary. In the case where a federal and a state ARAR are available or where there are two potential ARARs addressing the same issue, the more stringent regulation must be selected. However, CERCLA \$121(d)(4) provides several ARAR waiver options that may be invoked, providing that the basic premise of protection of human health and the environment is not ignored. A waiver is available for state standards that have not been applied uniformly in similar circumstances across the state. In addition, CERCLA $\$ 121(\mathrm{~d})(2)(\mathrm{C})$ forbids state standards that effectively prohibit land disposal of hazardous substances.

CERCLA on-site remedial response actions must only comply with the substantive requirements of a regulation and not the administrative requirements to obtain federal, state, or local permits [CERCLA \$121(e) and FFA \$XXII]. To ensure that CERCLA response actions proceed as rapidly as possible, EPA has reaffirmed this position in the final NCP (55 $F R$ 8756). Substantive requirements pertain directly to the actions or conditions at a site, whereas administrative requirements facilitate their implementation. EPA recognizes that certain of the administrative requirements (such as consultation with state agencies, reporting, etc.) are accomplished through the state involvement and public participation requirements of the NCP. These administrative requirements should be observed if they are useful in determining cleanup standards at the site (55 FR 8757).

In the absence of federal- or state-promulgated regulations, there are many criteria, advisories, guidance values, and proposed standards that are not legally binding but may serve as useful guidance for setting protective cleanup levels. These are not potential ARARs but are "to-be-considered" (TBC) guidance.

\subsubsection{Chemical-Specific ARARs}

Chemical-specific requirements set health- or risk-based concentration limits or discharge limitations in various environmental media for specific hazardous substances, pollutants, or contaminants (53 FR 51437). These requirements generally set protective cleanup levels for the chemicals of concern in the designated media or else indicate a safe level of discharge that may be incorporated when considering a specific remedial activity.

BCV OU 1 consists of five sites: the Burial Grounds (including the ORPs), the Oil Landfarm, the Boneyard/Burnyard, Sanitary Landfill I, and the S-3 Ponds. The sites include unlined ponds and trenches, walk-in pits, burial grounds, and landfills, both capped and uncapped. Some of the caps are RCRA caps. Shallow groundwater and surface water runoff drain into Bear Creek. Historical and current operating conditions at this OU are discussed in detail in Chap. 2. A preliminary list of COCs detected in soils, surface water, and groundwater at BCV OU 1 includes metals, PCBs, organics, inorganics, VOCs, and radionuclides. The sites are contaminated with RCRA hazardous wastes in addition to the radiological contamination. Although limit d in number, chemical-specific standards have been 
established under several statutes, including the SDWA, the Clean Water Act (CWA), and the Clean Air Act (CAA).

\subsubsection{Groundwater and surface water}

Available chemical-specific ARARs that have been promulgated under federal and state law are listed in Table 5.2 for COCs that have been detected in surface water and groundwater at BCV OU 1. They are presented here for comparison with analytical detection limits for contaminants in these media. If the RI determines that leachate and runoff from the contaminated soils at BCV OU 1 are causing contamination in surface and groundwater at levels that surpass ARARs for the contaminants, remedial alternatives to isolate and control the sources to prevent further contamination of surface water and groundwater will be addressed during the FS. If groundwater contamination from BCV OU 1 is confirmed, cleanup of the groundwater will be addressed as a separate OU, and a detailed analyain of applicable ARARs will be addressed at that time. Shallow groundwater and surface water runoff from BCV OU 1 flows into Bear Creek, which is classified by the Tennessee Water Quality Control Board for industrial water supply, fish and aquatic life, recreation, irrigation, and livestock watering and wildlife uses (TDEC Rules, Chap. 1200-4-4). The state water quality criteria for protection of fish and aquatic life and for the consumption of aquatic organisms (the criteria for protection of recreation uses) are listed in Table 5.2 for comparison with surface water sampling results to determine extent of any contamination. In the absence of a state criterion for a specific chemical, a federal criterion is listed if available. If surface water contamination from BCV OU 1 is identified, one goal of any remedial actions taken will be to control the on-site source of that contamination; surface water ilself will not be remediated as part of this OU.

\subsubsection{Air}

Primary National Ambient Air Quality Standards (NAAQS) for six chemicals appear in 40 CFR 50. The NAAQSs take into consideration all sources of exposure to a given chemical and establish ceilings that are not to be exceeded in the United States. NAAOSs are established as the criteria that state and local governments must plan to achieve and thus are not directly enforceable. Under $\mathbf{8 1 1 0}$ of the CAA, states are required to implement regulations to achieve the NAAQSs. The ambient air quality standards established by the TDEC Division of Air Pollution Control appear in Chap. 1200-3-3 of the Rules of the TDEC and are identical to the federal primary NAAQSs. The ambient standards of 1200-33.3 are translated into source-specific emission limitations (Rules of the TDEC, Chaps. 1200-3-4 10 1200-3-21) that must be considered ARARs if they apply to any of the remedial alternatives selected. Tennessee state air emission standards are considered "hybrid" ARARs and will be analyzed as action-specific ARARs following selection of remedial alternatives. In particular, the regulations governing fugitive dust emissions will be addressed.

National Emission Stundards for Hazardous Air Pollutants (NESHAPs) for various industrial sources that emit one of several pollutants are established in 40 CFR 61. Moat of the NESHAPs are generally neither applicable nor relevant and appropriate to cleanup at CERCLA sites because they regulate specific types of sources that would not be expected to be found at a CERCLA site. However, the NESHAPs will le considered as potential "hybrid" ARARs on a site-specific basis during the selection of remedial alternatives; in particular, the NESHAPs for radionuclides will be reviewed. 


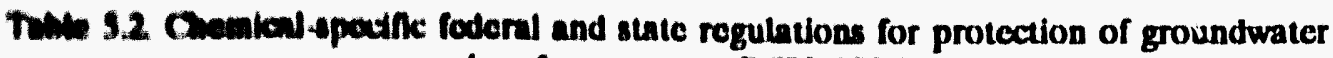
and surfuce water at BCV OU 1

( $\mu$ \& 2 except where noted) ${ }^{a}$

\begin{tabular}{|c|c|c|c|c|c|}
\hline Qumlol & $\begin{array}{l}\text { Sule } \\
\text { Drinking } \\
\text { Water Aa } \\
\text { MCLA }\end{array}$ & $\begin{array}{l}\text { Sufe } \\
\text { Drinking } \\
\text { Water } \\
\text { Act } \\
\text { MClot }\end{array}$ & $\begin{array}{l}\text { TDEC } \\
\text { WQC } \\
\text { Ingestion } \\
\text { of Aquatic } \\
\text { organisms }\end{array}$ & $\begin{array}{l}\text { TDEC } \\
\text { WQC Fish } \\
\text { and } \\
\text { Aquatic } \\
\text { Life CMO }\end{array}$ & $\begin{array}{c}\text { TDEC } \\
\text { wQC Fish } \\
\text { and Aquatic } \\
\text { Life CCd }\end{array}$ \\
\hline Trome & - & - & - & - & - \\
\hline Noninum & $0.03-0.2^{2}$ & $=$ & $\overline{-}$ & $750^{11}$ & $87^{n}$ \\
\hline Trium & $20 \times 0$ & $20 \times 0$ & - & - & - \\
\hline anilium & 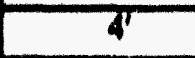 & $4^{\prime}$ & 1.3 & - & - \\
\hline Dimin & (XXXY) & $=$ & $=$ & $=$ & $750^{h, k}$ \\
\hline $\begin{array}{l}77 \text { utiomone (Meliny } \\
\text { einyl helone) }\end{array}$ & - & - & - & - & - \\
\hline commium & 3 & 5 & - & $4^{h m}$ & $1^{h m}$ \\
\hline cantin tormentoride & 5 & zero & 44 & - & $=$ \\
\hline chloworm & $T(x)$ & $=$ & 4700 & - & - \\
\hline Cortomium (10010) & $T(x)$ & $T(x)$ & $=$ & - & 100 \\
\hline Chromium (tivinent) & $=$ & $=$ & 670,000 & - & - \\
\hline $\begin{array}{l}\text { Thromium } \\
\text { (hesuvaleni) }\end{array}$ & - & - & - & 16 & 11 \\
\hline coppet & $\operatorname{cr}(13 x(x))^{6}$ & 1300 & $=$ & $18^{\text {hm }}$ & $12^{\text {Lm }}$ \\
\hline conil & - & - & - & - & - \\
\hline T.T. Dichlofoethune & $=$ & $=$ & $\overline{-}$ & - & - \\
\hline T.Tolentoreethylene & 7 & 7 & 32 & - & - \\
\hline $\begin{array}{l}\text { T, Dichorochylene } \\
\text { (es: comer) }\end{array}$ & 70 & 70 & - & - & - \\
\hline Tand & $T \pi(15)^{\circ}$ & zero & - & $82^{L m}$ & $3^{\text {hm }}$ \\
\hline Tereury & 2 & 2 & 0.15 & 2.4 & 0.012 \\
\hline Melinyene chloride & 5 & zero & 16,000 & - & - \\
\hline Nicke & 100 & 100 & 4600 & $1400^{m}$ & $160^{m}$ \\
\hline Nilrate & $10,0 \times 0$ & 10,000 & $=$ & - & - \\
\hline $\begin{array}{l}\text { Nitrole and nitrite } \\
(a N)\end{array}$ & $10,0 \times 0$ & 10,000 & - & - & - \\
\hline $\operatorname{PCB}($ (1)t4) & 0.5 & zero & 0.001 & $=$ & 0.001 \\
\hline Tetrachlorocthylene & 5 & zero & 88 & $=$ & - \\
\hline T.T.Tichorocthane & 200 & 200 & 170,000 & $\overline{-}$ & $=$ \\
\hline Acelone & $=$ & $=$ & - & - & - \\
\hline Trichlorocthylene & 5 & zero & 807 & - & $=$ \\
\hline Vinyl chloride & 2 & 2ero & 5250 & - & $=$ \\
\hline \multicolumn{6}{|l|}{ Rodionuclides } \\
\hline $\begin{array}{l}\text { Cross alpha aclivily, } \\
\text { pCin. }\end{array}$ & $15 p, 9$ & zero 9 & - & 一 & - \\
\hline
\end{tabular}


Table 5.2 (continued)

\begin{tabular}{|c|c|c|c|c|c|}
\hline Chemical & $\begin{array}{c}\text { Safe } \\
\text { Drinking } \\
\text { Water Act } \\
\text { MCLst,c }\end{array}$ & $\begin{array}{l}\text { Safe } \\
\text { Drinking } \\
\text { Water } \\
\text { Act } \\
\text { MCLGos. }\end{array}$ & $\begin{array}{l}\text { TDEC } \\
\text { WQC } \\
\text { Ingestion } \\
\text { of Aquatic } \\
\text { organisms }\end{array}$ & $\begin{array}{c}\text { TDEC } \\
\text { WQC Fish } \\
\text { and } \\
\text { Aquatic } \\
\text { Life CMd }\end{array}$ & $\begin{array}{c}\text { TDEC } \\
\text { wQC Fish } \\
\text { and Aquatic } \\
\text { Life COC }\end{array}$ \\
\hline $\begin{array}{l}\text { Gross beta activity, } \\
\text { mrem/year }\end{array}$ & $4^{r, s}$ & zeror $^{r}$ & - & - & - \\
\hline Strontium-90, pCi/L & 8 & $\overline{-}$ & $\overline{-}$ & $\overline{-}$ & $\overline{-}$ \\
\hline Technetium-99 & - & $\overline{-}$ & $\overline{-}$ & $\overline{-}$ & $\overline{-}$ \\
\hline Tritium, $\mathrm{pCi} / \mathrm{L}$ & $20,000^{7}$ & $=$ & $\overline{-}$ & $=$ & $\overline{-}$ \\
\hline Uranium (natural) & $20^{, 4}$ & - & - & - & - \\
\hline
\end{tabular}

${ }^{a}$ Federally promulgated regulations under the SDWA and Tennessee state regulations under the CWA are included in this table.

bTennessee state drinking water standards (Chapter 1200-5-1 of the Rules of the TDEC) are identical to the federal.

$\mathrm{MCL}=$ maximum contaminant level.

${ }^{d}$ MCLG = maximum contaminant level goal.

'Rules of the TDEC, Chapter 1200-4-3-.03; criteria for recreational use designation; a $10^{5}$ risk factor is assumed for carcinogens. WQC = water quality criterion.

$f_{C M C}=$ criterion maximum concentration; $\mathrm{CCC}=$ criterion continuous concentration;

Rules of the TDEC, Chapter 1200-4-3-.03.

sFederal and Tennessee secondary MCL; no primary MCL is available.

${ }^{h}$ Federal WQC; Tennessee does not have a fish and aquatic life criterion for this chemical. Value for aluminum is at pH 6.5-9.0. Source: EPA Region IV Criteria Chart (December 1992).

' 57 FR 31776 (July 17, 1992); effective January 17, 1994. Tennessee is in the process of revising its MCL to match this federal MCL.

jEPA Office of Drinking Water Lifetime Health Advisory (November 1992).

${ }^{k}$ Minimum standard for long-term irrigation of sensitive crops.

'Water hardness dependent criteria; based on a water hardness of $100 \mathrm{mg} / \mathrm{L}$ as $\mathrm{CaCO}_{3}$.

"Values are for the dissolved form of this metal.

"This number is the MCL for total trihalomethanes which includes the sum of the concentration of chloroform, bromodichloromethane, dibromochloromethane, and bromoform.

"Number in parentheses is an "action level" that, when measured in the 90th percentile at

the consumer's tap, triggers initiation of corrosion control studies and treatment requirements.

$P$ This interim MCL includes radium-226 but excludes radon and uranium.

9Proposed MCL and MCLG of $15 \mathrm{pCi} / \mathrm{L}$ and zero, respectively, excludes radon, uranium and radium-226 (56 FR 33050, July 18, 1991).

'Proposed rule (56 FR 33050, July 18, 1991); final rule expected 1994; current interim MCL is $4 \mathrm{mrem} / y$ ear, the same as the proposed $\mathrm{MCL}$.

'If two or more radionuclides are present, the sum of their annual dose equivalent to the total body or to any organ shall not exceed $4 \mathrm{mrem} / \mathrm{year}$.

'Average annual concentration assumed to produce a total body or organ dose of 4 mrem/year.

"Approximately equal to $30 \mathrm{pCi} / \mathrm{L}$. 


\subsubsection{Soils/sediment}

Very little legislation or guidance is available governing cleanup criteria : $\mathrm{J}$ r contaminated soils at CERCLA sites. RCRA has addressed land disposal of treated hazardous wastes in its land disposal restrictions (LDRs) (40CFR 268), and these will be addressed as action-specific ARARs during the FS. Since some of the sites under BCV OU 1 have been closed under RCRA, with RCRA caps and RCRA hazardous waste as defined in 40 CFR 261 present at the sites, they could be subject to RCRA corrective action regulations. Requirements for corrective action for SWMUs have been proposed as a new Subpart S of 40 CFR 264 (55 FR 30798, July 27, 1990). EPA has proposed a risk-based approach to establish media cleanup standards for surface water, groundwater, soil, and air. These standards are to be established at concentrations that ensure protection of human health and the environment and are to be set for each medium of concern during the remedy selection process. Target cleanup levels may initially be set at the RCRA action levels but modified as appropriate to reflect sitespecific exposure assumptions (55 FR 30826). Final promulgation of this rule is projected for December 1993.

A portion of the proposed Subpart $\mathrm{S}$ was promulgated as a final rule for corrective action at Corrective Action Management Units (CAMUs) and Temporary Units (TUs). This rule establishes two new sections in Subpart S ("Corrective Action for Solid Waste Management Units"): 40 CFR 264.552 (CAMUs) and 40 CFR 264.553 (TUs) (58 FR 8658, February 16, 1993). Both of these units function solely to manage wastes that are generated at a RCRA facility for the purpose of implementing remedial actions (i.e., remediation wastes). As a result of this rule, regulatory requirements for remediation wastes will differ from those for "asgenerated" wastes regulated under Subtitle C, especially the LDRs and minimum technology requirements (MTRs). The substantive requirements of this rule are expected to be ARARs for remediation of CERCLA sites that involve the management of RCRA hazardous waste. In this context, CAMU designations would be incorporated into CERCLA decision documents and will be analyzed further for action-specific ARARs when remedial alternatives are selected during the FS phase.

EPA has determined that the RCRA treatment standards are generally inappropriate or unfeasible when applied to contaminated soil or debris (55 FR 8760). Therefore, EPA proposed separate rulemakings to establish treatment standards for disposal of such contaminated soil and debris. The Notice of Proposed Rulemaking (NPRM) for debris appeared January 9, 1992 (57 FR 958), and the final rule on August 18, 1992 (57 FR 37194). The revised standards ( 40 CFR 268.45) require contaminated debris to be treated prior to land disposal using extraction, destruction, or immobilization technologies.

The NPRM for soil appeared October 24, 1991 (56 FR 55160); this rulemaking initiative is presently on hold while a new schedule for action is negotiated (Houlberg et al. 1993). The rule will be analyzed for ARARs or TBC when available. In the interim, EPA has developed guidance for obtaining and complying with a treatability variance for soil and debris that are contaminated with RCRA hazardous wastes for which treatment standards have already been set (OSWER Directive 9347.3-06FS, July 1989). These will be considered as TBC guidance when remedial alternatives are selected and more information becomes available on waste types.

TDEC has proposed a Hazardous Substance Site Remedial Action Rule (TDEC Rules, Chap. 1200-1-13) that is currently undergoing revisions based on public comments; it is 
unclear when this rule will be promulgated (Binford 1993). This rule states that, where numerical standards are not available for cleanup of soils at hazardous waste sites, soil cleanup levels shall be developed based on methods approved or determined by TDEC or by utilizing a site-specific risk assessment approved by TDEC. When promulgated, this rule will be legally applicable to cleanup at BCV OU 1 ; in the interim, it will serve as TBC guidance.

The regulations found in TSCA contain storage, disposal, and cleanup requirements for materials contaminated with PCBs. These regulations limit concentrations of PCBs disposed of in soil to $50 \mathrm{ppm}$ and require that any soils containing concentrations of PCBs greater than $50 \mathrm{ppm}$ (40 CFR 761.60) be incinerated (40 CFR 761.70) or stored in a chemical waste landfill (40 CFR 761.75). TSCA also specifies requirements that must be achieved for PCBs disposed of by incineration ( $40 C F R 761.70$ ), in a chemical waste landfill (40 CFR 761.75), or by other disposal methods [40 CFR 761.60(a)(5)(iii)].

\subsubsection{Other TBC guidance}

EPA has suggested cleanup values for lead in soils based on studies of blood lead levels in exposed children. The EPA OSWER Directive 9355.4-02 (dated September 7, 1989) recommends a cleanup level for soils of 500 to $1000 \mathrm{ppm}$ lead. However, EPA has distributed a draft memorandum (dated June 1992) recommending a cleanup level for lead in soil of 500 ppm, based on a new lead uptake/biokinetic model. This threshold level could be revised based on site-specific information (DOE 1993).

Although not an ARAR, EPA has published a TSCA PCB spill cleanup policy (52 FR 10688) which recommends cleanup standards for PCBs of 25 to $50 \mathrm{ppm}$ for sites with restricted access; a 10-ppm cleanup level is recommended for residential and unrestricted access rural areas. In this latter case, a $25-\mathrm{cm}(10-\mathrm{in}$.) cap of clean soil must cover the site. In the EPA guidance report for remedial actions at Superfund sites containing PCBs, preliminary remediation goals are set at $1 \mathrm{ppm}$ for residential land use (a risk of $10^{-5}$ ) and between 10 and $25 \mathrm{ppm}$ for industrial and/or remote areas (a risk of 10 $0^{-4}$ ) (EPA 1990d). Alternatives should reduce concentrations to these levels or limit exposures. These values are considered TBC guidance, not ARARs.

In the absence of federal- or state-promulgated ARARs, or in the case where ARARs are not adequately protective, EPA states a preference for Reference Doses (RIDs) or reference concentrations (RfCs) for systemic toxicants, carcinogen slope factors (CSFs) for carcinogens, or Office of Drinking Water (ODW) Health Advisories (EPA 1988b) for drinking water contaminants. The RfDs, RfCs, and CSFs are available through the Integrated Risk Information System (IRIS) (EPA 1991a) and the EPA Health Effects Assessment Summary Tables (EPA 1991b).

The EPA ODW has developed nonregulatory Health Advisories for concentrations of noncarcinogenic contaminants in drinking water at which no adverse health effects would be expected to oucur. Lifetime Health Advisories available for those COCs at BCV OU 1 which do not have promulgated MCLs and secondary maximum contaminant levels (SMCLs) are listed in Table 5.2. 


\subsubsection{Radiation Protection Standards}

Very few applicable standards are available for the cleanup of radioactively contaminated CERCLA sites. The Atomic Energy Act (AEA) of 1954 and its amendments delegated authority for control of nuclear energy to DOE, NRC, and EPA. In addition, certain states have regulatory authority and programs for radioactive waste. EPA's regulations are derived from several other statutes as well and cover many types of activities and all types of radioactive materials. The NRC licenses the possession and use of various types of radioactive materials at certain types of facilities. Tennessee is an NRC-Agreement state and, as such, has its own authority and licensing regulations.

DOE is authorized to control all types of nuclear materials at sites under its jurisdiction and is exempt from the NRC licensing and regulatory requirements. Therefore, NRC regulations are not generally considered to be ARARs for CERCLA cleanup at DOE facilities. The DOE regulations for handling and cleanup of radioactive materials are outlined in a series of internal DOE orders that are legally binding to DOE contractors but are not considered by EPA to be ARARs. The DOE orders, however, are functionally equivalent to the NRC requirements, and include all "appropriate" requirements from the NRC regulations. For the purposes of development of ARARs, DOE orders will be treated as TBC guidance rather than the NRC regulations. Sections of the NRC regulations may supply ARARs or TBC guidance in situations where the DOE orders do not adequately address a specific situation at a site, and these regulations will be addressed during selection of remedial alternatives during the FS.

In addition to RCRA hazardous wastes, BCV OU 1 shows evidence of contamination with radionuclides, including technetium-99, strontium-90, tritium, plutonium, and several isotopes of thorium and uranium, as well as gross alpha and beta activity. The proper definition of "mixed low-level radioactive and hazardous waste" has caused considerable debate with regard to dual jurisdiction by EPA and NRC. However, EPA has published a clarification of the problem (53 FR 37045, September 23, 1988), as did DOE previously [52 FR 15937, May 1, 1987, and DOE Order 5400.3 ("Hazardous and Radioactive Mixed Waste Program," dated February 22, 1989)]. In effect, mixed wastes are those containing a RCRA hazardous waste as defined in $40 C F R 261$ and a radioactive waste subject to the AEA. RCRA regulations apply to the hazardous component of the waste, and AEA regulations apply to the radioactive component. When the application of both standards is conflicting or inconsistent, RCRA yields to the AEA. Tennessee received final authorization to regulate radioactive mixed waste on July 3, 1986 (53 FR 37045, September 23, 1988); however, the state has not implemented any regulations or guidance related to the handling of mixed waste.

On May 26, 1992, EPA published a notice in the Federal Register (57 FR 22024) proposing to find that DOE has made all but one of the demonstrations required in its application, under RCRA rules in 40 CFR 268.5 , for a 1 -year, case-by-case extension of the May 8, 1992, effective date of the LDRs applicable to certain mixed wastes generated or stored at the K-25 Site, the Y-12 Plant, and ORNL, as well as 28 other DOE facilities. Comments were due back to EPA by July 27, 1992, and no official final action has been taken on this proposal as yet. In June, 1992, EPA and DOE signed a Federal Facilities Compliance Agreement (mixed-waste FFCA) to bring mixed waste generation and storage facilities on the ORR into compliance with environmental law. The mixed waste-FFCA allows DOE ORR facilities to continue to generate and store mixed wastes while addressing LDR mixed waste 
compliance issues. The mixed wastes covered under the mixed waste-FFCA include flammable and corrosive liquids, solvents, paint waste, waste oils and organics, and solid mixed wastes.

In addition, the Federal Facility Compliance Act of 1992 (Public Law 102-386, October 6, 1992) amends $\$ 6001$ of RCRA to waive immunity of the United States with respect to substantive and procedural requirements regarding control, abatement, or management of solid or hazardous waste. This waiver of immunity includes injunctive relief, administrative order, or civil or administrative penalties or fines, and subjects the federal government to the full range of available enforcement tools to penalize isolated, intermittent, or continuing violations. A delayed effective date of 3 years from enactment of the Federal Facility Compliance Act of 1992 is applied to the waiver of sovereign immunity for mixed waste regulated under RCRA $63004(j)$ so long as that waste is managed in accordance with other applicable requirements. Further, DOE is expressly exempt from the 3-year effective date for mixed waste in violation of RCRA 83004(j) so long as DOE has in effect a plan that has been submitted and approved pursuant to RCRA \$3021(b) and an order requiring compliance with such plan has been issued pursuant to RCRA \$3021(b). DOE has published its strategy for development of a national compliance plan for DOE mixed waste (57 FR 57170, December 3, 1992), and plans to publish a draft Compliance Plan in October 1993.

\subsection{EPA regulations}

EPA has promulgated MCLs for radionuclides in community water systems. These MCLs appear in two forms-concentration limits for certain alpha-emitting radionuclides (40 CFR 141.15) and an annual dose limit for the ingestion of certain beta- and gamma. emitting radionuclides (40 CFR 141.16). MCLs and maximum contaminant level goals (MCLGs) were proposed for radon and uranium and reproposed for ${ }^{226} \mathrm{Ra}$ and ${ }^{228} \mathrm{Ra}$, beta, and photon emitters on July 18,1991. Final promulgation of the concentration limits is not expected until 1994. As with the chemical-specific MCLs, these may be used to compare to detection limits for contaminants in groundwater at BCV OU 1; they are listed in Table 5.2.

Table 5.3 lists EPA and DOE radiation protection standards that are described below. These regulations and standards generally address specific types of activities and will be analyzed in detail for action-specific ARARs during the FS phase. General requirements are discussed below.

Subpart $\mathrm{H}$ of 40 CFR 61 addresses atmospheric radionuclide emissions from DOE facilities and may be applicable to airborne emissions during cleanup of BCV OU 1. EPA has issued a final NESHAP rule (54 FR 51654, December 15, 1989) that limits emissions of radionuclides to the ambient air from DOE facilities to amounts that would not cause any member of the public to receive an effective dose equivalent of $10 \mathrm{mrem} / \mathrm{year}$ (40 CFR 61.92).

Environmental protection standards for the management, storage, and disposal of spent nuclear fuel, high-level wastes, and transuranic (TRU) wastes are found in 40 CFR 191. Management and storage shall be conducted so as to provide a reasonable assurance that no member of the public in the general environment shall receive a combined annual dose equivalent of greater than 25 mrem to the whole body and 75 mrem to any organ (40 CFR 191.03). 40 CFR 191.04 established alternative standards for DOE facilities if EPA determines that such standards prevent any member of the public from receiving a continuous exposure 
Table 53. Radintion protection standards that myy be ARARs for BCV OU 1

\begin{tabular}{|c|c|c|c|}
\hline Regulation & Applicabllity & Epposure conditions & Standard \\
\hline 40 CFR 61 & $\begin{array}{l}\text { National Emmission Standards } \\
\text { for Hazardous Adr Pollutants } \\
\text { for DOE facillities }\end{array}$ & $\begin{array}{l}\text { Public exposure, } \\
\text { airborn emissions }\end{array}$ & 10 mrem/year \\
\hline 40 CFR 141 & $\begin{array}{l}\text { Drinking water maximum } \\
\text { contaminant levels }\end{array}$ & $\begin{array}{l}\text { Community water } \\
\text { systems, gross beta }\end{array}$ & $4 \mathrm{mrem} / \mathrm{year}$ \\
\hline 40 CFR 191 & $\begin{array}{l}\text { Spent nuclear fuel, high-level } \\
\text { and transuranic wastes }\end{array}$ & $\begin{array}{l}\text { Public exposure, } \\
\text { all sources }\end{array}$ & $\begin{array}{l}25 \text { mrem/year } \\
\text { (total body); } \\
75 \text { mrem/year } \\
\text { (thyrold) }\end{array}$ \\
\hline $\begin{array}{l}\text { DOE Order } \\
5400.5^{\circ}\end{array}$ & $\begin{array}{l}\text { Radiation Protection } \\
\text { of the Public and the } \\
\text { Environment }\end{array}$ & $\begin{array}{l}\text { Public exposure, all } \\
\text { sources } \\
\text { Temporary maximum } \\
\text { exemption } \\
\text { Aquatic organism } \\
\text { exposure, absorbed } \\
\text { dose }\end{array}$ & $\begin{array}{l}100 \text { mrem/year } \\
500 \text { mrem/year } \\
1 \mathrm{rad} / \mathrm{d}\end{array}$ \\
\hline $\begin{array}{l}\text { DOE Order } \\
5820.2 A\end{array}$ & $\begin{array}{l}\text { Radioactive Waste } \\
\text { Management }\end{array}$ & $\begin{array}{l}\text { Public exposure, all } \\
\text { sources, excluding air } \\
\text { Public exposure, } \\
\text { atmospheric relcases }\end{array}$ & $\begin{array}{l}25 \text { mrem/year } \\
10 \text { mrem/year }\end{array}$ \\
\hline
\end{tabular}

aPropoced as 10 CFR 834 (58 FR 16268, March 25, 1993). 
of more than $100 \mathrm{mrem} / \mathrm{year}$ effective dosc equivalent or an infrequent exposure of more than 500 mrem/year effective dose equivalent from all sources, excluding natural background and medical exposures.

\subsection{DOE onder}

DOE orders are not promulgated regulations and thus are not considered to be ARARs by EPA. They are, however, binding between DOE and Energy Systems because of contractual agreements. The radiation exposure limits for the general public defined in DOE Order 5400.5 ("Radiation Protection of the Public and the Environment," February 8, 1990) are an effective dose equivalent of 100 mrem/year from all exposure pathways and all DOE sources of radiation and a dose of less than 500 mrem/year as a temporary maximum exemption under specially permitted and DOE-approved circumstances (see Table 5.3). In addition, effuent releases to surface water must not result in exposures 10 aquatic organisms exceeding an absorbed dose of $1 \mathrm{rad} / \mathrm{d}$. The overriding principle of the DOE order is that all releases of radioactive material shall be as low as reasonably achievable (ALARA).

DOE Order 5400.5 lists Derived Concentration Guides (DCGs) for radionuclide isotopes which are based on a committed effective dose equivalent of 100 mrem/year for ingestion of air or water. For liquid wastes containing radionuclides that are discharged to surface waters, the best available technology must be used if the receiving water, at the point of discharge, would receive radioactive material at a concentration greater than the DCG. Implementation of the best available technology process is not required if annual releases to surface water are below the DCG. In the case of releases of multiple radionuclides, the sum of the fractional DCGs must not exceed unity. In addition, eflluent releases to surface water must not result in exposures to aquatic organisms which exceed an absorbed dose of $1 \mathrm{rad} / \mathrm{d}$. These DCGs will be addressed if any remedial alternatives result in effluent releases to air or water.

DOE Order 5400.5, Chap. IV, presents guidelines for cleanup of residual radioactive material and management of sites with residual radioactivity above the specified guidelines, and these guidelines will be analyzed for action-specific ARARs during the FS.

DOE has pruposed the 5400.5 radiation protection standards for the public and the environment for codification at 10 CFR 834 (58 FR 16268, March 25, 1993). When final, these standards will be legally applicable for cleanup at DOE sites.

DOE Order 5820.2A ("Radioactive Waste Management," September 9, 1988) states that the management of low-level radioactive waste must ensure that external exposure to the waste and concentrations of radioactive material that may be released into surface water and soil does not exceed $25 \mathrm{mrem} / y e a r$ to any member of the public. Releases to the atmosphere shall not exceed 10 mrem/year (Table 5.3). Reasonable effort should be made to maintuin releases to the environment to ALARA levels. Chapter II of the order addresses management of TRU wastes. The order pertains to the management of radioactive waste and contains closure and postclosure care requirements; these will be addressed for action-specific ARARs during the selection of remedial alternatives in the FS.

\subsection{Other TBC guidance for radiological risk asecasment}

The EPA Office of Radiation Programs has derived slope and unit risk factors for radionuclides of concern at remedial sites for each of three major exposure pathways 
(inhalation, ingestion, and external exposure to contaminated soil). These are available in the EPA Health Effects Assessment Summary Tables (EPA 1991b).

\subsubsection{Location-Specific ARARs}

Location-specific requirements "set restrictions upon the concentration of hazardous substances or the conduct of activities solely because they are in special locations" (53 FR 51394). Federal and state location-specific ARARs that might be pertinent to remedial actions at BCV OU 1 are identified in the remainder of this section and listed in Table 5.4.

Geologic characteristica.There are no indications of salt-dome formations, salt-bed formations, or underground mines on or near BCV OU 1. However, if any caves are located in areas where remedial activities may occur, the regulations found in RCRA [40 CFR 264.18(c)] which prohibit the placement of noncontainerized or bulk liquid hazardous waste in caves might be ARARs. The faults on the ORR are ancient (pre-Holocene) and stable, and the possibility of fault movement is considered extremely unlikely (Chance 1986); therefore, seismic regulations would not be applicable.

Aquatic resources. There are no known designated wilderness areas, wildlife refuges, or scenic rivers on the ORR or within range of the reservation such that remedial action would likely impact these resources. However, if any remedial action is taken which affects wildlife or alten Bear Creek, which is designated by the state of Tennessec for protection of fish and aquatic life, recreation, irrigation, and wildlife and livestock watering, then the Fish and Wildlife Coordination Act (16 USC $661 \mathrm{et}$ seq.), the Tennessee Water Quality Control Act of 1977 (TCA 69-3.101 et seq.), the Clean Water Act 8404, 40 CFR 230, 40 CFR 323, and 40 CFR 6.302(8) may be applicable. If any action involves the discharge of dredge or fill material into an aquatic system, the Clean Water Act 404 and 40 CFR 230 may also be implicated.

Slightly over 2023 ha (5000 acres) of the ORR have been designated as a DOE NERP, which also includes research areas both within and without the NERP itself. In addition, DOE has also designated areas on the ORR as DOE-NERP Reference Areas and DOE-NERP Natural Areas. However, none of the designated research areas, reference areas, or natural areas are on or near BCV OU 1 (Parr and Pounds 1987); therefore, none of the uses and restrictions applicable to these resources would be ARARs for BCV OU 1.

Wetlands and Doodplain. It appears that parts of BCV OU 1 may be located in the 100 and 500-year floodplains of Bear Creek. If any remedial alternatives are selected that would impact these floodplains, the requirements found in Executive Order 11988, 40 CFR 264.18(b), 40 CFR 6.302(b), 40 CFR 6 (Appendix A), and 10 CFR 1022 would provide ARARs for the BCV OU 1 site. A preliminary survey of the wetlands on the ORR revealed the presence of several wetlands areas near the BCV OU 1 sites, specifically, just north of the Burial Grounds (Parr 1992). If wetlands will be affected by any remedial alternative chosen for the BCV OU 1 site, consideration should be given to Executive Order 11990 , 40 CFR 6.302(a), 40 CFR 6 (Appendix A), 10 CFR 1022, CWA 8404, and 40 CFR 230 for applicable requirements.

Rare, threatened, or endangered species. There are a number of federal- and state-listed endangered or threatened plant and animal species on the ORR. An in-depth discussion of these species appears in Volume No. 24 of The Resource Management Plan of the Oak Ridge 
Thele 5.4 Temine bocmionepocific ARAPs for BCV OU 1

\begin{tabular}{|c|c|c|c|}
\hline 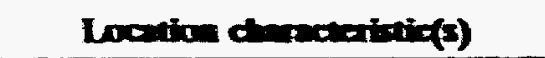 & Rot $-10-(0)$ & Operefing ondivion(s) & Cintong \\
\hline \multicolumn{4}{|c|}{ Wedtons } \\
\hline $\begin{array}{l}\text { Presence of wethands as defined } \\
\text { in Executive Order } 1199057(\mathrm{c}) \\
\text { and } 40 \text { CFR 6, Appeadir A } 54(0)\end{array}$ & 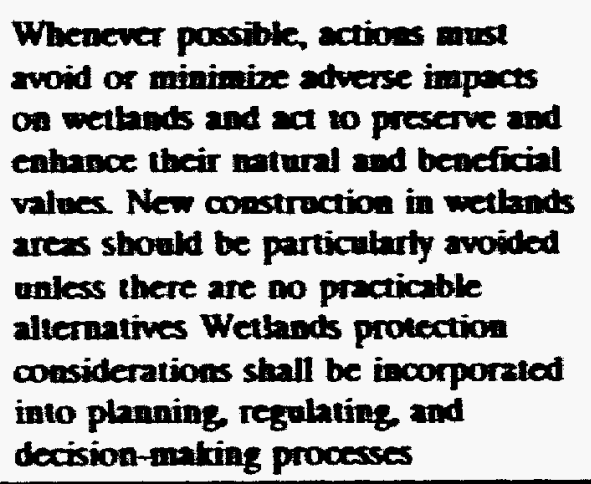 & $\begin{array}{l}\text { Agency action which imolves: } \\
\text { - acquiring manging and } \\
\text { disposing of lands and facilities } \\
\text { - providing federally undertaten, } \\
\text { finnoed, of assisted construc- } \\
\text { tion and improvements } \\
\text { - conducting federal activities } \\
\text { and programs affecting band } \\
\text { use }\end{array}$ & $\begin{array}{l}\text { Execative Order } 11990 \\
\text { 40 CFR 6302(a) } \\
\text { 40 CFR 6, Appendix A } \\
10 \text { CFR } 1022\end{array}$ \\
\hline $\begin{array}{l}\text { Presence of wethands as defined } \\
\text { in } 40 \text { CFR } 230.3(t) \text { and } 33 \text { CFR } \\
328.3(b)\end{array}$ & $\begin{array}{l}\text { Action to avoid degradation } \\
\text { or destruction of wethods must be } \\
\text { taken to the extent possible } \\
\text { Discharges for which there is a } \\
\text { practicable aherantive with less } \\
\text { adverse impacts or those which } \\
\text { wonld cause or contribute } \\
\text { to significant degruation are } \\
\text { prohibited. If adverse impacts are } \\
\text { unavoidable, action mest be taken } \\
\text { to eahance, restore, or create } \\
\text { alternative wetlands }\end{array}$ & $\begin{array}{l}\text { Action irvolving discharge } \\
\text { of dredge or fill material } \\
\text { into wetlands }\end{array}$ & $\begin{array}{l}\text { Clean Water Act } 5404 \\
40 \text { CFR } 230 \\
33 \text { CFR } 323\end{array}$ \\
\hline
\end{tabular}




\begin{tabular}{|c|c|c|c|}
\hline Lachibe chercterixtio(s) & Requiberiseno(s) & Openting ounthion(s) & coming(s) \\
\hline \multicolumn{4}{|c|}{ Foodphing } \\
\hline Within 100-year floodplain & $\begin{array}{l}\text { Facility must be designed, } \\
\text { constructed, operated, } \\
\text { and maintained to prevent weshout } \\
\text { of any trandous waste by 100-year } \\
\text { flood }\end{array}$ & $\begin{array}{l}\text { RCRA-defined listed or } \\
\text { characteristic bazardous waste } \\
\text { (40 CFR 261) -or- RCRA- } \\
\text { permittod treatment, storage, or } \\
\text { disposal faciliny }\end{array}$ & 40 CFR 264.18(b) \\
\hline $\begin{array}{l}\text { Within towland and relatively } \\
\text { flat areas adjoining inland } \\
\text { and coastal waters and other } \\
\text { floodprone areas such as offshore } \\
\text { islands, including at a minimum. } \\
\text { that area subjoct to a one percent } \\
\text { or greater chance of flooding } \\
\text { in any given year." [Executive } \\
\text { Order } 11988 \mathrm{S6}(\mathrm{c}) \text { and } 40 \text { CFR } 6 \text {, } \\
\text { Appendix A } 54(d)]\end{array}$ & 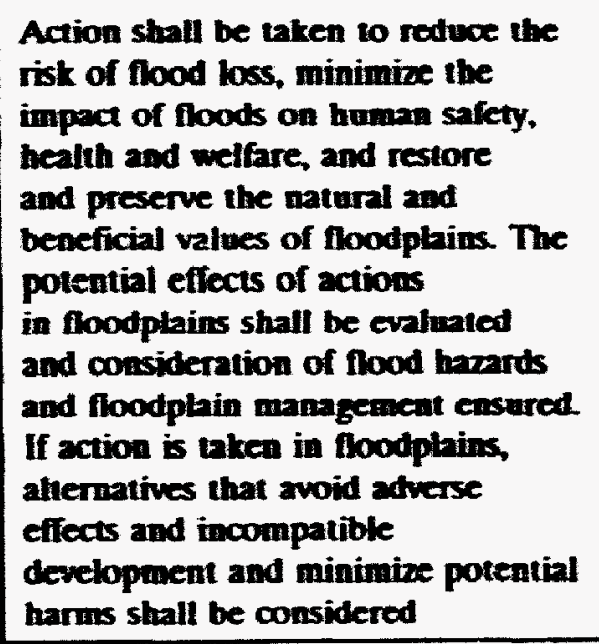 & $\begin{array}{l}\text { Action which involves: } \\
\text { - acquiring, managing. } \\
\text { and disposing } \\
\text { of lands and facilities } \\
\text { - providing federally undertaken. } \\
\text { financed, or assisted } \\
\text { construction } \\
\text { and improvements } \\
\text { - conducting federal activitics } \\
\text { and programs affecting band } \\
\text { use }\end{array}$ & $\begin{array}{l}\text { Executive Order (EO) } 11968 \\
40 \text { CFR } 6.302(\text { b) } \\
40 \text { CFR } 6 \text { (Appendix A) } \\
10 \text { CFR 1022 }\end{array}$ \\
\hline \multicolumn{4}{|c|}{ Aquatic resources } \\
\hline $\begin{array}{l}\text { Within area encompassing } \\
\text { or affecting waters of the state } \\
\text { of Tennessee as defined } \\
\text { in TCA } 69-3-103(32) \text { and the } \\
\text { presence of wildife or aquatic life }\end{array}$ & $\begin{array}{l}\text { Discharge of "substances" which } \\
\text { will result or will likely result } \\
\text { in harm. potential harm or } \\
\text { detriment to the health of animak, } \\
\text { birds, fish, or aquatic life" is } \\
\text { prohibited }\end{array}$ & $\begin{array}{l}\text { Action involving the discharge } \\
\text { of any pollutants into the waters } \\
\text { of the state [see TCA } 69-3 \text { - } \\
103(18) \text { and (21) for noninclusive } \\
\text { list] }\end{array}$ & $\begin{array}{l}\text { Tenuessee Water Quality } \\
\text { Control Act of } 1977 \text { (TCA } \\
\text { 69-3-101 et seq) Stream Use } \\
\text { Classifications (TDEC Rules } \\
\text { - Chap. 1200-4-4) }\end{array}$ \\
\hline
\end{tabular}


Trive 5.4 (oontimed)

\begin{tabular}{|c|c|c|c|}
\hline 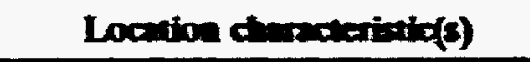 & Rogitheren(s) & Oparaing oondition(s) & Ormion(s) \\
\hline $\begin{array}{l}\text { Location encompassing aquatic } \\
\text { ecosystem with dependent fish, } \\
\text { wildlife, other aquatic life, } \\
\text { or habitat }\end{array}$ & $\begin{array}{l}\text { Degradation of destruction } \\
\text { of aquatic cocosystenes must be } \\
\text { avoided to the extent possible. } \\
\text { Discharges which cause or } \\
\text { contribute to significant degradation } \\
\text { of the water of such ecosystems are } \\
\text { prohibited }\end{array}$ & $\begin{array}{l}\text { Action inwolving the discharge } \\
\text { of dredge or fill material } \\
\text { into aquatic coosystem }\end{array}$ & $\begin{array}{l}\text { Clean Water Act } 5404 \\
40 \text { CFR } 230 \\
33 \text { CFR } 323\end{array}$ \\
\hline \multicolumn{4}{|c|}{ Entangered, thentesed, or rane species } \\
\hline $\begin{array}{l}\text { Presence of endangered } \\
\text { or threatened species or-critical } \\
\text { habitat of such species as } \\
\text { designatod in } 50 \text { CFR 17, } \\
50 \text { CFR 226, or } 50 \text { CFR } 227\end{array}$ & $\begin{array}{l}\text { Actions that jeopardize } \\
\text { species/habitat must be awoided } \\
\text { or appropriate mitigation measures } \\
\text { taken. Consultation with DOI, } \\
\text { FWS, andfor state agencies, as } \\
\text { appropriate, to ensure that proposed } \\
\text { actions do not jeopardize the } \\
\text { continued existence of the species } \\
\text { or adversety modify or destroy } \\
\text { critical habitat is recommended } \\
\text { for on-site actions }\end{array}$ & $\begin{array}{l}\text { Action which is likehy } \\
\text { to joopardize species or destroy } \\
\text { or adversely modify critical habitat }\end{array}$ & $\begin{array}{l}\text { Endangered Species Act } \\
\text { of } 1973 \text { (16 USC } 1531 \text { ef seq) } \\
50 \text { CFR } 402 \\
40 \text { CFR } 6302 \text { (h) } \\
\text { Fish and Wiblife } \\
\text { Coordination Act (16 USC } \\
661 \text { et seq) }\end{array}$ \\
\hline $\begin{array}{l}\text { Presence of endangered } \\
\text { or threatened species or critical } \\
\text { habitat (see above citation) } \\
\text { of same within an aquatic } \\
\text { ecosystem as defined } \\
\text { in } 40 \text { CFR 230.3(c) }\end{array}$ & $\begin{array}{l}\text { Dredge or fil material shall not be } \\
\text { discharged into an aquatic ecosystem } \\
\text { if it would jeopardize such species } \\
\text { or would likety result in the } \\
\text { destruction or adverse modification } \\
\text { of a critical habitat of the species }\end{array}$ & $\begin{array}{l}\text { Action involving discharge } \\
\text { of dredge or fill material } \\
\text { into aquatic ecosystem }\end{array}$ & $\begin{array}{l}\text { Clean Water Act } 5404 \\
40 \text { CFR 230.10(b) }\end{array}$ \\
\hline
\end{tabular}


Thele 5.4 (comisnod)

\begin{tabular}{|c|c|c|c|}
\hline Location charactistio(s) & Requiremene(x) & Oparating andition(s) & Citiono(s) \\
\hline $\begin{array}{l}\text { Presence of Teninessee state-listed } \\
\text { endangered or threatened animal } \\
\text { species as created and amended } \\
\text { pursuant to TCA } 70-8-105\end{array}$ & $\begin{array}{l}\text { Protected species may not be taken, } \\
\text { possessed, transported, exported, } \\
\text { processed, sold, offered for sale, } \\
\text { or shipped. Certain exceptions may } \\
\text { be allowed such as for educational, } \\
\text { scientific, etc., reasons or where } \\
\text { necessary to alleviate property } \\
\text { damage or protect human health } \\
\text { or safety. These exceptions require a } \\
\text { permit if the remedial action or its } \\
\text { attendant effects are ofl site }\end{array}$ & & $\begin{array}{l}\text { Tennessee Nongame } \\
\text { and Endangered } \\
\text { or Threatened Wildife } \\
\text { Species Conservation Act } \\
\text { of } 1974 \\
\text { (TCA 70-8-101 et seq.) }\end{array}$ \\
\hline \multicolumn{4}{|c|}{ Archoologic and historic resomerces } \\
\hline $\begin{array}{l}\text { Presence of archacological } \\
\text { resources on public land }\end{array}$ & $\begin{array}{l}\text { Steps must be taken to protect } \\
\text { archaeological resources and sites }\end{array}$ & $\begin{array}{l}\text { Action which would impact } \\
\text { resource }\end{array}$ & $\begin{array}{l}\text { Archaeological Resources } \\
\text { Recovery Act of } 1979 \text { (16 } \\
\text { USC 470a-11) } \\
43 \text { CFR 7 }\end{array}$ \\
\hline $\begin{array}{l}\text { Presence of archaeologic } \\
\text { or historic resources }\end{array}$ & $\begin{array}{l}\text { The Secretary of Interior must be } \\
\text { advised of the presence of the data. } \\
\text { A survey of affected areas for re- } \\
\text { sources and data must be conducted } \\
\text { and steps taken to recover, protech. } \\
\text { and preserve data therefrom or } \\
\text { request that DOI do so }\end{array}$ & $\begin{array}{l}\text { Action involving dam construction } \\
\text { or other alteration of terrain } \\
\text { which might cause irreparable loss } \\
\text { or destruction of significant } \\
\text { scientific prehistoric, historic, } \\
\text { or archaeologic data }\end{array}$ & $\begin{array}{l}\text { Archaeological and Historic } \\
\text { Preservation Adt } \\
\text { (16 USC } 469 \mathrm{a}-\mathrm{c} \text { ) } \\
40 \text { CFR } 6.301\end{array}$ \\
\hline
\end{tabular}

RCRA = Resource Conservation and Recovery Act; definitions appear at 40 CFR 260.10

'TCA = Tennessee Code Annotated.

TDEC = Tennessee Department of Environment and Conservation.

${ }^{d} \mathrm{DOI}=$ Department of interior.

FWS $=$ Fish and Wildlife Service. 
Reservation (Kroodsma 1987). The state of Tennessec has also designated approximately wo species of wildlife as "in need of management," and some of those occur in the area including the ORR (Tennessee Wildlife Rescources Commission Proclamation 86-29). Pursuant to TCA 70-8-104(b), it is unlawful for any person to knowingly destroy the habital of wildlife in need of management." Should any remedial actions at the BCV OU 1 site impact any federally listed endangered or threatened species, the provisions found in the Endangered Species Act of 1973 (16 USC 1531 et seq.), 50 CFR 492, 40) CFR 6.302(h), and the Fish and Wildlife Coordination Act (16 USC 661 et seq.) may be implicated as ARARs. If any proposed actions impact state-listed endangered or threatened animal species, the Tenncssec Non-Game and Endangered or Threatened Wildife Species Conservation Act of 1974 (TCA 70-8-101 el seq.) may provide ARARs. The prohibitions of the Tennessee Rare Plant Protection and Conservation Act of 1985 (TCA 11-26-201 et seq.) do not apply to a landowner, lesuce, of other person entitled to possession of the land on which the species is located (TCA 11.26209). This also includes managers in the case of publicly owned land and those with written permission of the landowner or manager (TCA 11-26-209). These exclusions would apparently apply to ORR. However, the purpose of the statute, to protect and preserve rare plants. should be considered TBC guidance for any remedial actions at BCV OU 1 if rare plants are identified.

Historic sites and archacological linding. The region surrounding ORR is rich in buth archaeological and historic resources, and a number of studies have indicated the presence of abundant resources on the reservation. These surveys are summarized in Volume 3 , Appendix B, of the Resource Management Plan for the U.S. Department of Enerzy Oak Ridge Reservation (Sanders 1984). No archaeological sites were identified at the Y.12 Plant; in addition, there are no historic buildings at BCV OU 1. In the event a NEPA survey indicales the presence of archeological resources at the BCV DU 1 site, the Archacological Resources Recovery Act (16 USC 470aa-11), the Archacological and Historic Preservation Act (16 USC 469a-c), 43 CFR 7, and 40 CFR 6.301 may provide ARARs.

\subsubsection{Action-Specific ARARs}

Performance, design, or other action-specific requirements set controls or restrictions on particular kinds of activities related to the management of hazardous waste (52 FR 324\%). Selection of a particular remedial action at a site will invoke the appropriate action-specific ARARs that may specify particular performance standards or technologies as well as apecific environmental levels for discharged or residual chemicals. Action-specific ARARs are established under RCRA, CAA, CWA. SDWA, and TSCA. Action-specific ARARs for BCV OU 1 will be developed during selection of remedial alternatives.

\subsection{IDENTIFICATION OF PRELIMINARY REMEDIATION GOALS}

The first step in the FS scoping process is to develop remedial action objectives (RAOs). RAOs are site-specific, qualitative goals that define the extent of cleanup required to achieve a CERCLA response action (EPA 1988a). RAOs address COCs, media of concern, potential exposure pathways and remediation goals (EPA 1991c). General RAOs for BCV OU 1 follow:

- Prevent current and future direct exposures to contaminants resulting in an incremental lifetime cancer risk greater than $10^{-6}$ or a hazard index greater than 1 . 
- Prevent transport of contaminants from the sources to the groundwater or surface water that would result in unacceptable risks to the humans and aquatic biota in the receiving water hodies (i.e., those media addressed as part of BCV OU 4).

- Prevent current and future exposures of ecological receptors to contaminants resulting in body burdens harmful to the receptors or their predators.

Preliminary remediation goals (PRGs) are a subset of RAOs. PRGs are chemical-specific, medium-specific numerical concentration limits that address all contaminants and all pathways found to be of concern at the site. Guidance is available from the EPA for developing riskhuned PROs (EPA 1991c). PRGs are developed early in the RI/FS process. They are dependent on the identification of ARARs as well as on the knowledge of the risk assessment procen (EPA 1991c). PRGs should be based on readily available environmental or healthbused ARARs, ambient water quality criteria, and other criteria, advisories, or guidance (EPA $1991 \mathrm{c})$. Many identified ARARs have been derived from risk levels that would not meet the CERCLA objectives of "protectiveness of human health." In other words, PRGs based on ARARs could be less stringent than critcria based on the $10^{-4}$ to $10^{-6}$ risk level.

PRG for BCV OU 1 must be developed that address both RAOs. Because few ARAR exist that address direct contact with soils, risk-based PRGs must be developed to address the nni objective. PRGs for the secund objective can be addressed using a simple fate and Iransport model developed specifically to establish soil cleanup levels based on potential migration to groundwater. Both of these methods are discussed in detail below.

\section{Soll PRG Baned in Direct Exposures}

Soil risk-based PRGs are developed using guidance from EPA, "Development of RiskBased Preliminary Remediation Goals" (EPA 1991c). Development of initial risk-based PRGs requires the following information:

- Chemicals of potential concern.

- Environmental media of potential concern (soil).

- Probable future land use and exposures.

- Chemical-specific toxicity information.

- Target risk levels.

A preliminary list of chemicals of potential concern have been identified in previous studies and are listed in Table 5.1.

As discussed in Section 4.1.1, it is premature to designate a probable future land use to develop PRGs. In lieu of actual knowledge of future land use, it would be premature to make screening decisions without considering EPA's default residential scenario, the same scenario on which RCRA soil action levels are based. Thus, PRGs will be presented for both industrial and residential land uses. Pathways evaluated for the residential scenario include incidental soil ingestion, inhalation of volatiles and particulates, and food chain uptake. The sole pathway evaluated for the industrial scenario is incidental soil ingestion (Fig. 3.33). 
Toxicity data used to develop PRGs are cancer slope factors and reference doses from the IRIS database (EPA 1992f) and Health Effects Assessment Summary Tables (HEAST) (EPA 1991b; 1992e).

Target risk levels (TR) must be established for carcinogens and a target hazard quotient (THQ) and target hazard index (THI) must be established for noncarcinogens. Once these levels are established, they can be used in conjunction with toxicity data and exposure equations to calculate PRGs. The NCP and EPA (1991c) suggest a default target risk of $10^{-6}$ and a cumulative site $\mathrm{HI}<1$ (EPA 1991c). Site-specific data can be collected on several parameters listed in Table 5.5. This will be done prior to using PRGs for Stage 1 risk assessment work. (See Sect. 6.4.1 in Chap. 6.)

The equations used to calculate industrial and residential exposures are derived from EPA (1991c). The parameters used are listed in Table 5.5. Some parameters used to determine the chemical-specific volatilization factors for volatile organics can be found in EPA (1991c).

PRGs for soil ingestion by biota can be calculated similarly. However, because RfDs for humans include larger safety factors than are necessary for biota, soil PRGs for biota are typically higher than those for humans. Therefore, the more conservative human values would take precedence.

\subsection{Soil PRGs Based on Migration to Groundwater}

The second RAO for BCV OU 1 is to prevent contaminants from leaching from the source to groundwater or surface water at levels that would be unacceptable in those water bodies. EPA has developed several models for use in determining soil cleanup levels based on potential contaminant migration to the groundwater (EPA 1989c). No such model is known to exist for migration to surface water at this time, but several models such as the Modified Universal Soil Loss Equation are being reviewed for use in this capacity. Soil PRGs for aquatic biota could be calculated from soil transport modeling results along with equilibrium partitioning data on COCs and the corresponding AWQC or State of Tennessee criterion continuous concentration.

One model for addressing migration to the groundwater is the revised Summers Model (Summers et al. 1980; EPA 1989c). Parameters used in the Summers Model are listed in Table 5.6. In some cases, default parameters were used, and these will be updated as sitespecific data are gathered during Phase 1 sampling. The revised Summers Model makes the following assumptions:

- The soil/water system is at equilibrium.

- No contaminant degradation is occurring.

- The unsaturated soil zone is homogeneous down to the aquifer.

- Contaminants are mixed throughout the depth of the aquifer beneath the contaminant source.

The model does not account for any contaminant dilution or attenuation due to horizontal transport within the aquifer. Acceptable soil concentrations are therefore 
Table 5.5. Parameters used to calculate preliminary remediation goals

\begin{tabular}{|c|c|c|c|c|c|}
\hline \multirow[b]{2}{*}{ Parameter } & \multirow[b]{2}{*}{ Units } & \multicolumn{2}{|c|}{ Industrial land use } & \multicolumn{2}{|c|}{ Residential land use } \\
\hline & & $\begin{array}{l}\text { Cancer } \\
\text { effects }\end{array}$ & $\begin{array}{l}\text { Noncancer } \\
\text { effects }\end{array}$ & $\begin{array}{l}\text { Cancer } \\
\text { effects }\end{array}$ & $\begin{array}{c}\text { Noncancer } \\
\text { effects }\end{array}$ \\
\hline Target risk (TR) & unitless & $1 \times 10^{-6}$ & & $1 \times 10^{-6}$ & \\
\hline Target HI (THI) & unitless & & 0.2 & & 0.2 \\
\hline Body weight (BW) & $\mathrm{kg}$ & 70 & 70 & & \\
\hline Averaging time (AT) & year & 70 & 25 & 70 & 30 \\
\hline $\begin{array}{l}\text { Exposure frequency } \\
\text { (EF) }\end{array}$ & days/year & 250 & 250 & 350 & 350 \\
\hline $\begin{array}{l}\text { Exposure duration } \\
\text { (ED) }\end{array}$ & year & 25 & 25 & & \\
\hline $\begin{array}{l}\text { Soil ingestion rate } \\
\left(\mathrm{IR}_{\mathrm{I}}\right)\end{array}$ & $\mathrm{mg} / \mathrm{d}$ & 50 & 50 & & \\
\hline $\begin{array}{l}\text { Age-adjusted soil } \\
\text { ingestion factor (IF) }\end{array}$ & $\begin{array}{l}\text { mg-year/ } \\
\mathrm{kg-d}\end{array}$ & & & 114 & 114 \\
\hline Inhalation rate (IR $)$ & $\mathrm{m}^{3} / \mathrm{d}$ & 20 & 20 & & \\
\hline $\begin{array}{l}\text { Particulate emission } \\
\text { factor (PEF) }\end{array}$ & $\mathrm{m}^{3} / \mathrm{kg}$ & $4.63 \times 10^{9}$ & $4.63 \times 10^{9}$ & & \\
\hline $\begin{array}{l}\text { Volatilization factor } \\
\text { (VR) }\end{array}$ & $\mathrm{m}^{3} / \mathrm{kg}$ & $\begin{array}{l}\text { Chemical- } \\
\text { specific }\end{array}$ & $\begin{array}{l}\text { Chemical- } \\
\text { specific }\end{array}$ & & \\
\hline
\end{tabular}

${ }^{a}$ EPA 1991c (page 29, equation 8). 
Table 5.6. Parameters used in the Summers Model

\begin{tabular}{||l|c|l|l|l||}
\hline \multicolumn{1}{|c|}{ Parameter } & Symbol & Value & \multicolumn{1}{|c|}{ Units } & \multicolumn{1}{|c|}{ Reference } \\
\hline $\begin{array}{l}\text { Volumetric flow rate } \\
\text { of infiltration }\end{array}$ & $Q_{p}$ & 6176.5 & $\mathrm{ft}^{3} /$ day & $\begin{array}{l}\text { Calculated by } Q_{p}=V_{d} \times A_{p} \\
\text { (EPA 1989c) }\end{array}$ \\
\hline $\begin{array}{l}\text { Darcy velocity } \\
\text { in downward direction }\end{array}$ & $V_{d z}$ & 0.28 & $\mathrm{ft} /$ day & $\begin{array}{l}\text { Hydraulic conductivity } \\
\text { for unsaturated zone }\end{array}$ \\
\hline $\begin{array}{l}\text { Horizontal area } \\
\text { of contamination }\end{array}$ & $A_{p}$ & 21789 & $\mathrm{ft}^{2}$ & $\begin{array}{l}\text { Default value from EPA, 1991a } \\
\left.\text { (2025 } \mathrm{m}^{2}\right) ; \text { Also used to calculate } \\
\text { VF and PEF }\end{array}$ \\
\hline $\begin{array}{l}\text { Volumetric flow rate } \\
\text { of groundwater }\end{array}$ & $Q_{a}$ & 37.7 & $\mathrm{ft}^{3} /$ day & $\begin{array}{l}\text { Calculated by } Q_{a}=V_{d} \times h \times w \\
\text { (EPA 1989c) }\end{array}$ \\
\hline Hydraulic conductivity & $K$ & 0.28 & $\mathrm{ft} /$ day & $\begin{array}{l}\text { Average value for Y-12 area } \\
\text { (Solomon et al. 1992) }\end{array}$ \\
\hline Hydraulic gradient & $I$ & 0.03 & unitless & $\begin{array}{l}\text { Estimated from potentiometric } \\
\text { maps of the Y-12 area }\end{array}$ \\
\hline Darcy velocity in aquifer & $V_{d}$ & 0.0085 & $\mathrm{ft} /$ day & Calculate by $V_{d}=K \times I$ \\
\hline Aquifer thickness & $h$ & 30 & $\mathrm{ft}$ & $\begin{array}{l}\text { Average thickness of shallow } \\
\text { groundwater zone at Y-12 }\end{array}$ \\
\hline Perpendicular spill width & $w$ & 147.6 & $\mathrm{ft}$ & $\begin{array}{l}\text { Default value from Risk } \\
\text { Assessment Guidance } \\
\text { for Superfund Part B } \\
\text { (EPA 1991c) }\end{array}$ \\
\hline
\end{tabular}


determined based on the assumption that groundwater must meet acceptable levels within the groundwater directly beneath the source. Groundwater PRGs are being developed as part of BCV OU 4. In lieu of risk-based groundwater PRGs, MCLs will be used as the acceptable groundwater level.

The equations presented below have been incorporated into a Microsoft EXCEL spreadsheet model to calculate PRGs. Because ranges or distributions of data exist for several of the above parameters, Crystal Balle software can be used to provide decision makers with the distribution of PRG values that reflect the uncertainty associated with the input parameters. Decision makers can than determine the confidence level on which they will select the PRG. Most decisions made in the early stages of CERCLA reflect at least an upper 95\% confidence on the mean result. This capability may be extremely useful at the point in the FS-Proposed Plan process when PRGs must be revised into final remediation levels. The Summers Model is described below.

The concentration of a chemical in groundwater is a function of the amount of the chemical infiltrating through the soil column to the groundwater and the amount of the chemical already present in the groundwater. The chemical concentration is also determined by the volume of water into which the leachate is dissolved. The equation for the Summers Model is

$$
C_{w}=\frac{\left(Q_{p} C_{p}\right)+\left(Q_{e} C_{e}\right)}{Q_{p}+Q_{a}}
$$

where

$C_{w}=$ PRG concentration in water $(\mathrm{mg} / \mathrm{L})$,

$Q_{p}=$ volumetric flow rate of infiltration into the aquifer ( $\left.\mathrm{ft}^{3} / \mathrm{day}\right)$, where $Q_{p}=V_{d z} \cdot A_{p}$, $V_{d z}=$ Darcy velocity in downward direction (ft/day) and $A_{p}=$ horizontal area of spill ( $\left.\mathrm{ft}^{2}\right)$,

$C_{p}=$ concentrations of pollutant in the infiltration at the unsaturated-saturated zone interface $(\mu \mathrm{g} / \mathrm{L})$,

$Q_{a}=$ volumetric flow rate of groundwater ( $\mathrm{ft}^{3} / \mathrm{day}$ ), where $Q_{a}=V_{a} \cdot h \cdot w$ and $V_{a}=$ Darcy velocity in aquifer (ft/day), $h=$ aquifer thickness ( $\mathrm{ft}$ ), and $w=$ width of spill perpendicular to flow direction in aquifer ( $f t$ ),

$C_{a}=$ initial or backward concentration of pollutant in aquifer $(\mathrm{mg} / \mathrm{L})$.

$V_{d z}$ is estimated as the average annual precipitation minus surface runoff and evapotranspiration for the area, assuming all precipitation infiltrated through the soil.

The Darcy velocity in the aquifer $\left(V_{d}\right)$ is estimated by

$$
V_{d}=\boldsymbol{K} \boldsymbol{l}
$$

where $K$ is the hydraulic conductivity (ft/day) and $I$ is the hydraulic gradient (unitless). 
It was assumed that the background concentrations of the chemicals $\left(C_{a}\right)$ were equal to zero, and equations were rearranged to solve for $C_{s}$, the PRG concentration in soil:

$$
c_{1}=\frac{C_{p w}\left(Q_{p}+Q_{d}\right) K_{d}}{Q_{p}}
$$

where $K_{d}$ is the soil/water equilibrium partitioning coefficient $(\mathrm{mL} / \mathrm{g})$.

\subsection{Soll PRG for BCV OU 1}

Table 5.7 presents soil PRGs for use in performing the BCV OU 1 RI. In keeping with the spirit of the guidance that PRGs should reflect readily available information and be health protective the table presents risk-based PRGS, ARARs/TBC, and other considerations for establishing PRGS, such as background and reasonable cost-effective detection limits.

Values are presented for each of the three methods described above: direct exposures, both industrial and residential land use, and exposures via potential migration to groundwater. Note that all PRGs are above CLP detection limits; thus these detection limits should provide data that is useable in the risk assessment process. Also of note is that PRGs for chemicals that are relatively soluble (i.e., tetrachloroethylene and trichloroethylene) are lower than PRGs based on direct contact. On the other hand, PRGs for PCBs (Aroclors) and several metals are more stringent via direct contact pathways because of the low migration potential of these relatively insoluble compounds. Information used to develop the PRGS based on the leaching potential is preliminiry and thus these values are subject to change.

In using initial PRG in the early stages of the alternative screening process, engineen should understand that PRGs may be modified and should make the design of alternatives flexible. Chemicals may be added or deleted from the list of chemicals of concern, or PRGs may need to be modified based on the identification or deletion of additional limiting pathways. Modified PRGs will be presented in the operable unit feasibility study reports. Modified PRGs are refined into final remediation levels and presented in the Record of Decision. Final remediation levels must meet threshold criteria of "protection of human health and the environment" and "compliance with ARARs" (EPA 1991c):

However, the NCP also allows for modification of PRCs during final remedy selection based on the "balancing" and "modifying" criteria and factors relating to uncertainty, exposure and technical feasibility. [EPA 1991c]

Note should be taken that, with the exception of recommending the inclusion of environmental ARARs in the selection of PRGs, the Risk Assessment Guidance for Superfund RAGS Part B (EPA 1991c) addresses mainly human health effects, especially for soil PRGs. The potential need for ecological-based soil PRGs is being evaluated. 


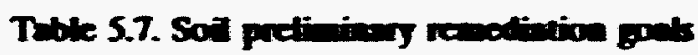

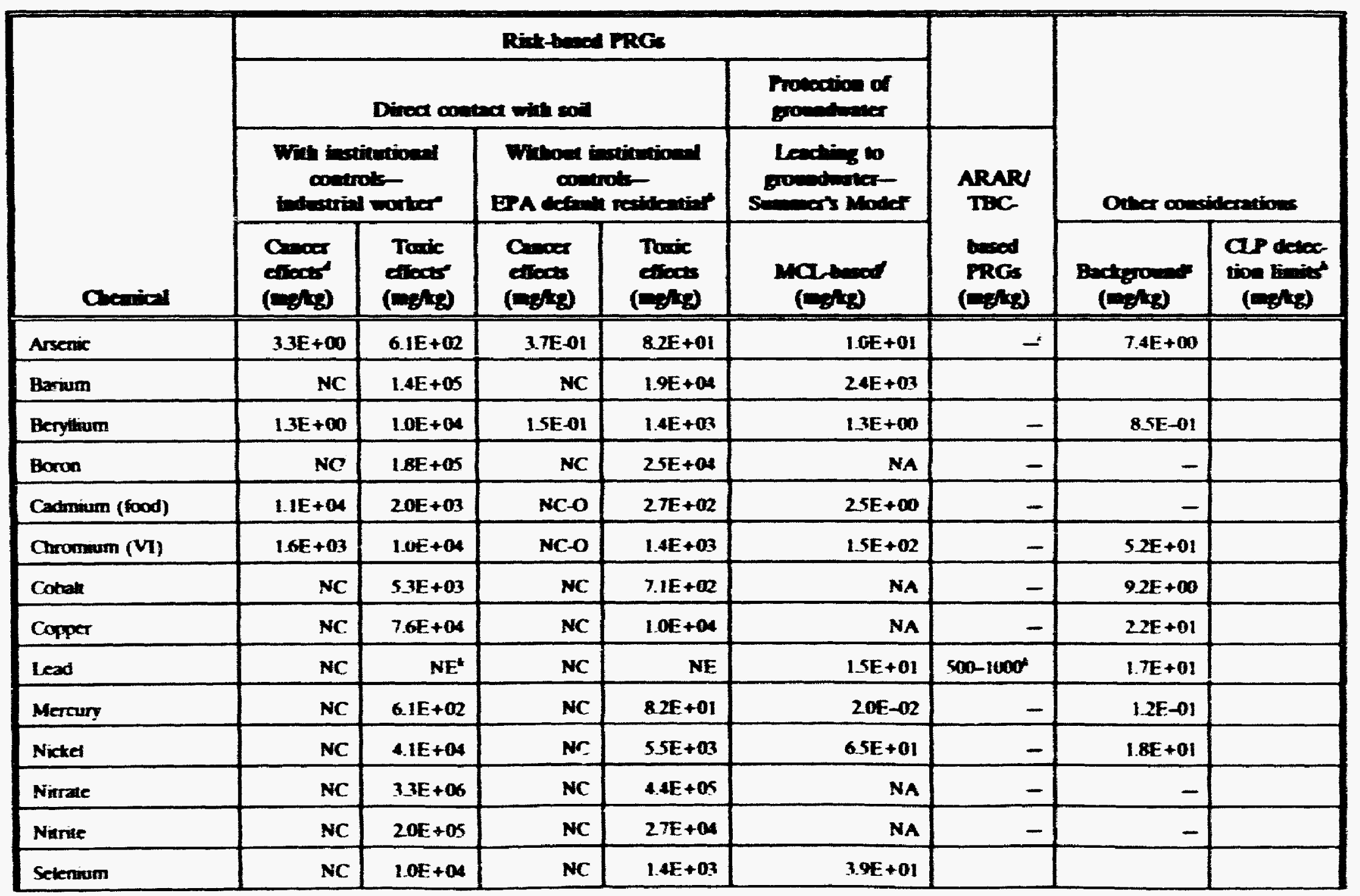


Thele 57 (osmingon)

\begin{tabular}{|c|c|c|c|c|c|c|c|c|}
\hline \multirow[b]{4}{*}{$a=-i$} & \multicolumn{5}{|c|}{ Dithed rach } & \multirow{4}{*}{ 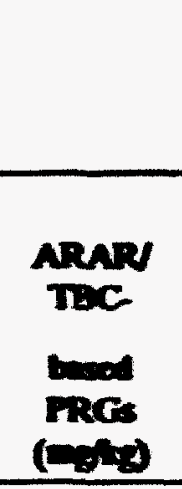 } & \multirow{3}{*}{\multicolumn{2}{|c|}{ Ovber on illowions }} \\
\hline & \multicolumn{4}{|c|}{ 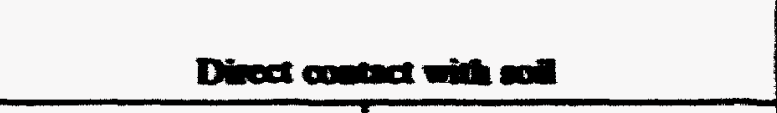 } & \multirow{3}{*}{ 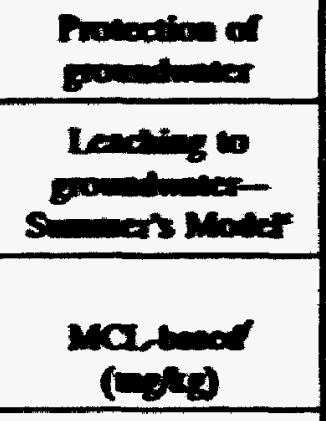 } & & & \\
\hline & \multicolumn{2}{|c|}{ 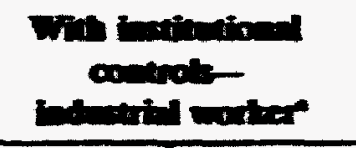 } & \multicolumn{2}{|c|}{ 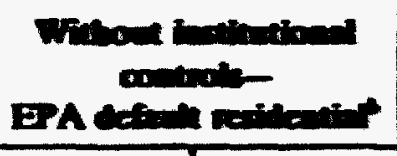 } & & & & \\
\hline & 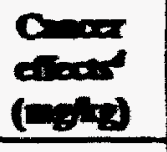 & 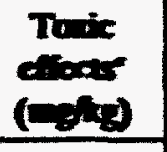 & $\begin{array}{c}a_{\infty}=0 \\
a_{0+1}\end{array}$ & 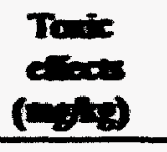 & & & Bedpere & 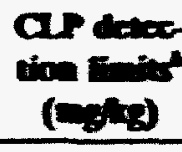 \\
\hline Thativen & $\mathbf{N C}$ & $1.4 E+02$ & $\mathbf{N C}$ & $1.9 E+01$ & $3.0 E+\infty$ & - & $86 E+\infty 0$ & \\
\hline Uranivat & NC & $6.1 E+03$ & NC & $82 E+02$ & $3.4 E+01$ & - & $1.0 E+\infty$ & \\
\hline \multicolumn{9}{|c|}{$a=$} \\
\hline Acetone & $\mathbf{N C}$ & $20 E+5$ & NC & $2 \pi+4$ & $\mathbf{M n}$ & - & - & \\
\hline Aroctor-1248 & 7.4E-01 & NT & Q3E-62 & $\mathbf{N T}$ & $5.4 E+\infty$ & $10-50$ & - & \\
\hline Aroctor-1254 & 7.4E-01 & $\mathbf{N T}$ & 83E-12 & $\mathbf{N T}$ & $1.0 E+01$ & $10-50$ & - & \\
\hline Arodor-1260 & 7.4E-01 & NT & 83E-02 & $\mathbf{N T}$ & $1.2 \mathrm{E}+01$ & $10-50$ & - & \\
\hline 2-Butanone & NC & $10 E+05$ & NC & $1.4 E+04$ & NA & - & - & \\
\hline Carton tetracthoride & $4.4 E+0 I$ & $1.4 E+03$ & $49 E+\infty 0$ & $1.9 E+02$ & 5.250 .02 & - & - & \\
\hline Chbraform & $9.4 E+02$ & $20 E+64$ & $1.0 E+02$ & $2 \pi E+03$ & LAEOI & - & - & \\
\hline 1.1-Dichloroetbone & $\mathrm{MC}$ & $20 E+05$ & NC & $2 \pi+\infty$ & G.3E. 0 & & & \\
\hline 1,1-Didthracthylene & 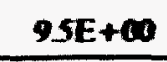 & $18 E+04$ & $1.1 E+\infty$ & $2 S E+03$ & LIE-B & & & \\
\hline 12-Diditivethyene & NC & $18 E+04$ & NC & 2SE+03 & 1.SE-01 & - & - & \\
\hline
\end{tabular}


Thale 57 (oonomed

\begin{tabular}{|c|c|c|c|c|c|c|c|c|}
\hline \multirow[b]{4}{*}{ Creniot } & \multicolumn{5}{|c|}{ Rithed reas } & & & \\
\hline & \multicolumn{4}{|c|}{ 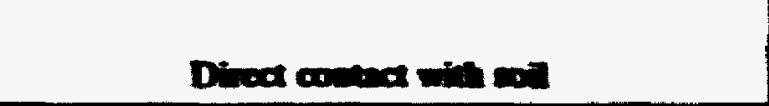 } & \multirow{2}{*}{ 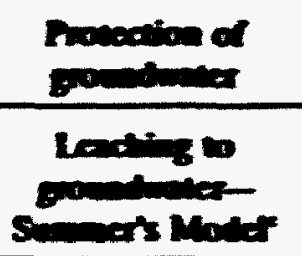 } & & & \\
\hline & \multicolumn{2}{|c|}{ 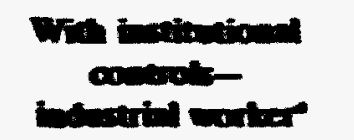 } & \multicolumn{2}{|c|}{ 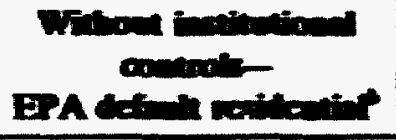 } & & \multirow{2}{*}{ 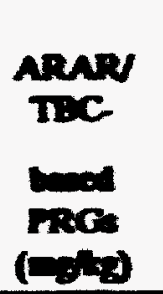 } & \multicolumn{2}{|c|}{ Otwer consilentions } \\
\hline & 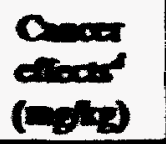 & 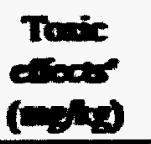 & 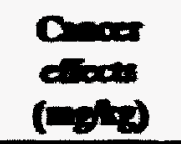 & 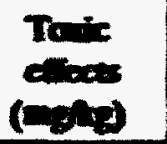 & mabed & & $(1, \theta+g)$ & ar dex \\
\hline Methylene dibride & $7.6 \mathrm{E}+02$ & $12 E+05$ & QSE+01 & $16 E+04$ & $1 . \pi=03$ & - & - & \\
\hline Tetractidaroethylene & $1.1 \mathrm{E}+\mathbf{Q 2}$ & $20 E+04$ & 1.3E*01 & $2 \pi E+03$ & 3.3E- & - & - & \\
\hline Tricturacethylone & $5 . \pi+\infty 2$ & $\mathbf{M T}$ & 6.4E+01 & $\mathbf{M T}$ & 3.3E-P & - & - & \\
\hline 1,1,1-Trictionocthene & $\mathbf{N C}$ & $1.8 E+04$ & wC & $25 E+64$ & NA & - & - & \\
\hline \multicolumn{9}{|c|}{ 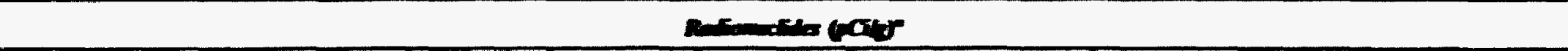 } \\
\hline Funosiuman-283 & $3.1 E+\infty$ & NT & $50 E-02$ & $\mathbf{N T}$ & MA & & & \\
\hline Strosinemen-90 & $9 \pi \mathrm{E}+01$ & $\mathbf{N T}$ & $24 E+01$ & $\mathbf{N T}$ & NA & & & \\
\hline Technetivin-99 & 1.TE+OR & NT & $23 E+\infty$ & $\mathbf{M T}$ & NA & & & \\
\hline Traion & 5.9E+04 & NT & ISE+OA & $\mathbf{N T}$ & MA & & & \\
\hline Tharium-22s & $20 E-01$ & NT & 26E-93 & $\mathbf{M T}$ & NA & & & \\
\hline Thanimen-200 & $21 E+\infty$ & NT & $26 E-6$ & $\mathbf{M}$ & MA & & & \\
\hline Thorium-232 & $42 E+\infty$ & $\mathbf{M T}$ & 5.4E-0. & $\mathbf{N T}$ & NA & & & \\
\hline Uranim-24 & $3 \pi E+\infty$ & NT & $4 \pi-\infty$ & NT & NA & & & \\
\hline
\end{tabular}




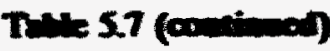

\begin{tabular}{|c|c|c|c|c|c|c|c|c|}
\hline \multirow[b]{4}{*}{$\alpha=m$} & \multicolumn{5}{|c|}{ Rint-bon Fra } & & & \\
\hline & \multicolumn{4}{|c|}{ 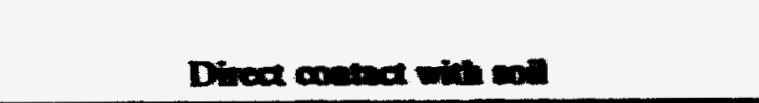 } & Provetion of & & & \\
\hline & \multicolumn{2}{|c|}{ 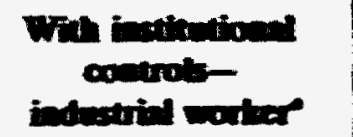 } & \multicolumn{2}{|c|}{ 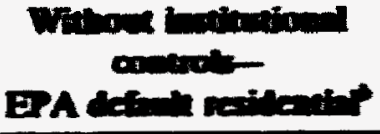 } & 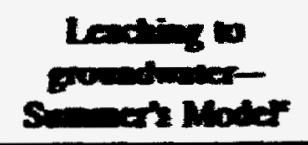 & \multirow{2}{*}{ 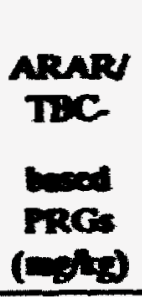 } & \multicolumn{2}{|c|}{ Other on internios } \\
\hline & $\begin{array}{l}\text { Consex } \\
\text { citocts } \\
(-\log / \mathrm{tg})\end{array}$ & $\begin{array}{l}\text { Touic } \\
\text { eloox } \\
\text { (ngteg) }\end{array}$ & 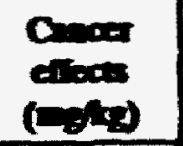 & 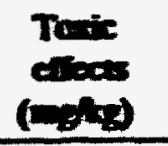 & Marbed & & Bofloon & 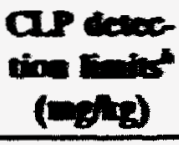 \\
\hline Uranium-235 & $4.7 E-04$ & NT & S.9E- -06 & NT & NA & & & \\
\hline Uranum-238 & $5.2 \mathrm{E}+00$ & NT & $6.7 \mathrm{E}-02$ & NT & NA & & & \\
\hline
\end{tabular}

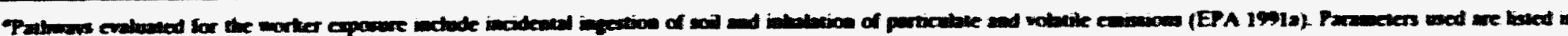
Tatic 5.1.

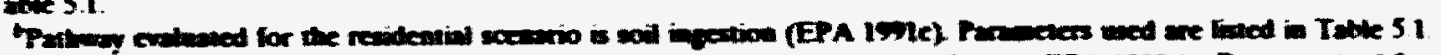

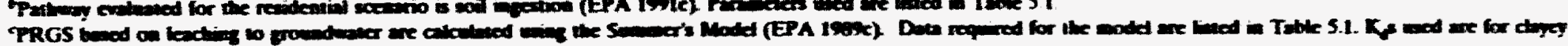
$\rightarrow$ (Eacts Syeder 1992).

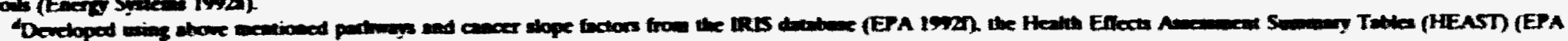
1991. 19pe).

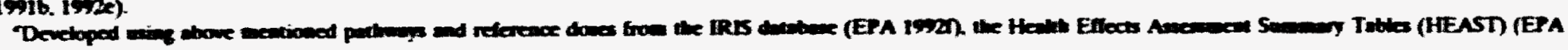

19916. 19921.

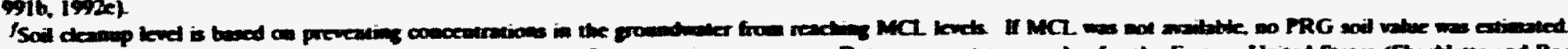

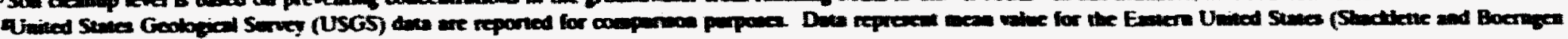

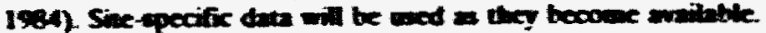

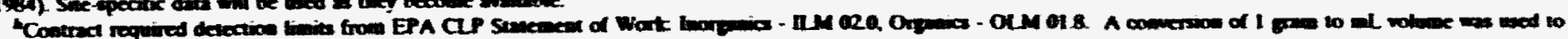

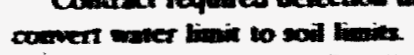

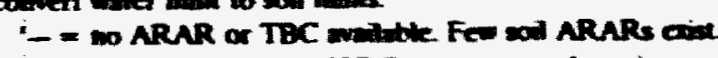

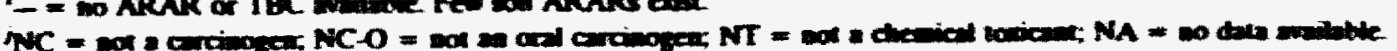

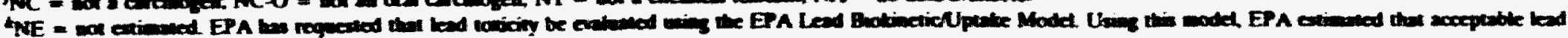

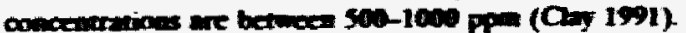

'PRG eximed beed on waried toricing.

From TSCA PCA spil demepp poticy (S2 FR 106es) 


\section{S.3 IDENTIFICATION OF POTENTIAL CLASSES OF REMEDIAL TECHNOLOGIBS}

The two types of response actions allowed by CERCLA regulations at a site are removal actions and remedial actions. A removal action is designed to respond to immediate threats to public health or welfare or to the environment and can be undertaken immediately upon the discovery of the threat. On the other hand, remedial actions are designed to reduce risk and must be preceded by the RI/FS process. A removal response can be followed by, or be a part of, remedial response.

\subsubsection{Removal Actions}

EPA-established requirements for removal actions taken at CERCLA sites are listed in Sects. 300.410 and 300.415 of the NCP. Classes of removal actions include the following:

- Cleaning up or removing released hazardous substances.

- Acting in the event of the threat of release of hazardous substances into the environment.

- Monitoring, assessing, and evaluating the release or threat of release of hazardous substances.

- Preventing, minimizing, or mitigating damage to the public health or welfare or to the environment.

Removal actions must, to the extent practical, contribute to the efficient performance of any long-term remedial action for the release [55 FR 8843 and CERCLA Sect. 104(b)].

The following is a list of potential removal actions that may be necessary at BCV OU 1:

- Removal or overpacking of drums and other containers.

- Excavation of highly contaminated soils, especially those that are radioactive.

- Drainage controls (i.e., capture and treatment) of contaminated shallow groundwater.

- Drainage controls (i.e., capture and treatment) of contaminated seeps.

- Installation of an airborne dust monitoring station.

- Fences, warning signs, or other security measures.

\subsection{Remedial Actions}

EPA-established requirements pertaining to the remediation of CERCLA sites are listed in Sect. 300.430(a)(1)(iii) of the NCP. These requirements have been considered in developing the PRGs, which help to identify appropriate remedial action alternatives. The classes of remedial technologies that may be appropriate to BCV OU 1 are summarized below.

- Institutional controls such as fences and deed restrictions may be used alone or as a supplement for engineering controls, as appropriate, to prevent exposure to hazardous substances. 
- Containment tochnologies such as capping, vertical barriers, horizontal barriers, and dust suppression may be used, as appropriate, to control contaminated areas that pose a relatively low long-term threat and for sites where treatment is impractical (e.g.. in a pyrophoric setting).

- Removal technologie such as excavation may be used, as appropriate, alone or in combination with treatment to remove contamination or to abate the further migration of contaminants.

- Treatment technologies such as solidification/stabilization or physicochemical, biological, thermal, or electrokinetic technologies may be used, as appropriate, alone or in combination with any of the above technologies to (1) abate principal threats such as highly mobile or toxic substances, (2) prevent further migration of contaminants, or (3) remove contamination. Where possible, treated material that no longer poses a threat to human health or the environment will be returned to the excavation site or treatment will occur in situ.

- Innovative technologies may be considered when they offer the potential for superior treatment performance or lower costs for performance similar to that of demonstrated technologies.

As the RAOs are revised throughout the RI/FS process, the development and evaluation of the remedial action alternatives will reflect the scope and complexity of the site problems being addressed. During the FS, alternatives will be developed to protect human health and the environment by eliminating, reducing, and/or controlling risks posed through each exposure pathway.

Table 5.8 presents a preliminary range of remedial action alternatives and associated technologies to achieve the RAOs discussed in Sect. 5.2. This table is not meant to present a detailed compilation of alternatives but to make an initial determination as to which general response actions might be applied to the units. This will be used later during the FS process to screen process options and entire technology types as to their implementability for each unit. Identifying potential technologies at this stage will help ensure that data needed to evaluate them can be collected as early as possible. Early identification of technologies will also determine whether treatability studies are needed.

The general response actions shown in Table 5.8 are (1) no action, (2) institutional actions, (3) source containment, and (4) removal/treatment actions. The "no-action" response required by CERCLA serves as a baseline comparison against which the risk association with all other actions can be measured. The potential principal contaminants of interest affecting the soil were listed earlier in Table 5.1. They consist mainly of metals, nitrates, organics, and radionuclides. As additional information becomes available, contaminants may be added or deleted. 


\subsection{2}

Tuble 5.8. Identificution of preliminary remedial action goals, preliminary general response ections, and preliminary remedial technology types for will and waste

\begin{tabular}{|c|c|c|}
\hline Remedil sction goals & General response ections & Remodial tochnology type \\
\hline $\begin{array}{l}\text { Por protection of human } \\
\text { bealith: } \\
\text { Prevent ingestion and/or } \\
\text { inhalation of and/or direct } \\
\text { contact with contaminated } \\
\text { soil and waste } \\
\text { Por protection } \\
\text { of eavironment: } \\
\text { Prevent migration } \\
\text { of contaminants that } \\
\text { would result or has } \\
\text { resulted in groundwater } \\
\text { contamination } \\
\text { Prevent stormflow water, } \\
\text { traveling within the } \\
\text { stormflow zone, } \\
\text { from migrating } \\
\text { into source areas }\end{array}$ & $\begin{array}{l}\text { No action: } \\
\text { 1. No action } \\
\text { Institutional actions: } \\
\text { 1. Access restrictions } \\
\text { 2. Legal restrictions } \\
\text { 3. Monitoring } \\
\text { Containment actions: } \\
\text { 1. Containment } \\
\text { Removal/treatment actions: } \\
\text { 1. Excavation/disposal } \\
\text { 2. Excavation/treatment/disposal } \\
\text { 3. Excavation/treatment/ } \\
\text { replacement } \\
\text { 4. In situ treatment }\end{array}$ & $\begin{array}{l}\text { Institutional options: } \\
\text { 1. Access barriers } \\
\text { 2. Deed restrictions } \\
\text { 3. Sampling and analysis } \\
\text { Containment tochnologies: } \\
\text { 1. Capping } \\
\text { 2. Vertical barriers } \\
\text { 3. Horizontal barriers } \\
\text { Removal tochnologies: } \\
\text { 1. Excavation } \\
\text { Treatment tochnologies: } \\
\text { 1. Physicochemical } \\
\text { treatment } \\
\text { 2. Biological treatment } \\
\text { 3. Thermal treatment } \\
\text { 4. Electrokinetic } \\
\text { treatment } \\
\text { 5. In situ treatment } \\
\text { Disposal technologies: } \\
\text { 1. On-site disposal } \\
\text { 2. Off-site disposal }\end{array}$ \\
\hline
\end{tabular}




\section{SITE DATA NEEDS}

The purpose of this chapter is to identify the data necessary to meet the objectives of the RI that were discussed in Sects. 1.7 and 1.8. As outlined in Chap. 1, the staged RI/FS process will be carried out in a three-stage approach:

- Stage 1 involves a preliminary hazard evaluation for each site, and a decision will be made whether a removal action, no action, or an additional RI is necessary.

- Stage 2 involves a baseline risk assessment and risk-based remedial goals, screening of remedial action alternatives for each site, and issuance of a ROD for interim mcasures.

- Stage 3 involves bringing the source $O_{B}$ and the integrator OU in BCV to a final ROD.

The objective of the RI is to provide legally defensible data that will allow the necessary decisions to be made at each stage of the RI/FS process.

The general data necds for this RI include physical property parameters for soils, contaminant concentration data for soils and shallow groundwater, data for waste characterization, and data concerning the hydrological and geochemical properties of soils and the shallow groundwater system. Much of these data are available in the literature from previous studies and, where possible, will be incorporated into the $R I$ to reduce the amount of sampling required to meet the DCOs. Data used for the RI must be supported by documentation that ensures that the data are valid and that decisions made using these data are legally defensible. At Stage 1, decisions for removal actions or RI continuance can be made based on data for which documentation of QA is below the equivalent of EPA Level III. Therefore, Stage 1 of the staged RI/FS process has been completed without further sampling at most of the sites in BCV OU 1, for which extensive historical data are available, and Stage 2 is beginning (Fig. 6.1). Where it is possible that a no-further-investigation decision will be made at a site, a goal of EPA Level III (or equivalent documentation at Stage 1) will be set to support this decision.

The sites in BCV OU 1 are at the following stages in the staged RI/FS process:

- Stage 1: Boneyard/Burnyard, HCDA, and SL 1.

- Stage 2: S-3 Site, Oil Landfarm, and the Burial Grounds.

In Stage 2, documentation equivalent to EPA Level III for $100 \%$ of the data (with an option for equivalent to EPA Level IV deliverable at a later date) will be the goal for screening of remedial alternatives. For historical data to reach this goal, sampling may be required in order to confirm values where documentation of historical OA data is insufficient. The general data needs for the BCV OU 1 sites are described in Table 6.1. Data needs for BCV OU 1 were developed using assumptions made with the site background information described in Chap. 2 and the historical data described in Chap. 3. 
Stages of the Source OU RI

\begin{tabular}{|c|}
\hline Stage 1 \\
Stage 2 \\
\hline
\end{tabular}

CERCLA process for sources sites not closed under RCRA

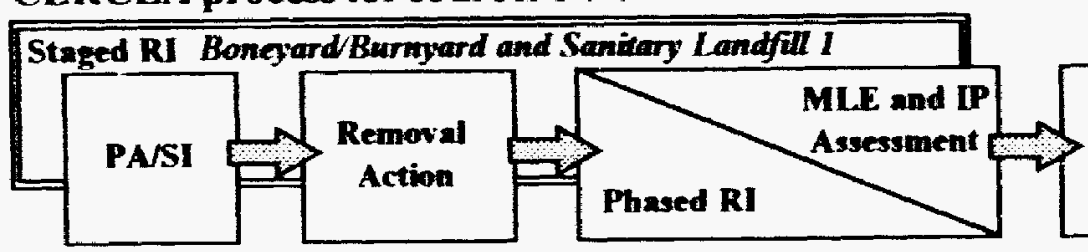

CERCLA process for sources sites closed under RCRA

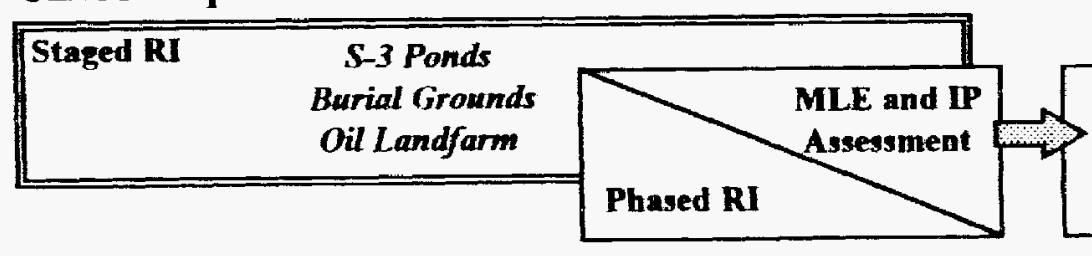

ROD for

Interim

Measures

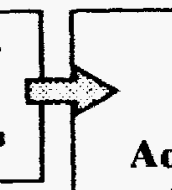

Additional remedial actions to source OUs indicated by the integrator OU RME assessment

\section{Stages of the Integrator OU RI}

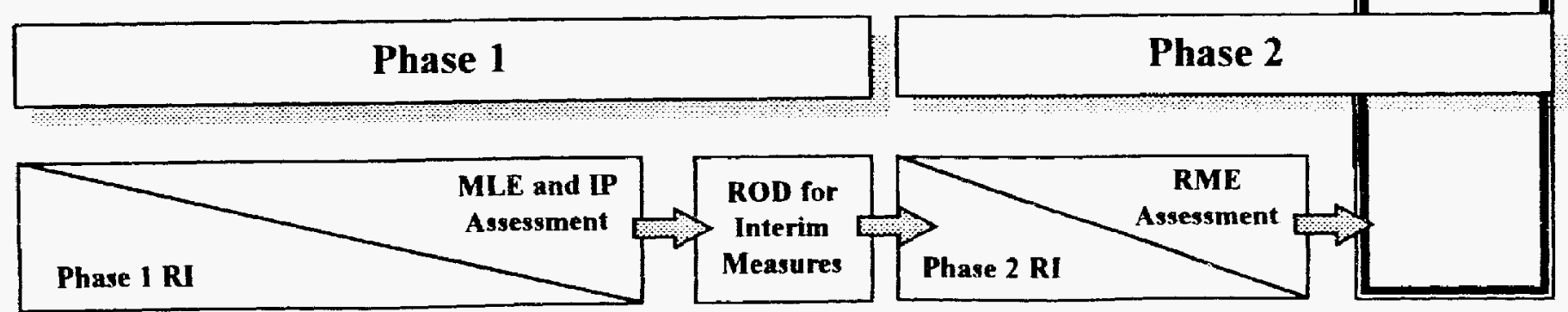

Fig. 6.1. The staged RIFS process.

The 
Table 6.1. BCV OU 1 RI work plan site data needs

\begin{tabular}{|c|c|c|c|c|c|c|}
\hline Data sood & Dete type & $\begin{array}{l}\text { Sminple type } \\
\text { or method }\end{array}$ & Medin & Dane we & $\begin{array}{l}\text { Des evaluntion } \\
\text { and interpetation }\end{array}$ & $\begin{array}{l}\text { Quality } \\
\text { keved }\end{array}$ \\
\hline \multirow[t]{3}{*}{$\begin{array}{l}\text { Physical } \\
\text { properties }\end{array}$} & $\begin{array}{l}\text { Soil grain size, } \\
\text { permeability, void ratio, } \\
\text { soil density, bulk } \\
\text { density, total organic } \\
\text { carbon content, cation } \\
\text { exchange capacity, soil } \\
\mathrm{pH}^{\circ}\end{array}$ & $\begin{array}{l}\text { Undisturbed } \\
\text { samples (Shelby } \\
\text { tubes) }\end{array}$ & $\begin{array}{l}\text { Unconsolidated } \\
\text { earth materials } \\
\text { (includes soil, fill, } \\
\text { saprolite) }\end{array}$ & $\begin{array}{l}\text { Evaluate release mechanisms } \\
\text { for transport from the source } \\
\text { to groundwater, surface water, and } \\
\text { air pathways } \\
\text { - Screen remediation technologies } \\
\text { - Remediation design }\end{array}$ & $\begin{array}{l}\text { These dats will be illustrated } \\
\text { on maps and cross-sections. } \\
\text { Data will be used } \\
\text { in conjunction with analytical } \\
\text { data to estimate the mass } \\
\text { flux of contaminants } \\
\text { transported from the source } \\
\text { to the saturated groundwater } \\
\text { ervironment }\end{array}$ & \\
\hline & $\begin{array}{l}\text { Hydraulic head } \\
\text { measurements }\end{array}$ & $\begin{array}{l}\text { Electronic probe } \\
\text { graduated } \\
\text { to } 0.01 \mathrm{ft}\end{array}$ & Groundwater & $\begin{array}{l}\text { - Determine hydraulic gradients; } \\
\text { establish thickness of unsaturated } \\
\text { zone; establish seasonal fluctuation } \\
\text { in water table } \\
\text { - Screen remediation technologies } \\
\text { - Remediation design }\end{array}$ & $\begin{array}{l}\text { Data will be illustrated as } \\
\text { potentiometric maps, } \\
\text { hydraulic gradients will be } \\
\text { input into mass transport } \\
\text { calculations. Hydrographs } \\
\text { will also be made to establish } \\
\text { seasonal variation in the } \\
\text { water table }\end{array}$ & \\
\hline & $\begin{array}{l}\text { Standard compaction } \\
\text { test }\end{array}$ & $\begin{array}{l}\text { Undisturbed } \\
\text { sample (Shelby } \\
\text { tube) }\end{array}$ & Soil & $\begin{array}{l}\text { - Determine compactibility } \\
\text { of soil, plastic and liquid limits, } \\
\text { and compressibility } \\
\text { - Screen remediation technologies } \\
\text { - Remediation design }\end{array}$ & $\begin{array}{l}\text { Volume reduction } \\
\text { of compacted soil } \\
\text { Soil behavior on wetting } \\
\text { Determine load bearing } \\
\text { capacity of soil } \\
\text { Data will be illustrated } \\
\text { on tables }\end{array}$ & \\
\hline
\end{tabular}


Table 6.1 (continuod)

\begin{tabular}{|c|c|c|c|c|c|c|}
\hline Data nood & Datn type & $\begin{array}{l}\text { Sample type } \\
\text { or nectiod }\end{array}$ & Molih & Detin we & Deter enderpretion & Qung \\
\hline & $\begin{array}{l}\text { Visually inspected soil } \\
\text { properties, and split } \\
\text { barrel penetration blow } \\
\text { counts }\end{array}$ & $\begin{array}{l}\text { Soil/split barrel } \\
\text { penetration teats }\end{array}$ & $\begin{array}{l}\text { Unconaolidated } \\
\text { earth materiaks } \\
\text { (inchudes soil, fill, } \\
\text { and saprolite) }\end{array}$ & $\begin{array}{l}\text { - Evaluate release mechanisms } \\
\text { for transport from the source } \\
\text { to groundwater and surface water } \\
\text { pathways; eatablish thickness and } \\
\text { volume of unconsolidated zone } \\
\text { with the site. These data will be } \\
\text { used to qualitatively interpret the } \\
\text { distribution of physical properties } \\
\text { determined from laboratory } \\
\text { analysis } \\
\text { - Screen remediation alternatives } \\
\text { - Remediation design }\end{array}$ & $\begin{array}{l}\text { Data will be plotted } \\
\text { on boring logs, maps, and } \\
\text { cross-actions and will be } \\
\text { used to establish the relative } \\
\text { degree of heterogeneity } \\
\text { within the unconsolidated } \\
\text { zone }\end{array}$ & \\
\hline $\begin{array}{l}\text { Contaminant } \\
\text { distribution }\end{array}$ & $\begin{array}{l}\text { Analytical parameters } \\
\text { to be determined } \\
\text { for each site to be } \\
\text { investigated }\end{array}$ & $\begin{array}{l}\text { Soil samples will } \\
\text { be collected } \\
\text { by hand auger or } \\
\text { split-sposn. CLP } \\
\text { methods will be } \\
\text { used } \\
\text { for laboratory } \\
\text { analysis }\end{array}$ & Soil (source) & $\begin{array}{l}\text { - Define the vertical and } \\
\text { horizontal extent of contamination } \\
\text { within the source area. Define the } \\
\text { boundary and volume of soil to be } \\
\text { rewediated. Data will also be input } \\
\text { into mass transport calculations } \\
\text { to assess the future threat } \\
\text { of release to groundwater and } \\
\text { surface water environments. Data } \\
\text { will be used as input for the } \\
\text { human health and ecological risk } \\
\text { assessments }\end{array}$ & $\begin{array}{l}\text { Data will be presented } \\
\text { on maps and cross-sections } \\
\text { along with physical property } \\
\text { data; qualitative correlations } \\
\text { will be made between soil } \\
\text { physical properties and } \\
\text { contaminant distribution and } \\
\text { occurrence; statistical } \\
\text { snatysis will be performed } \\
\text { and the dala presented } \\
\text { in table format }\end{array}$ & 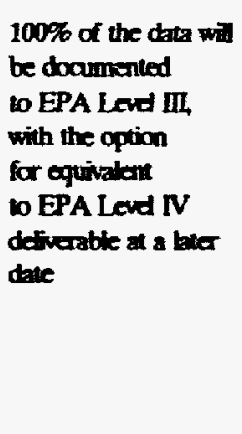 \\
\hline $\begin{array}{l}\text { Leactabitity } \\
\text { of contaninents }\end{array}$ & $\begin{array}{l}\text { Metals inctuding } \mathrm{H} \& \mathrm{U} \text {, } \\
\text { and organics anyles } \\
\text { detailed in } 40 \text { CFR } 260\end{array}$ & $\begin{array}{l}\text { EPA SW } 846 \\
\text { method will be used } \\
\text { for TCP }\end{array}$ & & $\begin{array}{l}\text { Define the rdative leachabitity of the } \\
\text { contaminanta Data will be used as } \\
\text { input in the coological risk assesement }\end{array}$ & $\begin{array}{l}\text { Data wili be evahratod } \\
\text { in conjunction with leaching } \\
\text { modds }\end{array}$ & \\
\hline
\end{tabular}


Table 6.1 (continued)

\begin{tabular}{|c|c|c|c|c|c|c|}
\hline Deta neat & Dan type & $\begin{array}{l}\text { Somple type } \\
\text { or wetinod }\end{array}$ & Modin & Dum e & Detan eroturion & Onengy \\
\hline & $\begin{array}{l}\text { Anabyical persmcters to be } \\
\text { determined for each sine } \\
\text { to be invexighed }\end{array}$ & 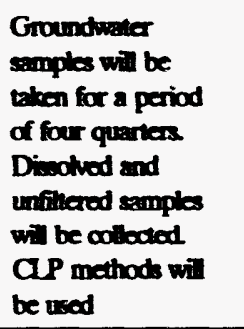 & $\begin{array}{l}\text { Groundwaser } \\
\text { (pethray) }\end{array}$ & 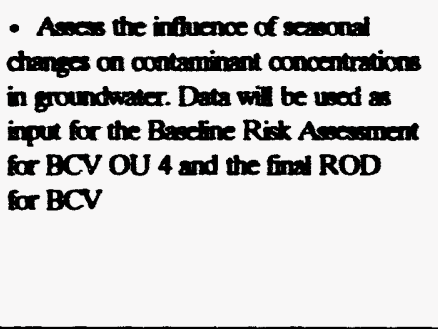 & 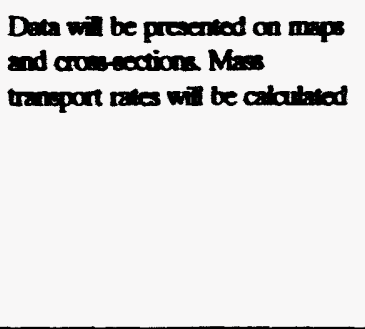 & 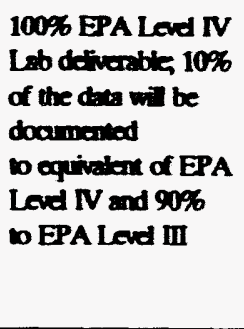 \\
\hline & $\begin{array}{l}\text { Analytical parameters to be } \\
\text { determined for each site } \\
\text { investigated }\end{array}$ & $\begin{array}{l}\text { Filiered and } \\
\text { unfiticred samples } \\
\text { wili be oollocted } \\
\text { during storm events. } \\
\text { CIP methods will } \\
\text { be used for analysis } \\
\text { Flow rates will ato } \\
\text { be measured }\end{array}$ & $\begin{array}{l}\text { Surface water } \\
\text { (pahway) } \\
\text { Sediunat (pethwey) }\end{array}$ & $\begin{array}{l}\text { - Determine if ocntaminants are being } \\
\text { traneported by surface water to BCV } \\
\text { - Use in the coological risk ancosmem }\end{array}$ & Data will be presented on tables & $\begin{array}{l}\text { 100\% EPA Levd IV } \\
\text { Lab deliverable, } 10 \% \\
\text { of the daes will be } \\
\text { documened to } \\
\text { oquivalent of EPA } \\
\text { Leid IV and } 90 \% \\
\text { o EPA Levd III }\end{array}$ \\
\hline & $\begin{array}{l}\text { Inorganic, PCBs } \\
\text { radionuctides }\end{array}$ & $\begin{array}{l}\text { Samples collocied } \\
\text { from ares } \\
\text { of contaninged sol } \\
\text { adjach to scurce } \\
\text { areas }\end{array}$ & $\begin{array}{l}\text { Tenestrial vegctation } \\
\text { Terrestrial animals }\end{array}$ & 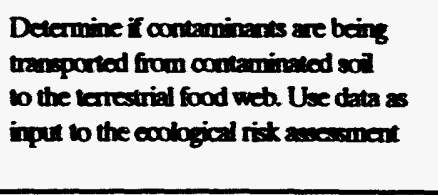 & Data wil be pracented in tiblos & CP Lad V (SAS') \\
\hline & $\begin{array}{l}\text { Inorganias, PCBa } \\
\text { radionuctides }\end{array}$ & $\begin{array}{l}\text { Semples collected } \\
\text { downstope } \\
\text { from seeps }\end{array}$ & $\begin{array}{l}\text { Terietrial vegetation } \\
\text { Terotrial animats }\end{array}$ & 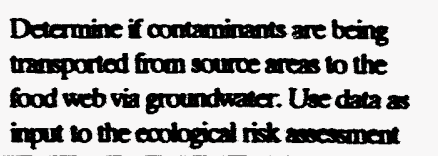 & Dean will be prescented in tubles & AP Levd V (SAS) \\
\hline & & $\begin{array}{l}\text { Sampling with socop } \\
\text { EPA-pprowed } \\
\text { tocicity lests }\end{array}$ & $\begin{array}{l}\text { Surface water } \\
\text { Sofinest } \\
\text { Soil }\end{array}$ & 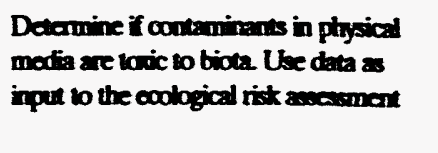 & Deta will be presoned in tholes & QP Lead V (SAS) \\
\hline
\end{tabular}

IIf these data can be collocted from nearty areas, fower samples will be needed.

bSpecial Analyical Services are used when CIP methods are not appropriate. 


\subsection{PHYSICAL CHARACTERIZATION ACTTVITIES}

\subsubsection{General Site Physical Characterization Activities}

\subsubsection{Soils and solid wastes}

Data are needed to characterize the nature and extent of contamination in soils and wastes and to evaluate current and future on-site and off-site contaminant migration pathways. Data indicating the nature and extent of contamination are needed not only to determine the extent of contamination at each site but also to allow evaluation of future fluxes of contaminants along migration pathways.

In order to determine the magnitude of the contamination and the relative location of the contaminant sources (trenches, pits, ponds) for these various contaminants, a two-phase sampling design is being proposed based on the DQOs previously discussed. During the first phase of the RI, the nature and magnitude of contaminant concentrations will be determined in OU 1. During the second phase, the distribution and extent of the major COCs (as identified during Phase 1) will be determined.

Phase 1 Sampling Design. A stratified and systematic random sampling design has been used during Phase 1 of the RI. As will be discussed in Chap. 7, BCV OU 1 is divided into a number of different strata (waste areas): the S-3 Site, the Oil Landfarm, the Boneyard/Burnyard, and the various waste areas (trench groupings) within the Bear Creek Burial Grounds. The Phase 1 sampling locations at the S-3 Site will be selected using data from an initial radiological and geophysical survey of the areas downgradient of the site. Sampling at the Sanitary Landfill I will be limited to one exploratory boring and groundwater well since it is possible that no hazardous material exists at this site. Within each of the remaining BCV OU 1 strata, a number (30-50) of potential sampling points have been selected that are located immediately downgradient from each of the waste areas (or capped areas) discussed in Chap. 7. A systematic random sample will then be selected for each area with the number of samples selected being proportional to the relative size of each area.

The following example should help to explain the proposed sampling design for Phase 1 of the RI. For Sample Area 2 in the Bear Creek Burial Grounds (Fig. 7.8 in Chap. 7 of this work plan), a sample spacing of $250-275 \mathrm{ft}$ has been selected. Potential sampling points are located immediately downgradient from the entire waste area (trenches A-8 to A-15) located on a transect parallel to the site boundaries. This transect is $1,300 \mathrm{ft}$ long and was divided into 52 twenty-five-foot segments with 53 potential sampling points at the nodes. A single starting location between 1 and 11 (one-fifth of 53 potential sampling points rounded to the next integer) has been selected at random, and four additional sampling points are systematically located every eleventh sample location. The randomly selected starting point is seven, and a sample will be collected at locations $7,18,29,40$, and 51 . This style of sample location is carried out for all areas of the Burial Grounds (with the exception of BG-B and the WIPs) and for the Oil Landfarm. All sample locations are $-250-275 \mathrm{ft}$ apart along the transects shown in Figs. 7.3 and 7.6-7.12 in Chap. 7.

After the samples for the Phase $1 \mathrm{RI}$ have been collected and analyzed, a five-part decision rule will be employed, using the EPA's Risk Assessment Guidance for Superfund, Vol: Human Health Evaluation Manual, Part A (EPA 1989d) to determine whether the concentration in the samples collected in BCV OU 1 exceeds established detection limits, 
background concentrations (if known), established action levels, or preliminary remediation goals. Specifically, potential COCs will be considered for further evaluation if any one of the following applies:

- The analyte was positively detected in at least one sample.

- The analyte concentration was measured at levels significantly higher than naturally occurring levels (background) of the same analyte.

- The analyte concentration exceeded established action levels.

- The analyte was identified but the exact concentration was unknown (i.e., J-qualified data) or was detected at levels significantly higher than the same chemicals detected in associated blank samples.

- The analyte concentration was higher than established preliminary remediation goals.

A systematic process, following the decision rule just discussed, will be used to narrow the list of potential COCs. All analytes that "fall out" as a result of applying the decision rule process will be declared COCs and will be further investigated during Phase 2 of the RI.

Phase 2 Sampling Design. The specific sampling design to be used in Phase 2 of the RI will largely depend on the results obtained in Phase 1. As with Phase 1, a statistically based sampling design will be used to characterize the distribution and extent of the specific COCs determined in Phase 1.

Since the list of contaminants to be investigated in Phase 2 should be considerably smaller than the list of contaminants analyzed in Phase 1 , many more samples can be collected to characterize the extent of contamination. A series of rapid field screening techniques that involve rapid sample collection and analysis techniques (including hydropunch sampling and field GCs) will be used to quickly identify locations of potential contamination. The results from these sample collections and surveys will be verified by subsequent analytical laboratory analysis for statistically selected subsets of samples.

Because of the inherent difficulty, potentially high risks, and high costs of evaluating the nature and extent of waste materials, an inventory of waste in the Burial Grounds and historical data concerning wastes in the Oil Landfarm and the S-3 Site will be used.

As was detailed in Chap. 2, - 50,000 individual disposals to the Burial Grounds have been tabulated from the Y-12 Plant records. The disposal records cover three main types of disposal practices: (1) blanket disposals that account for about two-thirds of the total waste in the Burial Grounds, (2) nonroutine hazardous disposals that account for a small proportion of the total wastes, and (3) other disposals that account for one-third of the total waste. Volumes or masses of wastes have been determined using, in order of completeness and usability of the data, the following sources:

- Y-12 Maintenance Division Monthly Activity Reports. These reports are available from January 1957 to the present (with roughly 1 month missing from the files per year).

- Requests for Hazardous/Classified Disposals (UCN-2109s and UCN-6538s). Approximately $11,300 \mathrm{UCN}-2109 \mathrm{~s}$ and 1,600 UCN-6538s have been entered into a computer data base. 
- Kardex Blanket File. Approximately $6(X)$ cards with 27,000 entries from the $1964-1980$ time period covering waste disposals under 170 blankets have been analyzed.

- Tanker Log. These records cover $-1,800$ liquid disposals on -25 different blankets during the 1971-1980 time frame. These logs have been transcribed into a computer data base.

- Vehicle Trip Log. These logs cover blanket, hazardous/classified, and other deliveries from the 1960 to 1980 time frame. Most of the information in vehicle trip logs is already recorded by the previous files and records, and the logs themselves are not standardized 20 they are difficult to evaluate. For these reasons, roughly $8 \%$ of vehicle trip logs (covering 290 days) were sampled and examined to statistically estimate the total deliveries for this time period. This analysis has been verified by comparison to the ongoing SWIMS program.

- Wate Management Inventory-Manifat Sytcm. Since 1980, all disposal information has been placed on a computerized data base. Over 13,000 disposals to the Bear Creek Burial Grounds have been recorded by this system. Since 1980, disposal records are complete and the quantities and compositions of wastes disposed of in the Burial Grounds since that time can be determined precisely.

The quantity and composition of $\mathbf{- 8 0 \%}$ of the blanket disposals mentioned in the Monthly Activity Reports have been tabulated. The blanket disposals account for approximately two-thirds of the total waste in the Burial Grounds; thus 53\% of the waste materials in the Burial Grounds has been tabulated using these records. It has been assumed that the waste documented by the $20 \%$ of blanket records that have not been tabulated are similar to those recorded in the $80 \%$ of records that have been tabulated. Therefore, using these blanket disposal records, wastes in the Burial Grounds can be characterized.

The total number of UCN-2109s for hazardous/classified waste disposals mentioned in the Monthly Activity Reports corresponds closely to the number of records tabulated, 80 the records of this type are essentially complete. The hazardous/classified deliveries account for a small fraction of total deliveries to the Burial Grounds, but the composition of many of these deliveries is of greater potential interest.

For the estimated one-third of all Bear Creek Burial Grounds deliveries that were neither hazardous nor blanket the Vehicle Trip Logs have been used to determine the quantity and makeup of the wastes. For these materials a random sample of working days with a statistical analysis of the sample was carried out and is detailed in the waste inventory report (Energy Systems 1983). Through the use of this random sample, the volume and composition of this remaining one-third of the wastes have been determined with ranges at specified levels of uncertainty.

In summary, the existing analysis of the waste delivery records and document activities at the Burial Grounds provides an inventory of the waste materials with a measurable degree of uncertainty. This provides a better characterization of waste materials than can be obtained by sampling all trenches in the Burial Grounds and with less risk posed to RI personnel.

Soil samples are needed to determine the nature and extent of secondary contamination that has migrated from the original location of the waste materials and has been captured by surrounding soils. Contaminants may have migrated either as nonaqueous-phase liquids and 
been trapped in pores or sorbed to soil particles, or as dissolved phase and been precipitated or sorbed at the surfaces of soil materials.

On the whole, past sampling of soils in BCV has not followed and/or documented QAVC procedures that meet current requirements. The historical soil database for each site is also relatively limited in extent; in many cases, the nature of the soils has changed since the last sampling event (e.g., a site has been capped or soils have been excavated). Where historical data are inadequate, soil sampling will be conducted to verify the level and extent of soil contamination.

The Summers Model for soll leaching (Summers et al. 1980; EPA 1989c) will be used to address the leaching of contaminants from the soil to the groundwater. Using a Monte Carlo Simulation will allow statistical ranges for parameter values to be input and will provide output in the form of a likely range of values. This model has been used to calculate eoil PRGs given the potential for contaminants in soll to leach to the groundwater. (See Chap. 5 of this work plan.)

Physical properties of selected soils will be determined to provide the information required for selecting engineering alternatives in the FS (Table 6.2).

\subsubsection{Groundwater and surfece water}

A substantial amount of groundwater monitoring data concerning the BCHR are available (HSW 1991, 1992); the Y.12 Plant groundwater data base contains information on 827 wells. Changes in groundwater quality that are the result of changes to a single source OU are more likely to be identified in shallow groundwater close to the source than in the deep aquifer where contributions from various sources conflow and become indeterminable. The groundwater data base was screened using the following criteria to obtain a list of wells that can be used to monitor shallow groundwater quality at the sites in BCV OU 1 and additionally support the BCV OU 4 RI work plan:

- Well beation-Wells within the boundaries and in the immediate vicinity of each site are used to monitor shallow groundwater.

- Aquifer and depth-Only wells that are screened in the unconsolidated deposits or that are leas than $9.1 \mathrm{~m}$ (30 ft) deep are used to monitor shallow groundwater.

Wells listed in Table 6.3 that are identified with a "W" in the OU 1 column meet the criteria for location, depth, and aquifer. Data from these wells will be used in the RI to analyze historical groundwater quality trends and to monitor groundwater quality. An " $S$ " in the OU 1 column indicates that data concerning soil analysis will be used from this boring, and reference is made to where these data are available.

The sample plan will not call for additional sampling of all of these wells because many will be sampled as part of the continued groundwater monitoring program at the Y.12 Plant and others will be sampled for the BCV OU 4 RI. Wells that will be sampled by this RI are listed in Chap. 7.

Data from deeper wells in the BCHR have been referred to in the site characterization sections of this RI work plan. 


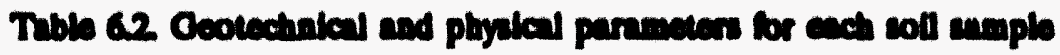

\begin{tabular}{|c|c|}
\hline Anclytiol parameder & Antyilol mothod \\
\hline Permeabllity & SW 846 Method 9100 \\
\hline Hydrnulic conductivity & SW 846 Method 9100 \\
\hline Poroulty & EM 1110.2 .1906 \\
\hline Orain slae (slove) & ASTM D422 \\
\hline Orain size (hydrometer) & ASTM D422 \\
\hline Mineral composition & X-Ray Diffraction/electron spectroscopy \\
\hline Bulk donsily & ASTM D4S31-86 \\
\hline Catlon exchange capacity & SW 846 Mathod S081 \\
\hline $\mathrm{pH}$ & SW 846 Method s045 \\
\hline Total organic carbon (bulk) & sW846 Method 9060 \\
\hline Total organic carbon $(<75 \mu \mathrm{m})$ & SW 846 Method 9060 \\
\hline Distribution coeflicient (Kd) & ASTM Method 4646 \\
\hline Molsture content & ASTTM D4959-89 \\
\hline
\end{tabular}

- As modined for colld modia per laboratory spectife methodolosy. Laboratory method will be submitted for review und approval. 
6. 11

Table 63. BCV OU 1 groundwater monitoriag wells

\begin{tabular}{|c|c|c|c|c|c|c|c|c|c|}
\hline Won & $\begin{array}{l}\text { Depeb } \\
\text { (i) }\end{array}$ & Prom & Aquiliat & $\operatorname{lom}_{\infty}^{\infty}$ & 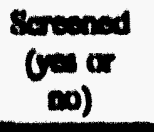 & suntur & ou 14 & $\operatorname{Pin}_{\min }$ & $\lim _{\lim }$ \\
\hline \multicolumn{10}{|c|}{ s.3 sin } \\
\hline $0 w \cdot 100$ & 20.7 & $\mathrm{Emn}$ & UNWB & $N$ & $\mathbf{Y}$ & $\mathbf{F}$ & $s$ & NA & NA \\
\hline OW.101 & 17.5 & En & UNB & $N$ & $Y$ & $\boldsymbol{F}$ & $W, s^{*}$ & 19.6 & 1991 \\
\hline ow.102 & 24.0 & En & $u$ & $N$ & & $\mathbf{P}$ & 5 & NA & $\mathrm{NA}$ \\
\hline OW.103 & 28.0 & $\epsilon_{n}$ & UNB & $N$ & & $p$ & $s$ & NA & NA \\
\hline OW.10s & 17.0 & en & UNWB & $N$ & $Y$ & $\mathbf{F}$ & $w$ & 1996 & 1990 \\
\hline aw.107 & 14.2 & $6 n$ & $u$ & $N$ & $y$ & $\mathrm{r}$ & $w$ & 1966 & 1900 \\
\hline OW.127 & 24.0 & $\mathrm{Emn}$ & UNEB & $N$ & $Y$ & $\underline{F}$ & $w$ & 1966 & 1990 \\
\hline OW.260 & $\mathbf{3 0 . 0}$ & $\epsilon \mathrm{m}$ & $u$ & $N$ & $Y$ & $\underline{F}$ & $w$ & 1926 & 1990 \\
\hline OW.276 & 18.5 & En & $w B$ & $N$ & $Y$ & $\mathbf{F}$ & $w$ & 1906 & 1990 \\
\hline OW.32S & 17.9 & En & $w B$ & $N$ & $Y$ & $\mathbf{F}$ & $w$ & 1987 & 1991 \\
\hline $0 W-617$ & 18.0 & $\mathrm{Emn}$ & U & $N$ & $Y$ & $\mathbf{F}$ & $w$ & 1990 & 1992 \\
\hline \multicolumn{10}{|c|}{ Bur Cont Buid Crounds } \\
\hline ow-014 & 13.2 & $\epsilon_{n}$ & UNWB & $N$ & $Y$ & $\mathbf{F}$ & $w, S$ & 1987 & 1990 \\
\hline ow-01s & 7.9 & En & UNBB & $N$ & $Y$ & $\boldsymbol{F}$ & s & NA & NA \\
\hline OW-016 & 17.1 & En & UNWB & $N$ & $\mathbf{Y}$ & $\boldsymbol{F}$ & $g$ & NA & NA \\
\hline OW-018 & 20.8 & En & WB & $\mathbf{N}$ & $\mathbf{Y}$ & $\mathbf{F}$ & W.S & 1991 & 1991 \\
\hline OW.020 & $\infty .1$ & En & WB & $\mathbf{Y}$ & & $\mathbf{p}$ & $g$ & NA & NA \\
\hline OW.021 & 15.0 & $\epsilon_{n}$ & WB & $\mathbf{N}$ & & $\mathbf{p}$ & $d$ & $i^{1987}$ & 1987 \\
\hline ow.024 & 79.7 & $E \mathrm{~m}$ & wB & $Y$ & & $\mathbf{P}$ & 5 & NA & NA \\
\hline OW-026 & 20.2 & $E \mathrm{~m}$ & WB & $\mathbf{N}$ & & $\mathbf{P}$ & $s^{\circ}$ & NA & NA \\
\hline OW-027 & 30.5 & $\epsilon m$ & $\mathbf{w B}$ & $\mathbf{N}$ & & $\mathbf{P}$ & $\boldsymbol{s}$ & 1987 & $h^{1988}$ \\
\hline OW-034 & 45.3 & $\mathrm{Em}$ & WB & $N$ & $y$ & $F$ & 5 & NA & NA \\
\hline ow-035 & 62.0 & $\mathrm{Em}$ & WB & $Y$ & & D & $s$ & NA & NA \\
\hline OW-036 & 39.1 & $\mathrm{Cr}$ & WB & $N$ & $y$ & $\mathbf{F}$ & $s$ & NA & NA \\
\hline ow-037 & 70.0 & $\varepsilon m$ & WB & $Y$ & $Y$ & $\mathbf{F}$ & $s$ & $?$ & $?$ \\
\hline OW-042 & 30.0 & Epv & WB & $N$ & $x$ & $\mathbf{F}$ & $w$ & 1987 & 1992 \\
\hline OW-04s & 15.2 & $\mathrm{Cmn}$ & U/WB & $N$ & $Y$ & $F$ & $w$ & 1987 & 1990 \\
\hline OW046 & 20.5 & $\epsilon_{n}$ & UNWB & $N$ & $Y$ & $\mathbf{F}$ & W,S & 1987 & 1990 \\
\hline
\end{tabular}




\begin{tabular}{|c|c|c|c|c|c|c|c|c|c|}
\hline$V N$ & VN & s & $d$ & $\lambda$ & $\lambda$ & GMN & 43 & g'cE & $810 \mathrm{MD}$ \\
\hline$V N$ & $\mathbf{V N}$ & $s$ & $d$ & $\lambda$ & $\lambda$ & $\mathbf{g}^{\mathrm{n}}$ & $\mathbf{u}_{3}$ & 809 & $110 \mathrm{MO}$ \\
\hline 0661 & 6861 & $N^{\prime} M$ & $a$ & $\lambda$ & $N$ & $a m n$ & 13 & o'st & OlomD \\
\hline$V N$ & $\mathbf{V N}$ & $s$ & d & & $\lambda$ & & 03 & 869 & $600 M D$ \\
\hline VN & $V N$ & s & 4 & $\lambda$ & $\lambda$ & $\mathbf{g}$ & 03 & 58 & $600 M D$ \\
\hline 0661 & 1861 & $S^{\prime} M$ & $d$ & $\lambda$ & $\mathbf{N}$ & $\mathbf{g m}$ & 13 & 591 & $\angle O O M D$ \\
\hline 1661 & 0.661 & $M S^{\prime} M$ & $d$ & $\lambda$ & $\mathbf{N}$ & $n$ & 13 & 521 & $500 M D$ \\
\hline$V N$ & $V N$ & s & $d$ & & $\lambda$ & & 13 & V'OS & $100 M D$ \\
\hline $\mathbf{V N}$ & VN & S & $d$ & & $\lambda$ & $\mathbf{g m}$ & $u_{3}$ & e'se & $\cos M D$ \\
\hline $\mathbf{V N}$ & $V N$ & $s$ & $d$ & $\lambda$ & $\lambda$ & $9 m$ & $\boldsymbol{w}_{3}$ & 009 & $200 M D$ \\
\hline $\mathbf{V N}$ & $V N$ & s & $d$ & $\lambda$ & $\lambda$ & $n$ & $\boldsymbol{\omega}_{3}$ & o'st & $100 M D$ \\
\hline \multicolumn{10}{|c|}{ Ex wo/p 1 no } \\
\hline 2661 & 1661 & $M$ & d & $A$ & $N$ & $\mathbf{g n}^{n}$ & $\omega_{3}$ & SSI & WSMD \\
\hline 2661 & 1661 & $M$ & $d$ & $\lambda$ & $N$ & an & $\omega_{3}$ & 862 & GMMD \\
\hline 2661 & 0661 & $M$ & $d$ & $\lambda$ & $\mathbf{N}$ & $\mathbf{g n}$ & 13 & 6 & IVMD \\
\hline 1661 & 0661 & $M$ & $d$ & $A$ & $N$ & $\mathbf{a n}$ & 43 & $c^{\prime} 48$ & $120 M \mathrm{MD}$ \\
\hline 2601 & 0661 & $M$ & $d$ & $\lambda$ & $N$ & $\mathbf{g} n$ & 43 & 506 & $89 \mathrm{MD}$ \\
\hline 1661 & 8861 & $M$ & $d$ & $\lambda$ & $N$ & g/an & $w_{3}$ & Bxyl & $162 \cdot M D$ \\
\hline 2661 & 2861 & $M$ & $d$ & $\lambda$ & $N$ & $\mathrm{~g} / \mathrm{gm}$ & 43 & 521 & $\angle 82 \cdot M O$ \\
\hline $0 \times 61$ & L86I & $M$ & $d$ & $\lambda$ & $N$ & $\mathbf{g}^{n}$ & ad 3 & $0^{\prime} \angle 1$ & $2 M \cdot M D$ \\
\hline 8061 & 8061 & $M$ & $d$ & $\lambda$ & $N$ & $g m n$ & บ413 & L'II & $48 \cdot M D$ \\
\hline 2601 & 0661 & $M$ & $d$ & $\lambda$ & $\mathbf{N}$ & $n$ & 13 & o's & $600 M D$ \\
\hline 2661 & 0661 & $M$ & $d$ & $A$ & $\lambda$ & $\mathbf{g m}$ & 43 & $\mathrm{O}^{\prime} \mathrm{Cl}$ & $600 M D$ \\
\hline 2661 & 0.661 & $M$ & I & $\lambda$ & $\mathbf{N}$ & $\mathbf{a n}^{n}$ & Iu & $00:$ & O:NMD \\
\hline 1661 & 0661 & $M$ & $d$ & $\lambda$ & $N$ & $g m$ & 13 & 112 & $8 \angle 0 M O$ \\
\hline 2061 & 6061 & $M$ & d & $A$ & $\lambda$ & gm & und & 0,5 & $190 M D$ \\
\hline 2661 & 1661 & $M$ & 4 & $\lambda$ & $A$ & gm & uw 3 & $0, s$ & $\angle S O M O$ \\
\hline 2681 & 0661 & $S^{\prime} M$ & $d$ & $\lambda$ & $A$ & ann & $u_{3}$ & L'68 & CSO-MO \\
\hline 2661 & 0661 & $M$ & $d$ & $\lambda$ & $N$ & $n$ & uw 3 & 561 & $250 M D$ \\
\hline 0661 & 2861 & $\boldsymbol{S}^{\prime} M$ & $d$ & $\lambda$ & $\mathbf{N}$ & $\mathrm{gm}^{m}$ & 43 & SSR & $\angle 6 N M D$ \\
\hline $\begin{array}{l}\operatorname{lip} \\
\operatorname{din} 5 \\
\ln 1\end{array}$ & nep & l no & Sinnos & $\begin{array}{c}(00) \\
000000\end{array}$ & $\begin{array}{c}(0 \pi \\
0 \times 0) \\
\infty \infty\end{array}$ & & & $\mathbf{a}$ & $m$ \\
\hline
\end{tabular}

(ponunuco) c9 994. 
$6 \cdot 13$

Table 6.3 (continued)

\begin{tabular}{|c|c|c|c|c|c|c|c|c|c|}
\hline well & $\begin{array}{l}\text { Depelh } \\
\text { (I) }\end{array}$ & Parme & Aquifor & $\underset{\text { (yes or }}{\operatorname{arr}}$ & $\begin{array}{l}\text { Saroened } \\
\left(\begin{array}{c}\text { (ves ox } \\
\text { no) }\end{array}\right.\end{array}$ & stutuse & Od $1^{d}$ & $\begin{array}{l}\text { Pint } \\
\text { your } \\
\text { inte }\end{array}$ & $\lim _{\ln }$ \\
\hline OW.044 & 70.0 & $E m$ & WB & $Y$ & $\mathbf{Y}$ & $\mathrm{F}$ & $\mathbf{s}^{i}$ & NA & NA \\
\hline OW.067 & 16.5 & Emn & $\mathbf{U}$ & $N$ & $\mathbf{Y}$ & $\mathbf{F}$ & $w$ & 1987 & 1990 \\
\hline OW-064 & 34.0 & $E m$ & WB & $\mathrm{N}$ & $\mathbf{Y}$ & F & $w$ & 1987 & 1992 \\
\hline OW.006 & 33.5 & En & wB & $\mathbf{N}$ & $\mathbf{Y}$ & $\mathbf{F}$ & $\mathbf{w}$ & 1990 & 1991 \\
\hline OW-087 & 19.0 & En & $\mathbf{U}$ & $N$ & $\mathbf{Y}$ & $\mathbf{F}$ & $w$ & 1987 & 1990 \\
\hline OW-097 & 19.2 & En & $w B$ & $\mathrm{~N}$ & $\mathbf{Y}$ & $\mathrm{F}$ & $w$ & 1987 & 1990 \\
\hline OW-637 & 27.5 & En & wB & $N$ & $\mathbf{Y}$ & $\mathrm{F}$ & w & 1991 & 1992 \\
\hline OW.638 & 12.0 & $E_{n}$ & UAWB & $\mathbf{N}$ & $Y$ & $\mathbf{F}$ & $w$ & 1991 & 1992 \\
\hline OW.64 & 23.4 & En & $w B / B$ & $\mathrm{~N}$ & $Y$ & $\mathbf{F}$ & $w$ & 1991 & 1992 \\
\hline GW649 & 20.8 & $E_{n}$ & wB & $\mathbf{N}$ & $\mathbf{Y}$ & $\mathbf{F}$ & $w$ & 1991 & 1992 \\
\hline
\end{tabular}

$E_{m n}=$ Maynaroville; $\epsilon_{n}=$ Nolichucky; $\epsilon_{m}=$ Marywille; $E_{r g}=$ Rogersville; $\epsilon_{p v}=$ Pumpkin Valley; Er $=$ Rutledge.

bU = unconeolidated overburden; WB = weathered bedrock; B = unweathered bedrock.

T = iniuhed; $P$ = pluered and abandoned; $D=$ destroyed.

is a eoll core data; $W$ - groundwater monitoring well data.

"Oeraghty and Miller 1935.

Horbes 1988.

Nell ampled in 1987 and then plusged.

"Well ampled in 1987 and 1988 and then pluaged.

'Mecauley 1984b.

jHerbes 1999. 
Validation of data concerning groundwater chemical analysis must be accomplished for the data set that is used in the RI. The repeatability of analyte concentrations displayed in the historical data partially validates these data, and $100 \%$ of these data are assumed to be validated to the equivalent of EPA Level III. Continued monitoring of all the wells listed in Table 6.3 is not warranted because sufficient historical data are available for each well to identify trends in groundwater quality for each of those wells. Sampling of sufficient wells to meet DQOs for data validation and continued monitoring of selected wells will be carried out in a manner equivalent to EPA Level IV to validate the existing data set. CLP methods will be used for all analyses.

Little information is available regarding the dynamics of groundwater recharge and the storm flow system in BCV. Studies performed on Solid Waste Storage Area (SWSA) 6 by ORNL (Solomon et al. 1991) indicate that a significant flux of contuminants can be transported by storm flow and that the presence of protective caps over waste trenches does not necessarily preclude recharge to groundwater through waste pits. The phenomenon of "bathtubbing," where water collects in a waste pit and slowly recharges to groundwater, has been observed in uncapped and capped pits at SWSA 6 (Ashwood and Spalding 1991). Lack of understanding of the storm flow system and aquifer recharge is a data gap at each waste site in this OU. Information will be gathered to identify recharge areas and flow paths of storm waters within each site. In general, this will require storm flow monitoring devices located upgradient and downgradient from sites that are likely to be affected by stormflow (Moore and Toran 1992) and shallow groundwater monitoring wells in trenches that are likely to "bathtub." Selected monitoring wells and all storm water monitoring devices will be equipped for continuous water level monitoring. Monitoring of the storm flow system at sites in BCV that have not been affected by waste sites was proposed in the draft RI work plan for the integrator OU (BCV OU 4). These data will be available to the BCV OU $1 \mathrm{RI}$ and will be evaluated as being representative of undisturbed storm water flow patterns and background storm water flow quality in BCV.

Surface water is an exit pathway for contaminants from BCV OU 1 and may be used to monitor contaminant migration from the sites. Stream sediments are also an exit pathway for soils eroded from sites in BCV OU 1. Surface water and stream sediments will be sampled to evaluate this pathway as part of the RI for BCV OU 4.

\subsubsection{Wetlands}

Wetlands are defined by three essential attributes: wetland hydrology, hydrophytic vegetation, and hydric soils. They generally include swamps, marshes, bogs, and similar areas. Wetlands at BCV OU 1 must be identified and evaluated because wetland function is legally protected. Wetlands may occur at BCV OU 1, especially near seeps or along Bear Creek or its tributaries, although the presence of wetlands at the S-3 Site is unlikely.

Wetlands at each source area will be identified from historical records, aerial photographs, and walk-over surveys. Soil and sediment samples within wetlands will be used to identify areas of contaminant deposition.

\subsubsection{Biological modia}

The baseline risk assessment includes consideration of both risk to humans and risk to natural resources (ecological risk). The process to be followed for ecological risk assessment 
(ERA) is outlined in Risk Assessment Guidance for Superfund, Volume II: Environmental Evaluation Manual (EPA 1989a), Ecological Assessments of Hazardous Waste Sites: A Field and Laboratory Reference Document (EPA 1989b), and Framework for Ecological Risk Assessment (EPA 1992c). The ERA process differs from the human health risk assessment in that the ERA focuses on populations and communities rather than on individuals. In the ERA process, risks to individuals are addressed only if the individuals are protected under the Endangered Species Act, are unique, or have sufficient other ecological value that individual consideration is merited. Therefore, the ERA will determine if and where there is imminent and substantial danger to the health of various animal and plant populations and habitats and if and where site remediation may be needed for long-term protection of the environment.

ERA for the source units will be based on entry of contaminants into the food web. Therefore, body burden analyses will be limited to organisms that have limited mobility, are exposed to contaminated physical media, and are important food items (i.e., grasses and browse, earthworms, terrestrial small mammals and burrowing mammals, and amphibian larvae).

Athough limited data are available to model biological effects of soil and surface water contaminants on biological receptors, modeled exposures may be much more conservative than field data support, therefore requiring more extensive remediation than actually needed. For this reason, it is prudent to gather direct data on biological exposures to ensure that realistic risk estimates arc made. Biota sampling will be designed to reveal movement of contaminants from BCV OU 1 sources into biotic receptors, including the food web as well as individual taxa; to evaluate ecological risks in source areas; and to provide the necessary information for ecological risk assessment of the integrator OU. Toxicity tests will reveal potential toxicological impacts to organisms exposed to physical media.

Specific objectives of the sampling and analysis of biota and associated physical media are as follows:

- To determine relative population levels of selected indicator species at various locations at BCV OU 1 and at nonimpacted reference sites.

- To determine whether species designated as threatened and endangered or in need of management are present in BCV OU 1 or whether habitat essential for their survival and reproduction is present.

- To determine concentrations of COCs in aquatic biotic systems.

- To determine concentrations of COCs in terrestrial ecosystems.

- To determine concentrations of COCs in BCV OU 1 surface water at the time of aquatic biota sampling.

- To determine concentrations of COCs in BCV OU 1 weiland soils and pond sediments at the time of aquatic biota sampling.

- To determine concentrations of COCs in natural vegetation used for food.

- To determine concentrations of COCs in the soils in which these plants were grown.

- To select exposure parameters and relevant scenarios for realistic exposures to higher trophic levels by ingestion of biota. 
Analytical data will be used to characterize exposures of aquatic biota and their predators and of terrestrial plants and small mammals and their predators to BCV OU 1 site contaminants. This information will be used along with population survey results to determine whether remedial actions are necessary for the protection of ecological populations at BCV OU 1. Chemical analyses of biota and the physical media by which they are exposed to site contaminants provide a link to demonstrate the extent to which contaminants move from the physical media to the exposed organisms. This link facilitates the identification of areas whose contaminants pose a threat to the biota present and thus helps identify areas in need of remediation. Consideration of uptake and biotransfer factors can help to set remedial goals for cleanup activities.

The primary sources of contaminants to aquatic and terrestrial biota in BCV OU 1 are releases of chemical and radiological contaminants by leaching from landfills. Surface runoff may serve as a primary release mechanism, transporting contaminants to soil. In addition, contaminants transported by surface runoff to tributaries within BCV OU 1 may expose aquatic biota, terrestrial animals, and waterfowl by ingestion or dermal contact. (Exposures in the tributaries to Bear Creek will be evaluated as part of the RI for BCV OU 4.) Contaminated soil is a secondary source of contaminants released to other environmental receptors and an exposure source to the biotic receptors. Vegetation may be exposed by root uptake or direct contact. Terrestrial animals and birds may be exposed to contaminants in soil directly by ingestion and dermal contact or indirectly by ingestion of vegetation contaminated by uptake of contaminants from soil. Air and groundwater are assumed not to provide significant direct exposures for biota.

Ecological communities will be characterized by historical and field data, using surveys designed to determine the number and distribution of indicator species chosen to reveal significant exposures of biota to site contaminants. Data from each sample site will be compared with data from the appropriate reference site and from each of the other BCV OU 1 sites to determine whether there are differences from an unaffected site or differences among sites related to their location on BCV OU 1. Historical survey information will also be used to determine whether there are threatened and endangered species or critical habitats in the BCV OU 1 area.

Earthworms will be sampled as indicators of biotransfers from soil into the food web. Terrestrial small mammals will be trapped, identified, and counted; and selected individuals will be analyzed for whole-body burden of COCs. Groundhogs will be sampled as integrators of contaminants potentially removed from subsurface soils by burrowing. Aquatic insects and amphibia will be sampled as indicators of contaminant uptake from surface water streams and seeps. Grasses and browse will be analyzed as sources of contaminants to herbivores by ingestion. Communities of terrestrial vegetation will be characterized by walk-over surveys. The sampling locations will be chosen to maximize the comparability of physical media sampling data with biological sample data. All populations and habitat characterizations will be compared with similar characterizations performed on reference areas of $B C V$ not affected by BCV OU 1 site contaminants.

Wetland vegetation will be sampled as an indicator of biotransfers of wetland contaminants into the food web. In wetlands whose surface waters are sufficiently ponded to support aquatic biota, sediment samples will be taken for sediment toxicity tests, and amphibian larvae will be sampled for contaminant body burdens. So that the exposure assessment can be limited to wetland surface water and sediment as contaminant sources, 
larvae must be sampled rather than adults, which are exposed via terrestrial food sources. Therefore, sampling of amphibians must be done during the short time period when tadpoles are present in surface water. Filtered surface water will be sampled to determine the direct exposure concentrations, as particulate contaminants are typically not available to aquatic biota. These samples may be scheduled to coincide with sampling for the integrator OU.

Based on historical data, contaminants detected above contract reporting limits in surface water, soils, and sediments at BCV OU 1 include metals, PCBs, polycyclic aromatic hydrocarbons (PAHs), and radionuclides. PCBs, PAHs, and some inorganics will be of concern because of their bioaccumulative properties. PCBs are toxic and persistent in the environment and will be analyzed in biota samples. Standard EPA SW-846 methods, with revisions as necessary, will be used to analyze for PCBs and PAHs. Volatile organics will not be analyzed in biological tissues. Neutron activation analyses for metals will be performed on all biota samples.

Toxicity testing of surfáce water, sediment, and soil will reveal cumulative toxic effects of contaminants in physical media to indicator animals and plants and, by extension, potential toxic effects to biota exposed on site to the contaminated soils. Toxicity testing will be done by standardized EPA-approved procedures.

A phased approach to sampling of biota will maximize the amount of useful information gained within the sampling budget. Small mammals are exposed to contaminants in surficial soils both directly and via the food web. If no soil contaminants are found in the rooting zone and above, it is unlikely that contaminants could be transferred to plants, earthworms, insects, or surface-dwelling animals. Burrowing animals may be exposed to contaminants at deeper levels, but they would need to be sampled only if contaminants are found in subsurface soils. Therefore, ecological sampling will be delayed until the results of the Phase 1 soil and wetland sediment sampling are reviewed.

The process for determining what ecological sampling will be done is outlined in Fig. 6.2. Areas where soil contaminants exceed twice background concentrations will be identified, and a vegetation sample and an earthworm sample will be taken within each of these hot spots. If contaminant concentrations in the biota indicate bioconcentration relative to the soil, additional samples will be taken according to a statistical design that will reveal the area of contamination. If vegetation appears unhealthy in the hot-spot area, soil samples will be tested for phytotoxicity by a seed germination assay. If the population density of earthworms is below the 5\% lower bound of the density at the reference site, the population will be tested during Phase 2 to indicate the boundaries of the toxic zone.

When amphibian larvae are found in ponds and wetlands, they will be observed visually to evaluate normal development and will be sampled as they reach maturity. One surface water and one sediment sample will be taken from each area in Phase 1. If contaminant concentrations are elevated, additional samples will be taken during Phase 2 to delineate the area of contamination. If amphibian larvae are not found in contaminated ponds or wetlands when they are present in reference areas, toxicity of the surface water will be evaluated by a Ceriodaphnia toxicity test. 


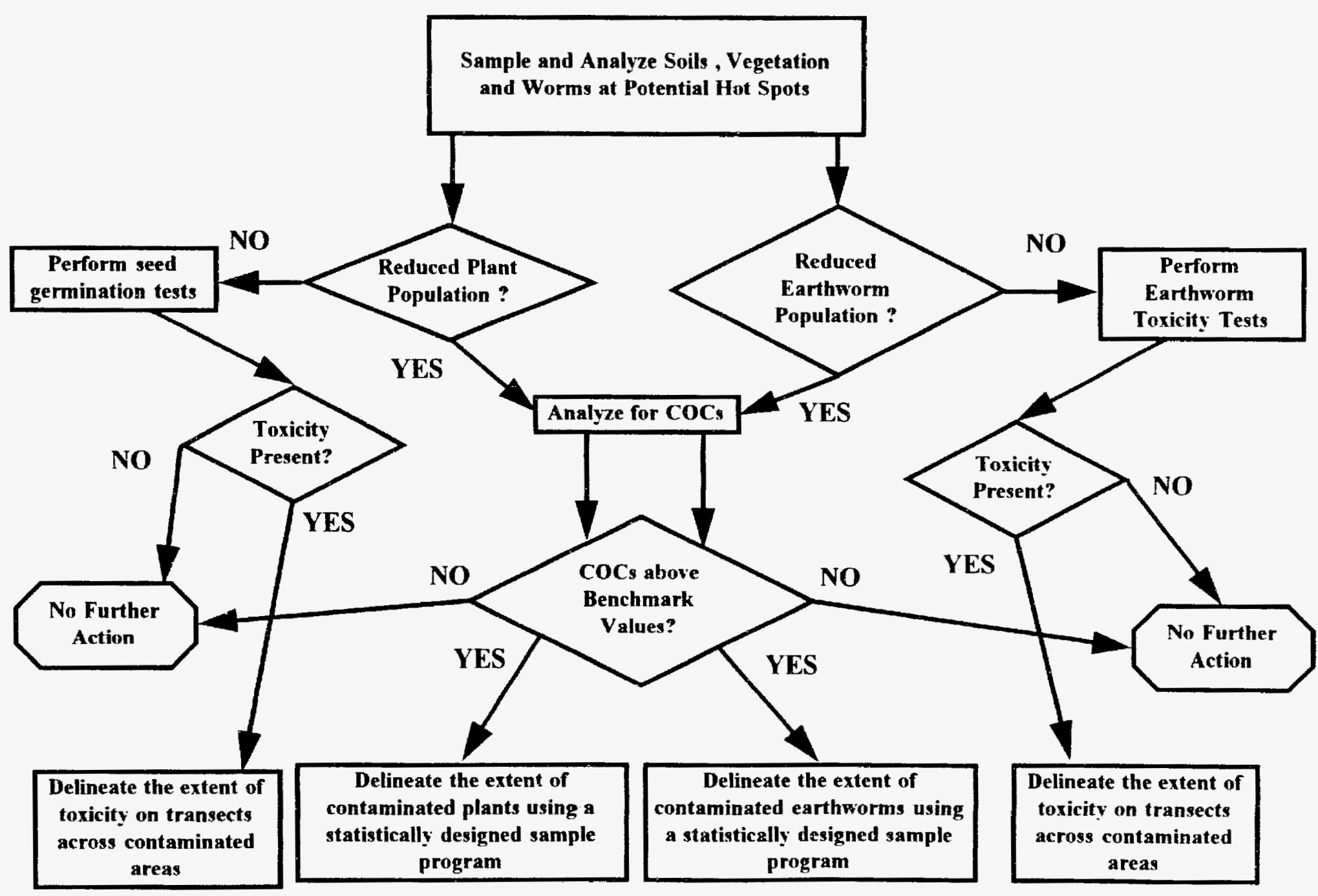

Fig. 6.2 Decision process for Phase 1 biota sampling and analysis. 


\subsubsection{Ecological endpoints}

An ecological endpoint is a characteristic of an ecological component (e.g., increased mortality in fish) that may be affected by exposure to a stressor (Suter 1990). Two types of endpoints are discussed in Suter's report: assessment and measurement endpoints. Assessment endpoints are explicit expressions of actual environmental value that is to be protected. Measurement endpoints are measurable responses to a stressor that are related to the valued characteristics chosen as the assessment endpoints (Suter 1990). When an assessment endpoint can be measured directly, the measurement and assessment endpoint are the same. In most cases, however, the assessment endpoint cannot be measured directly, so a measured endpoint is selected that can be related, either qualitatively or quantitatively to the assessment endpoint. Assessment policy goals and measurement endpoints are described in Table 6.4 and were developed within the context of the guidance in EPA (1992c) and Suter (1993).

\subsubsection{Site-Specific Physical Characterization Activities}

Site-specific data needs are summarized in Table 6.5. Figure 6.1 locates each site in the staged RI process that is described in Chap. 1.

\subsection{S-3 Site}

Historical data are sufficient to show that the S-3 Site constitutes no immediate hazard to human health or the environment; however, hazardous wastes are buried at this site and may pose a long-term risk to human health or to the environment. Therefore, using the staged RI process outlined in Chap. 1, Stage 1 was completed, and the decision was made to continue the RI. This section outlines the data needed to complete Stage 2 of the staged RI/FS process for the S-3 Site.

S-3 Site soils and solid wastes. Prior to installation of the RCRA cap, sludges in the ponds were analyzed for a range of contaminants and then stabilized using a coarse aggregate that was probably limestone. Outside the physical boundaries of the S-3 Ponds, little information has been gathered concerning the nature and extent of contamination in the soils that may have occurred as the result of reprecipitation or sorption of contaminants on particle surfaces in soils and that may contaminate groundwater by matrix diffusion. Data exist from four soil cores (GW-100, GW-101, GW-103, and GW-102) that indicate the presence of PCBs surrounding the S-3 Site both in shallow soils [<0.6 $\mathrm{m}(2 \mathrm{ft})]$ and at depth $[3.7 \mathrm{~m}(12 \mathrm{ft})]$. At GW-102, chlordane was found between depths of 4-12 ft. Traces of VOCs were also found in the soil samples from GW-102. Radioactivity (chiefly as uranium) and concentrations of metals above background levels (especially mercury) were detected in stream sediments and chemical precipitates in the main branch of Bear Creek adjacent to the S-3 Site and in NT-1 (Turner and Kamp 1984). This indicates that, during operation of the S-3 Ponds, radionuclides and metals migrated via groundwater to surface water and precipitated in the stream bed.

To address the nature and extent of contamination in waste materials, documentation to support validation of the existing data set concerning waste composition is needed. The nature and extent of contamination that has migrated to soils surrounding the S-3 Site by way of groundwater need to be determined. 
Table 6.4. Assessment policy goals and measurement endpoints

\begin{tabular}{|c|c|c|}
\hline Policy goal & Assessment endpoint & Measurement endpoint \\
\hline $\begin{array}{l}\text { The conservation } \\
\text { of threatened, endangered } \\
\text { and rare species and their } \\
\text { critical habitats }\end{array}$ & $\begin{array}{l}\text { No adverse impact on survival } \\
\text { or reproduction of any state or } \\
\text { federally designated threatened } \\
\text { or endangered species and } \\
\text { their critical habitat on the } \\
\text { BCV }\end{array}$ & $\begin{array}{l}\text { a. Surveys of the presence or } \\
\text { absence of species and their } \\
\text { habitats in the BCV } \\
\text { b. Maintenance of plant } \\
\text { community composition } \\
\text { and/or structure required } \\
\text { for rare plant and other } \\
\text { support species } \\
\text { c. The abundance and } \\
\text { distribution of plant and } \\
\text { animal species that would } \\
\text { support threatened, rare, or } \\
\text { endangered species }\end{array}$ \\
\hline $\begin{array}{l}\text { The protection } \\
\text { of migratory birds }\end{array}$ & $\begin{array}{l}\text { No killing of or adverse impact } \\
\text { to migratory birds as a result } \\
\text { of exposure to site-specific } \\
\text { stressors }\end{array}$ & $\begin{array}{l}\text { Contaminant concentrations } \\
\text { in selected } \mathrm{BCV} \text { food sources } \\
\text { for migratory birds (to be } \\
\text { evaluated as part of the BCV } \\
\text { OU } 4 \mathrm{RI} \text { ) }\end{array}$ \\
\hline $\begin{array}{l}\text { The preservation } \\
\text { of wetlands }\end{array}$ & $\begin{array}{l}\text { The presence and structure/ } \\
\text { function of wetlands in relation } \\
\text { to contaminants }\end{array}$ & $\begin{array}{l}\text { Survey of wetlands and } \\
\text { associated contamination levels, } \\
\text { if any, on the Bear Creek } \\
\text { floodplain }\end{array}$ \\
\hline $\begin{array}{l}\text { No adverse effects } \\
\text { from contaminants } \\
\text { to aquatic indicator } \\
\text { organisms and/or predators } \\
\text { that feed on them }\end{array}$ & $\begin{array}{l}\text { a. The ratio of concentrations } \\
\text { of contaminants in ponds } \\
\text { and wetland surface water } \\
\text { to water quality criteria } \\
\text { for protection } \\
\text { of aquatic life should be } \leq 1 \\
\text { b. The ratio of body burdens } \\
\text { of contaminants in indicator } \\
\text { organisms to levels expected } \\
\text { to cause toxicological } \\
\text { effects should be } 51 \\
\text { c. The ratio of body burdens } \\
\text { of contaminants in aquatic } \\
\text { biota to levels expected } \\
\text { to be protective } \\
\text { of predators should be } \leq 1 \\
\text { d. Surface water in ponds and } \\
\text { wetlands should not be } \\
\text { toxic to aquatic biota }\end{array}$ & $\begin{array}{l}\text { a. Contaminants in water } \\
\text { b. COC concentrations } \\
\text { in whole body samples } \\
\text { of indicator species } \\
\text { c. COC concentrations } \\
\text { in whole body samples } \\
\text { of aquatic indicator species } \\
\text { d. Ceriodaphnia toxicity tests }\end{array}$ \\
\hline $\begin{array}{l}\text { The existence of a } \\
\text { terrestrial animal } \\
\text { community indicative } \\
\text { of undegraded conditions }\end{array}$ & $\begin{array}{l}\text { Diversity, abundance, and } \\
\text { distribution of terrestrial } \\
\text { animals should not result in a } \\
\geq 20 \% \text { decrease compared } \\
\text { with background conditions }\end{array}$ & $\begin{array}{l}\text { Population abundance and } \\
\text { distribution by habitat }\end{array}$ \\
\hline
\end{tabular}


Table 6.4 (continued)

\begin{tabular}{|c|c|c|}
\hline Policy gon & Aseessment endpoint & Measurement endpoint \\
\hline $\begin{array}{l}\text { No adverse effect } \\
\text { from contaminants } \\
\text { to terrestrial indicator } \\
\text { organisms }\end{array}$ & $\begin{array}{l}\text { a. The ratio of body burdens } \\
\text { of contaminants in indicator } \\
\text { organisms to levels expected } \\
\text { to cause toxicological } \\
\text { effects should be } 51 \\
\text { b. Contaminated soils should } \\
\text { not be toxic to plants or } \\
\text { soil invertebrates }\end{array}$ & $\begin{array}{l}\text { a. COC concentrations } \\
\text { in whole body samples } \\
\text { of terrestrial indicator } \\
\text { species } \\
\text { b. Seed germination and } \\
\text { earthworm toxicity tests on } \\
\text { contaminated solls }\end{array}$ \\
\hline
\end{tabular}

Sources: EPA 1992c; Suter 1993; Suter 1990. 
Table 65. Rationale for sampling OU 1 sites

\begin{tabular}{|c|c|c|c|}
\hline Site name & $\begin{array}{l}\text { Sampling } \\
\text { proposed }\end{array}$ & $\begin{array}{c}\text { Sampling } \\
\text { type }\end{array}$ & Rationale \\
\hline S-3 Ponds & Yes & $\begin{array}{l}\text { Soil borings } \\
\text { Groundwater } \\
\text { Storm water }\end{array}$ & $\begin{array}{l}\text { Confirm nature and extent of waste materials currently in place. Determine nature } \\
\text { and extent of contaminants that have migrated away from the ponds and now } \\
\text { reside in the surrounding soils. Determine hydrogeologic and chemical properties } \\
\text { of contaminated soiks for transport models. Determine quality of shallow } \\
\text { groundwater immediately downgradient of the waste. Define the stormflow system. } \\
\text { Gather physical property data for FS }\end{array}$ \\
\hline Oil Landfarm & Yes & $\begin{array}{l}\text { Soil borings } \\
\text { Groundwater } \\
\text { Storm water }\end{array}$ & $\begin{array}{l}\text { Define nature and extent of soil contamination down gradient of the Oil Landfarm } \\
\text { cap. Determine surface water quality during the stormflow stage. Determine water } \\
\text { quality in shallow groundwater immediately downgradient of the cap. Evaluate the } \\
\text { impact of stormflow on contaminated soil beneath the cap. Gather physical } \\
\text { property data for FS }\end{array}$ \\
\hline $\begin{array}{l}\text { Boneyard/Burnyard } \\
\text { and Hazardous } \\
\text { Chemical Disposal } \\
\text { Area }\end{array}$ & Yes & $\begin{array}{l}\text { Walk-over survey } \\
\text { Radiological survey } \\
\text { Geophysical survey } \\
\text { Surface soils } \\
\text { Soil borings } \\
\text { Groundwater } \\
\text { Surface water }\end{array}$ & $\begin{array}{l}\text { Perform geophysical and radiological screening of the whole site to identify hot } \\
\text { spots. Sample soil to define the nature and extent of soil contamination in hot spot } \\
\text { areas and to determine if soil contamination exists outside of hot spot areas. } \\
\text { Determine quality of shallow groundwater in contact with and immediately } \\
\text { downgradient of hot spot areas. Define the surface water and soil erosion pathways. } \\
\text { Gather physical property data for FS }\end{array}$ \\
\hline SL 1 & Yes & $\begin{array}{l}\text { Soil borings } \\
\text { Groundwater }\end{array}$ & $\begin{array}{l}\text { Determine if groundwater immediately downgradient of SL } 1 \text { is impacted by this } \\
\text { site }\end{array}$ \\
\hline Burial Grounds & Yes & $\begin{array}{l}\text { Radiological survey } \\
\text { Geophysical survey } \\
\text { Soil borings } \\
\text { Surface soils } \\
\text { Groundwater } \\
\text { Surface water }\end{array}$ & $\begin{array}{l}\text { Define the nature and extent of waste materials in various waste trenches. Define } \\
\text { nature and extent of soil contamination in the vicinity of waste trenches. Identify } \\
\text { radiological hot spots outside the waste trenches. Determine surface water quality } \\
\text { during the stormflow stage. Determine water quality in shallow groundwater } \\
\text { immediately downgradient of trenches. Define the stormflow system and the } \\
\text { likelihood of storm water impacting contaminated soil beneath the cap. Gather } \\
\text { physical property data for FS }\end{array}$ \\
\hline
\end{tabular}


TCLP for listed metals and organics, hydrologic properties of contaminated soils, and data to address the potential for stormflow to access the waste are needed to address the potential for off-site migration of contaminants.

The data required to complete the $\mathrm{RI}$ at the S-3 Site will be obtained from soil borings in the area surrounding the site. The off-site soil borings will be located to intercept likely groundwater flow paths by locating borings in line with identified seeps in Bear Creek.

S-3 Site groundwater and surface water. Eight groundwater monitoring wells in the vicinity of the S-3 site meet the criteria for screen depth and location to be used by the RI (Table 6.3). For shallow groundwater in the unconsolidated deposits, no well exists upgradient of the S-3 Site; however, the S-3 Site is close to the groundwater divide between BCV and UEFPC hydrogeologic regimes, and it is unlikely that any sources for contamination exist upgradient. The present groundwater monitoring wells are adequate to monitor groundwater off site.

The effect of the S-3 Site cap on the hydrology of the stormflow system is not known. However, because the S-3 Site is almost completely surrounded by asphalt roads and other construction and is located on a topographic high, it is likely that the site is isolated from the stormflow recharge area; therefore, it is unlikely that the wastes below the cap at the S-3 Site will be affected by stormflow.

Historical data indicate that past contamination of surface water draining the S-3 Site has come mainly from contaminants migrating through the groundwater to seeps and springs in Bear Creek. The presence of the asphalt cap over the ponds precludes any direct contamination of surface water by contaminated soils and waste at the site. The contaminant pathways to surface water by way of groundwater will be addressed by the current groundwater monitoring network and surface water sampling proposed for BCV OU 4. Surface water sampling is, therefore, not warranted at this site.

Biota sampling and toxicity testing. Because there is very little natural habitat at the S-3 Site, biota sampling and toxicity testing will not be done at this site.

\subsection{Oil Landfarm}

Historical data are sufficient to show that the Oil Landfarm constitutes no immediate hazard to human health or the environment; however, soil contamination exists at this site and may pose a long-term risk to human health or the environment. Therefore, using the staged RI process outlined in Chap. 1, Stage 1 was completed and the decision was made to continue the RI (Fig. 6.1). This section outlines the data needed to complete Stage 2 of the staged RI/FS process for the Oil Landfarm.

Oil Landfarm eoils and solid waste. Before the Oil Landfarm was capped in 1990, extensive soil sampling was carried out in the various plots within the Landfarm. More than 200 samples were taken in a two-phase study and analyzed for PCBs, uranium, oil, and grease (Herbes 1988). Soils exceeding $25 \mathrm{mg} / \mathrm{kg}$ PCBs were excavated and removed from the site. The remaining soils were left in place.

Nineteen stream sediment samples and nine soil borings were taken in the vicinity of the Oil Landfarm, the Boneyard/Burnyard, and SL 1 during four studies between 1983 and 1991 
(McCauley 1984a; Herbes 1989; Geraghty and Miller 1985; Turner et al. 1991). PCB contamination has been recorded in soils outside the Oil Landfarm cap at a depth of $11 \mathrm{~m}$ (6 f ) (Chap. 8); however, no information concerning soil contamination is available for surface soils in this area. Tributary sediments show little or no contamination; this indicates that there is little contamination of shallow soils outside the Oil Landfarm cap.

To address the nature and extent of contamination in soils beneath the cap, documentation is needed to support $Q A$ procedures.

The Summers Model for soil leaching (EPA 1989c) will be used to evaluate the potential for off-site migration of contaminants from soil beneath the cap. Use of a Monte Carlo Simulation allows statistical ranges for parameter values to be input, and this model provides output in the form of a likely range of values. Data required for input to this model were listed in Table 6.2. These data can be obtained by testing native soils surrounding the Oil Landfarm cap. Large quantities of oils were disposed of at this site. The extent of soil contamination resulting from migration of LNAPL away from the site on groundwater needs to be determined.

Oil Landfarm groundwater and surface water. Eighteen groundwater monitoring wells in the vicinity of the Oil Landfarm meet the criteria for screen depth and location to be used by the RI (Table 6.1). Upgradient wells that were screened in shallow groundwater in the unconsolidated deposits are wells $\mathrm{GW}-13$ and $\mathrm{GW}-43$. The remainder of the wells in the unconsolidated deposits are located downgradient to the south and west of the Oil Landfarm. The present shallow groundwater monitoring wells are adequate to monitor changes in shallow groundwater downgradient of the Oil Landfarm cap.

The recharge area for the stormflow upgradient of the Oil Landfarm is isolated from this site by the Burial Grounds access road. Therefore, stormflow will not be evaluated at this site.

Habitats. Habitat delineations in the Oil Landfarm vicinity will reveal the locations of protected habitats and habitats where the ecological indicator receptors are likely to be exposed to site contaminants.

- Phase 1: Wetlands in the vicinity of the Oil Landfarm will be identified from historical information and walkover surveys. The size and location of each wetland, as well as a description of the associated vegetation, will be recorded. Aquatic and terrestrial habitats will be delineated throughout the Oil Landfarm site. The locations of various habitat types will be entered in the Goverment Information System mapping system.

- Phase 2: No additional habitat delineation is anticipated for Phase 2.

Biota sampling and toxicity testing. Organic constituents of waste oil are likely to be toxic to earthworms and other soil organisms. Metal and radionuclide contaminants are also likely to be transferred from soil to the food web. Biota sampling will be focused on areas shown during Phase 1 to contain physical media contaminants. Likely sampling sites are downslope from the cap, where leachate from the waste areas may have contaminated surface soils.

- Phase 1: Grasses and browse and earthworms will be sampled in areas of probable surface soil contamination as delineated by the screening radiological survey. If the populations are reduced (as described in Fig. 6.2), then the soil samples will be taken at 
each location for phytotoxicity and carthworm toxicity teats. Amphibian larvae will be sampled for whole-body contaminant burdens in wetlands that are found to be contaminated and that contain sufficient water to support the development of amphibians. One surface water sample and one sediment sample will be analyzed for $\mathrm{COC}$ at each location.

- Phase 2: Terrestrial small mammals will be sampled in appropriate habitat identified by the habitat survey. Statistically designed sampling of grasses and browse and earthworms will be done in areas shown in Phase 1 to contain contaminated biota (Sect. 6.1.1.4). Wetlands shown in Phase 1 containing contaminated amphibian larvae will be sampled further to delineate the extent of contamination in soil, sediment, and water by taking additional soil or paired surface water/sediment samples to be analyzed for COCs. Wetland areas will be divided into subareas, roughly $20 \mathrm{~m}^{2}\left(66 \mathrm{ft}^{2}\right)$, and a sample location will be placed at random within each subarea.

\subsection{Boneyard/Burnyard and HCDA}

Historical data are sufficient to indicate that the Boneyard/Burnyard and HCDA do not constitute immediate hazards to off-site receptors. These data are not sufficient to indicate whether these sites constitute immediate hazards to on-site human health or the environment. Uncontrolled soll contamination exists at this site and may pose both immediate and long. term risks to human health or the environment. Therefore, using the staged RI process outlined in Chap. 1, Stage 1 must be completed for the Boneyard/Burnyard before the staged RL/FS process can continue (Fig. 6.1). This section outlines the data needed to complete Stages 1 and 2 of the staged RI/FS process for the Boneyard/Burnyard and HCDA. Data needs for Stage 2 will be refined based on the results of Stage 1. The likely situation that may requirc a removal action at the completion of Stage 1 is the presence of partially buried uncontrolled hazardous waste that constitutes a hazard to on-site workers. This waste will need to be excavated before the staged RI/FS can continue.

Bongyand/Burayard coils and solid watca. A walk-over radiological survey and an electromagnetic conductivity survey (Energy Systems 1984a) have identified a number of areas of likely contamination in and near the Boneyard/Burnyard. Soil samples from soil borings on the northwestern perimeter of the Boneyard/Burnyard show contamination with VOCs, PCBs, and metals. A single stream sediment sample from NT-4, downstream of this point, recorded contamination with VOCs in 1984. The northwestern margin of the Boneyard/Burnyard is the location of a distinct conductivity high, suggesting a possible location for wastes. This area was also the site of high alpha and beta emissions in the walk-over radiological survey. The geophysical survey recorded sporadic conductivity highs throughout the Boneyard/Burnyard; however, the sample spacing was too great to define areas of high conductivity.

The Boneyard/Burnyard is a $\mathbf{- 3 . 2}$.ha (8-acre) area of land; to address the nature and extent of waste and contamination in soils, a systematic phased approach in which rapid field screening of contaminant distribution followed by stratified random sampling based on the results of the screening will be employed. The data needs for Stage 1 will be satisfied by the field screening, and a decision for removal action will be made on completion of this stage. Data from the screening process will then be used on which to base a stratified sampling plan in Stage 2 of the RI. 
The field screening will consist of a systematic observational and radiological walk-over survey followed by a geophysical survey. The walk-over survey will be conducted to identify partially buried waste material or waste material that is close to the surface and that constitutes a hazard. The locations of waste materials and trenches at the Boneyard/Burnyard are not known; geophysical screening methods will be used to determine the locations of the trenches. Electromagnetic conductivity has already proved to be an effective method for locating contamination at this site, and recent improvements to thesc techniques have resulted in better methods for data acquisition and interpretation (Nyquist and Emery 1993). To locate waste trenches and areas where solid wastes possibly exist, an electromagnetic survey will be carried out using equipment capable of screening the upper 1 to $2 \mathrm{~m}(3.3106 .6 \mathrm{ft})$ of the soils. Both the walk-over surveys and the geophysical survey will cover adequate ground outside the boundaries of the Boneyard/Burnyard to ensure that background levels are recorded. There are almost no data that relate to the nature and extent of soil contamination. For Phase 1, soil sampling needs to be carried out on a coarse grid over the whole site.

Phase 2 soil sampling will need to be carried out by trenching and/or soil boring at likely targets identified by the geophysical and radiological surveys. Trenches are preferable to borings because they provide substantially more information where heterogenous waste are concerned and require little additional effort at this site where groundwater is probably $<5 \mathrm{~m}$ (16.4 $\mathrm{ft}$ ) below ground surface. Soil samples will be taken from the trenches and borings and analyzed for the complete list of analytes.

To address the potential for contaminants to migrate away from the waste materials, the Toxicity Characteristic Leaching Procedure (TCLP) will be performed on selected soil and waste samples for Phase 2 samples. Hydrological and engineering properties of soils and wastes will be determined.

Boncyand/Burnyard groundwater and surface water. Groundwater at the Boneyard/Burnyard is presently monitored in five wells screened in the unconsolidated deposits (GW.5, GW-67, GW-84, GW-86, and GW-87).

Wells $G W-84$ and $G W .86$ are screened in the unconsolidated deposits upgradient of the Boneyard/Burnyard. Wells GW-67 and GW-87 are screened in unconsolidated deposits downgradient on the southern margin of the site near Bear Creek. Well GW.5 is located on the western bank of Tributary NT.3 and, therefore, may not capture groundwater from the Boneyard/Burnyard; however, the boundaries of the Boneyard/Burnyard are not well defined and contaminants associated with operations at the Boneyard/Burnyard may not be restricted to the eastern bank of NT.3. Groundwater for Well GW.087 has shown contamination with VOCs (trichloroethene, 1,1,1-trichloroethane, perchloroethene, dichloroethene, and benzene) and radionuclides (gross alpha, gross beta, and thorium), an indication that shallow groundwater at the Boneyard/Burnyard has been contaminated.

The present shallow groundwater monitoring wells are adequate to monitor changes in groundwater moving off site; however, no information is available concerning groundwater quality on site. Shallow groundwater wells will be installed in selected waste trenches, and the quality of the groundwater in the trenches will be monitored.

Habitats. Habitat delineations at the Boneyard/Burnyard and HCDA will reveal the locations of protected habitats and habitats where the ecological indicator receptors are likely to be exposed to site contaminants. 
- Phase 1: Wetlands in the vicinity of the Boneyard/Burnyard and HCDA will be identified from historical information and walkover surveys. The size and location of each welland, as well as a description of the associated vegetation, will be recorded. Aquatic and terrestrial habitats will be delineated throughout the site. The locations of various habitat types will be entered in the Goverment Information System mapping system.

- Phase 2: No additional habitat delineation is anticipated for Phase 2.

Blota sampling and toxicity teating. Organic constituents of hazardous wastes are likely to be toxic to earthworms and other soil organisms. Metal and radionuclide contaminants are also likely to be transferred from soil to the food web. Biota sampling will be done during Phase 2 and will be focused on areas shown during Phase 1 to contain physical media contaminants. Likely sampling sites are downslope from the cap, where leachate from the waste areas may have contaminated surface soils.

- Phase 1: Orasses and browse and carthworms will be sampled in areas of probable surface soil contamination as delineated by the screening radiological survey. If the populations are reduced (as described in Fig. 6.2), then the soil samples will be taken at each location for phytotoxicity and carthworm toxicity tests. Amphibian larvae will be sampled for whole-body contaminant burdens in wetlands that are found to be contaminated and that contain sufficient water to support the development of amphibians. One surface water sample and one sediment sample will be analyzed for COCs at each location.

- Phase 2: Terrestrial small mammals will be sampled in appropriate habitat identified by the habitat survey. Statistically designed sampling of grasses and browse and earthworms will be done in areas shown in Phase 1 to contain contaminated biota (Sect. 6.1.1.4). Wetlands shown in Phase 1 containing contaminated amphibian larvae will be sampled further to delineate the extent of contamination in soil, sediment, and water by taking additional soll or paired surface water/sediment samples to be analyzed for COCs. Wetland areas will be divided into subareas, roughly $20 \mathrm{~m}^{2}\left(66 \mathrm{ft}^{2}\right)$, and a sample location will be placed at random within each subarea.

\subsection{SL 1}

Historical data are not sufficient to indicate whether the SL 1 constitutes an immediate hazard to human health or the environment. Hazardous wastes may not exjst at this site; therefore, it is likely that this site poses no immediate or long-term risk to human health or the environment. Using the staged RI process outlined in Chap. 1, Stage 1 needs to be completed for SL 1 and may result in a recommendation for no further investigation, unless hazardous wastes are discovered (Fig. 6.1). Y-12 Maintenance records will be evaluated to determine whether hazardous wastes were put into SL 1. A groundwater monitoring well will be installed downgradient from the SL 1 site. If hazardous wastes are not being released from SL 1, then no further investigation will be recommended.

\subsection{Bear Creek Burial Grounds}

Historical data for the Bear Creek Burial Grounds indicate that there are substantial volumes of hazardous waste materials at this site that may pose long-term risks to human health or the environment. Activities at the Burial Grounds conducted under RCRA closure operations have substantially reduced the immediate hazards posed by these sites. BG.A 
North, BG-A South, BG.C West, and ORPs 1 and 2 have been capped with RCRA caps. A clay cap covers the original location of Tributary NT.7. Water now drains from this area through a constructed drainage channel. A leachate collection system, consisting of a series of buried porous and double-line pipes, captures leachate from various seeps in the NT.7 and NT.8 watersheds. Following the staged RI process outlined in Chap. 1, minimal data will be required to complete Stage 1 . The $\mathrm{RI}$ will continue whether removal actions are required or not; therefore, the data needs outlined in this section constitute those needed for completion of Stages 1 and 2 of the staged RI/FS process for the Burial Grounds.

Burial Grounds soils and eolid wastea. A total of 132 soil and 29 stream sediment samples have been taken within the boundaries of the Burial Grounds in three separate investigations between 1983 and 1990 (Geraghty and Miller 1985; Herbes 1988; Bogle et al. 1991).

Both liquid and solid wastes were deposited in the Burial Grounds during its operation. It is assumed that liquid wastes exit the trenches by leaching to groundwater or flowing through seeps to the tributaries to Bear Creek that drain the Burial Grounds. This process has been observed by past investigations, and a leachate collection system is currently operating at this site. Solid wastes remain in place, and leachate formed when water contacts these wastes may migrate by way of the same routes as liquid wastes.

Liquid wastes that migrated from the Burial Grounds were captured by the ORPs located in Tributaries NT-6 and NT.7. Sediments from these ponds that exceeded $25 \mathrm{mg} / \mathrm{kg}$ PCBs were excavated and removed; the remainder are in place and covered with RCRA caps.

PCB contamination has been recorded in stream sediments from Tributaries NT-7 and NT-8, which druin the central and western portions of the Burial Grounds; but PCB contamination was not detected in NT-6, which drains the eastern portion of the Burial Grounds. PCB contamination has also been recorded in the main stem of Bear Creek downstream of the Burial Grounds. Uranium was present in Bear Creek sediments and in tributary sediment samples taken from NT-6, NT-7, and NT-8 near their confluence with Bear Creek. Elevated concentrations of metals (nickel and lead) were also present in these samples.

Soil core data indicate PCB contamination of soils to the east of BG.A South in an area that has now been capped; however, PCBs were absent from soil samples taken south of BG-A South. PCB contamination associated with elevated uranium concentrations has been recorded in soil core samples taken northwest of BG-A North in an area that has since been capped.

Cores recovered from within the boundaries of the Walk-In Pits (North and South), BG-C East, and BG-B show that PCB-contaminated soils exist throughout the entire area in varying concentrations. A single soil sample recorded $\mathrm{PCB}$ contamination $(0.11 \mathrm{ppm})$ beyond the physical boundaries of BG-B to the east. Butyl benzyl phthalate has been recorded at levels from $4440 \mathrm{ppb}$ to $5300 \mathrm{ppb}$ in soil cores east of Walk-In Pit North and BG.B. Samples from the uppermost $1.8 \mathrm{~m}(6 \mathrm{ft})$ of soil in this area were reported to have elevated concentrations of arsenic $(17,000$ to $20,000 \mathrm{ppm})$. Analysis of an archived sample in 1985, however, indicated an arsenic concentration of $100 \mathrm{ppm}$.

No soil sample data exist for the areas to the south or west of BG-B, BG.C, and Walk-In Pits North and South. No soil sample data are available for the areas in the vicinity of the 
remaining pits. BG.B, the Walk-In Pits, and BG-C East are scheduled to be covered with a RCRA cap before the end of 1993. Any sampling of soils or seeps required for this area will need to be expedited to avoid postcap work.

Solid wastes in the Burial Grounds have been isolated from the environment either by covering with a RCRA cap or by institutional controls; therefore, they do not pose an immediate threat to human health or the environment through direct contact pathways. Data concerning surface water quality are not sufficient to determine if an immediate threat is posed by units in the Burial Grounds. Surface water is not adequately monitored in the vicinity of the Burial Grounds during storm flow events. To complete Stage 1 of the staged RI process outlined in Chap. 1, data are needed to determine the flux of contaminants from uncontrolled seeps to surface waters. This will require a comprehensive survey of all seepage areas in the Burial Grounds, during both base flow and storm flow conditions. Water samples will be taken from seeps that are outside the capture zone of the two leachate collection systems in the NT.7 and NT.8 drainage basins. If seepage is detected that constitutes an immediate hazard, a removal action will be required to remediate this problem. Likely removal action could be construction of a leachate collection system or modification of existing collection systems.

Trenches in the Burial Grounds received a variety of wastes; therefore, the most costeffective remedial alternative will probably address each trench on an individual basis, as well as addressing groups of trenches as a whole. In general, waste trenches that received liquid wastes will have very different remedial alternatives from those that contain only solid wastes. To determine the nature and extent of waste materials at the Burial Grounds in Stage 2 of the staged RI, Y.12 Plant Maintenance records will have been examined to create a preliminary inventory of waste materials known to have been placed in the waste trenches. (See Sect. 2.3.5.1.) Using the preliminary waste inventory and environmental data described in Chap. 3, trenches will be grouped into the following two categories: those that received combined liquid and solid wastes and those that received only solid wastes.

For trenches that received liquid wastes, it is assumed that the majority of the wastes have migrated away from the trench and are not present in their original forms. In this situation, characterization of the nature and extent of residual contamination in soils in the vicinity of the trench (derived from migration of liquid contaminants) will be determined. Where seeps have been identified that can be associated with individual trenches or groups of trenches, soils in the migration pathway from the trench to the seep will be sampled. Aqueous liquid wastes are assumed to have mixed with groundwater and to have migrated as plumes away from the trenches along the groundwater flow path. Contaminant plumes such as this may also have left contamination in soils along the flow path where metal contaminants have adsorbed to soil particles. LNAPL wastes will have migrated laterally away on top of the groundwater table and will have left a trail of residual LNAPL in soils above the groundwater table along the migration pathway.

DNAPLs will have migrated downward to an impermeable barrier, which most likely is the bedrock aquifer. These wastes will have left a trail of residual DNAPL droplets in the aquifer material and, in the case where a trench does not intercept the groundwater table, in vadose zone material below the trench.

Where liquid wastes have migrated away from Burial Ground trenches, residual oils remain in the soil. Soil sampling will be necessary to characterize the nature and extent of soil 
contamination. Soils will be sampled downgradient of trenches known to have had liquid waste materials deposited in them. Priority will be given to trenches located near observed seeps.

For trenches that contain solid wastes, the inventory of Y-12 Plant Maintenance records will be used to determine the types of wastes disposed in the trenches. The Y-12 Plant records are extensive and cover more than 30 years of waste deliveries to the Burial Grounds. The inventory of Y-12 Plant Maintenance records provides estimates on types and volumes of wastes disposed in the trenches.

To address the potential for migration of contaminants from the Burial Ground trenches, samples of waste leachate will be obtained, where possible. Leachability modeling of waste materials is not possible; however, measurement of the leachability of contaminated soil and modeling of leaching of contaminants from soils will be carried out. To enable modeling of the potential for contaminant leaching from contaminated soils, TCLP analyses for listed metals and organics and hydrologic and chemical properties of selected soil samples are needed. Data required for soil leachate modeling are listed in Table 6.2.

Burial Grounds groundwater and surface water. Twenty-six groundwater monitoring wells in the vicinity of the Burial Grounds meet the criteria for screen depth and location to be used by the RI (Table 6.3); three of these wells have been plugged and abandoned. One upgradient well (GW-042) is screened in unconsolidated deposits; two wells (GW-642 and GW-643) are screened in the shallow bedrock aquifer. The present shallow groundwater monitoring wells are adequate to monitor groundwater downgradient. Additional monitoring wells are required to monitor shallow groundwater in waste trenches.

The recharge area for the storm water flow system upgradient of the Burial Grounds is not covered. The effect on the stormflow system of roads in the Burial Grounds is not known; however, the waste trenches farthest upgradient are most likely to be affected by stormflow because there are no barriers to stormflow up slope of these trenches. Data are needed to address the potential for storm flow to come into contact with the waste. Stormflow monitoring tubes will be installed upgradient and downgradient of waste trenches likely to be affected by stormflow.

Habitats. Habitat delineations in the vicinity of the Burial Grounds will reveal the locations of protected habitats and habitats where the ecological indicator receptors are likely to be exposed to site contaminants.

- Phase 1: Wetlands in the vicinity of the Burial Grounds will be identified from historical information and walkover surveys. The size and location of each wetland, as well as a description of the associated vegetation, will be recorded. Aquatic and terrestrial habitats will be delineated throughout the site. The locations of various habitat types will be entered in the Government Information System.

- Phase 2: No additional habitat delineation is anticipated for Phase 2.

Biota sampling ard toxicity testing. Organic constituents of hazardous wastes are likely to be toxic to earthworms and other soil organisms. Metal and radionuclide contaminants are also likely to be transferred from soil to the food iwe b. Biota sampling will be done during Phase 2 and will be focused on areas shown during Phase 1 to contain physical media 
contaminants. Likely sampling sites are downslope from the cap and at surface seeps, where leachate from the waste areas may have contaminated surface soils.

- Phase 1: Grasses and browse and earthworms will be sampled in areas of probable surface soil contamination as delineated by the screening radiological survey. If the populations are reduced (as described in Fig. 6.2), then the soil samples will be taken at each location for phytotoxicity and earthworm toxicity tests. Amphibian larvae will be sampled for whole-body contaminant burdens in wetlands that are found to be contaminated and that contain sufficient water to support the development of amphibians. One surface water sample and one sediment sample will be analyzed for COCs at each location.

- Phase 2: Terrestrial small mammals will be sampled in appropriate habitat identified by the habitat survey. Statistically designed sampling of grasses and browse and earthworms will be done in areas shown in Phase 1 to contain contaminated biota (Sect. 6.1.1.4). Wetlands shown in Phase 1 containing contaminated amphibian larvae will be sampled further to delineate the extent of contamination in soil, sediment, and water by taking additional soil or paired surface water/sediment samples to be analyzed for COCs. Wetland areas will be divided into subareas, roughly $20 \mathrm{~m}^{2}\left(66 \mathrm{ft}^{2}\right)$, and a sample location will be placed at random within each subarea.

\subsection{SAMPLING AND ANALYTICAL REQUIREMENTS}

Sampling and analytical requirements for all sites in BCV OU 1 are detailed in Sect. 7.4.

\subsection{DATA EVALUATION AND INTERPRETATION}

All data collected as part of this RI will be entered into a database compatible with the Oak Ridge Environmental Information System (OREIS). Ten percent of the data will be validated to EPA Level IV quality standards, and the remaining $90 \%$ will be validated to EPA Level III as discussed in Sect. 8.9. The validated data will then be used for statistical analysis and data presentation as needed to accomplish the data use discussed in Sects. 1.8.1 and 1.8.3 of the DQOs and identified in Table 6.1. The $10 \%$ to be validated to EPA Level IV will be chosen by field observation.

Data generated from analysis of soil samples will be summarized statistically in data tables. The tables will contain the minimum, maximum, mean, and standard deviation for each potential COC. These data will be used to calculate human health risk as described in Sect. 6.4 and to aid in defining the nature and extent of contamination.

Contamination by depth profiles will be generated for all data from each borehole. All values above the PRGs established in Sect. 5.2 will be graphed in a different color to aid in establishing preliminary remediation boundaries. Cross-sections will also be prepared from selected profiles to establish the vertical and horizontal extent of contamination. Visually estimated soil characteristics will also be represented on soil logs and cross-sections. Potentiometric maps and contaminant concentration maps will also be prepared. Geotechnical data will be represented on data tables. 
Data from the geophysical survey will be interpreted by plotting on maps and contouring to identify likely locations of waste trenches. Conductivity data for soils will be contoured to identify spatial distributions of soil conductivity.

\subsection{RISK ASSESSMENT}

\subsubsection{Human Health Risk Assessment for BCV OU 1}

The regulatory agencies involved in Environmental Restoration activities on the ORR have partitioned the sites (in this particular case, the Oak Ridge Y-12 Plant Bear Creek Valley) into two categories of OUs: source OUs and integrator OUs. Source OUs are defined as on-site (property owned/managed by DOE-ORO) waste areas that are currently releasing or have the potential for releasing contaminants into the environment. Integrator OUs can receive the contaminants released from source OUs and transport them to an off-site receptor. Because of the complexity of the hydrogeologic regime and because many different sources could contribute to groundwater and surface water contamination, this classification was necessary. As a result, immediate attention can be given to source OUs while continued monitoring, characterization, and investigations of the integrator $\mathrm{OU}$ are being conducted.

The scope of the BCV OU 1 RI work plan entails using the data collected in the RI to accomplish three things: (1) to evaluate the current potential risk posed to human health from exposure to the potentially contaminated media, (2) to prioritize the sites in this source OU in terms of remediation needs, and (3) to prioritize how much each source $O U$ is contributing to off-source OU release of contamination (to the integrator OU). These objectives will be accomplished by evaluating on-source OU human exposure to BCV OU 1 media (i.e., soil and inventoried wastes) via a risk assessment. A reasonable RME risk assessment of this media will be performed in Phase 2 of the RI for BCV OU 4. Surface water and groundwater associated with BCV OU 1 will be evaluated in the BCV OU 4 RI in an integration point (IP) assessment (BCV OU 4 Phase 1) and in an RME risk assessment (BCV OU 4 Phase 2).

The methodology employed to conduct the risk assessments will follow guidelines established in the Risk Assessment Guidance for Superfund, Volume I: Human Health Evaluation Manual (Part A) (EPA 1989d) and the annotated outline for an RI/baseline risk assessment report. In addition, recommendations from the Risk Assessment Council and other supporting documentation, including the results of the Phase 1 and 2 Background Soil Characterization Project for the ORR, will be followed.

The exposure pathways evaluated in the MLE assessment include ingestion of and dermal contact with soil, inhalation of wind-generated dust and volatiles from the soil, and external exposure to radionuclide contaminants in the soil. The MLE assessment uses a modified industrial exposure scenario; the exposure time is reduced to $10 \%$ (48 min/day) of the 8-h work day, and this reduction is considered to be representative of actual exposures at most source OUs. The MLE assessments will be used to assist with these tasks: (1) prioritizing the source OUs in terms of necessary remedial actions; (2) establishing a lower bound on the risk posed to human health (where the RME gives the upper bound); and (3) identifying and prioritizing-in conjunction with the BCV OU 4 Phase 1 IP assessment-off-source OU migration of contaminants [into the integrator OU (BCV OU 4)]. The risk posed from the 
various source OUs is apportioned based on the contaminant flux into the integration point. Source control actions, taken at areas of a high flux of integrator COPC, are a quick means for reducing off-site and/or off-source OU exposure; effects of source control actions on the integrator OU (BCV OU 4) can also be evaluated using an IP assessment.

To evaluate the risk posed to human receptors from direct exposure to the inventoried wastes, a method will be used that includes an upper bound (acute exposure) and a lower bound (MLE assessment) on the risk.

\subsection{Ecological Risk Assessment for BCV OU 1}

The ecological risk assessment process differs from the human health risk assessment process in that it focuses on populations and communities rather than on individuals. Individuals are protected only if they are protected under the Endangered Species Act, are unique, or have such ecological importance that individual consideration is merited. Ecological risk assessment, as described in Framework for Ecological Risk Assessment (EPA 1992c), involves basic steps occurring in three primary phases: (1) problem formulation; (2) analysis, which includes exposure characterization and effects characterization; and (3) risk characterization. Problem formulation includes a preliminary characterization of chemical and physical stressors present in the ecosystem (Chap. 3), ecological components likely to be at risk (Sect. 4.2), and assessment and measurement endpoints (Sect. 6.1.1.4). Exposure characterization evaluates the interactions of the stressors with the ecosystem, especially each indicator population or habitat. Effects characterization evaluates the ecological response to the chemical and physical stressors in terms of the assessment and measurement endpoints. Data from both field observations and controlled laboratory studies are used to evaluate ecological effects. Risk characterization integrates the effects of exposure and stressor response on indicator populations or habitat components, using risk quotients as well as weight-of-evidence arguments and then further interprets the ecological significance, including the potential for ecosystem recovery.

\subsection{FEASIBIITY STUDY}

The following sections describe the tasks necessary to conduct and produce the FS report. The report will follow the format outlined in EPA's Guidance for Conducting Remedial Investigations and Feasibility Studies Under CERCLA (EPA/540/G-88/004) (EPA 1988a) and the annotated outline developed by the DOE-ORO Document Content and Review Committee. The FS report will be prepared to integrate NRDA and NEPA requirements. When EPA and TDEC approve the FS, a Proposed Plan will be submitted presenting the preferred alternative for an interim remedial action, followed by a ROD for interim action.

\subsubsection{FS Contractor Responsibilities}

The FS contractor will prepare the FS within project quality, cost, and scheduling goals. The FS contractor will also provide engineering and technical resources to support QC efforts, provide project management, and coordinate project activities to ensure that established goals are achieved. Monthly progress reports on the FS process will be issued to DOE. FS contractor activities for BCV OU 1 include scoping activities and technical support 
of the RI; these activities will be completed on final approval of the ROD for interim action prepared for this OU.

\section{5 .2 Scope and Assumptions}

As stated in Sect. 5.2, the general goal for BCV OU 1 remedial action is to protect human health and the environment from the contaminant sources within the OU. To meet this goal, the CERCLA process will be followed. The process will include characterization of this source control OU to the extent necessary to (1) identify, screen, and develop remedial action alternatives; (2) select a preferred remedial alternative or a set of alternatives; and (3) prepare the required decision documents.

The FS contractor will be responsible for completing the FS process for BCV OU 1. This process will require preparing the following milestone documents: (1) the FS report, which documents the process used to examine the remedial technologies and also incorporates the requirements under the Natural Resource Damage Assessment (NRDA) and NEPA; (2) the Proposed Plan, which is a summary plan for presenting the selected remedial alternative; and (3) the ROD for interim action, which is the legal document that confirms that selected remediation methods meet statutory and regulatory requirements. The FS/Proposed Plan/ROD process may include the following principal Work Breakdown Structure elements:

- FS scoping activities.

- Treatability studies.

- FS development.

- NEPA activities.

- NRDA activities.

- FS OU coordination/oversight.

- Proposed Plan development.

- ROD development.

\subsubsection{FS scoping activities}

Preliminary remedial alternatives have been selected to address the response actions for BCV OU 1. The response actions are listed in Sect. 5.3 and in Table 5.8. These or similar alternatives will be screened as part of the FS process to eliminate those judged too difficult to implement based on unproven technologies, those judged insufficient to remediate the site within a reasonable time period, or those judged to have limited application for the specific contaminant or site conditions. Those technologies judged to have a reasonable chance of success for remediation will be carried forward for more detailed development and analysis.

The following issues must be addressed before the techno' gies can undergo detailed development and analysis. This list may change as additional information becomes available.

- Results of the human health risk assessment.

- Results of ecological risk assessment.

- Treatability studies. 


\subsubsection{Treatability studies}

If necessary, treatability studies will be conducted to (1) provide data to allow treatment alternatives to be fully developed and evaluated during the detailed analysis and (2) support the remedial design of a selected alternative.

\subsection{FS development}

The FS contractor will use the format presented in the CERCLA RI/FS guidance document and the DOE-ORO Document Content and Review Committee FS annotated outline to develop the FS. As required, exceptions and modifications to the format will be made for site-specific conditions in BCV OU 1 . Based on the information obtained during the RI, selected alternatives will be analyzed and compared using the following 11 criteria:

- Overall protection of human health and the environment.

- Compliance with ARARs.

- Short-term effectiveness.

- Long-term effectiveness.

- Reduction of contaminant toxicity, mobility, and volume.

- Implementability.

- Cost.

- State acceptance.

- Community acceptance.

- Compliance with NEPA requirements.

- Compliance with I'RDA requirements.

NEPA and NRDA requirements are discussed in more detail in the following subsections.

The FS will be developed in sufficient detail to allow the preferred alternatives to be selected in the Proposed Plan. Criteria will be developed to assess the ability of the alternatives to meet the cleanup goals and to comply with administrative and regulatory requirements. The draft FS report will be issued to EPA and TDEC for review. Submittal of the draft FS report to EPA and TDEC is an FFA milestone.

\section{NEPA activities}

To comply with the federal facility requirements under NEPA, the remedial alternatives will be evaluated for their impact on the environment. NEPA establishes public policies and goals for protecting environmental juality and mandates procedural requirements to be considered when implementing decisions that may impact the environment. DOE Order 5400.4 requires that NEPA and CERCLA be integrated to the maximum extent practical to avoid duplication of effort. NEPA issues to be addressed include rare and endangered species, archeological studies, wetlands, and floodplains. The environmental impacts of the alternatives will be considered integral to the evaluation and selection process. 


\subsubsection{NRDA activities}

To comply with NRDA, the Natural Resource Trustees may assess damages for injuries to natural resources resulting from release of hazardous substances. The first step in the NRDA process is to perform a preassessment screen. If the screening indicates that NRDA is inappropriate, no further assessment actions will be taken. However, if the preassessment screen indicates that NRDA is appropriate, a type $B$ assessment will begin, requiring an Injury Determination phase, a Quantification phase, and a Damage Determination phase (Federal Register, April 29, 1991).

\subsubsection{FS OU coordination/oversight}

The objective of the Integrating Contractor for FS oversight activities is to provide review and technical input during the FS. This ensures that the data and information obtained during the RI are available for incorporation into the FS report and that they are adequate to prepare a Proposed Plan and support developmenı of the ROD.

\subsubsection{Proposed plan development}

The Proposed Plan for BCV OU 1 will be prepared to present the preferred remediation alternative to the public. The Proposed Plan documents the investigation process, administrative and regulatory actions, and remedial alternatives. The proposed plan is a primary milestone document made available for public comment and subject to administrative and regulatory reviews.

\subsection{ROD development}

The final step in the decision process for any interim remedial action for BCV OU 1 will be preparation of the ROD for interim action. This legal document formally describes the preferred interim remediation alternative and establishes the remediation schedule and monitoring plan for the site. The BCV OU 1 ROD for interim action will be written in accordance with the statutory requirements of CERCLA and applicable federal and state requirements. It will contain a decision summary outlining the nature and extent of the contamination and associated risks at BCV OU 1 , the evaluation and analysis of the remedial action (RA) alternatives considered, and an explanation of how the selected alternative(s) will meet statutory requirements. The ROD for interim action will also contain a responsiveness summary addressing the public comments obtained during public review of the Proposed Plan and public examination of the Administrative Record. The ROD for interim action is a primary FFA milestone.

\subsection{REMEDIAL DESIGN AND RA PLAN}

\subsubsection{Remedial Design}

This section presents the scope of the Remedial Design (RD) effort required to prepare an RD work plan; perform any required engineering studies; prepare a Title I $30 \%$ design package; and prepare Title II $60 \%, 90 \%$, and $100 \%$ final design reports for BCV OU 1 remediation. 


\subsubsection{Scope and assumptions}

The scope of the RD wopk Plan for the remediation of BCV OU 1 is to provide necessary supporting documents to implement each $R A$ activity. These documents require approval from TDEC and EPA. The following sections present details of the scope of work and assumptions associated with remediation of BCV OU 1.

\subsubsection{RD work plan}

The RD work plan will provide the technical and management approach for the RD work. The RD contractor will prepare a draft RD work plan based on the scope and design criteria specified in the Proposed Plan and the ROD for interim action. The RD work plan will include the detailed design process and schedule for the design effort and will be prepared in accordance with CERCLANNEPA regulations. The RD contractor will incorporate comments from EPA and TDEC and submit the final RD work plan for approval.

\subsubsection{RD work plan oversight activities}

During the preparation of the RD work plan, DOE will provide review and technical input to ensure that the scope of work is adequately defined in accordance with the criteria specified in the ROD for interim action. Review of the draft RD work plan will also ensure that the selected technologies do not violate the intent of the ROD and that the work plan meets all regulatory and administrative requirements.

\subsubsection{RD report Title I design}

Based on the engineering studies and other information available from the RI/FS, the RD contractor will prepare Title I (30\%) design/construction drawings for remedial activities showing the extent of remedial activities, site plan, details, and outline of specifications for the work involved.

\subsubsection{RD report Title II design}

On approval of Title I design document, the RD contractor will prepare Title II engineering designs, analyses, and calculations required for all civil, structural, mechanical, and electrical construction, construction drawings, technical specifications, and cost estimates.

All documents will be submitted to Energy Systems for comment at $60 \%$ completion. On resolution of comments, the $90 \%$ design package will be submitted to Energy Systems and DOE for review and comment. Upon resolution of $90 \%$ comments, the final design report $(100 \%)$ for remedial activities will be submitted to EPA and TDEC for review and approval. Agency comments will then be incorporated to prepare design documents certified for construction.

\subsubsection{RD oversight activities}

During the review of the Title I design documents at 30\% and the Title II design documents at $60 \%$ and $90 \%$, all participants will provide their review and technical input to help submit the final design document to TDEC and EPA in the given time frame. 


\subsubsection{Remedial Action}

This section presents the scope of the RA activities required to prepare an RA work plan and implement the remediation of BCV OU 1. The risk, uncertainties, and communication issues for the remedial activities are also identified in this section.

\subsubsection{Scope and assumptions}

The scope of the RA includes the RA work plan, construction management, Title III construction services, construction of one remediation design package, construction support, independent certification, and verification.

\subsubsection{RA work plan}

The RA work plan will (1) define the scope and objectives of the RA based on the ROD for interim action and the final RD report; (2) document the specific construction components of the RA; and (3) present the RA schedule, subcontracting strategy, QA plan, health and safety plan, and RA monitoring plan.

After comments from EPA and TDEC are incorporated, the final RA work plan will be prepared for approval and implementation.

\subsubsection{RA work plan oversight activities}

The purpose of this activity is to provide technical input and review during the preparation of the RA work plan. During this time, all the DOE prime contractors will review the work plan. This will ensure that the proposed construction efforts implement the selected remedial action consistent with the ROD for interim action and the final RD report. This oversight activity will also ensure that the bid process and implementation plans comply with administrative and regulatory requirements.

\subsubsection{RA integration}

The objective of this element is to provide construction management, independent certification, Title III services, and construction support as required.

RA integration for BCV OU 1 remedial activities includes the following tasks:

- Ensuring that subcontracted work is performed on schedule, in accordance with all technical requirements, and in compliance with the Environmental Safety and Health Program, the QA Program, the Waste Management Program, and the Security Program.

- Performing field inspections, providing as-built drawings, approving Design Change Notices and Field Change Requests as applicable, and ensuring that construction is accomplished according to final design requirements. 


\section{Bnvironmental Restoration Program \\ Fleld Sampling Plan \\ for \\ BCV OU 1 RI Work Plan Y-12 Plant \\ Revision 0}

Technical Support Contractor

Program Manager

Technical Support Contractor
Fleld Team Leader

Technical Support Contractor

Date

Field Team Leader

Site Health and Safety Officer

Date

Energy Systems ER Site Program Manager

Date

Energy Systems ER Site Project Manager

Date 


\section{FIELD SAMPLING PLAN}

\subsection{INTRODUCTION AND PURPOSE}

BCV OU 1 is one of two source OUs within BCV. The boundaries of the integrator OU for BCV (BCV OU 4) are from the crest of Chestnut Ridge to the crest of Pine Ridge and from the surface water divide near the S-3 Site to the groundwater divide west of State Highway 95 between Bear Creek and Grassy Creek. The source OUs in BCV are described below:

- BCV OU 1 comprises the S-3 Ponds; Oil Landfarm; Boneyard/Burnyard; HCDA; SL 1; Bear Creek Burial Grounds (BG-A North, -A South, -B, -C East, -C West, -D, -E, and -J); ORPs 1 and 2; Walk-In Pits; and Uranium Vaults.

- BCV OU 2 includes the Rust Spoil Area, Spoil Area 1, and the SY-200 Yard.

BCV OU 1 (source OU) is the focus of this RIWP. Groundwater and surface water will not be addressed as media to be remediated in this BCV OU 1 RI. Risk posed to off-source and off-site human receptors by means of groundwater and/or surface water pathways will be addressed in the BCV OU 4 (integrator OU) RIWP. Sediments and soils that constitute floodplain soils will be considered in BCV OU 4 RIWP. For this BCV OU 1 RIWP, risks from exposure to soils and sediments within the BCV OU 1 site boundaries will be evaluated.

The overall RI/FS goal for BCV OU 1 is to select remediation alternatives at reasonable cost that are protective of human health and the environment, that maintain protection over time, and that minimize the volume of untreated waste. The objective of the RI is to provide sufficient information to assess the risks posed to human health and the environment and to support the development, evaluation, and selection of appropriate response alternatives. This work plan provides justifiable rationale and guidance for the collection and analysis of the data required to fulfill the objectives of all stages of the RI.

A staged approach to this RI is outlined in Chap. 1 of this work plan. Though each stage of the RI has different objectives, a goal of the Work Plan is to ensure that data acquired during each stage of the $\mathrm{RI}$ are comprehensive and that no repeat sampling of any media at any location is required as a result of changing objectives. The goal of each sample detailed in the sampling plan is to provide sufficient information to support the final remediation of the site. The following objectives will be met to assess the risks contributed by this $O U$ to the overall risk to human health and the environment in BCV and to allow a ROD for interim actions to be issued:

- To determine whether the wastes pose an on-site risk to human health and the environment at the present time

- To determine whether the wastes will pose an on-site risk to human health and the environment in the future

- To determine whether the wastes pose an off-site risk to human health and the environment at the present time

- To determine whether the waste will pose an off-site risk to human health and the environment in the future 
- To determine whether the wastes and/or waste derivatives are in compliance with ARARs

- To support the screening of appropriate alternatives during the remedy selection and to provide technically and legally defensible data on which to base credible decisions regarding risk levels and cleanup alternatives

\subsection{PROJECT ORGANIZATION AND RESPONSIBILITIES}

The BCV OU 1 RI project organization is illustrated in Fig. 7.1. The responsibilities of Energy Systems and the RI subcontractor are presented in Table 7.1.

\subsection{PROJECT DESCRIPTION}

\subsubsection{History and Current Conditions}

Six sites at three discrete areas in BCV have been included in BCV OU 1 to be evaluated as contaminant source OUs. Some sites within BCV OU 1 have undergone environmental restoration under RCRA. Part of BG.A North, BG-A South, and BG-C West; the Oil Landfarm; the HCDA; and the S-3 Ponds were closed in place as landfills under RCRA. These actions were based on considerable data concerning contaminants in environmental media at these sites. SL 1 was capped and closed with a single-layer clay cap. No action has been taken at the Boneyard/Burnyard, and there is little or no inlormation concerning contaminants at this site.

The site name, unit number, and unit status of each site in BCV OU 1 are listed in Table 7.2. Detailed descriptions of site operating history and environmental background are presented in Chaps. 2 and 3 of this work plan. A brief description of each site in BCV OU 1 follows.

S-3 Ponds. The S-3 Ponds were constructed in 1951 and consisted of four unlined surface impoundments covering a total area of roughly $\sim 1.5$ ha $(3.7$ acres) with a storage capacity of 38 million L (10 million gal). During operation, up to $21,000 \mathrm{~L} / \mathrm{d}(5500 \mathrm{gal} / \mathrm{d})$ of effluent was pumped to the pond through a pipeline from the Y-12 Plant. The S-3 Site underwent RCRA closure in 1988 and now operates as a parking lot. Preliminary COCs are nitrate, uranium, metals, and organic solvents.

Oil Landfarm. The Oil Landfarm was used for the land application of waste oils and coolants contaminated with beryllium, depleted uranium, PCBs, and chlorinated hydrocarbons. Disposal operations were discontinued in 1982. Final RCRA closure of the site was certified by TDEC in December 1990.

Boneyard/Burnyard. The Boneyard/Burnyard consists of -3.2 ha ( 8 acres) that were used from 1943 to 1970 as a disposal site for waste from the Y.12 Plant. Burning and disposai of debris and sanitary, metallic, chemical, and radioactive wastes are known to have occurred. The site has been abandoned and is predominantly covered with grassy vegetation. The southeastern portion of this site is overlain by the HCDA. The HCDA covers -0.8 ha ( 2 acres) and was used to burn or neutralize liquid and gaseous wastes from 1975 until 1981. 


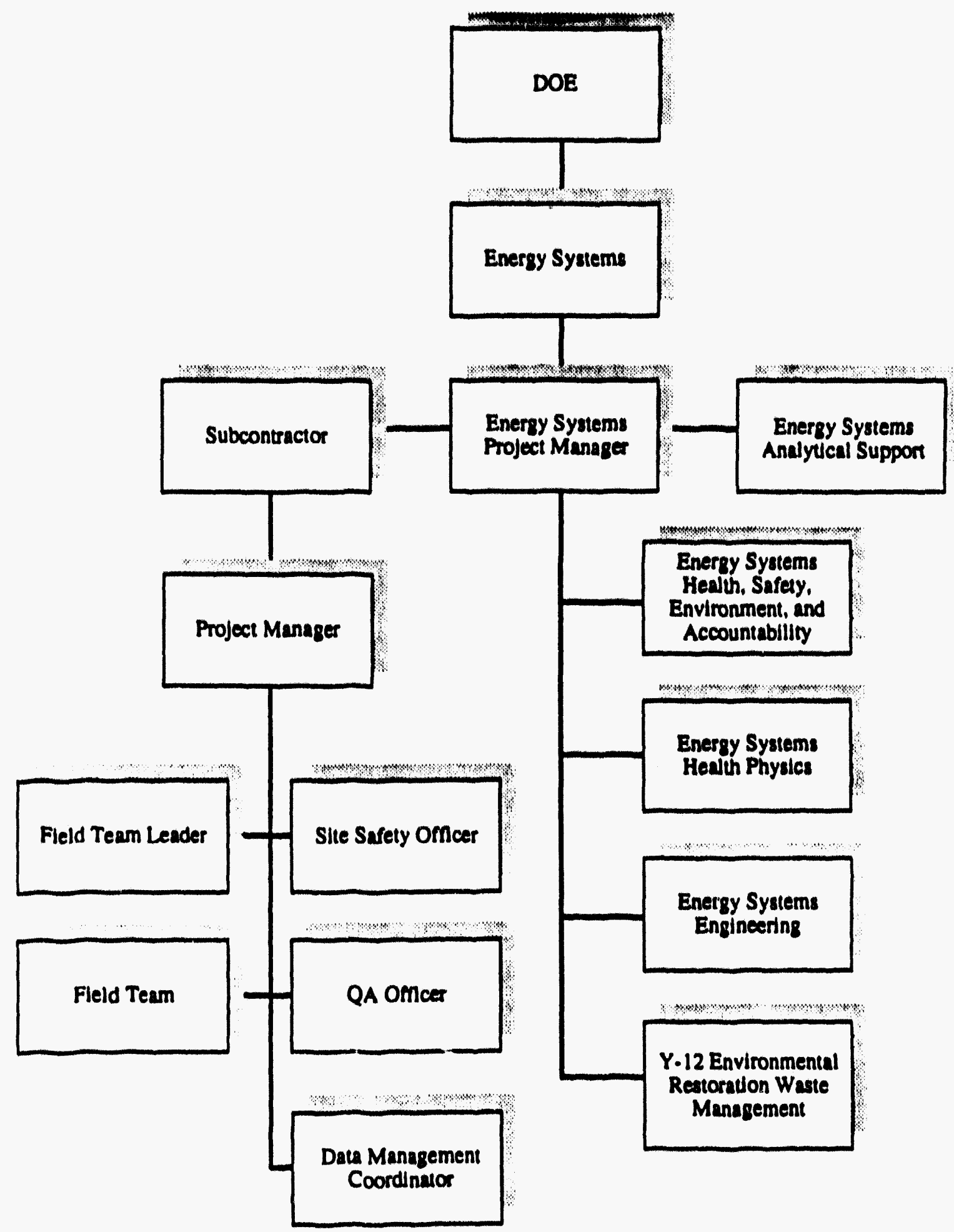

Fig. 7.1. BCV OU 1 RI functional organizational chart. 
Table 7.1. Energy Systems and RI subcontractor responsibilltics for the Y-12 Plant ER Program asecusment

\begin{tabular}{|c|c|c|}
\hline Role & Subcontract or responsibilitices & Bnerty Syutem responsibillites \\
\hline Project Manager & Coordinate all project plans and activities & $\begin{array}{l}\text { Identify project-specific requirements } \\
\text { Coordinate project activities, as } \\
\text { necessary }\end{array}$ \\
\hline $\begin{array}{l}\text { Medical } \\
\text { Monitoring }\end{array}$ & $\begin{array}{l}\text { Ensure all subcontractor project personnel } \\
\text { have updated yearly physicals } \\
\text { Ensure all subcontractor project personnel } \\
\text { have updated respirator fit lests }\end{array}$ & $\begin{array}{l}\text { Identify for the subcontractor any } \\
\text { additional or site-specific medical } \\
\text { monitoring requirements }\end{array}$ \\
\hline Health Physics & $\begin{array}{l}\text { Notify ER Division Project Manager of } \\
\text { need for an Energy Systems health } \\
\text { physicist (HP), including time and place } \\
\text { Provide an HP or trained designee to be } \\
\text { on-site during field activities to screen } \\
\text { samples, equipment, and personnel, as } \\
\text { necessary }\end{array}$ & $\begin{array}{l}\text { Provide an HP, when requested, for } \\
\text { screening work areas, samples, } \\
\text { equipment, or personnel } \\
\text { Prepare tags to approve off-site } \\
\text { shipment of samples }\end{array}$ \\
\hline $\begin{array}{l}\text { Industrial } \\
\text { Hygiene }\end{array}$ & $\begin{array}{l}\text { Provide site-specific health and safety } \\
\text { plans } \\
\text { Provide health and safety audits }\end{array}$ & $\begin{array}{l}\text { Review/approve health and safety } \\
\text { plans } \\
\text { Provide health and safety audits }\end{array}$ \\
\hline $\begin{array}{l}\text { Emergency } \\
\text { Response }\end{array}$ & $\begin{array}{l}\text { Contact the Plant Shift Supervisor in the } \\
\text { event of an emergency at the investigation } \\
\text { site } \\
\text { Follow Plant Shift Supervisor instructions }\end{array}$ & $\begin{array}{l}\text { Manage all emergency situations (i.e., } \\
\text { via the Plant Shiff Supervisor) }\end{array}$ \\
\hline Utillities & $\begin{array}{l}\text { Aert the ER Division Project Manager of } \\
\text { the need for a utillty check }\end{array}$ & Provide utility checks \\
\hline NEPA & $\begin{array}{l}\text { Ensure fieldwork is done in accordance } \\
\text { with NEPA documentation requirements }\end{array}$ & $\begin{array}{l}\text { Ensure assessment activities are cross } \\
\text { checked }\end{array}$ \\
\hline $\begin{array}{l}\text { Groundwater } \\
\text { Protection }\end{array}$ & $\begin{array}{l}\text { Provide location and design of monitoring } \\
\text { wells } \\
\text { Provide field oversight of well installation }\end{array}$ & $\begin{array}{l}\text { Approval of location and design of } \\
\text { monitoring wells } \\
\text { Install, plug and abandon, and } \\
\text { maintain monitoring wells } \\
\text { Sample monitoring wells }\end{array}$ \\
\hline Security (access) & $\begin{array}{l}\text { Provide necessary information for badges, } \\
\text { passes, and access }\end{array}$ & $\begin{array}{l}\text { Ensure badges, passes, and access are } \\
\text { requested and obtained }\end{array}$ \\
\hline Permits & $\begin{array}{l}\text { Identify project-specific permit } \\
\text { requirements } \\
\text { Provide necessary permit information }\end{array}$ & $\begin{array}{l}\text { Ensure permit is complete } \\
\text { Submit permit to correct Y.12 Plant } \\
\text { department } \\
\text { Coordinate permit approval }\end{array}$ \\
\hline $\begin{array}{l}\text { Analytical Project } \\
\text { Office }\end{array}$ & $\begin{array}{l}\text { Determine project-specific analytical } \\
\text { requirements and the rumber, types, and } \\
\text { delivery schedule for samples }\end{array}$ & $\begin{array}{l}\text { Coordinate ER Program analytical } \\
\text { requirements }\end{array}$ \\
\hline
\end{tabular}




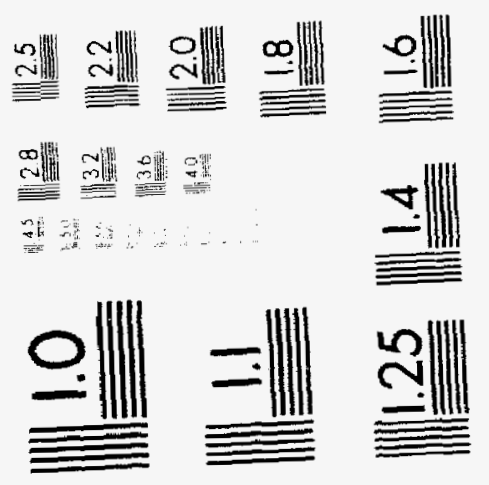



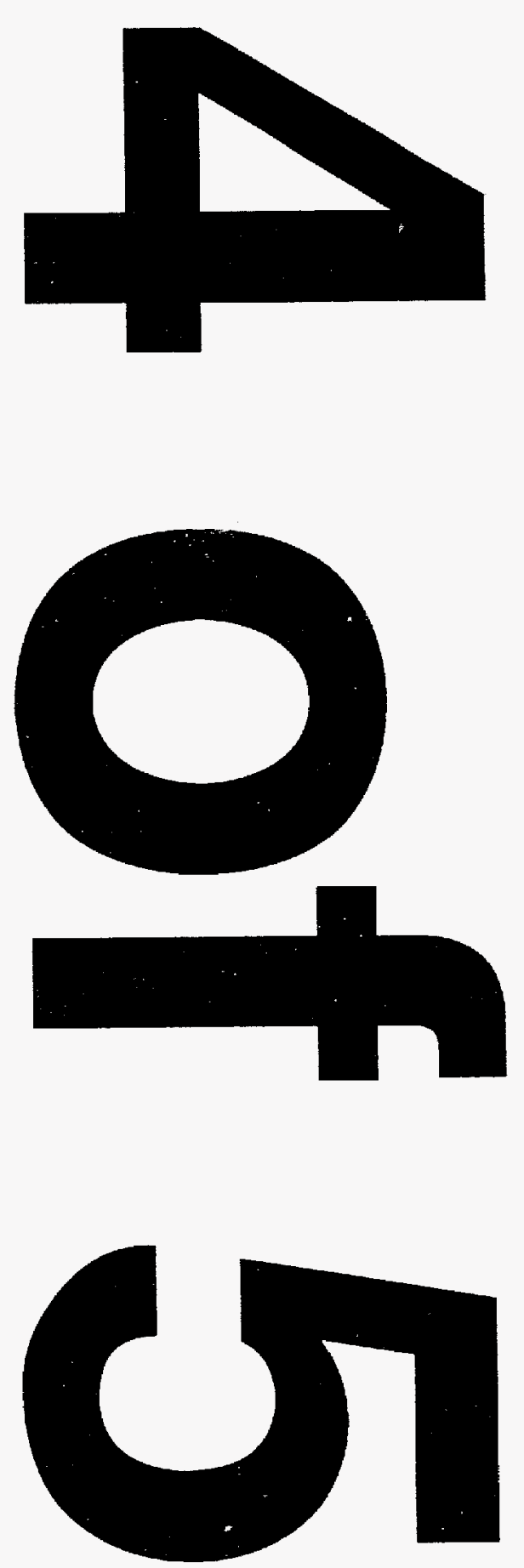
Table 7.1 (continued)

\begin{tabular}{|c|c|c|}
\hline Role & Subcontractor responsibilities & Rnergy Systems responsibilities \\
\hline $\begin{array}{l}\mathrm{Y}-12 \mathrm{Lab} \text { (if } \\
\text { required) }\end{array}$ & $\begin{array}{l}\text { Provide the number, types, and delivery } \\
\text { schedule for samples }\end{array}$ & $\begin{array}{l}\text { Provide lab space and sample } \\
\text { analyses } \\
\text { Approve project-specific analytical } \\
\text { requirements }\end{array}$ \\
\hline Quality assurance & $\begin{array}{l}\text { Develop site-specific QA plans } \\
\text { Provide OA audits }\end{array}$ & $\begin{array}{l}\text { Review QA plans } \\
\text { Develop ER programmatic } \\
\text { requirements } \\
\text { Provide QA audits }\end{array}$ \\
\hline Training & $\begin{array}{l}\text { Maintain up-to-date training records } \\
\text { Ensure project personnel have correct } \\
\text { training } \\
\text { Identify project-specific training } \\
\text { requirements }\end{array}$ & $\begin{array}{l}\text { Assist in identifying project-specific } \\
\text { training requirements } \\
\text { Audit training records for } \\
\text { subcontracted personnel } \\
\text { Identify, schedule, and reserve space } \\
\text { in required Energy Systems training } \\
\text { sessions }\end{array}$ \\
\hline Waste Treatment & $\begin{array}{l}\text { Develop project-specific waste } \\
\text { management plans detailing waste } \\
\text { treatment options } \\
\text { Provide estimates of types and quantities } \\
\text { of waste needing treatment }\end{array}$ & $\begin{array}{l}\text { Review/approve waste management } \\
\text { plans } \\
\text { Arrange for waste treatment with } \\
\text { various Y-12 departments }\end{array}$ \\
\hline $\begin{array}{l}\text { Waste } \\
\text { Transportation }\end{array}$ & $\begin{array}{l}\text { Notify appropriate Energy Systems } \\
\text { personnel that waste transportation is } \\
\text { needed } \\
\text { Correctly package and label waste for } \\
\text { transport }\end{array}$ & $\begin{array}{l}\text { Arrange for waste pick-up and } \\
\text { disposition of waste }\end{array}$ \\
\hline Classification & Identify project-specific activities & $\begin{array}{l}\text { Determine the level of classification } \\
\text { of project-specific activities }\end{array}$ \\
\hline $\begin{array}{l}\text { Sample } \\
\text { Transportation }\end{array}$ & $\begin{array}{l}\text { Follow Energy Systems-specific } \\
\text { requirements }\end{array}$ & $\begin{array}{l}\text { Provide guidance for sample } \\
\text { transportation }\end{array}$ \\
\hline
\end{tabular}


Table 7.2 Remedial units of BCV OU 1

\begin{tabular}{|l|l|l||}
\hline \multicolumn{1}{|c|}{ Remedial Unit } & \multicolumn{1}{|c|}{ Unit No. } & \multicolumn{1}{c|}{ Status } \\
\hline \hline S-3 Ponds & T-004 & Closed under RCRA in 1988 \\
\hline Oil Retention Ponds 1 and 2 & T-008, T-009 & Closed under RCRA in 1990 \\
\hline Oil Landfarm & T-014 & Closed under RCRA in 1990 \\
\hline Bear Creek Burial Grounds & D-024 & $\begin{array}{l}\text { Some sections closed, others } \\
\text { undergoing closure }\end{array}$ \\
\hline Sanitary Landfill 1 & D-101 & Closed in 1983 \\
\hline HCDA (Burnyard/Boneyard) & D-024-HC & HCDA covered with a RCRA-style cap \\
\hline
\end{tabular}


The HCDA is covered with a RCRA cap and was closed with the Oil Landfarm.

SL 1. SL 1 received various types of nonhazardous wastes from the Y-12 Plant. Waste disposal at SL 1 was carried out from 1962 to 1982 at which time the site was graded, capped with clay, and closed in 1983 under a TDEC-approved closure plan in accordance with TDEC rules and regulations for sanitary landfills.

Burial Grounds. The Burial Grounds comprise a series of waste disposal units covering an area of $\sim 140$ ha ( 350 acres). Each waste disposal unit consists of a series of trenches excavated to between 4.3 and $7.6 \mathrm{~m}$ (14 and $25 \mathrm{ft}$ ) below grade. The trenches received a variety of hazardous and nonhazardous solid and liquid wastes from the Y-12 Plant. All hazardous waste disposal operations were discontinued in 1981. All trenches known to have received RCRA hazardous material have been capped or are in the process of being capped as part of a RCRA closure. The Burial Grounds include ORPs 1 and 2, the Walk-in Pits, and the Uranium Vaults. The ORPs were constructed to intercept seepage from the Burial Grounds trenches. Both ponds were capped and closed under RCRA in 1990. The Walk-in Pits were used to dispose of solid or drummed liquid wastes including pyrophoric saw fines of uranium and thorium and shock-sensitive chemicals. A wide range of contaminants may have been disposed of in the Burial Grounds.

\subsubsection{Site Conceptual Model}

A site conceptual model that illustrates the potential pathways of contaminant migrations, or flows, among various abiotic media and, ultimately, to receptors is described in Chap. 3 of this RI work plan. The site conceptual model for transpori and exposure pathways is presented in Figs. 3.33 and 3.36. The development of the site conceptual hydrologic model for BCV OU 1 relies on a conceptual model for groundwater flow that is applicable throughout the ORR (Solomon et al. 1992). The components of that conceptual model are included in the conceptual model in general and applied to the specific needs of the shallow groundwater/surface water system within BCV. Contributions to the hydrologic system from the soils are by way of contaminant leaching from soils and wastes. Direct contact pathways to human and ecological receptors include direct or acute exposure to soils and waters, ingestion of contaminated soils and/or contaminated surface water or groundwater, food ingestion, dermal contact with soils, inhalation of volatiles, inhalation of dust, and penetrating radiation.

The site conceptual model is based on the hypothesis that potential contaminant migration pathways exist downgradient from waste trenches. Aqueous contamination may migrate laterally with stormflow or vertically to groundwater with recharge. Ionic contaminants dissolved in aqueous solutions may precipitate or sorb to mineral surfaces in soils along the pathway. LNAPLs may migrate downward until the groundwater table is reached. These chemicals may then migrate laterally away from the waste location, downgradient along the groundwater table. DNAPLs may migrate downward through the groundwater table and into the aquifer. Migration of DNAPL or LNAPL leaves a trail of residual contamination, and vertical changes in the groundwater table may spread this residual contamination in the soil over the range of groundwater table variation. 


\subsubsection{Identification of Investigation Requirements}

The strategy for a source $\mathrm{OU}$ in BCV is to stop releases from sources to the surface water and shallow groundwater system and to reduce risks to human health and the environment to acceptable levels based on current and future land uses at the source sites. The sources of contamination at the BCV OU 1 sites to be investigated are soils and waste materials. Because there are few specific ARARs pertaining to soils, the investigation requirements for soils in BCV OU 1 are set by the PRGs. PRGs for this RI were established by two methods. The first set of PRGs was determined by health-based standards based on direct contact pathways (i.e., ingestion and inhalation of contaminated material). The second set of PRGs was calculated using the Summers Model for soil leaching (EPA 1989c). The allowable level of soil contamination can be calculated using this method based on contaminant concentrations in the groundwater that result from soil leaching. To establish PRGs by this method, the Safe Drinking Water Act MCLs and MCLGs were used as an acceptable groundwater concentration, and the acceptable soil concentration was calculated by inverse modeling using the Summers Model. Assumptions used to calculate the PRGs are discussed in Sect. 5.2 of this work plan. Feasible treatment technologies are discussed in Sect. 5.3 of the work plan.

\subsection{SITE ACTION PLAN}

General site data needs for physical characterization of media in BCV are discussed in Sect. 6.1.1 and summarized in Table 6.1. Site-specific data needs and rationale for sampling at each site are discussed in Sect. 6.1.2 and summarized in Table 6.5.

At each site, data are needed to characterize the nature and extent of contamination in soils and wastes and to evaluate current and future on-site and off-site contaminant migration pathways. The nature and extent of contamination are needed not only to determine the extent of contamination at each site but also to allow evaluation of future fluxes of contaminants along migration pathways.

The site action plan described here uses the staged approach to the RI/FS that is detailed in Chap. 1 of the work plan. The Boneyard/Burnyard is at Stage 1 of the process; the Burial Grounds, S-3 Site, SL 1, and the Oil Landfarm are at Stage 2. This site action plan details the samples to be taken to complete Stage 2 for each site. Soil sampling activities for Stage 2 at the Burial Grounds and at the Boneyard/Burnyard will be carried out in two phases because of the large size of each site [ 69 and 3.2 ha (170 and 8 acres), respectively] and because of the uncertainty concerning probable locations of contaminants. For each site, the first phase of sampling is detailed here, and the rationale for locating samples in the second phase is described in Sect. 1.8 and in Chap 6. Ecological sampling will be completed for each site as a separate phase to be carried out after the first phase of soil sampling.

Historical data from the current groundwater monitoring well system in BCV will be used to analyze historical groundwater quality trends. Monitoring of groundwater in selected wells will be carried out to ascertain changes in grourdwater quality in the vicinity of the source sites. 


\subsubsection{Technical Procedures for Sample Collections}

Section 8.2 discusses the technical procedures that will be used as guidelines to implement the sampling activities at BCV OU 3. All sampling activities, where applicable, will follow the technical procedures established in Environmental Surveillance Procedures, Quality Control Program (Kimbrough et al. 1990) and in Vol. 1 of the Environmental Restoration Program Technical Support Contractor Technical Procedures Manual (Radian 1993b).

\subsubsection{Soils}

The soil sampling activities will include drilling and sampling soil borings and collecting shallow soil samples using a hand auger. The shallow soil samples will be collected in accordance with guidelines specified in method ESP-303-2, Revision 0. Soil samples collected from the soil borings will be collected in accordance with guidelines specified in method ESP-303-4, Revision 0. Soil samples will be put into containers, preserved, and handled in accordance with methods ESP-400, ESP-701, and ESP-800. During the sampling event all soils will be screened for potential organics and radiological contamination following the guidelines established in methods ESP-307-6 and ESP-307-7. To prevent the potential for crosscontamination of samples, each sample-rollecting device used during the sampling event will be decontaminated before its next use in accordance with method ESP-900.

Field activities during soil boring will be as follows:

- The split-spoon blow count will be recorded per American Society of Testing and Materials Method D 1586-84 on the soil lithology logs. The soil will be visually inspected and described using the Unified Soil Classification System; Munsell Color Charts will be used to describe soil color.

- Shelby tube samples will be taken following procedures outlined in ESP 303-5. All Shelby tube samples will be screened for radioactivity. The laboratory receiving samples will be licensed to process Special Nuclear Material (SNM) and posses adequate documentable ways to dispose of analysis residues.

- All sampling and drilling equipment will be decontaminated according to the procedures detailed in method ESP-901. All sample locations will be surveyed by a licensed surveyor to the nearest $0.3 \mathrm{~m}(1 \mathrm{ft})$ using Y-12 Plant coordinates. The elevation of the sample location will be surveyed to the nearest $0.003 \mathrm{~m}(0.01 \mathrm{ft})$ by the surveyor.

Analytical methods and detection limits used in this study for the analysis of water, soil, and sediment samples are listed in Appendix D.

\subsubsection{Groundwater}

The field sampling plan includes the installation of groundwater monitoring wells to evaluate the immediate response of groundwater levels to rainfall events and to establish hydraulic gradients at each site and to establish monitoring points for the quality of shallow groundwater. Wells in which groundwater levels react rapidly to rainfall are assumed to be connected to the active groundwater flow system in BCHR. Monitoring wells will be installed and modified for groundwater sampling in accordance with method ESP-600. All groundwater wells will be screened such that the screen intercepts the groundwater table and the likely range of vertical variation of the groundwater table. This will allow the well to sample 
groundwater at the water table/vadose zone interface and intercept any LNAPL that may be on the groundwater. All borings that are proposed to be converted to piezometers will bottom at $2.4 \mathrm{~m}(8 \mathrm{ft})$ below the current water table to allow sufficient screen length to ensure flow into the well during purging.

At each site all proposed and existing monitoring wells for which continued monitoring is proposed will be tested to evaluate the extent to which each well is connected to the active groundwater flow system. This will be done by monitoring water levels in each well over a period of at least 1 month or until enough data is assembled to establish the relationship between groundwater levels and rainfall. It is presumed that water levels in wells that are connected to the active groundwater flow system will change rapidly in response to rainfall events, whereas those that are not connected will not display as great a change in the water levels. The data generated by continued monitoring of water levels in wells will be used to identify wells that are connected to the active flow system. These data will also be evaluated in relation to storm flow tube and stream flow monitoring data. An example of a storm flow tube construction is shown in Fig. 7.2.

Before installing each well and initiating each groundwater sampling event, all equipment, well materials, and sampling devices will be decontaminated in compliance with ESP-900 and ESP-901. The piezometers and wells will be developed, purged, and sampled in compliance with the guidelines specified in ESP-302-2. Where soils are fine-grained, and likely to cause difficulty in the purging of wells, wells will be purged at low flow rates until dry. All groundwater samples collected will be put into containers, preserved, and handled in accordance with ESP-400, ESP-701, and ESP-800. Water level measurements recorded from the piezometers will follow the guidance specified in ESP-302-1.

\subsubsection{Surface water/sediments}

Surface water samples will be collected, as applicable, in accordance with ESP-301-1; storm event sampling will follow ESP-301-6. Before each surface water sampling event, all sampling equipment will be decontaminated following the guidelines established in methods ESP-900 and ESP-901. All samples collected will be put into containers, preserved, and handled in accordance with methods ESP-400, ESP-701, and ESP-800.

\subsubsection{Ecological samples}

Terrestrial small mammals will be trapped in snap-traps, identified, and counted; and selected individuals will be analyzed for whole-body burden of COCs following guidelines set forth in TP-309-3. Amphibia will be sampled with dip nets as indicators of contaminant uptake from surface water ponds following guidelines in procedure TP-309-5. Earthworms will be sampled according to the requirements of TP-309.8 as indicators of contaminant uptake from soil. A portion of each sample will be weighed, depurated, and reweighed before being analyzed for metals, PAHs, and PCBs. Grasses and browse will be clipped and analyzed as sources of contaminants to herbivores by ingestion following procedure TP-309-2. Toxicity tests will be done by standard EPA-approved laboratory procedures. The sampling locations will be chosen to maximize the comparability of physical media sampling data with biological sample data. All populations and habitat characterizations will be compared to similar characterizations performed on reference areas of BCV not affected by BCV OU 1 contaminants. Strict custody and quality control will be maintained for all of the sampling and analysis for the ERA. 


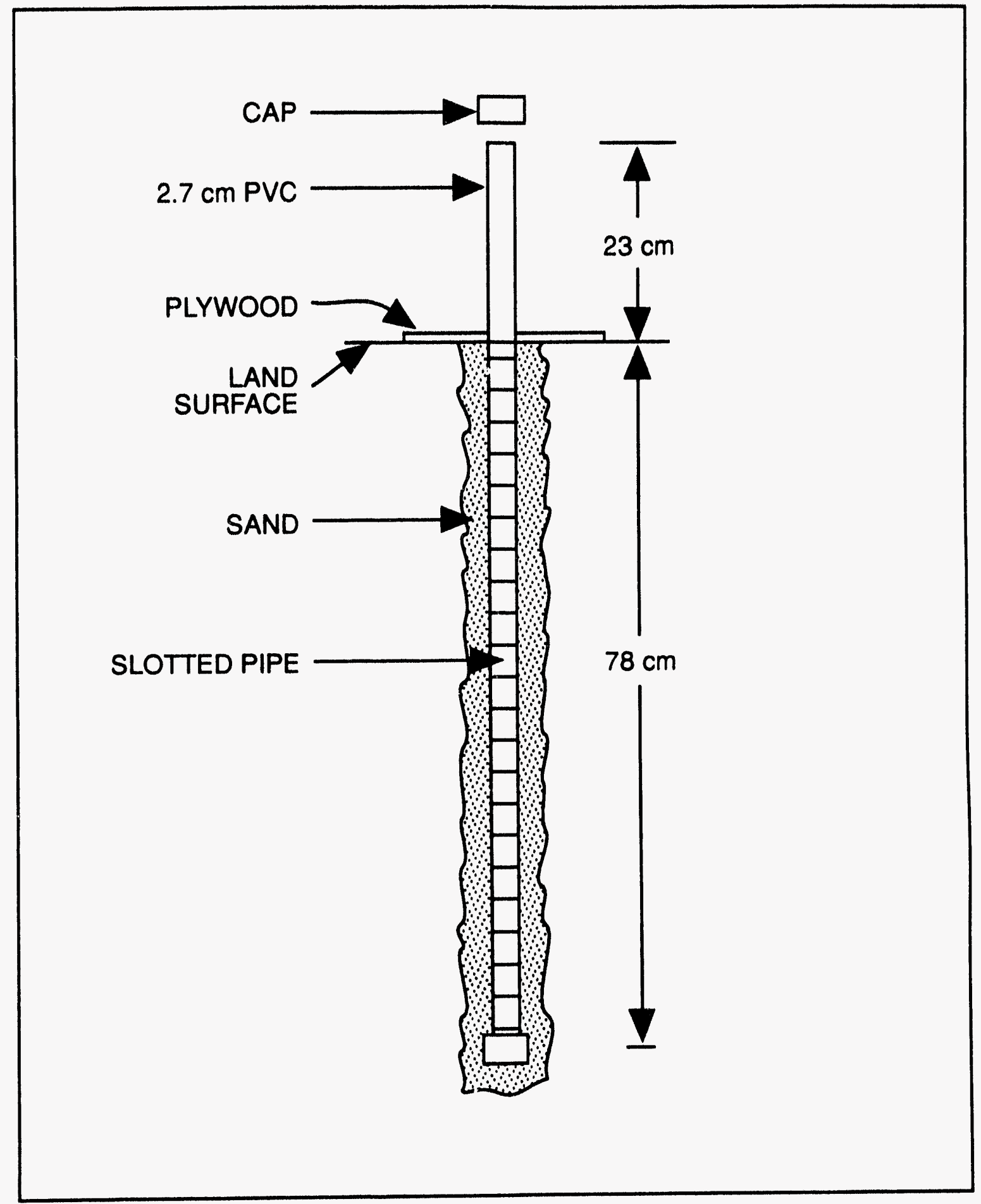

Fig. 7.2. Construction diagram of tubes used for monitoring of water levels in the storm flow zonc. 
Pond and wetland locations containing sufficient water for the development of amphibian larvae will be identified from the OU 1-wide habitat survey. Three of these locations within the are of contamination and one reference location upslope of contaminants will be chosen at random for evaluation of the potential for transfer of contaminants to amphibian larvae. At the appropriate time of year, the water bodies will be monitored for the development of amphibian larvae. Before they are mature, they will be sampled by dip-netting, individuals will be identified to the species level, and one composite sample of at least $165 \mathrm{~g}$ from each water body will be submitted for analysis. A field duplicate and a rinsate sample will be taken from one location, and a sample of at least $300 \mathrm{~g}$ will be taken at one location to allow for the preparation of method spike and method spike duplicate samples. Therefore, it is anticipated that 4 samples, 1 duplicate, 1 rinsate, and 1 method spike/method spike duplicate will be submitted.

Target analytes will be metals by neutron activation $(5 \mathrm{~g}), \mathrm{PAHs}(30 \mathrm{~g}), \mathrm{PCBs}(30 \mathrm{~g})$, and radiological parameters $(100 \mathrm{~g}$, limited to gross alpha, gross beta, and gamma spectroscopy because of the difficulty of obtaining sufficiently large samples for additional analyses). If amphibian larvae are not found in water bodies at a time when other similar water bodies contain them, the surface water will be sampled for Ceriodaphnia toxicity tests. If contaminant transfer or toxicity is evident in any of the water bodies, additional water bodies will be sampled during Phase II to evaluate the extent of exposure to amphibians, and by extension, to other aquatic biota and their predators.

\subsubsection{S-3 Site}

Operational information and previous sampling at the S-3 Site indicate that soil and groundwater are contaminated with metals, radiological contaminants, PCBs, and possibly VOCs. The sources of contamination at the S-3 Site are the sludge in the former ponds and the soils surrounding those ponds that were contaminated by reprecipitation or sorption of contaminants migrating from the ponds during their operation. A walk-over radiological survey will be conducted along the main stem of Bear Creek above its confluence with NT-1. This surveys will be used to identify likely locations of seeps in Bear Creek adjacent to the S-3 Site.

Soil boring and groundwater sampling will be conducted at the S-3 Site and the areas in the immediate vicinity. Six soil borings will be drilled at the locations downgradient of the S-3 Site (Fig. 7.3) to define the nature and extent of secondary contamination in soils. One upgradient soil boring will be made. Two samples of soils will also be used to determine the leachability of contaminants by toxicity characteristic leaching procedure (TCLP) to allow evaluation of the contribution of soil contamination to groundwater. Geotechnical data for the FS will be collected from two samples out of the same borings as those from which TCLP samples were taken. Four wells will be converted to groundwater monitoring wells. Table 7.3 presents the sample apportionment, and Table 7.4 presents a detailed summary of the number of samples and quality samples to be collected.

\subsubsection{S-3 Site soils}

Groundwater monitoring data (HSW 1991, 1992; Geraghty and Miller 1985, 1986, 1987 , $1989,1990)$ indicate that the groundwater table ranges between 1.8 and $4.3 \mathrm{~m}(6$ and $14 \mathrm{ft})$ below grade at the S-3 Site. Soil borings close to the S-3 cap (S-3 1, S-3 4, S-3 5, S-3 6, and $\mathrm{S}-3 \mathrm{3}$ ) will, therefore, be sampled to $4.9 \mathrm{~m}$ (16 ft) below grade; when the borings are to be 


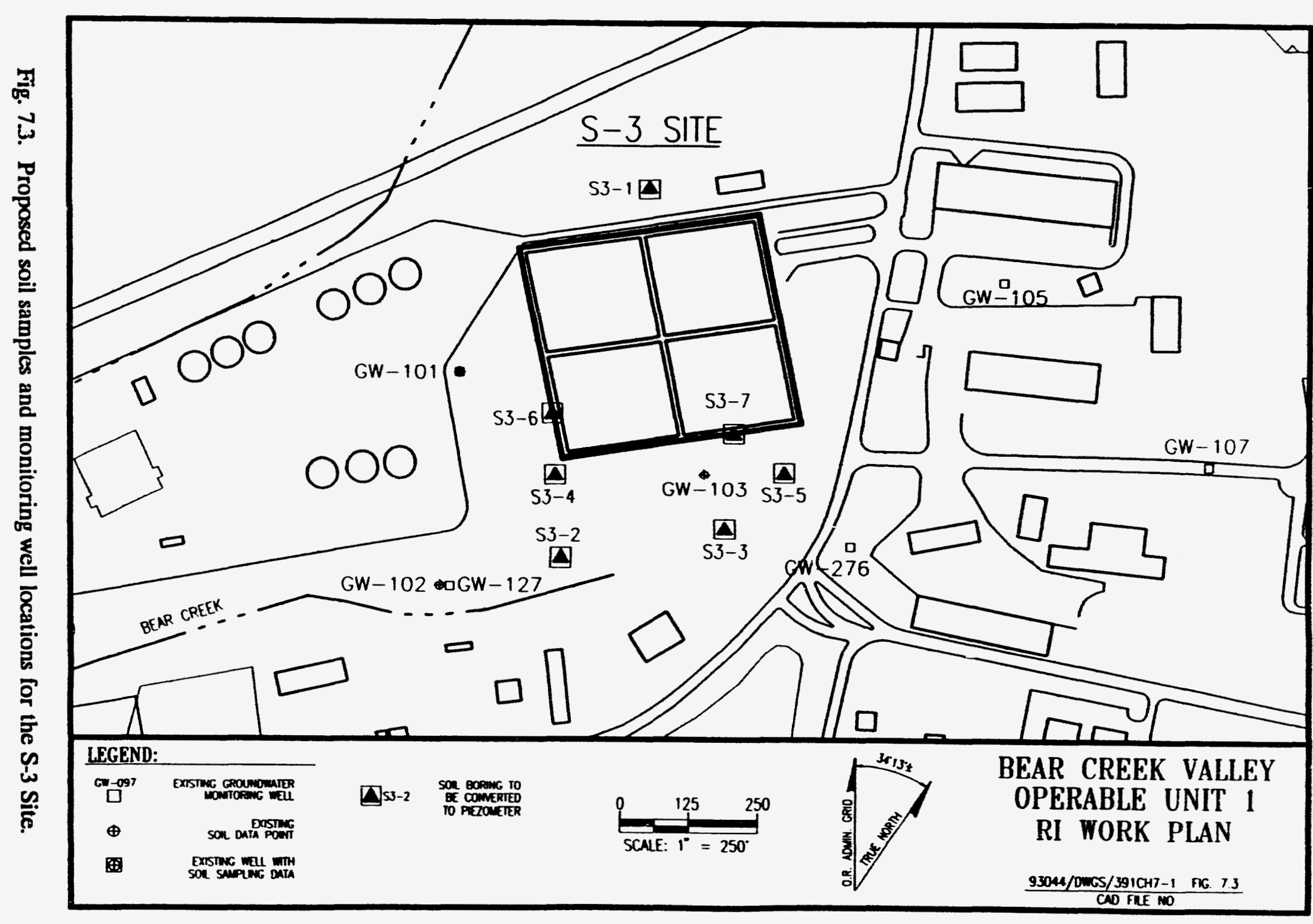


Table 7.3. Sample apportionment by medium for the S-3 Site

\begin{tabular}{|c|c|c|c|c|c|c|}
\hline Medium & Source & Location & $\begin{array}{c}\text { No. of } \\
\text { samples }\end{array}$ & Frequency & Analysis/procedure & Rationale \\
\hline Soils & Soil borings & S-3 1 through S-3 7 & 28 & Once & $\begin{array}{l}\text { Metals, VOCs, } \\
\text { radiological } \\
\text { parameters, }{ }^{d} \text { PCBs }\end{array}$ & $\begin{array}{l}\text { Define the nature and extent of } \\
\text { contamination in soils }\end{array}$ \\
\hline Soils & Soil borings & S-3 $1, S-33$ & 2 & Once & TCLP & $\begin{array}{l}\text { Evaluate the potential for } \\
\text { contaminants to leach from soils } \\
\text { and wastes }\end{array}$ \\
\hline Soils & Soil borings & $S-31$ and S-3 3 & 2 & Once & $\begin{array}{l}\text { Physical, hydrological, } \\
\text { and geochemical } \\
\text { properties }\end{array}$ & $\begin{array}{l}\text { Obtain information necessary to } \\
\text { evaluate the potential for } \\
\text { contaminant migration through } \\
\text { soils and for screening of } \\
\text { remedial technologies }\end{array}$ \\
\hline Groundwater & $\begin{array}{l}\text { Monitoring } \\
\text { wells }\end{array}$ & $\begin{array}{l}\text { Well list to be } \\
\text { determined by } \\
\text { monitoring teste }\end{array}$ & $24^{f}$ & 4 quarters & $\begin{array}{l}\text { Metals, VOCs, } \\
\text { radiological } \\
\text { parameters, }{ }^{d} \text { PCBs, } \\
\text { major ions, and field } \\
\text { parameters }\end{array}$ & $\begin{array}{l}\text { Assess the contribution to the } \\
\text { integrator unit from } \\
\text { contaminated soils and wastes }\end{array}$ \\
\hline
\end{tabular}

${ }^{a}$ Quality assurance samples are not included.

${ }^{b}$ Analytical methods are discussed in the Quality Assurance Project Plan (Chap. 8 of this RI work ptan).

'This number assumes samples will be collected at every 4-ft interval to a depth of $16 \mathrm{ft}$, from seven soil borings.

${ }^{d}$ Radiological parameters include gross $\alpha$, gross $\beta$, gamma spectroscopy, isotopic uranium, and isotopic thorium, ${ }^{\infty} \mathrm{Tc},{ }^{2} \mathrm{Pu}$, and ${ }^{\infty} \mathrm{Sr}$.

'See text for details.

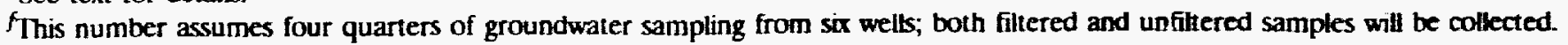




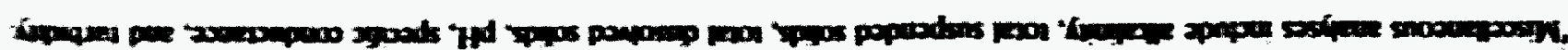

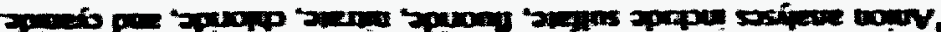

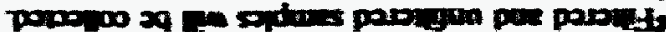

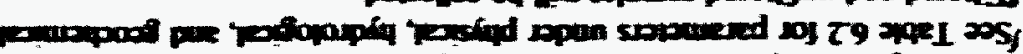

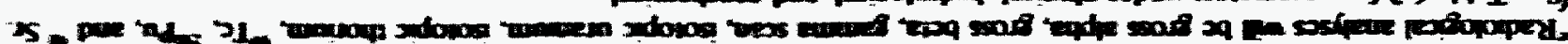

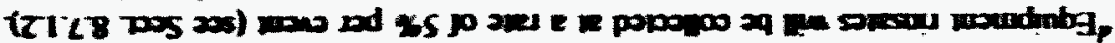

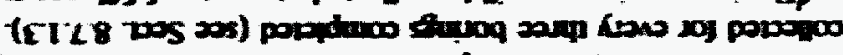

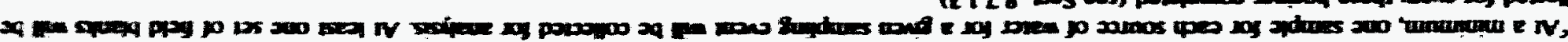

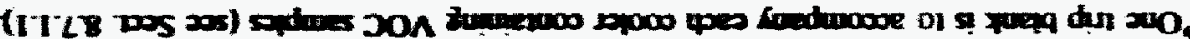

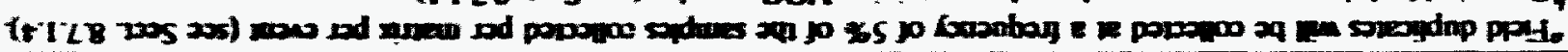

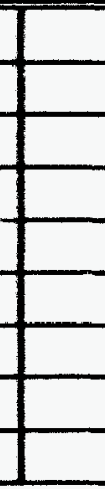

\begin{tabular}{|c|c|c|}
\hline$t$ & $\boldsymbol{z}$ & 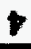 \\
\hline 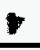 & $\boldsymbol{n}$ & 1 \\
\hline$\bullet$ & $\Delta z$ & $\downarrow$ \\
\hline 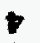 & $n z$ & $\boldsymbol{\nabla}$ \\
\hline 1 & $\mathbf{r 2}$ & $t$ \\
\hline 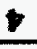 & $\$ 2$ & 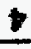 \\
\hline$\downarrow$ & $n z$ & $t$ \\
\hline
\end{tabular}

\begin{tabular}{|c|c|}
\hline 9 & snoonetiposin \\
\hline 9 & saOd \\
\hline 9 & Ptyetonitwos \\
\hline \multirow[t]{2}{*}{9} & mugon \\
\hline & sỵe? \\
\hline 9 & sronotueied jeglopolpey \\
\hline 9 & sagury \\
\hline \multirow[t]{2}{*}{9} & STEION \\
\hline & sinuessoul \\
\hline
\end{tabular}

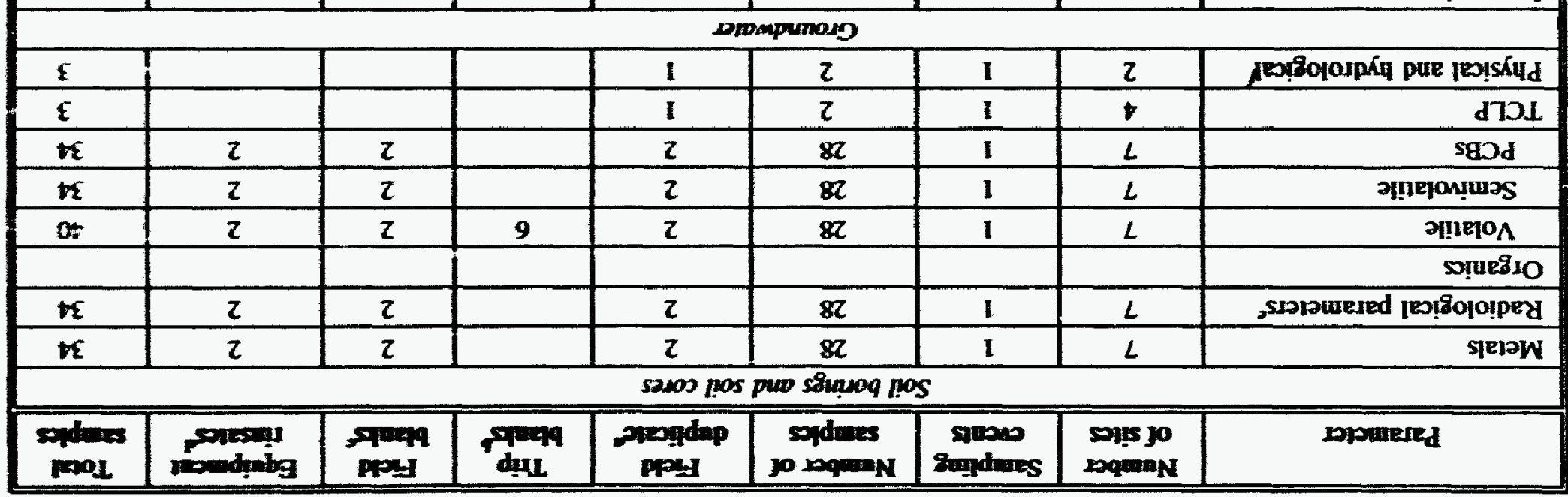

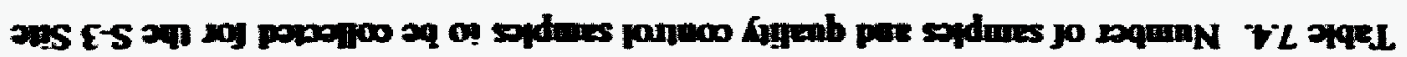


converted io monitoring wells, they will be advanced $106.7 \mathrm{~m}(22 \mathrm{ft})$ without sampling. Two boringa are propoued to be located close to seeps in Bear Creek, where groundwater will be chmer to the surface (S.32 and S.3). These wells will be sampled to $2.4 \mathrm{~m}(8 \mathrm{ft})$ below the groundwater table at the time of sampling and will be $3.7 \mathrm{~m}$ (12 ft) deep. Borings will be umpled uaing 0.6.m (2.f1) splir-spoon barrels. Soil borings from outside the S-3 Site will be umpled firat bacause they are likely to be the least contaminated borings (S-3 1 to S-3 5).

Al samples will be surveyed in the field with an OVA and scanned for beta and gamma radiation with OM pancake probe. The OVA reading will be taken immediately after opening the aplit spoon and will be followed by the GM pancake.

A portion of these sumples will be collected for chemical and radiological analysis. Table 7.3 presents an estimate of the number of samples to be analyzed per media at the S-3 Sile. The sumple estimate presented in Table 7.3 is based on seven vertical borings sampled $104.8 \mathrm{~m}$ (16 $\mathrm{fl}$ ) with continuous sampling at $1.2 \mathrm{~m}$ (4-ft) intervals. VOC samples will be collected from the firat $0.6 \mathrm{~m}$ (2 $(1)$ for each $1.2-\mathrm{m}$ (4-ft) interval sampled for chemical and radiological analyais. The remaining parameters will be composited over the entire 1.2-m (4-ft) interval.

Two Shelby lube samples will he collected at the S-3 Site from borings outside the S-3 cap. The samples will be analyzed for the geotechnical and hydrological parameters listed in Tuble 6.2. The sume samples will have TCLP carried out to determine the potential for contaminant leachability. All samples will be collected in the unsaturated zone. The exact location and sumple interval of the Shelhy tubes will be determined in the field by the project geokogiat after inspection of soil lithology logs prepared for the first soil boring drilled. When - Shelhy lube sample is taken, chemical and radiological parameters will be analyzed for the fini $0.6 \mathrm{~m}(2 \mathrm{fi})$ of a $1.2 \mathrm{~m}$ (4.ft) sample. The Shelby tube sample will be the second $0.6 \mathrm{~m}$ (2 fi) of the 1.2-m (4-ft) sample.

\section{4 .22 5.3 Slle groundwater}

Al soil borings outside the S-3 cap will be converted to monitoring wells, and water levels in these wells and existing wells GW-101, GW-127, and GW-276 will be monitored continuously by data logger over a 1 -month period. Continuously monitoring groundwater levelu will help to identify wells that are most likely to be connected to the active groundwater now anstem in the headwaters of BCHR. Wells for which groundwater levels fluctuate in response 10 rainfall events will be used as monitoring wells, and groundwater monitoring will be carried out for four consecutive quarters. Groundwater will be analyzed for VOCs, metals, radiological parumeters, anions, and those miscellaneous parameters identified in Table 7.4. Field measurements will include water depth, temperature, $\mathrm{pH}$, specific conductance, and diseolved oxygen.

\subsubsection{Oil Landfarm}

Operational information and previous sampling at the Oil Landfarm indicate that soil and groundwater are contaminated with metals, PCBs, and VOCs. The source of contamination at the Oil Landiarm is contaminated soils in the Landfarm and possibly soils surrounding the Landfarm that were contaminated by reprecipitation or sorption of contaminants or residual LNADL and DNADL migrating away from the site. Soil boring, groundwater, stream water, and sediment sampling will be conducted in areas around the Oil Landfarm cap. No borings 
will be made through the cap. Six soil borings will be made outside the Oil Landfarm cap, four downgradient and two upgradient (Fig. 7.4). Four soil samples will be used to determine

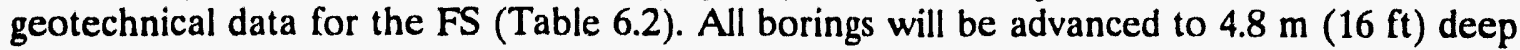
or to $2.4 \mathrm{~m}(8 \mathrm{ft})$ below the lowest recorded groundwater level in nearby wells, whichever is shallower. Five soil borings will be converted to piezometer wells and tested for how well they are connected to the active groundwater flow system. Groundwater from existing wells in the vicinity of the Oil Landfarm will also be monitored for water level fluctuations (GW-005, GW-007, GW-010). Table 7.5 presents the sample apportionment, and Table 7.6 presents a detailed st'mmary of the number of samples and quality samples to be collected.

\subsubsection{Oil Landfarm soils}

The soil borings will be sampled to refusal or $4.8 \mathrm{~m}$ (16 ft) (whichever is shallower), or to $2.4 \mathrm{~m}(8 \mathrm{ft})$ below the groundwater table. The borings will be sampled at $0.6-\mathrm{m}(2-\mathrm{ft})$ intervals using split spoons. All samples will be surveyed in the field with an OVA and scanned for beta and gamma radiation with a GM pancake probe. The OVA reading will be taken immediately after opening the split spoon followed by the GM pancake. The readings from these meters will be recorded for every $0.6-\mathrm{m}(2-\mathrm{ft})$ interval on the soil lithology log.

A portion of these samples will also be collected for chemical and radiological analysis. VOC samples will be collected from the first $0.6 \mathrm{~m}(2 \mathrm{ft})$ for each $1.2-\mathrm{m}(4-\mathrm{ft})$ interval sampled for chemical and radiological analysis. The remaining parameters will be composited over the entire $1.2-\mathrm{m}$ (4-ft) interval. Table 7.6 presents an estimate of the number of samples to be analyzed per media at the Oil Landfarm. The sample estimate presented in Table 7.6 is based on six borings advanced to $3.7 \mathrm{~m}$ (12 ft) with continuous sampling at $1.2-\mathrm{m}(4-\mathrm{ft})$ intervals. Groundwater is likely to be between 1.5 and $3.4 \mathrm{~m}(5$ and $11 \mathrm{ft})$ below ground surface; borings are proposed to be completed to at least $1.2 \mathrm{~m}(4 \mathrm{ft})$ below the lowest recorded level for the groundwater table in nearby wells.

Two Shelby tube samples will be collected from soils surrounding the Oil Landfarm cap and will be analyzed for geotechnical and hydrological parameters described in Table 6.2. All samples will be collected in the unsaturated zone. The exact location and sample intrival of the Shelby tubes will be determined in the field by the project geologist after inspection of soil lithology logs prepared for the first soil boring drilled.

\subsubsection{Oil Landfarm groundwater}

All soil borings, with the exception of OLF-4 (which is located next to GW-010), will be converted to monitoring wells, and water levels in these wells and existing wells GW-007 and GW-010 will be monitored continuously over a 1-month period. Continuously monitoring groundwater levels with pressure transducers and data loggers will help to identify wells that are most likely to be connected to the active groundwater flow system in the headwaters of BCHR. Groundwater will be analyzed for VOCs, metals, radiological parameters, anions, and those miscellaneous parameters identified in Table 7.6. Field measurements will include water depth, temperature, $\mathrm{pH}$, specific conductance, and dissolved oxygen.

\subsubsection{Oil Landfarm biota}

Up to five sampling locations will be chosen at random from contaminated areas identified by the initial radiological survey. Sample locations will be chosen from a maximum 


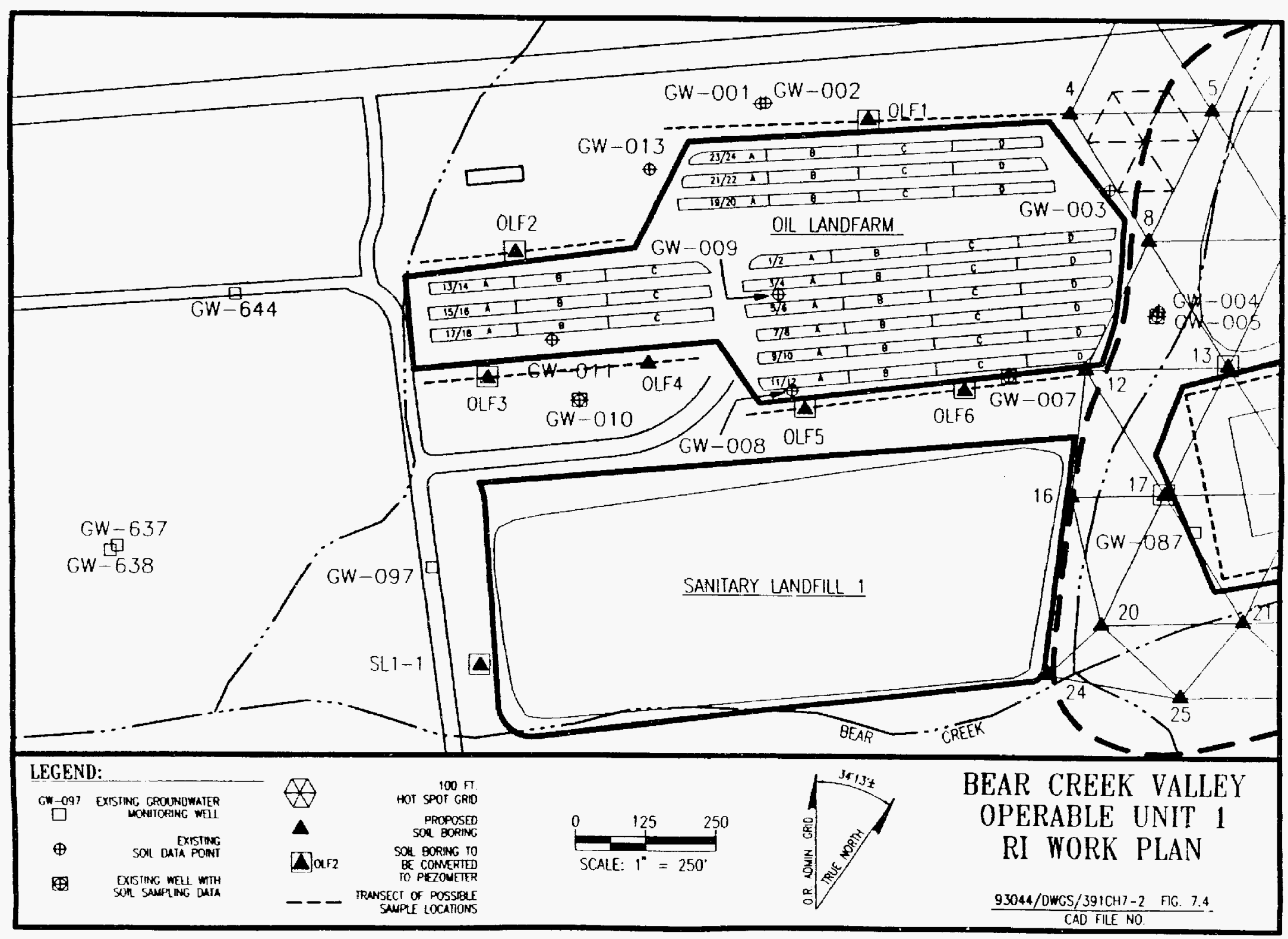

Fig. 7.4. Proposed monitoring well locations and soil, surface water, and stream sediment sample kocations for the Oil Landfarm. 
Table 7.5. Sample apportionment by medium for the Oil Landfarm and Sanitary Landfill I

\begin{tabular}{|c|c|c|c|c|c|c|}
\hline Medium & Source & Location & $\begin{array}{l}\text { No. of } \\
\text { samples }\end{array}$ & Frequency & Analysis/procedure & Rationale \\
\hline Surface soils & Hand auger & OLF 1 through 6 & $7^{c}$ & Once & $\begin{array}{l}\text { Metals, VOCs, } \\
\text { radiological parameters, } \\
\text { PCBs }\end{array}$ & $\begin{array}{l}\text { Define the nature and extent of } \\
\text { contamination in surface soiis }\end{array}$ \\
\hline Soils & Soil borings & OLF 1 through 6 & 28 & Once & $\begin{array}{l}\text { Metals, VOCs, } \\
\text { radiological parameters, } \\
\text { PCBs }\end{array}$ & $\begin{array}{l}\text { Define the nature and extent of } \\
\text { contamination in soils }\end{array}$ \\
\hline Soils & Soil borings & To be determined & 2 & Once & TCLP & $\begin{array}{l}\text { Evaluate the potential for } \\
\text { contaminants to leach from soils }\end{array}$ \\
\hline Soils & Soil borings & To be determined & 2 & Once & $\begin{array}{l}\text { Physical, hydrological, and } \\
\text { geochemical properties }\end{array}$ & $\begin{array}{l}\text { Obtain information necessary to } \\
\text { evaluate the potential for } \\
\text { contaminant migration through } \\
\text { soils and for screening of } \\
\text { remedial technologies }\end{array}$ \\
\hline Groundwater & $\begin{array}{l}\text { Monitoring } \\
\text { wells }\end{array}$ & $\begin{array}{l}\text { Well list to be } \\
\text { determined by } \\
\text { monitoring test }\end{array}$ & $20^{h}$ & 4 quarters & $\begin{array}{l}\text { Metals, VOCs, } \\
\text { radiological parameters, } \\
\text { PCBs, major ions, and } \\
\text { field parameters }\end{array}$ & $\begin{array}{l}\text { Assess the contribution to the } \\
\text { integrator unit from } \\
\text { contaminated soils }\end{array}$ \\
\hline Grasses & $\begin{array}{l}\text { Hand } \\
\text { clipping }\end{array}$ & $\begin{array}{l}\text { To be determined } \\
\text { from radiological } \\
\text { survey }\end{array}$ & 5 & Once & $\begin{array}{l}\text { Metals by NAA, } \\
\text { radiological parameters }\end{array}$ & $\begin{array}{l}\text { Assess the potential for } \\
\text { contaminant transfer from soil } \\
\text { to biota }\end{array}$ \\
\hline Browse & $\begin{array}{l}\text { Hand } \\
\text { clipping }\end{array}$ & $\begin{array}{l}\text { To be determined } \\
\text { from radiological } \\
\text { survey }\end{array}$ & 5 & Once & $\begin{array}{l}\text { Metals by NAA, } \\
\text { radiological parameters }\end{array}$ & $\begin{array}{l}\text { Assess the potential for } \\
\text { contaminant transfer from soil } \\
\text { to biota. }\end{array}$ \\
\hline
\end{tabular}


Table 75 (continued)

\begin{tabular}{|c|c|c|c|c|c|c|}
\hline Medium & Source & Location & $\begin{array}{c}\text { No. of } \\
\text { samples }\end{array}$ & Frequency & Analysis/procedure & Rationale \\
\hline \hline Earthworms & Excavation & $\begin{array}{l}\text { To be determined } \\
\text { from radiological } \\
\text { survey }\end{array}$ & 10 & Once & $\begin{array}{l}\text { Metals by NAA, } \\
\text { radiological parameters, } \\
\text { PAHs, PCBs }\end{array}$ & $\begin{array}{l}\text { Assess the potential for } \\
\text { contaminant transfer from soil } \\
\text { to biota }\end{array}$ \\
\hline
\end{tabular}

${ }^{\circ}$ Quality assurance samples are not included.

${ }^{b}$ Analytical methods are discussed in the Quality Assurance Project Plan (Chap. 8 of this RI work plan).

'This number assumes one surface sample per site.

${ }^{d}$ Radiological parameters include gross $\alpha$, gross $\beta$, gamma spectroscopy, isotopic uranium, and isotopic thorium.

This number assumes six sample borings will be sampled continuously with 4-ft intervals over $12 \mathrm{ft}$.

This number assumes four quarters of surface water sampling from four locations with two additional stormflow samples at each location.

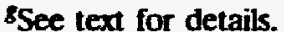

${ }^{h}$ This number assumes four quarters of groundwater sampling from four wells; both filtered and unfiltered samples will be collected.

Radiological parameters for ecological samples will be limited to gross $\alpha$, gross $\beta$, and gamma spectroscopy. 


\begin{tabular}{|c|c|c|c|c|c|c|c|c|}
\hline Parameter & $\begin{array}{l}\text { Number } \\
\text { of sites }\end{array}$ & $\begin{array}{l}\text { Sampling } \\
\text { cucats }\end{array}$ & $\begin{array}{l}\text { Number of } \\
\text { sampies }\end{array}$ & $\begin{array}{l}\text { Field } \\
\text { duplicate }\end{array}$ & Trip & $\begin{array}{l}\text { Ficld } \\
\text { blants }\end{array}$ & $\begin{array}{l}\text { Pquipment } \\
\text { ninsates }\end{array}$ & $\begin{array}{c}\text { Total } \\
\text { ramples }\end{array}$ \\
\hline \multicolumn{9}{|c|}{ Surface soils } \\
\hline Metals & 6 & 1 & 7 & 1 & & 1 & 1 & 10 \\
\hline Radiological parameters & 6 & 1 & 7 & 1 & & 1 & 1 & 10 \\
\hline Anions & 6 & 1 & 7 & 1 & & 1 & 1 & 10 \\
\hline \multicolumn{9}{|l|}{ Organics } \\
\hline Semivolatile & 6 & 1 & 7 & 1 & & 1 & 1 & 10 \\
\hline PCBs & 6 & 1 & 7 & 1 & & 1 & 1 & 10 \\
\hline \multicolumn{9}{|c|}{ Soil borings and soil cores } \\
\hline Metals & 6 & 1 & 28 & 1 & & 2 & 1 & 32 \\
\hline Radiological parameterse & 6 & 1 & 28 & 1 & & 2 & 1 & 32 \\
\hline \multicolumn{9}{|l|}{ Organics } \\
\hline Volatile & 6 & 1 & 28 & 1 & 7 & 2 & 1 & 39 \\
\hline Semivolatile & 6 & 1 & 28 & 1 & & 2 & 1 & 32 \\
\hline PCBs & 6 & 1 & 28 & 1 & & 2 & 1 & 32 \\
\hline TCLP & 2 & 1 & 2 & 1 & & & & 3 \\
\hline $\begin{array}{l}\text { Physical and hydrological } \\
\text { parameters }\end{array}$ & 1 & 1 & 2 & 1 & & & & 3 \\
\hline \multicolumn{9}{|c|}{ Groundwater } \\
\hline \multicolumn{9}{|l|}{ Inorganics } \\
\hline Metalss & 5 & 4 & 20 & 5 & & 5 & 5 & 35 \\
\hline Anions & 5 & 4 & 20 & 5 & & 5 & 5 & 35 \\
\hline
\end{tabular}


Table 7.6 (continusd)

\begin{tabular}{|c|c|c|c|c|c|c|c|c|}
\hline Parameter & $\begin{array}{l}\text { Number } \\
\text { of gites }\end{array}$ & $\begin{array}{l}\text { Sampling } \\
\text { events }\end{array}$ & $\begin{array}{c}\text { Number of } \\
\text { samples }\end{array}$ & $\begin{array}{c}\text { Ficid } \\
\text { duplicate }\end{array}$ & $\underset{\text { blantas }}{\text { Trip }}$ & $\begin{array}{c}\text { Field } \\
\text { bantas }\end{array}$ & $\begin{array}{l}\text { Equipinent } \\
\text { rinsates }\end{array}$ & $\begin{array}{c}\text { Total } \\
\text { sampies }\end{array}$ \\
\hline Radiological parameterse & 5 & 4 & 20 & 5 & & 5 & 5 & 35 \\
\hline \multicolumn{9}{|l|}{ Organics } \\
\hline Volatile & 5 & 4 & 20 & 5 & 5 & 5 & 5 & 40 \\
\hline Semivolatile & 5 & 4 & 20 & 5 & & 5 & 5 & 35 \\
\hline PCBs & 5 & 4 & 20 & 5 & & 5 & 5 & 35 \\
\hline Miscellaneousi & 5 & 4 & 20 & 5 & & 5 & 5 & 35 \\
\hline \multicolumn{9}{|c|}{ Vegetation and earthworms } \\
\hline Metals by NAA & 5 & 4 & 20 & & & & 3 & 23 \\
\hline Radiological parameters & 5 & 4 & 20 & & & & 3 & 23 \\
\hline \multicolumn{9}{|l|}{ Organics } \\
\hline PAHs & 5 & 2 & 10 & & & & 1 & 11 \\
\hline PCBs & 5 & 2 & 10 & & & & 1 & 11 \\
\hline
\end{tabular}

'Field duplicates will be collected at a frequency of $5 \%$ of the samples collected per matrix per event (see Sect. 8.7.1.4).

bOne trip blank is to accompany each cooler contarning VOC samples (see Sect. 8.7.1.1).

'Al a minimum, one sample for each source of water for a given sampling event will be collected for analysis. Al least one set of field blanks will be collected for every three borings completed (see Sect. 8.7.1.3).

${ }^{d}$ Equipment rinsates will be collected at a rate of $5 \%$ per event (see Sect. 8.7.1.2).

Radiological analyses will be gross alpha, gross beta, gamma scan, isotopic uranium, isotopic thorium and, for some samples, isotopic plutonium, $\mathrm{Tc}^{99}$, and $\mathrm{St} \mathbf{s}^{90}$

$f_{\text {See Table }} 6.2$ for parameters under physical, hydrological, and geochemical.

sFittered and unfiltered samples will be collected.

hAnion anabyses include sulfate, fluoride, nitrate, chloride, and cyanide.

'Miscellaneous analyses include alkalinity, total suspended solids, total dissolved solids, pH, specific conductance, and turbidity.

iBecause of limited sample availability, radiological parameters for ecological samples will be limited to gross alpha, gross beta, and gamma scan. 
of 50 areas showing the highest levels of contamination. Grasses, browse, and earthworms will be sampled at these locations; however, if their numbers are reduced, soil will be sampled for toxicity testing as described in Sect. 6.1.1.4. One equipment rinsate will be submitted for each medium (clippers and bowl for grasses, clippers and bowl for browse, and depuration chambers for earthworms).

Approximately $150 \mathrm{~g}$ of vegetation and $400 \mathrm{~g}$ of earthworms will be required per sample. Earthworm samples will be divided, and approximately $235 \mathrm{~g}$ will be depurated before being submitted for analysis. Samples of each matrix will be held at 4 degrees $C$ and will be combined in sample groups with like samples from the Boneyard/Burnyard and the Burial Ground. Vegetation and earthworm samples will be analyzed for metals and radiological parameters, and earthworms will also be analyzed for PAHs and PCBs (Table 7.6).

\subsubsection{Boneyard/Burnyard and HCDA}

Operational information from this site is limited, and soils at the Boneyard/Burnyard and HCDA may be contaminated with metals, radionuclides, PCBs, dioxin, furan, and VOCs. The sources of contamination at the Boneyard/Burnyard are the waste materials in trenches in both the Boneyard and the Burnyard, residues from burning wastes in those trenches, and contaminated soils resulting from operations at the HCDA. The site action plan describes activities at the Boneyard/Burnyard to be carried out to complete Stage 1 of the RI/FS process and the first phase of sampling to be carried out in Stage 2. Stage 2 activities will be conducted in two phases of soil sampling because of the large size of this site and the uncertainty concerning contaminant locations.

A walk-over observational and radiological survey will be performed, followed by a walkover soil electromagnetic induction (EM) survey and a magnetometry survey. The purpose of the observational survey is to identify unearthed items of waste that will need to be removed prior to RI work at the site. The radiological and geophysical surveys will be carried out to identify hot spots to target subsequent boring activities.

Soil boring and groundwater sampling will be conducted at the Boneyard/Burnyard. Locations of soil borings will be based on a coarse grid with 76.2-m (250-ft) sample spacing (Fig. 7.5). This grid will be refined, based on data from the geophysical surveys, to concentrate on areas with high radiologic emissions and/or with high conductivity. Surface water samples are proposed for NT-3 and are described above in Sect. 7.4.3.3.

\subsubsection{Screening surveys}

Surveys will be carried out over a grid designed to cover the known boundaries of the Boneyard/Burnyard and to incorporate possible sites of waste materials that are located outside the current boundaries. The UltraSonic Ranging and Data System (USRADS), developed by ORNL, will be used to obtain quadrature equipment readings simultaneously for each survey. The radiological survey will be carried out for beta and gamma radiation using a Geiger-Mueller type counter. The EM survey will use an EM.31 (Nyquist and Blair 1991); the magnetometry survey will use a Proton-precession type magnetometer. Each survey will be carried out on lines in a north-south direction. The whole area will then be repeated in an east-west direction. Rapid evaluation of high conductivity areas will allow closer spacing surveys of selected sites to be carried out in order to accurately locate soil borings for phase 2 soil sampling. The number of lines and the line spacing for the surveys will be determined 


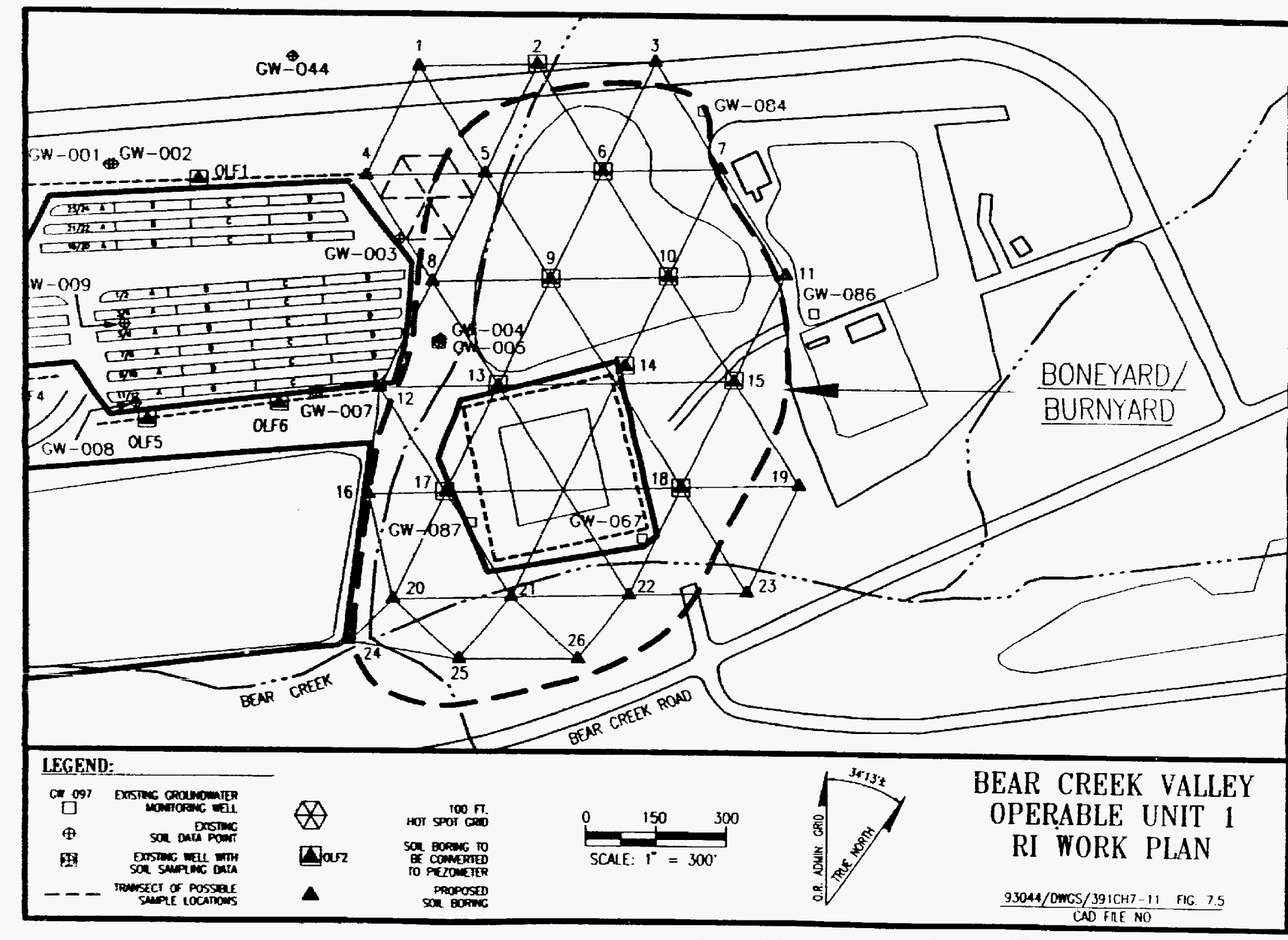

Fig. 7.5. Proposed soil samples and monitoring well locations for the Bonegard/Burnyard. 
after an initial walk-over by the project geologist and geophysicist. Line spacing will be close enough to delineate variations in soil conductivity and magnetism.

\subsubsection{Boneyard/Burnyard soils}

Soil borings will be located using the following two methods:

- Borings located on a regular grid.

- Borings located at hot spot areas (i.e., regions of the survey grid with abnormally high radiological emissions or high electrical conductivity)

Regularly spaced borings will provide sufficient samples to define the extent of soil contamination at this site and to identify, in conjunction with the geophysical and radiological surveys, areas of contamination that require evaluation using more detailed sampling. Boring locations were selected according to methods outlined in EPA 230/02-89-042 (EPA 1989e). Borings will be taken on a triangular based grid with a $76.2-\mathrm{m}(250-\mathrm{ft})$ spacing between samples (Fig. 7.5). One node out of this grid is located in the HCDA cap and will not be sampled. This method will result in 26 soil borings over the Boneyar//Burnyard (BYBY) site (BYBY 1 to 26), including soil samples from outside the currint Boneyard/Burnyard boundary. The regular grid is altered slightly where sample locations were either in SL 1 (BYBY 16), located close to the edge of the HCDA cap (BYBY 14), or located too close to Bear Creek Road (BYBY 24 and 25). The locations of these borings are shown on Fig. 7.5.

Second-phase soil borings will be made over a smaller grid spacing over "hot spot" areas. An example of a grid based on borings spaced at $30.5 \mathrm{~m}$ (100 ft) is shown on Fig. 7.4 over an area that had high conductivity in the Western Geophysical survey. The location and spacing of borings on finer grids will be determined after the screening surveys. Soil samples will be selected at random from nodes on these finer grids. The number of samples to be taken from each grid will be such that the concentrations of COCs are defined within acceptable bounds at the $95 \%$ confidence level. Soils sampled in this phase will be analyzed for COCs only. COCs at each "hot spot" will be determined from phase 1 sampling.

In phase 2, priority will be given to areas with identified soil contamination. For areas at which soil contamination was not indicated-though geophysical and radiological surveys suggested the presence of waste materials-the prioritization of "hot spot" will be as follows:

- Areas with both high conductivity and high radiological emissions

- Areas with high radiological emissions without identifiable high conductivity readings

- Areas with high conductivity without significant elevated radiological emissions

All borings will be sampled to $1.2 \mathrm{~m}(4 \mathrm{ft})$ below the lowest historical groundwater table for this site. The water table over most of the Boneyard/Burnyard is probably $<1.5 \mathrm{~m}(5 \mathrm{ft})$ below the surface, so borings are expected to be between 2.4 and $3.0 \mathrm{~m}(8$ and $10 \mathrm{ft}$ ) deep. All borings will be sampled continuously at $1.2-\mathrm{m}(4-\mathrm{ft})$ intervals. A portion of the samples taken from grid-spaced borings will be collected for chemical and radiological analysis. Table 7.7 presents the sample apportionment, and Table 7.8 presents a detailed summary of the number of samples and quality control samples to be collected. Borings that are to be converted to piezometer wells will be advanced an additional $1.2 \mathrm{~m}(4 \mathrm{ft})$ without sampling. 
Table 7.7. Sample apportionment by medium for the Boneyard/Burnyard

\begin{tabular}{|c|c|c|c|c|c|c|}
\hline Mediam & Souree & Location & $\begin{array}{l}\text { No. of } \\
\text { samples }\end{array}$ & Frequency & Anatsisprocedure & Rationale \\
\hline Surface soils & Hand auget & BYBY 1 through 26 & $26^{c}$ & Once & $\begin{array}{l}\text { Metak, VOCs, radiological } \\
\text { parameters, }{ }^{d} \text { PCBs }\end{array}$ & $\begin{array}{l}\text { Define the nature and extent of } \\
\text { contamination in surface soils }\end{array}$ \\
\hline Soils & Soil borings & BYBY 1 through 26 & $78^{e}$ & Once & $\begin{array}{l}\text { Metals, VOCs, radiological } \\
\text { parameters, }{ }^{d} \text { PCBs }\end{array}$ & $\begin{array}{l}\text { Define the nature and extent of } \\
\text { contamination in soils }\end{array}$ \\
\hline Soik & Soil borings & To be determined & 2 & Once & TCLP & $\begin{array}{l}\text { Evaluate the potential for } \\
\text { contaminants to leach from soils }\end{array}$ \\
\hline Soils & Soil borings & To be determined & 2 & Once & $\begin{array}{l}\text { Physical, hydrological, and } \\
\text { geochemical properties }\end{array}$ & $\begin{array}{l}\text { Obtain information necessary to } \\
\text { evaluate the potential for contaminant } \\
\text { migration through soils and for } \\
\text { screening of remedial technologies }\end{array}$ \\
\hline Groundwater & $\begin{array}{l}\text { Monitoring } \\
\text { wel's }\end{array}$ & $\begin{array}{l}\text { Well list to be } \\
\text { determined by } \\
\text { monitoring test }\end{array}$ & 288 & 4 quarters & $\begin{array}{l}\text { Metals, VOCs, radiołogical } \\
\text { parameters, }{ }^{d} \text { PCBs, major } \\
\text { ions, and field parameters }\end{array}$ & $\begin{array}{l}\text { Assess the contribution to the } \\
\text { integrator unit from contaminated } \\
\text { soils }\end{array}$ \\
\hline Grasses & Hand clipping & $\begin{array}{l}\text { To be determined } \\
\text { from radiotogical } \\
\text { surveys }\end{array}$ & 5 & Once & $\begin{array}{l}\text { Metals by NAA, radiological } \\
\text { parameters }\end{array}$ & $\begin{array}{l}\text { Assess the potential for contaminant } \\
\text { transfer from soil to biota }\end{array}$ \\
\hline Brouse & Hand clipping & $\begin{array}{l}\text { To be determined } \\
\text { from radiological } \\
\text { surveys }\end{array}$ & 5 & Once & $\begin{array}{l}\text { Metaks by NAA, radiological } \\
\text { parameters }\end{array}$ & $\begin{array}{l}\text { Assess the potential for contaminant } \\
\text { transfer from soil to biota }\end{array}$ \\
\hline Earthworms & Excovation & $\begin{array}{l}\text { To be determined } \\
\text { from radiological } \\
\text { surveys }\end{array}$ & 10 & Once & $\begin{array}{l}\text { Metak by NAA, radiological } \\
\text { parameters", PAHs, PCBs }\end{array}$ & $\begin{array}{l}\text { Assess the potential for contaminant } \\
\text { transfer from soil to biota }\end{array}$ \\
\hline
\end{tabular}

${ }^{a}$ Quality assurance samples are not included.

${ }^{b}$ Anatytical metbods are discussed in the Quality Assurance Project Plan (Chap. 8 of this RI work plan).

This number assumes one surface sample per site.

${ }^{d}$ Radiological parameters include gross $\alpha$, gross $\beta$, gamma spectroscopy, isotopic uranium, isotopic thorium, ${ }^{\infty 0} \mathrm{Tc},{ }^{288} \mathrm{Pu}$, and ${ }^{\infty 0} \mathrm{Sr}$.

This number assumes 26 sample borings will be sampled continuously with 4-ft intervals over $12 \mathrm{ft}$.

This number ascumes four quarters of groundwater sampling from seven welts; both filtered and unfiltered samples will be collected.

See tea for detaik.

"Radiological parameters for ecological samples will be timited to gross alpha, gross beta, and gamma spectroscopy. 
Table 7.8. Number of samples and quality control samples to be collected for the Boneyard/Burnyard.

\begin{tabular}{|c|c|c|c|c|c|c|c|c|}
\hline Parameter & $\begin{array}{l}\text { Number } \\
\text { of siles }\end{array}$ & $\begin{array}{l}\text { Somping } \\
\text { exents }\end{array}$ & $\begin{array}{c}\text { Number of } \\
\text { samples }\end{array}$ & $\begin{array}{c}\text { Fiedd } \\
\text { dupticate }\end{array}$ & $\begin{array}{c}\text { Trip } \\
\text { btants }\end{array}$ & $\begin{array}{c}\text { Field } \\
\text { btants }\end{array}$ & $\begin{array}{l}\text { Equiponed } \\
\text { rimsates }\end{array}$ & $\begin{array}{l}\text { Totad } \\
\text { samples }\end{array}$ \\
\hline \multicolumn{9}{|c|}{ Surface soils } \\
\hline Metaks & 26 & 1 & 26 & 2 & & 2 & 2 & 32 \\
\hline Radiological parameters & 26 & 1 & 26 & 2 & & 2 & 2 & 32 \\
\hline Anions & 26 & 1 & 26 & 2 & & 2 & 2 & 32 \\
\hline \multicolumn{9}{|l|}{ Organics } \\
\hline Semivotatile & 26 & 1 & 26 & 2 & & 2 & 2 & 32 \\
\hline PCBs & 26 & 1 & 26 & 2 & & 2 & 2 & 32 \\
\hline Pesticides & 26 & 1 & 26 & 2 & & 2 & 2 & 32 \\
\hline \multicolumn{9}{|c|}{ Soil borings and soil cores } \\
\hline Metals & 26 & 1 & 78 & 4 & & 9 & 4 & 95 \\
\hline Radiological parameters & 26 & 1 & 78 & 4 & & 9 & 4 & 95 \\
\hline Anicns & 26 & 1 & 78 & 4 & & 9 & 4 & 95 \\
\hline \multicolumn{9}{|l|}{ Organics } \\
\hline Volatile & 26 & 1 & 78 & 4 & 26 & 9 & 4 & 121 \\
\hline Semivolatile & 26 & 1 & 78 & 4 & & 9 & 4 & 95 \\
\hline PCBs & 26 & 1 & 78 & 4 & & 9 & 4 & 95 \\
\hline Pesticides & 2 & 1 & 78 & 4 & & 9 & 4 & 95 \\
\hline TCLP & 2 & 1 & 2 & 1 & & & & 3 \\
\hline $\begin{array}{l}\text { Physical and hydrological } \\
\text { parameters }\end{array}$ & 2 & 1 & 2 & 1 & & & & 3 \\
\hline
\end{tabular}


Table 7.8 (continued)

\begin{tabular}{|c|c|c|c|c|c|c|c|c|}
\hline Parameter & $\begin{array}{l}\text { Number } \\
\text { of ciles }\end{array}$ & $\begin{array}{l}\text { Sumpling } \\
\text { eveats }\end{array}$ & $\begin{array}{c}\text { Number of } \\
\text { samples }\end{array}$ & $\begin{array}{l}\text { Ficld } \\
\text { coplicate }\end{array}$ & Trip & $\begin{array}{c}\text { Ficld } \\
\text { ben'te }\end{array}$ & $\begin{array}{l}\text { Bquipwert } \\
\text { rinsaters }\end{array}$ & Total \\
\hline \multicolumn{9}{|c|}{ Groundwater } \\
\hline \multicolumn{9}{|l|}{ Inorganics } \\
\hline Metals's & 7 & 4 & 28 & 4 & & 4 & 4 & 40 \\
\hline Anions ${ }^{h}$ & 7 & 4 & 28 & 4 & & 4 & 4 & 40 \\
\hline Radiological parameterse & 7 & 4 & 28 & 4 & & 4 & 4 & 40 \\
\hline \multicolumn{9}{|l|}{ Organics } \\
\hline Volatile & 7 & 4 & 28 & 4 & 4 & 4 & 4 & 44 \\
\hline Semivolatile & 7 & 4 & 28 & 4 & & 4 & 4 & 40 \\
\hline 'CBs & 7 & 4 & 28 & 4 & & 4 & 4 & 40 \\
\hline Pesticides & 7 & 4 & 28 & 4 & & 4 & 4 & 40 \\
\hline Miscellaneous' & 7 & 4 & 28 & 4 & & 4 & 4 & 40 \\
\hline \multicolumn{9}{|c|}{ Vegelation and earthworms } \\
\hline Metak by NAA & 5 & 4 & 20 & 3 & & & 3 & 26 \\
\hline Radiological parameters & 5 & 4 & 20 & 3 & & & 3 & 26 \\
\hline \multicolumn{9}{|l|}{ Organics } \\
\hline PAHs & 5 & 2 & 10 & 2 & & & 1 & 13 \\
\hline PCBs & 5 & 2 & 10 & 2 & & & 1 & 13 \\
\hline
\end{tabular}

${ }^{a}$ Field duplicates will be collected at a frequency of $5 \%$ of the samples collected per matrix per event (see Sect. 8.7.1.4).

bone trip btank is to accompany each cooler containing VOC samples (see Sect. 8.7.1.1).

${ }^{c}$ At a minimum, one sample for each source of water for a given sampling event will be collected for analysis. At keast one set of tield blanks will be collected for every three borings completed (see Sect. 8.7.1.3).

${ }^{d}$ Equipment rinsates will be collected at a rate of $5 \%$ (see Sect. 8.7.1.2).

'Radiological analyses will be gross alpha, gross beta, gamma scan, isotopic uranium, isotopic thorium and, for some samples, isotopic plutonium, $\mathrm{TC}^{99}$, and $\mathrm{Sr}^{\circ}$.

See Table 6.2 for parameters under physical, hydrological, and geochemical

sFitered and unfittered samples will be collected.

${ }^{h}$ Anion analyses include sulfate, fluoride, nitrate, chloride, and cyanide.

iMiscellaneous analyses inctude alkalinity, total suspended solids, total dissolved solids, pH, specific conductance, and turbidity.

iBecause of limited sample availability, radiological parameters for ecological samples will be limited to gross alpha, gross beta, and gamma scan. 
Two additional samples will be taken for TCLP analysis, and two Shelby tube samples will be collected from soils at the Boneyard/Burnyard. The samples will be analyzed for the geotechnical and hydrological parameters described in Table 6.2 . All sumples will be collected in the unsaturated zone. The exact locations and sample intervals of the Shelhy tubes will be determined in the field by the project geologist after inspection of soil lithology logs prepared for the first soil boring drilled.

\subsubsection{Boneyard/Burnyard groundwater}

Initially, nine of the grid-based soil borings (BYBY $2,6,9,10,13,14,15,17$, and 18) will be installed as monitoring wells, and water levels in these wells and existing wells GW.(005. GW-067, GW-084, GW-086, and GW-087 will be monitored continuously over a 1-month period. Continuously monitoring groundwater levels will help to identify wells that are moat likely to be connected to the active groundwater flow system in the headwaters of BCHR. Wells for which groundwater levels fluctuate in response to rainfall events will be used as monitoring wells, and groundwater monitoring will be carried out for four consecutive quarters. Groundwater will be analyzed for VOCs, metals, radiological parameters, anions, and miscellaneous parameters identified in Table 7.8. Field measurements will include water depth, temperature, $\mathrm{pH}$, specific conductance, and dissolved oxygen.

\subsubsection{Boncyard/Bumyard biota}

Up to five sampling locations will be chosen at random from contaminated areas identified by the initial radiological survey. Sample locations will he chosen from a maximum of $\mathbf{5 0}$ areas showing the highest levels of contamination. Grasses, browse, and carthworms will be sampled at these locations; however, if their numbers are reduced, soil will be sampled for toxicity testing as described in Sect. 6.1.1.4. One ficld duplicate sample each of vegetation and earthworms will be submitted for aralysis. One equipment rinsate will be submitted for each matrix (clippers and bowl for grasses, clippers and bowl for browse, and depuration chambers for earthworms).

Approximately $150 \mathrm{~g}$ of vegetation and $400 \mathrm{~g}$ of earthworms will be required per sample. except that one sample will be twice as large to allow for preparation of a duplicate sample. Earthworm samples will be divided, and approximately $2.35 \mathrm{~g}$ will be depurated before being submitted for analysis. Samples of each matrix will be held at $4^{\circ} \mathrm{C}$ and will be combined in sample groups with like samples from the Oil Landfarm and the Burial Ground. Vegetation and earthworm samples will be analyzed for metals and radiological parameters, and earthworms will also be analyzed for PAHs and PCBs (Table 7.8).

\subsubsection{Sanitary Landfill}

There is almost no information for evaluating the extent (o) which SLI may contribute contaminants to groundwater or to surrounding soils. SLI is located on the Maynardville Limestone so it is difficult to separate contaminants in groundwater that can be identified as being derived for SLI as opposed to the S.3 plane.

One soil boring directly downgradient from SLI is proposed (SL-1 1). This boring will be converted to a monitoring well, and shallow groundwater will be monitored for four quarters. 


\subsubsection{Burial Orounds}

Operational information and previous sampling at the Burial Grounds indicate that soil and groundwater are contaminated with metals, radiological parameters, PCBs, and VOCs. The murces of contamination at the Burial Grounds are solid wastes in burial trenches, the realdues of liquid wastes that remain in trenches, and soils surrounding those ponds that were coniaminaled by reprecipitation or sorption of contaminants migrating away from the Irenches. Seeps identified in the Burial Grounds will be screened for ionizing radiation. A walk-over radiological sur/ey will be conducted over the entire Burial Grounds site, excluding the waste areas, 10 identify areas of soil contamination outside the known waste trenches.

Soll boring. groundwater, stream water, and sediment sampling will be conducted at the Burial Orounds. No direct sampling of the waste materials is proposed, and the nature and extent of waste will be determined using a statistical sampling of Y-12 Plant records (see Sect. 6.1.2.5). No borings through RCRA caps will be proposed. Soil sampling will be carried out in iwo phases. For phase 1, stratified random soil sampling will be performed outside the waste trenches. Stratification of sample locations will be based on knowledge of the location and the nature of the wastes. For the second phase of sampling, sample grids will be refined, based on data from the first phase, and areas will selected for closer study. The purpose of phase 2 sumpling is to determine the extent of secondary soil contamination within the Burial Orounds site boundaries. Table 7.9 presents the sample apportionment, and Table 7.10 presents a detailed summary of the number of samples and quality control samples to be collected.

\subsubsection{Sereening surveys}

A walk-over radiological survey will be carried out over a grid designed to cover the known houndaries of the Burial Grounds using the USRADS system and a Geiger-Mueller type counter. Geophysical surveys will be carried out over individual burial grounds to aid in identifying solid waste materials and the boundaries of waste pits. EM and magnetometry surveys will be carried out with lines in a north-south direction; the selected areas will then be repeated in an east-west direction. Rapid evaluation of high radiological areas and high conductivity areas will allow closer spacing surveys of selected sites to be carried out in order to accurately locate soil borings for phase 2 soil sampling. USRADS will be used to collect grid quadrature and in-phase readings simultaneously. The number of lines and the line spacing for the surveys will be determined after an initial walk-over by the project geologist and geophysicist. Line spacing will be close enough to delineate variations in soil conductivity and magnetism.

\subsubsection{Burial Grounds soils}

For the purpose of selecting soil sample locations for the Burial Grounds, and in anticipation of a second phase of sampling, the Burial Grounds area has been divided into seven sample areas (Fig. 7.5):

Area 1: BG-A South, ORP 1, south NT-7, and soils to the south of BG-A as far as Bear Creek

Area 2: BG-A North (except trenches A-16 and A-17), ORP 2, and north NT-7

Area 3: Trenches A-16 and A-17

Area 4: BG-B and Walk-in Pits 1 and 2 
Table 7.9. Sample apportionment by medium for the Burial Grounds

\begin{tabular}{|c|c|c|c|c|c|c|}
\hline Medium & Source & Location & $\begin{array}{l}\text { No. of } \\
\text { samples }\end{array}$ & Frequency & Analysis/procodure & Rationak \\
\hline Surface soils & Hand auger & BG 1 through 23 & $23^{c}$ & Once & $\begin{array}{l}\text { Metals, VOCs, radiological } \\
\text { parameters, }{ }^{d} \text { PCBs }\end{array}$ & $\begin{array}{l}\text { Define the nature and extent of } \\
\text { contamination in surface soils }\end{array}$ \\
\hline Soils & Soil borings & BG I through 23 & $77^{e}$ & Once & $\begin{array}{l}\text { Metals, VOCs, radiological } \\
\text { parameters, }{ }^{d} \text { PCBs }\end{array}$ & $\begin{array}{l}\text { Define the nature and extent of } \\
\text { contamination in soils }\end{array}$ \\
\hline Soils & Soil borings & To be determined & 3 & Once & TCLP & $\begin{array}{l}\text { Evaluate the potential for } \\
\text { contaminants to leach from soils }\end{array}$ \\
\hline Soils & Soil borings & To be determined & 6 & Once & $\begin{array}{l}\text { Physical, hydrological, and } \\
\text { geochemical properties }\end{array}$ & $\begin{array}{l}\text { Obtain information necessary to } \\
\text { evaluate the potential for contaminant } \\
\text { migration through soils and for } \\
\text { screening of remedial technologies }\end{array}$ \\
\hline Groundwater & $\begin{array}{l}\text { Monitoring } \\
\text { wells }\end{array}$ & $\begin{array}{l}\text { Well list to be } \\
\text { determined by } \\
\text { monitoring test }\end{array}$ & $120^{h}$ & 4 quarters & $\begin{array}{l}\text { Metals, VOCs, radiological } \\
\text { parameters, }{ }^{d} \text { PCBs, major } \\
\text { ions, and field parameters }\end{array}$ & $\begin{array}{l}\text { Assess the contribution to the } \\
\text { integrator unit from contaminated } \\
\text { soils }\end{array}$ \\
\hline Grasses & Hand clipping & $\begin{array}{l}\text { To be determined } \\
\text { from radiological } \\
\text { surveys }\end{array}$ & 5 & Once & $\begin{array}{l}\text { Metals by NAA, radiological } \\
\text { parameters }{ }^{i}\end{array}$ & $\begin{array}{l}\text { Assess the potential for contaminant } \\
\text { transfer from soil to biota }\end{array}$ \\
\hline Browse & Hand clipping & $\begin{array}{l}\text { To be determined } \\
\text { from radiological } \\
\text { surveys }\end{array}$ & 5 & Once & $\begin{array}{l}\text { Metals by NAA, radiological } \\
\text { parameters }^{i}\end{array}$ & $\begin{array}{l}\text { Assess the potential for contaminant } \\
\text { transfer from soil to biota }\end{array}$ \\
\hline Earthworms & Excavation & $\begin{array}{l}\text { To be determined } \\
\text { from radiological } \\
\text { surveys }\end{array}$ & 10 & Once & $\begin{array}{l}\text { Metals by NAA, radiological } \\
\text { parameteri, PAHs, PCBs }\end{array}$ & $\begin{array}{l}\text { Assess the potential for contaminant } \\
\text { transfer from soil to biota }\end{array}$ \\
\hline
\end{tabular}

${ }^{a}$ Quality assurance samples are not included.

${ }^{b}$ Analytical methods are discussed in the Quality Assurance Project Plan (Chap. 8 of this RI work plan)

This number assumes one surface sample per site.

${ }^{d}$ Radiological parameters include gross $\alpha$, gross $\beta$, gamma spectroscopy, isotopic uranium, and isotopic thorium

This number assumes all 23 sample borings will be sampled continuously with 4 -ft intervals 4 ft below the groundwater table.

This number assumes four quarters of surface water sampling from eight sites with two additional siormflow samples at each location.

${ }^{8}$ See text for details.

${ }^{h}$ This number assumes 4 quarters of groundwater sampling from 30 wells; both filtered and unfiltered samples will be collected.

'Radiological parameters for ecological samples will be limited to gross alpha, gross beta, and gamma spectroscopy. 
Table 7.10. Number of samples and quality control samples to be collected for the Burial Grounds

\begin{tabular}{|c|c|c|c|c|c|c|c|c|}
\hline Parameter & $\begin{array}{l}\text { Number } \\
\text { of sites }\end{array}$ & $\begin{array}{c}\text { Sampling } \\
\text { events }\end{array}$ & $\begin{array}{l}\text { Number of } \\
\text { samples }\end{array}$ & $\begin{array}{c}\text { Field } \\
\text { duplicate }\end{array}$ & $\underset{\text { blankss }}{\text { Trip }}$ & $\begin{array}{c}\text { Field } \\
\text { blanks }\end{array}$ & $\begin{array}{l}\text { Equipment } \\
\text { rinsatest }\end{array}$ & $\begin{array}{l}\text { Total } \\
\text { samples }\end{array}$ \\
\hline \multicolumn{9}{|c|}{ Surface soils } \\
\hline Metals & 23 & 1 & 23 & 2 & & 2 & 2 & 29 \\
\hline Radiological parameters & 23 & 1 & 23 & 2 & & 2 & 2 & 29 \\
\hline \multicolumn{9}{|l|}{ Organics } \\
\hline Semivolatiles & 23 & 1 & 23 & 2 & & 2 & 2 & 29 \\
\hline PCBs & 23 & 1 & 23 & 2 & & 2 & 2 & 29 \\
\hline \multicolumn{9}{|c|}{ Soil borings and soil cores } \\
\hline Metals & 23 & 1 & 77 & 4 & & 8 & 4 & 93 \\
\hline Radiological parameterse & 23 & 1 & 77 & 4 & & 8 & 4 & 93 \\
\hline \multicolumn{9}{|l|}{ Organics } \\
\hline Volatiles & 23 & 1 & 77 & 4 & 23 & 8 & 4 & 116 \\
\hline Semivolatiles & 23 & 1 & 77 & 4 & & 8 & 4 & 93 \\
\hline PCBs & 23 & 1 & 77 & 4 & & 8 & 4 & 93 \\
\hline TCLP & 3 & 1 & 3 & 1 & & & & 3 \\
\hline $\begin{array}{l}\text { Physical and hydrological } \\
\text { parameters }\end{array}$ & 6 & 1 & 6 & 1 & & & & 7 \\
\hline \multicolumn{9}{|c|}{ Groundwater } \\
\hline \multicolumn{9}{|l|}{ Inorganics } \\
\hline Metals ${ }^{8}$ & 30 & 4 & 120 & 8 & & 8 & 8 & 144 \\
\hline Anions $^{h}$ & 30 & 4 & 120 & 8 & & 8 & 8 & 144 \\
\hline
\end{tabular}


Table 7.10 (continued)

\begin{tabular}{|c|c|c|c|c|c|c|c|c|}
\hline Parameter & $\begin{array}{l}\text { Number } \\
\text { of sites }\end{array}$ & $\begin{array}{c}\text { Sampling } \\
\text { events }\end{array}$ & $\begin{array}{c}\text { Number of } \\
\text { samples }\end{array}$ & $\begin{array}{c}\text { Field } \\
\text { duplicate }\end{array}$ & $\underset{\text { blanks }}{\text { Thip }}$ & $\begin{array}{c}\text { Field } \\
\text { blanks }\end{array}$ & $\begin{array}{l}\text { Equipment } \\
\text { rinsates }\end{array}$ & $\begin{array}{c}\text { Total } \\
\text { samples }\end{array}$ \\
\hline Radiological parameterse & 30 & 4 & 120 & 8 & & 8 & 8 & 144 \\
\hline \multicolumn{9}{|l|}{ Organics } \\
\hline Volatiles & 30 & 4 & 120 & 8 & 12 & 8 & 8 & 156 \\
\hline Semivolatiles & 30 & 4 & 120 & 8 & & 8 & 8 & 144 \\
\hline PCBs & 30 & 4 & 120 & 8 & & 8 & 8 & 144 \\
\hline Miscellaneousi & 30 & 4 & 120 & 8 & & 8 & 8 & 144 \\
\hline \multicolumn{9}{|c|}{ Vegetation and earthworms } \\
\hline Metals & 5 & 4 & 20 & & & & 2 & 22 \\
\hline Radiological parameters & 5 & 4 & 20 & & & & 2 & 22 \\
\hline Organicsi & & & & & & & & 10 \\
\hline PAHs & 5 & 2 & 10 & & & & & 10 \\
\hline PCBs & 5 & 2 & 10 & & & & & \\
\hline
\end{tabular}

${ }^{\circ}$ Field duplicates will be colketted at a frequency of $5 \%$ of the samples collected per matrix per event (see Sect. 8.7.1.4).

${ }^{b}$ One trip blank is to accompany each cooler containing VOC samples (see Sect. 8.7.1.1).

'Al a minimum, one sample for each source of water for a given sampling event will be collected for analysis. Al least one set of field blanks will be collected for every three borings completed (see Sect. 8.7.1.3).

${ }^{d}$ Equipment rinsates will be collected at a rate of $5 \%$ per event (see Sect. 8.7.1.2).

'Radiological analyses will be gross alpha, gross beta, gamma scan, isotopic uranium, isotopic thorium and, for some samples, isotopic plutonium, Tc, and $\mathrm{Sr}$.

See Table 6.2 for parameters under physical, hydrological, and geochemical.

Filitered and unfitered samples will be collected.

"Anion analyses inctude sulfate, fluoride, nitrate, chloride, and cyanide.

'Miscellaneous anabyses inctude alkalinity, total suspended solids, total dissolved solids, pH, specific conductance, and turbidity.

iOne sample of earthworms will include sufficiem material $(100 \mathrm{~g})$ to allow for preparation of method spike and method spike duplicate samples. 
Area 5: BG.D East and -C East

Area 6: BG-D West, - E, and -J

Area 7: BG.C West and soils to the south of BG.C West as far as the access road to the Burial Grounds

Phase 1 borings in each area are located downgradient of waste trenches; the locations of the borings are shown on Figs. 7.6 through 7.12. Twenty-three soil borings were proposed for phase 1 sampling. The purpose of phase 1 sampling is to determine the nature of secondary soil contamination that has resulted from migration of contaminants downgradient away from waste trenches.

Second-phase soil borings will be made within a smaller grid spacing over "hot spot" areas identified by the radiological survey and over regions where downgradient soil contamination was indicated by phase 1 sampling. The location, number, and spacing of borings on finer grids will be determined after the screening surveys. Soil will be sampled at nodes from these finer grids selected at random. The number of samples to be taken from each grid will be such that the concentrations of COCs are defined within acceptable bounds at the $95 \%$ confidence level. COCs at each "hot spot" will be determined from phase 1 sampling. In phase 2, priority will be given to areas with identified soil contamination.

All borings will be sampled to $1.2 \mathrm{~m} \mathrm{(4ft)} \mathrm{below} \mathrm{the} \mathrm{groundwater} \mathrm{table.} \mathrm{The} \mathrm{depth} \mathrm{to}$ the water table over the Burial Grounds is variable from $<0.6 \mathrm{~m}(2 \mathrm{ft})$ near BG.A to $\sim 11$ $m(35 \mathrm{ft})$ below BG.J and BG.D and a maximum of $18.3 \mathrm{~m}(60 \mathrm{ft})$ below BG.B. The depth of borings will range from 1.8 to $12.1 \mathrm{~m}(6$ to $40 \mathrm{ft}$ ). All borings will be sampled continuously at 1.2-m (4-ft) intervals. A portion of these samples will be collected for chemical and radiological analysis. Borings that are to be converted to piezometer wells will be advanced

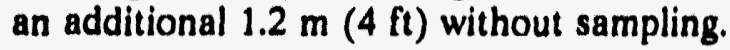

All samples will be surveyed in the fieid with an OVA and scanned for beta and gamma radiation with a GM pancake probe. The OVA reading will be taken immediately after opening the split spoon and will be followed by the GM pancake.

Three additional sanuples will be taken for TCLP analysis, and six Shelby tube samples (one from each type of residuum) will be collected from soils at the Burial Grounds. The samples will be analyzed for geotechnical and hydrological parameters described in Table 6.2 . All samples will be collected in the unsaturated zone. The exact location and sample interval of the Shelby tubes will be determined in the field by the project geologist after inspection of soil lithology logs prepared for the first soil boring drilled. When a Shelby tube sample is taken, chemical and radiological parameters will be analyzed for the first $0.6 \mathrm{~m}(2 \mathrm{ft})$ of a $1.2-\mathrm{m}$ (4-ft) sample interval. The Shelby tube sample will be the second $0.6 \mathrm{~m}(2 \mathrm{ft})$ of the $1.2-\mathrm{m}$ (4-ft) sample interval.

\subsubsection{Burial Grounds groundwater}

All soil borings will be converted to monitoring wells, and water levels in these wells and 23 existing wells listed in Table 7.11 will be monitored continuously over a 1 -month period at least. Continuously monitoring groundwater levels will help to identify wells that are most likely to be connected to the active groundwater flow system in the headwaters of BCHR. Wells for which groundwater levels fluctuate in response to rainfall events will be used as monitoring wells, and groundwater monitoring will be carried out for four consecutive 


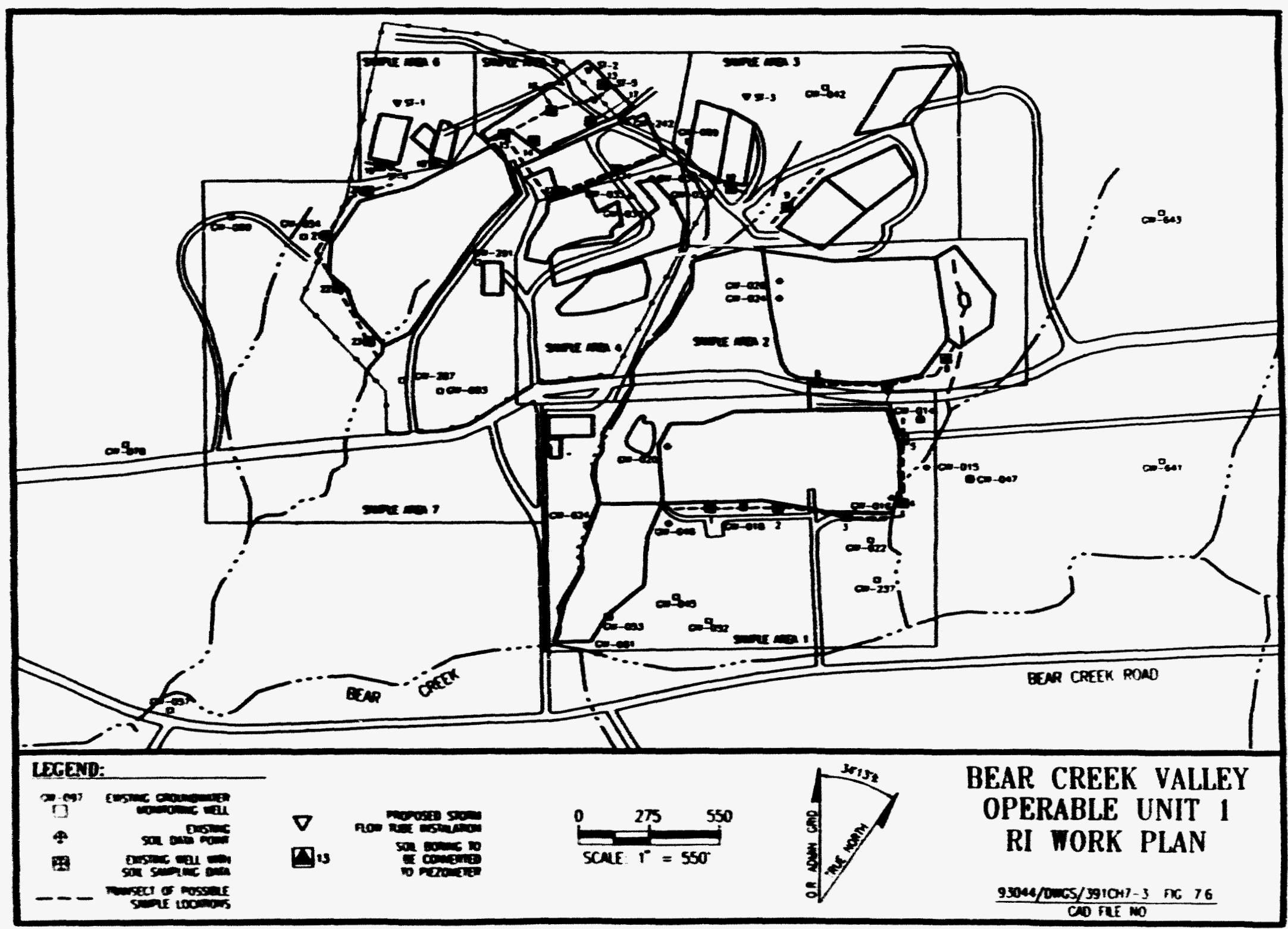




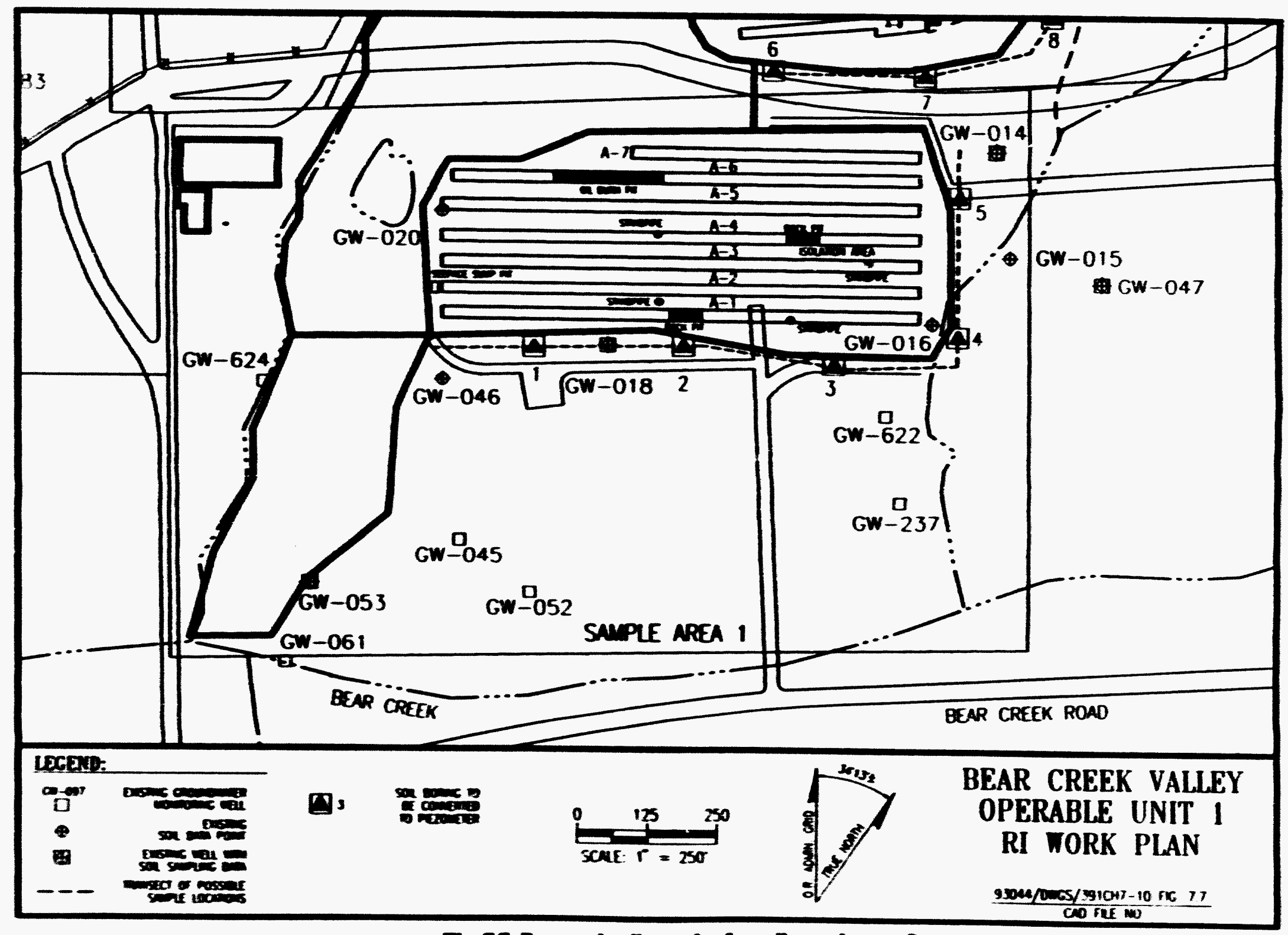

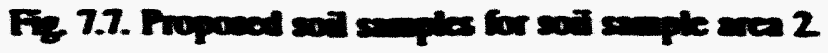




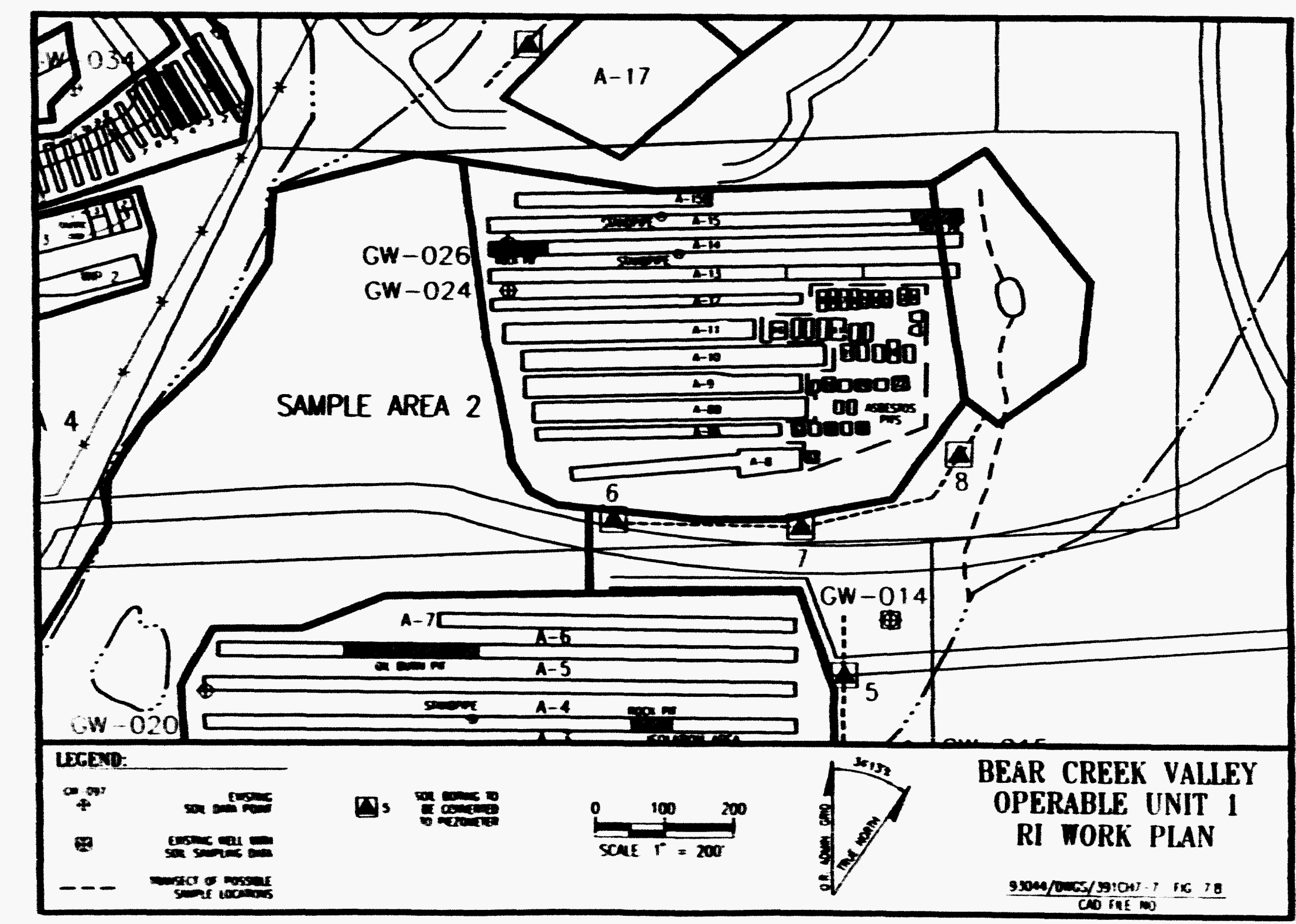

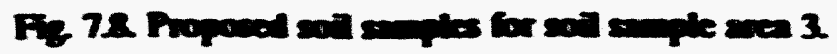




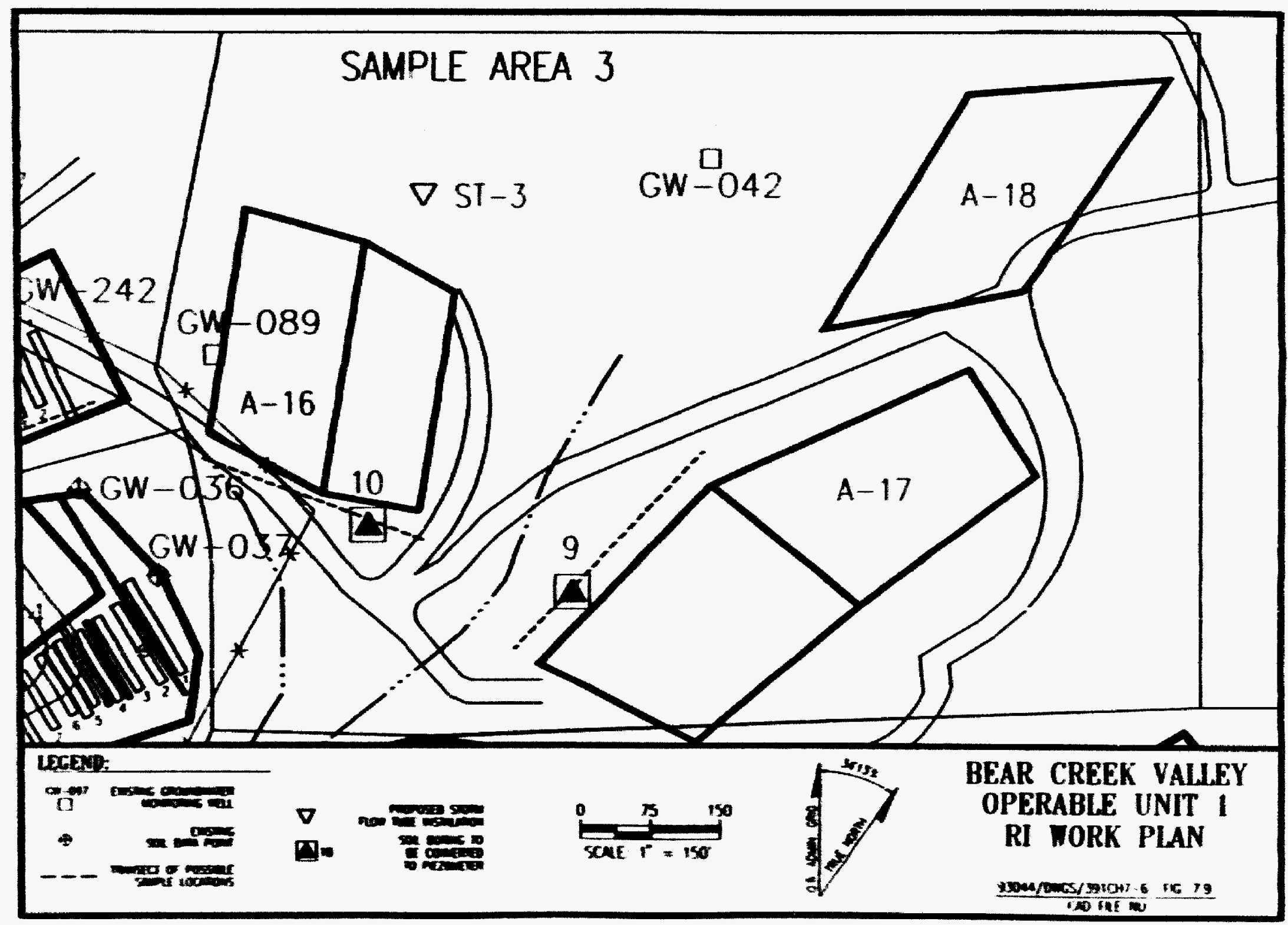

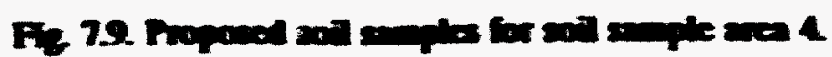




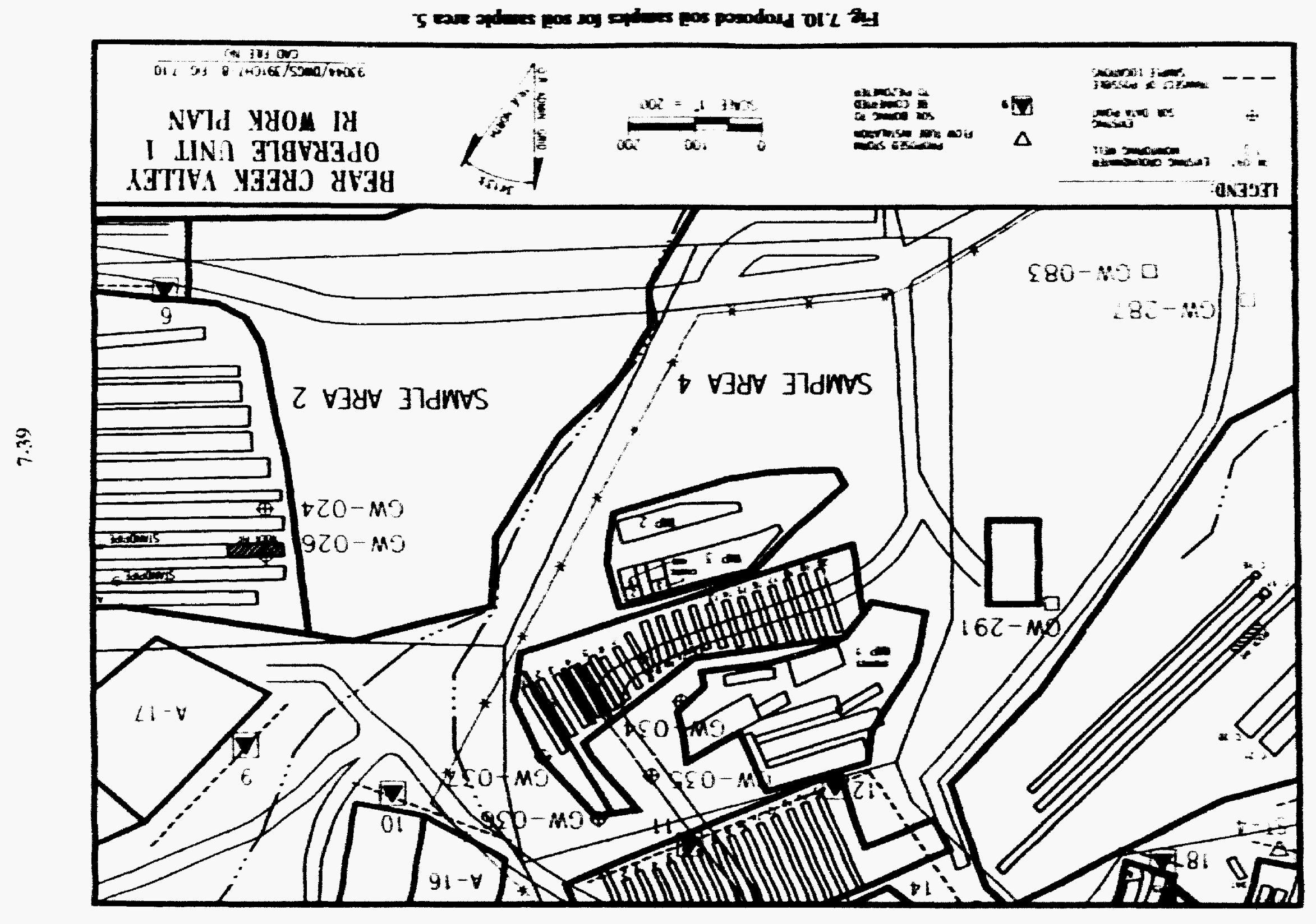




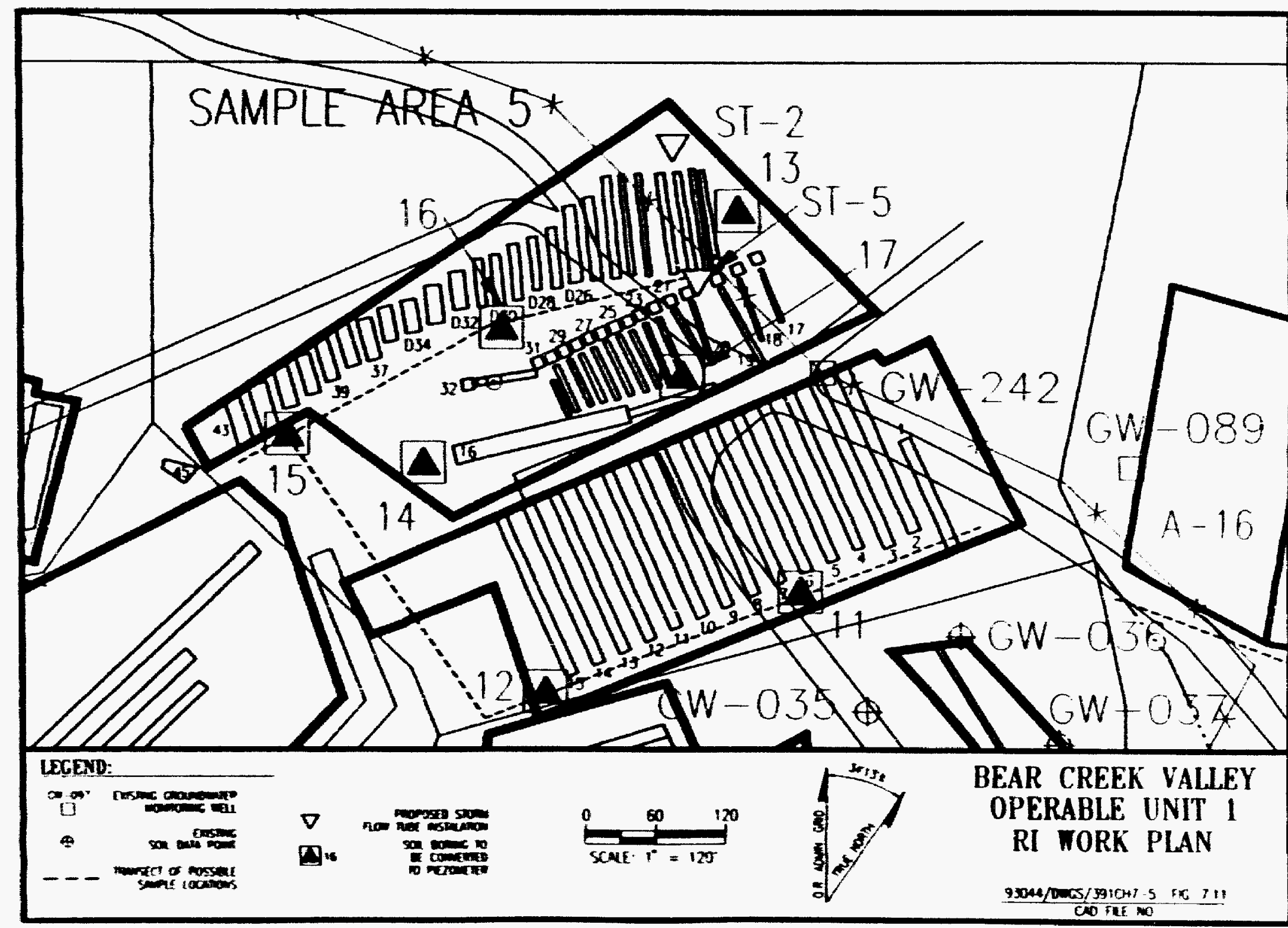

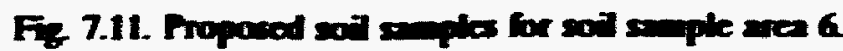




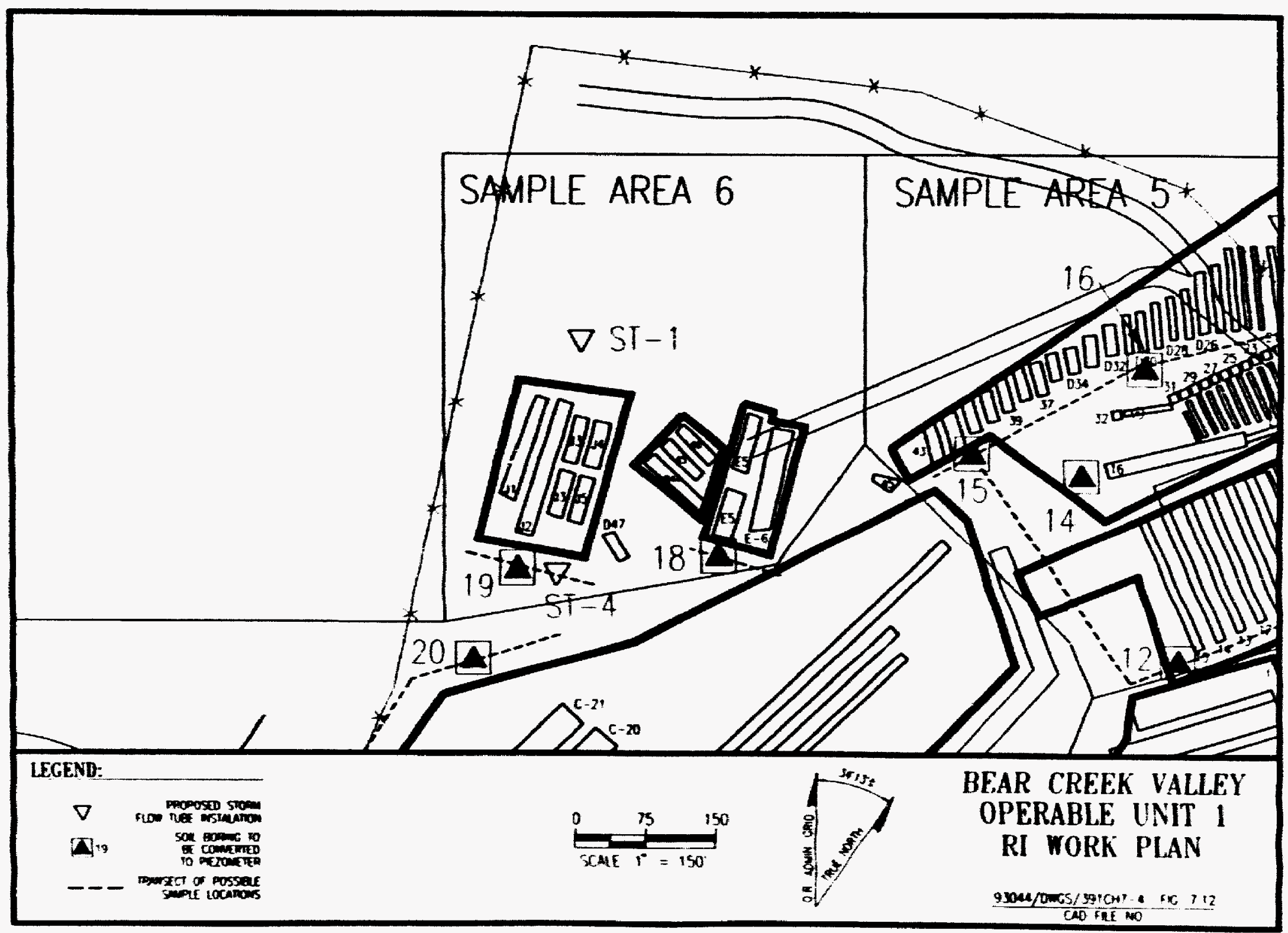

Fig 7.12 Proposed sol somples for soil somple aren 7. 
Table 7.11. Groundwater monitoring wells for the Burial Orounds

\begin{tabular}{|c|c|c|c|c|c|}
\hline Well & Depth & Formation" & Aquiler & Core & $\begin{array}{l}\text { Screened } \\
\text { (yes or no) }\end{array}$ \\
\hline GW.014 & 13.2 & En & U/WB & $\mathbf{N}$ & $Y$ \\
\hline GW.018 & 20.8 & En & wB & $N$ & $\mathbf{Y}$ \\
\hline GW.042 & 30.0 & Epv & $w B$ & $\mathbf{N}$ & $Y$ \\
\hline GW.045 & 15.2 & Emn & U/wB & $\mathbf{N}$ & $\mathbf{Y}$ \\
\hline GW.046 & 20.5 & En & U/wB & $N$ & $\mathrm{Y}$ \\
\hline GW.(1)47 & 25.5 & $E n$ & wB & $\mathbf{N}$ & $\mathrm{Y}$ \\
\hline GW.052 & 19.5 & $E m n$ & $U$ & $\mathrm{~N}$ & $Y$ \\
\hline OW.053 & 39.7 & Emn & U/WB & $\mathrm{Y}$ & $Y$ \\
\hline OW.057 & 25.0 & Emn & wB & $Y$ & $Y$ \\
\hline OW.061 & 25.0 & $\mathrm{Emn}$ & $w B$ & $Y$ & $Y$ \\
\hline GW.078 & 21.1 & En & $w B$ & $N$ & $Y$ \\
\hline GW.080 & 30.0 & En & WB & $\mathrm{N}$ & $Y$ \\
\hline GW.083 & 30.0 & En & WB & $Y$ & $Y$ \\
\hline GW.089 & 25.0 & Er & $U$ & $N$ & $Y$ \\
\hline GW.237 & 13.7 & $E m n$ & U/WB & $\mathbf{N}$ & $Y$ \\
\hline GW.242 & 17.0 & Epv & $w B$ & $N$ & $Y$ \\
\hline GW.287 & 12.5 & En & $w B / B$ & $\mathrm{~N}$ & $\mathrm{Y}$ \\
\hline GW.291 & 16.98 & $\mathrm{fm}$ & $w B / B$ & $\mathrm{~N}$ & $Y$ \\
\hline GW.622 & 20.5 & $E n$ & wB & $\mathrm{N}$ & $\mathrm{Y}$ \\
\hline GW.624 & 27.2 & En & WB & $\mathrm{N}$ & $\mathrm{Y}$ \\
\hline GW.641 & 24.3 & En & wB & $\mathrm{N}$ & $\mathrm{Y}$ \\
\hline GW.643 & 29.3 & $\mathrm{Em}$ & wB & $\mathrm{N}$ & $Y$ \\
\hline GW.654 & 15.5 & $\mathrm{Em}$ & $w B$ & $N$ & $Y$ \\
\hline
\end{tabular}

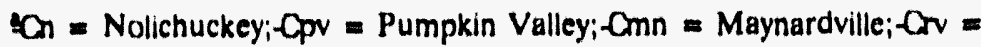
Rogersville; $-C T=$ Rulledge $_{-}-\mathrm{Cm}=$ Maryville 
quarters. Groundwater will be analyzed for VOCs, metals, radiological parameters, anions, and those miscellaneous parameters identified in Table 7.10. Ficld measurements will include water depth, temperature, pH, specific conductance, and dissolved oxygen.

\subsubsection{Burial Grounds stormflow}

It is possible that some of the upgradient trenches in the Burial Grounds will be affected by stormflow. Pine Ridge may act as a recharge area for the stormflow system, and there are no apparent barriers between the recharge areas and the up-slope trenches except some of the grading that has been carried out. Wastes that are likely Io he affected are BG.A North. BG-D, BG.E and BG.J. Based on the conceptual model for stormflow (Solomon et al. 1942), these trenches probably intercept most of the stormflow from Pine Ridge.

Stormflow tuhes will be installed at three locations (Fig.7.6) upgradient of the Burial Grounds and at two locations downgradient from trenches in BG.D. Construction and installation of the stormflow tubes will follow procedures oullined by Moore (1942). An example of a stormflow lube construction is shown in Fig. 7.2. Each location will he equipped for continuous water-level monitoring (eliminating the need to arrange for stormflow monitoring by field personnel). Three upgradient locations will provide sufficient dats, when accompanied by data from stormflow monitoring proposed in the integrator OU RI (BCV OU 4), for calculating an average for use in storm hydrograph analysis (Moore and Toran 1992). Downgradient stormflow devices will be used to test the hypothesis that stormflow will continue down slope from trenches that are full of water, in the event of "huthlubhing." The analysis of stormflow data will primarily identify periods of baseflow in the creck for analysis of temporal changes in direct groundwater discharge concentrations.

\subsubsection{Burial Ground biota}

Up to five sampling locations will be chosen at random from contaminated areas identified by the initial radiological survey. Sample locations will be chosen from a maximum of 50 areas showing the highest levels of contamination. Grasses, browse, and earthworms will be sampled at these locations; however, if their numbers are reduced, soil will be sampled for toxicity testing as described in Sect. 6.1.1.4. One field duplicate sample cach of vegetation and earthworms will be submitted for analysis. One equipment rinsate will be submilted for each matrix (clippers and bowl for grasses, clippers and bowl for browse, and depuration chambers for earthworms).

Approximately $150 \mathrm{~g}$ of vegetation and $400 \mathrm{~g}$ of earthworms will be required per sample. except that one sample of earthworms will be three imes as large lo allow for preparation of method spike and methods spike duplicate samples. Earthworm sumples will be divided. and approximately $235 \mathrm{~g}$ (or $700 \mathrm{~g}$ ) will be depurated before being submitted for analysis. Samples of each matrix will be held at 4 degrees $C$ and will be combined in sample groups with like samples from the Oil Landfarm and the Boneyard/Burnyard. Vegetation and earthworm samples will be analyzed for metals and radiological parameters, and earthworms will also be analyzed for PAHs and PCBs (Table 7.10). 


\subsection{SAMPLE TRACKING AND RECORDS MANAGEMENT}

\subsubsection{Objectives}

The primary objectives of an effective sample tracking and records management program are to provide timely feedback regarding laboratory performance and project status and to ensure that data are complete and auditable. Meeting this objective is critical to the overall success of this RI because (1) the data are important in determining potential environmental and human health effects, (2) the data must be technically defensible and legally admissible, and (3) data collection and analysis costs are high. Existing records management plans, information management procedures, and database management systems will be used to track, document, and manage all field and analytical data.

\subsubsection{Roles and Responsibilitics}

Data Coordinator. Cocrdinates data support for the technical team. Prepares work agreements as necessary, reviews sample-receipt acknowledgments, and receives laboratory data packages. Participates in QA/QC activities including nonconformance investigations and reporting and $Q A$ reviews.

Data Entry Clerk. Enters new or existing data generated by field activities or laboratory analyses. Performs data-entry verification.

Data Manager. Identifies and acquires all relevant data, including historical data. Ensures data completeness and consistency and resolves problems associated with data.

Ficld Team Leader. Helps prepare the sampling and analysis plan (SAP) and implements it in the field; assigns staff members to sampling teams and assigns sampling team members. Prepares for and coordinates sampling activities. Oversees field data collection, recording, and documentation activities. Supervises packing and shipping of samples.

Records Manager. Controls the recorded information about project activities that is generated and/or received by project organizations.

\section{5 .3 Presampling Database}

The SAP specifies all sampling and analysis data to be collected. A temporary presampling database with structures identical to the central OREIS data structures will be created by the Data Manager and populated with the project SAP data (i.e., sample locations, sample identification codes, sample media, sample depths, types of analyses, field QC data, and chain-of-custouy details). Before mobilizing the field team, the Field Team Leader and Data Manager will verify data entered into the presampling database. The verified presampling database will be used to print sample labels, sample tags, and field logbooks for each sampling event.

\subsubsection{Sample labels and tags}

Preprinted sample labels and tags will contain the following information: 
- Sample ID number

- Project number

- Sampling location, station code, and description

- Sample media

- Sample type

- Analysis

- Preservative

- Volume

- Destination laboratory

Field staff members will complete the remaining information during sample collection:

- Radiological screening information

- Date and time of sample collection

- Comments

- Name of collector

If preprinted blank sample labels are not used, all information will be recorded manually during field sample collection.

\subsubsection{Field logbooks}

Each sampling team will have a field logbook that will contain, at a minimum, a table of contents, task team activity log sheets, and sample log sheets. The unbound logbooks will be reviewed for accuracy and completeness by the Field Team Leader. After making any needed corrections, the Data Coordinator will have the logbooks bound and numbered. All bound logbooks will be kept in secure storage and access will be controlled at all times.

Logbooks will be completed by the field sampling team during sampling according to relevant procedures. Entries will include sampling date and time, details on field conditions, field instrument measurements, deviations from the sampling plan, QA concerns, and any noteworthy observations. The field team will also complete chain-of-custody information for each sample collected in accordance with Energy Systems chain-of-custody procedure ESP-500 (Kimbrough et al. 1991).

\subsubsection{Site Logbook}

The site logbook is the master field investigation document. It is a bound book with a hard cover and sequentially numbered pages. Its primary purpose is to document each day's field activities; the personnel on each sampling team; and any administrative occurrences, conditions, or activities that may have affected the fieldwork or data quality of any environmental samples for any given day. The site logbook will be kept by the Field Team Leader. The front of the logbook will be used to list the location, the names of the companies performing the field sampling, the client, and the contract number of the work being 
performed. The site logbook will be updated daily. Following his/her review, the Field Team Leader will sign the bottom of the last page of the day.

The site logbook will, at a minimum, contain the following information (Fig. 7.13):

- Day, date, time arrived on site, temperature, weather conditions, and names and titles of personnel present on site

- Names, titles, and organizations of any visitors who entered the site during the day

- Arrival time of any subcontractors on site, number of duplicate samples, number of split samples, laboratory to which split samples were sent, references to field logbook(s) or field forms that contain more specific field information for any of the above tasks

- Decontamination iterations, equipment decontaminated, and procedures used

- Specific comments relative to any problem areas that occurred during the day's activities, the final resolution, and the anticipated impact on the outcome of the field investigation or on data quality

- A record of telephone calls (incoming or outgoing) pertaining directly to the decisionmaking process of the field investigation, along with the outcome of each conversation, and a reference to the telephone log to obtain more specific information on the call

\subsubsection{Corrections to Documents}

All corrections to field logbooks and chain-of-custody forms will be made by drawing a single line through the error so as not to obliterate the correction, entering the correct information, and initialing and dating the change. If possible, the need for administering the change will be documented.

\subsubsection{Sample Identification Numbers}

To support the data management requirements specified in the CLP SOWs, sample identification will be limited to a length of six characters and/or numbers. While this may appear as a limitation, the data management system will provide additional data fields to describe specific sample identification information. Adhering to the CLP SOW requirements will facilitate the overall data reporting and ensure the integrity of project-derived data. Sample identification numbers will be coded to enable identification of the location, sample pattern, media, and depth.

Position 1: Sample Location. A single character or digit will be used to identify the sampling location within the specific study area. This position of the sample identification will be keyed to descriptive text specifically identifying the location.

Positions 2-4: Sample Station/Borehole/Well identification. Three digits will be used to identify the specific sampling station within the above sampling location (i.e., borehole number, well identification number). This position of the sample identification will be keyed to descriptive text or ER-assigned station identification numbers. This field will identify the station. 


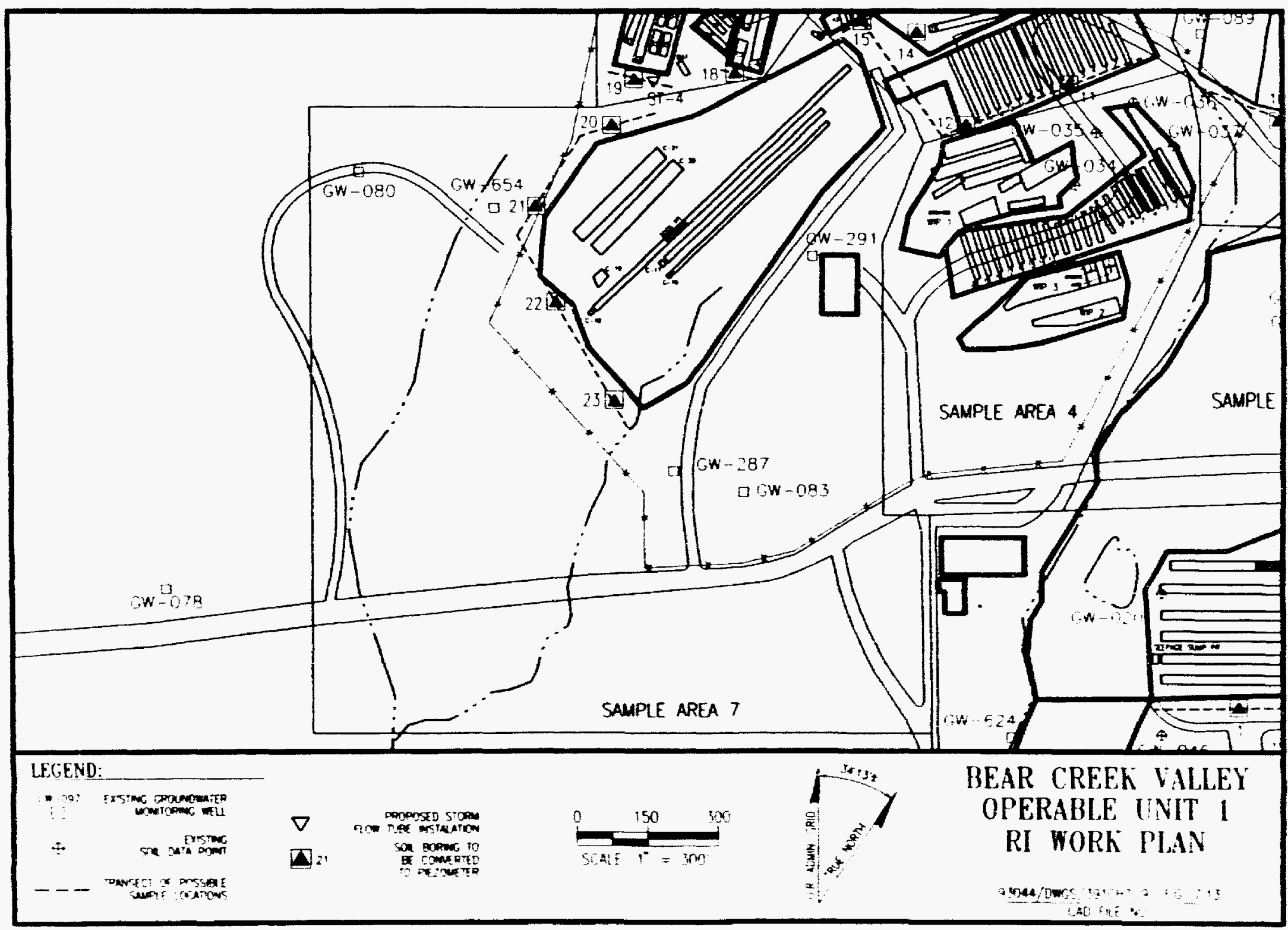


Position 5: Sample Type and Media. A single digit will be used 10 identify the sample type and medium being sampled. This position will account for duplicatc samples and will be keyed to descriptive text identifying the sample medium.

Position 6: Sample Depth. A single digit will be used to designate sample depth. This position of the sample identification will be keyed to descriptive text specifically identifying the depth in feet.

Trip Blanks, Equipment Rinsates, and Field Blanks. The first three positions of the sample identification will be used to identify trip blanks (TBL), rinsates (EQR), and field blanks (FBL). A sequential number in positions 4 through 6 will be assigned to each $Q C$ sample. Trip blank and field blank designations will be referenced to specific sampling dates and other pertinent sample information. Equipment rinsate designations will likewise be referenced to specific sampling equipment types, dates, and other pertinent information.

\subsubsection{Data Entry of Ficld Information}

The Field Team Leader will submit the field sampling documentation to the Data Coordinator on the schedule specified in the $\mathrm{Rl}$ work plan. After verifying the accuracy and completeness of this information, the Data Coordinator will ensure that the database is updated accordingly. Data entry will be performed following established procedures. The field data captured include field sample measures, well construction logs, lithologic descriptions, and field screening results.

After the data are acquired and verified, the Data Manager and Coordinator will deliver the complete hard copy set of field sampling documentation to the Records Management Team, which will index, process, and place the documents in the project file. Upon completion of the field effort for each media, the Field Team Leader will turn over field documentation to the Document Coordinator. The Document Coordinator will lock the documentation in a fireproof safe, and copies of the material will be supplied to the Data Coordinator for entry into the project database. Upon conclusion of the field effort, all field documentation will be clearly labeled and placed in the project file.

\subsubsection{Processing of Information on Samples Sent to and Received from Analytical Laboratorics}

The Field Team Leader will make available to the Data Coordinator copies of the chain. of-custody forms for samples sent to the laboratory. The laboratory also will return a Letter of Receipt indicating the sample identification, laboratory identification, and analyses scheduled for each sample along with the original or copy of the chain-ol-custody form. The letter will be reviewed by the Data Coordinator and compared to the contents of the database to ensure that scheduled analyses concur with the requirements of the SAP and that expected turnaround will meet holding-time requirements. Any deviations from established procedures will be documented as Nonconformance Reports. The Data Coordinator will update the database with Letter of Receipt information and generate a status report. Hard copies of the chain-of-custody forms, Lelter of Receipts, and periodic sample status reports will be forwarded to the Records Management Team for inclusion in the project files. 


\subsubsection{Rocelpt and Preliminary Procesaing of Analytical Dala Packages and Diakollos}

The Data Coordinator will receive and process the datu package hy date-stamping it, assigning it an accession number, photocopying it, and submilting the original to the project rile. A copy will be retained for use in verification, validation, and data entry. The Data Coordinator will initiate tracking of the analytical data by logsing the sample delivery group information into the database, linking sample identification numbers with the sumple delivery group number.

The unvalidated data will then transferred to the database for preliminary analyais. If an electronic deliverable exists, data will be stripped and added to the database using verified programs. If an error report is generaled afler louding. the Datu Manager will reaslve any discrepancies. If appropriate. Nonconformance Repurts will be generated. When subsequent deliveries of corrected data are submilted electronically, printouts of the changes will be reviewed to ensure that any Noncompliance Reports are addressed. When Noncompllance Report resolution is completed, the duta will be corrected in the database.

If reaulis were not submilted on diskelte, analytical results and laboratory information will be added to the database by the Data Entry Clerk. Data entry will be verilied by enterine data iwice and resolving any discrepancies between resultant files or by performing a complete review.

Because data will be added to the unvaliduted databasc, a series of checks and summarien will be performed to locule and correct any inconsistencies. This will include the use of data veriflcation programs deaigned for sorting and comparing fields to determine whether data are misaing, mislabeled, or duplicated. Al such errors will be reconciled and documented.

After data validation, the Data Coordinator will overnee manual entry of hapa and qualifiers into the database by the Data Eniry Clerk. This data eniry will be verifled either by double entry and a compare program or by total review. The Datu Coordinator then will migrate the completed records into a validated database and submit verification and validation documentation to the project file. All subsequent summaries, statistical analyses, and reports will be generated from the validated datubase using stundardized and quality-eonirolled retrieval programs and validated applicalion programs.

\subsection{Data Conasolidation and Storage}

Once the data for a given ample or group of sumples are complete and have been entered into the database, the Data Cocordinator will ensure that logbooks and other field records are complete and properly stored. This will include hoth the electronic form and all the asacociated data packages. Each piece of information will be documented as to ils sources. Hard-copy information will he appropriately indexed and filed. Metadata will be added to the validated database and linked 10 corresponding records.

Strict adherence to procedure-based routines established for data security, backup, and archival and the maintenance of proper database change procedures ensure dutabase integrity. The database, once loaded, will be safe from physical corruption (i.e., hurdware or aofiware failure) or from unauthorized acesss and illegal updating. Corruption of the data causes loss of integrity. Physical security requires recovery procedures, time-stamping, and other related 
stundard operating processes and controla. Any changes to the databuse will be documented using the Database Change Request Form.

\subsubsection{Datu and Document Archival}

The Project Manager will instruct the Datahase Administrator 10 archive project data. The Database Adminiatrator will archive project data to the appropriate elecironic media. The Database Administrator also will prepare a data archive information package that deacribea the data aystem, the file format, and the method of archival. A copy of the checklisi will be submilled io the Project Files.

Sufficient documentation will accompany the archived data to fully deacribe the source, contents, and atructure of the data to ensure fulure data usability. Compuler programs uaed in manipulate of report the archived data will be included in the datu archive information package to further enhance the data's fulure usability.

Hard copies of all original field and analytical resula, data reduction and summary programs, dais packnges, and auscelated QAOC forms will be clasaified, indexed, and stored in appropriate ille groups and record series within project nles. The Records Manager will enure that all required Adminiatrative Record File documents are acquired and indexed.

\subsection{DATA ASSBSSMENT AND INTERPRETATION}

Datu asseament procedures are diacussed in Sect. 8.10 of this RI work plan (l.e. in the QAPJP). Data interpretation is discussed in Sect. 6.3 of this work plan. 


\section{QUALITY ASSURANCE PROJECT PIAN}

\section{R.1 DATA QUALTTY OBECTIVES}

OA ohjectives for data collection will be develoned from DOO for this project. DOO are required for each data collection activity and may include OC Levels I, II, III, IV. and V. which correlate with QC Levels 1, 2, 3, 4, and 5 as deacribed by the EPA decument Data Quality Objectives for Remedial Response Activities Development Process (EPA 1987b). Duta derived from the sampling and analyals with EPA Level III and Level IV laboratory DOOn are of high quality and are both scientilically and legally defensible. For this RI work plan. Level III laboratory DOO will be used when development of a remedial strategy is required.

The BCV OU I location powes Iwo problems that the DOOn will addrea: (1) whether the wastes and acil contamination pose a risk io human health of the envifonment now of in the future and (2) if the wastes and contamination do pase a riak. what feasible alternativen extat for reducing the risk io accepiable levels.

A QC program for analyical dala develop information that can be used to accomplish the following:

- Evaluate the accuracy and prectaion of analytical data io establish their quality.

- Indicate the need for corrective actions. when a compariaun with exisiling regulatory of program crileria of dala Irenda shom that activilies must he changed of monitored to a differeni degree.

- Determine the effect of eorrective actions.

Because the laboratory for this project (and for wll projects conducted for the ER Program in Oak Ridge) has nol been specified. the OC crileria included herein should he considered minimum requirement. When the laboralony of laboralories have been specified. the $O C$ requiremenis defined herein will be communieated to those facilitien in analytical services statements of work. Any necessary changes to these requirements will be documented and approved through the variance aystem. Requirements for analytical decumentation lor the laboratory selected for this project will be similar io the documentasion requirements oullined for the CLP. These CLP requirementi are described in this OAPJP.

The OA objectiven for all analylical data are wo obiain reproducible, precise, and accurale measurements consistent with the intended use of the data and the limitations of the sumpling and analytical proceduret. The reasons for $O C$ are (1) in sereen oul data of unucceptable degrees of precision of accuracy and (2) In obiain data that will accomplish the objectives of this project. OC will be accomplished through the asignment of measurement laska to the appropriale analylical level ( 1 V) as defined in Dalu Quality Objectives for Remedial Response Activities Development Process (EPA 1987b). This OAP,P apecifies the documentation and OA requiremenis applieable io these data 
Precision is the determination of the reproducibility of a mensurement under a piven condilion. Precision of moniloring insiruments is decermined hy a comparison of mulliple readings during culibration. For sampling anulysis, it is measured ihrough ihe use of field and Iaboratory duplicaten.

Accuracy is a measure of the closeness of a reported concentration to the true value. $O C$ standards and inatrument calihrations will be used io measure accuracy in sampling and analyis. Accuracy of monitoring instruments is delermined hy comparing calibralion teadings 10 * known alandard. Accuracy in sampling is achicved by using slandard criletio for containet and equipment cleaning. sample collection, personnel training and performance criteria. uniform sample handling techniques, and hlanks Io detect contamination.

Representaliveneas expresses the extent it) which data reflect a site's characieriatica. Repiesentativeneas of samples collected and analyzed is controlled by whering in the aumpling plan and conforming with specilic lechnical procedurea and approved analytical procedurea. It may he mensured by collecting field hlanka and decontamination sumplea io determine if the field samples ure heing contaminated by hundling and, therefore, do nol repreaent that which was intended.

Completenew is a measure of the amount of usuhle data resuling from data collection activily. The OA completeness objective for this project is to whiain valid analytical results for at least 45\% of the samples collected during the project. This implies that completeneas of sumple collection (the number of sumplen collected compured to the number of samplea

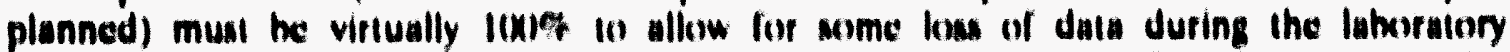
analyical proces. Accouniability of sumples collected. Irom field io final disposal, mus be 100\%. The goul for completenes for critical samples is $110 \% \%$. If is measured teith in number of fleld samples collecied versus planned and number of samples anulyced venus planned.

Objectives for comparability between samples will be met by (1) narrowly deflned umpling methodologien. (2) sile surveillance and the use of standard sampling and monitoring devices. (3) personnel Iraining. (4) documentaloun of sampling points. (5) application of stringent conirol limis firf daily OC checks, and (6) reperting of resulls if appropriate. comparable units. Comparability is achieved through the use of slandard lechniques for the collection und analyais of amples. Comparahility depends on the consiatency and knowledge of other DOO Data seis ean be compared only when precision, accuracy, representativeneas, and completeness of the measurements are known.

\section{M.1 OC Lovel of Fold Laboratory Analyals and Datu Ouality Parameten}

The DOOn for the plan will delermine the level(s) of feld laburatary analyis and dala quality parameters that will be required. Guides to measurcments iypical of the OC levels follow.

The collection and field screenindanalywis of envirunmental samples are used for initiol characterieaioun Io identily samples for further analynis. Io provide background and haseline monitoring. and II) extimale the extent of contamination on a rapid turnaround basis. $O C$ Level I and $O C$ Level II analytical support uptions may be used on sile to provide these data. 


\section{R1.1.I OC Lovel I analytical support}

OC Level I analytical support is used in generate field screening data 10 determine the extent of contamination at site, to provide real-time health and safely monitoring, to allow screenine/optimization of sampling. and to acquire qualitative measurements of ambient conditions. Oeneral data quality criterio for OC Level I field screening support are specified below. Analytical parameters typically apecified for OC Level I data collection include the following:

- Measurement of ambient lemperuture (soil/water/air)

- Measurement of electrical conductivity (soil/water)

- Measurement of pH (avil/water)

- Messurement of salinity (water)

- Measurement of disunlved oxygen (water)

- Total organic vapor concentration Iphotosionization detector/hame ionization detector (PID/FID)| (air/soil/gas)

- Radiological monitoring (alphaheta/gamma) (coil/air/equipment/personnel)

Calibration of OC Level I inatrumentation, in accordance with the manufacturer's instructions as uppropriate for the media and anulytes of concern, is required before and upon completion of dally umpling. Positive response verificution checks will be performed by the Healih and Safety Omeer, the Field Team Leader, or deaignee on these inatruments for every 20 sumples or every $4 \mathrm{~h}$, whichever is more frequent. These checks consist of expouing the inutrument to source of analyte (e.g., exposing PID to volatile organic source) and verifying - response. If no response is obtuined, corrective action will be taken and documented and the instrument recalibrated. Results of calibration and reaponse checks will be recorded in the instrument logbxok.

Personnel reaponsible for using and/or muintaining parlicular instruments must maintain - loe of calibration/response check procedures and performance. The Field Team Leader will inpect the logs, which will become part of the project records. Each operator muat be trained in the proper use of the inatrumenta, be familiar with their operation, be able to interpret dats from them, and be able to produce documentation certifying thewe skills. This documentation will facilitate comparability between samples.

OC Lovel I DOO for sampling conducted during the inveatigation are met by the following:

- Sampling procedures

- Site surveillunce

- Use of standard sampling and monitoring devices

- Personnel iraining

- Decumentation of sampling location, method, and media 
- Reporting of results in appropriate units

- Consistent use of types of screening/monitoring instruments

- Maintenance of measuring and test equipment (M\&TE) and M\&TE records

\subsubsection{OC Level II anulytical support}

OC Level II analytical support is used to provide real-time screening data for ongoing field activities, (1) identify samples for laboratory analyais, to allow for phased approach sampling. and to supplement OC Level I data with semiquantitative data. Data quality criteria for OC Level II field analynis are given below. Analytical parameters, instrumentation, and media typically apecified for OC Level II data collection may include the following:

- VOC analysis (mobile lah) (soil/water/air)

- Inorganic compound analyais (mobile lab) (soil/water/air)

- Pesicide/PCB and dioxin/furan annlysis (mobile lab) (soil/air/water)

- Special applicationa (c.g. down-hole monitoring, geotechnical applicationsa)

Calibration of $Q C$ Level II instrumentation. In accordance with the manufacturet's instructions as appropriate for the media and analytes of concern, is required at a minimum before and upon completion of the daily analyaes of as required by the appropriate EPA. recommended methodology. Decumentation and OC procedures for OC Level II field analyses are instrument. and analyte-specific. However, OC Level II data will be confirmed by submitting a minimum of $5 \%$ duplicute samples, with at least one sumple per matrix, to a OC Level III or IV laboratory facility for analyais.

\section{following:}

OC Level II DOO for sampling conducted during the investigation are met by the

- Sampling procedures

- Site surveillance

- Use of suandard sampling and monitoring devices

- Personnel training

- Decumentation of sampling lecation, method, and media

- Reporting of resules in appropriate units

- Consistent use of types of screening/monitoring instruments

- Stringent control limits for the daily OC checks

\subsubsection{OC Level of Analytical Laboratory and Dats Ouality Parameters}

Analytical laboratory datu will be generuted for environmental samples to provide confirmed identification and quansification of organic and inorganic compounds and radionuclides in each sampled media. Analytical methods that may be used include EPA CL.P. 
SW-846, and others as long as the $Q C$ information that is appropriate to DOOs is being reported and/or delivered.

\subsubsection{OC Level III analytical support}

QC Level III analytical support is used to provide confirmed identification and quantification of contaminants to determine the extent of contamination, to determine the presence or absence of contaminants with required detection limits, and 10 confirm the results of lower QC Level (I \& II) screening and analyses. OC Level III may provide data of comparable quality Io OC Level IV but with less OC documentation, at a lower cost, and a shorter turnaround time. Analytical parameters and media typically specified for QC Level III data collection include these:

- Organic and inorganic compound analysis (soil/water/air)

- TCLP

OC Level III laboratory OC procedures will follow requirements specified in the appropriate EPA-recommended methodologies. QC Level III protocols have built-in QA/OC, including calibration runs, surrogate standards, etc. External QA is employed in the form of trip blanks, replicate and duplicate sumples, and blind spikes, which may be submilted with the samples. Documentation requirements depend on the laboratory and type of analysis performed.

Accuracy, precision, and methesd detection limit (MDL) information representative of QC Lovel III analytical support is provided by adherence to SW-846 and/or EPA CLP.

Laboratories performing OC Level III analyses must maintain a record of instrument calibration and OAVOC results. Such records will become part of the project records. Each operator must be trained in the proper use of the instrument, be familiar with the instrument's operation, be able to interpret data from the instrument, and have documentation certifying these skills.

\subsubsection{OC Lovel IV analytical support}

QC Level IV analytical support conforms 10 the EPA CLP for performing routine analytical services for analyses of all types of media. QC Level IV is used to provide confirmed identification and quantification of contaminants, to determine the extent of contamination, and to determine the presence or absence of contaminants with low required detection limits. OC Level IV provides documented data for risk assessment and remedial investigations. Data quality criteria for QC Level IV laboratory analyses are given below. Analytical specifications and media that may requirc QC Level IV data analysis include the following:

- Hazardous Substance Lisl organic compounds (soil/water/air)

- Priority pollutant inorganic compounds (soil/water/air)

- TCLP 
QC Level IV laboratory QC procedures will follow requirements specified in the current EPA SOW revision for CLP methodologies. Methods not included in the CLP will be elevated to $Q C$ Level IV by meeting CLP-type requirements and submitting all raw data. $Q C$ Level IV CLP routine analytical services protocols are very specific concerning QAVC requirements and data package documentation. Routine analytical services deliverable packages contain information on initial and continuing calibration, gas chromatograph/mass spectrophotometer tuning, surrogate percent recovery, matrix spike duplicates (MSDs), and spectra for every sample and blank. External QA is employed in the form of trip blanks, replicate and duplicate samples, and blind spikes submitted with the samples.

QC Level IV precision, accuracy, representativeness, completeness, and comparability (PARCC) parameters are similar to those described for Level III. Routine analytical services documentation is sufficient to allow qualified personnel to review, verify, and validate analytical results and to evaluate data quality.

CLP routine analytical services documentation will be maintained as part of the project records. Chemists must be trained in the proper use of the instrument, be familiar with the instrument's operation, be able to interpret data from the instrument, and be able to produce documentation certifying these skills.

\subsubsection{OC Lovel V analytical support}

QC Level $V$ is analysis by nonstandard methods. The following is information only since Level $V$ is not proposed for this RI work plan. It is used to provide confirmed identification and quantification of nonstandard analytes and/or matrices. Typical data quality criteria for QC Level V laboratory analyses are given below. Analytical specifications and media that may require $Q C$ Level $V$ data analysis include the following:

- Radiochemical analysis (soil/water/air/biota)

- RCRA-modified Appendix VIll contaminants (soil/water/air/biota)

- Pure product/waste analysis

- Neutron activation analysis (soil/biota)

Level V laboratory QC procedures will follow analytical requirements specified by EPA or DOE, where applicable, in the project analytical SOWs.

External field QA will be employed in the form of trip blanks, replicate and duplicate samples, and blind spikes that may be submitted with the samples.

PARCC data quality parameters for special analytical services methodologies are defined on a case-by-case basis due to the limited availability and special considerations associated with these methodologies. Special analytical services $\mathrm{QA} / \mathrm{QC}$ and documentation requirements will be sufficient to allow qualified personnel to review, verify, and validate analytical results and to evaluate data quality. Laboratory procedures may include the following information, as applicable: 
- Chain of custody and holding times

- Calibration curves, initial and continuing

- Blanks

- Sample-specific chemical recovery

- Laboratory control samples (LCSs), matrix spikes (MSs), and ficld duplicates

- Duplicate samples

- Radionuclide quantification and implied detection limits

- Chemical separation specificity

- Tentatively identified target analytes

The special onalytical services laboratory must specify the methodologies used or developed and document modifications to these methods with appropriate justification.

Each laboratory chemist must be trained in the proper use of the instruments, be familiar with the operation of the instruments, be abic to interpret data from the instruments, and be able to produce documentation certifying these skills. Special analytical services laboratory documentation will be maintained as part of the project records. This documentation will facilitate comparability between sample analyses.

\subsection{SAMPLE COLLECTION PROCEDURES}

Subsurface and surface soil, surface water, groundwater, and sediment sampling are proposed for BCV OU 1. Characicrization efforts will focus on several potential contamination sources at the Burial Grounds, the Oil Landfarm, the Boneyard/Burnyard, and the S-3 Site. Prior to commencing field activities, a readiness review will be conducted. (See Appendix E.)

The following interim procedures will be used to conduct ficldwork associated with BCV OU 1. These procedures are derived from ESH/Sub/87-21706/1 (Kimbrough et al. 1997)), ORNL/TM-860) (Myrick 1987), requirements outlined in the RCRA Facility Investigation Plan General Documerit Y.12 Plant, Oak Ridge, Tennessee (Welch 1989), and approved procedures. Equipment rinsate, field blanks, and trip blanks will be collected according to the procedures described in this QAPjP.

\subsection{Soil Sampling}

The following discussion of soil sampling procedures is organized by collection method. Procedures common to all collection methods are presented first. Subsurface soil samples will be taken using a continuous split-barrel sample tube system. All cores of subsurface soil retrieved will be scanned with an OVA and radiation survey instruments before being boltled and forwarded to the laboratory for analysis. Surface soil samples will be collected using a hand auger. 
In general, the following protocol will be observed for collection of soil samples:

- The sample locations will be recorded on a suitable map. Sample locations will be surveyed to Y-12 Plant grid coordinates.

- The equipment for surface and subsurface soil sampling consists of hand tools, homogenizing pans, barrel augers, and split-barrel samplers made of stainless steel. This equipment will be decontaminated before sampling and between samples to prevent cross-contamination. The decontamination procedure is discussed in Sect. 8.3.1.2 of the QAPjP.

- All cores will be scanned with an OVA for organic contamination and a GM pancake meter for radiological contamination before sample bottling.

- Each sample will be scanned for radiological contamination before bottling.

- The section of the core that has the highest organic vapor concentration will be collected for VOC screening by the Field Gas Chromatography lab and laboratory volatile organic analysis. The part of the core that has the highest radiological contamination will be bottled for radiological analyses. If no section of the core produces noticeably higher readings, the samples will be collected from the center of the core.

- All samples will be labeled with the specified information (sample number, media, location, date, time, sampler, associated field measurements, project designator, and preservatives) and recorded in the field logbook.

- Analytical samples that are not immediately transported to the laboratory will be stored in a designated refrigerator maintained at $4^{\circ} \mathrm{C} \pm 2^{\circ} \mathrm{C}$. An internal thermometer will measure temperature throughout the storage period. The temperature will be noted and recorded before storage and noted in the field logbook at the time of transportation. Signed and dated paper chain-of-custody seals will be placed on the refrigerator door to indicate if any tampering occurs.

- Samples that are to be transported will be placed in an insulated cooler chilled with a reusable ice pack to $4^{\circ} \mathrm{C} \pm 2^{\circ} \mathrm{C}$. The temperature of the cooler will be monitored by a thermometer inside. The temperature in the cooler must be $4^{\circ} \mathrm{C} \pm 2{ }^{\circ} \mathrm{C}$ before any samples are placed in it. Once the samples are in the cooler, the thermometer will be positioned between sample jars. As the samples are checked in at the analytical laboratory, the temperature at the time of arrival will be checked and recorded. A sacrificial container of ASTM Type II water should be placed in each cooler for temperature measurement upon arrival at the laboratory. An adhesive thermometer (not $\mathrm{Hg}$ bearing) may also suffice. An extra VOC sacrificial container should be sent for a $\mathrm{pH}$ check at the laboratory.

- All samples will be delivered under chain of custody, and the original chain-of-custody form will accompany the samples to the laboratory. A carbon copy of the chain-of-custody form will be retained by the sampling crew and given to the Site Project Manager. The analytical laboratory will return the completed original chain-of-custody form and analytical results for inclusion in the project file. Upon project completion, analytical results will be delivered to the Y-12 ER Program database manager, and copies of the original chain-of-custody forms will be forwarded to Y-12 ER. 
Soil sampling will be conducted in accordance with ESP-303 methodologies. Sampling equipment will be as specified in the procedure, or the procedure will be amended to reflect any necessary changes.

The following changes will apply.

\section{ESP-303-1, Soil Sampling with a Spade and Scoop}

1. Section IV, page 1 of 5: Specify that spades are to be decontaminated after removing chrome or other plating materials and before their use for field activities.

2. Section VII, Part C, page 2 of 5: Specify that the spade used to remove the vegetation should be a decontaminated one.

3. Section VII, Part D, page 2 of 5: Change the word "of " to "to."

4. Section VII, Part E, page 2 of 5: Revise to state "Use a decontaminated scoop or spoon to remove a thin layer of soil, if necessary."

5. Section VII, Part F, page 3 of 5: Revise to state "Obtain an appropriate volume of sample with a separate decontaminated scoop or spoon."

6. Section VII, Part G, page 3 of 5: Insert "subsequent" between "each" and "sample."

7. Section VII, Part H, page 3 of 5: Delete "ESP-400 and."

8. Section VII, Part I, page 3 of 5: Insert "either" between "materials should" and "be used"; change "container" to "contained."

9. Section VII, Part F, page 3 of 5: Add "Place samples in containers, preserve, package, label, and prepare for shipment as per ESP-500, ESP-701, and ER/C-P2302" after the first sentence.

10. Attachment 1, Field Checklist: Add "Monitoring Instruments" to the checklist.

\section{ESP-303-2, Soil Sampling with an Auger}

1. Section VI, Paragraph 2, page 2 of 6: Delete the first sentence of this paragraph.

2. Section VII, Part E, page 3 of 6: Revise "B \& $C$ " to state ${ }^{\circ} C \& D^{n}$ and change "precleaned" to "decontaminated." Add "and repeat steps $A$ through $D$ " at the end of the second sentence.

3. Section VII, Part F, page 3 of 6: Insert "or Teflon" after "polyethylene." Add as second and third sentences: "The top 2 to 3 in. of soil in the auger should be discarded. Remove aliquot for volatile organic analysis." In the last sentence insert "the remaining" between "composite" and "soil." 
4. Section VII, Part G, page 3 of 6: Revise to read "Using a decontaminated stainless steel or Teflon spoon, spatula, or disposable scoop as appropriate, place soil samples in compatible containers, package, label, and prepare for shipment per ESP-500, ESP-701, and ER/C-P2302."

5. Section VII, Part I, page 3 of 6: Delete this step.

6. Section VII, Part K, page 3 of 6: Add "The borehole will be abandoned, if necessary, in accordance with ESP-600."

7. Attachment 1, Field Checklist: Add "Monitoring Instruments" to the checklist.

\section{ESP-303-3, Soil Sampling with a Trier}

1. Section VI, Paragraph 2, page 2 of 7: Delete the first sentence of this paragraph.

2. Section VII, Part D, page 2 of 7: Modify "the precleaned" to "decontaminated."

3. Section VII, Part G, page 3 of 7: Modify to state "Transfer the sample to a decontaminated Teflon sheet, glass bowl, or stainless steel bowl with the aid of a decontaminated stainless steel or Teflon spoon, scoop, or spatula. Remove any aliquot for volatile organic analysis. Mix or composite the remaining soil as directed by the sampling and analysis plan. If no mixing of sample is required, the soil should be placed directly into sample container from the trier."

4. Section VII, Part H, page 3 of 7: Omit this step.

5. Section VII, Part I, page 3 of 7: Revise to state: "Samples will be placed in containers, preserved, packaged, labeled, and prepared for shipment as specified in ESP-500, ESP-701, and ESP-800."

6. Section VII, Part J, page 3 of 7: Remove "ESP-400 and."

7. Attachment 1, Field Checklist: Add "stainless steel bowl" to the list.

\subsubsection{Sediment Sampling}

Sediment sampling will be conducted in accordance with ESP-304 methodologies. Sampling equipment will be as specified in the procedure, or the procedure will be amended to reflect any necessary changes.

The following changes will apply:

\section{ESP-3041, Sediment Sampling Procedures: Streambeds}

1. Section IV, Note, page 2 of 11: Replace with the following, "The manufacturer's calibration and maintenance instructions should be attached to the equipment, not the procedure." 
2. Section VI, Second paragraph, page 3 of 11: Delete the first sentence of this paragraph.

3. Section VII, Part A, page 3 of 11: Add "Don clean gloves prior to field activities" to the beginning of Subpart 1 .

4. Section VII, Part A, Subpart 1, page 3 of 11: Insert "clean, decontaminated, or not previously used" between "Use" and "Lexan."

5. Section VII, Part A, Subpart 2, page 3 of 11: Insert "inner" between "certain" and "piston."

6. Section VII, Part A, Subpart 10, page 4 of 11: Add another sentence that states "Measure the length of core in the tube and any other observations as per the Sampling and Analysis Plan."

7. Section VII, Part A, Subpart 13, page 5 of 11: Change the last word of the first sentence from "practical" to "possible."

8. Section VII, Part B, page 5 of 11: Add a new Subpart 1 that states "Don clean gloves prior to field activities. To avoid injury, keep hands and fingers away from open dredge jaws."

9. Section VII, Part B, Subpart 7, page 5 of 11: Change the last word of the first sentence from "practical" to "possible."

10. Section VII, Part C, page 5 of 11: Add a new Subpart 1 that states "Don clean gloves prior to field activities."

11. Section VII, Part C, Subpart 6, page 6 of 11: Add "as soon as possible" after "samples with ice" in the third line.

12. Section VII, Part C, Subpart 8, page 6 of 11: Change the last word of the first sentence from "practical" to "possible."

\subsection{Surface Water Sampling}

This procedure describes the method and equipment for collecting surface water grab samples using a dipper. This technique will be used for sampling storm water runoff. The dipper will be used to fill a sample bottle without contaminating the outside of the bottle, thus allowing the worker to avoid physical contact with the water. This method should not be used when a significant amount of material (such as oil on the water surface) might remain on the dipper after water is poured into the sample bottle. When samples are collected for volatile organic analysis (VOA), the sample containers may be immersed or filled directly from the source or outfall of interest, depending on the accessibility of the sample location. Extreme care must be taken to avoid disturbing or aerating the VOA sample, and the bottle should be completely filled. 
The following procedures will be used as modified:

\section{ESP-301-1, Water Sampling Using a Dipper}

1. Section 1. Third paragraph, Second sentence, page 1 of 7: Change the word "is" to "are."

2. Section IV, Second sentence, page 2 of 7: Revise this sentence to state "Sample for volatile organic analysis (VOA) should be collected first and extreme care must be taken to avoid disturbing or aerating the sample."

3. Section IV, page 2 of 7: Add another sentence that states "In this situation refer to the Sample and Analysis Plan."

4. Section V, Part A, page 2 of 7: Add another sentence that states "Composition of dipper should be appropriate for the nature of the sample and likely contaminants."

5. Section VI, Second paragraph, page 3 of 7 : Delete the first sentence.

6. Section VII, Part B, Page 3 of 7: Modify this part to state "Select appropriate bottles (see ESP-701), add preservative, if necessary, and place them ready for use."

7. Section VII, Part C, page 3 of 7: Change the word "clean" to "decontaminated." Add the following to the beginning of Part " $\mathrm{C}^{m}$ : "New latex gloves should be donned prior to collecting each sample. Dipper should be decontaminated prior to use as per ESP.900." Add another sentence that states "The sample must be taken upstream from where the sampler is standing and also upstream from where field personnel have been in the stream taking now measurements."

8. Section VII, Part F, page 3 of 7: Delete the third sentence of this part.

9. Section VII, Part I, page 4 of 7: Change the last word of the first sentence from "practical" to "pussible."

10. Section VII, Part J, page 4 of 7: Insert "appropriate field forms" between "logbook" and "and chain-of-custody."

11. Section VIII, page 4 of 7: Change the fourth sentence to state "Sampling personnel shall wear chemical resistant gloves when handling the water samples."

12. Attachment 1, page 6 of 7: Add "Extra sample jars/lids," "Bucket," "Pipettes," "Litmus paper," and add "and tags" after "Labels."

ESP-301-2, Peristaltic Pump for Sampling Surface Water

1. Section I, Last sentence, page 1 of 9: Change the word "is" to "are."

2. Section III, First sentence, page 2 of 9: Change the word "clean" to "decontaminated." 
3. Section IV. First sentence, page 2 of $9:$ Insert "or hand operated" between "electric" and "pump."

4. Section VI, Second paragraph, page 3 of 9: Delete the firat sentence of this paragraph.

5. Section VII, Part C. Third sentence, page 3 of 9: Change the word "or" 10 "on."

6. Section VII, Part C, Fifth sentence, page 3 of 9: Insert "with appropriate material" between "lubing" and "10."

7. Section VII, Part C, Last sentence, page 3 of 9: Change the words "vacuum flask" to "sample bottle."

8. Section VII, Part E, page 3 of 9: Replace "When possible" with "Unleas otherwise directed by site-specific Sarnpling and Analysis Plan."

9. Section VII, Part F, page 3 of 9: Add the following to the beginning of Part "F": "Prior to filling bottles, don clean gloves."

10. Section VII. Part G, page 4 of 9: Change the last word of the firat sentence from "practical" to "possible."

11. Altachment 1, page 6 of 9: Add the following to the Field Checklist: "Safety Equipment," "Sample Bottles with lids," "Pipettes," "Litmus Paper," "Ice/Cooler as required," and add "and Tags" to the ilem "Labels."

12. Page 8 of 9: Add "or Sample Bottle" to "Figure 1. Vacuum Flask."

ESP-301-3, Sampling with an Automatic Sampler

1. Section I, Last sentence, page 1 of 8: Change the word "is" to "are."

2. Section IV, Part A, page 2 of 8: Delete the last sentence of this part.

3. Section IV, Part B, page 2 of 8: Delete the last sentence of this part.

4. Section IV, Paragraph 4, page 3 of 8: Add another sentence that states "The sampler must be able to collect enough sample for the required analysis."

5. Section IV, Paragraph 5, page 3 of 8: Replace this sentence with "Manufacturer's calibration and maintenance instructions will be kept with the equipment, not the procedure."

6. Section V, Part A, page 3 of 8: Insert a comma in the third line between "container" and "sample." 
8.14

7. Section V, Part B. page 1 of 8: Insert "of decontaminated Teflon of Tygon" between "lubing" and "of." Alao add another sentence that states "The minimum intake line diameter should be $1 / 4$ in. inside diameter."

8. Section VI. Second paragraph, page 4 of 8: Delete the firat sentence of this paragraph.

9. Section VII, page 4 of 8: Add the following to the end of Part "A": "Prior to each field application, the sampler operation will be checked and calibrated per manufacturer's instructions."

10. Section VII, Part C. page 4 of 8: Add "add any other preservalive, If neceasary, "hetween "base" and "inatall" to the first sentence. Add to the Note "and maintain throughout the sampling event" to the end of the sentence. Add "cold" between "Ir" and "ample" in the Note.

11. Section VII. Part N, page 5 of 8: Change the last word of the firat sentence from "practical" to "possible."

12. Allachment 1, Field Checklist, page 7 of 8: Add the following: "Equipment Manufacturer's Operating Instructions," "Pipettes," "Litmus Paper," and add "and Taga" to the item "Labels."

ESP-3014, Grab Sampling with Kemmerer Bottlo

1. Section 1, Last Sentence, page 1 of 6: Change the word "is" to "are."

2. Section $\mathrm{VI}$, Second paragraph, page 2 of 6: Delete the firat sentence of this paragraph.

3. Section VIl, page 3 of 6: Add the following to the beginning of Part "B": "Select appropriate sample botlles (see ESP.701), add preservative, if necessary, and place them ready for use. Don clean gloves prior to sampling."

4. Section VII, Part C, page 3 of 6: Revise this section to stats: "Measure and mark sample line at the desired sampling depth or use a measuring spool to lower the sampler."

5. Section VII, Part E, page 3 of 6: Change "Step B" to "Step C."

6. Section VII, Part J, page 3 of 6: In the first sentence change the word "practical" to "possible."

7. Attachment 1, Field Checklist, page 7 of 8: Add the following to the checklist: "Messenger," "Equipment Manufacturer's Operating Instructions," "Extra Sample Containers/Lids," "Pipettes," "Litmus paper," and add "and tags" to the tiem "Labels." 


\section{BSP.301-5, Streamikw Mounuremon!}

1. Section I. Lasi Sentence, page I of b: Change the word "is " I0 "are."

2. Section V. page 3 of 6: Add a new Pafl "F" Ihat statea "Manufacturer's inatructions muat be present and followed for specific instruments used."

3. Section VII. Part F, page 4 of 6: Add - The use of a Iop selling wading rod will eliminate the need for a second staff gauge. Use the alx-Ienths depth method for depths les than $2 \mathrm{fl}$, and the two point method for depths greater than $2 \mathrm{fl}$ in measuring the velocity. Note the starting depth" to the end of this part.

4. Section VII, Part O, page 4 of 6: Delete this part.

5. Section VII, Part I, page 4 of 6: Change "is" I0 "are" in the second sentence.

6. Altachment 1. Field Checkliat, page 6 of 6: Add the following to the checkliat: "Equipment Manufacturer's Operaling Inutructions" and "Lube Oil."

\section{Oroundwater Sumpling}

Oroundwater sampling will be conducted in accordance with ESP.302 methodologies. An electric water level indicator will be used in place of the "Chalk Type" method. The procedures will be amended as follows:

BSP-302-1, Oroundwater Sampling Procedures: Water Lovel Measurement Using Wuter Loval Indicutor

1. Section 1. Firal Sentence, page 1 of 7: Inserl "or plezometers" to the end of the sentence.

2. Section IV, Paragraph 2, page 2 of 7: Delete "with a 'plopper'."

3. Section IV, page 2 of 7: Delete the third paragraph.

4. Section V. Part B, page 2 of 7: Change "plopper" to "raised markings."

5. Section VI, Second paragraph, page 3 of 7: Delete the first sentence of this paragraph.

6. Section VII, Part A, page 3 of 7: Change sentence to read "Don clean gloves, unlock and open well; note condition of well. Check the well with OVA. PID and/or Rad meters."

7. Section VII, Part C, page 3 of 7: Insert "inner" hetween "of" and "well."

8. Section VII. Part C. Subpart 1, page 3 of 7: Insert "inner well" between "of" and "casing." 
8.16

9. Section VII. Part D. Subpart 1, page 1 of 7: Change the wird "clean" in "decontaminated."

10. Section VII. Part D. Subpari 8, page 4 of 7 : Inaer "inner" hetween "or" and "casing."

11. Section VII. Purt D. Subpart 11. page 4 of 7: State "Pull M-acope from well and decontaminate."

12. Section VII. Part E. Subpart 1. page 4 of 7: Insert "deconiaminated" beiween "Inapect" and "Iupe." Delete "or applied length for 'plopper'."

13. Section VII, Part E. page 4 of 7: Add the following to the beginning of Subpart 2: "Chalk one of Iwo feet of iape."

14. Section VII. Part E, Subpart 3, page 4 of 7: Change the word "plopper" In "Iape." Add another sentence that states "Note reading at measuring puint on lop of well."

15. Section VII, Part E, page 4 of 7: Replace Subpart 4 with "Remove iape from well and note wet cul on tupe."

16. Section VII, Part E. Subpart 5, page 5 of 7: Replace "Read the tape 100.01 I." with " Subtract wet cul from measuring point reading." Insert "10 0.01 11." hetween "measurement" and "in field."

17. Section VII. Purt E. Subpart 7, page 5 of 7: Change "unalyilical" to "analyait."

18. Altachment 1. Field Checklist. page 7 of 7: Change second eniry to state "Steel or Iberglans tupe measure with ralsed markinga."

19. Altachment 1, Field Checklist, page 7 of 7: Add another entry that states "Monitoring equipment (PID, OVA. Rad meters)."

\section{BSP-302-2, Ouldalines for Woll Purging}

1. Section VI, Second paragraph, page 2 of 7: Delete the first sentence of this paragraph.

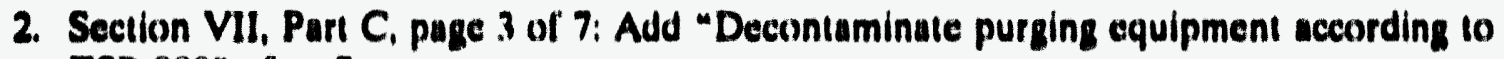
ESP.900" ufter first wentence.

3. Section VII. Part E, page 3 of 7: Add "around the base of the well and donning clean gloves" to the end of the sentence.

4. Section VII, page 3 of 7 : Add the following to the beginning of part "F" which states "Check the well with HNU, OVA, and/or Rad meters. Monitor the well for VOCs if applicable, using a PID."

5. Section VII, Part O, page 3 of 7: Change the word "known" to "measured." 
6. Section VII. Parl I. page \& of 7: Add "II clear stagnant water which in noI representalive," alter "required volumes," in the first sentence.

7. Section VII. Parl J, Subpart I, page 4 of 7: Replace "then begin measuring field parameters once during ench well vilume" wilh "measure field parameters at end of each purge volume."

8. Section VII, Part J, Subparl 2. page 4 of 7: Delele "(of more an apecified in the ampling and analyais plan)."

9. Section VII. Part L. page 5 of 7: Add "and on well purging form. The use of a purging form to record data is recommended to avoid the omiation of critical data" in the end of this part.

10. Section VIII. Second sentence. page 5 of 7 : Add "Purged waler," w) the heginning of the sentence.

11. Allachment 1. Field Checklist, page 7 of 7: Add entries "Moniloring equipment," "Cord of Approved Material," "Key for Well Luxk," "Bucket with Volume Murkings," "s9 Oallon Drums for Purge Waler," and "Funnel."

\section{BsP-302-3, Oroundwater Sampling Procodures: Uaing : Baller}

1. Section IV. Subpart A. page I of 7: Add another sentence that atules: "The wase of ballers with bollom empiying devicen is highly recommended in reduce apillage and sample agitation."

2. Section VI, Second puragraph, page 3 of 7: Delete the first sentence of this paragraph.

3. Section VII. Part A, page 3 of 7: Replace the word "near" with "uround the base of." Add "in" between "and" and "work." Add the following: "lo prevent equipment from coming in contact with potentially contaminuted uurfuces" in the end of the sentence.

4. Section VII. Part C. page I of 7: Add another sentence to the heginning of this part that states "The use of a well sumpling form in addition (o) the loghoxk record in recommended to avoid omisaton of critical data."

5. Section VII, page 3 of 7: Add the following to the beginning of Part "C": "Prior to umpling, check the well with PID, OVA, und/or Rad meters."

6. Section VII. Part D. page 3 of 7: Replace the word "cleun" with "decontaminated."

7. Section VII. page 3 of 7: Add the following to the beginning of Purt "E": "Select appropriate sumple bollles (ESP.701) add preservative, if necessary, and place them ready for use."

8. Section VII, page 4 of 7: Add the following to the end of part " $\mathrm{J}$ ": "which are filled with no air present and capped." 


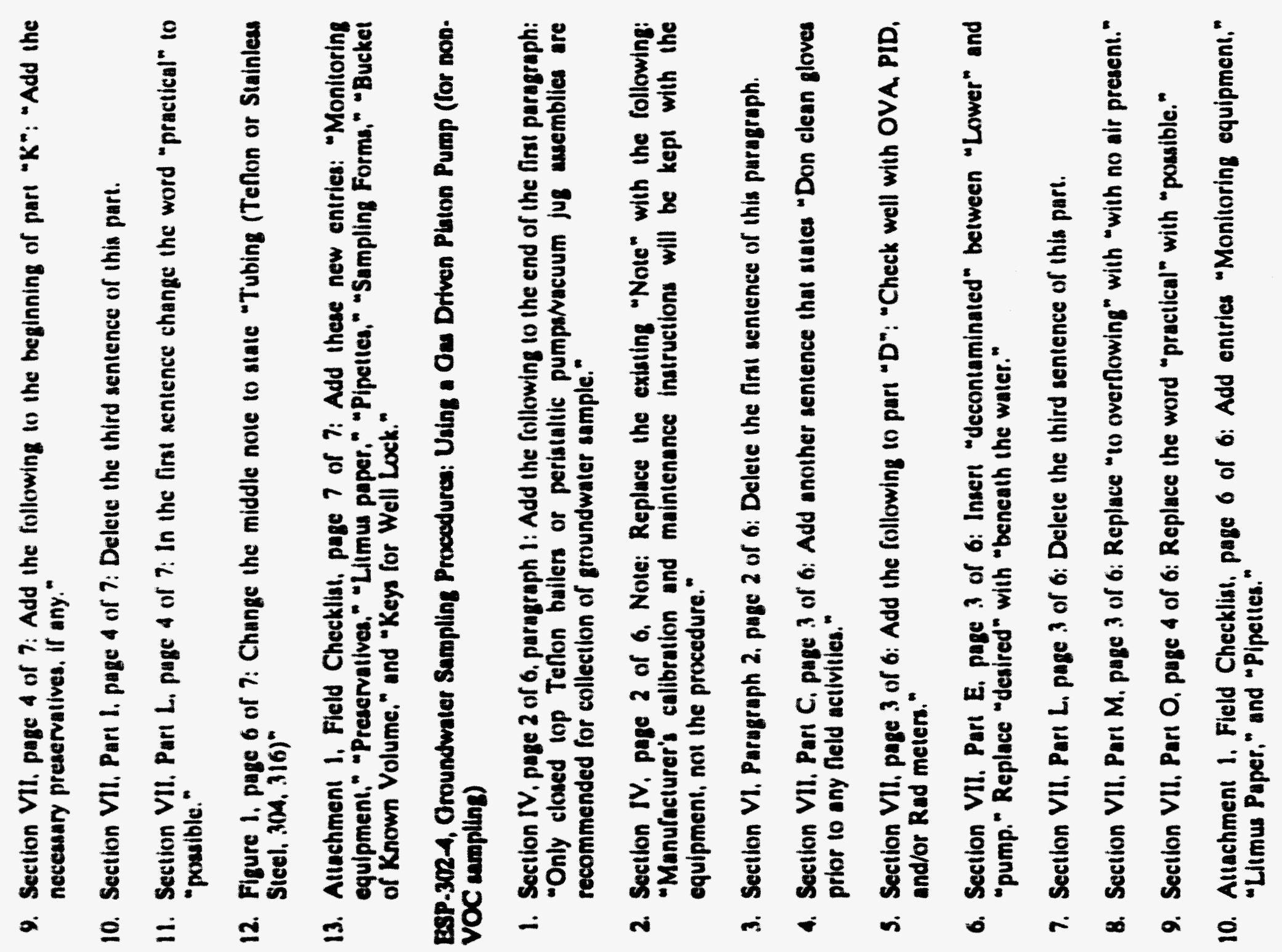


BSP-302-5, Oroundwater Sampling Prowedurcs: Using a Bladder Pump (for VOC sampling)

1. Section III. page 1 of 7 : In the first sentence change the word "cleaned" to "decontaminated."

2. Section IV, page 2 of 7. Note: Replace the existing note with the following: "Manufacturer's calibration and maintenance instructions will be kept with the equipment, not the procedure."

3. Section VI. Second paragraph, page 2 of 7: Delete the first sentence of this paragraph.

4. Section VII, page 3 of 7: Add the following to the end of part "A": "Select appropriate sample containers, add preservative (per ESP.701), if necessary, and place them ready for use."

5. Section VII. Part B. page 3 of 7: Add "and lo calch spills at the base of well" to the end of the senience.

6. Section VII. Part C. page 3 of 7: Add (wo) sentences that state "Don clean gloves prior to any field activities. Check the well with PID. OVA, and/or Rad meters."

7. Section VII. Part F. page 3 of 7: Insert "decontaminated" hetween "Lower" and "pump." Replace the word "desired" with "below water level."

8. Section VII. Part P. page 4 of 7: Delete the third sentence of this part.

9. Section VII. Part Q. page 4 of 7: Replace "to overflowing" with "with no air present."

10. Section VII, Part S, page 4 of 7: Replace the word "practical" with "possible."

11. Section VII. page 4 of 7: Add the following to the end of part "T": "The use of field forms to record sampling/purging data is recommended to ensure that all pertinent information is recorded without omission."

12. Altachment 1. Field Checklist, page 7 of 7: Add new entries "Monitoring equipment," "Litmus paper," "Pipeltes."

\subsection{Field Measurcment of Physical Paraneters}

Field measurement of physical parameters will be conducted in accordance with ESP-307 methodologies. Due to the wide variety and case-specific application of these types of instrumentation, each procedure may require amendment to include manufacturer's instructions for specific instrument operation and maintenance procedures. These tests shall be performed and documented so that a second party can reproduce and check findings from the recorded data. 
The following changes will apply:

BSP-307-1, Field Measurcments Procedures: Temperature

1. Section VII, page 3 of 5: Add a new Part " $A$ " that states "Don clean gloves prior to field activities."

ESP-307-2, Field Measurements Procedures: pH (Hydrogen Ion Concentration)

1. Section VII, Part B, page 3 of 6: Add the following to the end of Part "A": "Don clean gloves prior to use of instruments in the field."

2. Section VII, Part C, page 3 of 6: Revise the first sentence of this part to state "For pH meter without automatic temperature compensation, allow the sample and buffer to reach the same temperature, if possible."

3. Section VII, Part C, page 3 of 6: Add "using manufacturers operating instructions" to the end of this part.

4. Section VII, Part F, page 3 of 6: In the first sentence change the word "less" to "more."

5. Section VII, Part I, page 4 of 6: Add "of the day" to the end of this part.

\subsection{Sample Compositing and Special Sample Collection Procedures}

Sample compositing and specialized sample collection procedures will be conducted in accordance with ESP.308 methodologies. These include sample compositing, wipe sampling, and container sampling procedures. Sampling equipment will be as specified in the procedure, or the procedure will be amended to reflect any necessary changes.

The following changes will apply:

\section{ESP-308-1, Composite Procedurcs}

1. Section II, page 1 of 6: Add another Reference " $F$ " that states "Kimbrough, C. W., L. W. Long, and L. W. McMahon, eds., Environmental Surveillance Procedures Quality Control Program. ESH/Sub/87-21706/1, Martin Marietta Energy Systems, Inc., 1990.”

2. Section VI, Paragraph 2, page 2 of 6: Delete the first sentence.

3. Section VII. Part A, page 3 of 6: Add "Pyrex bowls may be substituted for stainless steel bowls. Samples will be homogenized before placing in containers except for VOA."

4. Section VIII, page 4 of 6 , after the first sentence add the following lines: "For composite samples of solid matrixes, such as soil and sediment, the sampling equipment will be cleaned of any solid residue for each aliquot (fraction or part) taken for the composite sample, but may not be decontaminated per ESP.900. The sampling equipment will be decontaminated per ESP.900 between each composite sample collected." 
ESP-308-2, Wipe Sample Collection,

1. Section I, page 1 of $6:$ In the third sentence change "is" to "are."

2. Section VII, Part A, page 3 of 6: Insert the word "decontaminated" hetween "Use" and "stainless" in this sentence.

3. Section VII, page 4 of 6, Subpart E, first sentence: Change "pad" to "pad(s)."

4. Altachment I, page 6 of 6, "Field Checklist": Add "Chemical Resistant" in front of "Gloves."

\section{ESP-308-3, Container Sampling: Drums and Tanks}

1. Section VI. page 4 of 36 , eccond paragraph: Delete the first sentence.

2. Section VII, Part A, page 4 of 36: Add to Subpart 1 a sentence that states "Don all appropriate Personnel Protection Equipment prior to any field activities."

3. Section VII, Part A, page 4 of 36: Add a new Subpart 2 that states "A sampling team of at least two people is required for sampling-one will collect samples, one will stand back to observe, ready to assist or call for help in an emergency."

4. Section VII, Part A. Subpart 2, page 4 of 36: Revise to state "Ensure drums are staged for easy access, preferably outside, if possible."

5. Section VII, Part A, Subpart 14, page 6 of 36: Add "seal container with custody tape" to the end of this Subpart.

6. Section VII, Part A, Subpart 16, first sentence, page 6 of 36: Delete the word "practical" and replace it with "possible and/or preserved according to the Sampling and Analysis Plan."

7. Section VII, Part B, Page 7 of 36: Add a new Subpart 3 that states "Record, in loghook, all pertinent information from visual inspection of tank, i.e., physical condition, leaks, labels, etc. Label each tank with a unique identifying number."

8. Section VII, Part B, page 7 of 36: Add a new Subpart 4 that states "Remove any standing material (water, etc.) from tank top. Carefully remove or open the tank lid while testing with appropriate instruments, if applicable. When contents are unknown, always use non-sparking tools. Check project specific health and safety plan for other applicable testing requirements."

9. Section VII, Part B, Subpart 6, page 7 of 36: Delete the word "practical" and replace it with "possible and/or preserved according to the Sampling and Analysis Plan." Add another sentence to the end of this subpart that states "Seal Containers with custody tape, if called for in the Sampling and Analysis Plan." 
10. Section VII, Part C, page 8 of 36: Add a new Subpart 1 that states "Don all appropriate Personnel Protection Equipment."

11. Section VII, Part C, Subpart 1, page 8 of 36: Revise the existing Subpart 1 to state "A sampling team of at least two people is required for sampling-one will collect samples, one will stand back to observe, ready to assist or call for help in an emergency."

12. Section VII, Part C, Subpart 2, page 8 of 36: Add "measure vented gas with organic vapor analyzer and explosimeter" after "release valve."

13. Section VII, Part C, Subpart 3, page 8 of 36: Delete the second sentence of this subpart.

14. Section VII, Part C, Subpart 8, page 8 of 36: Change the word "practical" to "possible and/or preserved according to Sampling and Analysis Plan." Also, add another sentence to this subpart that states "Seal with custody tape, if called for in the Sampling and Analysis Plan."

15. Attachment 1, Field Checklist, page 11 of 36: Add the following to the checklist: "Gloves," "Sample Containers," "Field Communication Device (in case of emergency)."

16. Procedure 1, Procedures for Use, page 12 of 36: Add a new Part 1 that states "Don all appropriate Personnel Protection Equipment prior to any field activities."

17. Procedure 1, Procedures for Use, page 12 of 36: Add "while testing with appropriate instruments, if applicable, see attachment IV for method of drum opening" to the end of the existing Part 1.

18. Procedure 1, Note, page 14 of 36 : Move all three parts of this note to page 12 of 36 and position them before the section "Procedures for Use" on page 12 of 36.

19. Procedure 2, Procedures for Use, page 15 of 36: Add a new Part 1 that states "Don appropriate Personnel Protection Equipment prior to any field activities."

20. Procedure 3, Procedures for Use, page 17 of 36: Add a new Part 1 that states "Don appropriate Personnel Protection Equipment prior to any field activities."

21. Procedure 3, Procedures for Use, Part 4, page 17 of 36: Change the word "of" in the fourth line of this part to "off."

22. Procedure 4, Procedures for Use, page 18 of 36: Add a new Part 1 that states "Don appropriate Personnel Protection Equipment prior to any field activities."

23. Procedure 4, Procedures for Use, Part 1, page 18 of 36: In the first sentence of the existing Part 1, change the word "precleaned" to "decontaminated."

24. Procedure 4, Procedures for Use, Part 3, page 18 of 36: Add "however, be careful not to splash. Sampler may wish to start free fall at surface of liquid rather than aboven to the end of this part. 
25. Attachment IV, Section I, First Paragraph, page 26 of 36: Add another sentence to the end of this paragraph that states "Visually inspect drum condition for leaks, bulges, labels, etc. before attempting to open drum."

26. Attachment IV, Section I, Second Paragraph, page 26 of 36: Add "preferably outside" to the end of the first paragraph.

27. Attachment IV, Section II, Part C, page 28 of 36: Delete this section.

\subsection{SAMPLE PREPARATION AND ANALYSIS PROCEDURES}

\subsubsection{Sample Containers, Sample Preservatives, and Holding Times}

The selection criteria for appropriate sample containers, sample preservatives, and holding times shall be in accordance with ESP-701 methodologies. Types of sample containers and sample preservation methods used will be documented in the sampling logbook. Field and laboratory records will indicate the sample holding time before analysis (Table 8.1).

The following changes will apply:

\section{ESP-701, Sample Preservation and Container Materials}

1. Section III, Part A, page 2 of 4: Revise first sentence to state "The most convenient preservative is a chemical which can be added to a sample bottle prior to or immediately following sampling."

2. Section III, Part A, page 2 of 4, Last sentence: Insert "Biochemical Oxygen Demand" between "with" and "BOD" and place parentheses around "BOD."

3. Section III, Part B, page 2 of 4: Replace Part B with the following: "When acids or bases are used to adjust the $\mathrm{pH}$ of a sample for preservation purposes, the $\mathrm{pH}$ of a representative number of samples will be checked after the preservative is added. This is necessary because the ambient $\mathrm{pH}$ of the water or its buffering capacity often causes the $\mathrm{pH}$ of the sample not to be adjusted correctly when a 'standard' amount of preservative is added. Document in the logbook that the $\mathrm{pH}$ was checked. The field supervisor will decide the number of samples in which to check the $\mathrm{pH}$ to ensure that similar types, batches, and sample groups are properly preserved. The $\mathrm{pH}$ paper should not be dipped into the sample, but a small amount of sample should be poured onto the pH paper."

4. Section III, Part D, page 2 of 4: Change "interfers" to "interfere."

5. Section IV, page 3 of 4: Add "Chemical preservation should not be added to concentrated waste samples."

6. Section V, page 3 of 4: The word "reagent" should be inserted on each line between "ACS" and "grade." 
Table 8.1. Recommended sample holding times, sample containers, sample preservation, and minimum sample size

\begin{tabular}{|c|c|c|c|c|c|}
\hline Parameter & Matrix & $\begin{array}{l}\text { Holding time (from } \\
\text { time of collection) }\end{array}$ & Container & Preservative & $\begin{array}{l}\text { Minimum } \\
\text { sample size }\end{array}$ \\
\hline \multirow[t]{2}{*}{ Volatile organics } & Water & $14 d$ & $\begin{array}{l}\text { Two } 40 \mathrm{~mL} \text { vials with } \\
\text { Teflon-lined caps }\end{array}$ & $\begin{array}{l}4 \text { drops conc. } \mathrm{HCl}, \\
4^{\circ} \mathrm{C}\end{array}$ & $40 \mathrm{~mL}$ \\
\hline & Soil & $14 d$ & & $4^{\circ} \mathrm{C}$ & $10 \mathrm{~g}$ \\
\hline \multirow{2}{*}{$\begin{array}{l}\text { Extractable organics } \\
\text { (semivolatile organics, } \\
\text { pesticides, PCBs) }\end{array}$} & Water & $\begin{array}{l}7 \mathrm{~d} \text {, extraction } \\
40 \mathrm{~d} \text {, analysis }\end{array}$ & $\begin{array}{l}\text { 1-L glass with Teflon } \\
\text { liner }\end{array}$ & $4^{\circ} \mathrm{C}$ & $1000 \mathrm{~mL}$ \\
\hline & Soil & $\begin{array}{l}14 \mathrm{~d} \text {, extraction } \\
40 \mathrm{~d} \text {, analysis }\end{array}$ & $\begin{array}{l}\text { Glass jar with Teflon } \\
\text { liner or core tube }\end{array}$ & $4^{\circ} \mathrm{C}$ & $50 \mathrm{~g}$ \\
\hline Metals (other than mercury) & $\begin{array}{l}\text { Water } \\
\text { Soil }\end{array}$ & $\begin{array}{l}180 \mathrm{~d} \\
180 \mathrm{~d}\end{array}$ & $\begin{array}{l}\text { Polyethylene, glass } \\
\text { Polyethylene, glass }\end{array}$ & $\begin{array}{l}\mathrm{HNO}_{3} \text { to } \mathrm{pH}<2 \\
4^{\circ} \mathrm{C}\end{array}$ & $\begin{array}{l}1070 \mathrm{~mL} \\
10 \mathrm{~g}\end{array}$ \\
\hline Mercury & $\begin{array}{l}\text { Water } \\
\text { Soil }\end{array}$ & $\begin{array}{l}28 \mathrm{~d} \\
28 \mathrm{~d}\end{array}$ & $\begin{array}{l}\text { Polyethylene, glass } \\
\text { Polyethylene, glass }\end{array}$ & $\begin{array}{l}\mathrm{HNO}_{3} \text { to } \mathrm{pH}<2 \\
4^{\circ} \mathrm{C}\end{array}$ & $\begin{array}{l}100 \mathrm{~mL} \\
10 \mathrm{~g}\end{array}$ \\
\hline Cyanide & $\begin{array}{l}\text { Water } \\
\text { Soil }\end{array}$ & $\begin{array}{l}14 d \\
14 d\end{array}$ & $\begin{array}{l}\text { Polyethylene, glass } \\
\text { Polyethylene, glass }\end{array}$ & $\begin{array}{l}0.6 \mathrm{~g} \text { ascorbic acid, } \\
\mathrm{NaOH} \text { to } \mathrm{pH}>12 \\
4^{\circ} \mathrm{C}\end{array}$ & $\begin{array}{l}1000 \mathrm{~mL} \\
10 \mathrm{~g}\end{array}$ \\
\hline Radjonuclides & $\begin{array}{l}\text { Water } \\
\text { Soil }\end{array}$ & $\begin{array}{l}180 \mathrm{~d} \\
180 \mathrm{~d}\end{array}$ & Polyethylene, glass & $\begin{array}{l}\mathrm{HNO}_{3} \text { to } \mathrm{pH}<2 \\
4^{\circ} \mathrm{C}\end{array}$ & $\begin{array}{l}2 \mathrm{~L} \\
150 \mathrm{~g}\end{array}$ \\
\hline Alkalinity & Water & $14 d$ & Polyethylene & $4^{\circ} \mathrm{C}$ & $500 \mathrm{~mL}$ \\
\hline Total dissolved solids & Water & $7 \mathrm{~d}$ & Polyethylene & $4^{\circ} \mathrm{C}$ & $500 \mathrm{~mL}$ \\
\hline Anions & Water & $28 \mathrm{~d}$ & Polyethylene & $4^{\circ} \mathrm{C}$ & $100 \mathrm{~mL}$ \\
\hline $\begin{array}{l}\text { TCLP } \\
\text { VOA } \\
\text { Extractable organics } \\
\text { Mercury } \\
\text { Metals (other than mercury) }\end{array}$ & $\begin{array}{l}\text { Soil } \\
\text { Soil } \\
\text { Soil } \\
\text { Soil }\end{array}$ & $\begin{array}{l}28 \mathrm{~d}^{e} \\
54 \mathrm{~d}^{e} \\
56 \mathrm{~d}^{e} \\
360 \mathrm{~d}^{e}\end{array}$ & $\begin{array}{l}\text { Two } 40 \mathrm{~mL} \text { vials } \\
\text { 1-L widemouth glass } \\
\text { 2-L amber glass } \\
\text { Sample from mercury } \\
\text { container }\end{array}$ & $\begin{array}{l}4^{\circ} \mathrm{C} \\
4^{\circ} \mathrm{C} \\
4^{\circ} \mathrm{C} \\
4^{\circ} \mathrm{C}\end{array}$ & $\begin{array}{l}10 \mathrm{~g} \\
50 \mathrm{~g} \\
10 \mathrm{~g} \\
10 \mathrm{~g}\end{array}$ \\
\hline Specific conduclance & Water & $28 \mathrm{~d}$ & Polyethylene & $4^{\circ} \mathrm{C}$ & $100 \mathrm{~mL}$ \\
\hline
\end{tabular}


Table 8.1 (continued)

\begin{tabular}{|l|l|l|l|l|l|}
\hline \multicolumn{1}{|c|}{ Parameter } & Matrix & $\begin{array}{l}\text { Holding timé (from } \\
\text { time of collection) }\end{array}$ & \multicolumn{1}{|c|}{ Container } & \multicolumn{1}{|c|}{ Preservative } & $\begin{array}{c}\text { Minimum } \\
\text { sample size }\end{array}$ \\
\hline \hline $\mathrm{pH}$ & $\begin{array}{l}\text { Water } \\
\text { Soil }\end{array}$ & $\begin{array}{l}\text { Analyze immediately } \\
24 \mathrm{~h}\end{array}$ & $\begin{array}{l}\text { In situ, beaker or } \\
\text { bucket } \\
\text { Polyethylene }\end{array}$ & None & $100 \mathrm{~mL}$ \\
\hline Temperature & Water & Determine on-site & $\begin{array}{l}\text { In situ, beaker or } \\
\text { bucket }\end{array}$ & None & $10 \mathrm{~g}$ \\
\hline Soil moisture content & Soil & $14 \mathrm{~d}$ & Polyethylene, glass & $4^{\circ} \mathrm{C}$ & $10 \mathrm{~g}$ \\
\hline $\begin{array}{l}\text { Percent organic matter, particle } \\
\text { size, cation exchange capacity, } \\
\text { ignitability, corrosivity, reactivity }\end{array}$ & Soil & $28 \mathrm{~d}$ & Polyethylene, glass & $4^{\circ} \mathrm{C}$ & $100 \mathrm{~g}$ \\
\hline
\end{tabular}

${ }^{a}$ Holding times are consistent with CLP validation guidelines

bissolved metals require filtration before $\mathrm{pH}$ adjustment.

${ }^{c}$ Additional sample must be collected for matrix spike/matrix spike duplicate samples or matrix spike/duplicate

Only use in the presence of residual chlorine.

These are total holding times for TCLP covering sampling through analysis. The holding times are broken down as follows: TCLP VOC - $14 \mathrm{~d}$ from collection to TCLP extraction plus $14 \mathrm{~d}$ from leach extraction to analysis; extractable organics $-7 \mathrm{~d}$ from collection to TCLP extraction plus $7 \mathrm{~d}$ to solvent extraction of leachate plus $40 \mathrm{~d}$ to analysis of extract; mercury-28 d from collection to TCLP extraction plus $28 \mathrm{~d}$ to analysis; other metals$180 \mathrm{~d}$ from collection to TCLP extraction plus $180 \mathrm{~d}$ to analysis. 
7. Superscripts in Table 1 refer to fontnotes on last page of Table 1.

8. Section VII, page 4 of Table 1: Under the heading "Parameter," change "Nutrients" to "Nutrients."

9. Section VII, page 6 of Table 1: Under the heading "Preservative," change "Acetate" to "Acetate"."

10. Section VII, page 7 of Table 1: Add "The containers for organics may be $40 \mathrm{~mL}$ vials with Teflon lined septum caps or $250 \mathrm{~mL}$ widemouth glass with Teflon lined septum caps."

\subsubsection{Sample packaging and transportation}

Handling, shipping, and storage of samples and data resulting from field activities will adhere to custody (Sect. 8.4) and will ensure the integrity for analytical purposes is maintained. The procedures required to properly preserve, package, ship, handle, and store containers of environmental samples are described in ER/C-P2302 methodologies.

\subsubsection{Decontamination of equipment and devices}

Decontamination of sample containers and sampling devices will be performed according to ESP-900 methodologies. Sampling equipment will be decontaminated before use and between sampling locations/intervals. Each decontamination activity will be recorded in the field logbook. Equipment used during field activities, including drilling equipment, soil sampling equipment, and field test equipment will be decontaminated in accordance with ESP-901 methodologies.

The following changes will apply:

\section{ESP-900, Cleaning and Decontaminating Sample Containers and Sampling Devices}

1. Section III, page 1 of 20: In the second sentence insert "decontaminated and allowed to air dry" after "must be cleaned." In the third sentence revise "cleaned and decontaminated" to state "cleaned, decontaminated and allowed to air dry."

2. Section IV, Part A, page 2 of 20, number 2: Delete "Alquinox," and the comma after "Liquinox."

3. Section IV, Part A, page 2 of 20 , number 7: Add to the end of the paragraph, "This water should be defined as containing no pesticides, herbicides, extractable organic compounds, and less than $50 \mu \mathrm{g} / \mathrm{L}$ of purgeable organic compounds as measured by a low level GC/MS scan. Organic free water and alcohol should be stored in only glass or Teflon $^{\oplus}$ containers and dispensed from only glass, Teflon ${ }^{\oplus}$, or stainless steel containers."

4. Section VII, Part C, page 4 of 20: Add the sentence "Cleaned equipment should be wrapped in aluminum foil after drying," before the last sentence in the paragraph. 
5. Section IX, Part C, page 5 of 20: Add the sentence "Note in the field logbook the equipment being used for the QC Rinsate" to the end of the paragraph.

6. Attachment 1, Part II, page 8 of 20, paragraph 2, last sentence: After the word "lids," add the following: "which have been solvent rinsed (if the actual sample containers were solvent rinsed)."

7. Attachment 2, Part I, number 1, page 9 of 20: Replace the word "hot" with the word "tap."

8. Attachment 2, Part I, page 9 of 20: Omit numbers 2 and 3.

9. Attachment 2, Part I, page 9 of 20 , number 5: Replace "deionized" with "organic free."

10. Attachment 2, Part I, page 9 of 20, number 6: Replace "solvent" with "pesticide grade isopropyl alcohol."

11. Attachment 2, Part I, page 9 of 20 , number 6: Add the line, "If it is not possible to allow $24 \mathrm{~h}$ drying time, rinse the equipment twice with organic free water."

12. Attachment 2, Part II, page 10 of 20 , number 1: Replace the word "hot" with the word "tap."

13. Attachment 2, Part II, page 10 of 20: Omit number 2 .

14. Attachment 2, Part II, page 10 of 20, number 3: Replace "deionized" with "organic free."

15. Attachment 2, Part II, page 10 of 20 , number 4 : Replace "solvent" with "pesticide grade isopropyl alcohol."

16. Attachment 2, Part II, page 10 of 20, number 4: Add the line, "If it is not possible to allow 24 h drying time, rinse the equipment twice with organic free water."

ESP-901, Equipment Decontamination

1. Section VI, Paragraph 2, page 3 of 11: Delete the first sentence.

2. Section VII, Part C, page 4 of 11: Delete the last sentence.

3. Table ESP-901-1, page 7 of 11: Add "Steam cleaner should consistently generate greater than 2500 psi."

\subsubsection{Sample identification and traceability}

Each environmental sample collected during these investigations will be assigned a unique sample identifier, which will be permanently affixed to the sample container and recorded in 
the field logbook and on the chain-of-custody form. The identifiers used for samples will be established and maintained in accordance with ESP.500 methodologies.

Identification systems will ensure traceability of samples to the appropriate source. Sample identification shall be transferred to each subdivision when the sample is split.

\subsubsection{Site surveying}

Site surveying will be conducted to establish location and elevation of sampling points and monitoring well measuring points in relation to the appropriate plant or site grid. A licensed surveyor will be contracted to perform this effort.

\subsubsection{Field variance system}

Procedures cannot fully encompass all conditions encountered during a field investigation. Variances from operating procedures, the work plan, the sampling and analysis plan, and/or health and safety plan will, therefore, likely occur and must be documented on a field change order form and/or a nonconformance report and noted in the appropriate logbooks. If a variance is anticipated (e.g., due to a change in field instrumentation), the applicable procedure should be modified and the change noted in the field logbooks.

The Field Team Leader or designee will initiate and chronologically maintain a field change order $\log$ and noncompliance report log. Field changes fall into three categories-minor, major, and other-as described below.

\subsubsection{Minor field change}

A minor field change is one that does not affect the objectives of the field sampling plan and may be approved by the Field Team Leader by noting it in the field logbook. A slight change in the sampling location due to a physical obstruction is an example of a minor change.

\subsubsection{Major field change}

A major field change is one that affects the field sampling objectives and/or schedule and may require EPA, DOE, and/or state approval. The major field change must be approved by the site Project Manager. These changes may require a change in the program. An example of a major field change is the decision to significantly change the number of wells.

\subsubsection{Other field change}

An other field change falls between the minor and the major change in that it significantly affects the sampling plan without requiring a program change. It is approved by the site Project Manager and may require EPA, DOE, and/or state approval. Changing the number of samples is an example of another field change.

As appropriate, regulatory agencies will be notified of any variances that significantly affect project scope or objectives, and approval from the agencies will be obtained as 
necessary. Any variances from the health and safety plan must be approved by the Health and Safety Officer. Copies of the field change order form will be maintained by the sampling teams until the fieldwork is complete and will then be forwarded to the Project Manager for inclusion in the project file and the subcontractor's Central Records Facility.

\subsubsection{Analytical Procedures}

Environmental samples collected during these projects will be analyzed for potential contaminants of concern using EPA-approved standard operating procedures, where applicable (Table 8.2). When unapproved procedures for analysis are employed (e.g., special analytical services), a written description of the analytical procedures to be used will be approved by the Office of Environmental Restoration before establishing a contract for analytical services.

The approved methods and protocols that may be used by the analytical laboratory are provided in the following documents:

- Test Methods for Evaluating Solid Wastes (EPA 1986)

- Methods for Chemical Analysis of Water and Wastes (EPA 1983)

- Prescribed Procedures for Measurement of Radioactivity in Drinking Water (EPA 1980a)

- Eastern Environmental Radiation Facility Radiochemistry Procedure Manual (EPA 1984)

- CLP SOWs for Organics and Inorganics (EPA 1990b,c)

- 40 CFR 136, Appendix A

- 40 CFR 141.30

- 40 CFR 136, Appendix C

- APHA, Standard Methods for the Analysis of Water and Wastewater

- EML Procedures Manual, HASL-300 (Krey and Beck 1992)

The MDL is defined as the minimum concentration of a substance that can be measured and reported with $99 \%$ confidence that the value is greater than zero. The MDL actually achieved in a given analysis varies depending on instrument sensitivity and interferences. Contracts will be established with analytical laboratories to analyze environmental samples collected during these investigations. Each contract laboratory that analyzes samples will provide quantification limits for each constituent analyzed.

Laboratory equipment $\mathrm{QA} / \mathrm{QC}$ will be drawn from the supporting laboratory's (or laboratories') QA plan(s). 
Table 8.2 Analytical methods, parameters, and quantitution limit goals for surface water/groundwater and wollhwediment amples

\begin{tabular}{|c|c|c|c|c|}
\hline \multirow[b]{2}{*}{ Parameters } & \multicolumn{2}{|c|}{ Anslytical mothods } & \multicolumn{2}{|c|}{ Quantitution Uimit goals } \\
\hline & Water & Sollhodimont & $\begin{array}{l}\text { Water } \\
(\mu \Omega \Omega)\end{array}$ & $\begin{array}{l}\text { Sollhodiment } \\
\text { (ug/ta) }\end{array}$ \\
\hline Volatile organic compounds (VOC) & CLP SOW' & CLP SOW' & & $\begin{array}{l}\text { Low solly } \\
\text { sedimente }\end{array}$ \\
\hline Chloromethane & & & 10 & 10 \\
\hline Bromomethane & & & 10 & 10 \\
\hline Vinyl chloride & & & 10 & 10 \\
\hline Chloroethane & & & 10 & 10 \\
\hline Methylene chloride & & & 5 & 5 \\
\hline Acetone & & & 10 & 10 \\
\hline Carbon disulfide & & & 5 & 5 \\
\hline 1,1-Dichloroethene & & & 5 & 5 \\
\hline 1,1-Dichloroethane & & & 5 & 5 \\
\hline 1,2. Dichloroethene (lotal) & & & 5 & 5 \\
\hline Chloroform & & & 5 & 5 \\
\hline 1,2-Dichloroethane & & & 5 & 5 \\
\hline 2-Butanone & & & 10 & 10 \\
\hline 1,1,1-Trichloroethane & & & 5 & 5 \\
\hline Carbon tetrachloride & & & 5 & 5 \\
\hline Bromodichloromethane & & & 5 & 5 \\
\hline 1,2-Dichloropropane & & & 5 & 5 \\
\hline cis-1,3-dichloropropene & & & 5 & 5 \\
\hline Trichloroethene & & & 5 & 5 \\
\hline Dibromochloromethane & & & 5 & 5 \\
\hline 1,1,2-Trichloroethane & & & 5 & 5 \\
\hline Benzene & & & 5 & 5 \\
\hline trans-1,3-dichloropropene & & & 5 & 5 \\
\hline Tribromomethane & & & 5 & 5 \\
\hline 4-Methyl-2-pentanone & & & 10 & 10 \\
\hline 2-Hexanone & & & 10 & 10 \\
\hline Tetrachloroethene & & & 5 & 5 \\
\hline Toluene & & & 5 & 5 \\
\hline 1,1,2,2-Tetrachloroethane & & & 5 & 5 \\
\hline Chlorobenzene & & & 5 & 5 \\
\hline Ethylbenzene & & & 5 & 5 \\
\hline Styrene & & & 5 & 5 \\
\hline Xylenes (total) & & & 5 & 5 \\
\hline
\end{tabular}


8.31

Tuble 8.2 (continuod)

\begin{tabular}{|c|c|c|c|c|}
\hline \multirow[b]{2}{*}{ Paramolen } & \multicolumn{2}{|c|}{ Andyileal mothods } & \multicolumn{2}{|c|}{ Quanulution limit goeis } \\
\hline & Waler & Sollhediment & $\begin{array}{l}\text { Water } \\
(\mu \varrho L)\end{array}$ & $\begin{array}{l}\text { Sollwadimeal } \\
\text { (uster) }\end{array}$ \\
\hline \multicolumn{5}{|l|}{ Additional compounds: } \\
\hline Trichlorotrinuoroethane & & & 10 & 10 \\
\hline $\begin{array}{l}\text { Semivolatile organic compounds } \\
\text { (svoca) }\end{array}$ & CLP SOW & CLP SOW & & $\begin{array}{c}\text { Low } \\
\text { sollhediment" }\end{array}$ \\
\hline Phenol & & & 10 & 330 \\
\hline bls(2.Chloroethyl) ether & & & 10 & 330 \\
\hline 2.Chlorophenol & & & 10 & 330 \\
\hline 1,3-Dichlorobenzene & & & 10 & 330 \\
\hline 1,4-Dichlorobenzene & & & 10 & 330 \\
\hline 1,2.Dichlorobenzene & & & 10 & 330 \\
\hline 2-Methylphenol & & & 10 & 330 \\
\hline $2,2^{\prime} \cdot$ Oxybis (1-chloropropane) & & & 10 & 330 \\
\hline 4-Methylphenol & & & 10 & 330 \\
\hline$N$-nilloso-di-n-dlpropylumine & & & 10 & 330 \\
\hline Hexachloroethane & & & 10 & 330 \\
\hline Nitrobenzene & & & 10 & 330 \\
\hline Isophorone & & & 10 & 330 \\
\hline 2-Nitrophenol & & & 10 & 330 \\
\hline 2,4-Dimethylphenol & & & 10 & 330 \\
\hline bis(2-Chloroethoxy) methane & & & 10 & 330 \\
\hline 2,4-Dichlorophenol & & & 10 & 330 \\
\hline 1,2,4-Trichlorobenzene & & & 10 & 330 \\
\hline Naphthalene & & & 10 & 330 \\
\hline 4-Chloroaniline & & & 10 & 330 \\
\hline Hexachlorobutadiene & & & 10 & 330 \\
\hline 4-chloro-3-methylphenol & & & 10 & 330 \\
\hline 2-Methylnaphthalene & & & 10 & 330 \\
\hline Hexachlorocyclopentadiene & & & 10 & 330 \\
\hline 2,4,6-Trichlorophenol & & & 10 & 330 \\
\hline 2,4,5-Trichlorophenol & & & 25 & 800 \\
\hline 2-Chloronaphthalene & & & 10 & 330 \\
\hline 2-Nitroaniline & & & 25 & 800 \\
\hline Dimethylphthalate & & & 10 & 330 \\
\hline Acenaphthylene & & & 10) & 330 \\
\hline
\end{tabular}




\begin{tabular}{|c|c|c|c|}
\hline OEE & ol & & 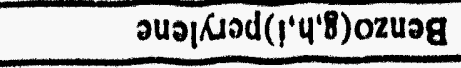 \\
\hline O\&E & OI & & 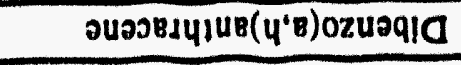 \\
\hline O\&E & 01 & & ouadKd (po- $\left.\varepsilon^{\prime} z^{\prime} l\right)$ ouvpuI \\
\hline OEE & 01 & & วuอdKd(8)ozuPg \\
\hline OEE & 01 & & 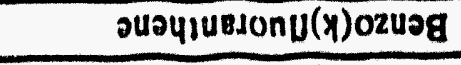 \\
\hline OEE & 01 & & suoyiuBsonv(q)ozuog \\
\hline OEE & 01 & & ग1в|вप14d|र150-u-1a \\
\hline OIE & 01 & & 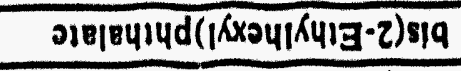 \\
\hline OEE & 01 & & 2uosर140 \\
\hline OEE & 01 & & DUองE. \\
\hline OEE & 01 & & 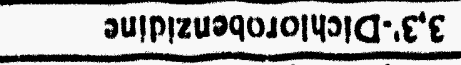 \\
\hline O\&E & 01 & & ग1в|в414d|KzUDq|King \\
\hline OEE & 01 & & ouoshd \\
\hline O\&E & 01 & & SusyiussonL \\
\hline OEE & 01 & & ग1в|в4Iyd।King-4-1Q \\
\hline o\&E & 01 & & ग0zвquBs \\
\hline OEE & ol & & DUPses4IUV \\
\hline ors & 01 & & oussulueusyd \\
\hline 008 & $\mathbf{s 2}$ & & lousydosolyoniued \\
\hline ofs & 01 & & 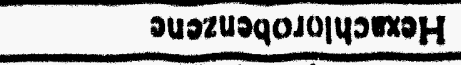 \\
\hline OEE & 01 & & saura|Kuoud-|Kuaydousosq-t \\
\hline OEE & ol & & sujuE|Kupyd|pososi|u-N \\
\hline 008 & $\boldsymbol{\Omega Z}$ & & jouoyd|Kप10uन-2.0d||u|a-9't \\
\hline 008 & $\$ 2$ & & oull|urosIIN-t \\
\hline OEE & 01 & & oussonted \\
\hline OrE & 01 & & say10 KKuayd-1Kuaydosolus-t \\
\hline O\&E & 01 & & 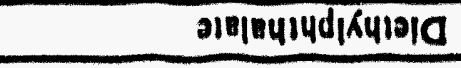 \\
\hline ofe & 01 & & ousnjoios!|uig.t'z \\
\hline O\&E & 01 & & unsnjozueqia \\
\hline 008 & $\$ 2$ & & IOUPYdoJIIN-t \\
\hline 000 & $\Omega$ & & jousydodi|ulalo'z \\
\hline of: & 01 & & susulydeusov \\
\hline 0008 & $\mathbf{S 2}$ & & sul|luEOJIIN-E \\
\hline ore & 01 & & 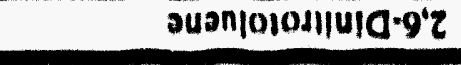 \\
\hline $\begin{array}{c}\text { (M/pm) } \\
\text { inewipen/los }\end{array}$ & $\begin{array}{l}(7 / m) \\
\text { solvm }\end{array}$ & Inompen/7ios & \multirow[t]{2}{*}{ 4ต๊ourerd } \\
\hline \multicolumn{2}{|c|}{ STod ywi vonmomo } & ponou foonhtury & \\
\hline
\end{tabular}

(ponunoco) 28 이나. 
8. 33

Tuble 8.2 (continued)

\begin{tabular}{|c|c|c|c|c|}
\hline \multirow[b]{2}{*}{ Panmeton } & \multicolumn{2}{|c|}{ Andyrical methods } & \multicolumn{2}{|c|}{ Qunatution Umit gonir } \\
\hline & Water & Sollhodiment & $\begin{array}{l}\text { Water } \\
(\mu \Omega \Lambda)\end{array}$ & $\begin{array}{l}\text { Sollhodiment } \\
\text { (uelte) }\end{array}$ \\
\hline Penticides & CLP SOW & CLP SOW' & & $\begin{array}{c}\text { Low } \\
\text { soll/sediment }\end{array}$ \\
\hline alpha-BHC & & & 0.05 & 1.7 \\
\hline beta-BHC & & & 0.05 & 1.7 \\
\hline della-BHC & & & 0.05 & 1.7 \\
\hline gumma-BHC (Lindane) & & & 0.05 & 1.7 \\
\hline Heptachlor & & & 0.05 & 1.7 \\
\hline Addrin & & & 0.05 & 1.7 \\
\hline Heptuchlor epoxide & & & 0.09 & 1.7 \\
\hline Endosulfan 1 & & & 0.05 & 1.7 \\
\hline Dieldrin & & & 0.10 & 3.3 \\
\hline $4,4^{\prime} \cdot D D E$ & & & 0.10 & 3.3 \\
\hline Endrin & & & 0.10 & 3.3 \\
\hline Endosulfan II & & & 0.10 & 3.3 \\
\hline 4,4'DDD & & & 0.10 & 3.3 \\
\hline Endolaulfan sulfate & & & 0.10 & 3.3 \\
\hline 4,4'DDT & & & 0.10 & 3.3 \\
\hline Methoxychlor & & & 0.5 & 17.0 \\
\hline Endrin ketone & & & 0.10 & 3.3 \\
\hline Endrin aldehyde & & & 0.10 & 3.3 \\
\hline alpha-Chlordane & & & 0.05 & 1.7 \\
\hline gamma-Chlordane & & & 0.05 & 1.7 \\
\hline Toxaphene & & & 5.0 & 170.0 \\
\hline PCBs & CLP SOW' & CLP SOWb & & $\begin{array}{c}\text { Low } \\
\text { soil/sediment }\end{array}$ \\
\hline Aroclor-1016 & & & 1.0 & 33.0 \\
\hline Aroclor-1221 & & & 2.0 & 67.0 \\
\hline Aroclor-1232 & & & 1.0 & 33.0 \\
\hline Aroclor-1242 & & & 1.0 & 33.0 \\
\hline Aroclor-1248 & & & 1.0 & 33.0 \\
\hline Aroclor-1254 & & & 1.0 & 33.0 \\
\hline Aroclor -1260 & & & 1.0 & 33.0 \\
\hline
\end{tabular}


8.34

Table 8.2 (continued)

\begin{tabular}{|c|c|c|c|c|}
\hline \multirow[b]{2}{*}{ Paramcters } & \multicolumn{2}{|c|}{ Analytical methods } & \multicolumn{2}{|c|}{ Quantitation limit goals } \\
\hline & Water & Sollsodiment & $\begin{array}{l}\text { Water } \\
(\mu g / L)\end{array}$ & $\begin{array}{l}\text { Sollhediment } \\
\left(\mu / / \mathrm{H}_{\mathrm{B}}\right)\end{array}$ \\
\hline Metals (target analyte list) & CLP SOWd & CLP SOWd & & $(\mathrm{mg} / \mathrm{kg})$ \\
\hline Aluminum & & & 200 & 20 \\
\hline Antimony GFAA & & & 3 & 0.3 \\
\hline Arsenic GFAA & & & 5 & 0.5 \\
\hline Barium & & & 200 & 20 \\
\hline Berylium & & & 5 & 0.5 \\
\hline Cadmium & & & 5 & 0.5 \\
\hline Calcium & & & 5000 & 500 \\
\hline Chromium & & & 10 & 1 \\
\hline Cobalt & & & 50 & 5 \\
\hline Copper & & & 25 & 2.5 \\
\hline Iron & & & 100 & 10 \\
\hline Lead GFAA & & & 3 & 0.3 \\
\hline Magnesium & & & 5000 & 500 \\
\hline Manganese & & & 15 & 1.5 \\
\hline Mercury CVAA & & & 0.2 & 0.02 \\
\hline Nickel & & & 40 & 4 \\
\hline Potassium & & & 5000 & 500 \\
\hline Selenium GFAA & & & 5 & 0.5 \\
\hline Silver & & & 10 & 1 \\
\hline Sodium & & & 5000 & 500 \\
\hline Thallium GFAA & & & 5 & 0.5 \\
\hline Vanadium & & & 50 & 5 \\
\hline Zinc & & & 20 & 2 \\
\hline \multicolumn{5}{|l|}{ Additional clements: } \\
\hline Molybdenum & & & 40 & 2 \\
\hline Tin & & & 50 & 5 \\
\hline Cyanide & CLP SOWd & CLP SOW & 10 & 1 \\
\hline Common anions & & & $(\mathrm{mg} / \mathrm{L})$ & $(\mathrm{mg} / \mathrm{kg})$ \\
\hline Nitrate-nitrite & E353.2 & NA & 0.2 & NA \\
\hline Chloride & $E 325.1^{\circ}$ & NA & 1.0 & NA \\
\hline Sulfate & E375.4 & $\mathrm{NA}$ & 5 & NA \\
\hline Fluoride & $E 340.2^{\circ}$ & $\mathrm{NA}$ & 0.1 & NA \\
\hline
\end{tabular}


Table 8.2 (continued)

\begin{tabular}{|c|c|c|c|c|}
\hline \multirow[b]{2}{*}{ Parameters } & \multicolumn{2}{|c|}{ Analytical methods } & \multicolumn{2}{|c|}{ Quantitation limit goats } \\
\hline & Water & Sollsediment & $\begin{array}{l}\text { Water } \\
(\mu g /)\end{array}$ & $\begin{array}{l}\text { Sollswediment } \\
\text { (ug/kB) }\end{array}$ \\
\hline \multicolumn{5}{|l|}{ Indicator paramelers } \\
\hline Total organic carbon (TOC) & E415.1/E415.2' & NA & 1 & NA \\
\hline Radionuclides & & & $(\mathrm{pCl} / \mathrm{L})$ & $(\mathrm{pCl} / \mathrm{g} d r y)$ \\
\hline Gamma spectrometry & EPA $901.1^{\prime}$ & EPA $901.1^{\prime}$ & & \\
\hline Cobali.60 & & & 20 & 20 \\
\hline Cesium-137 & & & 20) & 20 \\
\hline Gamma scan & & & $g$ & 8 \\
\hline Alpha spectrometry & EPA $907.0^{\circ}$ & EPA $907.0^{\prime}$ & & \\
\hline Americium.241 & & & 0.1 & 0.1 \\
\hline Plutonium-238,329,240 & & & 0.1 & 0.1 \\
\hline Thorium-228,230,232 & & & 1 & 1 \\
\hline Uranium-234,235,238 & & & 1 & 1 \\
\hline Nepunium-237 & & & 0.1 & 0.1 \\
\hline Strontium-90 & EPA $905.1^{\prime}$ & EPA $905.1^{\prime}$ & 1 & 1 \\
\hline Technetium-99 & E.TC-01 & & 30 & 30 \\
\hline Gross alpha & EPA 900.0 & EPA $900.0^{\circ}$ & 10 & 20 \\
\hline Gross beta & EPA 900.0 & EPA $900.0^{11}$ & 5 & 20 \\
\hline
\end{tabular}

NA $=$ not applicable.

These are expected quantitation limits based on reagent grade water or a purified solid matrix. Actual quantitation limits may be higher depending on the nature of the sample matrix. The limit reported on final laboratory reports will take into account the actual ample volume or weight, percent mointure (where applicable), and the dilution factor, if any. The quantitation limils for additional analytes attached to the Target Analyte Liat of CL.P SOW: may vary, depending on the results of laboratory atudies.

'Coniract Laboratory Program, Statement of Work for Organics Anahysis, Mulli-Media. Mulli-Concentration, EPA Document OLM01.8. Quantitation limits are contract-required quantitation limits with the exception of additional organic compounds. Minimum quantitation limits atated in the table will be reported by the laboratory.

'Medium soil/sediment contract-required quantitation limits are 120 times the low soil/sediment contract-required quantitation limits for volatile organic compounds and 30.3 times the low soil/sediment contract-required quantitation limits for semivolatile organic compounds. Estimated detection limits for metals in soil are based on a 1-g sample diluted $10100 \mathrm{~mL}$.

¿Contract Laboratory Prograin Statement of Work for Inorganics Analysis, Multi-Media, Mulli-Concentration, EPA Document ILM01.1. Determination limits are contract-required detection limits except for tin and molybdenum. Minimum detection limits stated in the table will be reported by the laboratory.

'Methods for Chemical Analysis of Water and Wastes, U.S. EPA. EPA-600/4-79-020 revision March 1983.

IPrescribed Procedures for Measurement of Radioactivity in Drinking Water, U.S. EPA, EPA-600/4-80-032, latent version.

The subcontracted laboratory will resolve and quantify nonspecified gamma-emitting radionuclides. These nonspecified gamma-emitting radionuclides should be detected and semiquantitatively determined based on photon yield and energy relative to the ${ }^{137} \mathrm{Cs} \mathrm{MDL}$ and standard. 


\subsection{SAMPLE CUSTODY}

\subsubsection{Ficiu Documentation}

An integral part of the QA/QC plan for the field activities will be to maintain current, accurate, and complete field records including logbooks, chain-of-custody, and appropriate field data forms. Field logbooks shall be of hardcover construction. All information pertinent to field activities will be recorded. Each page must be signed and dated. Entries in the logbooks or on the data forms will be made in water resistant black or blue ink and will include the information specified in ESP-500, Sect. VII, Part D methodologies. Corrections must be marked out with a single line, dated, and initialed. The following changes will apply:

\section{ESP-500, Manual Chain-of-Custody Procedures}

1. Section VII, Part D, number 7, page 4 of 8 : Delete this part.

2. Section VII, Part D, page 5 of 8: Add a new number "22" that states "Describe whether the sample was a grab or composite and field personnel in charge of sample custody."

3. Section VII, Part D, page 5 of 8: Add a new number "23" that states "Deviations will be documented in the logbook."

4. Section VII, Part E, number 6, page 6 of 8: Add "one of the collectors must be the first person signing as relinquishing custody as stated in No. 14 of this section and part."

5. Section VII, Part E, number 8, page 6 of 8: Insert "in Remarks Section of Chain-of-Custody Record" following "if known."

6. Section VII, Part E, number 9, page 6 of 8: Insert "number of containers and method of shipment. The container type will not be specified on the Chain-of-Custody Record but will be specified on the second page of each sample log sheet" after "Container type."

7. Section VII, Part E, number 10, page 6 of 8: Insert "in Remarks Section of Chain-of-Custody Record" following "on receipt."

8. Section VII, Part E, number 11, page 6 of 8: Insert "in Remarks Section of Chain-of-Custody Record" following "hazards."

9. Section VII, Part E, number 14, page 6 of 8: Add "The first person signing as relinquishing custody must be one of the collectors identified in No. 6 of this section and part."

10. Section VII, Part F, pages 6 of 8 and 7 of 8: Delete Part F because the Chain-of-Custody Record, Section VII, Part E, will be used as the Sample Request for Analysis Sheet as well as the Chain-of-Custody Record. A separate Sample Request for Analysis Sheet will not be used. 
Appropriate field data forms will be prepared based on the requirements of the current revision of the Environmental Restoration Quality Program Plan, ES/ER/TM-4/R2 (Energy Systems 1992b). No blank spaces should appear on completed forms. If information requested is not applicable, the space shall be marked "N/A."

Chain-of-custody procedures require documentation of sample possession from the time of collection to time of disposal. These procedures allow the possession and handling of samples from the time of collection through analysis and final disposal to be traced.

A sample is in a person's custody if one of these criteria applies:

- It is in their possession.

- It remains in their view after having been in their physical possession.

- Before being secured to prevent tampering, it was in their possession.

- It is in area designated as secure.

Samples will be accompanied by an original and a duplicate complet. $d$ Chain-of-Custody Record (see Appendix F). Should a sample be split, another copy will remain with the sample. As the samples are transferred, the present custodian and the new custodian will complete the required sections of the record as well as note any discrepancies. This Chain-of-Custody Record will remain with the sample from the field while it is being transported to the laboratory, and it will be checked upon receipt at the laboratory. The laboratory will retain one copy of the form, and the original will be sent to the designated subcontractor personnel. This original will be routed to the Central Records Facility and used in the final analytical report.

\subsubsection{Field custody procedures}

Sample custody will be initiated at the time of sample collection. Field samples will be identified by sample tags and appropriate labels. Descriptions of sampling activities and sample identification data will also be recorded in a field logbook. Field chain-of-custody forms containing the same information will be completed for each set of samples. A line item on the sample chain-of-custody form will be completed for each sample, and the sampling technician will confirm by signature the completeness of the information on the form. Each individual who assumes responsibility for the samples will sign and date the chain-of-custody form.

Field custody procedures include the following steps:

- Before sampling begins, the QAVQC Officer, or designee, will instruct sampling personnel on the chain-of-custody and sample labeling procedures, as necessary.

- A Chain-of-Custody Record, which corresponds to the sample identification label, will be initiated in the field for each sample.

- Each time sample custody is transferred, the person relinquishing the sample and the new custodian will sign the Chain-of-Custody Record and note the date and time. 
- The analyses to be performed for each sample will be recorded on the Chain-of-Custody Record.

- The Field Team Leader will confirm that proper custody procedures are followed during the fieldwork and that results were documented in the field logbook.

- Samples transferred to analytical laboratories will be recorded in the field logbook at the end of the collection period.

\subsubsection{Shipping Custody Procedures}

Sample custody will be maintained by personnel until custody is transferred to a common carrier/air freight company, if applicable. Shipments sent by common carrier/air freight will have a bill of lading/air bill accompanying them with the original Chain-of-Custody Record packed in the containers. These bills will be maintained as permanent records, and the air bill number will be noted on the Chain-of-Custody Record. The common carrier/air freight company delivers samples and transfers custody to particular analytical laboratories, where their intralaboratory chain-of-custody procedures will be in effect.

\subsubsection{Laboratory Custody Procedures}

Upon receipt at the laboratory, each sample identification will be compared to the information contained on the Chain-of-Custody Record. If discrepancies exist, appropriate notes (signed and dated) will be made on the Chain-of-Custody Record and the Project Manager or designated person will be notified.

At receipt and initial inspection of samples and accompanying forms, the following items will be checked:

- Seals and tapes on the transportation container to verify that they are unbroken.

- Sample containers in the transportation container to ensure that they are intact and at correct temperature.

- External activity with radiation survey instruments and smear surfaces for removal of contaminants.

- The $\mathrm{pH}$ of preserved samples (except VOAs).

- The identification on the sample bottles to verify that it corresponds to the entire description on the Chain-of-Custody Record.

- The number of sample containers received to verify that it is equal to the number of samples listed on the Chain-of-Custody Record(s).

If there are discrepancies, the Project Manager or designee shall be called immediately to rectify them. Discrepancies will be recorded on appropriate forms and incorrect information marked out with a single line, initialed, and correct information added. 
Once samples are in the possession of the laboratory, their internal chain-of-custody and sample handling procedures will be followed. If samples are to be shipped from one laboratory to another, proper chain-of-custody and packaging procedures will be maintained. Anticipation of reanalysis requires proper preservation of samples following analysis. Samples requiring refrigeration will remain refrigerated.

\subsubsection{Sample labeling}

Sample labels and tags will contain sufficient information to identify the sample in the absence of other documentation. The label and tag will be directly affixed to the sample container, will be completed with blue or black water resistant ink, and will include the following at a minimum:

- Project name

- Unique sample number

- Sample location/station

- Sample media

- Analysis to be performed

- Sampling date and time

- Signature of individual collecting the sample, and preservation method

Refer to Sect. 7.5 for details concerning the sample numbering system and preparation of pre-printed sample labels. In the event samples arrive damaged or custody seals are broken, a nonconformance report (Sect. 8.11.2) will be initiated. The Project Manager will be advised and will make a decision as to the fate of the nonconforming sample(s) and initiate corrective actions. The laboratories will retain tags in their project files.

\subsection{CALIBRATION PROCEDURES AND FREQUENCY}

All M\&TE will be calibrated against certified equipment and/or standards having known valid traceability to nationally recognized standards. M\&TE shall be calibrated, adjusted, and maintained at prescribed intervals and/or before use. (See Table 8.3). If no nationally recognized standards exist, the basis for calibration will be documented.

\subsubsection{Field Instrument Calibration Procedures and Frequency}

A list of all M\&TE to be used, along with a schedule for calibration, will be prepared before initiating fieldwork. Field instrumentation will be calibrated according to the procedures specified in the manufacturer's operating manual or more frequently should the conditions dictate it for the particular instrument. Instrument logbooks or notebooks will be established and maintained by the cognizant field team members, Field Team Leader, or the Health and Safety Officer, as appropriate. 
Table 83. Level I instrument uses, detection limits, and calibration"

\begin{tabular}{|c|c|c|c|c|}
\hline Instrument & Uses & Detection limits & Calibration & Comments \\
\hline $\begin{array}{l}\text { Total organic } \\
\text { vapor meters }\end{array}$ & $\begin{array}{l}\text { Sample screening for } \\
\text { VOCs } \\
\text { Soil gas screening } \\
\text { Health and safety } \\
\text { screening }\end{array}$ & $\begin{array}{l}\text { PID-0.2 ppm benzene } \\
\text { FID-1.0 ppm methane } \\
\text { Daily calihration }\end{array}$ & $\begin{array}{l}1 \text { point-PID benzene daily } \\
1 \text { point-FID methane daily } \\
\text { Verification check every } 20 \\
\text { samples }\end{array}$ & $\begin{array}{l}\text { Action level must be stated in } \\
\text { work plan } \\
\text { Instrument cannot differentiate } \\
\text { naturally occuring compounds } \\
\text { from contaminants } \\
\text { PID cannot detect compounds } \\
\text { with ionization potentials }>11 \\
\text { eV }\end{array}$ \\
\hline $\begin{array}{l}\text { Radiological } \\
\text { monitoring }\end{array}$ & $\begin{array}{l}\text { Monitoring of beta- } \\
\text { gamma surface, gross } \\
\text { gamma, alpha surface } \\
\text { contamination levels }\end{array}$ & $\begin{array}{l}\text { Daily calibration check } \\
\text { varies by equipment }\end{array}$ & $\begin{array}{l}\text { Daily source check per } \\
\text { manufacturer }\end{array}$ & $\begin{array}{l}\text { Validation labels include } \\
\text { minimum and maximum } \\
\text { acceptable levels }\end{array}$ \\
\hline $\begin{array}{l}\text { Indicator kits } \\
\text { (colormetric) }\end{array}$ & $\begin{array}{l}\text { Field screening for a } \\
\text { variety of analytes } \\
\text { Gross quantitation }\end{array}$ & $\begin{array}{l}\text { Varies kit by kit } \\
\text { One-time check }\end{array}$ & $\begin{array}{l}\text { Check color response } \\
\text { w/level of analyte }\end{array}$ & $\begin{array}{l}\text { Need to check expiration dates } \\
\text { One analyst should conduct the } \\
\text { test to ensure consistency in } \\
\text { interpretation } \\
\text { Interferences from other } \\
\text { compounds ate possible }\end{array}$ \\
\hline $\begin{array}{l}\text { pH kits (litmus } \\
\text { paper) }\end{array}$ & $\begin{array}{l}\text { Field screening-water } \\
\text { only }\end{array}$ & N/A & $\begin{array}{l}\text { Check color response } \\
\text { w/known pH standards of } \\
4.0,7.0,10.0\end{array}$ & $\begin{array}{l}\text { Instrument is not to be used on } \\
\text { samples to be submitted for } \\
\text { analysis } \\
\text { One-time check for each lot of } \\
\text { kits is necessary }\end{array}$ \\
\hline
\end{tabular}


Table 8.3 (continued)

\begin{tabular}{|l|l|l|l|l|}
\hline \multicolumn{1}{|c|}{ Instrument } & \multicolumn{1}{|c|}{ Uses } & \multicolumn{1}{c|}{ Detection limits } & \multicolumn{1}{c|}{ Calibration } & \multicolumn{1}{c|}{ Comments } \\
\hline pH meters & $\begin{array}{l}\text { Field screening-water } \\
\text { and soil }\end{array}$ & N/A & $\begin{array}{l}\text { 2 point with standards at } \\
\mathrm{pH} 7.0 \text { and } 4.0 \text { or } \mathrm{pH} 7.0 \\
\text { and } 10.0 \text { daily }\end{array}$ & Accuracy is to $\pm 0.5 \mathrm{pH}$ units \\
\hline $\begin{array}{l}\text { Conductivity } \\
\text { meter }\end{array}$ & $\begin{array}{l}\text { Determining conductivity } \\
\text { of water }\end{array}$ & N/A & $\begin{array}{l}1 \text { point in } 0.01 \text { in } \mathrm{KCl} \\
\text { solution }\end{array}$ & $\begin{array}{l}\text { Calculations and acceptance } \\
\text { criteria must be available in the } \\
\text { field }\end{array}$ \\
\hline $\begin{array}{l}\text { Dissolved oxygen } \\
\text { meter }\end{array}$ & $\begin{array}{l}\text { Determining amount of } \\
\text { dissolved oxygen in water }\end{array}$ & N/A & $\begin{array}{l}\text { To manufacturer } \\
\text { instructions }\end{array}$ & $\begin{array}{l}\text { Calculations must be available in } \\
\text { the field }\end{array}$ \\
\hline
\end{tabular}

PID $=$ photoionization defector, FID $=$ flame ionization detector, $\mathrm{N} / \mathrm{A}=$ nol applicable, VOCs $=$ volatile organic compounds 


\subsubsection{Laboratory Instrument Calibration Procedures and Frequency}

Laboratory equipment will be calibrated according to the procedures specified in the analytical methods and in the operating manual for the particular instrument. Calibration frequency will be based on the analytical methods employed, type of equipment, inherent stability, manufacturer's recommendations, values given in national standards, intended use, and experience.

For those cases for which analyses are governed by EPA CLP protocols, the calibration frequencies and procedures as designated in the CLP routine analytical services SOW will be followed. In this scenario, the calibration requirements in the CLP routine analytical services SOW take precedence.

For laboratory equipment, Class A volumctric glassware will be used to prepare calibration standards, bench standards, samples for analysis, etc. Class $\mathrm{A}$ glassware may be purchased with known accuracy per American Society of Testing and Materials specifications.

It should be noted that other nonanalytical instrumentation (such as thermometers) must be properly maintained and calibrated. The temperatures of ovens and refrigerators used in sample handling will be recorded and the control limits defined. If these limits are not met, corrective action will be required. All calibration and maintenance records will be kept with the equipment if practical. Otherwise, they will be maintained by the laboratory QA personnel.

\subsubsection{Equipment Categories}

Calibrated equipment will be uniquely identified by using either the manufacturer's serial number or other means. All equipment will be categorized as one of the following:

- Category A-Casual devices and systems (e.g., rulers, tape measures, graduated cylinders) that are not to be calibrated in service (i.e., not calibrated other than by the manufacturer).

- Category B-Routine devices and systems (e.g., balances, spectrophotometers) that are to be included in a regular calibration recall program.

- Category C-Field experiment devices and systems (e.g., pH meters, turbidimeters) that are to be calibrated before, during, and after use.

The appropriate category decal with the identification number and the due date of the next calibration will be attached to the equipment. If this identification is not possible, records traceable to the equipment will be readily available for reference.

\subsubsection{Calibration Failures}

Scheduled periodic calibration of equipment will not relieve personnel of the responsibility of employing properly functioning equipment. If an individual suspects an equipment malfunction, he/she should remove the device from service, initiate a nonconformance report, tag it so it is not inadvertently used, and notify project management. 
If equipment is found to be out of calibration, the appropriate project management personnel will evaluate and document (in the instrument logbook) the validity of previous inspection or test results and the acceptability of similar equipment previously inspected or tested. The responsible supervisor will ensure the devices that are out of calibration are (1) tagged or segregated from other equipment and (2) disposed of or not used until they are calibrated. Any equipment that is consistently found to be out of calibration will be repaired or replaced. Any such action should be recorded in the instrument logbook or notebook.

All standards used for equipment calibration will be traceable to the EPA, National Institute of Standards and Technology, or a commercially available certified standard. The source of the standard used must be documented in a calibration logbook.

\subsubsection{Calibration Records}

Calibration data will be recorded in the instrument logbook or notebook. The information will include the date, operator, signature, and standard that was used. Records will be prepared and maintained for each piece of calibrated equipment to indicate that established calibration procedures have been followed. The appropriate project management personnel will ensure that records of calibration data are kept current. Records for field equipment used will be maintained by the Field Team Leader and the Health and Safety Officer and kept in the project files. Records for laboratory equipment used will be maintained by the laboratory supervisor and kept in the project files.

\subsection{PREVENTIVE MAINTENANCE PROCEDURES/SCHEDULES}

Any equipment (an inclusive term for tools, gauges, instruments, and other items that require specific preventive maintenance) will be serviced and documented as specified by the manufacturer's recommended schedule. Should the equipment not have a specific maintenance schedule, the operator will develop one based on previous working experience with the equipment and on other documented maintenance that may have been developed.

All service will be performed by qualified and trained individuals. The operators are responsible for seeing that the equipment is scheduled for service, serviced, and properly maintained. Properly maintained equipment helps reduce unnecessary "downtime."

If the laboratory or field preventive maintenance schedule is more frequent than that of the manufacturer, then the laboratory or field preventive maintenance procedure will take precedence. Preventive maintenance frequency will be documented in the maintenance procedures.

A complete list of critical spare parts will be developed by the operator, and the parts will be immediately available (either from the supplier/manufacturer or on site). Having critical spare parts available minimizes "downtime."

The implementation of a preventive maintenance program depends on the specific instruments and equipment used for the field and laboratory. Each field operation and laboratory will prepare a preventive maintenance program that includes the following: 
- A list of the instruments and equipment that are included in the program, including backup alternatives.

- The frequency of maintenance, taking into consideration the manufacturer's recommendations and/or previous experience with the equipment. The list of instruments and equipment and the maintenance frequency should be provided on a schedule. The frequency should be stated in terms of monthly, quarterly, etc.

- For each instrument in the program provide the following:

- A list of spare parts maintained

- External service contracts

- Items to be checked and/or serviced during maintenance

- Directions for performing maintenance (if external service is not provided, or if directions are not stated in the manufacturer's instrument manuals)

Preventive maintenance will be documented. A file will be maintained for each instrument. The instrument file should include, at a minimum:

- A spare parts list

- External service contracts

- A checklist of items to be serviced and directions for maintenance or manufacturer's instrument manuals

- A record of periodic maintenance

- Comments noting any replacement of parts, observed deterioration, etc.

Equipment used throughout the laboratory must be controlled through a calibration program. Calibration of analytical balances must be performed by a trained and qualified instrument technician using weights traceable to National Institute of Standards and Technology specifications. The gas chromatograph/mass spectrophotometer instruments must be calibrated, tuned, and operated in accordance with EPA CLP protocol OLM01.8 (EPA $1990 \mathrm{c}$ ), which also meets the criteria specified in other EPA documents and the Federal Register. The ICP, atomic adsorption spectroscopy, gas chromatograph, and similar instruments must be calibrated and operated in accordance with requirements of the procedure being employed. The calibration of all equipment must be performed or verified with each analysis run, and the record of calibration for each analysis must be maintained as a permanent record. Any deviation from the calibrations required by the appropriate EPA method must be approved by the Y-12 ER QA Specialist and the Y-12 ER Project Manager.

Volumetric glassware must be used to prepare calibration standards, bench standards, and samples for analysis; therefore, the glassware used for these preparations nust be of known accuracy. The glassware must be purchased in accordance with federal and American Society for Testing and Materials specifications.

The standards used for instrument calibration, internal controls, bench standards, spike solution, and traceability of sample analyses to these specific standards must be documented. 


\subsection{DATA REDUCTION AND REPORTING}

Data reduction and reporting will be in accordance with the Environmental Restoration Quality Program Plan, ES/ER/TM-4/R2 (Energy Systems 1992b). The data reduction will follow the guidelines of the EPA CLP SOWs (EPA 1990b, 1990c) and the Test Methods for Evaluating Solid Waste, Physical/Chemical Methods (EPA 1990a). Generally, results must be expressed to two significant figures. The results for aqueous samples must be expressed in milligrams per liter or micrograms per liter, and the results for nonaqueous samples must be expressed on a dry weight basis in milligrams per kilogram, micrograms per kilogram, or micrograms per gram. The moisture content of samples must also be reported.

Table 8.4 depicts data set deliverables for Level III and Level IV QA. In addition to following field and laboratory documentation and QAVC procedures, data may be verified using a variety of computerized checks for reasonableness. These procedures will ensure that data are entered, encoded, manipulated in a consistent way, and available in a usable format.

\subsubsection{Field Data Reduction and Reporting}

Data collected during field activities will be evaluated by checking the procedures used and comparing the data to previous measurements. The QAVQC Officer or designee and appropriate field personnel will be responsible for checking field QC sample results to ensure that field measurement and sampling protocols have been observed. These reviews will check date and time sampled, preservation, standard operating procedures, calibration method and frequency, and chain-of-custody documentation.

Reviewers are responsible for ensuring that data reduction calculations are documented and checked by qualified personnel. Written reports including reduced and summarized data may include the raw data in appendixes. Specific calculations used for data reduction may also be included.

\subsubsection{Laboratory Data Reduction}

In general, the analyst will process the data, either manually or by inputting the data into a computer. All computerized programs used to reduce and analyze data should be in compliance with software QC [Energy Systems 1990 (Sect. 2.19)] and appropriate Energy Systems procedures. For manually processed data, all the steps in the computation must be provided, including equations used and the source of input parameters such as response factors, dilution factors, and calibration constants. If calculations are not performed directly on the data sheet or chromatogram, the calculations must be provided on company letterhead paper and attached to the data sheets. All pages of the calculations must be signed and dated by the analyst performing the calculations.

For data input by an analyst and processed using a computer, a copy of the input must be kept and uniquely identified with the project number and other pertinent information as necessary. The samples to which the data processing refers must be clearly stated, and the input must be signed and dated by the analyst performing the input. 
Table 8.4. Dats set deliverables for EPA Lovels III and IV quallty assurance"

\begin{tabular}{|c|c|}
\hline Method requirements & Deliverable \\
\hline \multicolumn{2}{|c|}{ Requirements for all methods } \\
\hline Holding time information and methods requested & Signed chain-of-custody forms \\
\hline Discussion of laboratory problems & Case narratives \\
\hline $\begin{array}{l}\text { LCS with results on control charts (run with each batch } \\
\text { of samples processed) }\end{array}$ & Control charts \\
\hline \multicolumn{2}{|l|}{ Organics } \\
\hline Sample results & CLP Form 1 or equivalent \\
\hline $\begin{array}{l}\text { Surrogate recoveries. Surrogates to be used in volatiles, } \\
\text { semivolatiles, pesticides/PCBs. For volatiles by } G C \text {, } \\
\text { surrogate names should reflect the appropriate surrogate } \\
\text { used }\end{array}$ & CLP Form 2 or equivalent \\
\hline $\begin{array}{l}\text { Matrix spike/spike duplicate (will be } 1 \text { spike and spike } \\
\text { duplicate per } 20 \text { samples of similar matrix) }\end{array}$ & CLP Form 3 or equivalent \\
\hline Method blank data & CLP Form 4 or equivalent \\
\hline OC/MS tuning for volatiles/semivolatiles & CLP Form 5 or equivalent \\
\hline GCMS initial calibration data for volatiles/semivolatiles & CLP Form 6 or equivalent \\
\hline $\begin{array}{l}\text { Pesticide/PCB calibration data if calibration factors are } \\
\text { used }\end{array}$ & CLP Form 9 or equivalent \\
\hline \multicolumn{2}{|l|}{ For volatiles by $G C$, initial calibration data: } \\
\hline & $\begin{array}{l}\text { CLP Form } 8 D \text { or equivalent, with five } \\
\text { columns for multilevel calibration factors }\end{array}$ \\
\hline If a calibration curve is used & $\begin{array}{l}\text { A plot of the calibration curve is } \\
\text { required and a linear regression } \\
\text { determination, with flagged correlation } \\
\text { coefficient, if it is less than } 0.995\end{array}$ \\
\hline $\begin{array}{l}\text { For volatiles by } G C \text {, continuing calibration data; if } \\
\text { calibration factors are used, calibration factors and their } \\
\text { percent differences from the initial calibration must be } \\
\text { reported; retention time (RT) windows and analyte RTs } \\
\text { for the analytes must be included on this form }\end{array}$ & CLP Form 9 or equivalent \\
\hline \multicolumn{2}{|l|}{$\begin{array}{l}\text { No chromatograms or mass spectra are presented for } \\
\text { calibration; these data should be filed in the laboratory } \\
\text { and available if problems arise in reviewing/validating the } \\
\text { data }\end{array}$} \\
\hline GC/MS internal standard area data & CLP Form 8 or equivalent \\
\hline $\begin{array}{l}\text { Second column confirmation for all } G C \text { work when } \\
\text { compounds are detected above reporting limits }\end{array}$ & $\begin{array}{l}\text { CLP Form } 10 \text { or equivalent for all } \\
\text { positive hits }\end{array}$ \\
\hline \multicolumn{2}{|l|}{ Metals } \\
\hline Sample results & CLP Form 1 or equivalent \\
\hline
\end{tabular}


Table 8.4 (continued)

\begin{tabular}{|c|c|}
\hline Method requirements & Deltuerables \\
\hline Initial and continuing calibration & CLP Form 2 or equivalent \\
\hline $\begin{array}{l}\text { Method blank taken through digestion (1 per } 20 \text { samples } \\
\text { of same matrix) }\end{array}$ & CLP Form 3 or equivalent \\
\hline ICP interference check sample & CLP Form 4 or equivalent \\
\hline $\begin{array}{l}\text { Spike sample recovery ( } 1 \text { per } 20 \text { samples of similar } \\
\text { matrix) }\end{array}$ & CLP Form $5 \mathrm{~A}$ or equivalent \\
\hline $\begin{array}{l}\text { Postdigestion spike sample recovery for ICP metals (only } \\
\text { done if predigest spike recovery exceeds CLP limits) }\end{array}$ & CLP Form 5B or equivalent \\
\hline $\begin{array}{l}\text { Postdigestion spike for graphite furnace atomic } \\
\text { absorption }\end{array}$ & Recovery noted on raw data \\
\hline $\begin{array}{l}\text { Duplicates (one per } 20 \text { samples will be split and digested } \\
\text { as separate samples) }\end{array}$ & CLP Form 6 or equivalent \\
\hline LCS & CLP Form 7 or equivalent \\
\hline $\begin{array}{l}\text { Standard addition. The decision process outlined in CLP } \\
\text { (p. E-3) will be used to determine when standard } \\
\text { additions are required }\end{array}$ & CLP Form 8 or equivalent \\
\hline Holding times & CLP Form 10 or equivalent \\
\hline \multicolumn{2}{|l|}{ Wet chemistry } \\
\hline LCS (one/batch) & Control charts \\
\hline Method blank (one/batch) & Report result \\
\hline Sample results & Report result \\
\hline Spike/spike duplicate & Percent recovery and percent RPD \\
\hline Continue calibration check & Recovery and percent difference \\
\hline \multicolumn{2}{|c|}{ Radiochemical analysis } \\
\hline Sample results & Report results \\
\hline Initial calibration & Efficiency determination \\
\hline Efficiency check & Percent difference from calibration \\
\hline Background determinations & Report results \\
\hline Minimum detectable activity & Report results \\
\hline Method blank & Report results \\
\hline Spike recovery results & Spike added and percent recovery \\
\hline Internal standard results & Standard added and percent recovery \\
\hline Duplicate results & Report results and percent RPD \\
\hline Self-absorption factors $(\alpha, \beta)$ & Report factors \\
\hline Run log & Copy of run log (Level IV only) \\
\hline
\end{tabular}

qCS = laboratory control standard, CLP = contract laboratory program, $P C B=$ polychlorinated biphenyl, $O C=$ gas chromatograph, $M S=$ mass spectrometry, ICP $=$ inductively coupled plasma. 
When processing data acquired through the use of instrumentation, the analyst must verify that the correct project, sample numbers, calibration constants, response factors, units, and numerical values used for detection limits are present.

After required chemical analyses have been completed, the samples will be maintained at a temperature of $4^{\circ} \mathrm{C}$ for at least 2 weeks after expiration of the appropriate holding time. The laboratory will be responsible for disposal of all laboratory-generated wastes. Upon the receipt of written notification from the subcontractor's Project Manager, the laboratory will return unused sample portions to the project.

\subsection{OC CHECKS}

\subsubsection{Field QC Checks}

The number of required $Q C$ samples per site is based on a set minimum percentage. The number of QC samples to be collected may change from site to site; however, the types of field QC samples remain constant. The types of QC samples are trip blanks, equipment rinsates, field blanks, and field duplicates.

In defining the number of field blanks required, it is important to note that a sampling event is from the time sampling personncl arrive at the site until personnel leave for more than $24 \mathrm{~h}$. For example, sampling personnel go to a site for $10 \mathrm{~d}$, conduct soil borings, and install groundwater wells. During this visit, soil and water samples are collected. The crew leaves the site for 2 months and later returns to collect another set of groundwater samples over a 3-d period. Two sampling events have occurred: a 10.d event and a 3-d event.

\subsubsection{Trip blanks}

Trip blanks are used to detect contamination by VOCs during sample shipping and handling. Trip blanks are 40.mL VOA vials of American Society of Testing and Materials Type II water that are generally filled in the laboratory, transported to the sampling site, and returned to the laboratory with VOA samples. Trip blanks are not to be opened in the field. One trip blank is to accompany each cooler containing VOA samples. Each trip blank is to be stored at the laboratory with associated samples and analyzed with those samples. Trip blanks are only analyzed for VOCs. Trip blanks are also sent with soil samples; however, because the blanks cannot be analyzed through the use of soil methods, they are analyzed and reported as water samples.

\subsubsection{Field blanks}

Field blanks are samples of the source water, American Society of Testing and Materials Type II, that was used in the decontamination and cleaning of equipment used in sample collection. A field blank is a sample container filled with American Society of Testing and Materials Type II water that is exposed during sampling and then analyzed to detect accidental or incidental contamination. Field blanks will only apply to samples requiring chemical preservation. They will be taken as one for every twenty. 


\subsubsection{Equipment rinsates}

Equipment insates are samples of American Society of Testing and Materials Type II water passed through decontaminated sumpling equipment. They are used as a measure of decontamination process effectiveness. Equipment rinsates will be collected at a rate of $5 \%$ of the samples collected per matrix per event (i.e., 1 to 20 samples collected equals 1 equipment rinsate; 21 to 40 samples collected equals 2 equipment rinsates). Matrices for this purpose are considered to be soils, sediments, groundwater, and surface water. If more than one type of equipment is used to obtain samples for a particular matrix, a rinsate blank must be collected from each type of equipment. For example, if groundwater samples are collected by both bailer and pump, a rinsate blank will be submitted for cach (one bailer and one pump). Equipment rinsates are analyzed for the same analytes as the associated samples. Equipment rinsates are reported as water samples.

Representative numbers of equipment rinsate samples will be sent to the mobile laboratory and the fixed analytical laboratory. Each laboratory will receive equipment rinsates in proportion to the number of routine samples received.

\subsubsection{Field duplicates}

Additional samples may be taken near the field sample co-located to determine total measurement error variance. Field duplicates for water samples will be collected simultaneously. Samples submitted for VOA will not be homogenized. Field duplicates will be taken at the rate of one for every 20 samples.

\subsubsection{Drilling water blanks}

QC samples of potable water sources used during BCV OU $1 \mathrm{RI}$ drilling and monitoring well installation operations will be obtained for laboratory analysis. The results will be used to assess the potential for contaminant introduction to the subsurface from drilling operations.

Before drilling activities begin, a sample of the potable water source will be obtained. In addition, one sample of the potable water source will be obtained from the containers or tanks used during drilling operations per drilling event. These samples will be analyzed for full Target Compound List (TCL) organics, TCL inorganics, TCL cyanide, and radionuclides. The results will be used to assess the adequacy of the source for use in drilling operations.

\subsubsection{Laboratory QC Procedures}

To ensure data quality, laboratory quality control samples, data review, and data validation are used to measure the quality of the sampling and analysis process. A quality control operation or component is only useful if it can be measured or documented. The components of analytical QC that are defined in this section are related to the analytical batch or to those samples that are analyzed together with the same method sequence, the same lots of reagents, and the manipulations common to each sample within the same time period or in continuous sequential time periods. Samples in each batch should be of similar composition. All QC data and records specified in this section will be reported as part of the 


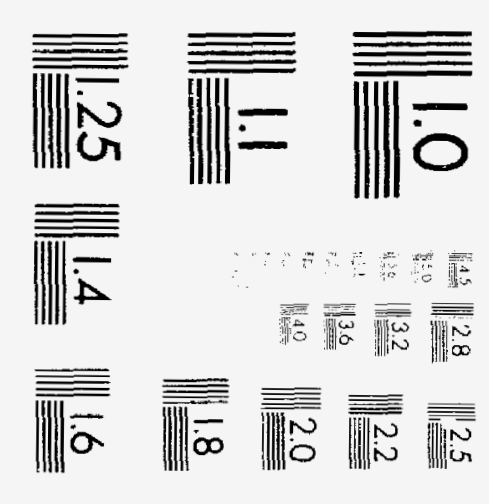



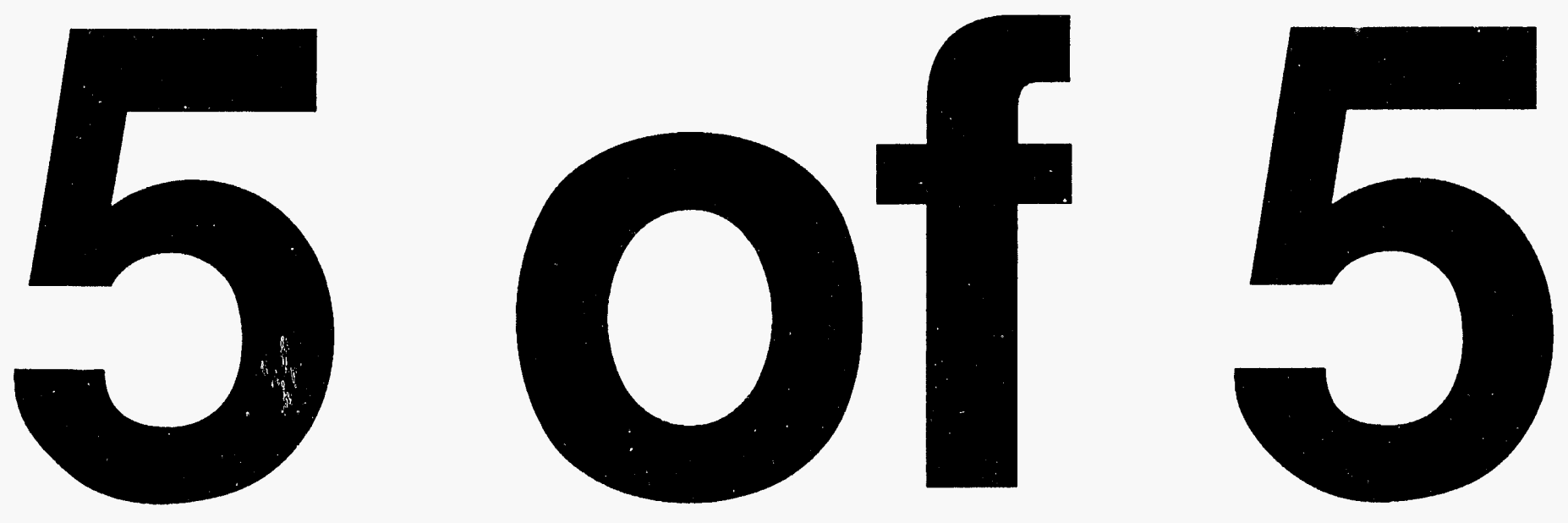
data deliverables package. These procedures will be performed at least once with each analytical batch with a minimum of 1 per 20 samples.

The types of laboratory QC samples are method blanks, LCSs (blank spikes), MSs, MSDs, and duplicates. These samples are defined in the following sections. More detailed ER Division requirements are found in Requirements for Quality Control of Analytical Data (DOE 1990a).

\subsubsection{Laboratory duplicates}

Laboratory duplicates are aliquots of a single sample that are prepared at the laboratory. This duplicate sample should not be a method blank, trip blank, or field blank. The primary purpose of the laboratory duplicate is to check the precision of the laboratory analyst, the sample preparation methodology, and the analytical methodology. If there are significant differences between the duplicates, the affected analytical results will be qualified. Five percent of the samples will be laboratory duplicates.

\subsubsection{Method blanks}

Method blanks are used to determine the existence and magnitude of possible contamination encountered during sample preparation and analysis. They consist of American Society of Testing and Materials Type II water for water sampies and clean sand or soil for soil samples. They are carried through the entire analytical procedure with the samples. At least one method blank must be prepared with each batch of samples. A batch cannot exceed 20 samples and is determined by the number of samples of similar matrix that can be processed simultaneously through the entire preparation process. Analysis is performed for the same analytes as those associated with the respective environmental samples.

\subsubsection{Sample container cleaning blanks}

If sample containers are cleaned in the laboratory, sample container cleaning blanks are taken for each batch of containers that are cleansed. If contamination is detected, the containers associated with that cleaning batch will be recleaned, and another blank will be taken and analyzed. Five percent of the samples will be cleaning blanks.

\subsubsection{Matrix spikes/matrix spike duplicates}

An MS is an aliquot of a sample spiked with known quantities of compounds and subjected to the entire analytical procedure. It is used to indicate the appropriateness of the method for the matrix by measuring recovery or accuracy. Accuracy is the nearness of a result or the mean of a set of results to the true or accepted value. An MSD is a second aliquot of the same sample as the MS with known quantities of compounds added. The purpose of the MSD, when compared to the MS, is to determine method precision. Precision is the measure of the reproducibility of a set of replicate results among themselves or the agreement among repeat observations made under the same conditions. MSs and MSDs will be performed per 20 samples of similar matrix. 


\subsubsection{Duplicate samples}

Duplicate samples are identical splits of individual samples that are analyzed by the laboratory to test for method reproducibility or precision. These samples are split in the laboratory during sample preparation. Duplicates are used mainly for inorganis analysis, while MSDs are used for organics. Duplicates will be performed per 20 samples of similar matrix.

\subsubsection{Surrogate spikes}

A surrogate spike is prepared by adding a pure compound to a sample before extraction. The compound in the surrogate spike should be of a similar type to that being assayed in the sample. The purpose of a surrogate spike is to determine the efficiency of recovery of analytes in the sample preparation and analysis. The percent of recovery of the surrogate spike is then used to gauge the total accuracy of the analytical method. Five percent of the samples will be surrogate spikes, as applicable.

\subsubsection{Laboratory control sample}

If specified in the SOW, the laboratory will use an LCS system to monitor sample preparation and analysis.

The laboratory will employ an LCS program that monitors sample preparation and analysis. The LCS program will be monitored through the use of control charts. The purpose of this program is to demonstrate that the laboratory process for sample preparation and analysis is in control. This type of program is required for all ER Waste Management projects.

An LCS is a laboratory blank with a known amount of analyte(s) added or a commercially available standard consisting of known analyte concentrations representative of the contaminants to be determined. Analytes selected for spiking should be representative of the compound class. It is suggested that these criteria be followed:

- For VOCs and semivolatile organic compounds the method blank surrogate standards can be used as the LCS. All surrogates in the method blank must be monitored on control charts.

- For pesticides, at least two target compounds are added to a blank other than the method blank. These compounds are monitored on control charts.

- For PCBs, at least one target Aroclor is added to a blank other than the method blank. The compound is monitored on a control chart. If pesticides and PCBs are both being determined, it is recommended that a single LCS with both pesticide and PCB spikes be used.

- For metals determined by ICP, an LCS must be monitored by means of control charts for at least three metals.

- For metals determined by atomic absorption (graphite furnace atomic absorption), furnace atomic absorption, and cold vapor atomic absorption), an LCS must be monitored by means of a control chart for each element. 
- For wet chemical and radiochemical methods, an appropriate LCS for each method must be used (e.g., for cyanide, a control standard of sodium cyanide from a source other than that used for calibration may be spiked into water and analyzed with the water samples). The value for the control is monitored on the control chart.

It is recommended that two types of matrix blanks be employed. One type of matrix is the laboratory blank water. The second type of matrix is a laboratory soil or blank sand. This soil can be pulverized and homogenized. If the soil used is known to contain some analytes of interest, no spiking may be required. The LCS matrix should be comparable to the sample matrix (i.e., analyze water control samples when water samples are analyzed).

In the LCS, problems encountered with matrix effects and sample nonhomogeneity will be minimized through the use of blank water and well characterized soil. This information, used in conjunction with sample MS recoveries, can aid in determining whether an out-of-control condition is due to laboratory problems or matrix problems.

Five percent of the samples will be LCSs, which may vary depending upon analytical method.

\subsection{DATA VALIDATION PROCEDURES}

\subsubsection{Analytical Laboratory Data Verification and Validation}

Data verification/validation is a systematic process for reviewing a body of data against a set of criteria to provide assurance that the data are adequate for their intended use. Data verification/validation consists of data screening, checking, auditing, verification, flagging, certification, and review.

Analytical data generated during and following field activities will be evaluated by the laboratory(s) and validated per the systematic requirements identified and defined in Sect. 8.3. Specifically, data will be evaluated per derived DQO requirements. This may include, but is not limited to, a review of sample chain-of-custody forms, photocopied pages of laboratory notebooks, and data forms completed by laboratory staff, including the following: sample weights, dilutions, laboratory data reduction, instrument logs, and all raw data. The analytical laboratory(s) will not perform data verification/validation. Verification/validation is independent of the analytical laboratory data review. The final task report will certify that the data have been verified/validated and flagged in accordance with the defined process.

Reviewers are responsible for ensuring that data reduction calculations follow data calculation procedures, are documented, and are checked by qualified personnel. Written reports, including reduced and summarized data, may include the raw data in appendixes. Specific calculations used for data reduction will also be included.

The following procedures will be used to assess data precision, accuracy, and completeness. These equations apply to both field and laboratory measurements. 


\subsubsection{Precision}

Precision is defined as the reproducibility or degree of agreement among duplicate measurements under a given set of conditions. The closer the measurements approach each other, the more precise the measurement. The level of precision is determined by calculating the relative percent difference (RPD) between the two measurements, using the following formula:

$$
\mathrm{RPD}=\frac{|S-D|}{(S+D) / 2} \times 100 \%
$$

where

$S=$ analyte concentration of the original sample,

$D=$ analyte concentration of the duplicate sample.

Precision is determined using MS/MSD analyses conducted on samples collected. The laboratory will select one sample in 20 to split into three aliquots. The first aliquot will be analyzed routinely for the parameters of interest, while the other two aliquots will be spiked with known quantities of the parameters of interest before analysis. The RPD between the two spike results will be calculated and used as an indication of the precision of the analyses performed.

When the analyte of interest provides a measurable quantity, these precision determinations can be obtained through duplicate analysis comparisons.

Analytical precision goals for the proposed radiochemical, metal, and other inorganic parameters will be $\sim 20$ RPD. Goals for analytical precision for organic parameters will be those identified in the analytical methods for specific analytes. In general these range up to 25 RPD (for volatile organics) and 50 RPD (for semivolatile organics) in soils. In the event analytical precision goals are exceeded, a determination will be made through the data validation process relative to the useability of that information.

\subsubsection{Accuracy}

Accuracy is defined as the degree of difference between measured values and true values. Sampling accuracy will be maximized by adhering to this QA program QAPjP. All procedures used will be documented as standard operating procedures or analytical operating procedures. The following equation will be used to calculate percent recovery $(\% \mathrm{R})$ :

$$
\%_{R}=\frac{A_{r}-A_{0}}{A_{f}} \times 100 \% \text {, }
$$

where 
$A_{r}=$ total compound or element concentration detected in the spiked sample,

$A_{o}=$ concentration of the compound or element detected in the unspiked sample,

$A_{f}=$ concentration of the compound or element added to the sample.

For situations in which a standard reference material (SRM) is used rather than or in addition to MS, the following formula is used:

$$
\% R=\frac{C_{m}}{C_{s r m}} \times 100 \%,
$$

where

$$
\begin{aligned}
& C_{m}=\text { measured concentration of SRM, } \\
& C_{s m}=\text { actual concentration of SRM. }
\end{aligned}
$$

One hundred percent recovery is equivalent to $100 \%$ accuracy. Values less than $100 \%$ may indicate a sample matrix effect and a false reading. A periodic program of sample spiking is required (e.g., $1 \mathrm{MS}$ and $1 \mathrm{MSD}$ per 20 samples).

The proposed radiochemical, metal, and other inorganic accuracy goals for this investigation will be 80 to $120 \%$ as expressed in recovery of known analytical spikes into the sample media. Analytical accuracy goals for organic parameters will be those identified in the CLP analytical methods for specific analytes.

In general volatile organic spike recoveries range between $60 \%$ and $150 \%$ in soils, while semivolatile organic spike recoveries range between $20 \%$ and $140 \%$. In the event analytical accuracy goals are exceeded, a determination will be made through the data validation process relative to the usability of that information.

\subsubsection{Representativeness}

Representativeness expresses the relative degree to which the data depict the characteristics of a population, parameter, sampling point, process condition, or environmental condition. The objective of this study is to accurately represent the chemical concentrations of target analytes.

Representative samples for this investigation will be acquired through implementation of approved sampling and analytical procedures that will generate data representative of the sampling point location. Sampling procedures are designed to minimally impact the sample obtained, so that conditions representative of the sampling location will be maintained. Analytical methods are selected that will most accurately represent the true concentration of the parameter of interest. The accumulation of quality control procedures and information (i.e., RPD values, blank QC concentrations, matrix spike percent recoveries, etc.) employed for a given analysis combine to exhibit the representativeness of the data generated. 
The goal for representative sample data will therefore be met through the proper documentation of field and analytical protocols. In the event these proceciures and methods are not able to be implemented, the appropriate corrective action docuinentation should encompass the impact on the representativeness of the information. When a review of the data and documentation determines the data to be nonrepresentative, the information will be qualified for its use or will not be used.

\subsubsection{Completeness}

Completeness is the measure of the amount of data obtained from a measurement process that achieves the project goals compared to the amount of data planned to be obtained for use in a project.

The following are three measures of completeness determined for the BCV Project.

Sample collection:

$$
\text { Completeness }=\frac{\text { number of sample points sampled }}{\text { number of sample points planned }} \times 100 \%
$$

Field measurements:

$$
\text { Completeness }=\frac{\text { number of valid measurements made }}{\text { number of measurements planned }} \times 100 \%
$$

Laboratory analysis:

$$
\text { Completeness }=\frac{\text { number of valid data points }}{\text { number of data points planned }} \times 100 \%
$$

Completeness goals established for this project for sample collection and field measurements are $95 \%$. If this goal is not met, the necessity for resampling will be determined on a case-by-case basis. The completeness goal for laboratory analysis for this project is $90 \%$ overall. For the critical data points, which consist of the background sample locations, the completeness goal for sample collection, field measurements, and laboratory analysis is $100 \%$. When a review of the data and documentation determines the data to be incomplete, the impact relative to the project objectives will be assessed and documented. 
To complete the intent of this project, all data will be validated versus the content of a Level III (C) analytical data deliverable, with a minimum of $10 \%$ of the data validation being completed at Level IV (D), to determine its usability. For determination of completeness in this project, all data flagged as estimated by the validation process will be considered valid.

Other formulas and statistically generated data may be required.

\subsubsection{Comparability}

Comparability expresses the confidence with which one data set can be compared to another. Comparability of the data produced for this investigation will be obtained through the implementation of the identified protocols for sampling and analysis of samples. Implementation of traceable reference materials as laboratory standards, expression of results in standard concentration units, and successful participation by the laboratories in external performance evaluation programs will enable the information produced through this investigation to be compared with future data sets, if required.

\subsection{AUDITS AND SURVEILANCES}

Audits are performed to review and evaluate the adequacy of field and laboratory performance and to ascertain whether the QA/QC plan is being completely and uniformly implemented. The following requirements are adapted from Basic Requirement 18, Audits, of ANSI/ASME NQA-1 (1986); Science Applications International Corporation audit procedures; Quality Control Requirements for Field Methods (DOE 1990b); Requirements for Quality Control of Analytical Data (DOE 1990a); and Environmental Restoration Quality Program Plan (Energy Systems 1992b). Planned and scheduled audits will be performed to verify compliance with all aspects of the QA program and to determine the program's effectiveness. These audits will be conducted in accordance with written procedures and checklists and will be performed by personnel who do not have direct responsibility for performing the activities being audited. Audit results will be documented and reported to and reviewed by responsible management. Follow-up action will be taken by the responsible line organization when necessary.

The objectives of performance and systems audits are to the following:

- To ensure that the QA program developed for this project is being implemented according to the specified requirements

- To assess the effectiveness of the QA program

- To identify nonconformiances/variances

- To verify that identified deficiencies are corrected

Upon discovery of any significant deviation from the QA program, the Project Manager will be informed of the nature, extent, and corrective action taken to remedy the deviation. 
An individual audit plan will be developed by the QA/QC Officer or his/her designee to provide a basis for each audit. This plan will identify the audit scope, the activities to be audited, the audit personnel, any applicable documents, and the audit schedule. Records of audits will be maintained in the Project Files. Audit files will include, at a minimum, the audit report, the reply to audit, and any supporting documents. It is the responsibility of the Project Manager to conform to audit procedures, particularly as to timely replies to audit reports and implementation of the corrective action indicated.

\subsubsection{Frequency of Audits}

The QAVQC Officer is responsible for internal audits and will perform them according to a schedule that coincides with appropriate activities on the project schedule and sampling plans. Such scheduled audits may be supplemented by additional audits for one or more of the following reasons:

- When significant changes are made in the QAVQC Plan.

- When it is necessary to verify that corrective action has been taken on a nonconformance reported in a previous audit.

- When requested by the Project Manager.

In addition to these internal audits, surveillance of selected activities may be performed on a periodic basis.

\subsubsection{Systems Audits}

A systems audit consists of an evaluation to determine if the components of a measurement system were properly selected and are being used correctly. A systems audit includes a careful evaluation of field and laboratory QC procedures to ensure that the QAVQC procedures are being adhered to. Systems audits are conducted as deemed necessary by the QA/QC Officer or a designee normally before or shortly after systems are operational. The systems audit is reported in formal audit reports.

\subsubsection{Performance Audits}

A performance audit can be defined as a review of the existing project and QC data to determine the accuracy of a total measurement system(s) or a component of the system. The auditor(s) will check the logging of the samples, proper chain-of-custody, and related documentation. The analysis of laboratory performance evaluation samples and the participation in scheduled interlaboratory studies may be included as part of the performance audit. Laboratory audits are further described in QA/QC procedures for particular analytical laboratories. Any irregularities in QA procedures that are not immediately corrected will be brought to the attention of the Project Manager.

\subsubsection{Surveillances}

Surveillance activities include monitoring and observing documents and work activities to provide an effective real-time means of evaluating the adequacy and effectiveness of 
methods for achieving quality and for assessing the quality of final results. The QA/QC Officer may develop a surveillance plan to provide a basis for each field or laboratory surveillance. This plan will identify the scope, activities, and personnel to be involved, any applicable documents, and the schedule for each surveillance. Checklists may be prepared and used to conduct surveillances. They will be developed to accomplish the review of necessary items and to document the results of the surveillance. Surveillances will follow ER Procedure ER/C-P1600 and the subcontractor's QAPjP.

Field and laboratory surveillances may involve an on site visit by surveillance personnel. Items to be examined may include, but are not limited to, the availability and implementation of approved work procedures; calibration and operation of equipment; packaging, storage, shipping, and transfer of samples; documented procedures and instructions; and nonconformance/field or laboratory change order documentation.

The records of field and laboratory operations may be reviewed to verify that field or laboratory-related activities were performed in accordance with standard procedures. Items reviewed may include, but are not limited to, the calibration records of equipment, daily activity logbooks, Chain-of-Custody Records, and data resulting from field and laboratory operations.

During a surveillance and upon its completion, the surveillance personnel will discuss observed deviations with the individuals surveyed and agree on corrective actions to be initiated. A surveillance report will be completed for each surveillance activity.

Minor administrative findings that can be resolved to the satisfaction of the surveillance personnel during a surveillance are not required to be cited as items requiring corrective action. Findings that are not resolved during the course of the surveillance and findings affecting the overall quality of the project will be noted on the checklists and included in the surveillance report.

\subsection{CORRECTIVE ACTION}

This section identifies methods and policies for the documentation, evaluation, corrective action, and verification activities necessary when a deviation from established procedure occurs. Requirements for the documentation and implementation of corrective actions are also included.

Any deviation or nonconformance will be evaluated with respect to its possible impact on reportable data. All deviations from standard operating procedures, equipment calibrations, or any aspect of the QA plan will be evaluated and documented on nonconformance reports. Programmatic and/or significant deficiencies will also be documented on corrective action reports.

Deviations or variances from standard operating procedures may be necessary given that procedures properly addressing the entire range of conditions encountered during a field sampling program cannot be prepared. Requirements for issue and implementation of variances from standard operating procedures are included. 


\subsubsection{Responsibilities of Project Participants}

Project personnel will ensure the prompt identification, control, and disposition of nonconforming items. Each person is responsible for submitting records of all nonconformance events to the appropriate field/laboratory supervisor and/or the QA/OC Officer immediately following the initial identification and documentation of the nonconformance. The nonconformance will then be evaluated by the field/Aaborntury supervisor, QAVQC Officer, Project Manager, and others as determined necessary. This evaluation will determine the disposition of the nonconformance.

\subsubsection{Nonconformance and Corrective Action Procedures}

Nonconforming equipment, items, activities, conditions, and unusual incidents that could affect compliance with project requirements will be identified, controlled, reported, and resolved in a timely manner. A nonconformance is defined as a malfunction, failure, deficiency, or deviation from specified requirements. The originator of a nonconformance report will describe the finding on the form provided for this purpose and notify the project management and the QA/QC Officer. When a nonconforming item exists, the personnel who identify the item will stop further processing or use of the item, as applicable. Each nonconformance report will be reviewed and a disposition given for the item, activity, or condition.

The disposition of a nonconformance will be documented and approved by the QA/QC Officer. Probable cause of the nonconformance may be determined and action to prevent recurrence may be identified. An evaluation will determine if the event justifies the issuing of a corrective action report. The coriective action report will document the event, the findings of the evaluation, and the required corrective action. The disposition of a nonconformance will be documented and approved by the QA/QC Officer. Corrective actions taken will be commensurate with the importance, complexity, and safety considerations of the condition or occurrence. The corrective action should resolve the root cause of the problem.

If, in the opinion of project management and the QA/QC Officer, the nonconformance does not significantly affect the technical quality or use of the work, the work may continue pending resolution of the nonconformance. The basis for such a decision will be documented on the noncompliance report and submitted to the QA/QC Officer for review and approval. The documentation will include the statement that the decision was made before continuing with the work. The records of nonconformances and their dispositions will be forwarded to the subcontractor's Central Records Facility.

\subsection{QA REPORTS TO MANAGEMENT}

The active participation of management in a project is fundamental to the success of this QAVQC plan. Management will be aware of project activities and will participate in development, review, and operation of the project. Management will be informed of QA status and activities through the receipt, review, and/or approval of these documents: 
- Regular quality status reports from the QAVQC Orfice

- Laloratory QA/QC plans and procedures

- Postaudit reports and audit closures

- Surveillance reports

- Corrective action reports

- Nonconformance reports

Copies of these reports will be distributed to appropriatc management. In addition periodic assessment of QA/QC activities and data PARCC will be conducted and reported by the analytical laboratories.

Project management will inform the QA/QC Officer, as appropriate, of the QA status of the project, especially any significant quality accomplishments and/or deficiencies. Project personnel are required to inform the QA/QC Officer, Project Manager, or project support staff of all nonconformances or quality failures.

All QA records concerning the project (e.g., internal and external correspondence, sampling and analysis plan, QAPjP, field logbooks and forms, chain-of-custody forms, data packages, audit reports, surveillance reports, nonconformance reports, corrective action reports, etc.) will be submitted to the Central Records Facility for dual storage and retrieval.

At the conclusion of the project, the QAVC Officer will prepare a complete report covering all aspects of $Q A$ as it pertains to the project. This will be in the final report. Included in this report will be all corrective actions reports, noncompliance reports, documented changes to the QAPjP, as well as the detailed data validation report.

The data validation report will be a detailed accounting of the data validation process. At a minimum, the report will cover holding times, calibration checks, and QC checks as stated in Sect. 8.7. Included will be an assessment as to whether the QA objectives were met as they relate to PARCC. 


\section{Environmental Restoration Program \\ Health and Safety Plan \\ for}

BCV OU 1 RI Work Plan Y-12 Plant

Revision 0

Technical Support Contiactor

Date

Program Manager

Technical Support Contractor

Date

Field Team Leader

Site Health and Safety Officer

Date

Energy Systems ER Site Program Manager

Date

Energy Systems ER Site Project Manager

Date 


\section{HEALTH AND SAFETY PLAN}

It is Energy Systems policy to provide all Energy Systems employees and subcontractor personnel with the information and procedures necessary to conduct investigative environmental field activities in a safe and healthful manner. This plan applies to all sampling being conducted at the Y-12 Plant BCV OU 1 sites that could expose subcontractor and Energy Systems personnel to hazardous substances. This health and safety plan does not attempt to provide specific requirements for all conceivable situations that might be encountered. It does provide general requirements that are applicable to all sites. Specific health and safety requirements are identified in the Site-Specific Health and Safety Checklists (Appendixes $\mathrm{G}$ and $\mathrm{H}$ ). DOE Orders that are pertinent to health and safety include DOE Order 5480.3 Safety Regulations for the Packaging and Transportation of Hazardous Materials, Hazardous Substances, and Hazardous Wastes; DOE Order 5482.1B Environment Safety and Health Appraisal Program; DOE Order 5480.1A Contractor Occupational Medical Program.

Energy Systems emphasizes the importance of conducting all activities in a safe and healthful manner and requires all personnel involved with sampling activities to receive safety and health training. Safety and health training, including site-specific training (as outlined in Sect. 9.3, Field Personnel Training Requirements), is required under OSHA standards to prepare site personnel to recognize and respond to site hazards.

It is impossible to anticipate all specific safety and health hazards; therefore, all personnel are expected to exercise common sense and good judgment in their approach to specific situations. All personnel are encouraged to bring to the attention of the Site Health and Safety Officer (SHSO) or the Project Health and Safety Officer (PHSO) any unsafe or hazardous conditions observed at their respective sites. Unsafe conditions are to be corrected by the subcontractor or Energy Systems as soon as possible.

\subsection{SITE HEALTH AND SAFETY PERSONNEL}

The PHSO will coordinate all health and safety corrective actions reported to the ER Project Manager. The PHSO will advise Energy Systems personnel and the SHSO of anticipated project activities or conditions that could adversely affect the health or safety of project personnel. The PHSO is authorized to take whatever actions are determined necessary to protect all site personnel and the environment during site investigations. The PHSO will perform the following duties:

- Determine the initial level of protective clothing needed at each site.

- Review the Health and Safety Plan.

- Provide guidance to the Field Operations Manager and SHSO, as needed.

The SHSO will coordinate health and safety activities in the field. The SHSO will perform the following duties:

- Verify that protective measures in use (including protective clothing) are adequate for current conditions. 
- Notify the Field Operations Manager of any unexpected conditions or hazards.

- Notify the Field Operations Manager of all instances of noncompliance with this health and safety plan or with Y-12 Plant safety procedures.

- Provide site personnel with information on site hazards.

- Maintain a list of Y-12 Plant and subcontractor phone numbers.

- Ensure that all site personnel know how to obtain emergency aid from the Y-12 Plant Shift Superintendent's office.

- Perform on-site air monitoring.

- Stop work if an unsafe situation occurs.

- Conduct site-specific health and satety briefings.

- Maintain copies of Material Safety Data Sheets (MSDSs) for hazardous materials brought on site.

The Field Operations Manager will be responsible for implementing this health and safety plan. Specific health- and safety-related responsibilities include the following:

- Coordinating on-site operations

- Minimizing the number of personnel in the exclusion zone

- Stopping work if any unsafe condition exists

- Coordinating with SHSO and PHSO to ensure safe operations

- Obtaining excavation/penetration permits

\subsection{SAFETY RISK ANALYSIS}

\subsubsection{BCV OU 1 Hazards}

BCV OU 1 was used for the treatment, storage, or disposal of hazardous wastes and metals. All of the sites are considered hazardous, though the Boneyard/Burnyard and Burial Grounds pose the greatest threats because of the properties of the chemicals and contaminants that were known to have been placed or that may have been placed in these areas.

Hazards directly related to the Boneyard/Burnyard include potential exposure to high levels of radiation, uranium, organic compounds, acids, and metals in soil and groundwater in the area of trenches that were filled and covered with soil.

Hazards associated with the Burial Grounds include all the hazards listed for the Boneyard/Burnyard. BG-B and the Walk-in Pits contain picric acid, uranium, and thorium saw-fines, which possess pyrophoric qualities. No foot or vehicle traffic will be permitted in these areas.

The S-3 Site, Oil Landfarm, and ORPs all present lesser hazards. Oils, PCBs. heavy metals, depleted uranium, acids, and other wastes were disposed of at these sites. 


\subsection{Physical Hazards}

\subsection{Utilities}

Before the start of sampling, drilling, or excavation, all underground utility lines, other underground structures, and above-ground utility lines must be clearly delineated in the selected work area. The SHSO will ensure that the proper excavation/penetration permit, including utility review and survey, has been acquired before sampling, drilling, or excavation activities begin.

\subsubsection{Heavy machinery}

During activities involving heavy equipment (drill rigs), care will be taken to avoid overhead equipment, falling or flying objects, or being caught between moving and idle pieces of machinery. At a minimum, the general protective clothing (Sect. 9.4) will be worn within the restricted access area around the sampling site as defined in Sect. 9.9.

\subsubsection{Traffic}

Traffic cones, flagging, or barriers appropriate for the traffic hazard will be used to cordon off the work area, if the operations are to be conducted in areas of vehicular traffic.

\subsection{Weather}

Serious hazards can result from adverse weather; therefore, the SHSO will be authorized to discontinue sampling or other field activity because of severe and threatening weather conditions (e.g., lightning, strong wind, heavy rain, temperature extremes). In hot weather, cool fluids and frequent breaks will be provided to help prevent heat exhaustion/stroke.

\subsection{Radiation Hazards}

Alpha, beta, and gamma radiation each pose different hazards. Alpha particles do not penetrate the skin but can pose serious internal exposure problems if the emitters are inhaled or ingested. Beta particles can penetrate the human body and are, therefore, internal radiation hazards. Beta particles can also cause skin burns at high doses. Gamma rays are a highly penetrating form of radiation and present an external radiation exposure hazard. Protective clothing, good personal hygiene, and decontamination afford good protection against alpha and beta radiation but will not provide protection against gamma radiation.

Radiation detection instruments are essential for detecting radiological contamination and determining external radiation exposure levels. Exposure measurements will be used to determine the time, distance, and shielding alternatives that will be considered to protect personnel from external radiation exposure.

All personnel will be issued a thermoluminescent dosimeter (TLD) upon entering the Y-12 Plant site. During sampling activities, downhole equipment and material will be surveyed when removed from the sample point. 
The Y-12 Plant Health Physics Department will determine radioactive dose limits and surveying requirements at sites within controlled areas. Their determination will be placed on the field checklist to be used by field personnel. The Health Physics Department must be notified before work commences in an area of potential radiation exposure.

\subsubsection{Chemical Hazards}

Because of the nature of the sampling activities, workers may encounter some of the following chemicals:

- Metals, including combustible metals

- Inorganic and organic compounds (acids, salts, polar and nonpolar solvents, halogenated hydrocarbons)

- Oils (hydraulic fluids, PCB-contaminated electrical equipment)

- Uranium and uranium-contaminated materials

- Thorium-contaminated materials

- Beryllium and beryllium-contaminated materials

- Laboratory wastes

- Plutonium wastes

Workers may encounter hazardous contaminants during sampling activities in a matrix of groundwater, soil, or rock cuttings, or as airborne contaminants. The most likely avenues of chemical exposure are direct contact with the waste or contaminated material (allowing possible dermal adsorption or ingestion) and inhalation of gases, vapors, or contaminated dust. The possibility of chemical exposure will be mitigated through the use of appropriate protective clothing and respirators. The level of protection necessary will be determined by on-site monitoring.

\subsection{FIELD PERSONNEL TRAINING REQUIREMENTS}

Before being permitted access to the site, each worker will be required to provide documentation of successful completion of the Energy Systems General Employee Training, Energy Systems Radiation Worker II training, 40-h Hazardous Waste Operations Emergency Response training, and an annual 8-h refresher training. Each worker must also obtain medical approval to perform the intended work and must provide documentation of a respirator fit test as required by 29 CFR 1910.134. OSHA 8-h supervisor training is required for the site supervisors. Additionally, before activities begin at each site, workers will be required to attend a site-specific health and safety briefing conducted by the SHSO. Certain sites may require health and safety briefings by Y-12 Plant health physics personnel or industrial hygiene personnel. Site-specific health and safety briefings will be coordinated through the SHSO or Y-12 Plant ER Project Manager. 


\subsection{PERSONAL PROTECTIVE APPAREL AND EQUIPMENT}

The SHSO will determine and specify the types of personal protective equipment (PPE) to be worn during site investigations based on specific hazards identified during preliminary site hazard evaluation and site characterization. All workers must be familiar with the use of protective clothing and its limitations. This includes disposable coveralls, gloves/inner gloves, goggles/safety glasses, hard hats, and safety shoes.

\subsubsection{Levels of Personal Protection}

\subsubsection{Level A}

Level A protection should be provided when either (or both) of the following conditions exist:

- A chemical has been identified on site that requires the highest level of respiratory and dermal protection because of its toxicity and high concentration.

- Visible emissions or other conditions indicate a high potential for exposure tu respiratory and dermal hazards. Level $A$ protection will be worn until the absence of substances requiring such protection is determined by air monitoring or other site characterization methods.

Level A protection includes a supplied-air respirator (approved by the Mine Safety and Health Administration and the National Institute for Occupational Safety and Health) worn with a fully encapsulating, chemical-resistant suit. The respirator may be a positive pressure-demand self-contained breathing apparatus or a positive pressure-demand airline respirator [with a 5-min escape bottle for Immediately Dangerous to Life or Health (IDLH) or potentially IDLH atmospheres].

\subsubsection{Level B}

Level B protection should be provided when any of the following conditions exist.

- A type and atmospheric concentration of contaminants has been identified that requires a high level of respiratory protection but not complete dermal protection.

- Airborne contaminant concentrations are high or suspected to be high, precluding use of air-purifying respirators.

- The atmosphere contains less than $19.5 \%$ oxygen.

Level B protection includes a Mine Safety and Health Administration- or National Institute for Occupational Safety and Health-approved supplied-air respirator. The respirator may be a positive pressure-demand self-contained breathing apparatus or a positive pressure-demand airline respirator (with an escape bottle for IDLH or potentially IDLH atmospheres). 


\subsubsection{Level C}

Level $\mathrm{C}$ protection should be provided when all of the following conditions exist.

- Oxygen concentrations are not less than $19.5 \%$ by volume.

- All potential atmospheric contaminants and concentration ranges have been identified through monitoring.

- Air concentrations of identified substances will be reduced by the respirator to below the substance's Threshold Limit Value (TLV), and the contaminant concentrations in air do not exceed the maximum protection level provided by the canister or cartridge.

- Atmospheric contaminant concentrations do not exceed IDLH levels.

- The airborne contaminants known to exist at the site would give sufficient warning, through odor, taste, or irritation, to alert the user that the canister/cartridge sorbent is saturated and/or is not functioning properly.

- The potential for encountering unknown airborne contaminants or high concentrations of known site contaminants is low.

Level $\mathrm{C}$ protection includes a full-face, canister- or cartridge-equipped air-purifying respirator (Mine Safety and Health Administration- or National Institute for Occupational Safety and Health-approved). Half-face respirators may be substituted for full-face respirators if conditions warrant and if approved by the SHSO.

The PHSO will determine the proper cartridge for use with Level C respiratory protectiun based on the contaminants known or suspected to occur at the site.

\subsubsection{Level D}

Level $D$ personal protection provides no respiratory protection; therefore, it should be used only when no potential for overexposure to airborne contaminants exists.

\subsubsection{Protective Clothing}

The PHSO will be responsible for selecting initial personal protective clothing. The selection will be based on a comparison of the specific materials and clothing ensemble limitations with the potential hazards expected to occur at the site. The PHSO will select the protective clothing that will be most impermeable to the mixture of the specific chemicals known or suspected to exist at the site.

In situations where maximum skin protection is not required, the protective clothing requirements will be reduced to levels appropriate for the contaminant exposure hazards during specific activities. The general protective clothing requirements include steel-toed boots, work clothing, gloves, and safety glasses or goggles. Protective clothing requirements will be upgraded or downgraded according to the actual known or suspected exposure hazards.

The PHSO and the SHSO will identify specific site conditions or project activities that influence the selection of protective clothing and the development of special use procedures. 
These factors may include heat stress, environments with unknown exposure hazards, lowtemperature environments, and differences in work activities within the same contaminated work zone. These factors will always be taken into account in selecting protective clothing. For example, protective clothing for site operations in high-temperature environments should have the lowest practical thermal insulation properties to allow body cooling. Long cotton underwear should be worn under protective clothing in warm environments to absorb moisture and to protect the skin from contact with heat-absorbing protective clothing. Insulating layers of clothing should be worn under protective clothing to protect against low-temperature environments.

Varying levels of protective clothing may be selected for workers performing different activities within the same work zone, if their activities involve different exposure hazards. For example, drillers who are frequently in contact with contaminated soil may be required to wear both inner and outer chemical-resistant gloves and polyvinyl chloride (PVC) chemical-resistant protective suits; however, soil samplers and geologists who have limited contact with contaminated soils may be required to wear only inner chemical-resistant gloves and disposable lightweight chemical-resistant suits. Protective clothing requirements for unknown environments will be made by the PHSO at the site on a case-by-case basis with the assistance of the Y-12 Plant ER Project Manager and the SHSO. Air monitoring will be performed in unknown environments to ensure that the protective ensembles are appropriate for the type and concentration of contaminants.

After daily fieldwork is completed, outer protective clothing will be removed. Disposable clothing will be collected and packaged in garbage bags on site and disposed of according to the waste management plan (Chap. 10). Reusable boots and gloves will be decontaminated and left on site for future use.

The SHSO will ensure that all field workers have the following items available for their use:

- Gloves: inner (surgical type, disposable) with outer (chemical-protective, neoprene or nitrile) or inner (chemical-protective, neoprene or nitrile) with outer (heavy-duty work gloves)

- Protective clothing: Tyvek ${ }^{\text {m }}$ (regular or coated, full length with zipper)

- Footwear: steel-toed boots

- Ear protection: disposable foam earplugs or industrial earmuffs

- Eye protection: safety glasses with side shields or safety goggles to fit over prescription glasses (to be worn at all times when sampling)

- TLDs: TLDs are to be worn at all times, as required by Energy Systems

- Head/face protection: hard hats (when power equipment is in use) or hard hats with face shield attached (used when decontaminating equipment)

- Respirator: full-face mask air-purifying respirator equipped with cartridges for protection against organic vapors and acid gases, dusts and mists, and radionuclides

- First-aid kits

- Portable emergency eyewash 
- Appropriate fire extinguisher

- Spill/cleanup materials

\subsection{PERSONAL HYGIENE}

A personal hygiene program helps to ensure that no workers are exposed to harmful levels of hazardous materials. The following rules will be entorced:

- Workers will consume food only after washing hands and only in a safe area removed from the work zone.

- No eating, drinking, using tobacco, chewing gum, or applying cosmetics will be permitted in the cordoned working area around the Contamination Reduction Zone or Exclusion Zone.

\subsection{ADDITIONAL EQUIPMENT}

In addition to PPE, other equipment will be maintained on site. This equipment will include the following:

- An appropriate fire fighting device, such as a 20 - or $30-\mathrm{lb} A B C$ fire extinguisher

- Plastic bags for trash, contaminated equipment, and clothing disposal

- A supply of clean water that is both potable and suitable for equipment decontamination

\subsection{MEDICAL SURVEILLANCE}

All hazardous waste and hazardous materials (HAZMAT) operations personnel will participate in a medical surveillance program.

The medical surveillance program will consist of the following required physical examinations:

- Preassignment

- Periodic (at least once every 12 months for each employee covered unless the attending physician believes a longer interval (not to exceed 2 years) is appropriate]

- Postemployment

- Postaccident

Medical examinations for hazardous waste and HAZMAT operations personnel will include the following:

- Medical and work history

- Physical examination 
- Audiogram

- Blood chemistry (SMAC 24)

- Complete blood count

- Chest X-ray (posterior, anterior, and lateral), initially and every 5 years thereafter

- Electrocardiogram (optional)

- Pulmonary function test (spirometry)

- Urinalysis

- Visual acuity

- Other tests as directed by the examining physician

If the SHSO suspects that an individual has been exposed to a significant level of hazardous materials, he/she will notify the PHSO and/or the Y-12 Plant ER Project Manager and request that either Y-12 Plant medical personnel or the subcontractor's physician examine the individual to determine the impact of the exposure.

\subsection{MONITORING EQUIPMENT}

The SHSO will ensure that all necessary monitoring equipment is provided, functioning properly, and currently calibrated before starting the investigation. Instrumentation will be used only by the SHSO or qualified personnel who have had prior experience or training in instrument calibration, operation, and care.

On-site monitoring of the immediate area (breathing zone) during all sampling activities will be essentially the same. Site personnel and sampling locations will be monitored with an $\mathrm{HNu}$ or OVA, Jerome mercury vapor analyzer, and radiation meters.

To assist in evaluating potential site hazards, the SHSO will use one or more of the following (or an equivalent):

- Foxboro-Century OVA Model 128 and/or HNu Model 33 Photoionization Detector (PID) or equivalent

- Ludlum Model 3 portable radiation survey meter with a Ludlum Model 44.9 pancake probe to detect beta and gamma radiation

- Ludlum Model 12 portable radiation survey meter with a scintillation counter probe to detect alpha radiation

- Portable explosimeter or Foxboro-Century OVA Model 108 to determine flammable/explosive gases or vapors

- Portable $\mathrm{pH} /$ conductivity meter to monitor drilling fluids and groundwater that may contact the skin

- Jerome mercury vapor analyzer 
It should be noted that all direct-reading instruments are limited in their ability to detect hazards, and no one instrument will detect all possible hazardous compounds.

TLD badges, which must be worn by all personnel working at the Y-12 Plant site, provide Health Physics Department personnel with radiological exposure data. Abnormally high exposure information will be reported to the SHSO, and appropriate investigations will be conducted by Y-12 Plant personnel as necessary.

\subsection{SITE CONTROL MEASURES}

Site access is tailored according to whether sampling activities will be conducted in noncontaminated sites, radiologically contaminated sites, or sites where hazardous substances are likely to be encountered (Fig. 9.1). Access requirements may be upgraded or downgraded as conditions warrant.

In noncontaminated areas, a working area large enough to accommodate all direct sampling activities (e.g., sampling, containerizing, logbook keeping) will be cordoned.

If drilling activities are to be conducted, the cordoned zone will have a radius equivalent to the rig mast height.

At hazardous work sites, only those persons directly involved in the site activities will be allowed in the exclusion zone. Visitors who must observe work being conducted in the exclusion zone must wear all appropriate PPE and must be properly trained before entering the area. Should respiratory protection be necessary, all visitors must also produce evidence that they have had a complete physical, respirator training, and a respirator fit test within the last 12 months. Visitor entry into the work zones will be left to the discretion of the SHSO. The following areas will be clearly identified at each site where required:

- Exclusion Zone-This is the area where physical, chemical, and/or radiological hazards exist or could occur. The purpose of this zone is to limit the spread of contaminants to clean areas and to provide for the safety of those persons not authorized to enter the zone. The boundaries will be clearly marked, and the flow of personnel and equipment will be restricted to the contamination reduction zone.

- Contamination Reduction Zone-This is the area located between the exclusion zone and the support zone. This zone serves as a buffer to further reduce the possibility of the spread of contamination to clean areas. Decontamination equipment will be available at the boundary between the exclusion zone and the contamination reduction zone.

- Support Zone-This is the area located outside the zones of potential contamination. The support zone serves as an entry area for personnel, material, and equipment to the area of site operations. It also serves as an exit area for decontaminated personnel, materials, and equipment. Uncontaminated safety and work equipment will be stored in the support zone. Eating, drinking, and all other activities supporting the sampling teams are permitted in the support zone. 


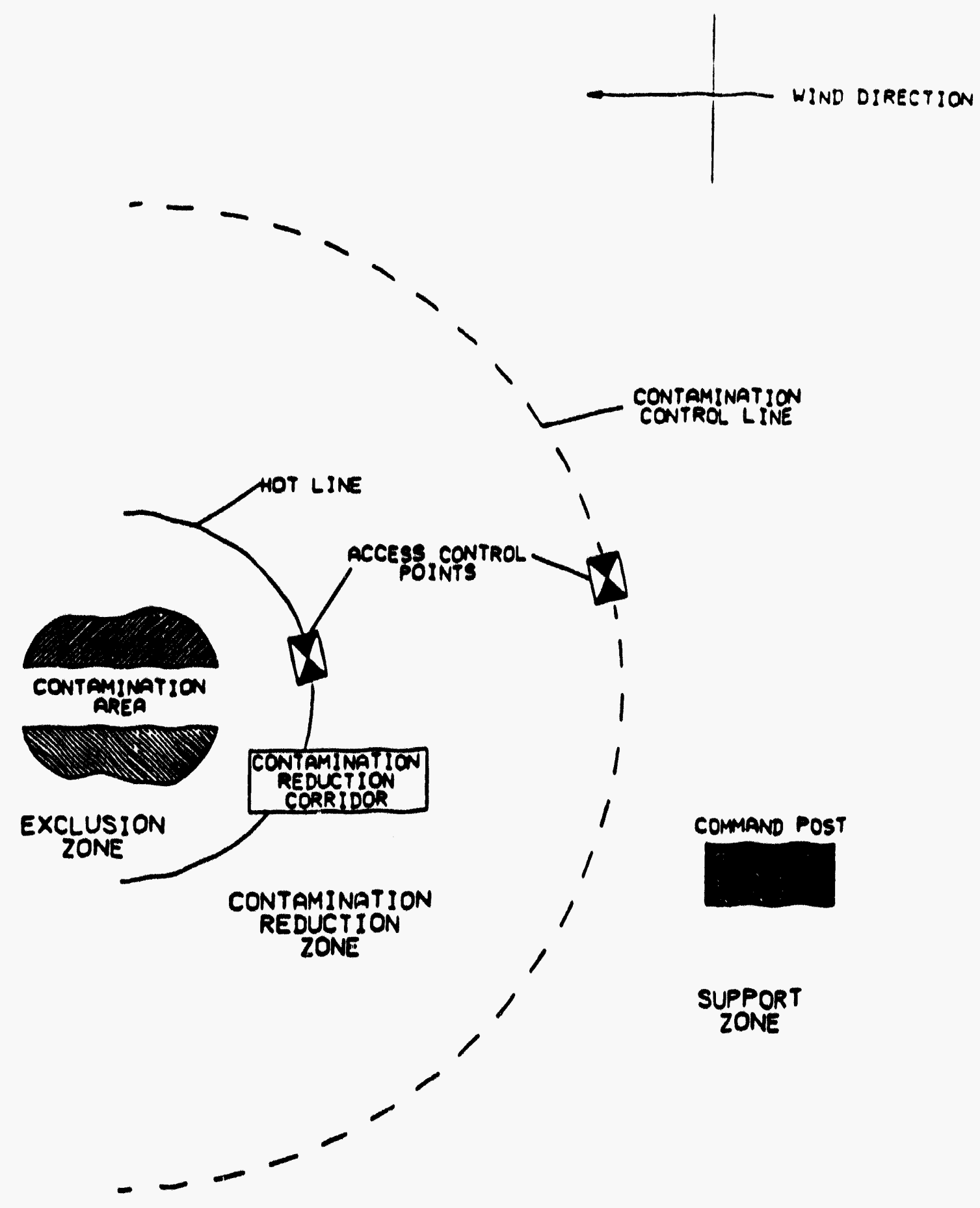

Fig. 9.1. Site control zones. 


\subsection{DECONTAMINATION AND DISPOSAL}

Each site in hazardous-substance or radiologically contaminated areas where reusable equipment is being worn will have one protective clothing decontamination location. The location will contain two large washpans and one large wash tub for equipment, rinse water, soap, brushes, and towels.

Workers will be responsible for decontaminating their boots, gloves, and equipment. Workers will also be required to check their clothing for radioactive contamination before leaving the site.

All noncontaminated disposable clothing will be packaged daily in a marked plastic garbage bag on site and disposed of according to the project waste management plan. Contaminated disposable clothing will be packaged in a marked plastic bag and disposed of according to the project waste management plan. The SHSO, at the direction of the Y-12 Plant ER Project Manager and PHSO, will ensure that waste minimization efforts are employed to keep contaminated and noncontaminated wastes segregated.

The Y-12 Plant Health Physics Department will survey all subcontractor field equipment before it leaves the Y-12 Plant area. All radioactive contamination will be less than the Green Tag limits as determined by $Y-12$ Health Physics when equipment is scheduled to be removed from the site. A property removal request will be initiated through the Field Operations Manager so that Y-12 Plant Health Physics personnel can conduct required radiation surveys.

\subsection{CONTINGENCY PLAN}

Emergency actions are tailored according to whether investigative activities are being conducted on sites in noncontaminated areas, on sites that have been designated as radiologically contaminated, or on sites that have been surveyed and may contain hazardous substances.

Emergency actions for noncontaminated areas are discussed in Sect. 9.11.1. Hazardouswaste-site emergency actions require additional precautions and are discussed separately in Sect. 9.11.2.

\subsubsection{Emergency Actions for Noncontaminated Arcas}

In the event of an accident involving actual or suspected personal injury, the Field Operations Manager will perform the following steps in the order shown here:

- Initiate emergency first aid and/or decontamination, if necessary.

- Contact the Y-12 Plant Shift Superintendent.

- Obtain transportation for injured persunnel (e.g., driller's service truck, SHSO vehicle, escort vehicle, ambulance), if required. A medical exam will be required after each accident that potentially exposes personnel to hazardous substances above the allowable limits or that results in injuries, other than minor first aid injuries, that might result in lost work days or reassignment of the injured worker. 
- Initiate necessary corrective measures to abate any unsafe conditions.

- Withdraw uninjured site personnel to a safe distance from the accident scene until the SHSO determines that it is safe for work to resume.

- Contact the Y-12 Plant ER Project Manager and/or the PHSO for immediate advice. Emergency telephone numbers are listed in Appendix 0 . Contact the appropriate person, department, and/or organization listed in Appendix $G$ of this document, as directed by the Y-12 Plant ER Project Manager or PHSO.

Personnel should not enter an area to attempt a rescue if their own lives would also be threatened because of inadequate personal protection (e.g., clothing, self-contained breathing apparatus). The SHSO will ensure that all employees can be rescued from any area of the site that they are allowed to enter and is responsible for developing any special decontamination procedures for injured personnel if necessary. Site personnel will be instructed to evacuate the work area if PPE fails.

Emergency planning will include establishing a procedure for evacuation from the site in case of a natural or man-made catastrophe. For work sites inside the Y.12 Plant, contractor and subcontractor personnel will assemble at the designated assembly point or where instructed by the Plant Shift Superintendent in the event of a plant emergency.

\subsubsection{Emergency Actions Within Contaminated Areas}

If personal injury or exposure of personnel to radiological contamination, suspected hazardous chemicals, vapors, or particulates occurs within a contaminated site, the following emergency procedures will be applied.

\subsubsection{Personnel injury in the exclusion zone}

All site personnel will assemble at the decontamination line. The rescue team will enter the exclusion zone (if required) to remove the injured person to the boundary (hotline) (Fig. 9.1).

- The SHSO or other qualified person will evaluate the nature of the injury. If the injury is determined not to be an immediate threat to life, the injured person will be decontaminated to the extent possible before being moved to the support zone. If the injury is determined to be an immediate threat to life, decontamination procedures will be postponed until the injured person stabilizes.

- The Y-12 Plant Shift Superintendent will be contacted for an ambulance, and the designated medical facility will be notified (if required). No person will re-enter the exclusion zone until the cause of the injury or symptoms is determined.

\subsubsection{PPE failure}

If any site worker experiences a failure or alteration of PPE that affects the protection factor, that person and his/her buddy will immediately leave the work aren for a safe location. Re-entry will not be permitted until the equipment has been repaired or replaced. The SHSO will have two air-purifying, full-face respirators on site for escape purposes in an emergency. 
Rescue operations from toxic atmospheres will be conducted by persons wearing either selfcontained breathing apparatus or suitable air-line respirators with escape bottles.

\subsubsection{First Aid}

Any person designated as an SHSO will be certified in first aid and cardiopulmonary resuscitation (CPR). Workers trained and certified in first aid and CPR will render first aid and will attempt to stabilize any ill or injured worker needing assistance. Life support techniques such as CPR and treatment of life-threatening problems such as bleeding, airway obstruction, and shock will be given top priority. All on-site emergency assistance, including medical assistance, will be obtained as rapidly as possible by calling 911 or the Plant Shift Superintendent at 574.7172 .

\subsection{ON-SITE COMMUNICATIONS}

On-site radio communication is required. For emergency communication, the SHSO will use one of the following communication methods:

- Mobile radio

- Mobile telephone

- Nearest plant or guard house telephone

- Fire pull-station

- Escort notification (in areas in which a security escort is required)

The Y-12 Plant ER Project Manager and the PHSO will be informed daily by the SHSO of proposed site investigative activities. 
Environmental Restoration Program

Waste Management Plan

for

BCV OU 1 RI Work Plan Y-12 Plant

Revision 0

Technical Support Contractor

Date

Program Manager

Technical Support Contractor

Date

Quality Assurance/Quality Control

Officer Concurrence

DOE ER Division Program Manager

Date

DOE ER Division QA Program Manager

Date

Energy Systems ER Site Program Manager

Date

Energy Systems ER Site Project Manager

Date

Energy Systems ER

Date

Site QA Specialist

Central ER Waste Management

Date

Energy Systems Waste Management Organization

Date

Site ER Waste Management Coordinator

Date

Site Health Physics Representative

Date

Site Waste Management Division

Date 


\section{WASTE MANAGEMENT PLAN}

\subsection{SCOPE}

The objectives of this Waste Management Plan for the BCV OU 1 RI are to identify analytical requirements, personnel responsibilities and types, anticipated characterizations, and volumes of waste that will be generated during RI activities conducted by the Y-12 Plant ER Division. Another goal of the Waste Management Plan is to establish TSD objectives for project-derived wastes prior to final remedial activities.

The BCV OU 1 Waste Management Plan will include management of soil, protective clothing, well development purge water, and decontamination water wastes. Table 10.1 outlines the ER Waste Management Plan Checklist for BCV OU 1 to be conducted by the Y-12 Plant ER Division. Investigation-derived wastes (IDW), waste types, waste categories, estimated generation volumes, and expected contaminants for each waste stream are provided. This Waste Management Plan defines the procedures for segregating, characterizing, and controlling all IDW from the point of generation through TSD including (1) the processes and methods for sampling, analyzing, characterizing, and certifying IDW; (2) waste staging areas, satellite and $90-\mathrm{d}$ accumulation areas, and permitted or interim status storage areas; (3) waste packaging and labeling procedures; (4) transportation routes and U.S. Department of Transportation (DOT) reporting requirements; (5) proposed treatment and/or disposal methods and facilities; and (6) waste minimization and reduction techniques to be used. Waste management plans in support of these RI activities are summarized below.

Decontamination procedures will be established to support equipment decontamination and reduce the potential for cross contamination during sampling activities. All equipment and personnel will be scanned for radioactive contamination before leaving a borehole location. Equipment or PPE exhibiting radioactive contamination will be decontaminated at the borehole location where it was used before being moved to another borehole location or returned to the temporary decontamination area. All equipment at each borehole location will be subjected to preliminary cleaning to remove surface dirt or mud that otherwise might be tracked to other areas of the Y-12 Plant.

Soil cuttings will be monitored for radioactivity and volatile organic contaminants in the field to screen the waste types (hazardous or norhazardous). Nonhazardous soil will be returned to the borehole in accordance with CERCLA guidance (Guide to Management of Investigation-Derived Wastes, EPA Publication 9345.3-03FS, April 1992.) The top $4 \mathrm{ft}$ of the borehole will be grouted for containment. Hazardous samples will be packaged as indicated in Sect. 10.10.2.2 and sent for analytical analysis and characterization. Hazardous solid wastes will be placed in appropriately labeled drums and coordinated through Y-12 Waste Management Organization for disposal at a hazardous waste storage facility with available capacity.

Protective clothing will be scanned for radioactive contamination; if not contaminated, it will be treated as nonhazardous solid waste and will be disposed of in a dumpster provided 
Table 10.1. Environmental Restoration Waste Management Project Plan

Environmental Restoration Waste Management Project Plan Revision No. Draft 1

1. Project Name: Bear Creek OU 1 RI ProjecI

Plant: Y.12

Organtzation: ER Division/RI Subcontractor

2. Responsible Project Manager. Y.12 ER

3. Expected Start/Completion Dates: 5-4-94/3-29-96

4. Project Description (Brief): Remedial Investigations to collect subsurface soil samples

5. Project Participants (for waste management interface only):

Waste Generator: RI Subcontractor

Waste Hanuler: Y.12 ER Division

Waste Transporter: Energy Systems Waste Treatment, Storage, and Disposal (WTSD)

Interim Waste Storage: RI Subcontractor

Permanent Waste Storage: WTSD

Waste Treatment: Y.12 Waste Treatment Organization (WTO)

Waste Disposal: Y-12 Sanitary Landfill and/or WTSD

6. Waste Generation:

\begin{tabular}{|c|c|c|c|c|c|c|}
\hline \multirow[t]{2}{*}{ Warte Stram } & \multirow[t]{2}{*}{ Type } & \multirow[t]{2}{*}{ Catcgory } & \multirow[t]{2}{*}{$\begin{array}{l}\text { Volume } \\
\left(\mathrm{ft}^{3} \text { or } \mathrm{gal}\right)\end{array}$} & \multirow[t]{2}{*}{ Contaminants } & \multicolumn{2}{|c|}{$\begin{array}{l}\text { Charactertzation } \\
\text { Buned on: }\end{array}$} \\
\hline & & & & & $\underset{\text { Knowledge }}{\text { Proces }}$ & $\begin{array}{l}\text { Samplins } \\
\text { and } \\
\text { Anntyis }\end{array}$ \\
\hline $\begin{array}{l}\text { Waste Stream } 1 \\
\text { Unused Soil will be } \\
\text { retumed to borehole il } \\
\text { came from. The upper } \\
4 \mathrm{ft} \text { of each borehole } \\
\text { will be grouted. Any } \\
\text { remaining soil will be } \\
\text { kept on site. }\end{array}$ & Soil & LLW & $\begin{array}{l}1.8 \mathrm{~m}^{\prime} \\
\left(60 \mathrm{ft}^{\prime}\right)\end{array}$ & $\begin{array}{l}\text { Depleted and } \\
\text { enriched } \\
\text { uranium. } \\
\text { nitrates, } \\
\text { metals, acids, } \\
\text { bases }\end{array}$ & $\checkmark$ & \\
\hline Waste Stream 2 & $\begin{array}{l}\text { Decon. } \\
\text { tamination } \\
\text { water }\end{array}$ & LLW & $\begin{array}{l}418 \mathrm{~L} \\
(110 \mathrm{gal})\end{array}$ & $\begin{array}{l}\text { Depleted and } \\
\text { enriched } \\
\text { uranium, } \\
\text { metals, acids, } \\
\text { bases }\end{array}$ & $\checkmark$ & $\checkmark$ \\
\hline Waste Stream 3 & $\begin{array}{l}\text { Solids } \\
\text { (clothing) }\end{array}$ & $\begin{array}{l}\text { Sanitary } \\
\text { (Dumpst } \\
\text { er) }\end{array}$ & $\begin{array}{l}0.45 \mathrm{~m}^{3} \\
\left(15 \mathrm{ft}^{3}\right)\end{array}$ & $\begin{array}{l}\text { Same as Waste } \\
\text { Stream } 1\end{array}$ & $\checkmark$ & \\
\hline Waste Stream 4 & $\begin{array}{l}\text { Purge } \\
\text { Water }\end{array}$ & LLW & $(2000 \mathrm{gal})$ & $\begin{array}{l}\text { Same as Waste } \\
\text { Stream } 2\end{array}$ & & $\checkmark$ \\
\hline Waste Stream 5 & $\begin{array}{l}\text { Unused } \\
\text { Samples } \\
\text { Returned } \\
\text { from Lab }\end{array}$ & LLW & $\left(85 f^{3}\right)$ & $\begin{array}{l}\text { Same as Waste } \\
\text { Stream } 1\end{array}$ & $\checkmark$ & \\
\hline
\end{tabular}

7. Waste Analysis and Characterization: None to date 
Table 10.1 (continucd)

Environmental Restoration Wastc Management Project Plan Revision No. Draf 1

8. Waste Staging Arca: Y/N YES

Location: Bear Creck Valley OU 1 Site

Special Requirements: Flagging around area to segregate drums

9. Transport Across Public Access Roads: N Energy Systems will be responsible for transporting drums from accumulation area

Road Involved:

DOT Regulations to be applied: $N$

Reportable quantities of anticipated DOT-rcgulated hazardous materials (if required): N/A

10. Waste Storage Requirements:

FIcld Staging Arca: YN/NA YES - CERCLA staging area

Location: Parking lot in $Y .12$ exclusion arca

Responsible Organization: SAIC

90-Day Storage Arca: Y/N/NA NO

Location:

Capacity:

Waste Acceptance Criteria Requirements:

Responsible Organization: Energy Systems

Permitted (or Interim Status) Storage: YN/NA

Location:

Capacity:

Waste Acocptance Critcria Requirements:

Responsible Organization:

11. Identification of Potential Treatment Options: SOIL - NO; CLOTHES - NO

Location: West End Water Treatment Plant - Water

Capacity: $418 \mathrm{~L}(110 \mathrm{gal})$

Responsible Organization: Energy Systems, Y.12 WTO

Spectal Waste Acoeptance Critcria Requirements: Analysis for process use

12. Identification of Potential Disposal Options:

Location:

Capacity:

Responsible Organization: Energy Systems

Special Wastc Acceptance Critcria Requirements: Pass through trash monitoring station before final disposal 
Table 10.1 (continuod)

\section{Environmental Restoration Waste Management Project Plan}

Revision No. Drafl 1

13. Waste Minimization and Reduction Techniques to be Implementod:

Segregation:

In-Field Pretreatment:

Decontamination:

Waste Handling (Spill Control):

Compaction:

Material Recycle (Solvents, Containers):

Solvent Substitution:

Materials Reuse (Solvents, Wash Waters):

Sludge Dewatering:

Culling Fluids Recovery:

Selection of PPE:

Selection of Equipment:

Other:

Description of Special Techniques and Expoctod Bffoctivonon:

Effort will be made $10 \mathrm{minimize}$ all waste generation. An altempt will be made 10 compact protective clothing that is put into drums. Soll from borings will be relurned to the borehole If came from.

Prepared by:

Roviow:

Plant Enviranmental Compllance Orgunization:

Central ER Waste Munagement:

ER Waste Reduction Manager:

Central Waste Management Organization:

Date:

Approvils:

Plant ER Waste Management Orgunization: Date:

Plani Waste Management Organization: 


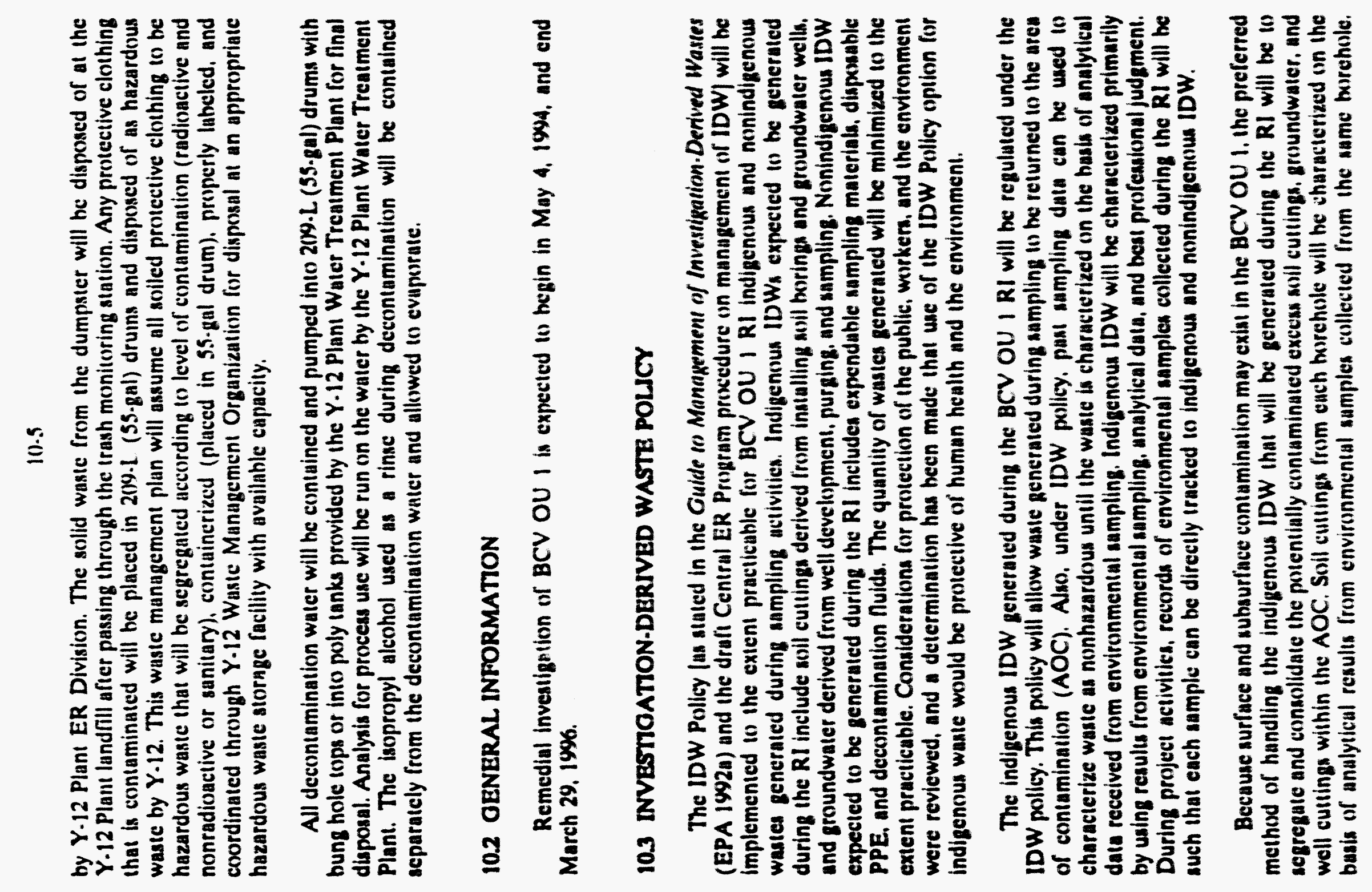


Based on this characterization, contaminated soils will be consolidated, containerized, and stored in a waste stockpile within the AOC until they can be remediated in conjunction with the site remediation. All unused soil obtuined during the drilling of borcholes will be returned to the borehole from which it came. in accordance with EPA guidance for management of IDW. The upper 4 fi of each borehole will be grouted, and any excess soil will be spread evenly around the borehole. Groundwater will be containerized within the AOC and characterized on the busis of analylical results from environmental sumpling and waste characterization sampling for on-site or off-site wastewater treatment according to TSD facilly waste acceptunce criteria. The nonindigenous IDW (expendable sampling materials. disposable PPE, and decontamination solutions) will be containerized and analyzed for on-site or off-site wastewater treatment according Io TSD facility waste acceptance criteria.

Nonindigenous wastes such as liquids (decontamination water/soap solutions, and decontamination water/isopropyl alcohol solutions) and compactible wastes (expendable sampling materials and disposable PPE) generated during the BCV OU I RI will be coniainerized in DOT specification drums nnd will he slored in lielc staging areas within the AOC for fulure TSD. Until analytical data are received characterizing the IDW as RCRA hazardous waste, the waste will he managed in a protective manner in licld stuging areas (FSAs). The FSAs will be clearly marked hy signs and roping. Slorage of suspected RCRA hazardous IDW within the BCV OU I AOCs will comply with the requirements of RCRA set lorth in 40 CFR Parl 262. with respect to labeling. inspecting. containerizing, and management of RCRA hazardous wastes. Storage of nonhazardous wastes within the BCV OU I AOC will be managed in a manner that is prolective of human heallh and the environment. Figure 10.1 indicales the AOC designations (encircled by heavy lines) for the BCV OU I RI.

\subsection{HISTORY AND EXPECTED CONTAMINANTS}

Facility history and expected contaminants are presented in Chap. 2 of this RI work plan. An all-inclusive list of contaminunis expected to be eneountered by the RI subeontractor pernonnel during field activities would be unrealiatic. Typical COCs include radionuclides (urunium, thorium, radium, and Tc), meials (mercury, lead, chromium. and beryllium). organica (PCBs, Irichloresethene, tetrachloroethene, Irichlorsethene, petroleum producta), and nitrates. Table 5.1. presented earlier. contains a complete list of preliminary COCa for sites in BCV OU 1.

\subsection{APPLICABLE AND REFERENCE DOCUMENTS}

The applicable lawa governing waste management and related activities at the Y.12 Plant include the following:

- Alomic Energy Act of 1954, Public Law (P.L.) 83.703, as amended

- NEPA of 1969, P.L. 91.19), as amended

- RCRA of 1976. P.L. 94.581), as amended

- CERCLA of 198U, P.L. M. \$II, an amended

- TSCA of 1976, P.L. 4.4.46\%, as amended 
10.7

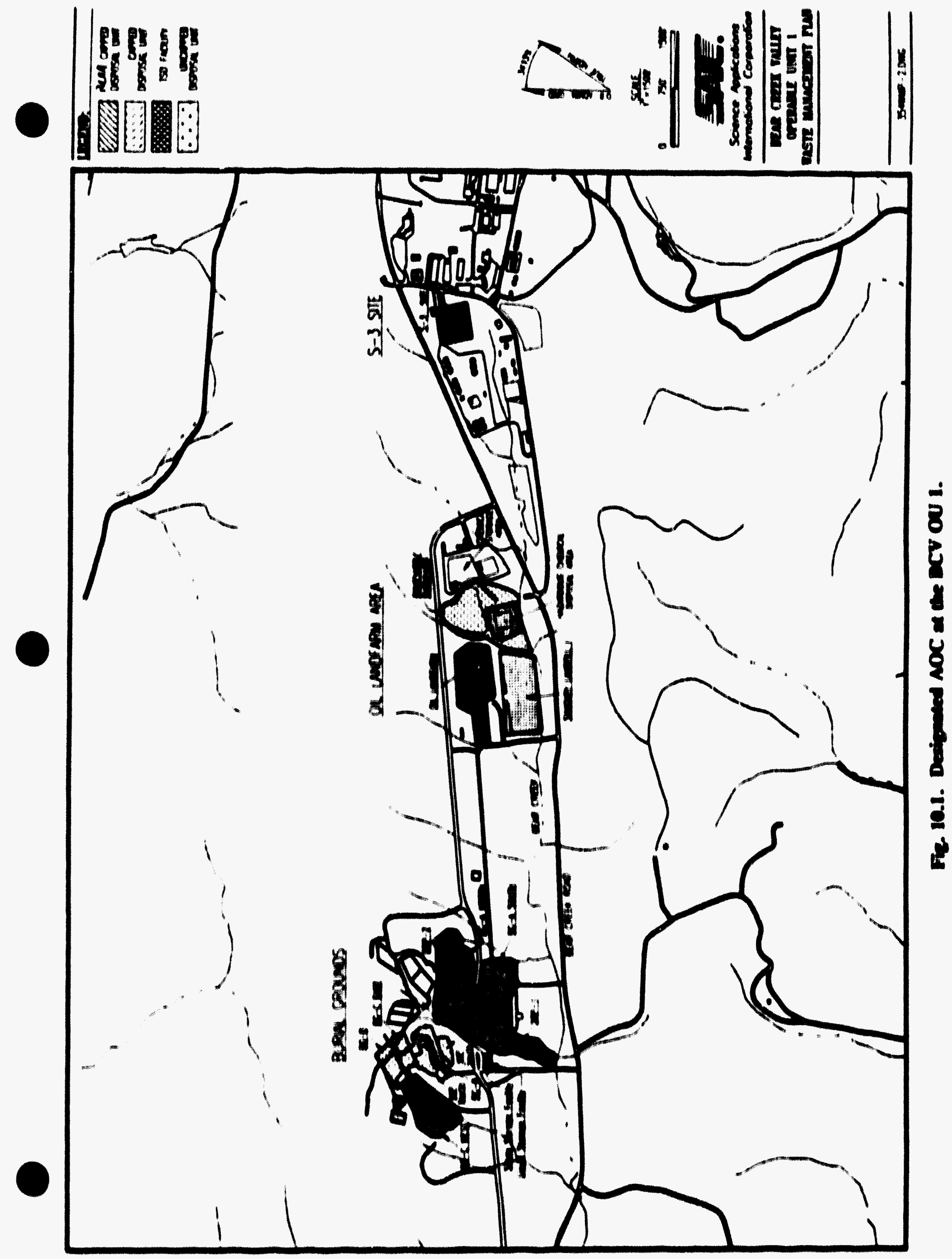


$10 \cdot 8$

- Water Pollution Control Act (Clean Water Act) of 1972, P.L. 92.50), as amended

- Safe Drinking Water Act of 1974, P.L. 93.523, as amended

- Ar Pollution Control Act of 1955, P.L. 84.159; the Clean Air Act of 1963, P.L. 88-206; the Air Quality Act of 1967, P.L. 90.148; Clean Air Act Amendments of 1970, P.L. 91. 604; Clean Air Act of 1977, P.L. 95.190; and the Clean Air Act Amendments of 1990, P.L.101.549; as amended

- OSHA of 1970, P.L. 91-596, as amended

- Transportation Safety Acl of 1974, P.L. 93.633, as amended

- State of Tennessee Water Quality Control Act, Tennessee Code, Title 69-Waten, Waterways. Drains and Levees, Chapter 3: Water Pollution Control; enacted by Tennessee Public Act of 1971, Chapter 164, a amended

- Tennessee Solid Waste Disposal Act, Tennessee Code, Tille 69-Waten, Watenwaya, Drains and Levees. Chapter 3; Water Pollution Controli enacted by Tennessee Public Act of 1971. Chapter 164, as amended

- State of Tennessce Hazardous Waste Management Act, Tennessee Code, Tille 68-Safely and Healih. Chapter 46: Hazardous Waste Management; enacted by Tenneasee Acts of 1977, Chapter 175, as amended

- Siate of Tennessee Peiroleum Underground Storage Tunk Act. Tennessee Code. Title 68-Safely and Healih. Chapler 53: Petroleum Underground Storage: enacted by Tennessee Acts of 1988, Chapler 984, as amended

\subsubsection{Regulation}

Numerous federal and state regulations, including DOE orden, derive their authority from, and provide atandards for, regulation of provisions contuined in the foregoing lawn. Regulations relevant to various aspects of waste management at the $\mathrm{Y} .12$ Plant include the following:

- DOE Order 5440.1C. "National Environmentul Policy Act"

- DOE Order S480.1A "Environmental Protection, Salety, and Health Protection Programs for DOE Operation:"

- DOE Order 5440.18. "Implementation of the National Environmental Policy Act" canceled and replaced by: DOE Order 5440.1C. "Nutional Environmenial Policy Act," April 9, 1985

- DOE Order 5480.1A. "Environmental Protection. Sufely, and 6/22/82 Health Protection Programs for DOE Operallons"

- DOE Order 5480.10, "Contractor Industrial Hygiene," February 25, 1986

- DOE Order 5482.1B, "Environmental Safety and Healih Appraisal"

- DOE Order 5483.1A. "Occupational Safety and Health Program for DOE" canceled and roplaced by: DOE Order 5483.1A: "Occupational Sufety und Health Program for DOE." June 24, 1983 
- DOE Order 5484.1, "Environmental Protection, Safety, and Health Protection Information Reporting Requirements," May S, 1982

- DOE Order 5500.2A. "Emergency Planning. Preparedness, and Responses for Operations" canceled and replaced by DOE Order $55(0) .2 \mathrm{~A}$ "Emergency Notification." April 13, 1988

- DOE.ORO Notice 55(X).2A. "Procedures for the Classification, Notilication, and Reporting of Emergency and Nonroutine Events"

- DOE Order 5820.2A, "Radioactive Waste Management"

- NRC Regulation 10 CFR 61, "Licensing Requirements for Land Disposal of Radioactive Waste"

- DOE Regulation 10 CFR 1021, "Compliance with the National Environmental Policy Act"

- EPA Regulation 40 CFR 61. "National Emission Standards for Hazardous Air Pollutants"

- EPA Regulation 40 CFR 122. "National Pollutant Discharge Elimination System"

- EPA Regulation 40 CFR 136, "Regulations on Test Procedures for the Analyais of Pollutants"

- EPA Regulation 40 CFR 141, "National Primary Drinking Water Regulations"

- EPA Regulation 40 CFR 142. "National Primary Drinking Water Regulations Implementation"

- EPA Regulation 40 CFR 143, "National Secondary Drinking Water Regulationa"

- EPA Regulation 40 CFR 190, "Environmental Radiation Protection Standards for Nuclear Power Operation"

- EPA Regulation 40 CFR 191. "Environmental Radiation Protection Standards for Management, and Disposal of Spent Nuclear Fuel. High-Level, and Transuranic Radioactive Wastes"

- EPA Regulations, Title 40, "Protection of Environment, " Subchapter I, "Solid Waste," Parts 240 through 299

- EPA Regulations. Title 40, "Protection of Environment," Subchapter I. "Superfund Programs" Parta 300 through 399

- EPA Regulations, Tille 40, "Prolection of Environment," Subchapter R, "Toxic Substances Control Act," Parts 7(X) through 799

- Council on Environmental Quality Regulations. Title 40. "Protection of Environment," Parts is(0) through 1508, "Regulations on Implementing National Environmental Policy Act Procedures"

- Department of Labor Regulation 29 CFR 1910, "Occupational Safety and Health Standards"

- DOT Regulations, Title 49, "Transportation," Subchapter C. "Hazardous Materials Regulations," Parts 171 through 179

- TDEC Regulations Chapter 1200-1.11. "Hazardous Waste Management Rules" 
10.10

- TDEC Regulations Chapter 1200)-1-7, "Solid Waste Regulations"

- TDEC Regulations Chapter 1200)-4-1, "Oeneral Regulations"

- TDEC Regulations Chapter 1200-4-3, "Water Quality Criteria"

- TDEC Regulations Chapter 1200-4-5, "Efluent Limitations and Standards"

- TDEC Regulations Chapter 1200.1-15, "Underground Storage Tank Program"

10.5.2 Energy Syatems Policien, Standards, and Procedures

- ESS-EP-125 - "Management of Polychlorinated Biphenyls (PCBs) Immediate Action Directive" (IAD)

- ESS.ENV.1- "Environmental, Safely, Health, and Waste Management Quality Assurance"

- ESS-TR-101 - "Transportation and Packaging Safety"

- ESP.IH.161- "Worker Protection in Hazardous Waste Operations and Energy Response"

10.5.3 Energy Sytems Environmental Surveillance Procedures (Kimbrough et al. 1990)

- ESP.307- "Ficld Measurement Procedures"

- ESP.500- "Manual Chain of Custody Procedures"

- ESP.80- "Packaging Environmental Samples for Transportation"

- ESP.900- "Cleaning and Decontaminating Sample Containers and Sampling Devices"

- ESP.901- "Equipment Decontamination"

- ESP.1000- "Waste Management"

\subsubsection{ER Division Procedurcs}

- ER/C.P1300) " Reporting of Occurrences and Noncompliances for the Environmental Restoration Division"

- ER/C.P1301 - "Implementation of Training Program Requirements for Environmental Restoration Division Employee"

- ER/C.P1719_ "Controlling and Documenting Field Changes to Append Field Sampling Plans"

- ER/C.P2101 - "Preparation of ER Task/Project Specilic Waste Management Plans"

- ER/YP2102- "Waste Removal and Disposition Through the Y-12 ER Program" (IAD)

10.5.5 Waste Management Division Opcrating Procedures

- WMD-HS-5402 - "Intra-Plant Movement of Hazardous Material" (old 1430.31 "IntraPlant Movement of Hazardous Materials")

- SMD.HS-5501 - "Orf-Site Shipment of Hazardous Waste-Administration" 
$10 \cdot 11$

- WMD-OP-2025 - "Temporary Outside Storage of Waste Containers"

- WSO-OP-2001 - "Waste Storage Inspection Requirements"

- WSO-OP-2004- "Fissile Material Storage Unit Operations"

- WSO.OP-2008 - "Waste Container Handling and Stacking Operations" (old "Handling and Storage of Hazardous Waste")

- WSO-OP-2014- "Corrosion Inspection of Storage Containers"

- WTDO.HS-5403 - "Asbestos Waste Shipment Tracking and Reporting"

- WTDO-HS-5404- "K-25 Site Fill Area I Operations"

- WTDO-OP-2006- "Hazardous Waste Manifest and Tracking"

- WTO-HS.5502_ "Packaging and Verification of Lab. Pack Quantity Waste for Off-Site" (old "Waste Verification and Waste Packaging")

\subsubsection{Y-12 Plant Procedures and Standard Practices}

- 70-303 - "Control of Indystrial Wastes"

- 70.903- "Transfer, Storage, or Disposal of Waste"

- 50.41-WT8-2.64- "Hazardous Waste Collection, Packaging, Storage and Disposal"

\subsection{PROJECT CONTACTS}

Names and affiliations of key personnel involved in the generation, management, and disposal of wastes in association with the BCV OU $1 \mathrm{RI}$ project are identified in Table 10.2. Active waste management facilities at the Y-12 Plant are identified in Table 10.3.

\subsection{PROJECT WASTE MANAGEMENT/WASTE HANDLING}

The types of waste most likely to be generated and managed during field investigations on the Y-12 Plant include decontamination fluids, well development/purge water, debris, sludge, soil, solvents/oils, PPE, trash, PCB equipment, equipment, metal, miscellaneous solid waste, and miscellaneous liquid waste. The RI Subcontractor will characterize all IDW according to the eight categories identified: (1) RCRA waste, (2) TSCA waste, (3) lowlevel radioactive waste (LLW), (4) LLW/RCRA waste, (5) LLW/TSCA waste, (6) LLW/ RCRA/TSCA waste, (7) RCRA/TSCA waste, or (8) sanitary/industrial wi te.

\subsubsection{Anticipated Decontamination Activities}

Field activities conducted by the RI subcontractor on the Y.12 Plant will require decontamination of equipment, sampling devices, the outside portion of sample containers, and personnel. The subcontractor's project Health and Safety Officer will be responsible for personnel decontamination, which will not be permitted in the same wash tubs used for equipment decontamination. To decontaminate sample containers, the RI subcontractor will follow the procedures outlined in ESP.900 Part VII D (Kimbrough et al. 1990). 
Table 10.2. Key project personnel, amliations, and telephone numben

\begin{tabular}{|c|c|c|}
\hline Amliation & Name & Tolophone \\
\hline $\begin{array}{l}\text { Project Manager, Science Applications } \\
\text { International Corporation (SAIC) }\end{array}$ & Duncan Moss & 481.4107 \\
\hline Field Operations Manager, SAIC & Greg Schank & 481.8760 \\
\hline Site Health and Safety Officer, SAIC & Eric Corbin & 481.8726 \\
\hline Y.12 Site Health Physics Department & Rick Howard & 574.4085 \\
\hline Y-12 ER Field Operations Manager & Steve Walker & 576.5364 \\
\hline Y.12 ER Field Coordinator & Ricky Walker & $576-2151$ \\
\hline $\begin{array}{l}\text { Y.12 Site Waste Transportation and } \\
\text { Disposal Department }\end{array}$ & Ken Delius & 576.4965 \\
\hline Y.12 Site Waste Disposal Coordinators & Chris Smith & $576-6526$ \\
\hline Y.12 ER Project Manager & Judy Hodgins & $576-2368$ \\
\hline Engineering Division Principal Engineer & $\begin{array}{l}\text { BIII Barton } \\
\text { John Baker }\end{array}$ & $\begin{array}{l}576.0519 \\
574-1064\end{array}$ \\
\hline Y-12 Site Industrial Hygiene & Rudy Weigel & 241.2487 \\
\hline Y.12 Site Environmental Management & Wayne McMahon & 574.7535 \\
\hline Y-12 Site Industrial Safety & John Peters & 574.2178 \\
\hline
\end{tabular}


$10-13$

Table 10.3. Active waste management facilities at the Y-12 Plant

\begin{tabular}{|c|c|c|c|}
\hline \multicolumn{2}{|r|}{ Facility } & Waste managed & Contact \\
\hline 1 & Y-12 Centralized Sanitary Landfill & Sanitary Waste & $\begin{array}{l}\text { J.R. McDeerman } \\
\text { 576-8461 }\end{array}$ \\
\hline 2 & New Salvage Yard & $\begin{array}{l}\text { Clean scrap metal and } \\
\text { unserviceable equipment }\end{array}$ & $\begin{array}{l}\text { B.R. Patton } \\
574-0446\end{array}$ \\
\hline 3 & Inciustrial Waste Landfill IV & $\begin{array}{l}\text { Classified, nonhazardous, } \\
\text { nonradioactive, solid waste }\end{array}$ & $\begin{array}{l}\text { J.A. Coffey } \\
576-7898\end{array}$ \\
\hline 4 & 9720-12 Non-SNM Warehouse & Low-level radioactive waste & $\begin{array}{l}\text { V.W. Tassey } \\
576-8462\end{array}$ \\
\hline 5 & $9720-25$ & $\begin{array}{l}\text { Classified, radioactive, classified } \\
\text { hazardous, and mixed storage } \\
\text { wastes }\end{array}$ & $\begin{array}{l}\text { M.C. Wiginton } \\
576-7768\end{array}$ \\
\hline 6 & Spoil Area I & Clean demolition spoil & $\begin{array}{l}\text { J.A. Coffey } \\
\text { 576-7898 }\end{array}$ \\
\hline 7 & Interim Reactive Treatment (NAK) & Water reactive waste & $\begin{array}{l}\text { S.R. Fain } \\
\text { 576-5816 }\end{array}$ \\
\hline 8 & OD-8 & $\begin{array}{l}\text { Clean, PCB, radioactive, hazardous } \\
\text { and mixed oils and solvents }\end{array}$ & $\begin{array}{l}\text { C.F. Wisener } \\
\text { 574-6847 }\end{array}$ \\
\hline 9 & OD.9 & $\begin{array}{l}\mathrm{PCB} \text {, radioactive, hazardous and } \\
\text { mixed oils and solvents }\end{array}$ & $\begin{array}{l}\text { C.F. Wisener } \\
574-6847\end{array}$ \\
\hline 10 & 9407.7 PCB Storage & PCB and uranium solids & $\begin{array}{l}\text { L.C. Duncan } \\
574-0882\end{array}$ \\
\hline 11 & 9720-31 (RCRA Motel) & RCRA waste, nonradioactive & $\begin{array}{l}\text { S.A. Bowen } \\
574-1707\end{array}$ \\
\hline 12 & PCB Shed & PCB waste & $\begin{array}{l}\text { L.C. Duncan } \\
574-0882\end{array}$ \\
\hline 13 & DARA Solids Storage Facility & $\begin{array}{l}\text { PCB, uranium } \\
574-0468\end{array}$ & R.W. Sellers \\
\hline 14 & DARA Oil Land Soils Storage & $\mathrm{PCB}$, uranium & $\begin{array}{l}\text { L.C. Duncan } \\
574-0882\end{array}$ \\
\hline 15 & Uranium Oxide Storage Vaults & Radioactive solid waste & $\begin{array}{l}\text { V.W. Tassey } \\
576-8462\end{array}$ \\
\hline 16 & Waste Feed Preparation Facility & Radioactive solid waste & $\begin{array}{l}\text { V.W. Tassey } \\
576-8462\end{array}$ \\
\hline 17 & Old Salvage Yard & Radioactive scrap metal & $\begin{array}{l}\text { B.R. Patton } \\
574-0466\end{array}$ \\
\hline 18 & Interim Drum Yard & Hazardous and mixed waste & $\begin{array}{l}\text { S.R. Fain } \\
576-5816\end{array}$ \\
\hline 19 & East Chestnut Ridge Waste Pile & Mercury-contaminated soil & $\begin{array}{l}\text { J.A. Coffey } \\
576-7898\end{array}$ \\
\hline 20 & Contaminated Soils Storage Area & $\begin{array}{l}\text { Hazardous and mixed soils and } \\
\text { spoil material }\end{array}$ & $\begin{array}{l}\text { S.R. Fain } \\
\text { 576-5816 }\end{array}$ \\
\hline 21 & Interim Reactive Waste Area & Water reactive waste & $\begin{array}{l}\text { S.R. Fain } \\
\text { 576-5816 }\end{array}$ \\
\hline
\end{tabular}


Decontamination of equipment and sampling devices will be accomplished in accordance with ESP-900 and ESP-901.

\subsubsection{Investigation Derived Waste}

Liquid, soil, and solid waste resulting from decontamination activities will be managed as CERCLA hazardous substances and placed in appropriately labeled drums. The RI subcontractor will obtain empty drums from the ER Division Project Manager. In the event that Energy Systerns is unable to supply drums, they will be supplied by the drilling subcontractor. The subcontractor project manager will contact the Y-12 Plant Waste Disposal Coordinator (WDC) to arrange for treatment or disposal of the filled drums at the close of the field activity.

\subsubsection{Liquid IDW}

Most liquid IDW resulting from decontamination activities will be generated by steam cleaning of equipment such as hollow-stem augers and drill rods. Smaller quantities of liquid IDW will be generated as a result of washing and rinsing sampling devices such as hand augers and bailers. All decontamination water will be placed in 209-L (55-gal) drums with bung openings and analyzed for using $\mathrm{pH}$ and conductivity measurements.

\subsubsection{Soil IDW}

Soil IDW resulting from decontamination activities will include large soil clumps removed from equipment and soil cuttings from each borehole. Soil wastes derived from each borehole will be placed in open-top, 209-L (55-gal) drums, managed and stored separately within the AOC. Soil cuttings from each borehole will be characterized on the basis of analytical results from environmental samples collected from the same borehole. Based on this characterization, contaminated soils will be consolidated, containerized, and stored in a waste stockpile within the AOC until they can be remediated in conjunction with the site remediation. All unused soil obtained during the drilling of boreholes will be returned to the borehole from which it came, in accordance with EPA guidance for management of IDW. Any excess soil will be spread evenly around the borehole.

\subsubsection{Solid IDW}

Solid IDW resulting from decontamination activities will include used disposable PPE and expendable cleaning items, such as paper towels, brushes, and rags used in decontamination activities. Solid waste will be placed in open-top, 209-L (55-gal) drums. Solid and soil wastes will not be stored in the same container.

\subsection{CONTAINERIZING AND LABELING REQUIREMENTS}

Wastes generated by the RI subcontractor during field investigations and sampling activities may be collected, disposed of immediately, or provided some level of interim storage management. Until the IDW is positively identified as a RCRA hazardous waste, the subcontractor Field Operations Manager must manage IDW in a protective manner but not necessarily in accordance with RCRA Subtitle $C$ requirements. Under CERCLA, IDW may be stored in a container within the $A O C$ and returned to its source without meeting the 
specified LDR treatment standards. When IDW is disposed of off site or is transported on public roads, DOT requirements for manifesting, containerizing, labeling, and transporting waste may apply. Samples collected and shipped for analysis are exempt from the RCRA packaging, labeling, manifesting, and transportation requirements. These samples will be managed in accordance with approved procedures.

\subsubsection{Containerization}

Containers used to store RCRA waste, TSCA waste, and LLW will comply with the DOT regulations specified in 49 CFR $171-179$ for hazardous and radioactive waste as appropriate. LLW will be packaged according to DOE Order 5820.2A and $49 C F R$ 273. Each container type will be reviewed for compatibility with wastes before use. IDW will be placed only in containers approved by the Y-12 Plant Waste Management Organization.

Oak Ridge Y-12 PP 70-903, "Transfer, Storage, or Disposal of Waste," contains specific instructions for selecting the type of container for the waste type being containerized. The RI Subcontractor Project Manager will coordinate with the Y-12 Plant WDC to ensure appropriate containers for the waste generated are used. Subcontractor drilling teams normally will provide containers for their field activities; however, the subcontractor Project Manager will obtain containers for supporting subcontractor field activities and the decontamination pad in the central staging area.

Empty containers that are stored in the central staging area while awaiting use must be kept on clean pallets in good condition.

Accessory equipment required includes pallets (including clean pallets for new containers), vent plugs, bung wrenches, plastic liners for open-top-drums, labels (see Sect. 10.8.2), PPE, and handling equipment (such as forklifts and/or a pickup or flatbed truck with a hydraulic tailgate and tie-down straps).

\subsubsection{RCRA hazardous waste container requirements}

RCRA hazardous waste will be placed in containers or containers with liners that are compatible with the hazardous wastes being stored. Tanks containing RCRA hazardous waste will have a secondary containment system that includes a liner, a vault, or an equivalent device.

\subsubsection{TSCA waste container requirements}

PCB or TSCA waste containers will comply with the specifications of 49 CFR 178. Nonliquid PCB waste will be placed in containers that comply with 49 CFR 178.

\subsubsection{Low-level waste}

LLW will be placed in containers that are approved in writing by the Waste Management Officer. 


\subsubsection{Mixed waste-RCRA/LLW, LLW/TSCA, and LLW/RCRATSCA}

Mixed waste will be placed in containers compatible with the waste contents and will meet the regulatory requirements for each component of the waste characterization.

\subsubsection{RCRAVTSCA}

RCRA/TSCA waste will be contained in a DOT-specification container compatible with the RCRA waste and in compliance with the DOT waste container specification for PCB waste.

\subsubsection{Sanitary waste}

Sanitary waste will be stored and handled in accordance with the generator's agreements with site-specific utilities and maintenance personnel.

\subsubsection{Empty containers}

Empty containers that are stored in the central staging area while awaiting use must be kept on clean pallets in good condition and labeled with an "Empty" label. Labels are never to be placed on the top of the container lid. Labels are to be applied adjacent to but not covering the container's seam which is to be visible for inspection purposes.

Accessory equipment required includes 120 - by $120-\mathrm{cm}$ (48- by 48 -in.) pallets (including clean pallets for new containers), vent plugs, bung wrenches, plastic liners for open-top drums, labels (see Sect. 10.8.2), PPE, and handling equipment (such as forklifts and/or a pickup or flatbed truck with a hydraulic tailgate and tie-down straps).

\subsubsection{Labeling}

Each container of waste generated during field investigations at the Y-12 Plant will have a label identifying its contents. Information on the container contents label will include contents, location generated, hazard class (if known), name of contact, and the date that the waste was first placed in the container. Specific and any additional requirements for labeling are provided in the appropriate plant-specific waste operations procedures and/or ER site procedures.

In addition to the container contents label, other labeling requirements are required for wastes known or suspected to be hazardous and for wastes determined to be radioactive, as specified in the waste management project plan. The RI Subcontractor Project Manager will coordinate with the Y-12 Plant WDC to obtain the appropriate labels for IDW containers.

Labeling requirements are further described in Y-12 PP 70-903. The RI Subcontractor Project Manager will ensure that the following tags/accessories are available:

- Forms UCN-2114A and UCN-2114B-Hazardous Waste Identification and Waste Identification Tags

- Form UCN-100732-Classified Information Tag

- Form UCN-14B-Health Physics Material Transfer Clearance Form 
10.17

- Form UCN-15C-Contamination Radiation Form

- Form UCN-2491B-Health Physics Restriction Tug

- Form UCN-15265-Emply Label

- Form UCN.119(1)4A-Beryllium Label

- "<50 ppm PCBs" and "PCB Label" labels

- Self-adhesive vinyl envelopes

- "CONTAINER" bar code labels (tankers, polytanks, or tuff tanks will have permanent bar code labels applied hy the Y.12 Plant Waste Management Division)

\subsection{WASTE ESTIMATES}

Volume estimates for each anticipated waste stream are given in Table 10.1. These estimates were prepared based on anticipated sampling activities described in Chap. 7. Table 7.3. Table 10.4 provides an estimate of waste generation volumes per site during the BCV OU $1 \mathrm{RI}$.

\subsection{SAMPLE MANAGEMENT-WASTE ANALYSIS AND CHARACTERIZATION PLAN FOR DISPOSAL}

The subeontractor will manage samples collected during field investigations and sampling activities investigations at the Oak Ridge Y.12 Plant in accordunce with relevant federal, state, and DOE guidelines and existing Energy Systems policies and procedures. Samples collected during these CERCLA driven activities shall be collected in accordance with Energy Systems Environmental Surveillance Procedures, ESP-301-1 through 301-5; ESP-302.1 through 302-5; ESP-303.1 through 303.7; ESP-304-1 and ESP-3(1)4-2; ESP-305-1 and 305-2; ESP.306; and Y.12 Plant Procedures, "Waste Transportation, Storage, and Disposal Department Sampling Procedures." Samples will be categorized as "Classified" or "NonClassified" and will be packaged, labeled, marked, and shipped for analysis accordingly. "NonClassified" samples will be managed in accordance with the procedure, "Sample Classifying, Packaging, Marking, Labeling, and Shipping for Analysis Through Y.12 and K-25 Environmental Restoration Programs." QA Samples and sample residuals will be archived as required by the Project Manager. An overview of the applicable provisions of the referenced procedures and management strategies is provided in the sections that follow.

Sample management is regulated at the federal and state level. Hazardous waste samples as defined in 40 CFR 261.3 are exempt from RCRA regulation if the terms of 40 CFR 261.4(d) are met. This exemption does not apply if the laboratory determines that the waste is hazardous because the laboratory is no longer meeting any of the conditions stated in paragraph $(d)(1)$ of that section. No such standards, exclusions, or limitations exist for hazardous substance samples. However, managing of hazardous substance samples as if they were hazardous waste may be appropriate based on Section $104(c)(3)(B)$ of CERCLA, which requires that any off-site treatment, storage, or disposal of hazardous substances be conducted in compliance with Subtitle C of the Solid Waste Disposal Act. 
$\stackrel{\underline{x}}{\underline{\underline{z}}}$

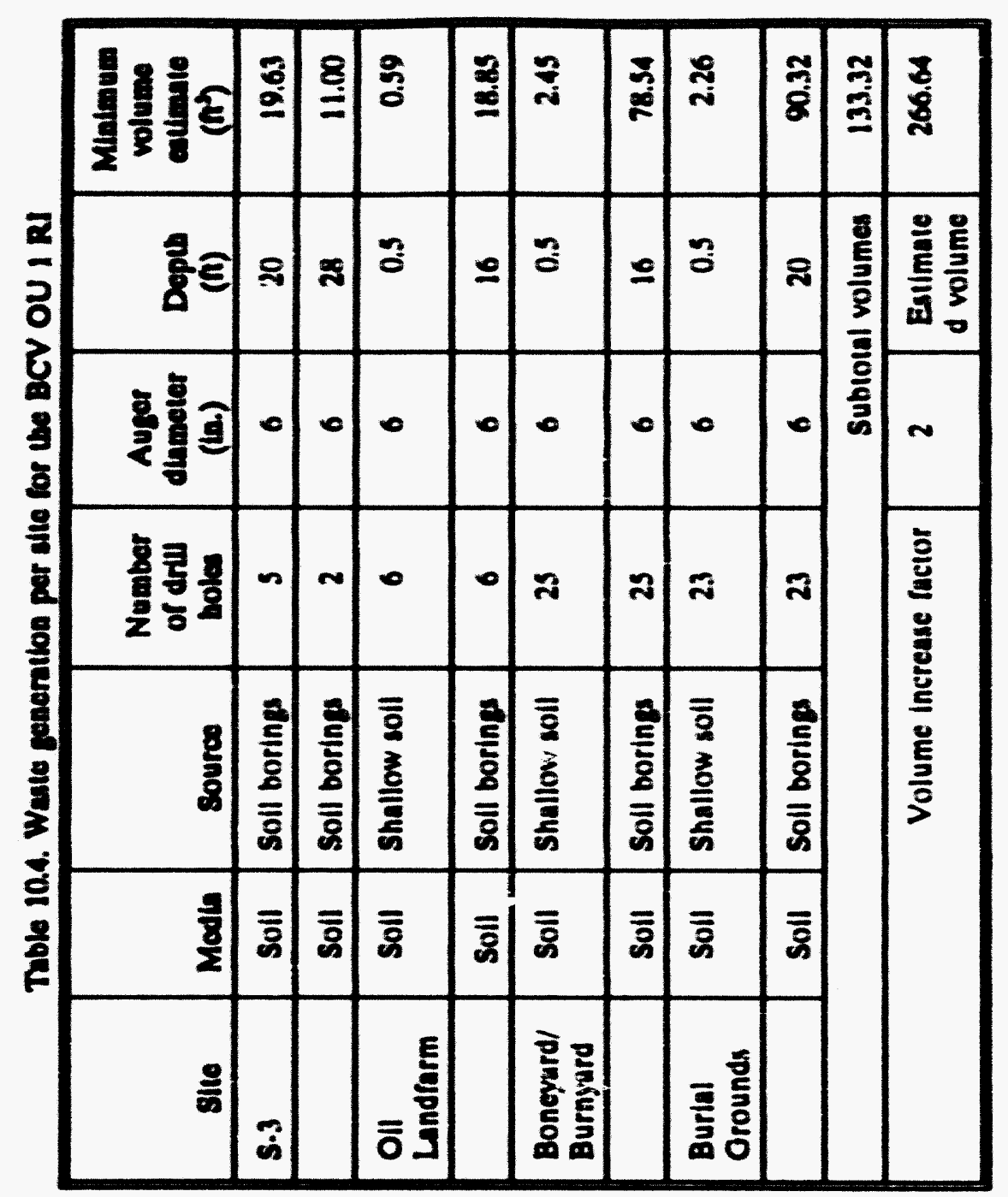




\subsubsection{Conified Suniplow}

Samples will be calegorized as "clasaified" when the sample, due li lis componition. structure, of function, eithet direclly of through analyais, reveals resiticied dath of othet clasified information. Y.12 Plant ER peraonnel must be contacled and will delermine whether the anmples will be categorited and managed an clasifned.

\subsubsection{Colloceting}

Samplex will be collected in accordance with the ESP prexedures governing the apecine sampling activity (c.g., groundwater sumpling). Additionally, special prectautionary actiona musi be taken to ensure that information recorded in the field loghosk and the Requeat for Analyals form dover not include clasilied information of include enough bits and pieces of

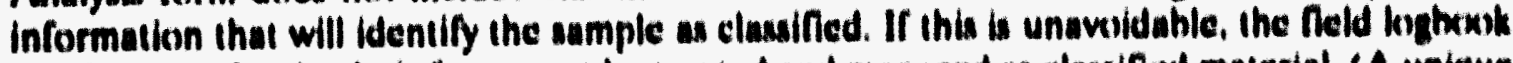
and Requeal for Analyais form mual be treated and managed as clasifled malerial. (A unique clasified numbering aysiem will he developed for clamillied samples an ihat no one olher than the individual mainiaining the numbering antem liat can ldenilify the sample as clauifled by the sumple number alone.)

\subsubsection{Packaging}

Al classilied samples must be packnged such that the clasulfled component of the wate is not revealed during routine material handling and Iranaport. Y.12 Plani ER and the Warle Trealment. Storage, and Disposal (WTSD) Department will be contacted fot specific packoging requirementa. Waste and containera musi be computible. Containen will he labeled with the properly completed Form UCN.2114A (1ag).

\subsubsection{Documentution}

The following doxumentation must be generated and maintained as a minimum for uample management: quality control records. Feld logbexok, field laborutcory equipment calibration and maintenance records, chain.of ccustody records. and shipping papen.

Chain-of-Cuntody Recorda. The chain-ol-custedy form will be completed by the sumplins ream in accordance with ESP.S(X). "Manual Chain of Cualexdy Procedurea." "the lime of the sampling event. This record documents sample cusiody iransfer from the sumplet, ofien through another person, to the sumple cuatodian in the laborutory. The form(a) will be algned a relinquished or received each time the sample changex pusucasion. from collection in final deposition in the laboratory. The chain-oflecustiody record will include the following information:

- Header information (project number and name. Contract Laboratory case number of SAS number): for cach wiation number, enter date, line, compouile/grab, ulation location. number of contuiners, analytieal parameters, and Sample Identilleation Tag number

- Signature, date, and the time next to "Relinquished by" eniry

- Person receiving the sample signature next to the "Received by" eniry, or enter the name of the carrier (c.8. United Parcel Service, Federal Expreas) under "Received hy" (Receiving laboratory will sign "Received for Laboratory by" on the lower line and enter the date and time) 
- The bill of lading of Federal Express air hill number under "Remarks or Reanon for Change of Custody." if approptiale

Place the original (lop, signed copy) of the chain-of cualudy record lorm in the appropriate sample ahipping package. Retain a cony with project nles.

Ouality conirol reoorda. Sample labels and sample seals will he used during all sampling evenis as quality control documents. Sample labels will be afthed lo all sample containen priof is of at the lime of sampling. To the exient practicable, sample hollles will be labeled prior io filling. Sample lahels will be waterprovol paper of plastic with summed hacks of waterprosol tags. an appropriate. Sample labels will contain the following information:

- Unique sample number

- Sample location

- Date and lime of sample collection

- Sample media (oil. water, soil, aludge, other)

- Anulyser required

- Commenis and special precaulions as needed

- Sumpler signature

Sample seals will be used to deleet poushle tampering with samples following sample collection and prior to the lime of analyals. The seal will be allached in such s way inat if is neceasury to break the seal in order to open the sumple contuiner. Samples that are deatined for off-alie laboratories. lor overnight storage, of lo leave the sumpler's sile will have a sumple seal affxed io the sumple contuinet of will be keked to prevent tampering with samples. Sample seals are not required for containers delivered directly from the fleld to the on-alte labotatory. Sample seals will include the following information:

- Requisilion number of chuin of acumlixdy number

- Name(a) of collector(a)

- Date and lime of inmple collection

Fold koghook. Field logbeoks will be maintained during all sampling events. An eniry will be made is the fleld logbxik and completed at the time the sample is iaken. This entry will include the following information at minimum:

- Unique sample number

- UCN.2109 number

- Date and lime of ample collection

- Sample media (oil, water, moil, sludge, ele.)

- Suspected composition, including concentration, as appropriale (e.g. mercury or PCBs)

- Analytical parameters to he measured

- Presenvatives used and number of ample bolles 
$\mid 1121$

- Location of sampling point (e. field or huilding corerdinales of sample location. arid number, well number, elc.)

- Designation of OC samples (c... duplicates, tinsates, or hlanks)

- Sampling methodolong (equipment uned and depih in ctoniainet from which sample wa (aken)

- Observationa made during sampling (c, R., odom, colon, and lexlures)

- Chain.of ccualiody conirol number

- Field observalions and measurements

- Sample diaribulion (appropriale lab)

- Identilication of sampling Ieam

- Diagenal line drawn from the heginning of the las eniry lo the next in the holiom line (for any partially emply pages at the end of the day)

At the complesion of each day, the sumpling leam will give the field loghoost in the sumpling leam leader for review. The sampling leam lender will review all he eniries and will sign off daily on the las line on the mollom of the page.

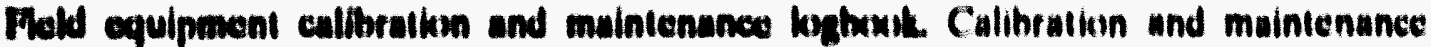
activitios must be entered into the reapective equipment calibration of maintenance logkwok. These entrias should be longed at the lime the activiliee are iniliated and completed and the reaulu of ench doxumenied.

\subsection{Nonchallined Sampla}

Sumples that are not "clasuified" will be termed "nonclasuifled" Nonclasaified samples will Include environmenial, hasardous, of radiolongical samplen. Based on Irest judgement of regulatory knowledge. historical knowledge of the sile, and fleld screening activities. the umpling leam leader of desiznee will calegorioe the sample. A sample will be calegorized a radiological based in historical knowledge of when reading three II He limes above backyround are delected. A sumple will be calegorized an haeardous when ils characteriatica

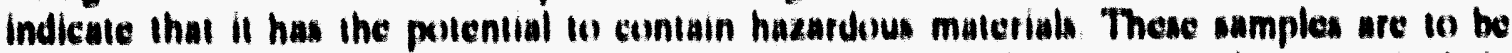
shipped and packaged in accordance with DOT regulation. Environmental samples include unmples of nalurally oceurring matrices such as soil, sediment, yroundwater, surfoce water, and alr. Environmental samplen containing hacardous materials are exempt from the RCRA packoging. labeling, marking, Iransporting, and manifeating requirements when these sumples are ahipped for analyais.

\subsubsection{Cullecting}

Samples will be cellected in accordance with appropriale ESP proxedure(s) for a specille sampling activity. The sampling leam leader is responsible for ensuring the sumple team members are knowledgeable of the proper collecting lechniques. 


\subsubsection{Packaging}

Nonclasaified amples must be packaged in accordance with the procedure. "Sample Clasalfying. Packaging. Marking. Labeling, and Shipping for Analyais Through the K.25 and Y.12 Environmental Realoration Programs." Y.12 ER and WTSD Department will be contacted for specific packaging requirements. Waste and containers must be compaible. Containen will be labeled with the properly completed Form UCN.2114A (1ag). A brief descripition of these packaging requirements are discusaed helow for each reapective sample clasification.

Rediokgleal samples. Radiological sumples will be packaged in accordance with EPA. Energy Syatems guidance, and DOT requirements. Accordingly, the inner package of radiological amples are packuged by:

- Wiplng down the sample containet exterior, placing the container in al least one plasic bag. and securely laping the bag shut with duct lape (note: closure of Zip. Lox baga is not sufficient: these bags must be iaped closed)

- Marking Inner packnges with appropriale radionactive materials tagn (UCN.2785) based on the resulis of radiological survey(1) conducted by the survey lechnician

- Annotating the dose rate at the surface of the container provided by survey technician

These inner packuges will be placed in elther "strong light container of . Type A package lor use a required by the category of shipping. Samples will be packed to prevent shifilng of the inner containers during shipment. Nove Chempack" or other K.25/Y.12 approved packing materials will be used io pack all water and soil samples.

Samples requiring Type A packaging will be packuged in the same munner a LSA materials, with the addilional requirement that the cooler or sirong light container must be placed in ateel drum that conforms io DOT specification 7A Rigid polyethylene foum inserts will be placed around the containe lo keep il from ahifling within the drum.

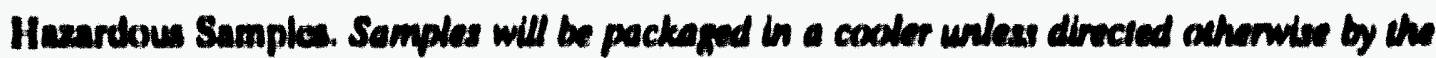
sien Tranponation Operations Group. Hazardous materials will be packaged in accordance with DOT HM:181 requirements and proxedure. "Sample Classifying. Packaging. Marking. Labeling, and Shipment for Anulysis."

\subsection{Marking and Iabeling of the shipplne packugo}

The sampling team leader of designee will mark and label each outer package with the proper shipping name, identification number (HM.IBI Classification number), and the names, addreasen, and telephone numbers of the conalgnee and consignor. Note: Envirommental samples do not need shipping nameinumber. In addition. Type A packages will be clearly

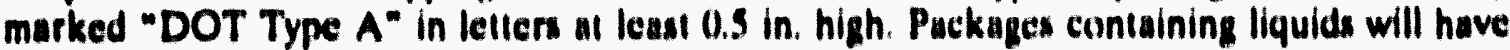
"This Side Up" or "This End Up" orientation markings and a double orientation arrow. Packagen in excess of $49 \mathrm{~kg}(110 \mathrm{lh})$ will be plainly marked with the gros weight, and packages containing glass will be marked "Fragile." Packages sent by commercial courier will he marked in aceordance with the courier's procedures. 
Labels will he printed on the package or aflixed to the packuge near the marked proper shipping name. Labels will be placed on a lag if the package has irregular surfaces. Labels will be placed on Iwo sides or Iwo ends of the package (excluding the bollom) and will not be obacured by markings or allachments. A "Cargo Aircrafi Only" label will be placed on all Type A shipments. Place this label near the proper shipping name in such a manner that any other labels or markings are nol obscured. Packages sent by commercial courier will he labeled in accordance with the courier's procedures.

\subsubsection{Documentution}

The following documentation must be generated and maintained as a minimum for sample management: quality control records, field logbook, field laboratory equipment callbration and maintenance records, chain-of-custody records, and shipping papen. These documenta will be prepared and maintained in accordance with guidance outlined in Sect. 10.10.1.3.

\subsubsection{Shipment for Analyals}

The sampling team leader will determine whether the sample(s) will be transported on or off sile for analyais. Shipment will be conducted in accordance with ER/C.P2302, "Sample Clasaifying. Packuging. Marking. Labeling. and Shipping for Analysis Through the K.25 and Y.12 Environmental Restoration Programa." The sumpling team leader will enuure that a copy of the contracted laboratory's radiation license is in his pousemion before any mixer wase or radiological samples are shipped for analyais. In addition, applicable packaging. handling. and shipping requirements identified by the contracted laboratory will be followed.

\subsubsection{Anubytical Wuste}

Conformance with 40 CFR 261.4 (d) requires that hazardous samples be returned to their generator for proper management after the analyais. This return should be apecified as an agreed-upon last iask in analytical contracts for hazardous samples if the project manager whtses to avoid the effort entalled in treating the material as other than a sample. Without the RCRA sample exclusion. sumples would require manifesting for shipment io the Iaboratory; the receiving facility would need to be a RCRA TSD facility; and off site ultimate diaposal would require yet another manifest.

When samples received by laboratorics are clearly not hazardous by RCRA or CERCLA definitions or are determined by unalysis to be nonhazardous, they are not required to be managed in accordance with the RCRA exclusion paragraph. However, before any nonhazardous sumples are disposed of as part of laboratory solid refuse or wastewater, the state and local solid waste codes and industrial wastewater discharge codes should be examined to ensure that their terms are being met. Even for these nonhazardous samples, it might be necessary to have contract conditions or additional fees to cover the disposal of samples.

Analytically derived waste may or may nol he classified as hazardous wastes or hazardous substances. Nonhazardous analytical waste may be disposed of in accordance with state and local solid waste and industrial waste water discharge requirements. Typically, these wastes can be dispessed of in the wastewater discharged from the laboratory to the sanitary sewer. However, analytical waste derived from listed hazardous wastes, or the chemicals used to 
obtain the derivative. could cause the waste to be classified as hazardous. RCRA regulations provide for such waste to be disposed of with laboratory wastewater if certain conditions are met. Wastes that are considered hazardous only because of a characteristic are no longer hazardous once they are mixed to eliminate the characteristic. Mixing small volumes of analytical waste with the sanitary sewer fow would cause the waste to become so diluted that it no longer exhibits hazardous characteristics.

CLP laboratories will assume responsibility for sample residuals at the laboratories, with the exception of mixed waste; all unused mixed waste will be returned. Non.CLP laboratories will not assume rexponsibility of sample residuals; accordingly, the project manager must make arrangements for the proper disposal of archived or unused samples.

\subsubsection{Archiving of Samples}

Unused samples returned from laboratory analysis and testing, will be characterized based on analytical analysis. Nonhazardous solid wastes will be returned to AOC; Hazardous solid wastes will be coordinated through Waste Management Organization for disposal at a hazardous waste treatment, storage, disposal facility with available capacily. Liquid hazardous wastes will be coordinated through Y.12 Plant WTO and treated at Y.12 WETF.

At EPA's direction and for quality assurance reasons, duplicate samples are often collected and stored or archived for later use. The project manager will identify samples to be archived, determine where and for how long samples will be archived, and make the necessary arrangements with the storage facility. It is important I0 manage these samples properly because reanalysis may he required. However, reanalyses may yield unreliable data if the samples are stored past their holding time.

Unused samples generated by the on-site analytical laboratories will be stored by the laboratories for a predetermined period before repackaging for management at the appropriate treatment, storage, or disposal facility. Unused samples generated at an off-site analytical laboratory will be returned to the site from which the sample originated. Unused samples accountability upon return from the off-site laboratory will be the responsibility of the project manager.

\subsection{WASTE MINIMIZATION}

As described in Sect. 10.3, efforts will be implemented to minimize the generation of IDW and to segregate waste generated during the field investigations.

\subsection{PROJECT PARTICIPANTS}

Table 10.1 provides names of project participants including waste generator, waste handler, waste transporter, waste treatment and disposal organizations, and responsible parties. 


\subsection{FIELD STAGING AREAS}

In accordance with the work plan, the RI Subcontractor Project Manager will select an area within the AOC to serve as the FSA for the site. The Project Manager will base selection of the FSA on the preliminary assessment of the site and IDW volume estimates by type to be generated during RI. The FSA will be clearly posted and adequate aisle spacing will be provided. In accordance with this same procedure, a logbook will be maintained to record weekly inspections of the containers stored in this area. Record of any leaks or spills, missing labels, tags, placards, or unusual conditions will be maintained. Inspections will be conducted weekly until completion of remediation activities.

Upon completion of RI activities, the RI Subcontractor Project Manager will decide if continued storage of the IDW is appropriate until the remedial action is implemented. Following characterization of wastes that will be transferred to a permitted TSD facility, the Project Manager will notify the Waste Management Organization of the quantities of IDW involved (i.e., those IDW that cannot be returned within the AOC) and will make arrangements for disposition of IDW and transfer of responsibility to the Waste Management Organization.

In addition to the FSA. the RI Subcontractor may need to establish project-specific equipment and material FSAs when an investigation site is located within a secured area of the Y-12 Plant that has restricted access. The ER Division Project Manager will be responsible for locating and securing access to an area that can be used for temporary staging and decontamination.

All FSAs will be clearly posted and will have barriers. FSA barriers will be constructed of fencing and will be marked with hags, identification markers, and tape, as deemed necessary. The type of barrier used will depend on the condition of the site, its accessibility/ocation, its security level (i.e., restricted/unrestricted), the equipment/materials stored in the FSA, and the activity or testing being performed.

Access to all FSAs will be properly maintained and controlled. Necessary precautions will be taken to prevent unauthorized access, damage, alteration, or tampering in FSAs that contain expensive or critical test equipment, irreplaceable test data, and records.

\subsubsection{Locations}

Waste FSAs will be designated within the confines of the BCV OU 1 RI where appropriate. Figure 10.2 denotes the general location of the FSAs. There will be three staging areas, one located in the vicinity of each waste area: the S-3 Site, the Oil Landfarm area (to serve the Oil Landfarm and the Boneyard/Burnyard, and the Burial Grounds. This will reduce the amount of sample transport on site and will reduce the possibility of cross-contamination between waste areas.

\subsubsection{Special Requirements}

Special requirements for the FSAs will involve the use of DOE-specification drums and poly tanks for solids and liquids as stated in Sect. 10.8. for low-level solids wastes, Waste Management Division-approved B-25 boxes will be used. Labeling requirements (Sect. 10.8.2) for these areas will apply for drums and boxes. Areas will be llagged or roped off and 


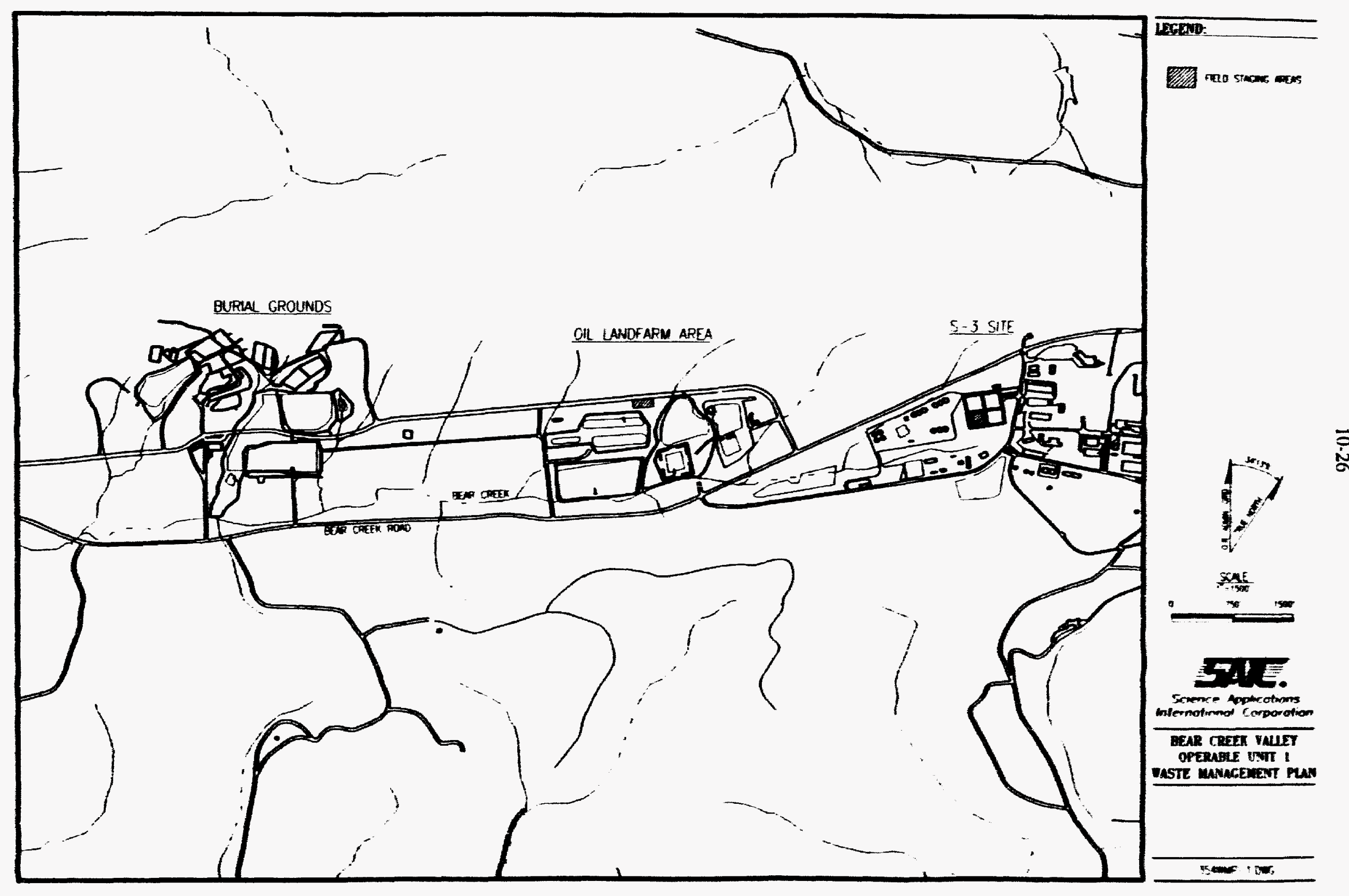

Fig. 102. General beation of FSAs. 
applicable warning signs will be posted at areas where needed indicating either a 90-d accumulation area or a radiological area. Indigenous waste (contaminated soil) will be placed in a central location in the AOC. The soil will be stockpiled in separate piles according to contamination (hazardous, low-level, or mixed waste) with adequate protection and labeling for each pile. Stockpiles will be flagged or roped off with applicable warning signs where needed, indicating characterization of waste. Poly tanks will be used to store decontamination fluids, groundwater, and well water. The poly tanks will be labeled according to the labeling requirements in Sect. 10.8.2. All wastes are to be inspected weekly and handled in a manner that is protective of human health and the environment and in accordance with K-25 Site standard operating procedure (WSO-OP-2008) and in accordance with Energy Systems ER IDW policy ER/Y.P2103 (IAD).

\subsubsection{Responsible Organizations}

RI Subcontractor will be responsible for transporting wastes from the point of generation to designated FSAs, under the guidance and direction of the Y-12 Plant ER Division. The Y-12 Plant ER Division will be responsible for transporting the wastes from the field staging area to a permitted or interim status TSD facility.

\subsection{REQUIRED TRANSPORT ACROSS PUBLIC ACCESS ROADS}

IDWs generated during the RI investigations will remain on the Y-12 Plant site and are not expected to be transferred across public access roads. Before transporting waste from the field investigation site for treatment, storage, or disposal, the Project Manager, in coordination with the Y-12 Plant WDC identifies a TSD facility; completes a request for disposal package lusing Form UCN.2109. Request for Transfer, Storage, or Disposal of Waste, or WSIN CALL-IN FORM or State Identification Form (see Y-12 PP 70-903, Appendix A)I: selects a route of transport: and performs a visual inspection of the waste containers. These activities are described below.

After verifying that all waste transfer requirements have been met, the Y-12 Plant WDC coordinates on-site and off-site waste transportation with Y-12 Plant waste management personnel and the Energy Systems Central Waste Management Division.

\subsubsection{TSD Evaluation and RFD Documentation}

The WDC prepares a request for disposal package that includes iie original site-approved request for disposal, copies of analytical results, and supporting documentation [i.e.. MSDSs]. The WDC reviews the request for disposal package for technical accuracy, and determines the appropriate TSD option.

\subsubsection{Visual Inspection of Waste Containers}

The WDC will conduct a visual inspection of waste containers before they are removed from the project site. This review shall determine if transfer standards are met and if wastes are ready for transport. Additionally, the WDC verifies, in accordance with DOT regulations and the EPA waste manifest requirements in 40 CFR 262, the following: 
- The container count according to the manifest (RFD form for on-site transportation and the EPA uniform Hazardous Waste Manifest for off-site transportation)

- Each container is labeled properly, legibly, and in accordance with the instructions provided by the WDC on the manifest

- The contents of each container have been characterized

- The containers are sealed securely

- Each container has been surveyed by health physics personnel for external gross alpha, beta, and gamma radiation and approved for transport. If approval is granted, the WDC shall sign the RFD form and waste container tags

\subsubsection{Transportation}

Upon verification that all waste transfer requirements have been met, the WDC coordinates on-site and off-site waste transportation with the Site Waste Management personnel and Central Waste Management Division. Waste scheduled for removal from the project site shall be transported on a public thoroughfare to an on-site or off-site TSD facility in accordance with all DOT regulations.

\subsection{WASTE STORAGE REQUIREMENTS}

Waste stored for on-site or off-site disposal (outside an AOC) will be characterized, packaged, and labeled in accordance with the waste acceptance criteria associated with the designated waste storage facility.

Under certain circumstances the Project Manager may place IDW within the AOC by returning the waste to its source as described in the scenarios of the ER procedure for management of IDW. If IDW is determined to be a RCRA hazardous waste and subject to LDRs, "land disposal" of the IDW will be prohibited unless specified treatment standards are met. "Land disposal" applies to wastes from different AOCs that are consolidated into one $A O C$; wastes that are moved outside an $A O C$ (for treatment or storage) and returned to the same or a different AOC; or wastes that are excavated, placed in a separate hazardous waste management unit, and then redeposited into the AOC. However, RCRA waste stored in a container (as defined in 40 CFR 260.10) within the AOC and then returned to its source is permissible without meeting the specified LDR treatment standards. This action does not constitute "land disposal" because a container does not constitute a hazardous waste management unit. Therefore, returning IDW that has been stored in containers (not tanks or other RCRA-regulated units) within the AOC will be an acceptable waste management option, as long as containers are not managed in such a manner as to constitute a RCRA storage unit as defined at 40 CFR 260.10.

\subsection{RCRA SATELLITE AND 90-D ACCUMULATION AREA REGISTRATION NUMBERS AND LOCATIONS}

RCRA hazardous constituents are not the primary contaminants of concern during the RI. However, if analytical data indicate that IDW is RCRA hazardous, these wastes will be stored in the satellite or 90-d accumulation areas. In accordance with IAD-SPP-4603, 
"Satellite and 90-d Accumulation Area Management," dated April 14, 1992 (see Appendix I), the satellite and 90-d accumulation areas will be registered with and approved by the Y-12 Site Environmental Management Department and Y-12 Plant Waste Management Division for waste characterized by analytical data as RCRA hazardous. A unique registration number will be assigned to each identified satellite and accumulation area.

\subsubsection{Waste Storage Area Locations}

Waste that is stored in 90-d accumulation or low-level waste storage areas after being characterized by analytical data will be transported to permanent storage by the Y-12 Plant WTSD.

\subsubsection{Waste Acceptance Criteria Requirements}

Waste acceptance criteria requirements for the satellite areas and the 90-d accumulation area will be in accordance with 40 CFR 262, "Standards Applicable to Generators of Hazardous Waste," with respect to containers, labeling, accumulation times, and inspections.

\subsubsection{Responsible Organization}

The Y-12 ER Division Project Manager, or designated representative, will be responsible for registering the satellite and accumulation areas with the $\mathrm{Y}-12$ Plant ER Division RI Subcontractor, under the direction and guidance provided by the Y-12 Plant ER Division Project Manager, will be responsible for transferring wastes from the satellite area to the $90-\mathrm{d}$ accumulation area, and ensuring that the standards set forth in 40 CFR 262 are followed.

\subsection{IDENTIFICATION OF POTENTIAL TREATMENT OPTIONS AND FACILITIES}

Potential treatment options identified by the Y-12 Plant ER Division for liquid wastes are the Y-12 Plant's West End Treatment Facility, the K-25 Site's Central Neutralization Facility (CNF), Central Pollution Control Facility, or the Groundwater Treatment Facility upon meeting the specific facility's waste acceptance criteria. An option identified for solid low-level wastes may be incineration and compaction by Scientific Ecology Group, Inc.. Another potential option could be the K-14.35 TSCA Incinerator. Treatment options will be decided based on analytical results, waste acceptance criteria requirements for treatment facilities, and type of waste that is generated.

\subsubsection{Special Waste Acceptance Criteria Requirements of Potential Treatment Facilities}

Specific waste acceptance criteria for the K-25 Site CNF are specified in K/SS-538, The Oak Ridge Gaseous Diffusion Plant K-1047-H and K-1407-A Central Neutralization Facility Waste Acceptance Criteria; and the K-1435 TSCA Incinerator waste acceptance criteria are specified in K/HS-252/R2, Waste Acceptance Plan and Analytical Protocol for the K-1435 Toxic Substances Control Act Incinerator. The Y-12 Plant's West End Treatment Facility, Central Pollution Control Facility, and Groundwater Treatment Facility waste acceptance criteria are not identified in formal documents. The analytical data provided by the waste generator to the treatment facility operator are reviewed against permit limits to determine acceptance criteria are not identified in formal documents. The analytical data provided by 
the waste generator to the treatment facility. The Y-12 Plant WDC will review the analytical data provided by the waste acceptance criteria are not identified in formal documents. The analytical data provided by the waste generator to the treatment facility. The Y-12 Plant's West End Treatment Facility, Central Pollution Control Facility, and Groundwater Treatment Facility waste acceptance criteria are not identified in formal documents. The analytical data provided by the waste generator to the treatment facility operator are reviewed against permit limits to determine acceptance of wastes at the treatment facility. The Y-12 Plant WDC will review the analytical data to be provided to determine if contaminant levels are below or exceed the criteria established for he treatment facilities. If the contaminant levels exceed the criteria, the wastes may require on-site storage.

\subsection{IDENTIFICATION OF POTENTIAL DISPOSAL OPTIONS AND FACILITIES}

The WDC prepares a request for disposal package that includes the original site-approved request for disposal, copies of analytical results, and supporting documentation (i.e., MSDSs). The WDC reviews the request for disposal package for technical accuracy, and determines the appropriate TSD option.

\subsection{AMENDMENTS}

Amendments and revisions to the Waste Management Plan will be documented and submitted to the ER Project Manager for approval. Amendments will be numbered and dated consecutively and submitted through the review and approval cycle.

\subsection{WASTE MANAGEMENT PLAN REVIEW/APPROVAL SIGNATURES}

An example of the Approval Signatures form is shown in Fig. 10.3. 
Approval sigmatures indicate concurrence with and approval of the contents and intent of this WMP.

APPROVAL SIONATURES

Y.12 ER Waste Certification Officer

Date

Y.12 ER Project Manager

Date

SAIC Project Manager

Date

Y-12 Site Waste Management Division

Date

Prepared by: SAIC

Y-12 ER Program

March 1993

Revision No.

Fig. 10.3. Sample Approval Signatures Form. 


\section{REFERENCES}

Aluhuller, A. P., and R. A. Linthurst (eds). 1983. The Acidic Deposition Phenomenon and its Effects, Vol. II: Effects Sciences. EPA/600/8-83/016B, U.S. Environmental Protection Agency, Washington, D.C.

ANSI/ASME (American National Standards Institute/American Society of Mechanical Engineers). 1986. Quality Assurance Program Requirements for Nuclear Facilities. NOA-1, Now York.

APHA. Standand Methods for the Analysis of Water and Wastewater.

Ashwood, T. L, and B. P. Spalding. 1991. SWSA 6 Imterim Comective Measures Environmental Monitoring: FY 1990 Results. ORNL/TM-11360, Oak Ridge National Laboratory, Oak Ridge, Tennessee.

Bailey, J. K. 1979. History: Y.12 Oil Disposal. Y-12 File Report, Union Carbide Corp., Oak Ridge Y-12 Plant, Oak Ridge, Tennessee.

Battelle (Battelle, Inc.). 1986. Geologic Report and RCRA Clasure Plan for Oll Retention Ponds, DOE Y.12 Plant, Oak Ridge, Tennessee. Columbus, Ohio.

Binford, A 1993. Tennessec Department of Environment and Conservation, Division of Superfund, personal communication to E. L. Etnier, April 13.

BNI (Bechtel National, Inc.). 1983. Preliminary Characterization and Remedial Action Plan for the Y.12 Plant Oil Landfarm. Y/Sub/83-47974C/1, Oak Ridge Y.12 Plant, Oak Ridge, Tennessee, October.

BNI. 1984. Geologic and Hydrogeologic Data for Bear Creek Valley Burial Grounds $A$ and B. Y/Sub/84-47974C/2, Oak Ridge Y-12 Plant, Oak Ridge, Tennessee.

BNI. 1991. Characterization Repon for the Elza Gate Site, Oak Ridge, Tennessee. DOE/OR/20722-278, U.S. Department of Energy, Oak Ridge, Tennessee.

Bogle, M. A. R. R. Turner, and S. D. Easterling. 1991. Characterization of Contamination Along the Upper Reaches of the East Fork of Tributary 8 at Burial Ground $C$ in Bear Creek Valley, Y/TS-720, Martin Marietta Energy Systems, Inc., Oak Ridge Y.12 Plant, Oak Ridge, Tennessee, February.

Bohrman, D. E. 1989. Oil Landfarm Summary of Closure Under Rules Goveming Hazardous Waste Management in Tennessee. Y/TS-394/2, Martin Marietta Energy Systems, Inc., Oak Ridge Y-12 Plant, Oak Ridge, Tennessee, November.

Bowen, H. J. M. 1966. Trace Elements in Biochemistry. Academic Press, New York. 
Bradburn, D. M., and E. H. Rowenbalm. 19\%4. Resource Manazement Plan for the U.S. Depariment of Enery Oak Ridge Resenvation, Appendix o: Forest Management. ORNL6026-V6, Oak Ridge National Laboralory, Oak Ridge, Tenneasee.

Callahan, M. A et al. 1979. Water-Relator Environmental Fate of 129 Priority Pollutants, Vol. I: Introduction and Technical Backwound, Metals, and Inomganics, Pesticides and PCBs. EPA/40/4-79/029A. U.S. Environmental Protection Agency, Washington, D. C.

Chance, W. W. 1986. Resource Management Plan for the Oak Ridge Resenvation: Resource Information and Site Analysis (V. 22). ORNLESH.1N22, Martin Muriella Energy System, Inc., Oak Ridge National Laboratory, Oak Ridge, Tennewsee.

Clay, D. R., Asaiatant Administrator, Solid Wate and Emergency Reaponse, Environmental Protection Agency. 1991. Memorandum tilled "Update on OSWER Soll Lead Cleanup Guldunce," Auguat 29.

Collins, E. T. 1990a. Oll Retention Ponds (T.008, T.009) Summary of Closure Under Rules Goveming Hazandous Waste Management in Tennessee. Y/TS-392/2, Onk Ridge Y.12 Plant, Oak Ridge, Tenneasec, May.

Collins, E. T. 1990b. Bear Creek Burial Ground C.West Summary of Clasure Under Rules Governing Hazandous Waste Management in Tennessee. Y/TS-395/3, Onk Ridge Y.12 Plant, Oak Ridge, Tennesee, December.

Cushman, R. M., S. O. Hildebrand, R. H. Strand, and R. M. And 'on. 1977. The Taxiciny of 35 Trace Elements in Coal to Freshwater Blota: A Data Base with Automated Retrieval Capabilities. ORNLTM-5793, Oak Ridge National Laboratory, Oak Ridge. Tennesuee.

Davis, B. E. 1990. Applied Soll Trace Elements. John Wiley and Sons, Now York.

deLaguna, W., et al. 1963. Engineering Development of Hydraulic Fracturing as a Method for Permanent Disposal of Radioactive Wastes. ORNL/4259, Oak Ridge National Laboratory, Oak Ridge, Tennessee.

DOE (U.S. Department of Energy). 1980. Oak Ridge Reservation Land-Use Plan, Rev. I. DOE/ORO-748, Oak Ridge Operations Office, Oak Ridge, Tennessec, March.

DOE. 1982. Environmental Assessment, Y.12 Plant Site, Oak Ridge, Tennessee. DOE/EA-0182.

DOE. 1990a. Requirements for Quality Control of Analytical Data. DOE/HWP-65/R1, July.

DOE. 1990b. Quality Control Requirement for Field Methods.

DOE. 1993. RCRA/CERCLA Update, Vol. 92(4). Office of Environmental Guidance, January.

Dreier, R. B., D. K. Solomon, and C. M. Beaudoin. 1987. "Fracture Characterization in the Unsaturated Zone of a Shallow Land Burial Facility," in Flow and Transport Through Fractured Rock. American Geophysical Union Monograph 42, pp. 51-59. 
DuBuchanne, O. D. and R. M. Richardwon, 1956. Groundwater Resources of East Tennessee. Bulletin 58, Part I, Diviaion of Ceology. State of Tenneasee Depariment of Conservation.

Enercy Systems (Mortin Martelti Energy Systeme, Inc.). 1964a. Prelliminary Assessment of Extoting Consamination in Bear Creek Valloy Waterehed Area and Aprential Remedial Actions for Mirtyating Its Impact on Bear Creek. Y YTS.91/1, Oak Ridge Y.12 Plant, Oak Ridge, Tenneavee.

Energy Syltems. 19:4b. Appendices: Preliminary Assesument of Extuting Contamination in Bear Creek Valley Watershed A mea and Potencial Remedial Actions for Mitigating iss Impact on Beer Creek. Y/TS-51/2. Oak Ridge Y.12 Plant, Ouk Ridge, Tennewece.

Enercy Systema. 1987a. Posp.Clasure Permil Application for the S.J Ponds Hazardow Waste Dispoval Unit at the Y.12 Plant. Y/Sub/87.00206C/12, Onk Ridge Y.12 Plant, Oak Ridge, Tenneace.

Enercy Systems. 1987b. Past.Closure Permil Application for the Oll Landfarm Hazardous Waste Disposal Unit ar the Y.12 Plant. Y/Sub/87.00206C/10, Oak Ridge Y.12 Plant, Oak Ridge, Tennesuce.

Energy Systems. 1987c. Envinonmental Sunvelllance of the U.S. Departinent of Enery Oak Ridge Reservation and Surmounding Environs Durng 1986. ES/ESH-1N12V2, Oak Ridge Y.12 Plant, Oak Ridge, Tenneasee.

Energy Systems. 1983. Revised RCRA Clasure Plan for the S.3 Ponds. Y/TS-393, Oak Ridge Y.12 Plant, Oak Ridge, Tennewee, Fobruary.

Energy Sytems. 1990. Clinch River RCRA Facility Inwestipation Plan. ES/ER.1/DI, Martin Marieltu Energy Sytems, Inc., Oak Ridge, Tennewee, March.

Enercy Systems. 1991. Oak Ridge Reservation Envinavmental Repor for 1990. ES/ESH.18V1\&V2, Martin Mariella Energy Syatems, Inc., Onk Ridge, Tennewec, Seplember.

Energy Systems. 1992a. Oak Ridge Reservation Site Management Plan for the Environmental Resioration Program. DOE/OR-1001/R2, Oak Ridge. Tennescec, June.

Energy Systems. 1992b. Environmental Restoration Quality Program Plan. ES/ER/TM-4/R2, Martin Marietta Energy Systems, Inc., Oak Ridge, Tennewee, August.

Enercy Systems. 1992c. Y.12 Environmental Restonation Remedial Action Surveillance and Maintenance Program Plan. Oak Ridge Y.12 Plant, Oak Ridge, Tenneasec.

Energy Syatems. 1993a. Pages Excerpted from Documents Pertaining to Bear Creek Burial Grounds Inventory. Y YSA-839, Oak Ridge Y-12 Plant, Oak Ridge, Tennessee, Auguat.

Enercy Systems. 1993b. Annual Repart on the Background Soil Characterization Project on the Oak Ridge Reservation, Oak Ridge, Tennessee: Results of Phase I Investigation. DOE/OR/01-11.36 (ES/ER/TM-43), Oak Ridge, Tennessec, May. 
Engelder, T. 1935. 'Louding Path to Joini Propagation During a Tectonic Cycle: An Example from the Appalachian Plateau, U.S.A. J. Simacrural Geol. 7(34), pp. 494-476.

EPA (U.S. Environmental Protection Agency). 1976. Qualio Criteria for Water. EPA4409.76023, Wahington, D.C.

EPA 1900. Prescribed Procedures for Measursment of Rodloactivity in Dilnkins Water. EPAVOOK4+0032.

EPA 1900b. Inedin Oubdalines and Speclfications for Arparing Qually Assurance Project Pans. OAMS oOs/an, Wahington, D.C.

EPA 19a3. Mothods for Chemical Anabsis of Warer and Wastes. EPA600/4-79020, March.

EPA 1934. Easem Envtronmental Radiation Facllin Radiochemisny Procedunes Manual. EPA 520/s-84+006, Montgomery, Alabama.

EPA 1930. Test Mothads for Evaluating Solld Waste. PhysicallChemical Methods, 3rd Ed. EPA SW

EPA 1937a. Dnafl RCRA Factlly Investhation (RFI) Culdance. EPAS30/SW+87/M01. July (with December 1987 revision 10 Sect. 8).

EPA 1937b. Data Qually Objectives for Remedial Response Activities Development Process. EPAS40/0-87/003.

EPA 1989. Guldance for Conducting Remedial Inventipations and Feasibillin Studies Under CERCLA. EPAS4010.89004.

EPA 1989b. CERCLA Compllance with Other Laws Manual, Draft Guidance, Vol. I. OSWER Directive 9234.1-01, Omice of Emergency and Remedial Reaponse, Washington. D.C.

EPA 1989c. Labonatony Data Valldation Functional Guidelines for Evaluating Organics Anabois.

EPA 1989u. Rlsk Assessment Guidance for Superfund Vol. II: Envinonmental Evaluation Manual Par A. OSWER Directive 9285.701A. OMces of Solld Waste and Emergency and Remedial Response, Wahington, D.C.

EPA. 1939\%. Ecologtcal Assessments of Hazardous Waste Sices: A Fleld and Laboratory Reference Document. EPA600/3-89/0113, Washington, D.C.

EPA 1989c. Determining Soll Response Action Levels Based on Potential Contaminant Migration to Ground Water: A Compendium of Examples. EPAS40/2-89/057, Omce of Emergency and Remedial Reaponse, Wuhington, D.C., October.

EPA. 1989d. Risk Assessment Guidance for Superfund, Vol. I: Human Health Evaluation Manual, Part A. EPA/340/1-89/002, Washington, D.C. 
EPA. 1989. Methods for Evaluaring the Altainment of Cleanup Standands. Volume 1. Solls and Solld Media, EPA 230N2+19.(042, Wahingion, D.C., February.

EPA 1990. Ten Methods for Evaluating Solld Warre, PhysicallChemical Meehads.

EPA 1900h. Contrant Labontony Prowram Statement of Wonk for Inorganic Anabsts. ILM02.0.

EPA 1901e. Contract Laboraton Prowam Starement of Wook for Onganir Anahwis. OLM01.8.

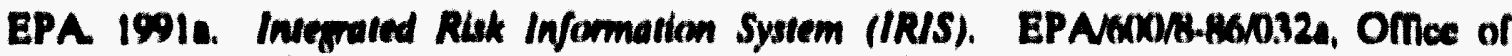
Healih and Environmental Ameument, Cincinnall, Ohio.

BPA 1991b. Health Efjects Assessment Summary Tables (HEAST). Fint Quarrer, FY 1991. OERR 9200.6-303.(91-1), Omee of Emergency and Remedial Reapone. Wuhington. D.C.

EPA 1991c. Rlsk Assesument Ouldance for Superfund, Vol. I: Human Healeh Evaluation Manual Par B. Sa35.7.01B, Omce of Emergency and Remedial Reaponec, Wahington. D.C.

EPA 1992. Ouble to Management of Investipation.Derived Wastes. EPA 9345.3-03PS, January.

EPA 1992b. Requirements for Quallin Control of Anabyical Dara.

EPA 1992. Promowat for Ecological Risk Assesumens. Wuhington, D.C.

EPA 1992d. Region IV Criteria Chartu (December).

EPA 1992. Health Effects Assessment Summany Tables (HEAST), FY 1991. OECR 9200, 6363. Omce of Emergency and Romedial Reaponse. Wuhington. D.C.

EPA 19928. Integrated Risk Information Sytem. Computer data base, Wahington. D.C.

ERDA (Energy Research and Development Administration). 1975. Preliminary Draft Envinonmenual Anabysis Oak Ridge Operations, Vol. VI.

Foreman, J. L. et al. 1991. Slope and Basinal Carbonate Deposition in the Nolichurky Shale (Upper Cambrian), Enst Tenneuses: ElTect of Carbonate Suppresalon by Siliciclestic Deposilion on Basin.Margin Morphology." in Mixed Carbonares-Silliciclastic Sequences. SEPM Core Workhop, No. 15, Dallus, Texus.

Oeraghty and Miller. 1985. Remedlal Altermatives for the Bear Creek Valley Waste Dispossal Arra, Y/Sub/35-00206C/3, Martin Marietta Energy Systems, Inc., Oak Rldge Y.12 Plant, Oak Ridge, Tenneasee.

Oeraghty and Millor. 1986. Aquifer-Test Data and Design of Recovery Wells, S.3 Ponds. Y/Sub/26-00206C/2, Martin Marietta Energy Systems, Inc., Oak Ridge Y-12 Plant, Oak Ridge, Tennessee. 
Ceraghty and Miller. 1987. Hydroneologic Investigation of the S.3 Pond Area at the Y.12 Pland. Y/Sub/B7-00206C/18, Martin Marictia Energy Sytems, Inc., Onk Ridge Y.12 Plant, Oak Ridge, Tenneusec.

Oeraghty and Miller. 19x8. Groundwater Qually Assessment for the S.3 Ponds Hazandous Waste Dlppasal Unil at the Y.12 Plant, 1987. Y/Sub/88-00206C/1, Martin Marietiu Enercy Syatema, Inc., Oak Ridge Y.12 Plani, Oak Ridge, Tennescec.

Oerughty and Miller. 1989. Trucer Study of the Hydrologic System of Upper Bear Creek, Y.12 Planu, Oak Ridge, Tennessee. Y/Sub/89-(0)206C/4, Martin Mariettu Energy Syltems, Inc., Oak Ridge Y.12 Plant, Oak Ridge, Tennewee.

Oeraghty and Miller. 1990. Comprehensive Groundwater Monitoring Plan for the Deparrment of Enery Y.12 Plani, Oak Rldge, Tennessee. Y/Sub/90-00206C/S, Martin Marielia Energy Syatems, Inc., Ouk Ridge Y.12 Plant, Oak Ridge, Tenneasee, September.

Hase, C. S., and H. L. King. 1990. Report and Preliminary Assessment of Occurrence of Dense Nonaqueous Phase Llquils in the Bear Creek Burlal Grounds Hazandour Waste Disposal Unil at the Oak Ridge Y.12 Plant. Y/TS-629, Oak Ridge Y.12 Plant, Martin Marictia Energ Syatems, Inc., Oak Ridge, Tenneasee.

Hasue, C. S., E. C. Walls, and C. D. Farmer. 19:3. Smectural and Stratigraphic Data for the Conasauga Group and Rome Fomation on the Copper Creek Thrust Sheet Near Oak Rider, Tennessee: Prillminary Data from Test Bonehole ORNLJoy No. 2. ORNLTM-9159, Martin Mariette Energy Syttems, Inc., Oak Ridge National Laboratiory. Ouk Ridge, Tenneanee.

Hardy, C., L. Poundh, and R. Cook. 1992. Results of the Y.12 Area Rave Plant and Wesland Survy. Martin Mariettu Enery Systems, Inc., Oak Ridge National Laboratory, Oak Ridge, Tennesce.

Hatcher, of al. 1992. Status Repon: The Geoloy of the Oak Ridge Resenvation. ESD Publication No. 3860, ORNLTM.12074, Martin Marietta Energy Systems, Inc., Oak Ridge National Laboratory, Oak Ridge, Tenneasee, October.

Herbes, S. E. 1988. PCB Contamination in the Sediments of the Oil Retention Ponds and Associated Tributany Channels at the Burial Grounds of the Oak Ridge Y.12 Plant, Y/TS-431, Martin Marietta Energy Systems, Inc., Oak Ridge Y.12 Plant, Oak Ridge, Tenneasee.

Herbes, S. E. 1989. PCBs, Uranium, and Oil/Grease in Soil at the Oak Ridge Y.12 Plani Oil Landfarm: Results of a 1985.1986 Sampling and Analysis Program, Y/TS.538, Martin Marietta Enercy Systems, Inc., Oak Ridge Y.12 Plant, Oak Ridge, Tennessec.

Hoon, A.B., and 2.C. Bailey. 1986. Reconnaissance of Surficial Geology, Regolith Thickeness, and Conflguration of the Bedrock Surface in Bear Creek and Union Valleys, Near Oak Ridge, Tennessee. Water Resources Investigations Report 86-4165, U.S. Geological Survey. 
Houlberg. L. M., O. T. Hawkins, and M. S. Salk. 1993. Envimnmental Regulatony Update Table, January/February 1993. ORNL/M.2648, Martin Marietto Energy Systems, Inc., Oak Ridge National Laboratory, Oak Ridge, Tennessee, March.

Howell, C., Tennessee Department of Conservation. January 3, 1986. State Natural Areas Registration, letter to P. T. Marquess, Assistant Manager for Administration, DOE Oak Ridge Operations, Oak Ridge, Tennessee (as cited in Parr and Pounds 1987).

HSW (HSW Environmental Consultants, Inc.). 1991. Groundwater Quality Assessment for the Bear Creek Hydrogeologic Regime at the Y.12 Plant, 1990: Data Interpretation and Propased Modifications for 1991. Y/SUB/91-YP507C/P1\&P2, Martin Marietta Energy Syitems, Oak Ridge Y.12 Plant, Oak Ridge, Tennessec.

HSW. 1992. Groundwater Quality Assessment for the Bear Creek Hydrogeologic Regime at the Y.12 Plant: 1991 Groundwater Qualiny Data Interpretations and Proposed Program Modifications. Y/Sub/92.YP507C/1/P1\&P2, Martin Marietta Energy Syatems, Inc., Oak Ridge Y.2 Plant, Oak Ridge, Tennessce, August.

Jetcr, I. W. 1983. The Chemical and Radiological Characterization of the S.3 Ponds. YMA-6400, Union Carbide Corporation Nuclear Division, Oak Ridge Y.12 Plant, Oak Ridge, Tenneasee.

Johnson, R. M. 1964. Heppetofauna of the Oak Ridge Area. ORNL/3653, Oak Ridge National Laboratory, Oak Ridge, Tennessee.

Jones, S. B., B. K. Harrington, and S. M. Field. 1992. Updated Subsurface Data Base for Bear Creek Valley, Chestnut Ridge, and Pants of Bethel Valley on the U.S. Department of Enery Oak Ridge Resenvation. Y/TS-881, Oak Ridge Y.12 Plant, Oak Ridge, Tennessee.

Kimbrough, C. W., and R. R. Turner. 1987. Field Notebook: Sampling and Analysis of Sludges in the S.3 Ponds at the Y.12 Plant. Y/TS.294, Martin Marietta Energy Systems, Inc., Oak Ridge National Laboratory, Oak Ridge, Tennessee.

Kimbrough, C. W., L. W. Long, and L. W. McMahon. 1990. Environmental Surveillance Procedures, Qualiny Conurol Program. ESH/Sub/87-21706/1. Martin Mariella Energy Systems, Inc.

King, H. L., and C. S. Hasse. 1987. Subsurface.Controlled Geological Maps for the Y.12 Plant and Adjacent Areas of Bear Creek Valley. ORNLTMM-10112, Martin Marietta Energy Systems, Inc., Oak Ridge National Laboratory, Oak Ridge, Tennessec.

Krey, P. W., and H. L. Beck. 1990. Environmental Measurement Laboratory Procedures Manual. HASL 300, U.S. Department of Energy, New York, November.

Kroodsma, R. L. 1987. Resource Management Plan for the Oak Ridge Reservation, Volume 24: Threatened and Endangered Animal Species. ORNL/ESH-1/N24, Martin Marietta Energy Systems, Inc., Oak Ridge National Laboratory, Oak Ridge, Tennessee, January.

Kroodsma, R. L. 1993. Personal communication to C. Pergler, Science Applications International Company (SAIC). 
11.8

Law (Law Engineering Testing Company). 1975. Preliminary Safety Analysis Report for Nuclear Fuel Recovery and Recycling Center. Prepared for the Exxon Nuclear Company.

Law. 1983. Results of Groundwater Monitoring Studies: Oak Ridge Y-12 Plant. Y/Sub/83-47936/1, Oak Ridge Y-12 Plant, Oak Ridge, Tennessee, September.

Lee, R. R., and R. H. Ketelle. 1988. Subsurface Geology of the Chickamauga Group at the Oak Ridge National Laboratory. ORNL/TM-10749, Martin Marietta Energy Systems, Inc., Oak Ridge National Laboratory, Oak Ridge, Tennessee.

Lietzke, D. A. S. Y. Lee, and R. E. Lambert. 1988. Soils, Surficial Geology, and Geomorphology of the Bear Creek Valley Low-Level Waste Disposal Development and Demonstration Program Site. ORNL/TM-10543, Oak Ridge National Laboratory, Martin Marietta Energy Systems, Inc., Oak Ridge, Tennessec.

Lozier, W. B., C. A. Spiers, and R. Pearson. 1987. Aquifer Pump Tests with Tracers. ORNL/Sub/86-32136, Oak Ridge National Laboratory, Oak Ridge, Tennessee.

Lutz, C. T., and R. B. Dreier. 1988. "Differences in Local Deformation History as Indicated by Fracture Orientations in Two Foreland Thrust Sheets." Geol. Soc. Am. Abstracts with Program 20(7).

McCauley, L. L. 1984a. Sediment Assessment and Inventory of Existing Contamination and Biological Data for Two Oil Retention Ponds in the Y.12 Plant, Bear Creek Valley Waste Disposal Area, Y/A-165, Martin Marietta Energy Systems, Inc., Oak Ridge Y-12 Plant, Oak Ridge, Tennessee.

McCauley, L. L. 1984b. Inventory of Existing Contamination in the Y.12 Plant Bear Creek Valley Oil Landfarm Area. YMA-166, Oak Ridge Y-12 Plant, Oak Ridge, Tennessee.

McCauley, L. L. 1985a. Remedial Altematives for the Bear Creek Valley Waste Disposal Area. Y/Sub/85-00206C/3, Oak Ridge Y-12 Plant, Oak Ridge, Tennessee.

McCauley, L. L. 1985b. Analytical Quality Assurance/Quality Control Data for 1983-1984 Bear Creek Valley Sampling and Analysis Program. Y/TS-111, Oak Ridge Y.12 Plant, Oak Ridge, Tennessee.

McCauley, L. L. 1985c. Analytical Results for Water, Sediment, and Soil Samples Collected in the Y.12 Plant Bear Creek Valley Waste Disposal Areas. Y/TS-112, Oak Ridge Y.12 Plant, Oak Ridge, Tennessee.

McElhaney, R. J. 1982. PCB in Fish from East Fork Poplar Creek and Bear Creek. Mimeo from R. J. McElhaney, Y-12 Plant, to W. Van Winkle, Environmental Sciences Division, ORNL, September 22, 1982.

McMahon, L. W. 1988. Sampling and Analysis to Support Excavation of Blue Lagoon Sediment Build-up. Y/TS-481, Oak Ridge Y-12 Plant, Oak Ridge, Tennessec.

McMaster, W. M. 1967. Hydrologic Data for the Oak Ridge Area, Tennessee. Water-Supply Paper No. 1838-N, U.S. Geological Survey, Washington, D.C. 
Moore, G. K. 1988. Concepts of Groundwater Occurrence and Flow Near Oak Ridge National Laboratory, Tennessee. ORNL/TM-10\%69, Martin Marietta Energy Systcms, Inc., Oak Ridge National Laboratory, Oak Ridge, Tennessee.

Moore, O. K. and L. E. Toran. 1992. Supplement to a Hydrologic Framework for the Oak Ridge Reservation, Oak Ridge, Tennessee. ORNL/TM-12191, Martin Marietta Energy Systems, Inc., Oak Ridge National Laboratory, Oak Ridge, Tennessee.

Murphy, J. L. February 1989. Supplement to Solid Waste Management Unit Information for Y.12 Plant RCRA 3004 (u) Facility Assessment. Y/TS-273, Suppl.-4, Martin Marietta Energy Systems, Inc., Oak Ridge Y-12 Plant, Oak Ridge, Tennessee.

Myrick, T. 1987. Procedures Manual for the ORNL (Oak Ridge National Laboratory) Radiological Survey Activities (RASA) Program, ORNL/TM-8600, Martin Marietta Energy Systems, Inc., Oak Ridge National Laboratory, Oak Ridge, Tennessee, April.

Nyquist, J. E., and M. S. Blair. 1991. "A Geophysical Tracking and Data Logging System: Description and Case History," Geophysics 56(7), pp. 1114-1121.

Nyquist, J. E., and M. S. Emery. 1993. Electromagnetic Survey of the K1070A Burial Ground at the Oak Ridge K.25 Site, Oak Ridge, Tennessee, KJER-56, Martin Marietta Energy Systems, Inc., Oak Ridge K.25 Site, Oak Ridge, Tennessee, January.

Parr, P. D. 1992. Oak Ridge National Laboratory, Environmental Sciences Division, personal communication to E. P. McDonald, March 19.

Parr, P. D., and L. R. Pounds. 1987. Resource Management Plan for the Oak Ridge Reserva. tion, Volume 23: Oak Ridge National Environmental Research Park, Research Sites, and State Natural Areas. ORNL/ESH-1/V23, Martin Marietta Energy Systems, Inc., Oak Ridge National Laboratory, Oak Ridge, Tennessee, May.

Petrich, C. H., et al. 1984. Resource Management Plan for the U. S. Department of Energy Oak Ridge Reservation. Appendix G: Geography, Demography, Topography, and Soils. ORNL/6020/V7, Martin Marietta Energy Systems, Inc., Oak Ridge National Laboratory, Oak Ridge, Tennessee.

Pulliam, Pamela J. 1985. Water-quality Data for 34 Sites, April and June 1984, Near the Y.12 Plant. The Oak Ridge Reservation, Tennessee. Open File Report 85-553, U.S. Geological Survey.

Radian (Radian Corp.). 1993a. Y.12 Plant: Bear Creek Burial Grounds Remedial Investigation Data Adequacy Summary, DOE/OR-996\&D2 (92-225-161-63), Oak Ridge, Tennessee, January.

Radian (Radian Corp.). 1993b. Environmental Restoration Program Technical Support Contractor Quality Assurance Technical Procedures Manual, Vol. I. DOE/OR-933\&R14, U.S. Department of Energy, Oak Ridge, Tennessee, April. 
Rothschild, E. R., et al. 1984. Investigation of Subsurface Mercury at the Oak Ridge Y-12 Plant. ORNL/TM-9092, Martin Marietta Energy Systems, Inc., Oak Ridge National Laboratory, Oak Ridge, Tennessee.

Sanders, M. 1984. Resource Management Plan for the U.S. Department of Energy Oak Ridge Reservation, Volume 3, Appendix B: Archaeological Considerations. ORNL/6026/V4, Oak Ridge National Laboratory, Oak Ridge, Tennessee, July.

Shacklette, H. T., and J. G. Boerngen. 1984. Element Concentrations in Soils and Other Surficial Materials of the Conterminous United States, U.S. Geologic Survey, Professional Paper 1270, U.S. Govt. Printing Office.

Shevenell, L. S., R. B. Dreier, and W. K. Jago. 1992. Draft Summary of Fiscal Year 1991 and 1992 Construction, Hydrologic and Geologic Data Obtained from the Maynardville Limestone Exit Pathway Monitoring Program. Y/TS-814, Oak Ridge Y-12 Plant, Oak Ridge, Tennessee.

Smith, E. D., and N. D. Vaughn. 1985. "Aquifer Test Analysis in Nonradial Flow Regimes: A Case Study," Groundwater 23(2), pp. 167-175.

Solomon, D. K. et al. 1991. Transport of Contaminants During Storms in the White Oak Creek and Melton Branch Watersheds, ORNL/TM-11360, Martin Marietta Energy Systems, Inc., Oak Ridge National Laboratory, Oak Ridge, Tennessee, January.

Solomon, D. K, et al. 1992. Status Report-A Hydrologic Framework for the Oak Ridge Reservation. ORNL/TM-12026, Martin Marietta Energy Systems, Inc., Oak Ridge National Laboratory, Oak Ridge, Tennessee, January.

Southworth, G. R., et al. 1992. Ecological Effects of Contaminants and Remedial Actions in Bear Creek. ORNL/TM-11977, Oak Ridge National Laboratory, Oak Ridge, Tennessee.

Starnes, W. C., and D. A. Etnier, D. A. 1980. "Fishes" in Tennessee's Rare Wildlife, D. C. Eager and R. M. Hatcher, eds. Tennessee Department of Conservation, Nashville, Tennessee.

Stone, J. E. 1990. S-3 Ponds (T.004) Summary of Closure Under Rules Governing Hazardous Waste Management in Tennessee. Y/TS-393/2, Martin Marietta Energy Systems, Inc., Oak Ridge Y-12 Plant, Oak Ridge, Tennessee, August.

Summers, K., S. Gherini, and C. Chen. 1980. Methodology to Evaluate the Potential for Groundwater Contamination from Geothermal Fluid Releases. EPA/600/7-80/117.

Suter, G. W. 1990. "Endpoints for Regional Ecological Risk Assessments," Environ. Manage. 14(1), pp. 19-23.

Suter, G. W. 1993. Ecological Risk Assessment. Levis Publisher, Chelsea, Michigan.

Turner, R. R., and G. E. Kamp. 1984. Characterization and Remedial Alternatives for Sediments in Upper Bear Creek, Y/TS-56, Martin Marietta Energy Systems, Inc., Oak Ridge Y-12 Plant, Oak Ridge, Tennessee. 
Turner, R. R., S. E. Lindberg, and K. Talbot. 1977. Dynamics of Trace Element Export from a Deciduous Watershed, Walker Branch, Tennessee, CONF-770209-3, Martin Marietta Energy Systems, Inc., Oak Ridge National Laboratory, Oak Ridge, Tennessee.

Turner, R. R., et al. 1991. Remedial Investigation Work Plan for Bear Creek (Y02-S600) at the Oak Ridge Y-12 Plant, Oak Ridge, Tennessee, ES/ER-19\&D2 (Y/ER/Sub-90/99928/2), Martin Marietta Energy Systems, Inc., Oak Ridge Y-12 Plant, Oak Ridge, Tennessee, June.

TVA (Tennessee Valley Authority). 1986. Instream Contaminant Study, Task 5: Summary Report. ZZ-86-06-08.

Union Carbide Corporation-Nuclear Division. 1984. Inventory of Existing Contamination in the Y-12 Plant Bear Creek Valley Oil Landfarm Area, Y/IA-166, Oak Ridge Y-12 Plant, Oak Ridge, Tennessee, Jan. 31.

USDA (U.S. Department of Agriculture). 1978. Predicting Rainfall-Erosion Losses: $A$ Guide to Conservation Planning. USDA-SEA Agriculture Handbook 537, U.S. Government Printing Office, Washington, D.C.

USDA. 1983. National Soils Handbook. USDA-SEA Agriculture Handbook 430-VI-NSH, U.S. Government Printing Office, Washington, D.C.

U.S. Department of Commerce. 1991. 1990 Census of Population and Housing: Census Tracts (Knaxville). Bureau of the Census, Washington, D.C.

Van Winkle, W., et al. 1984. Mercury Contamination in East Fork Poplar Creek and Bear Creek. ORNL/TM-8894, Martin Marietta Energy Systems, Inc., Oak Ridge National Laboratory, Oak Ridge, Tennessee.

Welch, S. H. 1987. Supplement to Solid Waste Management Unit Information for Y-12 Plant RCRA 3004(u) Facility Assessment. Y/TS-273, Suppl. 1, Martin Marietta Energy Systems, Inc., Oak Ridge Y-12 Plant, Oak Ridge, Tennessee, August.

Welch, S. H. 1989. RCRA Facility Investigation Plan General Document Y-12 Plant, Oak Ridge, Tennessee. Y/TS-352, Vol. 1 (Rev. 1), Martin Marietta Energy Systems, Inc., Oak Ridge Y-12 Plant, Oak Ridge, Tennessee, April.

Welch, S. H., and M. A. Poore. 1987. Solid Waste Management Unit Information for the Y-12 Plant RCRA 3004(u) Facility Assessment-Container Accumulation Areas. Y/TS-723, Supplement 2, Oak Ridge Y-12 Plant, Oak Ridge, Tennessee. 


\section{DISTRIBUTION}

1. D. T. Bell

2. V. J. Brumback

3. E. T. Collins

4. M. F. P. DeLozier

5. J. D. Gass

6. C. D. Goins

7. J. T. Grumski

8. A. Halouma

9. P. J. Halsey

10. J. A. Hodgins

11. J. B. Hunt

12. W. K. Jago

13. C. Kimbrough

14-15. A. K. Lee/DOE-OSTI

16. J. M. Loar

17-20. D. M. Matteo

21. M. McKinney

22. G. K. Moore

23. T. I. Nakamoto

24. H. C. Newsom/D. C. White

25. M. J. Norris

26. B. Nourse

27-28. P. T. Owen

29. T. J. Pierce

30. G. E. Rymer

31. C. M. Smith

32. G. W. Suter

33. T. S. Tison

34. R. R. Tumer

35. C. S. Walker

36. D. R. Watkins

37. R. W. Weigel

38. R. K. White

39. Y-12 Technical Library

40-44. ER Document Management Center

45. Y-12 ER Document Center

46. Y-12 Central Files

47-56. S. L. Lankford, DOE Oak Ridge Operations Office, P.O. Box 2001, Oak Ridge, TN 37831-8541

57. Duncan Moss, Science Applications International Corporation, 800 Oak Ridge Turnpike, Oak Ridge, TN 37831

58-59. R. L. Nace, Branch Chief, Nonenrichment Facilities, Oak Ridge Program Division, Office of Eastern Area Programs, Office of Environmental Restoration, EM-423, Trevion 2, U.S. Department of Energy, Washington, DC 20585

60. R. C. Sleeman, DOE Oak Ridge Operations Office, P.O. Box 2001, Oak Ridge, TN 37831-8541

61. D. W. Swindle, Radian Corporation, 120 South Jefferson Circle, Oak Ridge, TN 37830

62-63. H. M. Thron, Chief, Enrichment Facilities, Oak Ridge Program Division, Office of Eastern Area Programs, Office of Environmental Restoration, EM-423, Trevion 2, U.S. Department of Energy, Washington, DC 20585

64. R. L. Carlson, Radian Corporation, 120 South Jefferson Circle, Oak Ridge, TN 37830 

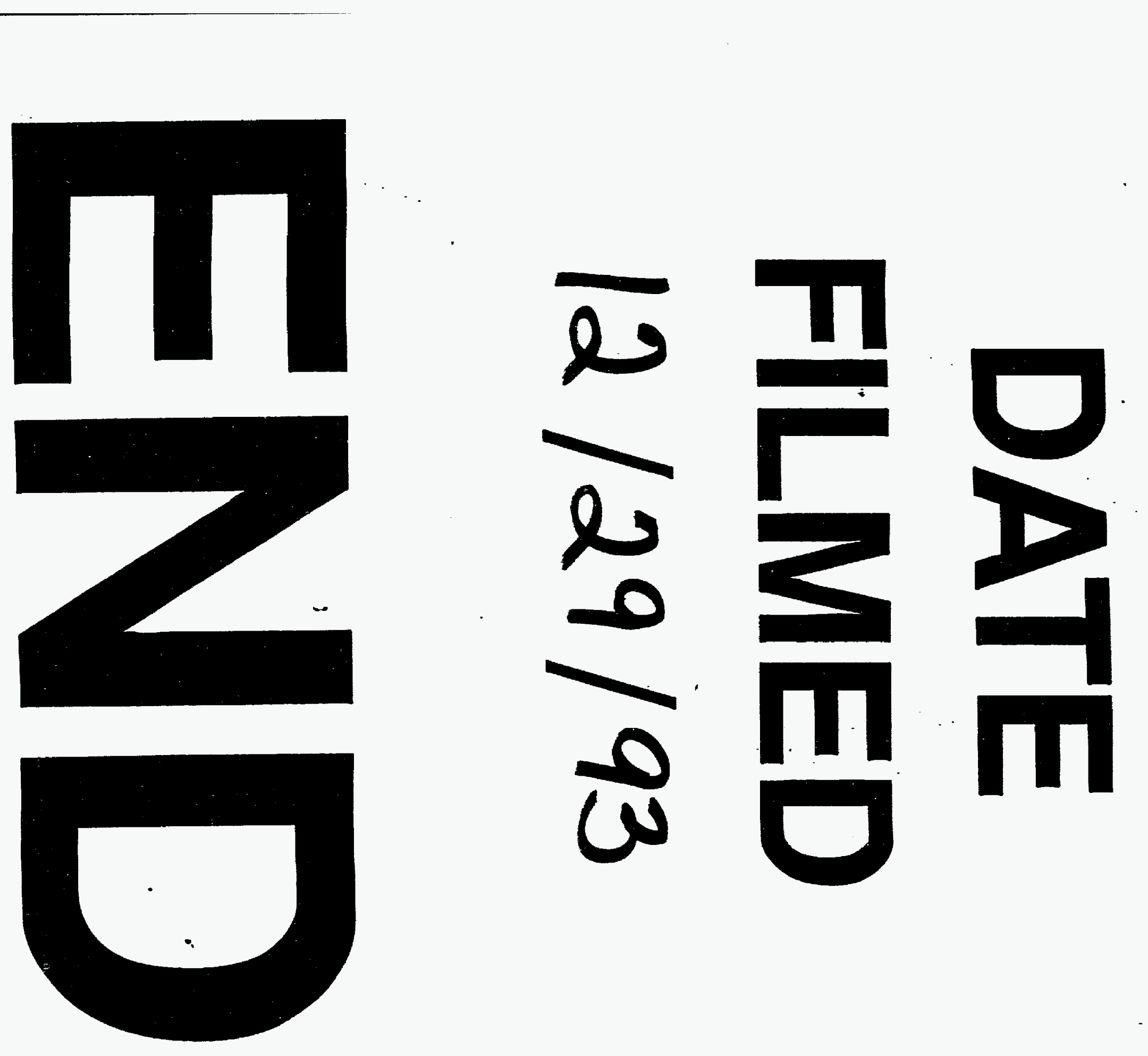

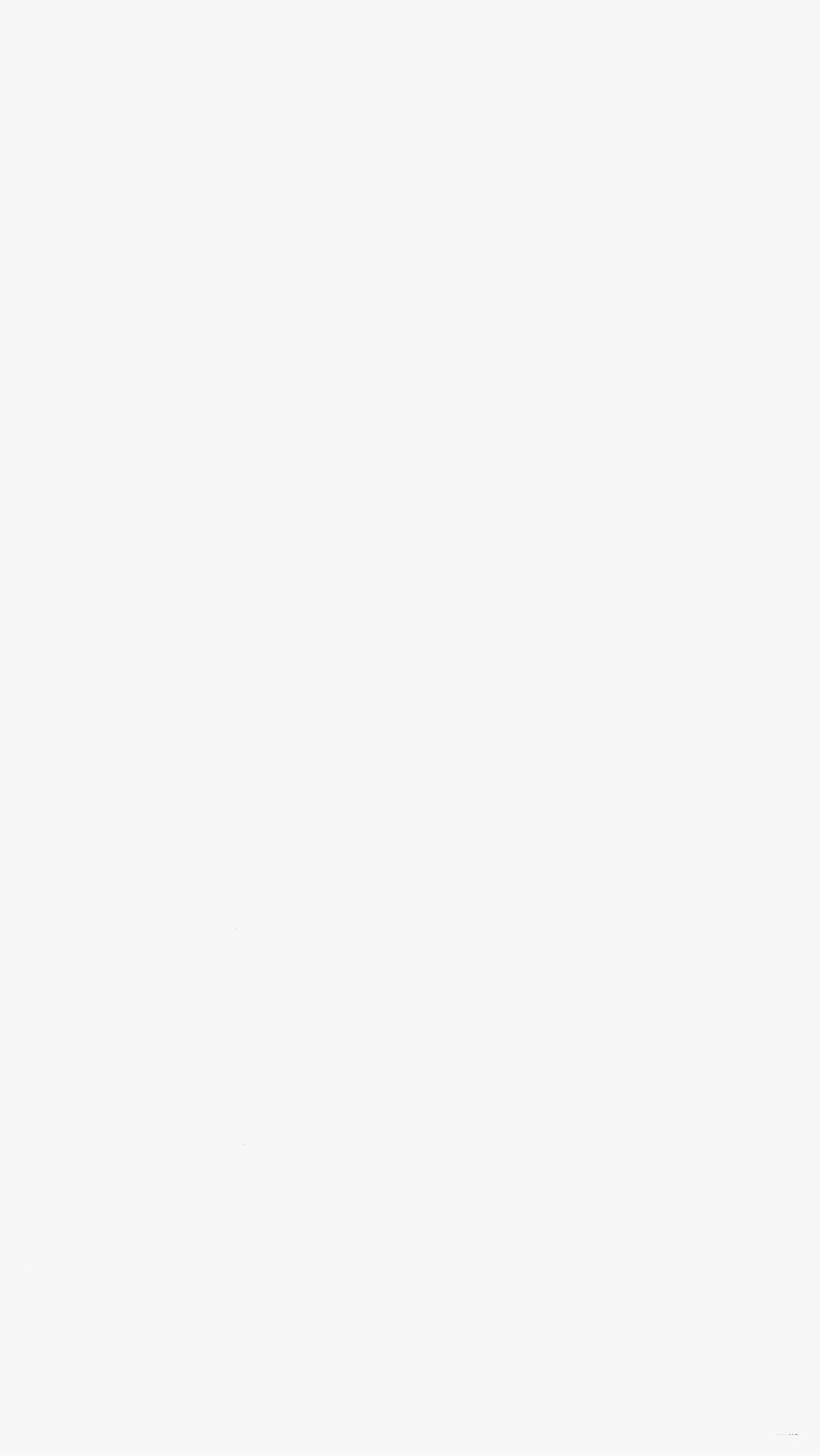